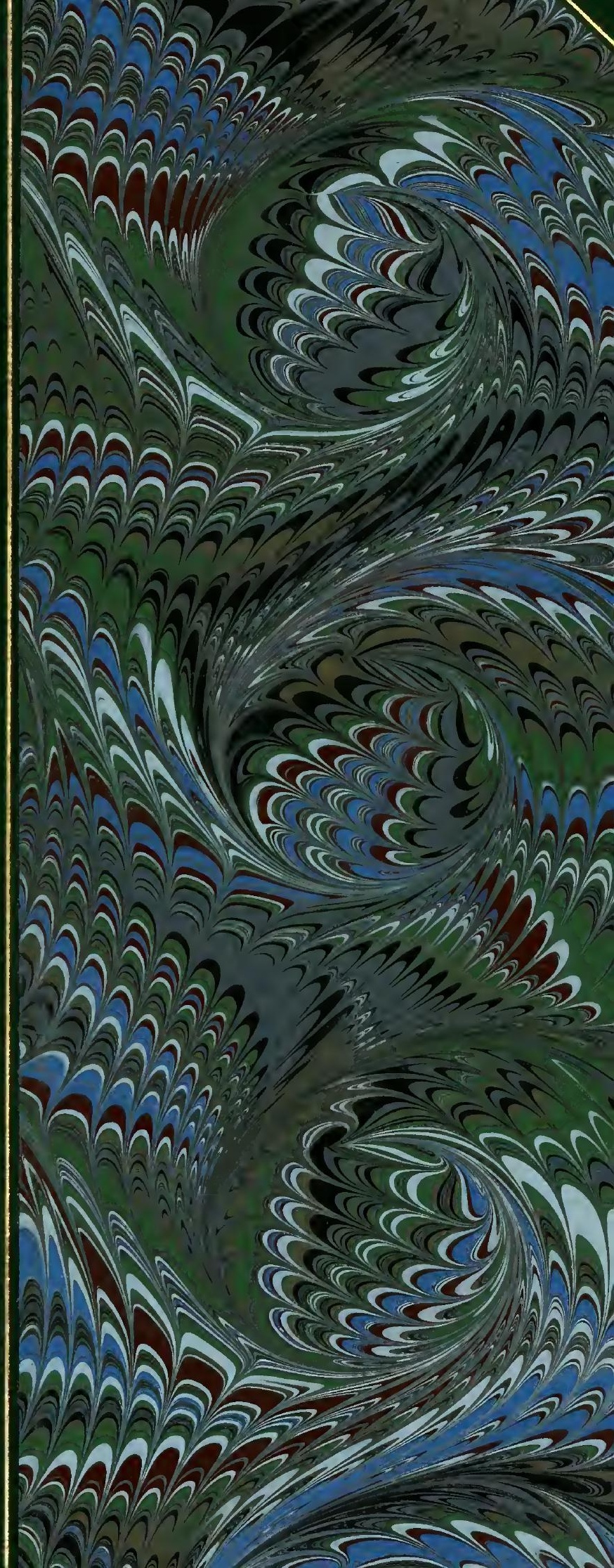









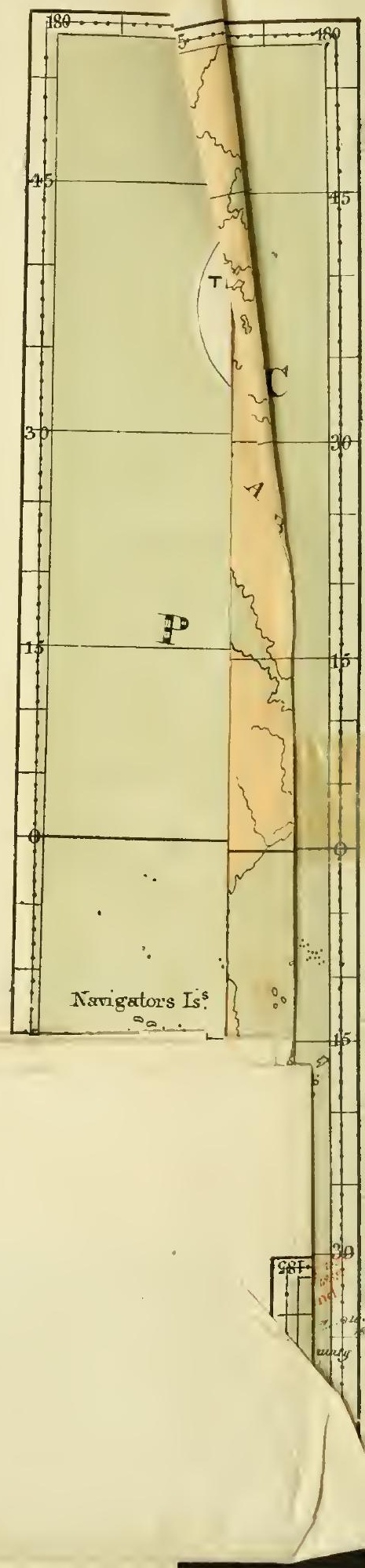




\title{
Circumnavigation of the Globe
}

\author{
BY THE AUSTRIAN FRIGATE
}

\section{N O V A R A.}

(COMMODORE B. VON WULLERSTORF-URBAIR,)

Undertaken by Order of the Imperial Government,

\section{IN THE YEARS I857, I858, \& I 859,}

\author{
UNDER THE IMMEDIATE AUSPICES OF HIS I. AND R. HIGHNESS
}

THE ARCHDUKE FERDINAND MAXIMILIAN, COMMANDER-IN-CHIEF OF THE AUSTRIAN NAVY.

BY

\section{DR. KARL SCHFRZER,}

MEMBER OF THE EXPEDition, AUthor of "Travels in CENTRAL america," etc.

VOL. I.

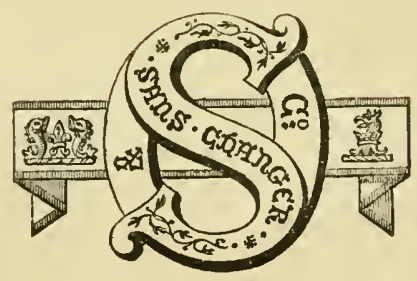

LONDON :

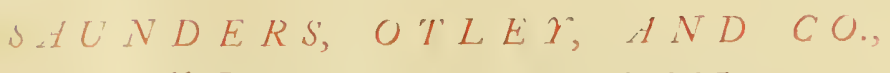

66, BROOK STREET, HANOVER SQUARE.

$186 \mathrm{I}$. 



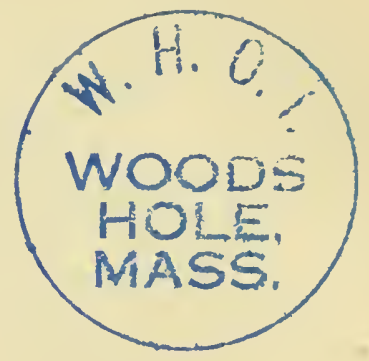

TO

\title{
SIR RODERICK IMPEY MURCHISON,
}

\author{
G.C.S.ST., M.A., D.C.L., v.P.R.s., G.S., L.S., F.R.G.S.,
}

DIRECTOR-GENERAL OF THE GEOLOGICAL SURVEY OF GREAT BRITAIN AND IRELAND, TRUST. BRIT. MUS., ETC., ETC.,

\section{THE GREAT PROMOTER OF GEOGRAPHICAL KNOWLEDGE,}

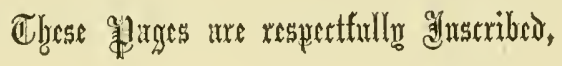

IN RECOGNITION OF HIS VALUABLE EXERTIONS IN ADVANCING THE SCIENTIPIC OBJECTS

OF THE AUSTRIAN EXPEDITION,

AS WELL AS

IN GRATITUDE FOR THE HOSPITABLE RECEPTION SECURED TO THE NAVIGATORS

THROUGHOUT THE BRITISH DEPENDENCIES,

WHEREVER IT WAS THEIR GOOD FORTUNE TO CAST ANCHOR,

BY

THE AUTHOR OF THE FOLLOWING NARRATIVE. 

Les.12/860

hes dan tin

$$
\text { mikish wacke t } 3 w
$$

flattenos requet that I wored attur zom aras

yt toryegh Novara

Fijet the dedireles to

Ine.

Hany telen a dech interest $i$ the surrep ofs thei furmerantly efpert if te Mustion Genenort $t$ enluryo or. Hailv Schergen 
the trumes of Ocientifue

tharteger, I har $\rightarrow$

tine sidificter un

lanasiy thet to

courdet of bo iebertin.

war en liasted to

The atter haches

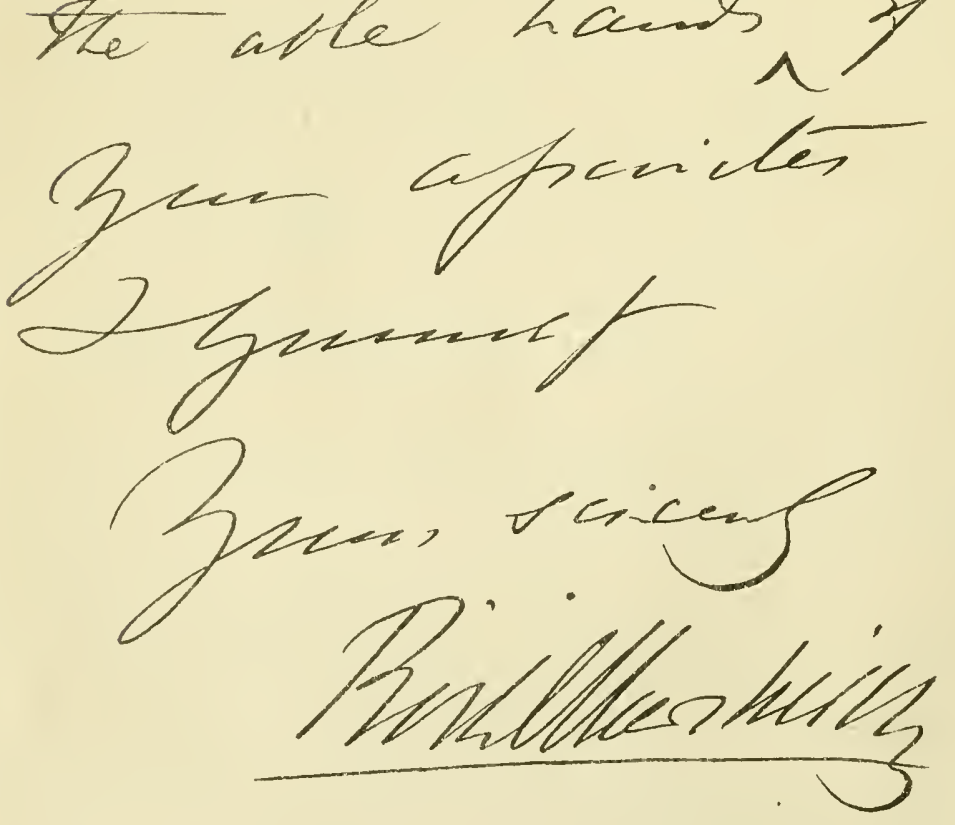




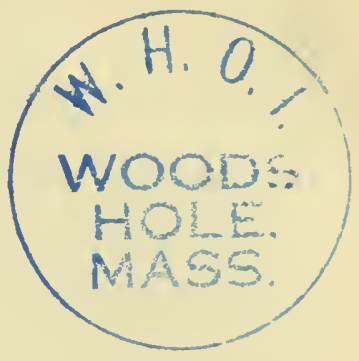

\section{PREFACE TO THE ENGLISH EDITION.}

A member of the scientific corps attached to the Expedition, which, under the auspices of that enlightened friend of science and liberty, the Archduke Ferdinand Maximilian, was despatched on a voyage round the globe, the high honour has been conferred upon me of having entrusted to my care the publication of the Narrative of our Cruise.

In this not more difficult than enviable task, I have been most liberally assisted by my eminent fellow-labourersthe whole literary material collected during the voyage having been kindly placed at my disposal. The comprehensive journals and reports of the venerable Commanderin-Chief of the Expedition, Commodore Wullerstorff-Urbair, as well as the various memoranda of the other members of the Scientific Commission, contributed materially to the elucidation of my own general notes, as well as my observations upon special subjects, which latter chiefly referred to the Geography, Ethnography, and general Statistics of the various countries visited. 
While preparing the details of our voyage for publication in my own language, the idea perpetually presented itself that a translation of this narrative into English might prove not unacceptable to the British public. And although fully aware that a voyage round the globe, in the course of which little more than the coasts were visited of the various countries we touched at, could not pretend to offer much new information to the greatest of maritime nations, it seemed, nevertheless, that it might interest a people so eager in the pursuit of knowledge as the English, to know the impression which has been made upon travellers of education by the Colonies and Settlements of Britain through, out the world.

The English language, moreover, being spoken more or less over the greater part of the earth's surface, geographically speaking, the author who addresses his readers in that tongue is sustained by the flattering conviction that he will be understood by the majority of the nations of the globe! For it is not alone the educated classes of all countries that seek to master a language which possesses such a grand-all but unrivalled literature! The political and commercial development which Great Britain enjoys under the benign infuence of liberal institutions, has made English the medium of intercourse among almost all sea-faring nations; nay, even barbarous tribes find it their obvious interest to get a slight inkling at least of the language of a people whose civilizing and elevating energies 
they may not, it is true, understand, far less appreciate, but whose imposing power inspires them with awe, while they are more closely attached by the tie of material advantage.

The following narrative describes the most important occurrences and most lasting impressions of a voyage during which we traversed 51,686 miles, visited twenty-five different places, and spent 551 days at sea, and 298 at anchor or on shore.

As the purely scientific results of the Expedition will be published separately under the supervision of Commodore Wullerstorf and the other members of the scientific corps, I shall, in this place, only attempt to place before the reader a general outline of the countries and races visited during our cruise in different regions of the world.

In relating simply and concisely what was seen and experienced, I have endeavoured to avoid incurring the reproach, so frequently launched by English crities against German works of travel, of dryness and minute detail, such as render them distasteful to the English reader, and make it almost impossible to enlist his attention or evoke his sympathy.

If, as is specially the case with respect to natural science, many a doubtful point still remains undecided-if the ingenious "Suggestions" of the immortal Alexander von Humboldt (for the translation of which I feel particularly indebted to that profound scholar, my learned and esteemed friend Mr. Hardinger, whose name will be familiar to the 
scientific world in Great Britain), could not be acted upon to the extent and in the effectual manner each of us could have wished, the reason for such deficiencies will be found in the peculiar mission of the Expedition, and in the arrangement of our route, which was specially laid out with reference to the numerous and widely different objects, which it was specially intended to keep in view throughout the voyage.

Among the more prominent of these, may be specified the opportunity thus afforded for the practical instruction of our young and rapidly-increasing navy; the unfurling of the Imperial flag of Austria in those distant climes, where it had never before floated; the promulgation of commercial treaties; the aid afforded to science in exploration and investigation, as well as by the collection of those objects of Natural History, the acquisition of which is all but impossible to the solitary naturalist, owing to the expense and difficulty of transport,* and the establishment everywhere of friendly

* Notwithstanding the short period at our disposal at each port, which concomitant necessity militates so much against the practical utility of a circumnavigation of the globe as compared with an expedition solely directed to one single centre of scientific observation, the collection of objects of Natural History made during the cruise aro very extensive, and unusually rich in new or rare species. The zonlogical department alone embraces above 23,700 individuals of different kinds of animals: viz. 440 minerals, 300 reptiles, 1500 birds, 1400 Amphibia, 1330 fish, 9000 insects, 8900 Molluses and Crustacea, 300 birds' eggs and nests, besides numerous skeletons. The botanical collection consists of IIerbaria, seeds of useful plants, special regard being had to those best adapted for the various climates of the respective Austrian provinces, drugs, specimens of dye-woods, and timber, fruits preserved in alcohol, \&c. The Geological and Palæontological Museums of our country have likewise been enriched with various rare and valuable specimens, particularly in consequence of Dr. Hochstetter, the geologist of the Expedition, having prolonged his stay in New 
correspondence between our own scientific institutions and those in remote regions. I have considered it necessary to invite the attention of the British reading public to these circumstances, in order to make them more intimately cognisant of our various and manifold tasks, and thus make them the more readily disposed to overlook the deficiencies and discrepancies of this book, which I now respectfully commit to their perusal.

Before concluding, I beg leave to express my hearty thanks to all those who have contributed in such various ways to aid my humble efforts-to specify some were invidious, as in so doing I must wrong others. To each and all I return the most heartfelt gratitude.

May the indulgent reader peruse the following pages with an approving eye-may they afford him as much satisfaction and as much interest as I experienced in committing to paper the descriptions and impressions therein set forth, since in so doing, I, so to speak, made the delightful voyage for the second time, and in thought visited once more the different localities, from every one of which I, and my fellowtravellers, brought away none but the most friendly and agreeable recollections.

It inspires a German traveller with a peculiar and lofty

Zealand, where, at the special request of the Colonial Government, he explored the province of Auckland. The Ethnographical and Anthropological collection consists of above 5็0 oljects, among which are 100 skulls, representing the craniology of almost all the races of the globe. 
feeling of pride and delight that he can look upon himself as belonging to a race, to whom seems to have been reserved the diffusion of a New Life over the earth-whose special mission it appears to be to make even the most primitive tribes in the remotest corner of the world acquainted with the blessings of Christian civilization, of political liberty, of intellectual culture, and, standing triumphant on the ruins of slavery and despotism, to proclaim to the great family of universal mankind, the advent of a new, a vernal era of Faith, Freedom, and Happiness !

Dr. Karl Scherzer.

Trieste, 18th March, 1861. 


\section{CONTEN'TS.}

\section{CHAPTER I.}

PREPARATIONS FOR THE VOYAGE.

Approval of the Plan to fit out an Austrian Man-of-War for a Voyage round the World.-Object of the Expedition.-Appointment of a Scientific Commission.-Preparations.-Fitting out the Frigate Novara at Pola.Departure for Trieste.-Visit of the Archduke Ferdinand Maximilian on board

\section{CHAPTER II.}

FROM TRIESTE TO GIBRALTAR.

Departure.-Fair Voyage down the Adriatic.-A Man lost and found again.Passage through the Straits of Messina.-The Steamer Sta. Lucia returns to Trieste.-Regulations and Instructions for further Proceedings. - A Day on Board the Novara.-Sunrise.-Cleaning the Ship.-Mental and Physical Occupation.-Moonlight at Sea

\section{CHAPTER III.}

GIBRALTAR.

Political Significance of the Rock.-Courtesy of the British Authorities.Fortifications.-Signal Stations.-The only Place in Europe frequented by Monkeys.-Calcareous Caves.-Chief Entrances into the Tornn.-Shutting the Town Gates.-Public Establishments.-Inhabitants.-Elliott's Gardens.-The Isthmus, or Neutral Ground.-Algeziras.-Centa:-Commeree and Navigation.-Excellent Regulation in the English Navy relative to Officers' Outfit.--Small-pox appears on board the Curoline.-Departure from Gibraltar.- $\Lambda$ Fata Morgana.-The Novara passes the Straits.Takes leave of Europe.--Voyage to Madeira.-Floating Bottles to ascertain the Currents.-Arrival in the Roads of Funchal . . . . .

CHAPTER IV.

MADEIRA.

First Impressions.-Difficulty in Landing.-Description of the Island.-History.-Unfayourable Political Circumstances connected with the Cultivatiou 
of the Ground.-Aqueducts.-First Planting of the Sngar-cane.-Cultare of the Vine.-Its Disease and Decay.-Cochineal as a Compensation for its Loss.-Prospects of Success.-Climate.-A favourableWinter Residence for the Consumptive.-Strangers.-First Appearance of the Cholera.Observations with the Ozonometer.-Great Distress among the Lower Classes.-Liberal Assistance from England.-Decline of Commerce.-Inhabitants and their Mode of Lifo--Decrease of the Population, and its Causes.-Benevolent Institutions.-Public Libraries.-The Cathedral.Barracks.-Prison.-Environs of Funchal.-Excursion to St. Anna.Ascent of the Pico Ruivo.-Singular Sledge Party.-Return to Funchal.Departure .

\section{CHAPTER V.}

RIO DE JANEIRO.

Brazil the Land of Contrasts.-Appearance of the City of Rio and its Environs. -Excursion to the Peak of Corcovado, and the Tejuca Waterfalls.-Germans in Rio.-Brazilian Literary Men.-Assacú (Hura Brasiliensis.) Snake-bite as an Antidote against Leprosy.-Public Institutions.-Negroes of the Mozambique Coast.-The House of Misericordia.-Lunatic Asylum. -Botanical Garden.-Public Instruction.-Historico-Geographical Institution.-Palastra Scientifica.-Military Academy.-Library.-Conservatory of Music.-Sanitary Police.-Yellow Fever and Cholera. - Water Party on the Bay.-Chamber of Deputies.-Petropolis.-Condition of the Slave Population.-Prospects of German Emigration.-Suitability of Brazil as a Market for German Commerce.-Natural Products, and Exchange of Manufactures.-Audience of the Emperor and Empress.-Extravagant Waste of Powder for Salvoes.-Songs of the Sailors.-Departure from Rio. -Retrospect.-South-east Trades. - Cape Pigeons.-Albatrosses-Cape Tormentoso.-A Storm at the Cape.-Various Methods of Measuring the Height of Wares.-Arrival in Simon's Bay

\section{CHAPTER VI.}

CAPE OF GOOD HOPE.

Contrasts of Scenery and Seasons at Cape Colony.-Ramble through Simon's Town.-Malay Population.-The Toad-fish, or Sea-devil.-Rondebosch and its delightful Scenery.-Cape Town.-Influence of the English Element.-Scientific and other Institutions.-Botanical Gardens.-Useful Plants.-Foreign Emigration.-A Caffre Prophet and the Consequences of his Prophecies.-Caffre Prisoners in the Armstrong Battery.-Five young Caffres take Service as Sailors on Board the Norura.-Trip into the Interior.-Stellenbosch.-Paar._- Worcester.-13rand Vley.-The Mission of Moravian Brethren at Gemaadendal--Masticatorics and intoxicating 
Substances used by the Hottentots.-Caledon.-Somerset West.-ZandPAGE vlict.-Tomb of a Malay Proplet.-Horse Sickness.-Tsetsé-fly.-Vineyards of Constantia. - Fêto Champêtre in Honeur of the Novara.-Excursion to the actual Cape of Good Hope.-Departure.-A Life saved.Experiments with Brook's Deep-sea Sounding Apparatus.-Arrival at the Island of St. Paul in the South Indian Occan .

\section{CHAPTER VII.}

THE ISLANDS OF ST. PAUL AND AMSTERDAM, IN THE SOUTH INDIAN OCEAN.

Former History.-Importance of the Situation of St. Paul--Present Inlabitants.-Preliminary Observations.-To whom do the Islands belong? -Fisheries.-Hot springs.-Singular Experiment.-Penguins.-Disembarkation.--Inclement Weather.-Remarks on the Climate of the Island.Cultivation of European Vegetables.-Animal Life-_Library in a Fisherman's Hut.-Narrative of old Viot.-Re-embarkation.-An official Document left behind.-Seme Results obtained during the Stay of the Expedition.-Visit to the Island of Amsterdam.-Whalers.-Search for a Landing-place.-Remarks on the Natural History of the Islands.-A Conflagration.-Comparison of the Two Islands.-A Rencontre at Sea.-Trade-wind. -Christmas at Sea.- " A man overboard!"-Cingalese Canoe.-Arrival at Point de Galle, in Ceylon .

\section{CHAPTER VIII.}

CEYLON.

Neglect of the Island hitherto by the English Government.-Better Prospects for the Future.-The Cingalese, their Language and Customs.-Buddhism and its Ordinances.-Visit to a Buddhist Temple in the Vicinity of Galle. -The sacred Bo-tree.-Other Aborigines of Ceylon.-The Weddahs.Traditions as to their Origin.-Galle as a City and Harbour.-Snakecharmers.-Departure for Colombe.-Cultivation of the Cocoa-nut Palm a benevolent, Buddha-pleasing work.-Pelyandria; or, Community of Husbands-Supposed Origin.-Annual Exportation of Cecoa-nuts.-Restheuses for Travellers. - Curry the national Dish. $-\Lambda$ Misfortune and its Consequences.-The Catholic Mission of St. Sebastian de Makùn, and Father Miliani.-Annoying Delays with restive Horses.-Colombo.-A Stroll through the "Pettah," or Black Town.-Ice Trade of the Americans with Tropical Countries.-Cinnamon Gardens and Cinnamon Cultivation. - Consequences of the Monopoly of Cinnamon.-Rise and Expansion of the Ceffee Culture in Ceylon.-Pearl-fishery.-Latest Examination of the Ceylon Banks of Pearl Oysters, by Dr. Kelaart, and its Results. - Aripe at 
the Serson of Pearl-fishing.-The Divers.-Pearl-lime, a chewing Substance of wealthy Malays.-Aunual Profit of the Pearl-fishery-Origin of the Pearl.-Poctry and Natural Science-Artificial Production of the Pearl.-The Chank-shell.-The Wealth of Ceylon in Preeious Stones.Visit to a Cocoa-nut Oil Manufactory.-The Cowry-shell, a Promoter of the Slave Trade.-Diseorery of valuable Cingalese MSS. on Palm-leares. -The heroic Poem of "Mahawanso," and Turnour's English Translation of it.-Hospitality of English Officials in Colombo.-A second Visit to Father Miliani.-Agreeable Reception.-The Antidote-oil against Bites of Poisonous Snakes.-Adrentures on the Journey back to Galle.-Ascent of Adam's Peak by two Nembers of the Expedition.-The Sacred Footprint. -Deseent.-The "Bullock-bandy," or Native Waggon.-Departure from Galle for Madras.-The Bassos (Shallows). - A Berlin Rope-dancer among the Passengers.-Nyctalopia; or, Night Blindness.-Fire on Board.Arrival in Madras Roads

\section{CHAPTER IX.}

MADRAS

"Catamarans" and "Masuli " Boats.-Difficulty of Disembarkation, and Plans for remedying it.-History.-Brahminism.-Festival in Honour of Vishnù. -Employment of Heathens under a Christian Gorernment.-Politics and Religion.-Laws of Brahminic Faith.-The Observatory.-Museum of Natural History and Zoological Garden.-Academy of Fine Arts.Medical School.-Infirmary.-Orphan Asylum.-Dr. Bell.-Laneastrian Method of Teaching Children first Applied in Madras.-Colonel Maekenzie's Collection of Indian Inscriptions and MSS.-The Palace of the former Nabob of the Coromandel Coast.-Journey by Rail to Vellore. -Fête giren by the Gorernor in Guindy Park.-Visit to the Monolithic Nonuments of Mahamalaipuram.-Excursion to Pulicat Lake.-Madras Club.-Fête in Honour of the Members of the Norara Expedition."Tiffin" and Danee on Board.-Departure from Madras.-Zodiaeal Light. -Shrove Tuesday in the Tropies.-Arrival at the Island of Kar-Nicobar. 


\title{
LIS'T OF ILLUSTRATIONS.
}

\author{
VOL. 1 .
}

1. Departure

PAGF

2. Gun-room of the Novare

3. Geodetical and Astronomical Instruments .

4. Look-out Man . . . . . . . . . . . 11

5. "Palinurus" . . . . . . . . . . . . 16

6. Seamen off duty . . . . . . . . . . . . . . 21

7. View of Gibraltar from Seaward . . . . . . . . . 28

8. Rock of Gibraltar . . . . . . . . . . . . . 29

9. Rock Cavern in Gibraltar . . . . . . . . . . . 30

10. South Gate, Gibraltar . . . . . . . . . . . 34

11. Inhabitant of Frangola . . . . . . . . . . . . . 48

12. Cape Trafalgar . . . . . . . . . . . . . 52

13. Loo Prock (Madeira) . . . . . . . . . . . 57

11. Scene in Madeira . . . . . . . . . . . . . 58

15. Bridge over the Ribeiro Seco . . . . . . . . . . 71

16. Carapuça, or Cap worn by the Natives of Madeira . . . . . . 91

17. Cathedral of Madeira . . . . . . . . . . . . . 95

18. Sleigh party in Madeira . . . . . . . . . . . . . . . . 97

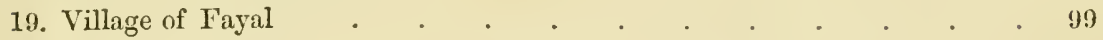

20. "El Homem em pié" . . . . . . . . . . . 101

21. Erica Trees . . . . . . . . . . . . 104

22. Cape Frio . . . . . . . . . . . . . . . 120

23. The Quay at Rio . . . . . . . . . . . . . . 121

24. Island of Paquità, Bay of Rio . . . . . . . . . . 156

25. Cabo Tormentoso . . . . . . . . . . . . . . . . . 195

26. Cape Town . . . . . . . . . . . . . . . . . . . . . . . . . . . . .

27. Rifle Volunteer Fête at Stellenbosch . . . . . . . . 218

28. Paine's Kloef as it was . . . . . . . . . . 220

29. Paine's Kloef as it is . . . . . . . . . . . 221

30. Crossing the Breede Rivier . . . . . . . . . . 220 
31. Hot Springs of Brand Vley . . . . . . . . . 227

32. Hottentot Huts at Genaadendal . . . . . . . . . . . 233

33. Church and Mission Houses of the Moravian Settlement at Genaadendal 237

34. Tomb of a Malay Prophet at Zandvliet . . . . . . . . 245

35. Interior of the Mausoleum . . . . . . . . . . . 247

36. Tsetsé Fly . . . . . . . . . . . . . 252

37. Arrival at St. Paul . . . . . . . . . . . . 266

38. View of St. Paul . . . . . . . . . . . . . . . 267

39. Distant view of Crater-Basin of St. Paul . _ _ . . . . . . . 275

40. Rainy day at St. Paul . . . . . . . . . . . 300

41. Cingalese Canoe . . . . . . . . . . . . 344

42. View of Adam's Peak from Colombo . . . . . . . . . 345

43. Buddha Temple near Galle . . . . . . . . . . 354

44. Interior of a House at Galle . . . . . . . . . . . . 360

45. Masuli Boat at Madras . . . . . . . . . . . . . . . . . 423

46. View of Madras (and Proposed Pier) . . . . . . . . . 424

47. The Holy Mountain . . . . . . . . . . 458

48. The god Ganeza $\quad . \quad$. $\quad . \quad$. . . . . . . . . . 461

49. Bivouac at Mahamalaipuran . . . . . . . . . . . . . . . 464

50. Bas-relief on one of the Monolith Temples _ . . . . . . . 467

51. Entrance to one of the Temples . . . . . . . . 470

52. Arrival at Kar-Nicobar . . . . . . . . . . . 482 



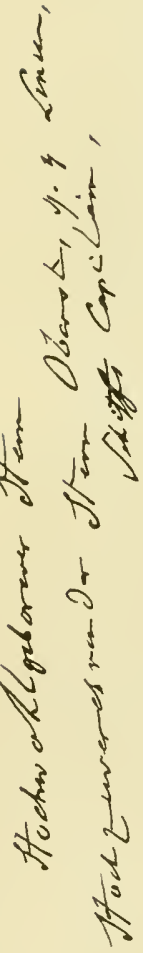

3
3
3
3

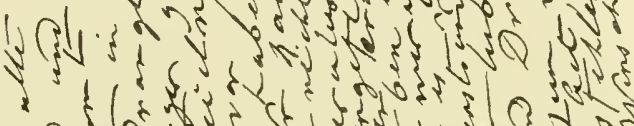

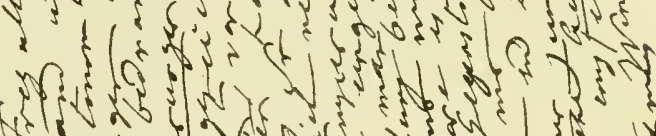

4.j.

if

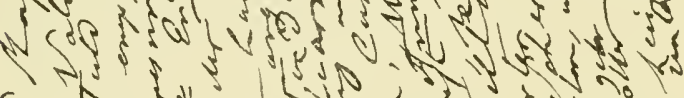

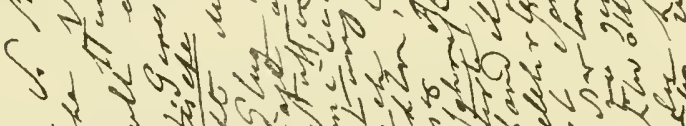

Lny

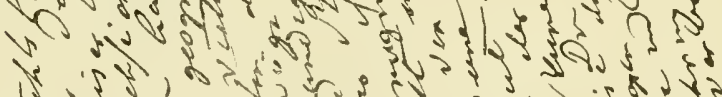

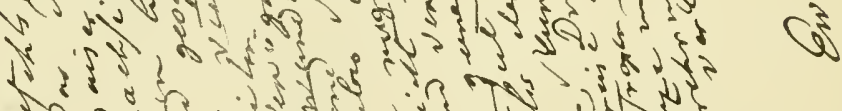

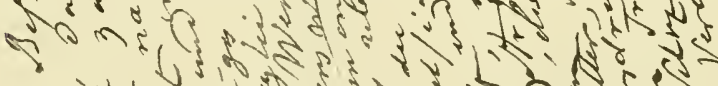

$\sqrt{3}$
3
3

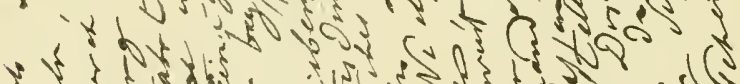

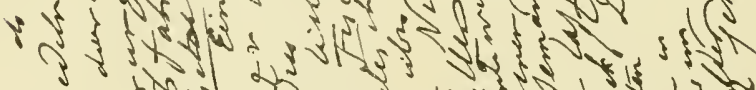

\&.

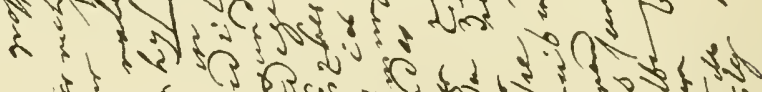

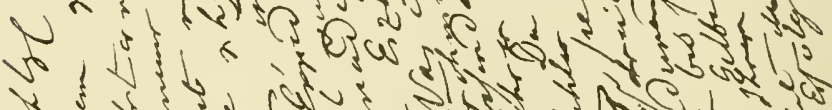

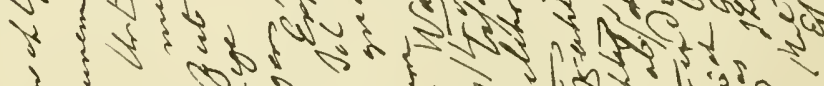

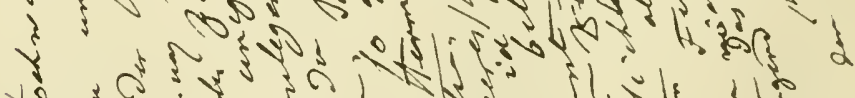

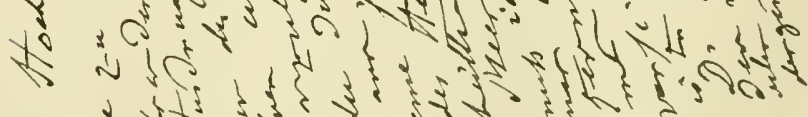

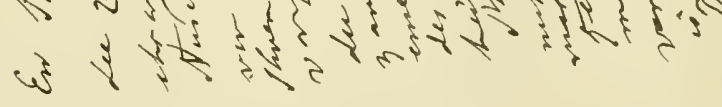




\title{
PHYSICAL AND GEOGNOSTIC SUGGESTIONS,
}

\author{
BT \\ ALEXANDER VON HUMBOLDT.
}

IN compliance with the gracious invitation which H.I.H. the Archduke Ferdinand Maximilian was pleased to address to me from Trieste (December 12th, 1856), and as yet barely recovered from an indisposition, I jot down these hasty notes, without presuming to give definite instructions, such as those I drew up, conjointly with M. Arago, for the guidance of the French expeditions, or for Lord Minto, then First Lord of the Admiralty, on the occasion of the Antarctic Voyage of Discovery of Sir James Ross (1840-43). The following pages consist simply of hints which may possibly prove serviceable to the distinguished and highly informed gentlemen, who have the good fortune to sail on board the Imperial Frigate, Novara, under the command of Commodore von Wüllerstorf. With two of these savans, Dr. Ferdinand Hochstetter and Dr. Karl Scherzer, I have lad the pleasure, here in Berlin, to agree verbally on various subjects. 
xviii Pliysical and Geognostic Suggestions,

As I do not exactly know what course it is intended the Novara shall follow in navigating the Atlantic, nor in what meridian it is proposed to cross the Equator, (in conformity with the sound and useful directions of my friend Lient. Maury, of Washington), on her voyage to Rio de Janeiro, nor how near she shall keep to Cape San Roque and Fernando de Noronha, I must content myself with inviting the attention of the voyagers in a general way to the temperature of the sea, as also to the variations and aberrations of the magnetic curves, and their currents.

A lower degree of temperature is usually observed W. of the Canaries, and Cape Verde Islands, commencing with the Salvages, the thermometer indicating as low as $72^{\circ} \mathbf{7}^{\prime}$ Fahr. This has been already ascertained by Mr. Charles Deville, in his chart of temperature on the voyage "aux Antilles, à Ténériffe et à Fogo." I consider this diminution of temperature results from the North Guinea current, bringing with it cold water from the north southwards as far as the Bight of Biafra and the River Gaboon, at which point it is encountered by an opposite current flowing northwards along the south-western coast of Africa from Loando and Congo.

In 1825, Captain Duperrey had accurately laid down the point of intersection of the magnetic, with the terrestrial equator. In 1837, we learned from Sabine's investigations of magnetic inclination near the Island of St. Thomas (on the Equator, adjoining the above portion of the coast of Africa), 
that this point of intersection had already shifted four degrees to the westward. A period of twenty years having elapsed since Sabine's expedition for determining observations with the pendulum, it would be most desirable that fresh investigations should be made in that neighbourhood, for the purpose of verifying the secular changes of all magnetic curves, especially with regard to their variation. In 1840, the line of no declination in America began $9^{\circ} 30^{\prime}$ E. of South Georgia, whence it ran to the S.E. coast of Brazil, near Cape Frio, thus traversing the mainland of South America only between the latter point and the parallel of $0^{\circ} 36^{\prime} \mathrm{S}$., when it leaves the continent a little to the east of Gran Parà, near Cape Tigioca, cutting the terrestrial equator again, but in $50^{\circ} 6^{\prime} \mathrm{W}$. According to Bache's Map of Equal Magnetic Declination, it reaches the coast of North America near Cape Fear, to the south-west of Cape Lookout. This line, along which the magnetic declination is nil, extends to a point in Lake Erie, $2^{\circ} 40^{\prime} \mathrm{W}$. of 'Toronto, where the declination is already $1^{\circ} 27^{\prime} \mathrm{W}$.*

It is evident from the observations of Captains Bcechey and Findley, and still more particularly from those of the French Captain Kerhallet, that the remarkable subdivision of the main equinoctial current, flowing from east to west into two branches, one directed to the N.W., the other to the S.S.W.,

* Wherever, in this paper, it is not precisely expressed to the contrary, the scale of the Centigrade Thermometer, the longitude from the Meridian of Paris, the French foot ( pied $d u$ roi=12. 79 inches English), and the geographical mile, 15 to a degree of the Equator, measuring 3807 "toises," are meant. 
commences at a considerable distance from the Capes of St. Roque and St. Augustin. This bifurcation has always, and with good reason, been ascribed to the protruding convexity of the South American continent at these two promontories. It would be an important step gained in verifying the theory of currents, could the precise distance be ascertained by chronometer. It is apparently like an "actio in distans," probably a phenomenon of what is known as "packing." As the frigate, on leaving Rio de Janeiro is to make for the Cape of Good Hope, the opportunity will present, should she steer sufficiently southerly, for many interesting observations with respect to the connecting current W.N.W. and E.S.E. which encounters that from Madagascar and Mozambique, close to the Cape, more especially with regard to the temperature of the sea.

If the frigate is intended to approach the small cluster of islands of Fernando de Noronha, E. of Pernambuco (Lat. $3^{\circ}, 50^{\prime} \mathrm{S}$.), I would recommend to that excellent geognostic, Dr. Hochstetter, the hornblendic phonolithe rock found there, far from a volcanic crater, but with trachytic dykes and basaltic amygdaloid. The flat little island of St. Paul (Peñedo de San Pedro), $1^{\circ}$ N. Lat., singular to say, is not volcanic at all, containing, like the Malouin or Falkland Islands, slaty green-stone passing into serpentine.

Should the frigate alter her course and cross the Equator more to the eastward, without touching at Rio de Janeiro, she might possibly fall in with the Marine Volcanic region, 
(Lat. $0^{\circ} 20 \mathrm{~S}$., Long. $22^{\circ} \mathrm{W}$.), which has quite lately become famous again by the U.S. Expedition of the Brig Dolphin (1854), commanded by Lieutenant Lee. On 19th May, 1806, columns of black smoke were seen issuing from the sea by Krusenstern, and volcanic ashes were gathered, after a singular bubbling of the sea from 1748 to 1836, according. to careful investigations by Daussy.

As the frigate is commissioned to visit Ceylon and the Nicobar Islands, she cannot sail direct from the Cape to Australia; and the hope must therefore be abandoned of her visiting the small basaltic islands, known as Prince Edward's ( $47^{\circ} 2^{\prime}$ S. $38^{\circ}$ E.), and Possession ( $46^{\circ} 28^{\prime}$ S., $47^{\circ} 30^{\prime}$ E.), belonging to the Crozet's Group, or the two islands, long confounded with each other, of Amsterdam (Lat. $37^{\circ} 48^{\prime}$ S.) and St. Paul (Lat. $38^{\circ} 38^{\prime}$ S.) The latter island, the more southerly of the two, (a very characteristic drawing of which was given by Willem de Vlaming so far back as 1696), is supposed to be volcanic, not only by its form, which will at once remind the geologist of Santorin, Barren Island, and Deception Island, (one of the New Shetland group), but also in consequence of the cruption of steam, and the flames occasionally observed there.

As for Amsterdam, which consists of a single denselywooded mountain, the puzzle remains for solution as to how, during the expedition of D'Entrecasteaux in 1799, the whole island seemed, during two entire days, enveloped in smoke ; whereas, on landing there, the naturalists of that expe- 
$\mathrm{xxii}$ Physical and Geognostic Suggestions,

dition were satisfied that the mountain was not an active volcano, and that the columns of steam issued out of the ground near the shore! As yet, the phenomenon remains entirely unexplained.

If we examine any map of the Indian Ocean, we may trace the continuation of the Sunda group from Sumatra, N.W., through the Nicobar, and Great and Little Andaman Islands, and thence through the volcanoes of Barren Island, Narcondam and Cheduba, nearly parallel with the coasts of Malacca and Tenasserirn, all on the eastern part of the Bay of Bengal. The minor volcanoes just enumerated will present valuable opportunities of geological enquiry.

Along the coasts of Orissa and Coromandel, the western portion of the Bay of Bengal is quite free of islands, Ceylon, like Madagascar presenting rather the type of a continent.

Off the W. coast of the peninsula of India, (that is opposite the Neilgherrie hills, and the coast of Canara and Malabar), there is a series of three archipelagoes, extending from $14^{\circ} \mathrm{N}$. to $8^{\circ}$ S., viz., the Laccadives, the Maldives, and the Chagos, which appears, as it were, continued through the banks of Sahia di Malha, and Cargados Carajos, to the volcanic group of the Mascarenhas and Madagascar. As the first-named archipelagoes, so far as is yet known, consist solely of coral, and are, consequently, true "atolls," or reef-lagoons, the bottom of the ocean should be examined over a large extent, adopting the ingenious hypothesis of Darwin, that it is to be considered as an area of subsidence, rather than an elevated region. 
It would also be a matter of great importance to get observations respecting terrestrial magnetism, particularly so as to define the position of a given segment of the magnetic equator. Capt. Elliott, as the result of his comprehensive studies, (1846-49), ascertained that the magnetic equator passes through the north end of Borneo, and thence nearly due W. to the northern extremity of Ceylon. In this region the curve of minimum intensity is nearly parallel to the magnetic equator, which intersects the Continent of Africa near Cape Guardafui-according to Rochet d'Héricourt, in lat. $10^{\circ} \mathbf{7}^{\prime} \mathrm{N}$., long. $38^{\circ} 5^{\prime}$. E. Between this point and the Bight of Biafia nothing is known.

The Sonth Asiatic islands comprise Formosa, the Philippines, the Sunda group, and the Moluccas. The great and little Sunda Islands and the Moluccas embrace 109 volcanoes, with fiery eruptions, and 10 what are called mud-volcanoes. This is not a mere estimate, but is the result of an enumeration by Junghuhn, who, within the last year (1856), has returned to Java, and thoronghly equipped by M. Pahud, Governor-General of the Indian Netherlands, will be of great assistance to the Imperial Expedition.

An exact mineralogical determination of the volcanic rocks (trachytes) is unfortunately wanting everywhere.

The most active volcano of Sumatra is the Gunung Merapi (8980 feet), which must not be confounded with a volcano in Java, of the same name. That of Sumatra was ascended by Dr. L. Horner, and Dr. Korthals in 1834. We may 
$\mathrm{xxiv}$ Physical and Geognostic Suggestions,

pronounce Indrapura (11,500 feet, but this measurement is very uncertain), and Gunung Pasoman (9010 feet), the Ophir of our maps, to be utterly unknown geologically. The highest of the Java volcanoes is Gunung Semeru (11,480 feet), ascended by Junghuhn in 1844,1220 feet higher than the Etna. The largest craters of the 45 which are disposed in a line along the shores of Java, are Gunung Tengger, and Gunung Raou. Dr. Junghuhn has recently given the outlines of each separate volcano in his splendid topographical and geological map of Java, in four sheets, published in 1856, which does great credit to the Dutch Government.

The following subjects are worthy of special attention while the frigate is at Java.

1. The curious phenomenon of the ribbed surface. (Vide Junghuhn, Java, Part II., p. 608.)

2. The disposition, as yet unaccounted for, of a series of regularly-shaped hills, formed by the mud-streams ejected in the year 1822 by the volcano of Gunung Galungung. (Vide ut suprà, pp. 127-731.)

3. The ejection of water by the Gunung Idjen, on 21st January, 1817. (pp. 707, and 717-121).

4. The erroneousness of the assertion that the volcanoes of the Island of Java do not emit streams of real lava.

It must be admitted that the mighty Javanese volcano, Gunung Merapi, already alluded to, has not, within the historic period, presented any coherent compact streams of lava, but mere fragments and boulders; although in 1837, 
lines of fire were seen running uninterruptedly from the top down the sides of the cones in eruption. But each of the three volcanoes, Tengger, Idjen, and Slamat, present examples of black lava currents, descending as far as the tertiary strata.

Streams of stone-boulders, red-hot, similar to those of the Cotopaxi, but scarcely touching each other, flowed from Gunung Lamorgan on 6th July, 1838.

No active volcano is known in the island of Borneo. The highest mountain of the whole island, perhaps of the whole insular world of Southern Asia, is the Hina Bailu (12,850 feet?) on the northern point of Borneo. It is as yet unexplored. According to Dr. Lewis Horner, son of the astronomer of the Krusenstern expedition, there occur among the syenite and serpentine mountain range of Rathus, on the S.E. of the island, deposits yielding gold (which has even been worked by diggings), diamonds, platinum, iridium, and osmium,-presenting; in fact, a similar association to those of the Ural mountains. No mention is made of palladium. Rajah (now Sir James) Brooke describes in the province of Sarawak in Borneo, a low hill, Gunung Api ("hill of fire" in Malay), the slags of which attest former volcanic activity. A visit to Borneo would be of very great service.

There are eleven volcanoes in Celebes, and six in Flores, all active.

It is still uncertain whether the conical mountain Wawari, 
xxvi

Plysical and Geognostic Suggéstions,

or Atiti, which is more generally known as the volcano of the island of Amboyna, ever poured out anything except hot mud (1674), or whether it should be merely classed as a solfatara. The main group of the South Asiatic Islands is connected through the Moluccas and the Philippines with the Papua and Pellew islands, and the Caroline Archipelago of the South Sea.

The most important geological fact to be remarked with reference to the island of Formosa, abounding in mineral coals, is the break in the line of direction of the open vents, when, instead of N.E. to S.W., the central line follows the meridian line, which it pursues nearly as far as $6^{\circ} \mathrm{S}$., passing through Formosa and the Philippine Islands (Luzon and Mindanao), respecting which deviation nothing certain is known, and in which region every mountain of conical shape, or outline is invariably set down as a volcano, even though there should be no indications of a crater. The Sooloo Archipelago forms the connecting link between the islands of Borneo and Mindanao, the long, narrow island of Palawan, constituting that between Borneo and Mindoro.

The Island of Yesso, separated from that of Niphon by the Straits of Saugar, or Tsugar, and from the islands of Krafto (Saghalien) and Tschoka, or Tarakai, by the Straits of La Pérouse, connects, through its North Eastern Cape, with the archipelago of the Kuriles. From Broughton's Southern Vulcan Bay up to its northernmost point, Yesso is traversed by an uninterrupted range of volcanoes-a fact the more worthy 
of being recorded, as in the expedition of La Pérouse there were found red porous lavas, as well as wide areas, covered with slags, in the Baie des Castries, in the narrow island of Krafto (Saghalien), which is, as it were, merely a continuation of Yesso. In our own day these regions command a higher interest, from a political point of view, more especially since Russia, dissatisfied with the situation of Okhotsk, at the sanded mouth of the Amoor, was anxious, after the destruction of Petropaulowski, on the coast of Kamtschatka, to obtain, on the S. E. coast, a harbour suitable for a military station.

Among the three islands which form the main portion of the Japanese Empire, six volcanoes are known to have had eruptions in the historic period. The volcano, Fusi Jama, in Niphon, province of Suruga (Lat. $35^{\circ} 18^{\prime} \mathrm{N}$., Long: $136^{\circ} 15^{\prime}$ E., altitude 11,675 feet), is said to have risen out of the plain 286 years before the Christian era. Its last eruption was in 1707. The volcano, Asama Tama, in the district of Saka, between the meridians of the two capitals, Miaco and Jeddo, was last in eruption in 1783. On the island of Kiusiu, adjoining the peninsula of Corea, four volcanoes are situated, from one of which, called Wanzen, there was a most destructive eruption in 1793.

The beautiful work of Commodore Perry, U.S.N., detailing his mission to Japan, on the part of the United States Government, in 1852, containing excellent photographs of races, as also drawings by the Berlin artist, Wilhelm Heine, 
does not, as yet, comprise the scientific results of that expedition.

Proceeding northwards, the volcanoes are more densely crowded, and are found arranged in series. Of the fiftyfour which I enumerated as still in activity among the islands of Eastern Asia, there are thirty-four on the Aleutian, and ten on the Kurile Islands. The Peninsula of Kamtschatka contains nine volcanoes, which have been in activity within the historic period. Lying under the 54th and 60th degrees of northern latitude, we see a long strip of seabottom between two continents undergoing a perpetual process of destruction and re-arrangement.

The South Sea, the superficial extent of which is onesixth greater than that of the entire solid crust of our planet, actually presents a smaller number of active volcanoes, less vents for communication between the centre of the earth and its atmospheric envelope, than the single Island of Java! Out of 40 volcanic cones, including. those which are extinct, only 26 have been seen in eruption during the historic period. They are not scattered at random, but, on the contrary, as was pointed out by Mr. James Dana, the ingenious geologist of the great United States Exploring Expedition, under the command of Capt. Wilkes (1838-42), they have been thrown up, at widely extending clefts, communicating by submarine mountain systems. They are arranged in groups and distinct regions, analagous to the mountain chains of Central Asia and 
Armenia (in the district of the Cancasus), and belong to two quite distinct systems, one running S.E. to N.W., the other S.S.W. to N.N.E.

In the Hawaiian Archipelago (or Sandwich Island group), we find Mauna Loa, according to Wilkes, 12,900 feet in height, which does not present any cone of volcanic scoriæ (resembling, in this particular, the volcanoes of the Eifel), but has emitted streams of lava. The lava basin of Killauea, 13,000 feet in its greatest, by 4800 in its smallest diameter, is not a solfatara, but a true lateral vent on the flank of the powerful Mauna Loa itself, exactly resembling the less elevated sheet of water of Arak. Mauna Kea is 180 feet higher than Mauna Loa, but is extinct. Tafoa and Amangura, in the Tonga group, are still in eruption, the last discharge of lava having occurred in July, 1847. The volcano of Tanna was in full eruption during Capt. Cook's Voyage of Discovery in 1774, as was also the volcano of Ambrym, west of Malicollo in the archipelago of the New Hebrides. At the south point of New Caledonia, lies Matthew's Rock, a small smoking rocky island. The volcano of Santa Cruz, N.N.W. of 'Tina Kora, with periodical eruptions occasionally occurring at intervals of 10 minutes, had been already noticed as a volcano by Mendana, so far back as 1595. In the Salomon Archipelago, there is found the volcano of Sesarga, while others are said to be in full activity in the Marianas or Ladrones, just like those of Guguan, Pagon, and El Volcan Grande de 
Asuncion, which appear to have broken forth along a line that follows the meridian. In New Britannia, three conical mountains were observed romiting streams of lava, by 'Tasman, Carteret, and Labillardière. There are two volcanoes in full activity on the nortli-east const of New Guinea, opposite Admiralty Islands, which themselves are so rich in obsidian. In New Zealand, numerous regions abound in basaltic and trachytic rocks. Of active volcanoes there are Puhia-i-Wakati (the volcano of White Island), and the lofty cone of Tongariro (5816 feet). To the absence of centres of volcanic agency in New Caledonia, where sedimentary formations and seams of coal have recently been discovered, is ascribed the vast development of coral reefs. Dana was the first to ascend the Peak of Tafua, in the Island of Upoln, one of the Samoa group, not to be confounded with the still active volcano of 'Tafoa, south of Amangura, in the Tonga Archipelago. Dana found in it a crater overgrown with thick forest. So, too, on the isolated Vaihn of the Easter Island group, there is found a range of conical mountains with craters, but inactive.

Of the volcanic groups of the South Sea, the most violent is the farthest east, adjoining the shores of the New World, viz., the archipelago of the Gallipagos, which consists of five considerable islands, very admirably described by Darwin. There are streams of lava down to the very shore of the sea, but no pumice. Some of the trachytic lavas are said to abound with crystals of albite. It is important toexamine 
whether or not this is oligoclase, as on Teneriffe, Popocatepetl, and Chimborazo; or labradorite, as on Etna and Stromboli. Palagonite, exactly similar to that of Iceland or in Italy, was discovered by Bunsen in the specimens of tufa from Chatham Island, one of the Gallipagos.

New Holland does not show any signs of recent volcanic activity, except at its most southern point (Australia Felix), at the foot of the Grampian Mountains. N.W. from Port Philip, as also towards the Murray River, there are numbers of volcanic cones and schists of lava.

It would be of great interest and utility to observe the relative inclinations of the Magnetic and the Geographical Equators, by means of the dip of the magnetic needle, thongh this will be rendered more difficult, from the fact of the ship's course being easterly, that is, contrary, to the Equinoctial current. As regards the low temperature of the current, which I discovered in 1802, running up from $40^{\circ} \mathrm{S}$. to the Gallipagos along the coast of South America, and then turning westward, it would be highly important to investigate whether in the eastern part of the South Sea in $7^{\circ} \mathrm{N}$. and between $117^{\circ}$ and $140^{\circ} \mathrm{W}$, there really exists in every season a counter current from west to east. But I need not enlarge upon this topic to such attentive navigators.

The line of no inclination was crossed six times by Duperrey between 1822 and 1825. When I first discovered, near Truxillo, the low temperature of the cold Peruvian current, 
it was $12^{\circ} \cdot 8$ Réaumur $\left(60^{\circ} \cdot 8\right.$ Fahr.). The temperature observed in the course of twenty years by Mr. Dirckinck von Holmfeld, in the neighbourhood of Callao, expressed in degrees of Réaumur, were as follows :-

\begin{tabular}{|c|c|c|c|c|c|c|c|}
\hline September 1802 & & & & . $12^{\circ} \cdot 8$ & (Fahr. & $\left.60^{\circ} \cdot 8\right) 7$ & \\
\hline Norember ,, & & - & & - $12^{\circ} 4$ & $(n$ & $\left.\left.59^{\circ} .9\right)\right\}$ & $13^{\circ} \cdot 3$ Réaumur. \\
\hline December, end of & & . & & . $16^{\circ} \cdot 8$ & $(,$, & $\left.69^{\circ} \cdot 8\right) \mathrm{J}$ & \\
\hline January 1825 . & • & . & - & $12^{0} \cdot 7$ & $(n$ & $\left.60^{\circ} \cdot 57\right)$ & \\
\hline February," . & - & - & - & $15^{\circ} \cdot 3$ & $($, & $\left.66^{\circ} \cdot 42\right)$ & \\
\hline March ," & • & - & - & $15^{0} \cdot 7$ & $($, & $\left.67^{\circ} \cdot 32\right)$ & \\
\hline April & & & . & $14^{0.5}$ & $(, n$ & $\left.64^{\circ} \cdot 62\right)$ & \\
\hline
\end{tabular}

The temperature of the sea I found to be $22^{\circ}$ Réaumur ( $81^{\circ} 5$ Fah.) north of Cape Blanco, when on my way from Callao de Lima, at which point the cold current diverged towards the Gallipagos.

Between the Gulfs of Guayaquil and Panama, north-east of the cold current, the temperature of the sea during the month of April rose as high as $24^{\circ} 5^{\prime}$, (87 $12^{\prime}$ Fahr.). Within the range of the current, $\mathrm{Mr}$. Dirckinck had carried on his observations in compliance with my instructions, by means of thermometers that had been compared by Alago. Everywhere in the current, in December 1824, he found from $16^{\circ}$ to $18^{\circ}\left(68^{\circ}\right.$ to $72^{\circ} .5$ Fahr.); between Quilca and Callao, in January, 1825 , from $18^{\circ}$ to $19^{\circ}\left(72^{\circ} 5^{\prime}\right.$ to $74^{\circ} 75^{\prime}$ Fahr.); between Chorillos, near Lima (Lat. $12^{\circ} 39^{\prime}$ S.) and Valparaiso, in August, 1825, from $13^{\circ} \mathrm{S}^{\prime}$ to $10^{\circ} 5^{\prime}\left(63^{\circ} .05\right.$ to $5^{\circ} 62^{\prime}$ Fahr.); between Chorillos and San Carlos de Chiloe, in June, 1825 , fiom $18^{\circ} 8^{\prime}$ to $9^{\circ} 2^{\prime}\left(74^{\circ} 3^{\prime}\right.$ to $\left.52^{\circ} 7^{\prime}\right)$. 
In sailing from the Sandwich Islands to the west coast of America, the Imperial Expedition will have to choose between the Ports of San Francisco or Acapulco. The first choice would be of great mineralogical advantage for those regions of the United States, lying North of the river Gila.* Parallel with the chain of the Rocky Mountains, which, according to Marcou, contains up to the present day several volcanoes in full activity in its northern part (Lat. $46^{\circ} 12^{\prime} \mathrm{N}$.), run single, and at certain points double ranges of coast chains from San Diego to Monterey, from $32^{\circ} 15^{\prime} \mathrm{N}$. to $46^{\circ} 45 \mathrm{~N}$. They begin with the coast range specially so-called, which is a continuation of the high ridge of the Peninsula of Lower or Old California ; after which, farther to the North, there follow in succession, first the Sierra Nevada di Alta California, between $36^{\circ}$ and $38^{\circ} \mathrm{N}$. the lofty Shasty mountains, and the Cascade Range, nearly twenty six miles distant from the littoral, inclnding many high and active volcanoes, and extending far beyond Fuca Straits. The following are still in eruption:-Mount St. Elias (46 $2^{\circ}$ N.); Mount Regnier, or Rainier, (46 $46^{\circ}$ ); and Mount Baker, $\left(48^{\circ} 48^{\prime}\right.$.) These three active cones would be most conveniently visited by the geologist of the expedition from San Francisco, as would likewise the whole Cascade Range. We have as yet no certain intelligence as to the geology of the entire longitudinal auriferous valley of the

* The Gila falls into the Colorado about forty miles above the embouchure of the latter into the head of the Gulf of California. 
xxxiv Physical and Geognostic Suggestions,

Sacramento River, (where a trachytic crater, in a state of disintegration, is known as the Butt of Sacramento). Does the auriferous quartz occur in veins, and are these still in situ, or are they broken up? What description of rock is traversed by these veins? Does the wash-gold here contain occasionally, as in the Ural Mountains, fragments of vein-stones with isolated cavities, in which are found impressions of leaves and membranes, clearly proving that they have not been rolled, or transported by water, any great distance to the spot they now occupy? Have these been found, alongside of gold, diamonds, platinum, osmium, iridium, or mercury?

Should the frigate steer for Acapulco, it may be assumed that there exists an intention to cross the Continent to Mexico and Vera Cruz, from the volcano of Colima (1877 toises) as it were, along the parallel of the range of volcanoes, and greatest heights rising in detached groups between the two seas, about the parallel of $19^{\circ} \mathrm{N}$. New astronomical observations are greatly needed for determining the position of the volcanoes of Colima and Jorullo (667 toises). The volcano of Colima, with its twin peaks de fuego and de nieve, should be carefully examined, as also the volcano of Jorullo, with the fragments of granite enclosed in its lava; the Nevado de Toluca (2372 toises), Popocatepetl (2772 toises), Itztaccihuatl (2456 toises), Cofre de Perote (2098 toises), and the volcano of Tuxtla $\left(18^{\circ} 28^{\prime} \mathrm{N}\right.$.), on the eastern slope of the Sierra St. Martin, from which a column of flame shot up with great violence on 2nd March, 1793, a fair specimen of 
what the Spaniards term Malpays, the Sicilians Sciarra viva. The face of the country is covered over with boulders of lava, at Sim Nicolas de los Ranchos, at the foot of Popocatepetl, adjoining the city of Puebla de los Angeles, after which, on the road from Puebla to Vera Cruz, will be observed two narrow strips of boulders of cooled basaltic lava, rich in olivine. Similar examples will be found at Parage de Carros, near Tochtilacuaja and Loma de Tablas, between Cancas and the Casas de la Hoja. The mere ascension of volcanic cones is geologically of far less importance, than the bringing away numerous specimens, carefully selected, of various trachytic rocks, which, by their oryctognostical composition, are characteristic of each volcano. I would nevertheless recommend that the Pico del Fraile of the Toluca volcano (2372 toises) should be ascended, proper caution being used. From this very sharp peak, I brought away thin plates of trachyte perforated by lightning, and internally of a matted texture, resembling those brought from Little Ararat. Both for the miner and geologist, an interesting and useful visit might be paid to the rich mines of Guanaxuato and the Mines de la Biscaina and Regla, on the road from Mexico to Real del Monte, so as to observe the close connection subsisting between the richer silver ores, occurring in trachytic porphyry without quartz, but with felspar, (glassy felspar?), and the thoroughly volcanic Cerro del Gacal, abounding in obsidian, and the Cerro de las Navajas (Razor Range), which remind one of the environs of 
Schemnitz, with the sole exception, that the trachytes "porphyres meulières" of Bendant, are wanting here.

As it is highly desirable that considerable time should be devoted to the volcanoes of Quito, Peru, and Chili, it appears uncertain whether the course of the frigate, on leaving Acalpulco, will be shaped direct for Guayaquil, thus reversing the route taken by mysclf, or whether she will not touch at some of the central American ports-Realejo or Sonsonate. The crowded series of volcanocs in Central America, of which no less than eighteen, conical or dome-shaped, may be considered as still in active eruption, would yield a rich harvest of facts of all kinds in elucidation of the theory of volcanic action, such as have never hitherto been sufficiently taken advantage of. We are still in need of the mineralogical determination of the rocks, while the form and situation of the mountain masses have been well described by Squier, Oersted, and other modern travellers. The greater number, indeed, of the eruptions of scoriae and slag were unaccompanied by streams of lava, as, for example, those of Mount Isalco, abounding in ammonia. But recently eyewitnesses have furnished us with quite different accounts regarding these eruptions, in the case of several rolcanoes -as the Nindiri (a twin volcano with that called Massaya), on which Dr. Scherzer has lately shed much light; the Volcano el Nuevo, crroneously called Volcano de las Pilas, that of Coseguina, situated on the Great Bay of Fonseca, and that of San Miguel de Rosotlan, from which 
there flowed an extensive stream of lava in July 1844. It would be most tempting to pass by land from Mexico southwards to Oaxaca, and thence to the Isthmus of Guasacualco or Tehuantepec, and Chiapas, so as to rejoin the frigate at Realejo or Sonsonate. Facts might be obtained, in such a journey, of great value in determining the dependence of geological phenomena on each other; but it is to be feared it would be attended with too much fatigue and loss of time. For similar reasons, it cannot be proposed that the scientific gentlemen attached to the Expedition, should leave the frigate for three or four months, when they reach Central America, in order to cross by rail the Isthmus of Panama, with the object of examining the Volcancitos of Turbaco and Gabra Zamba, both active, and thence ascend the Rio Magdalena from Carthagena de las Indias, as far as Honda, whence they could proceed by Bogotà and Popayan to Quiló.

It will be also unavoidable to forego the examination of the sedimentary rocks, rich in fossils, between Honda, Bogotà and Ibagues, the Mastodon fields (Campos del Gigante), and the Salto de Tegumidama on the platean of Bogotà, the wax palm (Ceroxylon Andicola), and the Azufirales of the Posto de Quindici, the volcanoes of Tolima, measured by myself and ascended by Boussingault, and of Paramo de Ruiz ( $4^{\circ} 15^{\prime}$ N.), as also the two volcanoes of Popayan, the Puracé and the much more interesting but now extinct Sotará. As a middle course, I may suggest a disembarkation, not exactly at Guayaquil, but on the gold 
xxxviii Pliysical and Geognostic Suggestions,

and platinum coast of the Choco, near San Buenaventura, so as to proceed thence to Popayan, and afterwards return to the volcanoes of the province of Pasto, which are highly important, and so on to Quitó, by way of Guachucal, Tulcan, and Villa de Ibarra, rejoining the frigate only at Guayaquil.

I believe, however, it would be more advisable to select Quitó as the starting-point, whence to examine the important elevated volcanic region De los Pastos (between $2^{\circ} 20^{\prime}$ and $0^{\circ} 56^{\prime} \mathrm{N}$.), containing the volcano of the town of Pasto, the volcanoes of Tuguerres, Chiles and Cumbal, and the Azufral de Pasto, and not to land at any port of the Choco coast, not even from the Bahia de Cupica, which for half a century I have recommended in vain on account of its vicinity to the Rio Naipi, one of the tributaries of the Atrato. In drawing up a list of names of the volcanoes of the renowned lofty plateau of Quitó, I may include, Imbaburu, Cotocachi, Rucu, Pichincha, Antisana, the much-disputed question of the stony walls like streams of lava, on the east slope of Tana Volcan, and Reventazon de Ausango; Cotopaxi, with its strange inexplicable quarries of pumice, of Guapecho and Zumbalica, in the neighbourhood of Llactacunga and San Felipe, the pumice containing oligoclase, not glassy felspar, deposited in strata, unlike any rock in situ for a considerable distance on all sides of Cotopaxi; Tunguragua (mica slate), studded with garnets, and beds of granite, which dip under the former, and have themselves been pierced by the trachytes of Tungurahua at Rio Pullo and the Hacienda de Ganace; 
the hills of Moya, near the village of Pelilco, cast up in the celebrated earthquake of 7 th February, 179\%, and still in a state of activity; the Chimborazo, which M. Jules Rémy, accompanied by an Englishman named Princkley, was in the belief they had ascended, on the 3rd of November, 1856, to the very summit, "mais sans s'en douter." Poggendorff, (Vol. X. p. 480), has clearly demonstrated that the boiling point given by Rémy for the summit, would not give 6544 mètres (little different from my own trigonometrical admeasurement of 6530 mètres), but fully 7328 mètres. As I distrust my own half-barometical measurements, I have vainly implored travellers, these fifty years past, to have a new series of trigonometrical observations made of the summit of Chimborazo. The merit, then, of settling this moot point, it also remains for the members of the Novara Expedition to obtain.

It would be important to examine the Sangay $(16,068$ feet)-which, like Stromboli, is in constant activity, yet without any traces of lava-streams-on account of the veins of quartz discovered by Weise in the trachytic boulders ejected by the volcano, which is of such rare occurrence in the trachytes of Hungary; and also on account of the close vicinity of beds of granite and gneiss, which are broken through by the Sangay trachyte, forming an island, as it were, of not hardly two miles in breadth. Still more deserving of attention is the extinct volcano El Altar de los Collanes (Capac Ur'cù) a sketch of 
which I presented in the atlas published in my "Kleine Schriften" (Plate V.p. 461), formerly higher than Chimborazo, and still (?) 16,380 feet. Not a single specimen of its trachyte has ever been deposited in a European museum. The Altar itself is readily accessible from Riobamba Nuevo. In its vicinity may also be seen mica slate and gneiss, cropping out at the Paramo del Hatillo near Guamote, and Teocaxas, which are so seldom fallen in with in the highlands of Quitó. Tradition relates that gold-mines were worked here during the days of the Incas, in the neighbourhood of volcanic trachytes. From the Altar the geologist might proceed, by way of San Luis, (Query, whether the primitive clay-slate found here be of the Silurian formation?) and Guamote, to Paramo del Assuay (2428 toises), and Cuenca, as far as Atausca $\left(2^{\circ} 13^{\prime} \mathrm{S}\right.$.), where an immense mass of sulphur, lying in a quartz seam is worked, forming a bed in the mica slate. Of what rock does the easily accessible Cayambe Urcù $(18,170$ feet) consist, crossing the Equator, S.E. of Otavalo? En route from Quitó to Cayambe, the rich deposits of obsidian near Quinche should also be inspected, which furnished the large mirrors to the Incas, and farther to the north of which are the volcanoes of Los Pastos, which form a separate system by themselves.

For examining the rocks and exploring the volcanoes of Southern Peru and Bolivia-respecting which see the last edition of Pentland's Maps, not those published between 1830 and 1848, in which the height of Sorata was indicated at 
3949 toises $(25,257$ feet), and Illimani at 3753 toises $(24,004)$, and accordingly both as much more lofty than Chimborazo, which is 3350 toises (21,426 feet)-the best starting-point would be the port of Arica, which may be reached, sailing the whole distance against the cold current, from Guayaquil, after a short stay at Callao de Lima. Of the volcanoes of Peru and Bolivia only three are now active.

(a.) The volcano of Arequipa, three miles N.E. of the town of the same name, which, according to Pentland and Rivero, is situated about $\mathbf{7 3 6 6}$ feet above the level of the sea. The measurements of M. Dolley, of the French navy, which were published under my superintendence, give the summit of the volcano as 10,348 feet above the town of Arequipa, so that. its total elevation above the sea would be 17,714 feet. In the table of heights for Mrs. Somerville's "Physical Geography," Mr. Pentland speaks of the summit as being 20,320 English feet in height, or 19,065 Paris feet, closely approximating to the old trigonometrical measurement (19,080 feet) given by Thaddeus Haenke, a Bohemian, who accompanied the expedition of Malaspina, in 1769. What a deplorable state for the science of hypsometry to be in! which the Novara ought to put an end to. Samuel Anzon, a North American, in 1811, and Dr. Weddell, in 1847, have ascended the volcano of Arequipa.

(b.) Sahama ( $18^{\circ} 7^{\prime} \mathrm{S}$. ), according to Pentland's new map of 1848, is 871 feet higher than Chimborazo (which he gives as 20,970 feet), and is still active. The true heights of Illimani 
xlii

Physical and Geognostic Suggestions,

and Sorata, ascertained since 1848, are, instead of 3949 and 3753 respectively, only 3329 toises (21,266 English feet), and 3307 toises (21,145 English feet).

(c.) Volcano Gualatieri, in the Bolivian province of Carangas ( $18^{\circ} 15^{\prime} \mathrm{S}$.), height 20,604 feet.

The southern group of South American volcanoes, that, of Chili, presents the largest number of active fire-mountains -only second, indeed, to that of Central America, there being from eleven to thirteen. In order to increase the geological exploration of this region which has been so well prepared by the memorable expedition under Captain Fitzroy, in the ships Adventure and Beagle, the excellent generalizing theories of $\mathrm{Mr}$. Darwin, and the naval astronomical expedition of Mr. Gilliss, for 1849-51, the Novara will probably land at Valparaiso. A great desideratum between Coquimbo and Valparaiso is an exact measurement of-

$A$. The volcano of Aconcagua ( $32^{\circ} 39$ S.). Its height has been stated, in 1835, by Captain Fitzroy, as 21,767 feet, Pentland's correction assigning 22,431 feet; while Captain Kellet, of the frigate Herald, gives it as 21,584 feet. Miers and Darwin are both of opinion that the Aconcagua is still in activity, which is denied by Pentland and Gilliss. The most recent measurement of Aconcagua-that by Pissis in 1854 (see Gilliss, Vol. I. p. 63)-makes the height 20,924 feet. M. Pissis has published, in the "Anales de la Universidad de Chili," for 1852, the geodetical elements of his survey, which is based upon eight triangles. Aconcagua being probably 
the highest mountain in the New World, a new measurement is eminently desirable. Neither Dhawalagiri, with his 4930 toises, nor Kintsinjunga, measured by Colonel Waugh, with his 4.406 toises, are any longer considered the highest mountains in the Himalaya range, but the Deodunga (Mount Everest), which is 29,003 English feet, equal to 27,212 Paris feet, or 4535 toises.

B. The volcano Maipu (34 $14^{\circ}$ S., height 16,572 feet), ascended by Meyen. The trachytic rock on the summit has broken through the Jurassic strata, in which Leopold von Buch has ascertained, from heights of 9000 feet, the existence of Exogira contoni, Trigonia costata, and Ammonites biplex. This volcano has no streams of lava, but only eruptions of volcanic slags. It would be most desirable that Dr. Hochstetter should examine this remarkable protrusion of dislocated strata.

C. The volcano Antuco ( $37^{\circ} \mathbf{~}^{\prime}$ S.), the geology of which was described by Pöppig, is a lofty basaltic crater, having a trachytic cone rising up in its centre to an elevation of 8672 feet. It was observed in full activity by Domeyko in 1845 . Gilliss gives an account of an eruption in 1853. According. to Domeyko, a fresh-burning cone was thrown up on the 25th of November, 184\%, which remained in activity for a whole year. Molina considers the Nevada Descabezado (35 $1^{\prime}$ $\mathrm{S}$.), ascended by Domeyko, to be the highest mountain in Chili ; but its height is estimated by Gilliss at only 12,300 feet. The most southerly volcanoes are the still active Corcovado 
xliv Physical and Geognostic Suggestions,

(4. $13^{\circ}$ S.), 7016 feet; Yanteles or Yntales ( $43^{\circ} 29^{\prime}$ S.), 7534 feet; and the Volcan de San Clemente, opposite the granite formation on the peninsula of Tres Montes. Still further south, in $51^{\circ} 41^{\prime} \mathrm{S}$., another, the Volcan de los Gigantes, is laid down on the old maps of South America, by La Cruz, as opposite the archipelago of La Madre de Dios.

Should the Novara return to Europe through the Straits of Maghellanes, it would be very desirable the members of the Expedition should visit the locality from which Prince Paul of Würtemberg, after long zoological travels through North America, has, within the last year, bronght back to Germany a very large collection of specimens.

Altogether, I calculate the number of active volcanoes on the surface of the earth to be upwards of 225-one-third of which, or 75, are upon the various continents, and the remainder upon the insular world. The Western Continent has 53 active volcanoes-of which, North-Western America, north of the river Gila, has 5; Mexico, 4; Central America, 18: South America about 26. Viewing the globe as a whole, there presents itself an extensive oblique region in which rolcanoes most abound, stretching from S.E. to N.W. in the more westerly part of the Pacific, between $75^{\circ} \mathrm{W}$. and $125^{\circ} \mathrm{E}$. of Paris, and between $47^{\circ} \mathrm{S}$. and $66^{\circ} \mathrm{N}$. In this region, the fused elements of the interior of our earth may be said to be most permanently in communication with the atmosphere.

The greatest attention should be paid, with the view of 
improving them, to the sections and maps of Chili, contained in the work, "Buenos Ayres and the Provinces of Rio de la Plata," published in 1852 by Sir Woodbine Parish, and still more so, to that entitled "Map of the Republic of Chili, compiled from the Surveys of Gilliss, Pissis, Allen, Campbell, and Clande Gay, between $23^{\circ}$ and $44^{\circ} \mathrm{S}$., as contained in Gilliss' 'United States Astronomical Expedition, 1847-52 Washington, 1855." "

The chief object to be aimed at by the Novara, with respect to scientific enquiry, seems to me to be the formation of a collection in the Geological Institute of Vienna, in comparison to which all the collections which at present aspire to be considered rich in volcanic specimens, (such as those of Berlin, Paris and London), should appear to be insignificant. In all periods of history, travellers are only the representatives of the state of knowledge of their own time, and consequently, collections always present the readiest means of promulgating new discoveries by oryctognostical examination or chemical analysis. In order to set on foot a grand Volcanic Museum, it would be necessary to bring home from every one of the volcanoes visited, not less than 10 or 12 , but still better 15 or 18 , specimens of the porphyritic trachytes, all carefully selected, well-shaped, containing crystals not disintegrated, and of sufficient size to admit of a fresh fracture being made. For such quantities, however, there cannot be provided on board ship, even with the kindest patronage of the commanding officer, sufficient space for 
the accumulations of two years' arduous efforts in forming a collection. The greatest part, therefore, should be sent by other conveyance to Trieste, the most secure channel being through the consuls of the Austrian Empire, or those of allied powers, or through the medium of British, Dutch or American mercantile establishments, or by the regular packets.

Duplicates, say four or five specimens, from each volcano, should be taken on board the Novara in boxes of about 3 feet long. It would be too disheartening to have any misgivings of the success of this glorious scheme for getting together a Museum of Volcanic Rocks in Viemna, of all the regions of the globe, arranged upon a regular geographical system, each labelled with its own name, so as to promote a general acquaintance with these branches of knowledge.

1. Europe.

2. Atlantic Islands.

3. Continent of Asia, South Coast of Arabia (Aden), Kamtschatka.

4. Islands of Eastern Asia and India.

5. The Indian Ocean.

6. The Pacific.

7. Continent of South America: Chili, Peru, Bolivia Quitó and New Grenada.

8. Central America.

9. Mexico, south of the river Gila.

10. North-Western America, north of the river Gila.

11. West Indies. 
Much of this work might be done on board the Novara. As to Nos. 3 and 4, Kamtschatka, the Kurile and Aleutian Islands, the Red Sea, and the West Indies, it will not be difficult to procure specimens at some future period.

Our piping times of peace are favourable to the execution of this project, which should be zealously kept in view throughont the Expedition. Travelling as I was, during: the great wars, I did not dare shrink from the difficulty of having to carry along with me 44 large boxes, as I did on the road through Mexico from Acapulco to Vera Cruz, whence they were sent to Cuba, Philadelphia, and so to Bordeaux. The mechanical labour of having the collections carefully packed, keeping duplicates distinct, and sending away geological, botanical, zoological and ethnographical collections, is itself quite as important as the purely scientific work.

The exhibition of comprehensive volcanic collections brings to light the strong analogy subsisting between the trachytes belonging to volcanoes, far distant from one another, while it indicates the existence of great differences in the mineralogical composition of volcanoes situated very near each other. My most excellent friend and fellowtraveller in Siberia, Professor Gustavus Rose, recently subjected the trachytes of the Berlin Museum, the greater number of which were collected by myself, to careful crystallographical and chemical investigation. He found oligoclase and pyroxene on the trachytes of Chimborazo, Popocatepetl, 
Colima, Tunguragua, Puracé, Paramo de Ruiz, and the Peak of Teneriffe, which has recently been accurately examined by Mr. Charles Deville. The trachytes of Toluca, Orizaba, Gunung Barang, and Burung Agung; on the Island of Java, Argæus, in Asia Minor, Cuneguilla, south of Sta. Fé de Nuevo-Mexico, the Sièrra de San Francisco, west of the Rocky Mountains and Pueblo Zuni, consist of hornblende, oligoclase, and brown mica. The trachytes of Stromboli and Etna, those of the Siebengebirge (Drachenfels), and of Kara Hissar in Phrygia, consist of large crystals of glassy felspar, with numerous smaller crystals of oligoclase, some hornblende and mica. Oligoclase, having been mistaken for albite, led to the fantastic idea of a peculiar rock, the Andesite, prevailing in the Andes, and even led our great master, Leopold von Buch, to make some curious distinctions, (Déscription des Iles Canaries, 1836, pp. 186-87.)

To ascertain the average height above the level of the sea, I propose that furrows should be cut in the rocks of the different regions along with inscriptions, which might carry information to unborn ages, as has been done, on my suggestion, now some 25 years ago, by the Academy of Science at St. Petersburg, on the Caspian Sea, while Sir James Ross, in his "Voyage of Discovery in the Southern and Antarctic - Regions," 1839-43, Vol. II. p. 23, regrets not having done so, or, at least, of having only once adopted this plan.

I would also, with all deference, suggest observations regarding the daily atmospheric variations or tides, so as to 
obtain tables of maxima and minima. In order to obtain these, whenever the frigate is at anchor near any coast, but particularly within the tropics, hourly observations with the barometer and thermometer (the latter affixed to the barometer, and also freely suspended in the open air), should be made through several consecutive days and nights. During the occurrence of an Aurora Borealis (or Australis), attention should be paid to the perturbations of the magnetic variation, and the magnetic intensity of the horizontal needle. Boreal Auroras have been seen in the southern latitudes of the Peruvian Pacific, as low down as $12^{\circ} 13^{\prime} \mathrm{S}$. ; but the occurrence of such phenomena there is of much less frequent occurrence than that of Austral Auroras in Scotland. It is important to keep an exact register of the intensity of blackness in the "coalbags," when the smallest stars surrounding them are still visible to the naked eye. The daily meteorological observations, as also those on the temperature of the sea, will probably be made on board ship, in conformity with the views of Lieutenant Maury, and the method agreed upon at the last nautical congress.

As I shall have long ceased to be numbered with the living, when the Novara returns to Trieste, richly freighted with scientific treasures of all kinds, with fresh information relating to organic and inorganic nature, to the races of man, their habits and languages, I now pray to Almighty God that His blessing may rest upon this great and noble enter- 
Physical and Geognostic Suggestions, \&e.

prise, to the honour of our common German Fatherland! And concluding, in this night, these crooked, illegible lines, I remember, not without emotion, and with very mingled feelings, that joyous period of my life when, fifty-eight years ago, in the beautiful gardens of Schönbrunn, preparing myself for a long journey, I was enjoying with grateful mind the friendly kindness of the venerable Jacquin and Peter Frank.

\section{A. v. HUMBOLDT.}

Berlin, in the night of 7 th April, $185 \%$. 


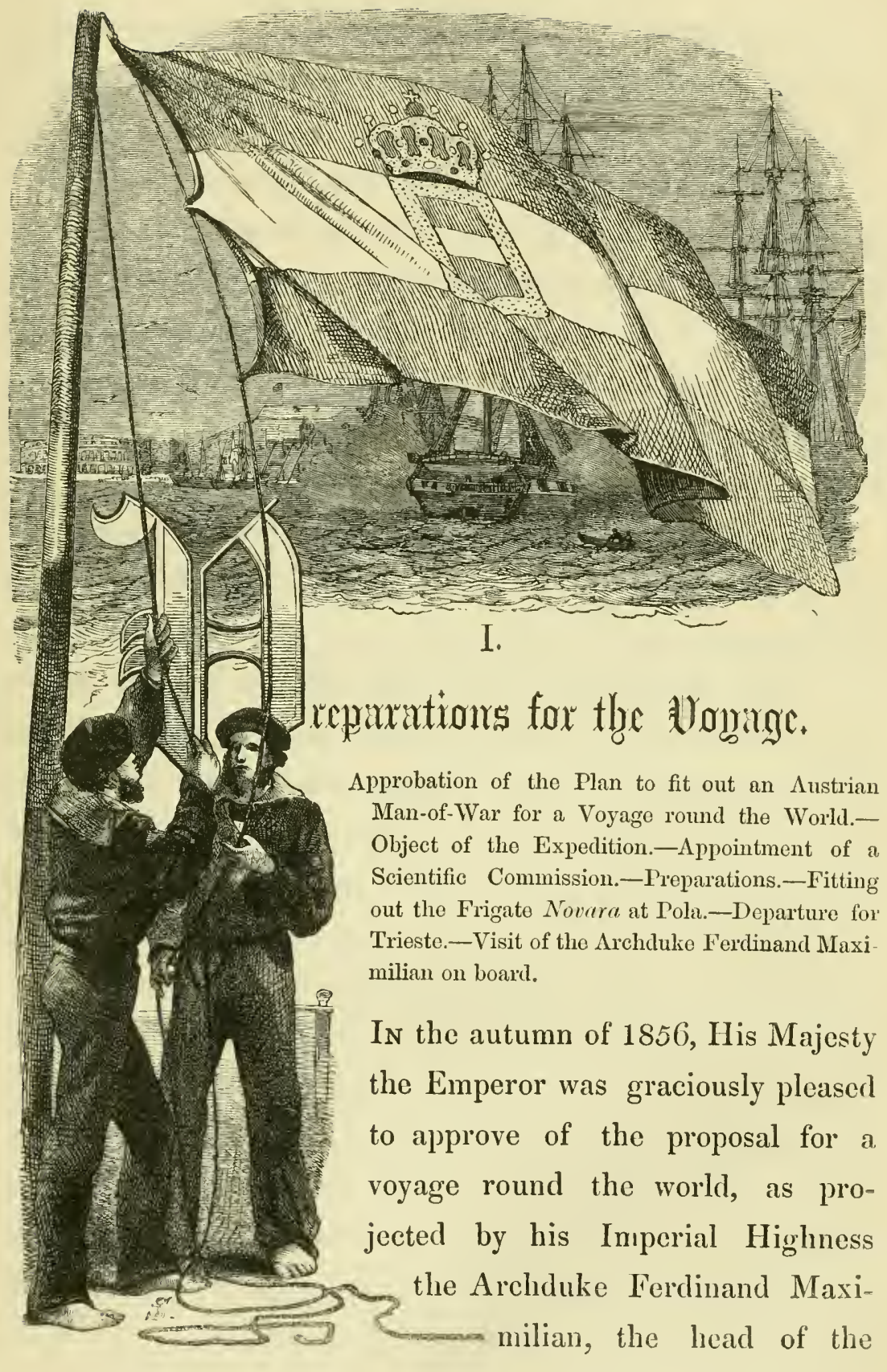


Austrian navy, and to commission the sailing frigate Novara for that purpose, a vessel qualified to meet every requisite condition.

The chief object of the Expedition-a circumstance which must not be lost sight of - was to afford the officers and cadets of the ship an opportunity of acquiring that practical acquaintance with naval affairs which, added to the theoretical knowledge previously attained, would render them thoroughly familiar with nautical routine, and thus materially contribute to the further development of the Austrian navy.

This branch of the public service, placed since 1848 on an entirely new basis, has with difficulty worked its way through all those embarrassing circumstances inseparable from the organization of a new system; but the honest zeal and energy of the board appointed, supported by favour from the highest quarters, have succeeded in introducing many improvements, and in increasing by degrees the numerical strength of the men, thereby laying a secure foundation for the rising naval force, the importance of which, at this moment, every reflecting patriot will acknowledge.

The intended Expedition offered, besides the advantages for the service, another not less important for the State, namely, the recognition of the Austrian flag in remote quarters of the globe, to which it had never hitherto penetrated; and by thus opening new channels for the outlet of our natural products and manufactured goods, to promote the industrial, commereial, and maritime interests of the empire. 
In order to satisfy the scientific requirements of the age, the illustrious head of the navy issued orders, that the officers on board should in every way assist in the researehes to be made, connected with navigation and geography; and was, morcover, pleased to invite the Imperial Academy of Sciences to nominate two members, he himself naming a third, to accompany the Expedition for the purpose of observing and investigating phenomena pertaining to the different branches of physieal science, as well as collecting rare specimens and interesting objects of natural history. To this commission were ultimately attached a botanist, a practical zoologist, an artist, and a flower-gardener.

The Academy had, for the guidance of these gentlemen, drawn up instructions which, with a multitude of other papers containing useful hints and interesting queries, received from the Imp. Geographical, Geological, and Medical Societies, as well as from numerous foreign and native scientific men, formed a most valuable collection of materials for the purposes of the Expedition.*

Foremost amongst these savans stood Alexander von Hum. boldt, that illustrious nan, who up to the last moment of his existence was alive with youthful enthusiasm for every scientific enterprise. In England great interest in the success of the Expedition was evinced by Sir Roderic Murchison, Sir W.

* Of these instructions, "The physical and geoguostical remarks," with which the Nestor of natural science homomred the voyagers of the Novara, being of a more general interest, are published at the end of this volume, together with the facsimile of an autograph lettor of Baron von Humboldt to the commander of tho Expedition. 
Hooker, Sir Charles Lyell, General Sabine, Admiral Smyth, Admiral Fitzroy, Professor Robert Owen, Professor Philips, Professor Bell, Professor W. A. Ramsay, Professor Goodsir, of Edinburgh, W. J. Hamilton, Esq., Charles Darwin, Esq., L. Horner, Esq., James Yates, Esq., B. Davis, Esq., \&e., \&e. From the United States of North America, we received most valuable communications from Commander M. F. Maury, National Observatory, Washington, D.C.-Captain Rodgers, and others.

Letters of introduction were received from Germany, and particularly from England, to influential parties and soeieties in a variety of places abroad, amongst which were many warm and friendly recommendations from the English Government and Admiralty, as well as the Directors of the then East India Company, to various administrative authorities in the British Colonies.

The frigate Novara was laid up in the arsenal of Pola, where all requisite steps were taken to complete her outfit, and

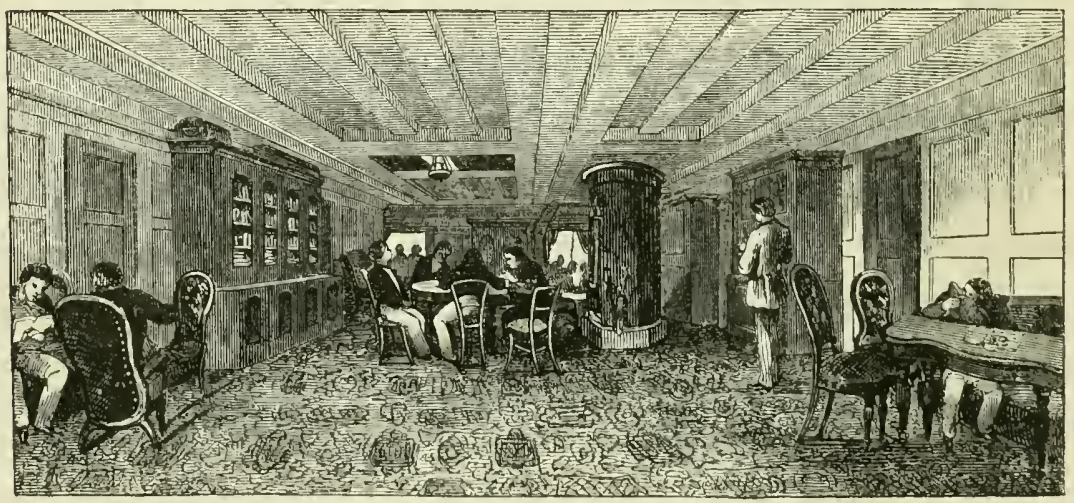


prepare her thoroughly for the voyage. The ventilation of the lower deck was improved, and the number of cabins increased in proportion to the number of individuals for whom accommodation was to be provided.

The gun-room was, by command of the Archduke, converted into a reading-room, and provided with a well-selected library as well as with all the charts and maps necessary for the information of the officers, who here made their calculations and executed their drawings.

The store-rooms for the sails and tackle were enlarged, so as to hold a double quantity.

A distilling apparatus, the same as patented by M. Rocher, of Nantes, was fixed on the gun-deck, and being placed in connection with the ship's coppers, it was found that, during the few hours each day that the latter were used for cooking, enough sea-water was distilled to supply the entire ship's company with excellent water to drink. This distilled water, after having been kept in iron tanks for a month, was found pleasant to the taste, and agreed very well with the health. The excellent health enjoyed by all the crew throughout the voyage must, in a great measure, be ascribed to the circumstance, that scarcely any other but this distilled sea-water was used, so that the men were enabled entirely to forego drinking river or spring-water, which in the tropics are frequently found injurious.

The use of such an apparatus permits a great diminution in the store of water usually carried by a vessel. The space 
gained by this diminished bulk of water, enabled us to take on board a larger eargo of coal and provisions, such as preserved beef and compressed vegetables. The sailors were not, however, particularly fond of the preserved beef, because in cooking it loses a great part of its flavour (though the broth is strong and good); nor does it seem as an article of diet to have had a particularly heneficial influence on the health, for the sanitary condition of the crew was equally satisfactory, and the number of scorbutic patients not materially increased when, towards the end of the voyage, the fresh stores were exhausted, and only salt and pickled rations were issued.

Compressed dried vegetables were of great benefit to the health of our men, and cannot be sufficiently recommended. The so-called mélange d'équipage of Chollet, as well as sauer kraut, potatoes, and other vegetables, have an excellent taste, improve the soups when mixed with them, and are easily preserved, provided they be protected from the effect of damp. Hence it might be advisable to keep them enclosed in wellsoldered tin boxes. The price of these vegetables is so moderate, that it is surprising they are not more generally employed.

The long-continued satisfactory state of health of the crew must also partly be sought for in the constant use of showerbaths. For this purpose, apertures, three-quarters of an inch in diameter, were bored in the planks of both the deck and forecastle, under which a perforated disc could be screwed, and 


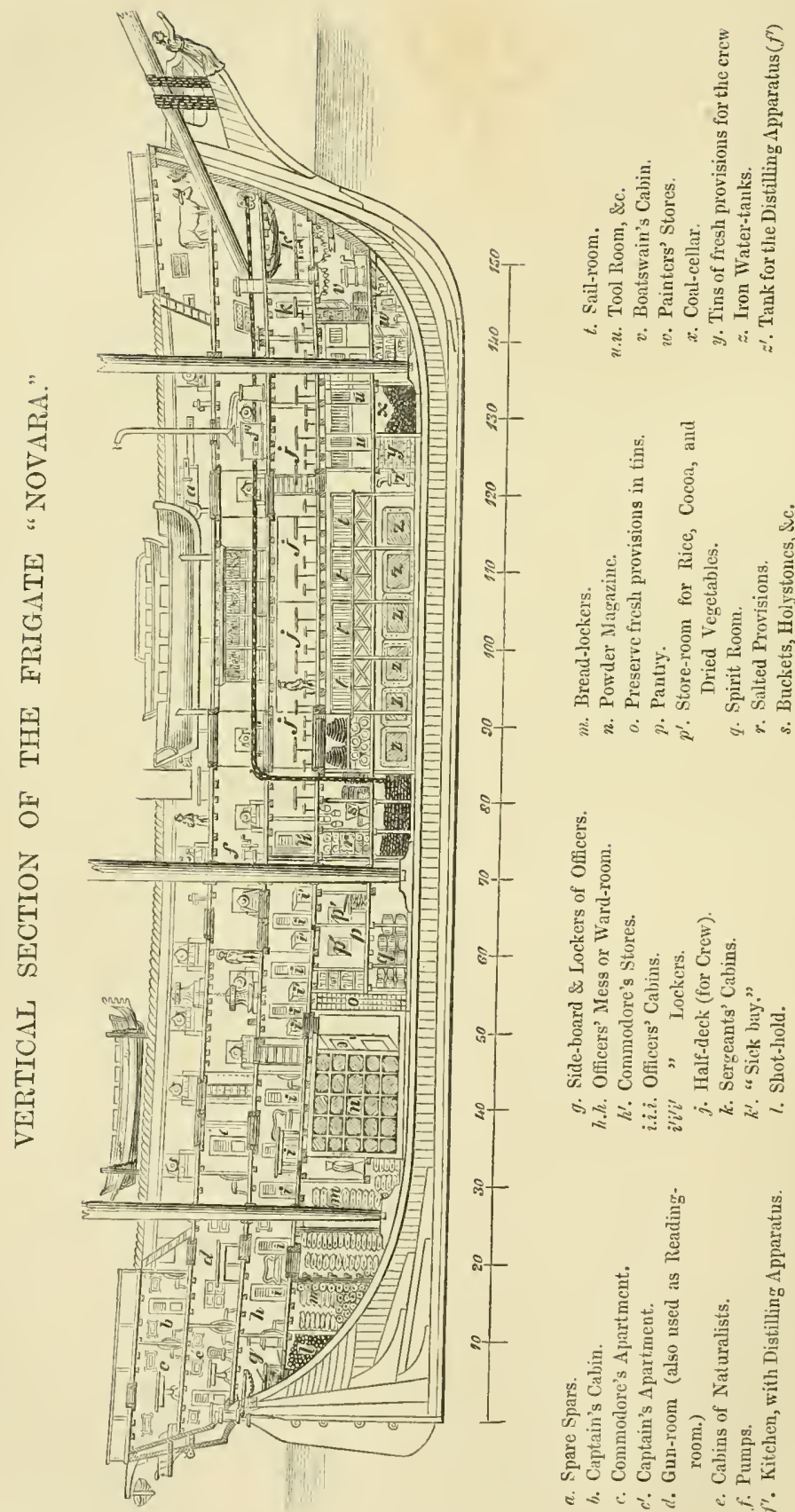

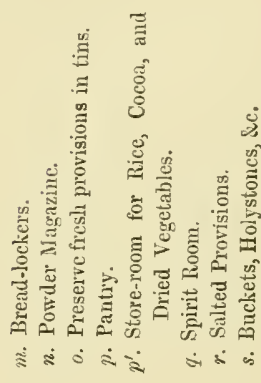
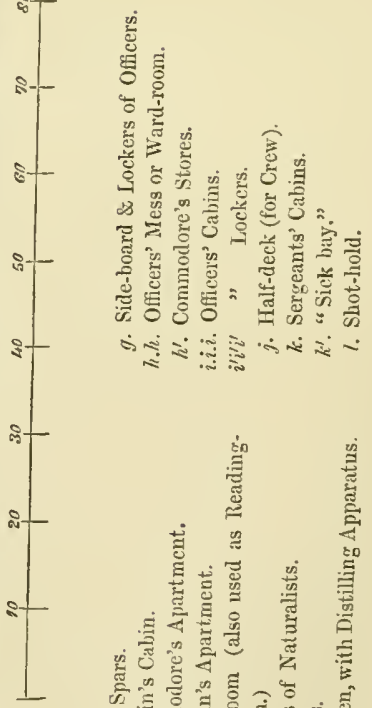

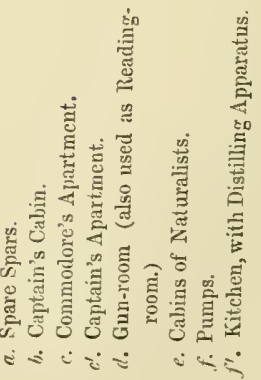


above which a pail of water was placed. By these simple means every one was cnabled to enjoy the luxury of a bath; when, howerer, the desire for that refieshment became general, so that the arrangement above-mentioned was insufficient, a hand fire-engine was made use of, so as to accommodate as many at once as might present themselves - a process which found great favour with the jolly tars, as affording abundant opportunities for fun and merriment.

The frigate Novara had been placed on the stocks in the arsenal of Venice in the month of February, 1845, and was launched in April, 1850. She was pielced for 42 guns, but during the vojage carried only thirty 30-pounders, * and four of smaller calibre.

The principal dimensions of the frigate (Vienna measurement) are :-

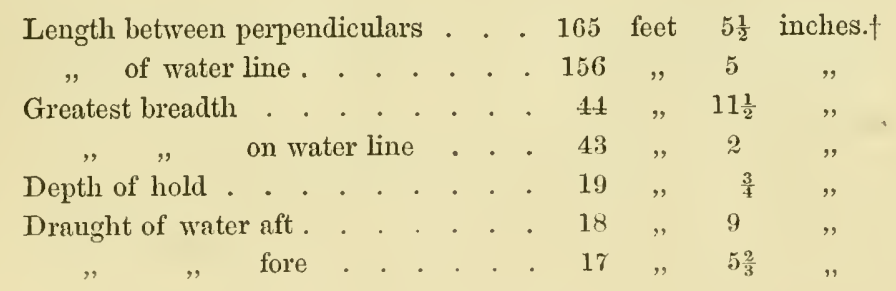

The superficial area of the ship, or the load-water line, amounted to 5685.35 square feet; quantity of water displaced 2107 Austrian, or 2630 English tons. The superficial area of the principal sails amounted to 18,291 square feet.

* The 30-poumder marine guns answer very nearly to the English 32-pounders. 
The frigate proved herself to be an excellent sailer, as, of the various vessels which, throughout the voyage, sailed in company with us, only three clippers outstripped her

The question may here be asked, why, in the present state of navigation, a sailing-vessel was preferred to a steamer for this voyage? The principal consideration which decided this selection was the greater disposable area which a sailingvessel offers in comparison with a steamer of the same dimensions, in which coal and machinery occupy so large a space. On the present occasion, it will be perceived that what was specially wanted was room for as great a number of officers, cadets, and men as possible, who were, as has been stated, to make this voyage for improvement in nautical affairs. Plenty of space was also required for the numerous instruments and bulky collections of objects of natural history; while in most parts of the ocean which we were to traverse, the winds blow so regularly, that, with very rare exceptions, sails form the best motive power. 'The expense of fuel requisite for a steamer, and the trouble of replacing it during the voyage, are thus saved; whilst, finally, the space occupied by the men employed in the management of the machinery, and that required for the stowage of special stores, would be withdrawn from more important objects.

After the frigate had been properly fitted up in the arsenal of Pola, she sailed on the 15th March, 1857, for Trieste, where she cast anchor on the 17th in the Bay of Muggia. H.I.M.'s corvette Caroline, likewise fitted out at Pola for a voyage 
to the coast of South America and Western Africa, followed in her wake, and it was now seen that the frigate was a better sailer than the corvette, a eireumstance so much the more satisfactory, that the latter had hitherto been considered the swiftest ship in our navy.

The unfavourable state of the weather interfered so much with the works which were to be finished at Trieste, that the embarkation of provisions, swinging the compasses, \&c., \&c., could only be proceeded with very slowly.

At last, the members of the Commission arrived, and the vessel only waited for sailing orders.

Before leaving on so interesting an enterprise, with which the most pleasing recollections of our lives will ever be associated, we had the gratification of being honoured by a visit on board from the Archduke Ferdinand Maximilian. The commander of the Expedition introduced the officers and scientific gentlemen to his Imperial Highness, who addressed them in affecting terms, and concluded his remarks by expressing a hope that the frigate Novara would, with God's help, return happily from her mission to her own honour and that of the country.

The narrative of the voyage is now presented, and, probably, the results of the various scientifie investigations will very shortly be offered to a discerning public, leaving it to them to judge how far we have succeeded in realizing the hopes of the illustrious Prince. But if we have not satisfied all the expectations entertained, it certainly was not from insuf- 
ficiency of means; for everything was complete in that respect, and we owe it chiefly to the circumspection and.kind care of the Commander-in-chief of our navy, that this enterprise had been so wisely planned, and its details brought in so short a time to such a degree of perfection that, during the whole voyage, it was not found necessary to make the slightest alteration in the original arrangements and regulations.

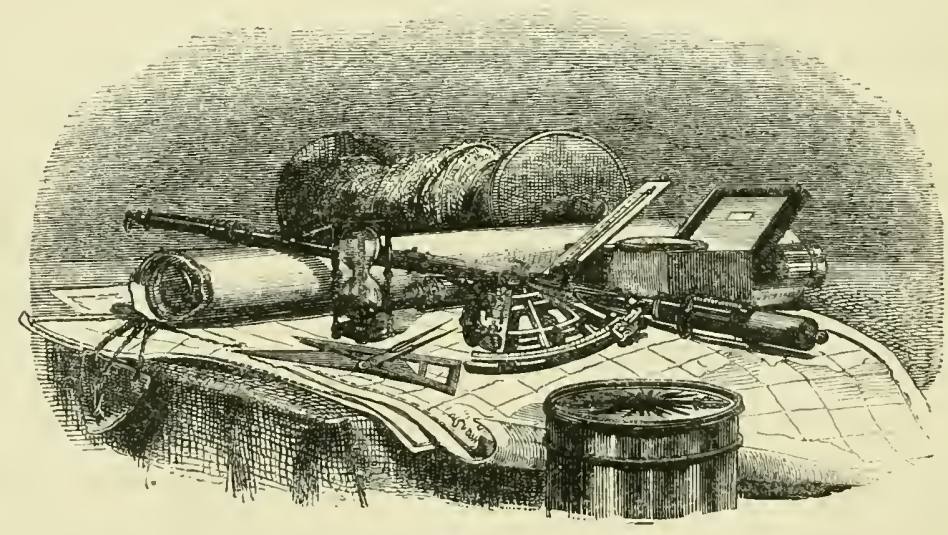



FROM TRIEST TO MADEIRA.

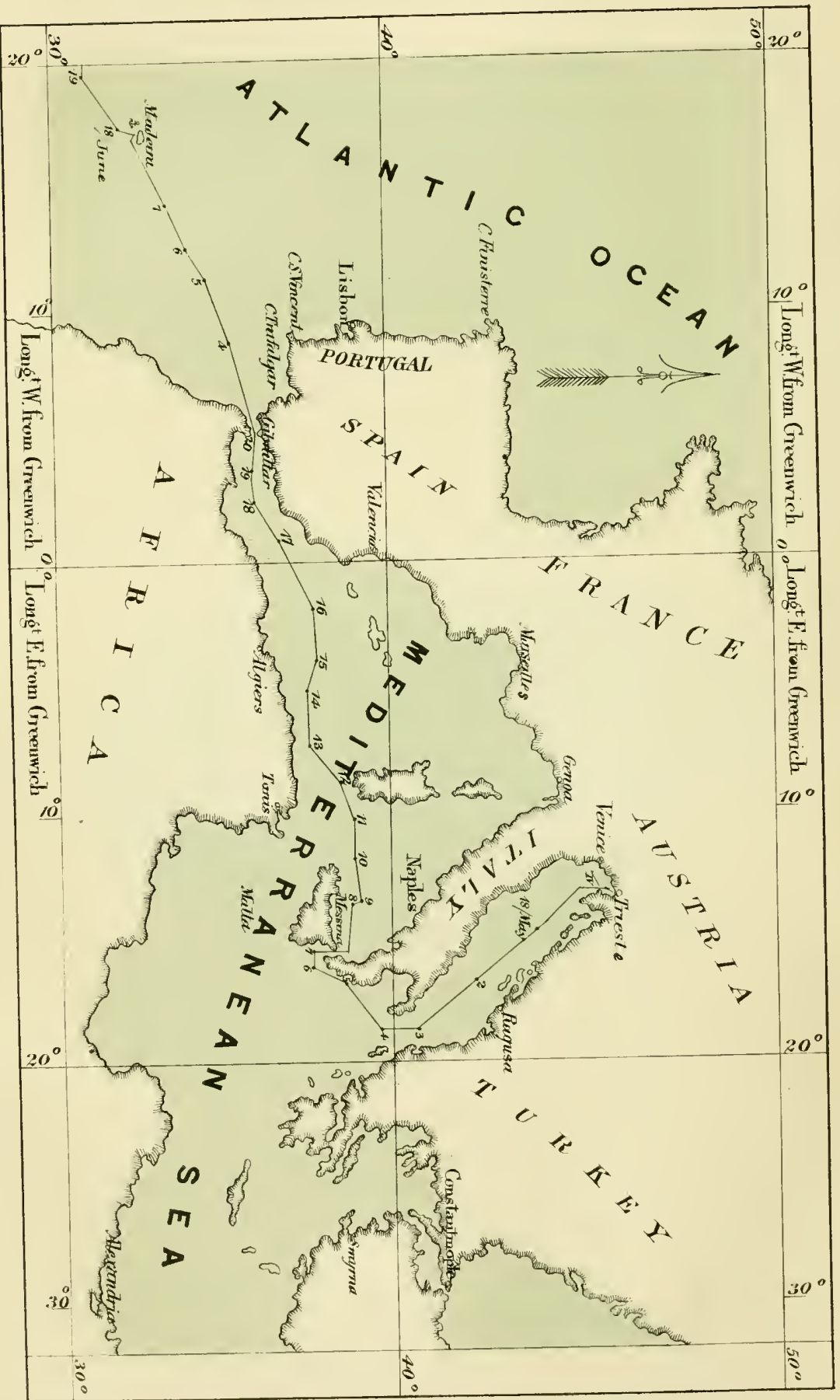




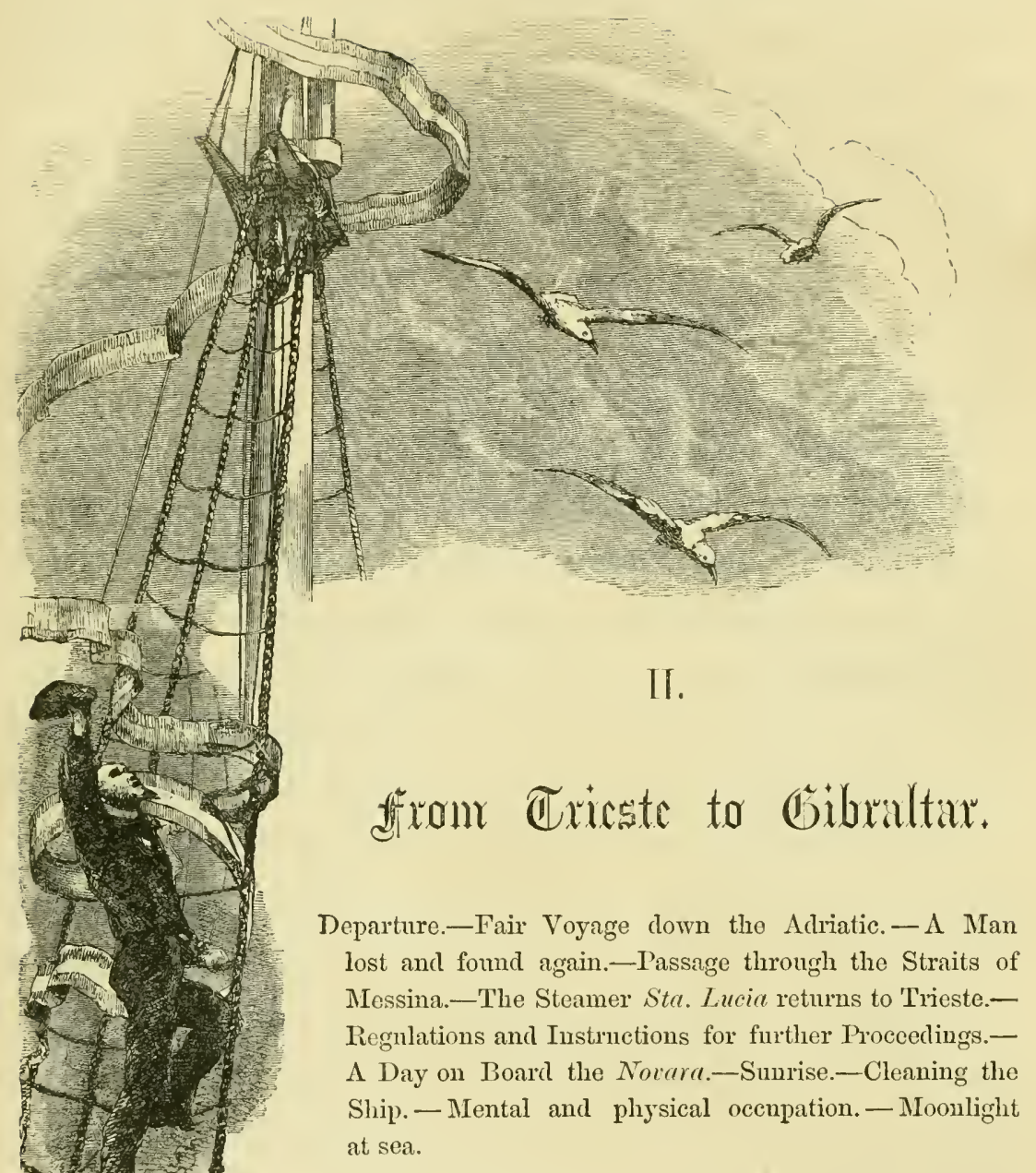

Departure.-Fair Voyage down the Adriatic.-A Man lost and found again.-Passage throngh the Straits of Messina.-The Steamer Sta. Lucia returns to TriesteRegnlations and Instructions for further Proceedings.A Day on Board the Nocara.-Sumrise-Cleaning the Ship. - Mental and physical occupation. - Moonlight at sea.

The departure of the frigate was fixed for the 30th April, 1857, and H.I.M.'s corvette Caroline, Captain Kohen, was ordered to accompany her as far as the coast of South America. H.I.M.'s steamer, Sta. Lucia, Captain von Littrow, received orders to tow both ships as far as the extre- 
mity of the Straits of Messina to avoid loss of time, such as frequently arises in the Adriatic during the spring, from calms and unfavourable winds.

With the dawn of the day fixed for the departure of the ships, all was bustle on board; craft of all kinds hovered around, and relatives and friends had assembled in great numbers to take leave. The verdant and thickly-wooded slopes of the promenade to St. Andrea, near the shore, were thronged with spectators, and the fair and lovely picture of our native coast developed itself once more before our eyes, clad in all its charms of spring, as if to wish us a hearty farewell, an auspicious voyage, and a happy return!

At 8 o'clock A.Mr. we weighed anchor, and the steamer Sta. Lucia approached the Novara for the purpose of towing her from the Bay of Muggia into the roads of Trieste. She had all her colours displayed, and saluted the city of Trieste, Austria's chief and most important emporium, with 21 guns. The salute was answered from the castle, whilst the band on board struck up Haydn's beautiful hymn: "God preserve the Emperor!" The frigate moved out of the road-stead, accompanied by a great number of boats, and followed by the best wishes of the numerous crowds assembled on shore, and of all true patriots, who looked upon this Expedition as a cheering evidence that a new and energetic spirit of enterprise had arisen in their native country.

The corvette Caroline, which was waiting outside the roads, was attached to the frigrate, and soon Trieste appeared like 
a dim cloud on the distant horizon. The outlines of the Carinthian Alps became fainter, and the excitement of the parting scene was calmed by that busy activity required from every one embarking on a long voyage, if he desires to attain any degree of comfort, however little, in the cramped and limited space of a crowded ship.

A perfect calm, a smooth sea, and a but-slightly-clouded sky, prognosticated fair weather, and promised leisure to complete those arrangements which had been left undone. The steamer Sta. Lucia performed her task of towing the two vessels most satisfactorily, and, favoured by the prevailing currents of wind and water, we made five miles an hour, and came, on the day of departure, in sight of the promontory of Pola.

'The passage down the Adriatic was on the whole most pleasant, with the exception of some showers of rain near the heights of Isola Grossa; which, however, on this occasion saluted us only with a slight puff of wind. The ship moved so gently and quietly on her way, that those occupying the lower cabins could scarcely have fancied themselves at sea, had they not been made aware of it by other impressions.

On the 1st of May, the crew became highly excited by a man being missed, when the morning watch was called. Some thought he had, from fear of a slight punishment hanging over him, jumped overboard, but as nothing of the kind had been observed by the watch on deck, every corner was scarched, but without success, upon which the man was given over as 
lost. When, however, the dimner hour arrived, and the tables and benches were being removed from the lower deck, how great was the surprise, when the culprit was discovered crouching among them! A peal of laughter roused the poor fellow, who this time was let off with the fright and the punishment of being made an object of ridicule by his comrades.

On the 3rd of May, being clear of the Adriatic, the steamer Sta. Lucia was at midnight despatched to Corfu to complete her store of coal, whilst we sailed for Cape Spartivento, on the Calabrian coast, which had been assigned as our rendezvous. On the 5th, we sighted this the most southerly promontory of Italy, when, in consequence of a fresh breeze, the sea began to make itself rather disagreeably felt. The novices on board became somewhat alarmed. A feeble voice was even heard, which endeavoured to prove from this phenomenon that man is a creature made for terra firma, and not for the watery element; but this excellent idea came rather late; mankind are obliged to submit to existing circumstances, and this thought alone held out some hope, that a longer stay on board would prove the best cure for the evil. Such indeed was the case; though pale faces, want of appetite, and even worse effects, were produced, whenever the ship made a heavier roll than usual. But these slight inconveniences of sea life became rarer and rarer, till at last they appeared only in really stiff gales. On the 7 th the steamer Sta. Lucia returned and took us again in tow.

The weather during our passage through the charming 
straits of Messina was delightful. The colossal Etna exhibited in all its glory its snow-capped summit, gilded by the rays of the rising sun, and Messina shone with all the attractions of its splendid situation. The coast of this part of Italy is mostly bare and rugged, the broken outlines of the mountains imparting to the landscape that characteristic peculiarity which makes so deep an impression on the mind. We passed the famous Charybdis, in which a multitude of dolphins were disporting themselves. The neighbouring coast formed a brilliant panorama, and we kept so close in shore as to be able to distinguish the novements of the people. The appearance of our three goodly ships seemed to have attracted the attention of the inhabitants, for they stood in groups in the streets and squares of Reggio and Villa San Giovanni, saluting us by waving their handkerchiefs. When towards the evening we had passed the straits, we could desery the Neapolitan coast as far as Monte Bulgario, in the Bay of Policastro, and distinguish the imposing Stromboli, with its volume of smoke, far on the Western horizon.

'The following morning found us in sight of the small island of Alicudi, situated on the north of Sicily. The estimable captain of the Lucia came on board to take leave, on his return to Trieste. The steamer, being relieved of her burden, made her way briskly towards her destination; and, before an hour had elapsed, we could perceive nothing but a small streak of smoke in the haze of the horizon.

With light breezes, we came, on the following day, in sight 
of the island of Ustica. Sea-gulls (Thalassidroma pelagica) enlivened the scene, as they, from time to time, flew after the garbage thrown from the ship, or sought for sea-nettles and other small inhabitants of the sea's surface. These birds much resemble our land swallows, and their movements are so graceful, that one cannot but admire them, especially when they lightly touch the agitated water with their little webbed feet, and directly, as if repclled, withdraw. The muscular power of these feathered creatures is truly wonderful; they follow the ship for entire days continually on the wing, ever on the watcl to snatch at the little food which the sea seems but scantily to supply to them.

Whilst we were passing down the Mediterranean, a great

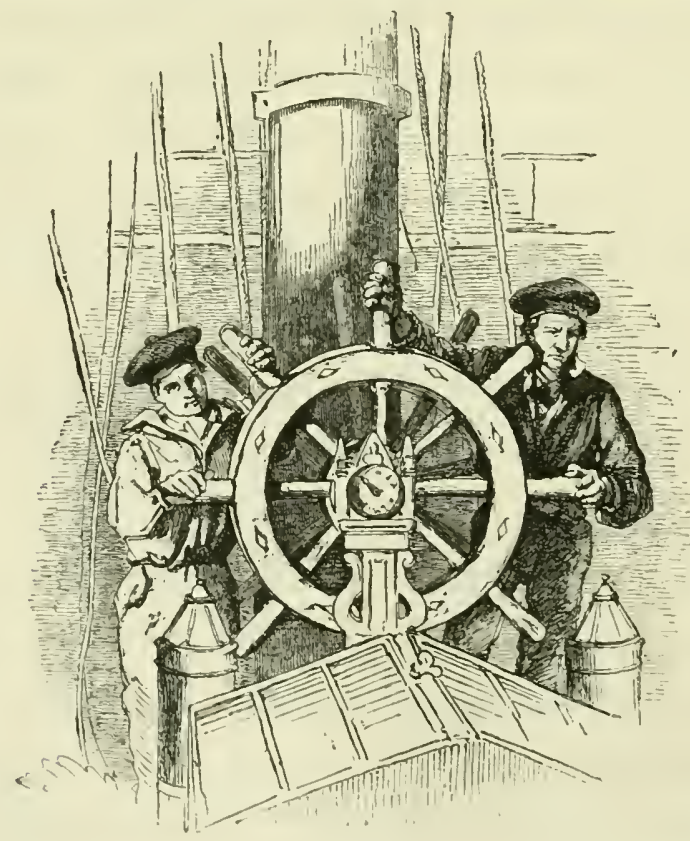


deal of time was employed in drawing up regulations, and in digesting all those instructions which had reached the Commander of the Expedition from all sides, and by which we were to be guided in our future proceedings.

The scientific gentlemen were the first who received certain rules for their guidance; for, life on board a ship, and especially of a man-of-war, is so entirely different from that on shore,-the etiquette and usages practised appear, to those unused to the sea, so vexatious and annoying, that it was absolutely necessary to inform them of the regulations which are essential in order to keep so singular an organization as that of a ship at sea in working order. Erelong every one perceived, that the matutinal annoyance of holystoning the decks, the daily cleaning of everything on board, \&c., are measures of importance, which contribute materially to the preservation of the health of the crew, and that a strict observance of discipline is absolutely necessary to exercise their powers, and thus to fit them for all eventualities.

For the better accommodation of the naturalists, a place on the lower gun-deck was fitted up for those operations which, on account of the limited space and noxious exhalations, could not well be performed in the cabins.

We had a large quantity of alcohol on board, destined for the preservation of interesting objects of natural history. In order to prevent any calamity by fire arising therefrom, the whole quantity was put in a large iron tank placed in the hold, and covered over with sand. It will, however, be seen 
in the sequel, that even this precaution proved insufficient to protect the ship from the ignition of this highly-combustible substance.

The meteorological observations, and those connected with the physical geography of the sea, were entrusted to four officers, who, like those attached to the watches, had alternately to be at their posts, and had, at prescribed hours, to observe the barometer, thermometer, and psychrometer, as well as the temperature of the surface of the sea, the state of the sky and the ocean, and to note down the obtained results. One of the junior officers was intrusted with the nautical observations on shipboard, as well as the astronomical and magnetical on shore.

The midshipmen were at the same time trained by study and practice, so as to enable them to assist the officers in their duties. Besides the men on the look-out, one of the midshipmen was employed on the same service. In stormy nights, when the wind is howling, and rain or snow falling, this post is certainly not very pleasant, but is, as may readily be imagined, most important.

Life in the limited space of a ship, completely cut off from the external world, is so peculiar and interesting to those unacquainted with the sea, that we will endeavour to describe a day passed on board the Novara, from the instant when at daybreak the bustle and activity begin, till the late hour when night reminds one of repose, those sweet monents which carry the voyager to his distant home on the wings of a dream. 
As the sonorous bell strikes the fifth hour of the morning, the crew are called on deck by the boatswain's whistle, the hammocks are slung up and stowed away, and the work begins.

This is the busiest time of the day, and for the mere spectator the most uncomfortable. On all sides scouring, rubbing, sweeping are going on, floods of water are streaming along the decks, and he who is not as yet familiar with these cleaning processes, runs some risk of a ducking as soon as he makes his appearance outside his cabin. These morning ablutions are, however, indispensable evils on board ship, for cleanliness is a condition essential to the preservation of health, and even the quantity of humidity which penetrates the timber, and renders the air damp, appears to be less injurious than the omission of these daily scourings.

When the cleaning of the various parts of the ship is finished, the idlers, and such of the officers as are off duty, appear on deck, whither people come to enjoy the fresh air, and to greet the opening day. It may, however, be permitted to observe, that a sunrise at sea, notwithstanding its various charms, is by far less imposing than the same scene on a lofty mountain, where the veil of night seems to vanish as if by magic, and luxuriant nature lies at our feet like a smiling infant awaking from a lovely dream. That wild majesty of scenery, that overpowering grandeur of gigantic mountain forms, such as one sees in the Swiss or Tyrolese Alps, is wanting at sea, where the rising sun pours his beams only over a boundless world of water. 
The sailors breakfast at 7 , the officers at 8 , and the Commander at 9 . At the latter hour the bugle sounds the order to "clear the ship," when the cleaning of arms, guns, and all other articles of metal connected with the ship's armoury, begins. During this process the band plays cheerful airs, so that the work is done whilst keeping time with the music, which serves to lighten the labour. This duty requires to be completed within forty-five minutes, and terminates with an inspection of the men and their ar'ms.

This being over, officers and midshipmen off duty assemble together with the naturalists in the readingroom. Most of the books in the library referred to those countries likely to be visited by the Expedition, so that every one might previously obtain useful information relative to their physical, historical, and social conditions.

The naturalists employ the greater part of the day in their cabins, noting down their observations, and preparing for those to be made in the course of the voyage. The crew are kept in activity by being drilled and otherwise occupied.

The men dine at 12; the dinner of the officers is served up at 3, and that of the Commodore at half-past 3 o'clock P.M. The remainder of the afternoon is spent in prosecuting the labours begun in the morning. Thus steals on the evening, when a general assemblage takes place on deck, for air and exercise. 


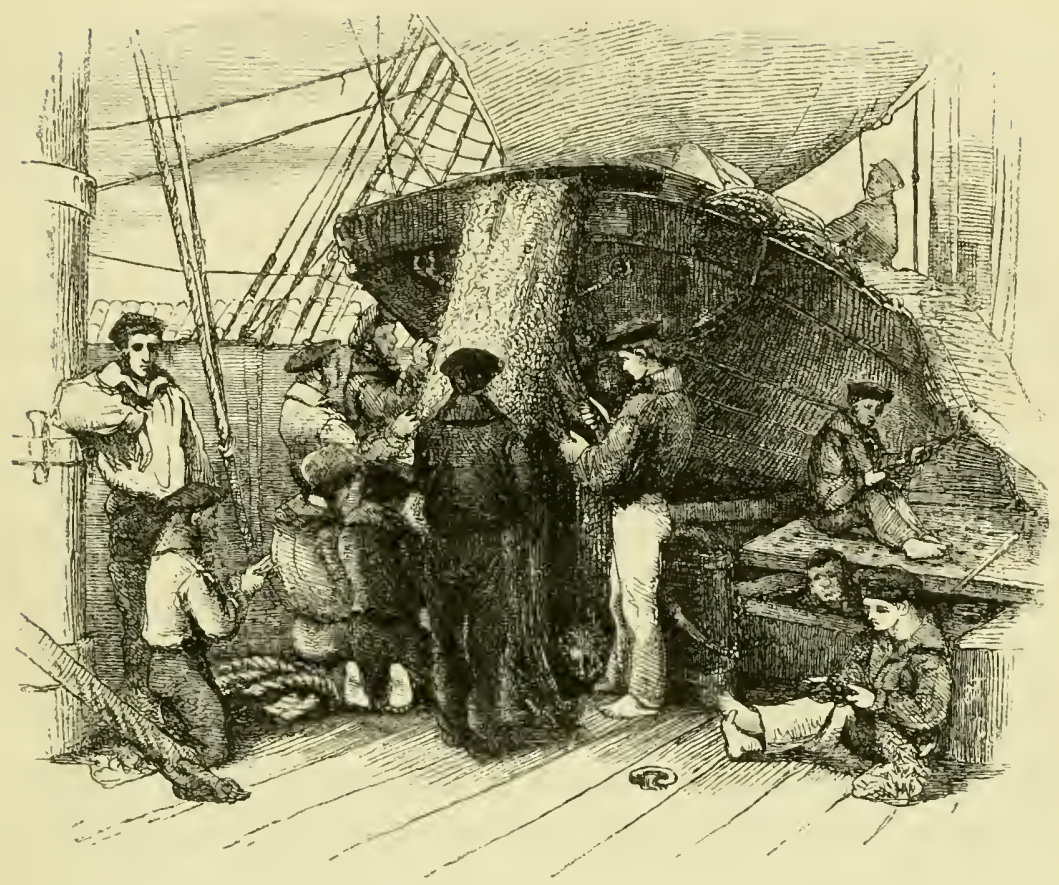

The occurrences of the day, the sunset, the curious formation of the clouds, or the bewitching beauty of a brilliant tropical sky at night, form interesting topies for lively discussion. It is, however, rather daring to institute a comparison between the splendour of the sky in the tropics and that of our higher latitudes. For, most men become more or less unjust towards the beauties of a new and foreign natural scenery, in consequence of their not being able to divest themselves of former impressions produced in them by phenomena of a similar nature. What impressions are, for instance, deeper in young and old, and excite more delightful recollections than the starry sky of home? And can it be disputerl that the 
association of icleas has a most powerful efrect upon the impressions made by those phenomena of nature which are so peculiariy attractive and so deeply fixed in the liuman mind?

The conversation generally becomes more lively on those evenings when the moon, placid friend of the sailor, appears on the distant horizon, shedding her silvery beams over the unbroken expanse of water. The influence which she exercises on the state of the weather, even the prejudices and superstitions connected with our satellite, offer subjects of interesting debate; involuntarily the mariner looks with grateful feelings towards that heavenly luminary, the mild soothing light of which diminishes the number of his anxious nights, protects him in present, warns him of remote dangers, and influences so powerfully that vast element on which he passes the greater part of his life. Indeed he who has ever spent a dark and stormy night on the ocean, when the ship, lashed by the fury of the waves, and borne resistlessly along, stands in constant peril of coming in violent collision with a vessel similarly circumstanced, or of being dashed to pieces on some ironbound coast of rugged rock, easily comprehends and will excuse the sailor who ascribes to the moonlight somewhat of a supernatural and mysterious power.

In this manner, and notwithstanding the continued sameness, days and months glide away like hours, until we again east anchor, and only the work accomplished gives an idea of the length of time which has been passed at sea. 
Sunday alone breaks the monotony of life on board, when, after the diurnal cleaning of the ship, and the inspection of the crew, the officers, and all the men who are not on duty, assemble for divine service on the lower gun-deck, where the chaplain says mass on a temporary altar, whilst the ship's band performs sacred music. In the afternoon the men off duty amuse themselves for a couple of hours with the "tombolu," a game much liked by our sailors. Between 6 and 7 P.M. the band plays on deck, whilst the sailors are cutting grotesque figures to the music. The singular capers by which all evince their happiness; the good-humoured awkwardness with which each clings to the brawny arm of his companion; the mock graceful air those who enact the gentler sex assume in the dance, and, finally, the affected attitude with which the cavaliers bow to their partners as if they really were of the gentler sex-all this is most ludicrous and amusing. The playing the national dance "Monferina" always elicits a particularly hearty reception. There is a peculiar charm in national melodies, even though they awaken no political reminiscences like the Marseillaise, or the Rakoczy; they electrify alike the educated and the men of the people; a thousand pleasing recollections suddenly crowd into the memory, and when the well-known tunes strike the ear, the heart seems to live again in bygone times! As if touched by magic, the sailor from the Adriatic, as soon as the Monferina is struck up, seizes his neighbour by the arm with a noisy shout and hurls him about in wild hilarity; his thoughts scem as if flying towards his distant home, where, in the country inn, with a 
buxom lass on his shoulder, he has waltzed away many a happy hour. The whole village, with all its familiar faces, seems to revive in his memory during the playing of the melody,-now he fills his glass; now he clinks it merrily with that of his companion; now he presses his sweetheart more closely to his side: Lo! suddenly a shrill whistle pierces the air, the music ceases, the call is heard "to fall in," and the yet dance-stricken sailor, suddenly, as if awakening from a sweet reverie, is once more standing on the deck of the Novara!

The frigate, in the Mediterranean also, maintained her superiority as a sailer. The corvette Caroline was able to keep the prescribed distance from the Novara only by the latter reefing some of her sails. As some magnetic observations were to be made at Gibraltar, and, as we had to ascertain the results of the various chronometers on board, on the 12th of May we signalled the corvette to take her own time and rejoin us at Gibraltar, as we were anxious to avoid unnecessary detention.

The acquisitions of the naturalists had, as yet, been rery scanty: to their great annoyance they could not eren obtain any of the tortoises, which, from time to time, approached the ship, though they were repeatedly fired at, and on one occasion a boat was launched, in the hope of catching some of them. The specimens which we saw were from fifteen to twenty inches in diameter; they mostly floated quietly on the surface, and seemed sleeping or basking themselves in the sun.

The night of the 16th May was exceedingly boisterous, 
and almost tangible darkness prevailed; thunder, lightning, and occasionally strong easterly squalls, raged furiously, and only subsided towards the morning, when it cleared up with fresh southerly breezes. Not being far from Cape de Gatt, on the Spanish coast, prudence required us to change course, and, during the continuance of stormy weather, to keep at a respectful distance from the shore. Here a merchantman, apparently an American, bore down so close upon us, that, in the darkness, an unpleasant collision seemed unavoidable. However, we tacked about, and thus, fortunately avoiding our dangerous neighbour, safely proceeded on our course.

It is truly astonishing how often merchantmen, entirely forgetful of their own safety, from want of caution, or presumption, or it would occasionally scem, sheerly from acting upon peculiar and abnormal principles of navigation, wantonly expose ship, men, and cargo to many dangers, which might easily be avoided, particularly in cases where no tacking is required, and only a slight touch of the rudder would suffice to prevent a collision, which is always attended with danger to the smaller ship. In this respect the North Americans are very unpleasant neighbours on account of their national vanity, and the Dutch for their phlegmatic temperament and the indifference they evince on such occasions.

On the 18th of May, the small rocky island of Alboran, in the narrow part of the sea between Africa and Spain, was observed; being flat and without vegetation, it is scarcely perceptible, and the land-fall during the night should be carefully avoided. The erection of a lighthouse on this island 
would certainly be regarded as a great boon by all who navigate the Mediterranean.

On the 19th of May, the sea suddenly assumed a peculiar orange colour; a dust-like covering was observed on the surface of the water, and at some depth white points might be seen, mingling with each other in the wake of the ship. Clouds of this orange-like matter appeared spread upon the sea, which thereby lost its usual transparency. On closer examination this phenomenon appeared to arise from a mass consisting of myriads of minute animalculæ, which had a yellow opaque kernel, the gelatinous covering of which was transparent and colourless. A quantity of sea-water impregnated with this matter, having been brought into a dark room, gave out a light, and when agitated, such brightness proceeded from it, as justified the anticipation that, during the night, the whole sea would be illuminated. Accordingly the wake of the ship was illuminated by a wonderful stream of light, in the depths of which larger masses of luminous matter could be discerned, whilst on the surface there was a sparkling and glittering, as if all the stars of the firmament were reflected in the water.

This phosphorescence of the sea, for the explanation of which we are chiefly indebted to Professor Ehrenberg, proceeds for the most part from the emanations of light from mollusca of the genus Medusa, and other living phosphoric animalcula; sometimes, however, as for instance in Venice, it arises from the putrescent fibres of decayed mollusca, and other organisms in a state of decomposition. 
On the evening of the 20th the splendid Ceuta Light was seen, which, even at a distance of twenty miles, looks as if it were quite near. This lighthouse is of the utmost importance to ships emerging into the Atlantic from the Mediterranean, as the current is exceedingly powerful, and during the night is apt imperceptibly to carry a vessel out of her course. On the morning of the 21st, the ship lay in a calm before the rock of Gibraltar. Barren, gray, and gloomy rose now before our sight this rocky, gun-studded, colossal sentinel of that vigilantly-prudent, energetic, and jealous Power, which is so constantly seeking to extend her rule wherever her own interests are concerned, or where she thinks it advisable to make herself respected by other nations.

A light breeze sprang up, and at half-past 3 P.M. the anchorage, eleven and a half fathoms in depth, was reached. The frigate now lay in front of the Alameda or public gardens of Gibraltar, situated near the town gate, called the Ragged Staff. This anchorage is tolerably safe at this season, but in autumn and winter, as well as generally in strong easterly winds, it is not to be recommended, it being preferable to haul further in towards the place where the merchant-vessels usually lie. We saluted the English flag on the fortress with twenty-one guns, which were immediately answered from the ramparts. There were no English men-of-war in the Roads, except the sloop Curlew, Capt. Horton. The following morning our consort, the Caroline, anchored in our vicinity.

The first day of the arrival of a man-of-war in harbour is attended with much inconvenience, particularly if she carries 
the flag of the Commodore, or it happens that the mail packets are arriving or departing, or that there are many ships of war in the Roads. The latter was not now the case, but so many visitors, letters, and newspapers arrived at once, that neither the one nor the other could be thoroughly enjoyed.

The local authorities, the governor, Sir James Fergusson, at their head, were extremely obliging and attentive; $\mathrm{Mr}$. Falkland, an officer of the Engineers, was placed at our disposal; a specially-reserved site was assigned us for astronomical and magnetical observations; huts were erected by the workmen of the arsenal for the protection of the instruments, and in short everything, calculated to promote scientific labours, was provided. The Chancellor of the Austrian Consulate, Mr. John Frembly, himself a geologist, proved likewise to be of great service to our scientific men: and it was considered a fortunate omen to have found, at this our first anchorage, so much sympathy with the objects of the Expedition.

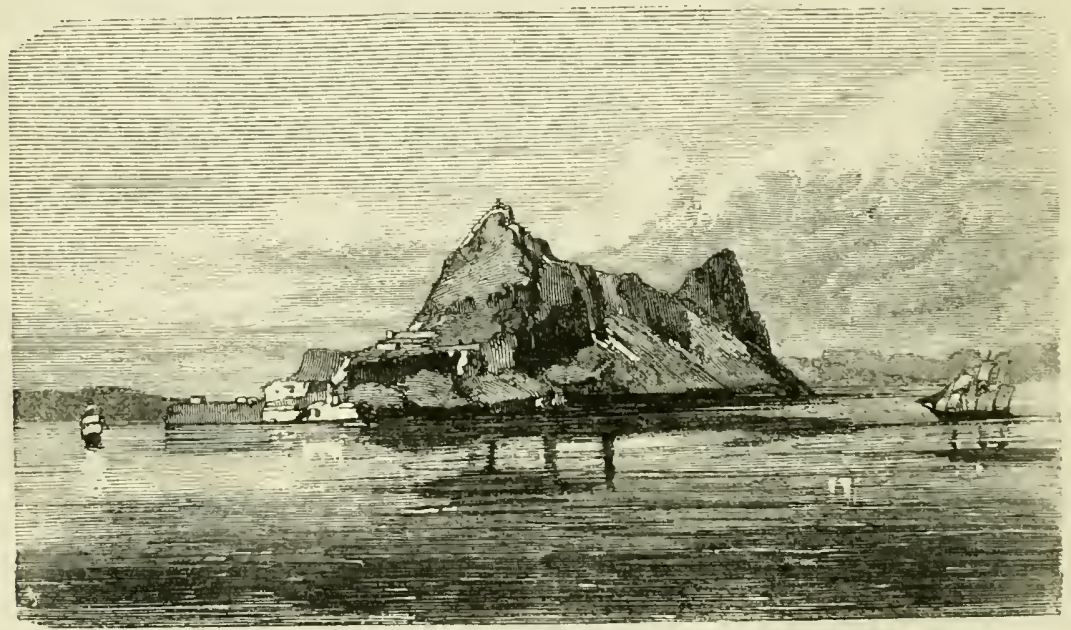




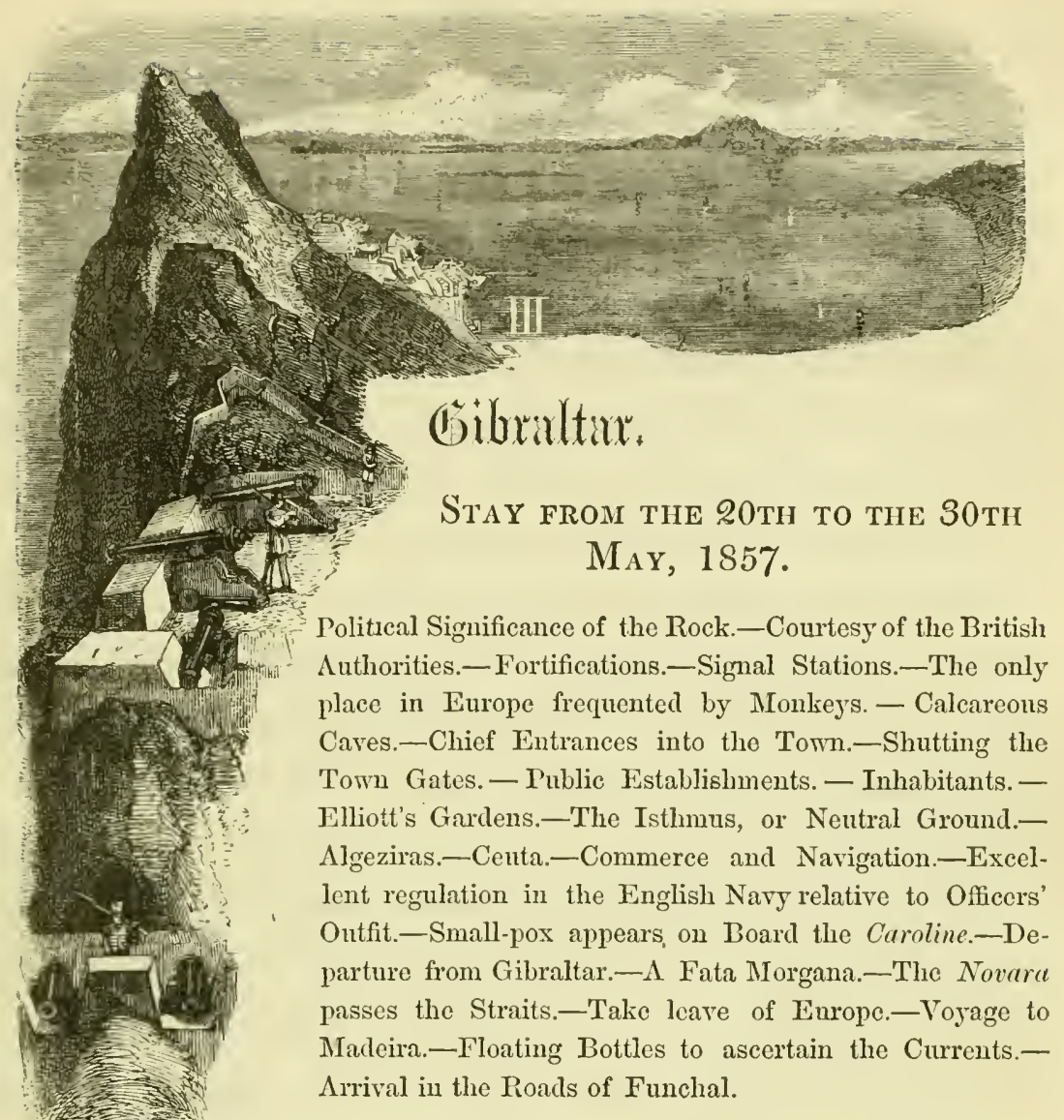

THIs remarkable promontory, which in our days has obtained so much political importance, the Calpe of the ancients, constituted of old, with the opposite Abyla, * the so-called pillars of Hercules, celebrated, at the same time, as the boundary of the then-known world. It derives its name from the corrupted Arabic Gebel (mountain) and Tarik, the name of a Moorish conqueror, who had pitched his camp here (A. D. 711 ).

* 'The present $\Lambda_{\text {pes }}$ Ilill. 
Like a colossal giant, guarding the portal of Europe, and converted, by the energy and ingenuity of the British, into an almost impregnable outpost, this precipitous rock has, as regards the Mediterranean, the same high strategic importance for that great maritime people, as Heligoland for the German Ocean, Aden for the Red Sea, Ceylon and Singapore for the Indian Archipelago, Hongkong for the Chinese waters, or the Cape and St. Helena for the Atlantic Ocean.

Gibraltar was already strongly fortified, when it belonged to the Andalusian kingdom, but its grandest fortifications date from the treaty of Utrecht (1713), when it became an appanage of the British crown. Stupendous and incomparable are the works which since that period have been executed on it, though the calcareous formation of the locality and its numerous caves may have considerably facilitated their construction.

The English authorities, who so kindly assisted in the scientific researches, obligingly furnished each individual of the frigate's staff with a written permission to inspect the fortifications as often as they pleased, and thereby afforded them the particular gratification of being able to view and arlmire these vast structures in all their details.

Excellent and well-kept roads lead to the principal fortifications, which only begin at an elevation of several hundred feet above the town. The galleries, hewn in the solid rock, forming a kind of casemates, are of such breadth and height that they may be conveniently traversed by a man on horse- 
back with his hat on. They have been constructed at an immense expense of labour and money, and are designated by various names, as "Upper gallery," “Lower gallery," “Queen’s gallery," “St. George's Hall," and so on. Their extent is estimated at an English mile, but is probably much greater. Besides these galleries, passages run for miles in the interior of the rock, affording the garrison a thoroughly-protected connection with all points that may chance to be threatened.

The grandest and most imposing of these marvellous excavations are the "Queen's gallery" and "St. George's Hall." According to carved inscriptions, most of them were begun and completed between the years 1783 and 1789. At the period of our visit, there were mounted on the different fortifications 707 guns, about one hundred of which peeped out of the smaller embrasures. Since that date, however, the number is said to have been increased so as to amount now to about 1500 .

During the stay of the Novara, it fortunately happened that the birthday of Queen Victoria was celebrated, and thus an opportunity was offered of secing the fiery mountain in full activity. Though the occasion was peaceable, yct the imposing spectacle gave a tolerable idea of the elements of destruction which Gibraltar could put in action if really attacked. The governor of the fortress, surrounded by a brilliant staff, in which the Spanish governor of Algeziras and his officers played but a sorry part, reviewed the garrison, consisting of infuntry, cavalry, and artillery, to the number of 
from 5000 to $6000 \mathrm{men}$; and whilst the troops defiled in slow and quick step, lightnings and thunders issued from all the crevices and embrasures of the artificially-perforated rock; huge volumes of dense smoke followed, and a rolling subterraneous rumbling gave the mountain exactly the character of a rolcano suddenly burst into action. The echo of these salvoes of rejoicing must have been heard, not only in the adjacent parts of Spain, but also on the more remote coast of Africa; and he who was ignorant of the real cause, might hare supposed it a grand rehearsal of that fearful tragedy which the English seem determined to perform in the erent of an attack. The supposition, however, that the guns of Gibraltar are able entirely to command the Straits is erroneous, for these, at their narrowest part, are $12 \frac{1}{2}$ miles wide, and not even the Armstrong guns, with which the fortress has lately been furnished, have so extensive a range. The English are, however, able to command the Straits by a fleet, which would find in the Bay of Gibraltar a sufficiently safe and roomy anchorage.

From the fortifications, a narrow and rather steep path leads to the telegraph station, at an elevation of 1300 feet above the level of the sea. Steamers and men-of-war, as soon as visible, are signalled from this point by means of immense balls and flags. It would be very difficult to signal merchantmen in the same way, as, during a prevailing westerly wind, multitudes of ships often appear to the eastward of the rock, anxiously waiting for a favourable casterly breeze to 
carry them through the Straits; in the same way the westerly horizon is sometimes crowded with ships, prevented by contrary winds from entering the Mediterranean.

We found at the station an Aneroid-barometer, and a thermometer. The advantages for navigation and physical science of extensive meteorological observations, regularly made, are so evident, that it is astonishing to see how often opportunities are neglected for making them, such as are offered here.

There was no opportunity for seeing any of those families of monkeys, the occasional appearance of which on the Rock of Gibraltar has given rise to tales found in books of travel of the existence of a submarine communication, through which this single representative of the genus in Europe has found its way to this rock from Africa. Sometimes, however, during easterly winds, single individuals are observed on the highest peaks on the eastern side of the rock, where it is completely inaccessible; probably the remnants of that species (Inuus ecaudatus), which at some former time, either by chance, or human agency, have found their way hither from the Moorish coast.

The calcareous caves are very remarkable. That on the western side, called St. Michacl's, situated at a height of 800 feet, is the most important. It contains beautiful stalactite formations, and seems to be of considerable extent; it has, however, not been closely examined hitherto, as only a small part is conveniently accessible. St. Martin's Cave, on the southeast, likewise about 800 feet above the level of the sea, is smaller, but its stalactites are of a purer whiteness. A third 
was discovered a few years since on the eastern side of the rock at a height of only 80 feet, the lower portion of which

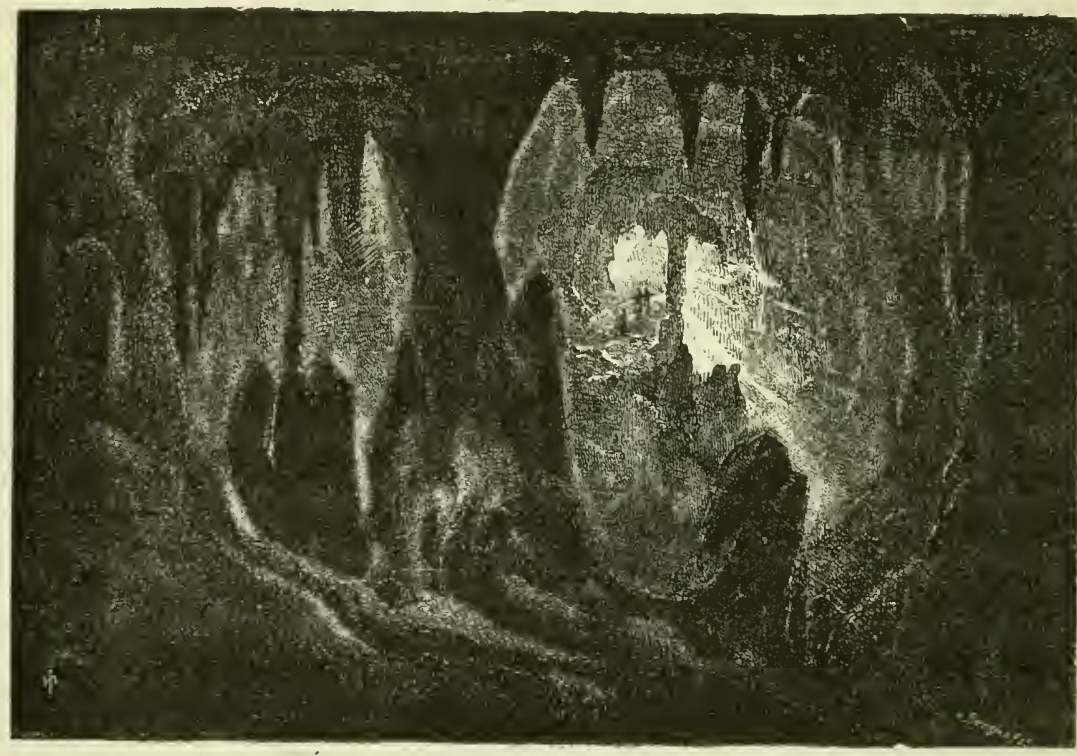

consists of accumulations of sand and recent shells. There have also been found bones and teeth of large herbivorous animals.

The characteristic vegetation of the mountain is Spanish broom (Spartium junceum), the yellow blossom of which strikes the eye pleasingly at a great distance. There is also one species of cactus, and one of the dwarf palm (Opuntia vulgaris, and Chamcerops humilis), which grows in great abundance, and forms, on the south face of the rock, almost the only vegetation, whilst, on account of difference of temperature, it is altogether absent on the remaining sides.

Gibraltar has little to attract strangers to settle; bar- 
racks, military store-houses, and fortifications, render the appearance of the place peculiarly monotonous, the more so that there are no elegant buildings, or fine shops, on the rock. There was nothing observed, however, to confirm the statement, in a celebrated geographical work, copied by all later compilers, that " most of the houses are painted black, to soften the glare of the sun, and prevent an attacking enemy having a distinct view of the place." The town, which is built in terraces on the side of the rock, is accessible only from three points. The greatest portion of the traffic passes through the so-called Old Mole at the north end, whilst the entrances on the south are generally used by men-of-war sailors only. All are opened at 5 in the morning, and, according to the season, shut between 7 and 8 in the evening, precisely twenty-five minutes after the first signal-gun. This closing of the gate is attended with ceremonies verging on the comic. A broadshouldered corporal, carrying in his hand a heavy bunch of immense keys, marches, visibly impressed with the importance of his mission, in measured steps, accompanied by a number of red jackets with fixed bayonets, towards the massive towngate; the bridge is then, with much ado, drawn up, and the horribly-creaking gate, with great exertion, closed, bolted, and finally locked. After "gun fire" no one can leave the town by the Old Mole; at 10 P.M., however, and at midnight, a little postern is opened, through which those jolly stragglers, who have forgotten in merry company the measure of time, may slip out 
to return to their floating abodes. From this hour till morning all communication with the harbour is arrested, and the utter impossibility (except in extraordinary cases) of leaving the town after this hour, has given rise amongst the people to the saying, "There is only one thing more difficult than to get out of the town after midnight, and that is to get in."

There are in the city two Anglican churches, one Wesleyan, one Presbyterian, two Catholic chapels, and two synagogues. The garrison library, where likewise a great number of journals and magazines are kept, possesses 22,000 volumes, amongst them several very rare and costly works, especially of ancient Spanish literature. It was founded in 1793 by Captain Drinkwater, and has been hitherto kept up by private subscriptions and the profits arising from a printing-establishment attached to it.

Gibraltar owes to the energy and public spirit of the governor, Sir James Fergusson, the foundation of several important establishments and undertakings. Since the beginning of his administration in 1856, the number of public schools has been considerably increased, the town supplied with gas, and well-arranged public baths established.

'The city does not possess a single well or spring; the water used is obtained from tanks, in which the rain is collected. The quantity of rain that fell during the twelve months of 1855 amounted to 78 inches; in 1856 , it is said to have been only 24 inches. Nevertheless, there is at no time any scarcity of water. The Government have lately caused the 
erection of a distilling apparatus for making sea-water fit for domestic purposes, which, however, hitherto has not been used.

The population of Gibraltar, including the garrison of 6000 men, amounts to about 20,000 souls, consisting of Spaniards, English, Italians (mostly Genoese), Portuguese, Moors, Turks, Greeks, and Jews; indeed, a mixture of races, customs, and manners such as scarcely can be found at any other place in Europe. The native residents call Gibraltar briefly the rock, and themselves, with a kind of pseudo-patriotism, rock people, though by the officers of the garrison and navy generally complimented with the name of " rock-scorpions."

The permanent settling of foreigners, in consequence of its being a fortress, requires a number of formalitics, which have the effect of limiting the population; and even the English portion must be considered migratory, as it consists chiefly of military and government officers, who, after the lapse of certain intervals, exchange in regular order.

The only really beautiful walk in the place is Elliott's Gardens, situated at the south end of the town, laid out in a grand style, but disfigured by a tasteless bronze statue of General Elliott (afterwards Lord Heathfield), the heroic defender of Gibraltar in 1782. In the evenings, when one of the military bands is performing, the grounds are thronged by visitors on foot, horseback, and in carriages, whilst loving couples, of all races and grades, ramble in happy union through the shady avenues. 
Near the gardens, towards the south, is a second quarter of the city, which mostly consists of government buildings.

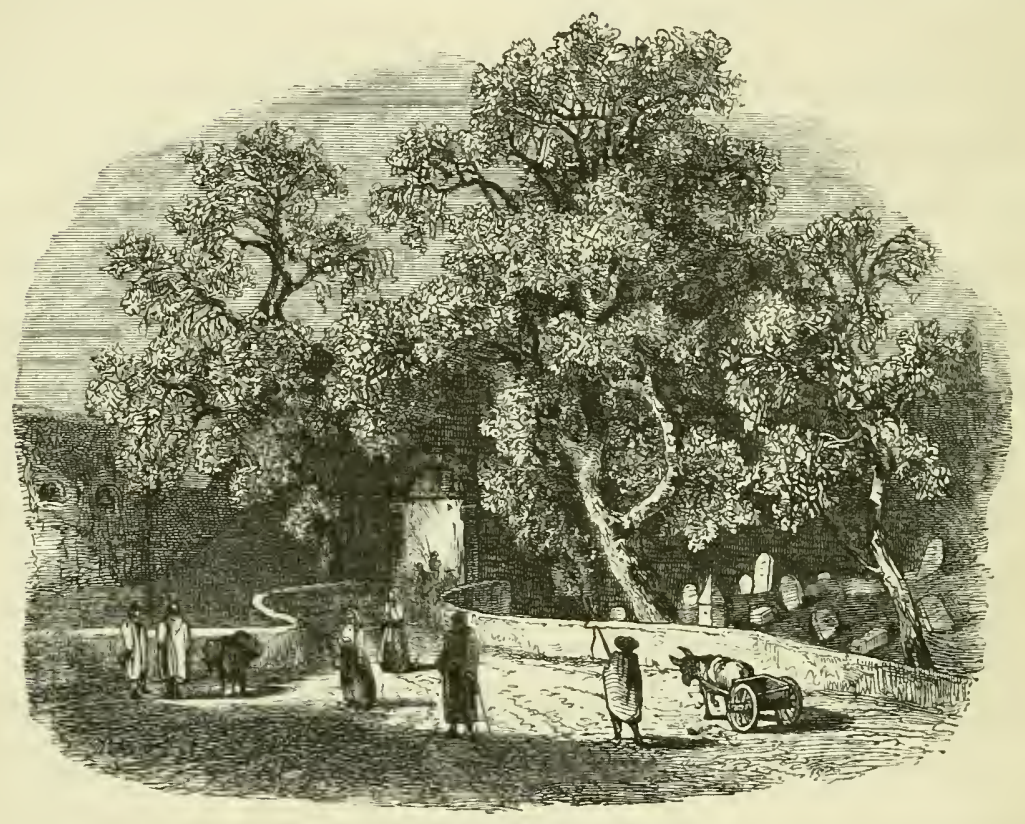

On the lowest terrace, which juts furthest into the sea, stands the lighthouse, on the celebrated "Europa Point."

Gibraltar is connected with the Spanish continent by a sandy neck of land, called by the Spaniards El Istmo, and by the English "the neutral ground." It runs between the Mediterranean and the bay, one mile and a half in length and 2700 feet in breadth. This plain, which is not more than 10 feet above the water, owes its origin to the formation of a dune in the rocky bed of the ocean. Strong easterly gales seem by degrees to have accumulated the sand on this shallow run of the sea, which formerly separated Gibraltar from Spain. 
A similar sand formation, near Catalan Bay, has attained the enormous leight of 1000 feet. The Government have caused a portion of the sand, at the point where the isthmus joins the rock, to be excavated, and the water of the bay to be let in, so that there only remains a narrow low dyke of firm ground, which probably in time of war may be completely submerged. The stagnant water of this cut must, however, during the hot season, considerably increase the amount of fever.

From May till October the troops are encamped under tents on this isthmus, along which the neighbouring Spaniards come to market daily in crowds, with provisions of all kinds, displaying their rancour against the foreign intruders by endeavouring to make them pay the highest possible price for their produce.

The adjacent Spanish settlements, Campamiento and St.Roque, are much resorted to by excursionists from Gibraltar, and, during the summer, are selected by numerous families for even a longer stay; for however little pleasure or interest a ride over this arid and sandy plain affords, once arrived at Campamiento, the rider enjoys a most charming prospect, while there is probably no other point from which the isolated rock appears more grand or picturesque than from this neat little village.

In following the road that runs from Campamiento along the bay, the charming little town of Algeziras is reached. It lies on the western shore, exactly opposite Gibraltar, with which it is in regular correspondence by daily steamers. 
Algeziras, formerly a poor fishing-village, has greatly increased in extent and prosperity, through the smuggling trade. This clean and pretty-looking place has a population of 10,000 souls, and makes by contrast an extremely pleasant impression on coming from the dismal and gloomy fortress. Men and things here have quite an Andalusian appearance. The small but neat one-storied houses are mostly painted a bright white, and ornamented with green verandahs; at almost every window beautiful flowers are exhibited; and the public promenade, shaded by fine trees, is delightful. The principal square is likewise planted with trees, and the lower stories of its houses are occupied by apothecaries' shops, coffeerooms, confectioners, and one by a bookseller even. 'The churches appear in every respect insignificant; the hospital of San Juan de Dios, however, is an ancient and noble structure, the management of which is admirable. One of the arrangements here was eminently characteristic of Spain : in the ward for male patients stands at the upper end, by the sicle of the beds for common patients, a large, broad, elegantly-polished bedstead, which, the porter told us, was intended for "caballeros."

At a short distance from the town is the Amphitheatre Constantia, a large wooden booth, said to hold nearly 9000 spectators. It is chiefly used for bull-fights, which always attract a large audience. The aqueduct here, taken with the fine scenery around, forms an exceedingly picturesque object.

The inhabitants of Gibraltar sometimes make excursions to the peninsula of Ceuta (the Sebta of the Moors), situated on the 
opposite coast of Africa. The lighthouse of this little promontory has been lately furnished with a Fresnel apparatus, throwing out a most intense light, which is visible at a greater distance than any other observed during our voyage. This place, which is used by the Spaniards as a penal settlement, numbers 6500 inhabitants, and has a very indifferent harbour. The "rock people" also occasionally make excursions to Tangier, the most westerly town of the strait, and the most important as regards the commerce of Morocco.

A great number of steamers on their various routes touch at Gibraltar, for discharging and embarking freight and passengers, and to coal. The quantity of the latter thus shipped is estimated at 30,000 tons annually, all imported from England. There is also a regular correspondence by sailing vessels with all the leading Italian ports, and those of the Levant, as well as with Constantinople, Corfu, and Trieste.

Gibraltar being a free port, there are no customs' dues, except those on wines and spirits. All flags enjoy equal privileges, and in all disputes the English law decides. It is impossible to obtain a satisfactory statement of the amount of imports and exports, as no Custom-house exists, and the official reports merely give the number and nationality of the flags of the ships that arrive and depart. Smuggling is carried on to a great extent, and, being a lucrative trade, will continue to be so, as long as Spain retains her prohibitory duties on English goods. 
The principal items of commerce in Gibraltar are English cotton goods, which are exported to Barbary in considerable quantities. To compete successfully with the English in this branch of trade would be very difficult for any other nation; but there are a great number of other articles which might find a ready sale on the African coast, and which are produced cheaper in several States of the European continent than in England; a consideration of so much the more importance in trading with the Moors, that these people regard lowness of price rather than the quality of the goods.

For this very reason, small but industrious Belgium has become a powerful competitor of mighty England. Thus, for instance, that country exports to Morocco, by way of Gibraltar, sugar, both in loaves and crushed,* hardware and cutlery, nails and screws, zinc, as well as all sorts of earthenware and glass. A portion of these articles goes into the neighbouring Spanish provinces.

It is rather singular that the Belgian glass goods are in Gibraltar represented as of German manufacture, and thereby obtain a readier sale. This seems to be a proof that German (i. e. Bohemian) glass articles have been patronized before the Belgian, and lost the market only through the importation of the latter.

* The superior quality and cheapness of Belgian sugars have of late in a great measure driven all others out of the market. It is also worthy of remark, that though Gibraltar is a British eolony, all the aceounts are kept in Spanish currency, and that there are more Spanish and French coins in cireulation than English, which, when changed, even sustain a small loss. The Spanish measures and weights also are more in use than the English. 
The intercourse between Gibraltar and Spain is carried on by coasting vessels, and by French as well as Spanish steamers, while the postal communication with Great Britain is conducted by the Peninsular and Oriental Steam Packet Company.

Correspondence with Spain and other parts of the Continent is carried on overland, but is little to be relied upon, as, owing to the horrible condition of the Spanish roads, a delay of from six to eight days sometimes occurs in bad weather. Between Gibraltar and Cadiz, a distance of only sixty English miles, the letter-bag is said to have often been six days on its way.

The narrative of our stay at Gibraltar would be defective if we omitted mention of the numerous proofs of hospitality we experienced on all sides. Invitations were repeatedly received from the Convent (Government House), as well as from private families, and everywhere we experienced the most cordial reception.

We must in particular mention a visit paid to Captain Warden, the superintendent of the station and arsenal, as it afforded an opportunity of becoming acquainted with a feature in the English naval service, as practical as it is worthy of imitation. The superintendent of the arsenal inhabits a beautiful roomy house, belonging to the Government, situated in a large garden, well planted with splendid plane-trees, laurel, and orangetrees, and ornamented with most beautiful and odoriferous flowers. As a superintendent's income would not admit the outlay necessary properly to furnish so large an edifice, 
this is done by contractors, who let out the furniture at the rate of five per cent. annually on the value. This sum is deducted monthly from the pay. The same system is also adopted on board English men-of-war. The cabins of the officers are there furnished and provided with all the requisite comforts by contractors under the superintendence of the Admiralty. The value of each article is marked in a printed list deposited with the authorities. The captain pays a yearly rate of five per cent. on the valuation, and binds himself besides, in the event of the ship's being paid off, or of being appointed to another vessel, to return in good condition all the articles specified, and pay the value noted in the list for everything missing. This agreement is registered at the Admiralty, and the contractor receives the amount monthly. The advantage of such an arrangement to the commander of a ship will be more fully appreciated by those who, from personal experience, are aware of the expense attending an outfit, and the great loss which an officer transferred from one ship to another suffers through a sudden and forced sale of his property. The commander of a ship is moreover often not in a condition to spend for his personal outfit a sum of perhaps a thousand pounds sterling, but he can conveniently pay annually from $£ 40$ to $£ 50$ for the hire in monthly instalments; and it thus becomes easier for him to maintain the appearance due to his position.

The commander and officers of the Caroline, which, after an absence since the 12th of May, had rejoined us on the 
23rd, were, like ourselves, received in the kindest manner by all the authorities of Gibraltar.

It had been arranged that we should make the voyage to Madeira in company with the Caroline, but an unexpected ineident prevented it. The small-pox* made its appearance on board, and although in a mild form and in but a few cases, yet it was sufficiently alarming to interrupt, as a matter

* As there has lately been some difference amongst the medical men of Europe as to the utility of vaccination, the following observations from the report of Dr. Wawra, the principal physician on board the Curotine, regarding the appearance and the course of this epidemic, may not be ont of place:- "A day before our departure from Trieste a man complained of a slight fever and headache, and his skin was corered with spots which were judged at once to be indications of an approaching eruption of small-pox. The man was immediately sent on shore as a matter of precaution; but, nevertheless, eight days after our departure we had a second, and ten days after that a third case: the epidemic was on board, and though in a mild form, yet serious consequences were apprehended. The re-vaccination of the men was therefore decided upon, and carried out, as far as the virus on board would admit. Only five individuals of the whole had not been vaccinated at all; some had undergone the operation in their childhood, a great part of them, however, had been vaccinated on board other vessels, from two to five years before. Only fourteen cases occurred. Most remarkable, and evidently in favour of those who advocate re-vaccination, is the fact, that amongst most of those who had been vaccinated in their childhood, the disorder was more severe than among those who had been re-vaccinated on board the ship. Among those who had never undergone the operation before, the vaccination on board was most successful; not one of them caught the disorder. Among the re-vaccinated only four cases oceurred, with slighter symptoms than among those who had been once only operated upon. We met with several instances of the kind at other places where we touched. At Buenos Ayres, where the vaccination laws are stricter than anywhere else, the small-pox is extremely rare. Among the Brazilians, who entertain an absolute prejudice against vaccination, the variola is one of the most common and most frightful diseases. It prevails still worse amongst the negro slaves, among whom, from the ignorance and prejudice of their masters, vaccination is neglected. The white marks of the disease are particularly visible in the black skin, and are evident proofs how virulently it has raged amongst them." 
of precaution, all communication, and to postpone indefinitely her departure, as a great part of the crew might be overtaken with the disease whilst at sea, exposed to sudden changes of temperature, thereby causing the most serious consequences. Such is not the case with diseases which are in some degree localized, as cholera, yellow fever, dysentery, \&c., when it is even prudent to set sail, notwithstanding the presence of the malady, as a change of place and climate is frequently accompanied with beneficial results.

After we had got through our duties at Gibraltar, an attempt was made, with the first favourable wind, to set sail anḍ reach the Atlantic; the Caroline remaining behind for the benefit of the sick on board. She was to follow only when the health of the erew no longer excited any apprehension.

On the 30th May the wind changed to south, and as the current in the harbour was also favourable, we weighed anchor in the hope that in the Straits we might meet with an easterly wind. The Novara passed the Caroline, which saluted with a round of cheers, when we tacked to clear the roads, after which all sail was hoisted to beat out against the western current in the Straits. The sea was covered with a mucous substance, which generally indicates that there is scarcely a chance of a fresh breeze; however, even the little we had, would have sufficed to carry us through the Straits, but towards 6 P.x. a perfect calm overtook us, and notwithstanding the press of sail, we were carried back towards the Last, and about midnight found ourselves again in the Medi. 
terranean, which did not seem disposed to part with us. There was no improvement next day, and at sunset we were exactly twenty-five miles east from the point we had occupied the preceding day. The clouds passed from West to East across the moon, and in the night from the 31st of May to the 1st of June the westerly wind became so fresh that we had even to reef the sails.

Current, wind, sea, everything was against us; cven tacking was of no service, as we lost ground visibly with each tack. When at last all hope of making the West had disappeared, we anchored, like many others of our companions in sorrow, on the 1st June, at 6 P.r., in the Bay of Frangerola, fifteen miles north of Malaga.

Here were anchored nearly sixty merchantmen, all windbound. Behind the Punta Molinos, near Malaga, there must have been quite as many more. Fresh additions were constantly being made to the already considerable fleet, which had inviuntarily collected together, whilst those merchantmen which with fruitless obstinacy kept on tacking about us, were getting more and more out of their course, as with every successive hour their position was changed for the worse.

In the hope of a favourable wind we were all a-taunto on the 2nd June, perfectly prepared for a start. Under these circumstances no one could go on shore, but an officer was despatched in a boat to make inquiries as to whether there were any sanitary board in the neighbouring village. A relative of the President of the Junta de la Sanidad came 
on board, and stated that, though as a rule only vessels clearing from Spanish harbours were permitted to have intercourse with the shore, an exception should be made in favour of ourselves. This Andalusian was very communicative, and amongst other things told us that the inhabitants werc supported almost entirely by fishing. Many ships had now been waiting several weeks for a favourable wind to pass the Straits. Some had thrice attempted to sail towards the West, but in every case were driven back by wind and current. In 1847, a year of scarcity, Louis Philippe had caused several French steamers to be stationed in the Straits in order to take in tow ships coming from the Black Sea laden with grain, and thereby to facilitate their passage between the Mediterranean and the Atlantic. In the afternoon we had a visit from about thirty inbabitants of Frangerola, who came on board in fishing-boats to view the

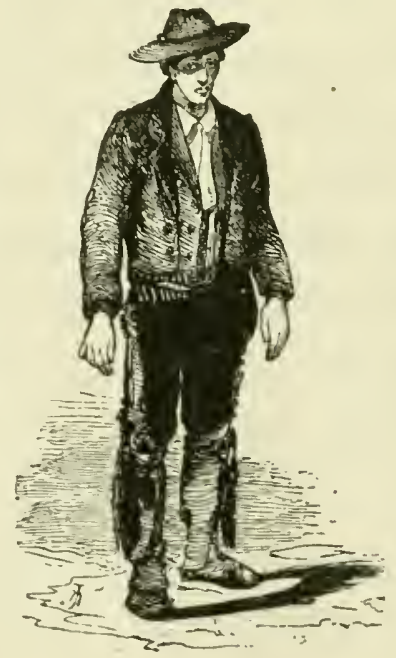


ship. None of these people had ever seen so large a manof-war, and they all therefore regarded the ship with great curriosity. The ship's band greatly delighted them, but the signal-gun at sunset secmed to terrify them and to hasten their departure.

In the evening we felt from time to time some warm blasts of wind from the east, and enjoyed for nearly an hour the delightful spectacle of a "Fata Morgana." This phenomenon, as is well known, arises from two currents of air of a different density, separated by a distinctly-formed plane, generally produced when the temperature of the two currents happens to vary. When, for instance, as is frequently the case at sea, a considerably warmer current of air comes suddenly in contact with a colder current having a lower position, the plane of separation of the former becomes condensed, and forms a mirror for all those objects which are in the lower current, so that their image is inversely reflected. As this surface of separation is not level throughout, various contractions and distortions result, which impart to the whole a singular appearance. On land, as for instance in the deserts of Africa, where the warmer current of air is on the surface of the ground, the aërial mirror is formed bencath the eye of the observer, by which the same phenomenon is produced that results from the reflection of objects on the surface of the water.

In the present case the temperature of the atmosphere was about ten degrees higher than that of the sea's surface at the 
point of observation. The surface of the current of warm air appeared like a light fog, inclining in the East towards the Spanish coast, and in the South-east to South towards the surface of the sea. Where it was highest it reached nearly five degrees above the horizon. The images of the ships at anchor near Malaga, and those at sea under sail, appeared reversed, and assumed curiously fantastic forms, particularly in those places where the reflecting surface became irregular, and inclined towards the horizon. The appearance of these distorted ships in the air, joining in the most singular way the real ones actually floating on the sea,- - the warm vapour which is from time to time wafted on the face of the observer, as well as the perfect and almost death-like stillness which, under such circumstances, prevails both on the sea and in the atmosphere, may easily produce the belief in a mysterious power, among a people who are generally prone to ascribe to supernatural agencies every phenomenon they cannot understand or explain.

This "Fata Morgana" * was not merely interesting in itself, but also gave reason to indulge in the hope of a favourable wind. A light easterly brecze accordingly sprang up towards midnight, the current became reversed, the anchor was weighed, and all sail made with this favourable wind towards Gibraltar, the rock of which was distinctly recognizable through the misty air, at a distance of nearly sixty miles.

* The namo Morgana is of Breton origin, and signifies "sea woman," from mor, sea, and yan, a time woman; - the fairy mermaid of English legentary tales. 
A calm still prevailed near Europa Point, but as the day wore on, the easterly breeze blew strong through the Straits, and, in company with innumerable other ships, the Pillars of Hercules were at length passed. The wind freshened, and the frigate cracked merrily on down mid-channel; for, though the set of the current was dead against us, yet the wind proved more than a match for it, which in our case was the more apparent, that those merchantmen which sailed along the coast, not having the advantage of this wind, seemed as though left motionless in the rear.

When towards noon the Novar $\alpha$ was off the place where the Caroline had been anchored, that ship was no longer visible. She had probably set sail in the morning. We supposed her to be among the crowd of ships which were sailing in the fog, but did not discover her, even after we had overtaken and examined all of them. We now endeavoured to reach the Atlantic as speedily as possible, making from nine to ten knots an hour, and, with joyful sensations, sailed through those beautiful straits, on whose shores the ancient world unrolled its grand panorama, thanking Providence here, at the entrance of that vast ocean, which now shone so brilliantly, that we were permitted to carry the Austrian flag into distant regions.

At 4 P.M., aided by the fresh evening breeze, we passed the most southerly point of Europe. We were just going to dinner when the last glimpse of the old world passed before the cabin windows, and we gazed once more with sorrowing 
eyes at the rapidly-disappearing coast, which, illuminated by the rays of the setting sun, seemed to wave us a last farewell in letters of fire. However beautiful, however inspiring the prospect of our task; however inviting the magnificent ocean that lay extended under our eyes, magically lit up by the silvery beams of the bright moon shining from a starry sky, yet the painful sensations of parting with that old world, with which so many pleasing associations-so many cherished recollections were bound up, had a powerful influence, and gave rise to melancholy impressions, of which we were only relieved by the comforting hope that we should one day return to all so dear to us.

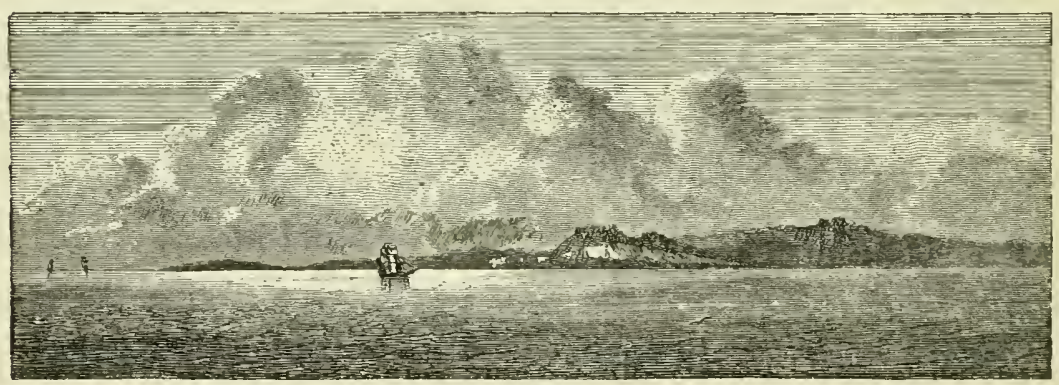

The night was delightful. Not a single cloud obscured the sky, and the ship, with all sails swelled by a fair wind, ploughed the dark waves, leaving a glittering track behind. We were now on the ocean! Below, blue, foam-crested billows; above, the sky studded with stars; - below, the wide desert of the sea; above, the infallible guides to lead us safely through it.

We awoke to new activity on that great element, which 
conceals so many charms and so many hardships, where the continued alternations of hope and fear, of enjoyment and privation - where weariness and disappointment, and yet again the new strength imparted by returning success -so excitingly animate, and so gloriously manifest the innate power of the human mind.

Life on board, the various excitements at sea, the different countries and people seen during a voyage, all tend to arouse feelings and sensations which are reserved for the mariner alone, and which render his life, if he knows how to use it properly, happy and most enviable. At sea the mental and physical eye gains strength, man there seeks to unravel Nature in all her phases, and to know and to admire more thoroughly her works. The seaman owes his energy, his straightforwardness, and his piety, to a life spent in the midst of nature, to his direct intercourse with creation. Between him and the Sovereign of the Universe there is, as it were, no mediator-he lives and labours uninterruptedly on the steps of the throne of his Creator and Preserver. In this great temple he directs to Him alone his complaints, his thanks, and his prayers. At sea he learns law and order from Nature herself in her constantlyrecurring functions; here he admires the omnipotence and goodness of God in the sunrise after a stormy night, and in the brightness of the moon that lights up his path; here he learns by his actual experience the truth of that maxim of life, that "God only helps him who helps himself." 
The wind, hitherto easterly, chopped round to the Northeast, which, according to Maury's excellent directions and charts, may be considered as a trade wind, and in this season might be called so. In fact, the trade winds are produced by a current of air, which is directed towards the Equator, and only in consequence of the earth's motion round its axis acquires a north-easterly direction to the north of the equator, and a south-easterly to the south of it. But the trade winds become perceptible at a certain distance from the equator, or rather from the hottest zone of the earth's surface; and it is clear, that when the zone assumes a greater breadth, the boundary of the trade winds is extended further towards the poles, as the pasition of this zone and its heat obtained from the sun are the eauses of these phenomena.

This is exactly the case in these waters; Africa, with its sandy deserts, presents a broader zone of the greatest heat than is possible on the sea, and the trade winds, accordingly, reach further towards the north. Its direction, however, cannot always be north-easterly, and depends necessarily on the direction of the northern boundaries of this zone of greatest heat. Accordingly, we at first had a more northerly wind, which in our progress towards Madeira became much more easterly. The weather continued on the whole beautiful, the sea was calm, and only the increased length of the waves showed the greater expanse of water we were now navigating. 
We overtook some other ships, which were sailing towards the west. As we saw nothing of the Caroline, we concluded that she was considerably ahead. The current, which near Gibraltar has a westerly direction, tending towards the Mediterranean, loses its power at a distance from the land, and half-way to Madeira it changes its direction in such a way that the ship is carried imperceptibly southwards, though only a few miles a-day. This current is a lateral branch of the great Gulf Stream, which from the Gulf of Mexico is directed towards England, but about the latitude of New York sends off a branch in a south-easterly direction, which passes round Madeira, and, near the Canaries, takes a parallel direction with the coast of Africa and forms the commencement of the Guinea current. The temperature of the sea water, which in the midst of this current is generally rather higher than that of the air, indicates to the mariner that he is in the Stream, and he must take care that his ship is not carried more to the south out of its course than he wishes. This shows clearly of what importance ocean-currents are to navigation; and it becomes evident that it is the duty of the scientific navigator not only to find out their direction and strength, but to use all means at his command, in order to ascertain their general movement in given districts of ocean.

For this latter purpose, it is customary (as often as circumstances seem to render it advisable) to throw overboard, and commit to the mercy of these currents, a well-corked empty bottle, in which has been deposited a card with the name and position of the ship. The bottle thus prepared, and made 
conspicuous by a covering of white linen cloth, or some such material, wanders hither and thither with the current, until it is picked up by some other ship, or is stranded anywhere on terra firma. The fact of such a bottle having been picked up is usually published, together with the particulars enclosed, by means of which it is obvious that an estimate can be formed of the average strength and direction of the current.

At 1 P.M. each afternoon, it was our custom to despatch one of these ocean-posts, under given conditions; but only rarely did we afterwards receive any information with respect to them. In each bottle was placed a card with the following particulars, written in German, English, French, Italian, and Spanish :-

"H.I.M. frigate, Novara, such and such a day of the week and month, hour at which thrown overboard, Longitude from Greenwich, Latitude. Whoever finds this bottle, which is about being thrown overboard well-corked and in good order, is requested to forward for publication, to the nearest spot at which there is a newspaper, the day, hour, latitude and longitude, in which the bottle has been found, together with the particulars of a similar nature already enclosed."

On the 7 th June, towards evening, we were not more than 55 nautical miles distant from the E. point of Madeira, and as the wind was favourable and pretty fresh, it became necessary to shorten sail, so as to reach the anchorage by daybreak.

About 2.30 A.M., a vessel was perceived, which, by its lights, was made out to be a man-of-war. We now burned a port fire 
which was not merely replied to, but accompanied by signalling the number of the Caroline. She was steering exactly our own course, and after having had to struggle with calms on nearing the coast, we cast anchor together, in the roads of Funchal, in 32 fathoms, sandy bottom, immediately South of the Loo Rock, a singular-looking, lofty, conical rock, which marks the best anchorage for large ships. The U. S. corvette, Dale, lay in our vicinity, and sent a boat on board with an officer to extend to us the usual greetings, after which she saluted the Commodore's standard with a salute of thirteen guns, ${ }^{*}$ which, as is the etiquette, we returned, gun for gun. We now had the pleasure of hearing that the small-pox had entirely disappeared on board the corvettc Caroline, those attacked being now in a fair way of convalescence, while on board the Novara, the health of the ship's company was eminently satisfactory.

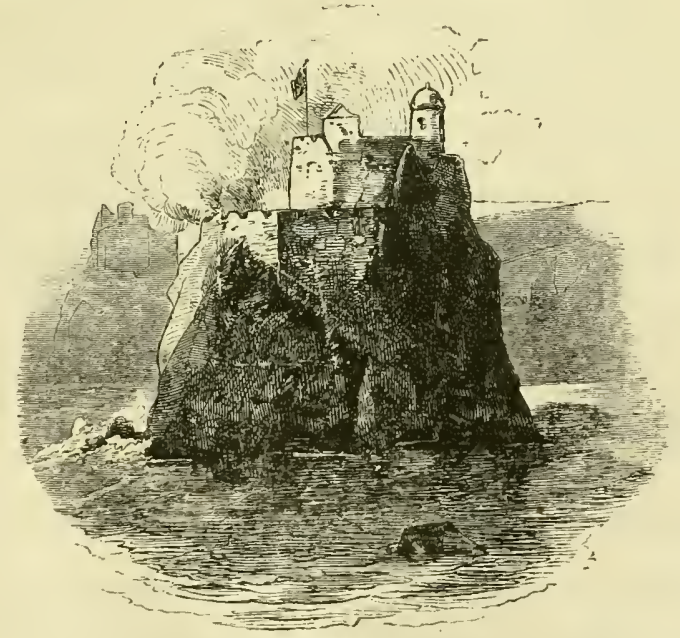

* Commorlores of other nations receive only eleven "guns by way of salute. 


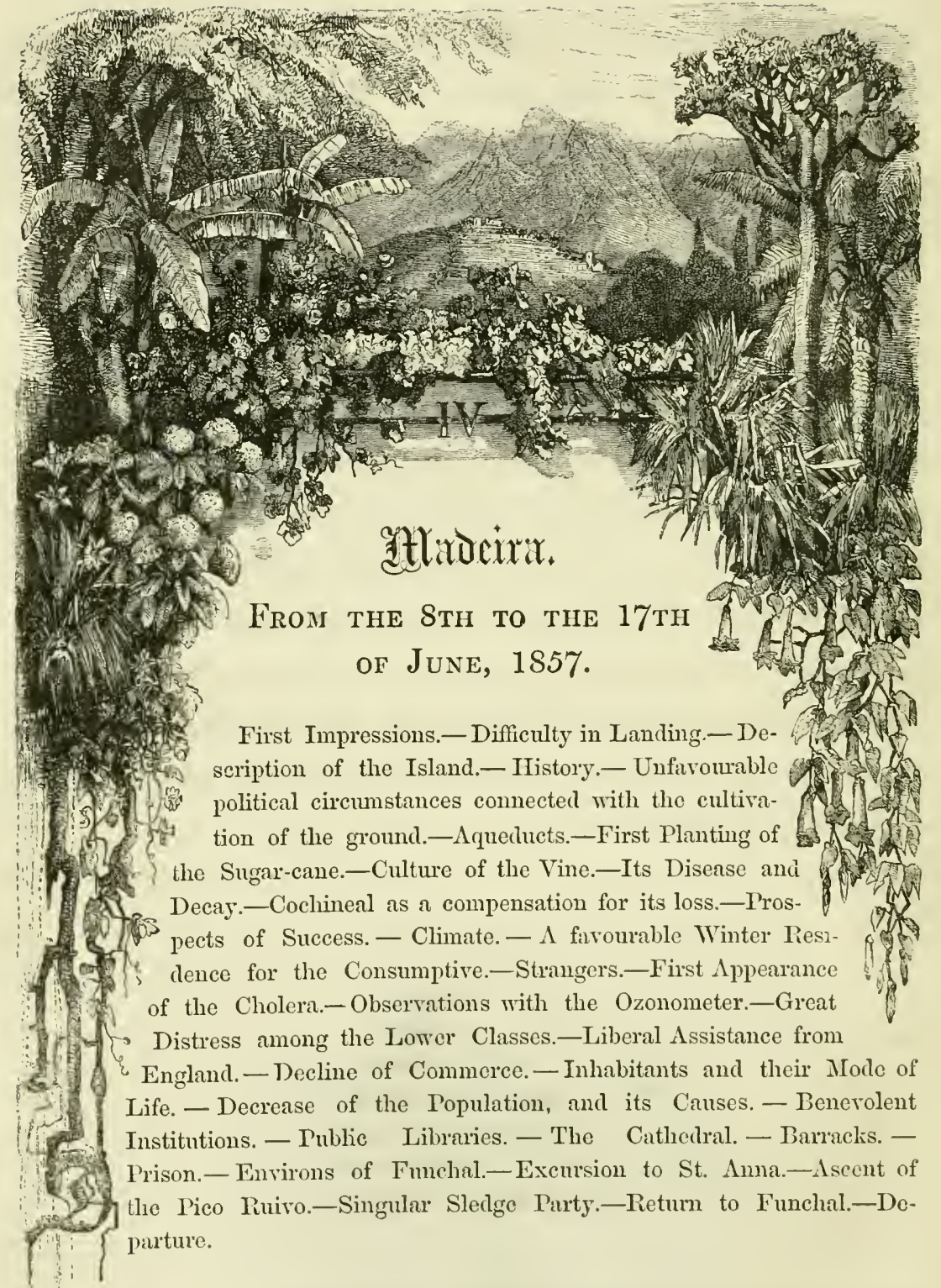

Delightful and striking is the first impression of Funchal, its luxuriant gardens smiling with gorgeous flowers, and its mountain sides cultivated almost to their summits; and although 
the grander and more gigantic forms of truc tropical vegetation are wanting, and the landscape displays rather the character of an island off the shores of Italy than of the torrid zonestill Nature exlibits herself here with such varied charms that imagination can scarcely conceive a swecter or lovelier scene. The most beautiful plants of the temperate and subtropical zones meet here in their highest development, whilst some representatives of the tropics intermixed enhance the richness of the wonderful picture. Odoriferous magnolias, large flowering tulip trees, plane trees, laurels, myrtles, acacias, passion and trumpet flowers, tree-like fuchsias with immense blossoms, gaudy hortensias, sweet-smelling roses, blooming oleanders, aloes, .40 feet high, in full flower, imposing camellias with shining green foliage, covered with beautiful rose-like flowers, chestnut trees, Brazilian pincs, cypresses-all delight the eye, together with pomegranates, tamarinds, bananas, sugar-canes, coffeeshrubs, gigantic dragon trees, pine-apples, mangroves, papayas, and aquacatés. Certainly, at a later date, we met in the primitive forests of the Nicobar islands, or in Java, Luzon, and the Caroline islands, with grander and more imposing scenery; but none that surpassed in fragrance, luxuriance, and loveliness the floral beauty of Madeira.

The anchorage of Funchal* is merely an open, exceedingly unsafe roadstead, which affords so little protection to

* The Portuguese for fennel-field, because the first discoverers of the island found this plant in great abundance. 
ships that often in southerly winds they are obliged to get under sail. This is especially the case in the winter, when the sea often rushes into the small unprotected bay with fearful violence. In October, 1842, five vessels were cast on shore within the space of a few hours, and another sank whilst at anchor; a similar violent gale from the south raged in December, 1848, when a like number of ships met with the same fate, and were dashed to pieces. The British sloop of war Daphne only escaped by making the open sea in time. In order to run less risk of being surprised by such gales, sailing vessels generally cast anchor to the south of the Loo Rock, where there is tolerably safe anchorage at a depth of twenty-five to thirty fathoms. In that position they are clear of the rocky headlands, and can therefore more easily set sail before the sea rushes in with all its irresistible violence. Steamers, which are better able to resist the force of the waves than sailing vessels, generally cast anchor nearer the shore, so that passengers may be more easily landed, and coals shipped with greater facility.

The Portuguese Government has done nothing to compensate for the shortcomings of nature with regard to safe landing-places in this island, otherwise so highly favoured. Though the rocky condition of the Funchal roads, (the only anchorage for larger ships which the island possesses, ) offers sufficient means for the construction of a harbour for boats and small vessels, yet the Government has hitherto done so little, that the landing of passengers can only be effected 


\section{Rigorous Custom-house Formalities.}

by small, peculiarly-built boats, which, whilst tossed by the waves, have to be drawn on shore by the natives wading kneedeep in the water. If, therefore, the ship remains any length of time at Funchal, the communication with the land is attended with considerable expense. We laid out, in payments to the boatmen, during a stay of nine days, the sum of forty-fire Spanish piastres* ( $£ 9$ 15s. sterling), although they had not over-charged us.

The formalities at the custom-house, which strangers-even those belonging to a ship-of-war of a friendly Power-have to go through, are extremely annoying, and entail a great loss of time. Before landing, passengers' boats are boarded in the open roads by officers, who are stationed a few cable lengths from the shore. On landing, the stranger is obliged to repair to the custom-house, where even small and open packages are subjected to a second rigid examination. The time lost during this process, unnecessarily minute, is exceedingly unpleasant. The reason assigned for these vexatious regulations is the extent to which, of late, smuggling has been carried on in the island, and which, in the opinion of the Governor, required these measures of precaution. It seems, however, that this system rather promotes contraband trading, by making it very lucrative. The Austrian consul, Charles Bianchi, Esq., did all in his power to diminish the frequency of the continual examinations, and likewise, in all other respects, endeavoured to promote the objects of the Expedition. 
The greatest length of the island of Madeira, from Ponta Furado in the east, to Ponta do Pargo, in the west, amounts to 30 miles; its greatest breadth, from Ponta do Cruz in the south, to Ponta do Saõ Jorge in the north, is $12 \frac{1}{2}$ miles, and its area is about 240 square miles. This volcanic and mountainous island is intersected by innumerable deep ravines and defiles, and its whole surface is so much broken and irregular, that the representation Columbus once gave to Queen Isabella, of the Island of Jamaica, when she asked him for a description of its configuration, might perfectly be applied to the aspect of Madeira also. The great navigator, after having crushed a sheet of paper in his hand, and partly opened it again, placed it on the table, saying, he could convey to Her Majesty no clearer idea of that island than that crumpled piece of paper afforded.

A large portion of the island is not susceptible of cultivation; for the heathy region which constitutes nearly one-third of its surface, and rises to a height of about 2500 feet above the level of the sea, is extremely steep, and too much exposed to winds and rains in summer, to admit of any kind of cultivation, even that of grain; whilst another not less considerable tract is too rocky and precipitous for that purpose. In the south of the island, the highest limit of cultivation is estimated to be at a height of 2500 feet, though in several places rye and barley grow at 2800 feet. In the north of the island, where a better system of irrigation prevails, the extreme boundary of cultivation reaches a higher altitude, 
and on the declivities of the Ribeiro Frio, it is met with at an elevation of above 3000 feet.

The earlier history of the island has had such a great influence upon its present industrial and social condition, that a few remarks on the most important features of its history may find a place bere.

Madeira was discovered in 1419, by two Portuguese, Joaõ Gonsalvo da Camara* and Tristaõ Teixeira, and, about 14,21, a colony of Europeans settled on the island. Camara obtained, as a gift for his discovery, the south-eastern, and Teixeira the north-eastern part of the island, together with the most extensive powers and privileges. Funchal was then the principal place of Camara's territory, and Machico that of 'Teixeira's. These two recipients (donatarios) enjoyed the exclusive privileges of erecting flour and saw mills; they alone were allowed to build ovens for public baking (private baking being permitted to all); they, moreover, had the monopoly of trading in salt, had claims upon the tithes of the royal revenues, and were empowered to grant portions of the land to settlers. Every settler was required to erect within five years a house, a cottage, or barn, on his ground, and to cultivate the land. If these conditions, at the expiration of the fixed period, had not been complied with, the donor had the right of granting the land to some one else. These grants were hereditary, and lapsed to the crown, or the donors, if alive, in the event of there being no direct successors. Such ex-

$$
\text { * Vulgarly called Zargo, or the Squinter. }
$$


traordinary privileges and immunities were deemed necessary in order to reconcile the holders with the dubious character of the early settlers in the island; for, though in those times the highest families in Portugal took part in all adventurous expeditions, yet most of the settlers were taken from prison and convict hulks; and the first settlement of Madeira had much more the character of a place of banishment for criminals than that of a colony of free emigrants.

With a view to obtain more ground for cultivation, the first settlers are said to have set on fire so large a portion of the primeval forests, that they were soon unable to check the conflagration. According to old writers, the fire, particularly in the south of the island, lasted several years; and the heat is said to have been so intense, that many persons in order to escape from it, sought refuge on board the ships in the roads of Funchal.*

This act of vandalism against nature, which is confirmed by ancient and modern authors, is being avenged even at present, though centuries have passed since the deed. The cedar, once a denizen of the island, is no longer to be found; and only the ceilings of the cathedral and of old houses, which are constructed of this costly material, show the magniturle which this noble tree formerly attained in the island. Of the dragon tree (Dracana Draco), which was once the ornament of the forests of Madeira, there are at present, in the whole

* The name Mruleira, signifying in Portuguese "timber or wood," justifies the statement that the island was at one time richly wooded. 
island, only six or seven specimens in existence, which are shown as curiosities to strangers. The Til-tree (Oreodaphne foetens), the Vinhatico (Persea indica), and the Folhado (Clethra arborea), formerly the most numerous representatives of the native flora, are likewise at present very rarely to be met with, and their places are occupied by plants and trees of the temperate zone, particularly the Spanish chestnut, the fruit of which furnishes the inhabitants with food, whilst the tree itself has served hitherto in the north of the island as a support to the vine. 'The destruction of the forests has, at the same time, considerably contributed to the modification of the climate in general, and to the diminution of humidity in particular. At the date of the discovery of the island, and a long time after, the Rio Socorridos, the largest river in the island, is said to have been so deep, as to float timber from the interior to the sea; at present this river is quite insignificant, and almost dried up.

The island remained for two centuries in the possession of the direct heirs of the original owners, and when at last, from want of legal successors, these privileges lapsed, the crown granted them to other favourites; but with some restrictions. The exclusive right to corn and saw mills was then entirely abolished, and the salt monopoly with other privileges was retained by the crown. The descendants of the first settlers had in the mean time acquired considerabie property in land, whilst the cultivation of the sugar-cane, now very generally adopted, the introduction of negro slaves 
from Africa, and the foundation of large estates, contributed materially to the prosperity of the inhabitants. The ruins of many large buildings in various parts of the island are even now mute witnesses of the opulence of their former occupants.

This prosperous state of the island was, however, at the beginning of the last century, materially affected by the introduction of the so-called vinculos or entails, which, introduced under the protection and in favour of the church, were a great burden upon the land. Frequently, rich proprietors left to the church portions of their incomes in order to have masses said for the repose of their souls, and encumbered their lands with so many burdens, that only a small remainder fell to their heirs. So long as these claims were in existence the proprietors could not grant leases for a longer period than four years, nor impose fresh burdens on their lands. The union of several such vinculos was called a morgado (entailed property). Under the severe but wise administration of the Marquis of Pombal, a law was passed which forbade the future creation of morgados (unless the property yielded an income of 1200 piastres annually, and even then the special licence of the crown had to be obtained), declaring the whole system of entails "as contrary to the rights of property and the wellfounded claims of the other members of the family." The law of Dom Pedro, dated the 4th February, 1802, was still more severe, as it allowed at the same time the abolition of single entails, the value of which was below 200 Spanish 
piastres annually, as well as that of every morgado, the annual value of which did not exceed the sum of 600 piastres. As, however, a great number of these entails exceed 200 piastres, these oppressive restrictions still weigh upon fourfifths of the land, notwithstanding the above-mentioned laws. Among the creditors who still have claims, there are three nunneries (which alone, of all other similar institutions, outlived the revolution of 1821), the hospital of Funchal, and the Portuguese Government. The institution of these vinculos and morgados produced a kind of feudal dependency between the cultivator of the estates (caseiro) and the landlord or holder of the morgado. On the occasion of his marriage, or the birth of an heir to the latter, the caseiro brought presents of such fruits as his land produced; when the landlord removed from the town into the country, the caseiro carried his litter and luggage; in conversation the caseiro addressed the landlord as meu amo (my lord). The revolution of 1821 did away with many of these usages, and in various ways altered the relation between the caseiro and the landlord.

Another impediment to the improvement of agriculture, is the system of parcelling ground into small allotments, which has been continued up to the present time. The farms are in general extremely small. In the richer and more fertile parts of the island they rarely exceed an acre in extent, very often they are not half so large, and sometimes not even the tenth part of an acre. The late Conde de Carvalho, 
the proprietor of nearly one-third of the whole island, had upwards of eight thousand tenants. Supposing that this mode of farming existed in the remaining two-thirds, there would be in Madeira 24,000 farmers, caseiros or tenants; or, taking the population at 100,000 souls, nearly every fourth inhabitant would be a tenant farmer. This state of things is not to be wondered at, considering that almost every day-labourer farms a small patch of ground, the extent of which is not greater than the ordinary size of a large garden bed, on which he grows vegetables, potatoes, figs, peaches, sugarcane, and sometimes even grain.

In the north and west of the island, where agriculture has made more progress than in the south, rent is paid in money; generally, however, the system of paying in kind is still in existence, in which the harvest, (after deducting the tithe, which, at Madeira, belongs to the State and not to the church,) is divided between the landlord and the tenants. According to this principle the landlord receives half of the produce of the ground, be it grain, sugar-cane, wine, fruit or vegetables, which are brought for sale, and not consumed on the farm itself. It sometimes happens, however, that the harvest is sold in a lump, while yet on the ground. Oxen are the only animals employed in agriculture. They are diminutive and singularly unsightly, but of a very powerful breed, and furnish very good meat for the table. They are generally fed in stalls, but in the mountainous districts they graze in open pastures. There are only a few badly- 
fed sheep on the island, so that the mutton is almost unfit for consumption. Pigs and fowls are in abundance, and the rearing of poultry is gencrally the principal means of living possessed by the peasantry. What is asserted by some authors regarding wild rabbits and boars to be met with on the island, wants confirmation. The few rabbits we saw were perfectly identical with the European species (Lepus cuniculus), and lead to the supposition that rabbits as well as pigs, now found in a wild state here and there on the island, are only the progeny of those which have formerly been introduced from Europe.

The numerous open and walled water conduits (levadus), which are of considerable height, and lead to all parts of the cultivated land, are of particular importance. Each levada is placed under the superintendence of a committee, selected mostly from the landowners, who have a direct interest in them. Sometimes one person only, generally the most considerable landowner of the district, under the title of juiz da levada, is entrusted with the control of the water, and receives for his services the use of the water during twenty-four hours. The right of using these levadas is very strictly guarded, and often leads to law proceedings. Every piece of ground within a district through which such a conduit runs, is entitled to the use of the water by turns, during a certain number of hours (generally not more than twentyfour). These turns are different, according to the extent of the district, from fifteen to forty days. The distribution 
of the water is entrusted to a so-called levadeiro, who places himself at the upper end of the land through which the water is to flow, and with an hour-glass in his hand measures-a modern Saturn-the time during which the owner is entitled to the use of the beneficent element. After the expiration of the fixed period, the water is made to pass on to the ground of another proprietor. These conduits, so extremely important to the farmer, were constructed partly at the expense of the Government, and partly by the contributions of the landed proprietors. Those who have no other title may obtain the right to this privilege either by purchase or by government grant. For every twenty-four hours' use of the levadas 4.00 reis* are paid, which tax is employed to keep them in good order.

The high roads of Madeira are, with but few exceptions, in a deplorable condition. They are generally laid with small pointed stones, and at numerous places they have an inclination of from 23 to 27 degrees. Every adult male native is obliged to pay annually one Spanish piastre, or to give five days' labour for their repair. On account of the bad condition of the roads in the interior of the island, most of the natural produce is conveyed from one place to another in boats, or, as is the case with wine, is carried to the harbour in skins and casks, on the backs of the inhabitants.

The first attempt at cultivation in Madeira was the planting of sugar-canes, introduced soon after the discovery 


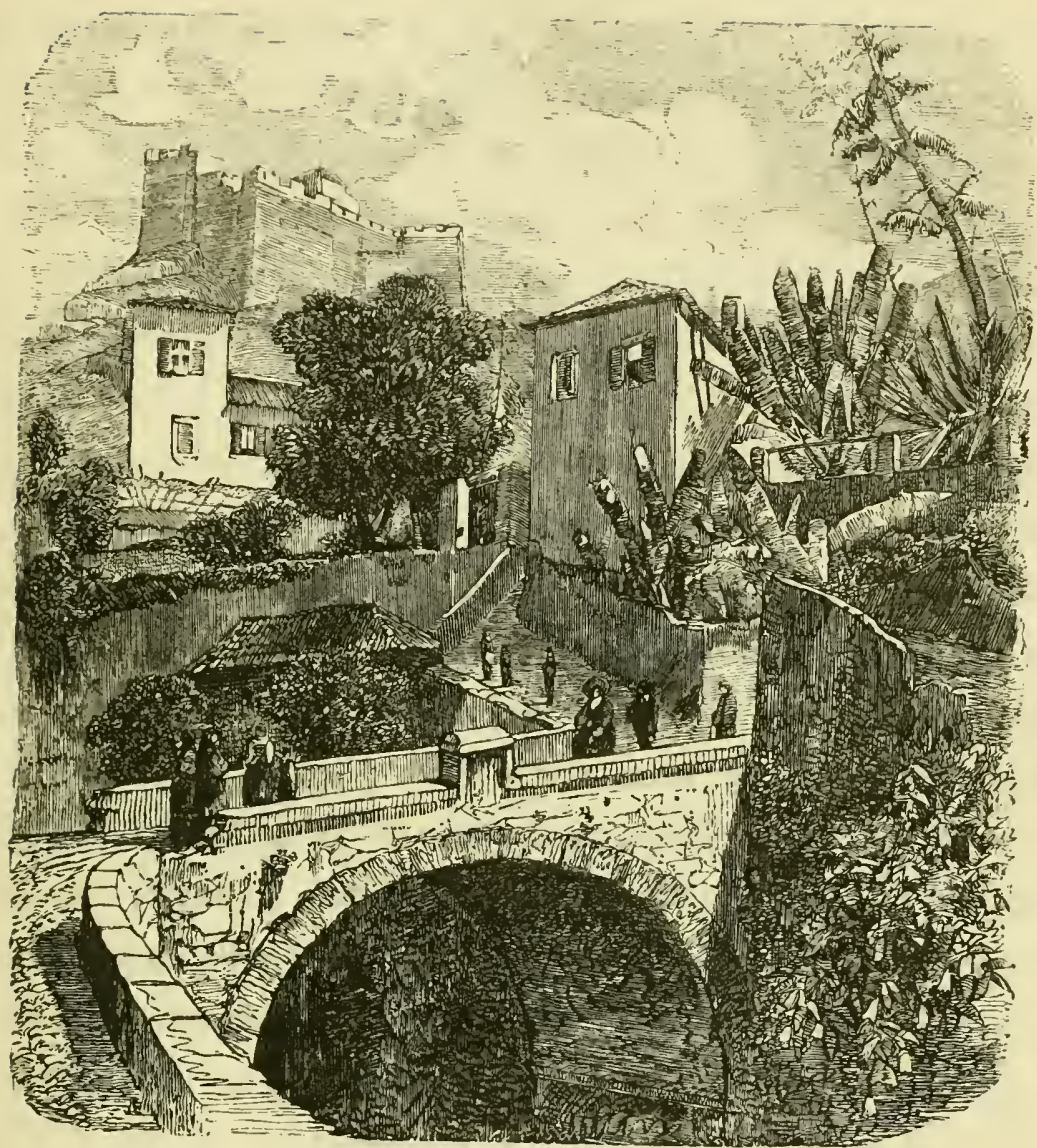

of the island, through the instrumentality of Prince Henry of Portugal (son of John I.), which grew so abundantly, that for a considerable period the produce of the island sufficed for the supply of the whole kingdom of Portugal. In commemoration of this flourishing epoch, as regards the cultivation of the sugar-cane, two sugar-loaves were introduced into the arms of the island. In the year 1452 was erected the first sugar factory, near Machica, and at the end of 
the fiftecnth century there existed as many as 120, in which slaves chiefly were employed. The Jesuit, Antonio Cordeyro, who wrote his Historia Insulana Lusitana at the beginning of last century, makes mention of a considerable number of sugar factories, which had been erected in almost every part of the south coast. On the estate of the Genoese, Juan Esmeralda, half a league from Ribeiro do Taboa, there were annually manufactured 20,000 arrobas* of sugar. By degrees, however, the culture of the cane fell, into decay, whether through disease of the plant or its cheaper production in the Brazils and West Indies is not known, so that in the year 1840, only two sugar factories were at work in the whole island; and even these only produce molasses and rum, of which the latter, in the year 1856, amounted to 1500 pipes. The cultivation of the sugar-cane, however, has increased since the vine disease has fallen so heavily on the landowner. In the summer of $185 \%$, there were eighteen factories again in activity on the island, though so late as 1855, the importation of sugar, for the consumption of the island, amounted to but 31,176 arrobas. +

The greatest elevation at which, in the south of the island, the sugar-cane can be grown, is, like that of the banana tree, about 1000 feet above the level of the sea. In the

* One arroba $=32$ arrateles or pounds. One pipe $=108$ gallons.

+ From 64 lbs. of sugar-cane are obtained 4 galls. of juice, and from 4 galls. of juice are made 8 galls. of rum. The average price was 2200 reis per gal. of sugar-juice. The rum of commeree (from 22 to 23 degrees) is sold at one Spanish piastre the gallon. 
north, the cultivation of the cane would be remunerative only at those points where, as, for instance, at Fayal and San Jorge, ground and temperature are most favourable for it. To judge by the soil and climate, the cultivation of the cane in Madeira might, with care, even at the present time, prove advantageous. In the south-west part of Lousiana, where, in 1796, this plant was introduced exclusively for the manufacture of Taffia, * there exist at present as many as 1500 sugar factories, producing annually, on an average, 200,000 hogsheads of sugar. The planter of Madeira is not, as in Lousiana, obliged by the frost to cut the cane before it is ripe; there it ripens thoroughly, blooms in January, and is harvested in March.

The motive power of the sugar-mills is mostly water and steam. There are also a dozen large distilleries at work, possessing the most modern English improvements. An acre of land, planted with sugar-cane, is said to yield from 100 to 120 Spanish piastres, a result for the landowner more profitable than that arising from the cultivation of the vine, even in its best days.

As regards the culture of cotton, for which the climate and soil are peculiarly suitable, no attempt has as yet been made. The same remark applies to olive trees; though the Government ordered the latter to be planted so long ago as 1768. The cultivation of tobacco, however, is prevented from extending, being a government monopoly. As

* A boverage resembling brandy in taste, much liked in the West Indies. 
for wheat, it is not produced in sufficient quantity to meet one quarter of the consumption of the inhabitants. In the year 1854, wheat, to the amount of 216,918 bushels, was imported from the north of Africa alone, a quantity nearly twice as great as that which the island produces. Wheat and maize, or Indian corn, are also imported from the Azores, and some ports of the Mediterranean; an importation which is likely rather to increase than decrease.

The potato belongs to that small class of vegetables which grow at considerable elevations, and, by proper irrigation and dressing of the ground, three harvests may be obtained in the course of the year.

The Inhame [not the Yam (Dioscorea alata) of the West Indies and South America, but a kind of grume (Colocasia esculenta)] grows in large quantities near to rivers and water conduits, where the ground is humid. It is much sought for by the people, on account of its cheapness, though rather a coarse kind of food, which, as Cordeyro naïvely says, "picao algum tanto na garganta" (scratches the throat).

Sweet potatoes (Convolvulus edulis, Lin.), water-melons, gourds, as well as all kinds of European garden vegetables, are found throughout the year in the market, though not of a particularly good quality. Oranges, lemons, bananas, guavas, pine-apples, figs, apricots, and peaches, are abundant during the summer season, and on higher ground even apple and pear-trees are to be met with.

On the "Desertas," three uninhabited little islands south- 
east of Madeira, and belonging to it, there grows on the rocks the orchilla (Rocella tinctoria), a species of lichen, celebrated for yielding a fine purple colour, much used in dyeing. Considering the great importance for industrial purposes of this lichen, it might, with some care, be advantageously grown in Madeira. Formerly there was a small quantity brought to market, and sold for 14,000 reis the quintal. At the present time the yield has entirely ceased, though it is found in large quantities in the neighbouring islands. It is considered not to be of such good quality as that of the Azores, where, as is the case with all lichens, that grow in more southern and warmer climates, it is of a better quality, and more highly esteemed.

The product, however, which hitherto has yielded the largest profit to the natives, and made the name of Madeira famous and familiar, even to those who do not profess a particular interest in the beauties of nature in this romantic island, is its wine. Though this article of exportation has, through the vine disease, entirely lost its former importance, yet it may be of some interest to take a glance at its history and culture, in order the better to comprehend the magnitude of the calamities that have overwhelmed the people of Madeira, in consequence of the bad vintages of the last seven years.

The vine was introduced from Cyprus, almost at the same time with the sugar-cane, under the auspices of Prince Henry of Portugal, in 1425, but its culture did not attain much 
importance till the beginning of the sixteenth century. Some authors even suppose that the wine of Madeira owes its reputation chiefly to those plants which were, at a much later date, imported by the Jesuits from Candia. This much is certain, that the produce grown on the estates of the Jesuits greatly surpassed in quality all others in the island, and maintained a higher price in the market even when those estates had changed hands. The grape ripens in the north at an elevation of 2700 feet, but such as are fitted for the manufacture of wine, grow only as high as the Curral das Freiras (2080 feet).

Hitherto four sorts of vines have been cultivated in the

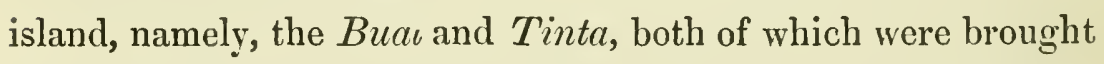
from Burgundy, the Sercial from the Rhine, and the Malvasia or Malmsey from Candia. There are four species of the lastmentioned, (candila, roxa, babosa, and propea); the delicious flavour of which by many people is considered to have a great similarity with the Hungarian Tokayer. The most esteemed sorts were grown west of Funchal, near Cama de Lobos, and Estreita. Excellent qualities were grown also at Santa Cruz, on the north side of the island, and the valleys near Ponta da Cruz; in general, however, the grape of the northern district proved to be of inferior quality, and was therefore only used in the manufacture of rum. In the north the vines were trained on chestnut trees, but in the south, as in Lombardy and the Tyrol, in festoons, supported by a kind of cane (Arundo sagittata), and tied up by 
a species of willow (Salex rubra), specially cultivater for that purpose.

Though nearly a fifth of the cultivated portion of the island was thus planted, yet the individual vineyards were but small in extent, the largest of them not exceeding three or four acres. In the wine-growing countries of Europe fresh plants are set at least every twenty years; but in Madeira they are allowed to remain in the ground so long as they yield any fruit. The native growers do not relish improvements; of all the agricultural implements which some English landowners, settled near Funchal, wished to introduce, the garden-rake alone was adopted by these enemies of innovation. The vineyards of Madeira were usually let out to farmers (caseiros), and rarely cultivated by the proprietors themselves. The yield of an acre was estimated at from one to three pipes. In 184.8 the cost of producing a pipe of Madeira amounted to from 12 to 40 Spanish piastres. In the same year the total production of the island amounted to 30,000 pipes, of which only 10,000 were exported, as the inferior sorts, not keeping well, are not suited for the foreign markets. Of the wines exported, half went to Russia and the Baltic provinces, the other, comprising the best kinds, were sent to England, the West.Indies, and the United States. Up to the year 1851, when the last good vintage occurred, the price of a pipe varied from 12 to 14 Spanish piastres. So late as 1845 , when the Danish corvette Galatea, on her voyage round the world for scientific pur- 
poses, put in at this island, the inferior sorts were so cheap that Captain Steen Bille considered it more profitable to supply the crew with wine mixed with water than beer. Since that time prices have become ten times higher, and the best quality now sells for from $£ 110$ to $£ 150$ a pipe, and will doubtless rise in proportion as the older stores are exhausted.

Though the yield of the vine had been decreasing, year after year, for a considerable time, yet the actual vine disease only made its appearance in 1852, when the leaves and fruit were covered with a kind of fungus (Ö̈dium Tuckeri), white dust. The Portuguese Government sent a eommission for the purpose of investigating the causes of the calamity. The report $t$ is not decisive on the point, whether the fungus is the real cause or only a symptom of the disease, nor does it offer any advice as to how it may be checked. Dr. Hermann Schacht, $\ddagger$ who resided during a period of 18 months in the island, and has published a valuable treatise, states that the vine-disease appears there in the same form as in Germany, even as regards the season, which is soon after the blossom disappears. At first the young leaf is covered with a whitish matter, chiefly on its lower side; it then assumes a crumpled appearance, becomes spotted,

* Vide Botanical Gazette of 1852 , page 9 ; of 1853 , page 583 ; and of 1854 , page 137 ;-Fulasne, "Sur le Champignon, qui cause la Maladic de la Vigne."Comptes Rendus, vol. xxvii. 1853;-Dr. Schacht on Madeira, pages 52 to 58.

+ Memoria primero sobre a mangra e doenza das vinhas nas ilhas da Madeira e Porto Santo, por Joao de Andrade Corvo. Lisbon. 1854.

+ Madeira und Teneriffa mit ihrer Vegetation, \&c. Vou Dr. II. Schacht. Berlin. 1859. 
and at last decays. The young diseased grape likewise becomes covered with a white dust, at first partially, and then entirely, the green skin by degrees assuming a brown colour, the grape increasing at same time in size, until it as large as a currant, or a small cherry, when it becomes black, and perishes together with its diseased stock. In this decayed condition the grapes remain on the vine till late in the autumn. Dr. Schacht was successful in arresting the progress of the disease in its earlier stages, by washing all parts of the plant with a solution consisting of one part of glue to sixteen parts of water; an operation which had been likewise performed with good effect in the Royal hothouses of Sans-souci in Prussia. He rubbed the leaves and grapes infected by the fungus with this solution, and, where possible, dipped the grapes in it. The solution very soon dried, and gave the grapes and leaves a glossy appearance. All that had once been operated upon in this way remained in a healthy condition, and even those affected by the fungus recovered beneath the crust, the operation thus seeming to afford a protection against the fungus. The practice of strewing the plant over with powdered sulphur, which was so much lauded, seems to be of little use. At Teneriffe, Dr. Schacht found the fungus widely spread, notwithstanding the application of sulphur. Keeping the grape close upon the ground is also recommended as a protection against the disease, having proved very successful in the south.

The pecuniary loss sustained since the first appearance 
of the malady amounted in the autumn of 1852 to $1,137,990$ Spanish piastres, $£ 190,000,{ }^{*}$ and after having waited in vain a period of five years, for a better state of things, the impoverished landowners entirely gave up cultivating the vine. A traveller who chances now to visit Madeira can scarcely believe that but a few years ago the greater portion of the island was covered with the plant. The cause of its disappearance must, however, not be ascribed entirely to the disease, but partly also to the utter neglect of its culture in favour of that of other products, so much so that of late it was scarcely possible to procure a sufficient quantity of grapes for invalids to whom they were medicinally prescribed. Moreover, the sugar plantations, which annually increase in extent, have contributed to the destruction of the vines, as the former require irrigation, which causes the roots of the latter to rot in the humid ground. $\dagger$

The present situation of the people of Madeira claims alike the sympathies of the philanthropist and the attention of the political economist. We here behold a population of upwards of a hundred thousand souls, deprived at once of a product, which has been for more than three centuries

* The quantity of wine produced amounted, in the year 1851, to 10,374 pipes; in the following year (1852), only to $1413 \frac{1}{2}$ pipes.

† The vine disease seems, however, to have been already prevalent in Madeira at a former period. In an old lease, referring to land or property in the west of the island, there is a clanse to the effect that "In the event of the young grape being covered with millew (mumyrit), the contract would bo null and void." In Portugal also, the disease is said to have existed more than fifty years ago, though not to a great extent. 
the principal means of obtaining their living, and by which many an industrious grower made a considerable fortune.

The farmer of Madeira, accustomed for generations to this branch of industry, is now forced to apply his energies to another, on the fortunate selection of which will depend his welfare for the future, or at least for years to come.

Some of the wealthier growers have not entirely abandoned the culture of the vine, and have been assisted in their endeavours by the Consul of the United States in Funchal, the liberal-minded Mr. Marsh; experiments were made by engrafting and setting fresh and healthy plants, brought from the banks of the Ohio. They proceeded on the principle, that it is most advisable, and likely to be productive of the best success, to obtain young plants only from countries where the disease has never appeared. The choice fell upon the Isabella and Catawba grapes, which are indigenous to the United States; and, whatever may be the final success, the merit of transplanting, at a considerable expense, these two North-American grapes to Madeira, is due to $\mathrm{Mr}$. Marsh. It is, however, a question, whether they will be able to replace those hitherto cultivated, the conditions of climate and soil being so different. As is well known, none of the European vines succeed in North America; and the two indigenous sorts, which are grown in great quantities on the banks of the Ohio and the Missouri, cannot stand a comparison with any of our finer kinds. The juice of the American grapes is best suited for the manufacture of what 
is called sparkling hock, which is very like the Austrian Schaumwein.

Some of the wealthier landowners formed an association for the purpose of introducing the culture of cochineal, to supply the place of that of the vine. Several plantations of nopal, or cactus, were laid out, and the first harrest was gathered in 1858. The nopal (Opuntia cochinillifera) is the only kind of cactus on which the cochineal insect breeds, and the south of the island, up to an elevation of 500 feet, the only part adapted for its cultivation. An attempt was made to introduce the culture of cochineal in the island by Señor Miguel de Carvalho, as far back as 1836. But the indifference of the people, and their prejudices against innovation, as well as the limited spirit of enterprise possessed by the native merchants, rendered the attempt, in that instance, abortive. In consequence, howerer, of the vine disease, the idea of cultivating cochineal was resumed, without considering, as it would appear, the probable results in a mercantile point of view. At the time of our visit there were about thirty acres of land planted with cactus, and the "seed" of the cochineal insect was expected from the Canary Islands. One cannot but think the notion of substituting the cultivation of cochineal for that of the vine was not a lucky one, the large enpital required, and the limited market for the article, holding out small chance of success. The entire consumption of cochineal in the whole world amounts to no more than about 30,000 quintals, and towards this 
quantity, Guatemala furnishes 15,000, the Canary Islands 6000, Mexico S000, Java and the Philippine Islands together 1000 quintals. There is little prospeet, therefore, that the cochineal eulture of Madeira will ever become an important source of gain, or advantageously compensate for the loss of the vine. Few landowners in the island seem to possess sufficient means to withstand the ehances and fluctuations to which its culture is subject. To illustrate this, it may be mentioned, that during our visit to the highlands of Guatemala, in 1854, when the cochineal harvest was bad, the tercio (150 lbs.) of cochineal cost 140 Spanish piastres. In the following year, when it was unusually productive, the price declined to 80 piastres. A tercio of dried cochineal costs the grower, or nopalero, about 50 piastres; a nopal plantation must lie fallow every third year, being consequently only productive during two years. Have the landowners of Madeira considered all these disadvantages, and will they be able to bear all the drawbacks peculiar to the culture of cochineal? The elimate and soil seem to hold out far greater advantages for the cultivation of the sugar-cane, coffee, cotton, and tobacco.

There are few spots on the earth's surface which possess a elimate so delightful, and so little subject to extremes as Madeira, the mean annual temperature being 64 degrees Fahrenheit, or only 5 degrees higher than in the most southern parts of Europe. The lowest temperature during five years' observation was 50 degrees, the highest, 74. An. invalid residing at Funchal, within his own doors, may always 
have a temperature not lower than 64, nor higher than 74 degrees. Violent siroccos occur in the course of the summer, which drive the thermometer up to 90 degrees in the shade; these storms, however, occur only twice or thrice a year, and rarely last longer than a couple of days. Dr. Renton, who lived in Madeira from 1825 to 1831, only once during all that time saw the thermometer marking 90 degrees, two hours after sunset. The rainy season, marked by west and southwest winds, begins at the end of September or the beginning of October. In November the weather clears up, and generally keeps fine till the end of December. At this period snow falls on the mountains, and rain at Funchal, accompanied by north-westerly winds, lasting till about the end of $\mathrm{Fe}$ bruary, during which time the weather is wet. The remainder of the year is comparatively dry, the annual fall of rain at Madeira amounting, according to Sir James Clark, " to 36 inches, there being in all about 73 wet days, $t$ whilst at Rome, for instance, it rains, on an average, during 117 days, though the amount of rain-fall is only 29 inches.

In some respects the winter is warmer at Madeira than the summer, owing to the north-westerly winds and the regular sea-

* On the Sanative Influence of the Climate of Madeira. By Sir James Clark. London. 1841.

† The fall of rain, according to Dr. Hoberdon's observations, is, on a seren years' arerage, 30.62 inches per annum. Dr. Mittermayr, from Heidelberg, states, on a three years' average, the rainy days to be 95 per year. Johnston, in his Pliysical Atlas of Natural Phenomena, states the fall of rain on an average to be 29.8: iuches, and the number of rainy days 100 per anmum, viz. 48 in the winter, 17 in the spring, 4 in the summer, and 31 in the autumu. 
breezes of that season, which keep the atmosphere continually at an even temperature; and hence the island is the favourite resort of consumptive patients during the winter season. England, which seems to possess the very unenviable privilege of furnishing to the amnual mortality in Europe the most numerous contingent of phthisical patients, provides this island likewise with the greatest number of this, the most to be pitied of all classes of patients. The climate of Madeira will, however, be of little benefit in advanced and decided cases; although it seems to have a curative effect on young people in the first stage of the malady, as well as in cases where, being hereditary, its presence is merely apprehended.

The number of strangers who annually, during the winter, resort to Madeira for the benefit of their health, amounts to from 400 to 500 , and the money thereby circulated in the island reaches the sum of about $£ 30,000$. The number of English alone in the year 1855 was 285 . But in the winter of 1856-5\%, the English invalids who came to Madeira scarcely reached 100. The reason of this was another calamity, the cholera, which suddenly made its appearance in Funchal on the 4th of July, 1856. Until this epoch, the island had been spared this devastating scourge of our time. The epidemic is said to have been introduced by a detachment of Portuguese troops, which shortly before had arrived from Lisbon, where cholera was then raging. The circumstances under which this epidemic appeared in Madeira leave little doubt of the correctness of this supposition, and 
seem to confirm the view of Professor Pettenkofer, ${ }^{*}$ relative to the importation of the disease by ships, and its propagation by human excrements, a theory advanced by this learned German physician in his famous work, with as much soundness as sagacity.

The first individuals attacked were four soldiers of the 1 st battalion of infantry, and the first who fell a victim to the epidemic was a boatman, who had landed some of the soldiers from the steamer. He was attacked on the 7th of July, at 1 P.x., and nine hours afterwards was a corpse. A few weeks later the scourge had spread over the whole island, raging with fatal severity, in consequence of the poverty, distress, and helplessness of the inhabitants. We cannot forbear mentioning a phenomenon observed at the time of the first appearance of the pestilence by Major Dom Pedro de Azevedo, one of the most distinguished men in Funchal. According to the observations regularly made by him, during two years, with reference to the quantity of ozonef contained in the atmosphere, he found that, as long as the pestilence was raging, it scarcely amounted to 2, whilst, under normal circumstances, the quantity, according to the ozonometer of Schönbein, is said to reach 6 to 7 .

* Dr. Pettenkofer's Investigations and Obserrations on the Spread of Cholera. Munich. 1855.

+ Ozone, or oxrgen in an allotropic condition, is found in more perceptible quantity in pure localities than in those where great quantities of putrescent substances are accumulated, as the ozone disappears by oxiclation. Obscrvations on the quantity of ozone contained in the air during an epidemic are, therefore, of great interest, because they may throw a light on the influences of the atmosphere in the propagation of certain diseases. 
In the beginning of October the malady gradually began to decrease, the last ease which happened on the island occurring at Funchal, on the 16th December, 1856. It appears, from official reports, that out of a population of 102,837 souls, 7041 fell victims to the epidemic; other statements, that seem not less reliable, even raise the number of fatal cases to a much larger figure. A variety of local circumstances tended to heighten the fearful violence of the epidemic: the great distress among the people, arising from the deficiency of the vintages during several years; the potato disease, which occurred in the summer of 1856 , and deprived the population, whilst suffering from other ealamities, of one of their most important means of sustenance; and finally; to bring misfortunes to a climax, even that source of gain was dried up which the people derived from the temporary residence of numerous wealthy families. Terrified by the reports which were in circulation as to the ravages caused by the cholera at Madeira, hundreds altered their original plan of passing the winter there, and even resident strangers, horror-stricken, left the island, which had been so suddenly converted from a paradise into a burial-ground. The loss arising from the latter cause is estimated at $\mathfrak{L} 20,000$, an immense sum at a time when pestilence and famine were raging so fiercely. The British Government, as well as English philanthropists in general, deserve the highest praise for the liberality with which they promptly and generously hastened to the assistance of the sufferers. Soon as intelligence of the great distress arrived 
in London, two steamers of war, the Salamander and Hesper, with provisions, medicine, clothing, bedding, and money, were despatched to Funchal, where the former arrived on the 18th and the latter on the 31st of October, 1856. This assistance essentially contributed to the rapid extinction of the epidemic, as it sufficed to relieve the more pressing wants." Considerable contributions arrived also from the United States; and, according to public statements, the relief that came from foreign countries amounted to £SS95.

The commerce of the island was, as a matter of course, seriously affected by such a train of calamities. The principal exports had hitherto consisted of wine, cattle, fruit, and wicker-work; the first and most important of these articleswine-had, as already stated, all but entirely disappeared from the list for several years, the small quantities still exported being merely the remnants of old stocks.

According to custom-house registers, the entire value of the produce exported in 1851 amounted to $£ 164,960$, of which $£ 96,950$ were shipped in English, $£ 26,500$ in American, and 16,650 in Portuguese vessels. The exports of 1855 were only $£ 95,470$, and in 1855 , when the wine export had entirely ceased, the value did not exceed $\mathfrak{E} 2400$ !

The imports were of a more numerous and varied description; calico, cotton and woollen goods, hardware, spices and provisions from England; timber, salt meat, and other articles from the

* Old chronieles report that Madeira has been visited by a pestilential disease, that raged within the years 1521 to 1535 . But the clolera was never in the island before the year 1856. The ycllow ferer is altogether unknown. 
United States; grain from the Mediterranean and the Black Sea; and sugar, coffee, oil, rice, and other colonial produce from Lisbon and the Portuguese settlements. The commerce is almost entirely in the hands of the Linglish,* whose liberality during the cholera epidemic has much raised then in the estimation of the inhabitants.

The absence of a regular banking establishment is much felt by the trading community, particularly in times of temporary distress. Singularly enough there are few Portuguese coins to be met with, and even these are not liked by the inhabitants. The moneys chiefly in circulation are English and American gold and silver coins, French five-franc pieces, and Spanish dollars. The sailing vessels in the roads of Funchal are mostly under English and American flags. The steamers which keep up the intercourse between Europe and the Brazils call regularly at Funchal for mails and passengers, $\uparrow$ and a steam-packet arrives regularly every fortnight on its way from Europe to South America.

The trade carried on under ordinary circumstances is, as we have seen, by no means inconsiderable, and by proper management might enable the people to extricate themselves from their present depressed position; but though not exactly lazy, they are entirely deficient in the energy requisite for effectively improving their condition. Whenever they have enough of yams and potatoes, they no longer think of exerting themselves or

\footnotetext{
* Three-fifths of the 50,000 tons annually imported are Eng7ish manufactures.

4 An English coal depôt has been established in Funchal since 1848.
} 
of acquiring a more comfortable or independent mode of existence. Neither in Ireland, nor in the Silesian mountains, nor even amongst the Indians in North or South America, have we witnessed such a degree of poverty and wretchedness as we beheld among the labouring elasses in the mountainous districts of this island. On entering a village, shoals of haggardlooking beggars covered with rags were seen, whose features indicated their unhealthy way of living, and an utter laek of the most common neeessaries of life. The calamities of the last five years have certainly contributed to this excess of misery, and a traveller who visited Madeira twenty years ago, may have carried away with him quite a different impression of its inhabitants.

The raee inhabiting the island, notwithstanding some favourable exceptions, is rather unprepossessing and decrepit, owing to the elements of which it is composed. The first settlers, as already stated, belonged by no means to the better classes of Portugal, but consisted of a motley assemblage of ruffians, who eame to the newly-discovered island merely in seareh of adventure. The admixture which afterwards took place with the black race imported from Africa, materially contributed to deteriorate the people both plysically and morally. Though there is not one single pure negro in the whole island, yet the features of a considerable proportion of the inliabitants denote their African descent. In the population of Punta da Sol, a village on the west side of the island, the negro type is said to be exhibited in its strongest eharacter. 
The dress of the native is extremely simple; a pair of white trowsers, a shirt, and linen jacket, constitute the entire

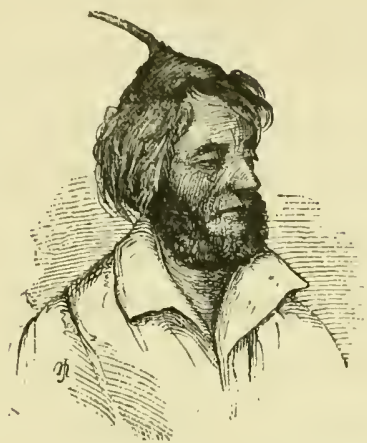

toilette; with a few rare exceptions we never saw shoes : but even the poorest of the poor wears a curiously-shaped small cloth cap (carapuça) of a blue colour, with red lining, terminating in an erect pointed tail, six inches long. This seems to be a remnant of a turbaned head-dress, worn formerly by the inhabitants of the African coast, with whom the first settlers, allured by the slave-trade, once carried on an active intercourse.

Many of the inhabitants of Funchal obtain their livelihood by acting as guides to strangers. The roads being very steep, and formed of pointed stones, horses of an excellent breed are used in going even short distances; however fast the visitors may gallop, the guide follows the horses on foot, to which the natives are habituated from their earliest years. This practice is undoubtedly one of the principal causes of consumptive complaints, which are more frequently met with here than might have been expected considering the climate, though bad nourishment and unhealthy dwellings may have their part in 
causing the prevalence of the malady. The common people are mostly lodged in small low cabins of wood or timber, thatched with straw, the only opening being the door, through which air and light are admitted. Their sleeping-places are wooden benches, covered with straw, raised only one or two feet from a ground which, during nine months of the year, is damp.

It is scarcely necessary to state that the wealthier classes offer a more pleasing aspect. They are extremely obliging, kind, and attentive towards strangers, and evidently endeavour to impress the visitor with favourable ideas of themselves and the island. To the hospitality of the Austrian Consul, as well as to Major P. A. de Azevedo and Don Juan Muniz, so deservedly celebrated for his knowledge of the flora of Madeira, the members of the Novara expedition are indebted for many a happy and delightful hour.

The population is perceptibly on the decrease. The causes are emigration to the British West Indies, and devastation by the cholera. 'The number' of inhabitants in the two islands, in 1836, amounted to 115,446; in 1854, to 103,296; and in 1855, to only 102,183. The emigrants during the last twenty-five years (1835 to 1860) are said to have amounted to 40,000 , many of whom depart secretly, in order to avoid the heavy emigration tax.

Numerous benevolent institutions indicate the charitable disposition of the inhabitants. The hospital, or Santa Casa de Misericordia, standing in a beautiful square, planted with planes and magnolias, can receive 104 patients, and is exceedingly well 
managed. It appears, however, rather singular that the surgical are separated from the medical cases, whilst no separation exists amongst the patients who may happen to be labouring under contagious diseases. The most frequently recurring diseases are cutaneous, a circumstance which need excite no surprise in a country where the natives pay so little attention to the eleanliness of their bodies, and where Government itself favours as it were this carelessness by levying a considerable tax upon the importation of soap! Dysentery prevails throughout the year; intermittent fever and inflammatory discases occur more rarely; but apoplectic cases are at times very numerous. The nominal amount of the funds of the hospital is estimated at $£ 40,000$; the annual income being about $£ 1 S 00$ sterling.

The hospital for lepers is fitted up for the reception of about forty patients, most of whom come from places in which the black has least mixed with the white race.

The workhouse, for 230 paupers, was founded in 1847 by public subscription, and has an annual income of from 3000 to 4000 piastres.

The nunnery of St. Isabel, for the reception of female orphans, was erected as early as 1726. Great care is taken of the education of the inmates, who are not permitted to leave the establishment, except in case of getting married or respectably employed.

Foundlings, of whom, in one single year, 839 were maintained by the commune of Funchal, are given out to nurse; 
and there has been a most singular expedient adopted, in order to prevent abuse as regards obtaining the board money, which amounts to about one piastre a month, for each. A piece of tape is put round the infant's neck, the two ends of which are fastened with a lead seal, and stamped, so that, in the event of death, it cannot be taken off and put on another child's neck. The witnessing of the process of fastening and stamping this necklace is most unpleasant, although no real pain is inflicted on the child.

In the year 1855 there existed in the entire island twelve elementary schools, attended by about 200 scholars, and likewise forty-nine Sunday schools, having about 2400 pupils. Funchal also possesses a college, with six professors and 120 students, an ecclesiastical seminary for twenty-four pupils, and a medical school, with four professors, which, however, during the year of our visit, had only seven students. Though the Government is very rigid in exacting the attendance of the children at school, yet only about a seventh part of the whole number living in the island really avail themselves of the benefit.

A hospital for the consumptive is now in course of erection, at the expense of the Empress dowager of the Brazils, as a memorial of her daughter, who, in 1853, died of this disease on the island.

There exist several public libraries and book societies at Funchal; and in several of the elubs a great many of the leading English, French, Spanish, Portuguese, and German journals, are to be found. Four weekly papers, in the Portuguese 
language, are published at Funchal. The first newspaper ever published there was the Patriota Funchalense, the first number of which appeared on the 2nd of June, 1821.

'The public buildings offer little to attract notice; the

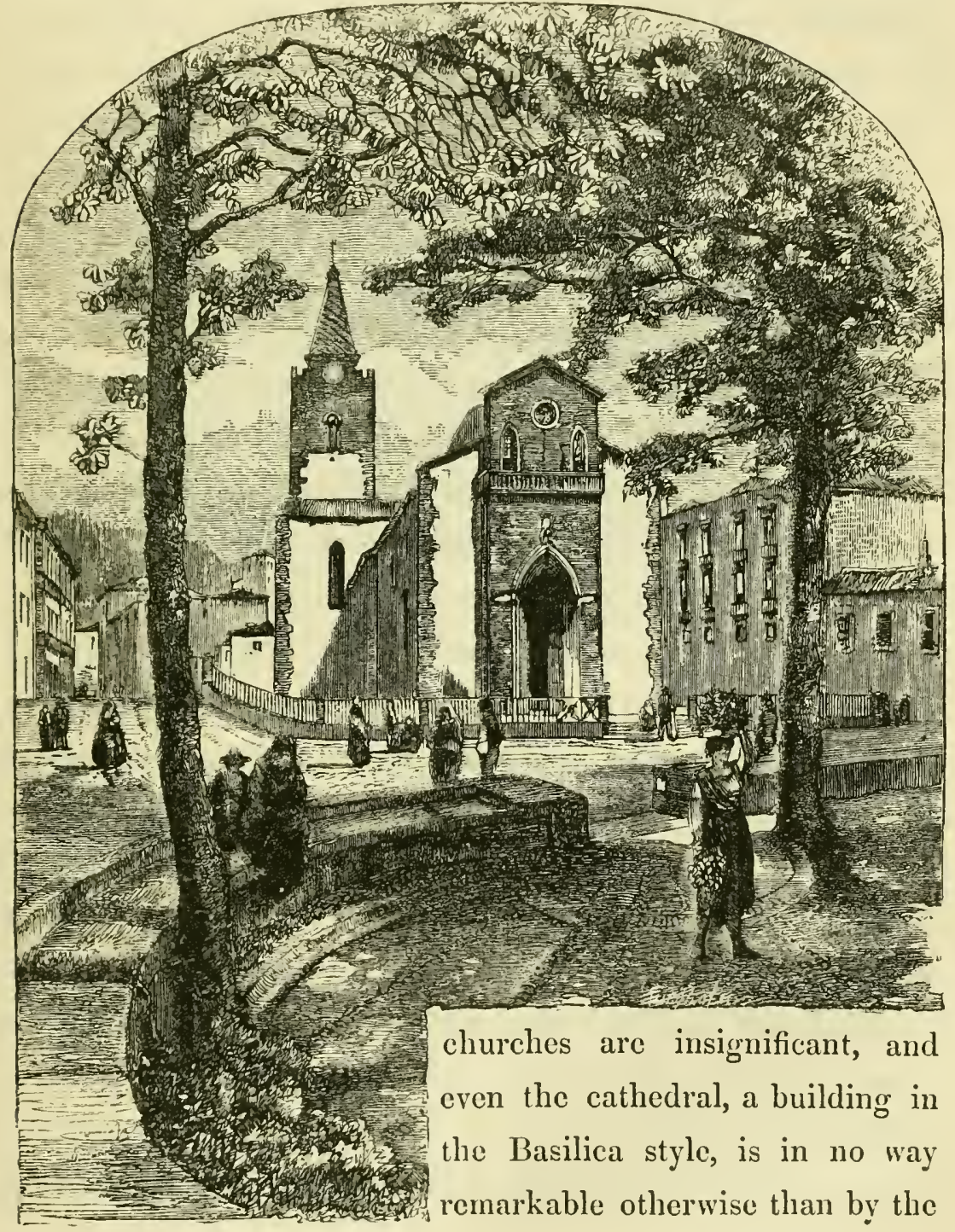


innumerable garlands and nosegays, offerings of pious derotees, which as it were transform its interior into a fragrant temple of flowers.

That which was once a Jesuit monastery, has been now converted into a barrack, in which the whole garrison of the island, amounting to $4.00 \mathrm{men}$, are lodged. The daily pay of these soldier's amounts to 20 reis, or about one penny?

An ordinary dwelling-house has lately been converted into a town gaol, in which the prisoners are very humanely treated. Passers-by may have an undisturbed talk with them through the lattice-work; and once we even obserred a man who had thrust his foot through the iron bars, in order to have his measure taken by one of the inmates for a pair of shoes!

The charms of beautiful walks, and a most enchanting neighbourhood, enhance the pleasantness of the climate of Funchal so much resorted to by invalids. In the interior of the town, not far from the sea-shore, splendid avenues of magnificent planes, large-flowered magnolias, and massive oaks, form delightful promenades, and afford repose and shade on numerous seats under the dense foliage of their wide-spreading branches.

Seated on a gently-ambling steed, one may reach most pleasantly the summits of those lofty mountains, which rise close to Funchal, where a balmy fragrance perfumes the air, and the eye roams with delight in all directions over scenery of the most striking description.

One of the favourite points from which such a view may 
be obtained in all its beauty, is the terrace in front of the church of Nossa Senhora de Monte, situated 1965 feet above the level of the sea, on a ridge of the Arrebantao mountain, reached in less than an hour by one or other of the existing conveyances; these are either horses, or hammocks and sedanchairs, or sledges, covered with tasteful canopies, and drawn by a couple of small oxen.

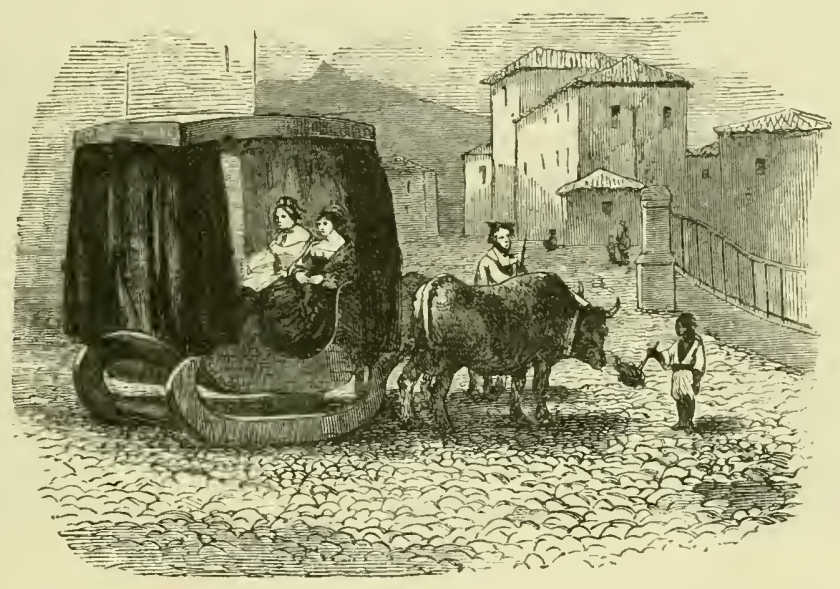

Though a vehicle, reminding one so strongly of a northern winter, appears rather odd in a climate such as that of Madeira, yet its praeticability and convenienee is very soon pereeived, when comfortably sliding away over the smooth stones of Funchal. Wheel carriages, such as used in Europe, are unknown here.

But he who has bodily strength and health enough to be able to wander through the interior of the island, will find spots which command landscapes by far more grand and sublime than that seen from Nossa Senhora de Monte. Cape 
San Lorenzo, with its petrified fauna;-the awe-inspiring Entroza pass, that wonderful sculpture of nature which bears so powerful a witness to the corroding action of water; - the lovely and solitary cascade of Rabacal;-the Pic Arrieiro, with its craggy rocks, offering to the geologist such a remarkable peep into the geognostical history of the island;-the numerous gigantic rocky skeletons of volcanic cones, on which the geologist is able to make the most interesting studies and investigations, just in the same manner as the anatomist on a corpse;-all these wonders of nature are calculated to awaken the reflection and excite the admiration of the beholder.

The most deliglitful erent during our stay in the island was an excursion of several days, made to the romantic localities of the northern coast. A stately caralcade of twentytwo horsemen set out, early on a fine June morning, from Funchal to Nossa Senhora, and from thence orer the Pic Poizo, through the glens of Metade to St. Anna. After a ride of two hours, the Casa de Abrigo was reached, a small house, situated about 4500 feet above the level of the sea, erected by the Government some years ago for the shelter of travellers. From this point the path runs through a hilly country covered with heath, from which the majestic Pico Ruivo, with the fantastic forms of its rugged rolcanic walls bathed in gold by the rays of the rising sun, presents a most imposing sight. On the whole route only one small miserable village, called Fayal, was passed, consisting of a few straw thatched huts, exhibiting a picture of poverty and wretched- 
ness, which can scarcely be paralleled in any part of the habitable globe.

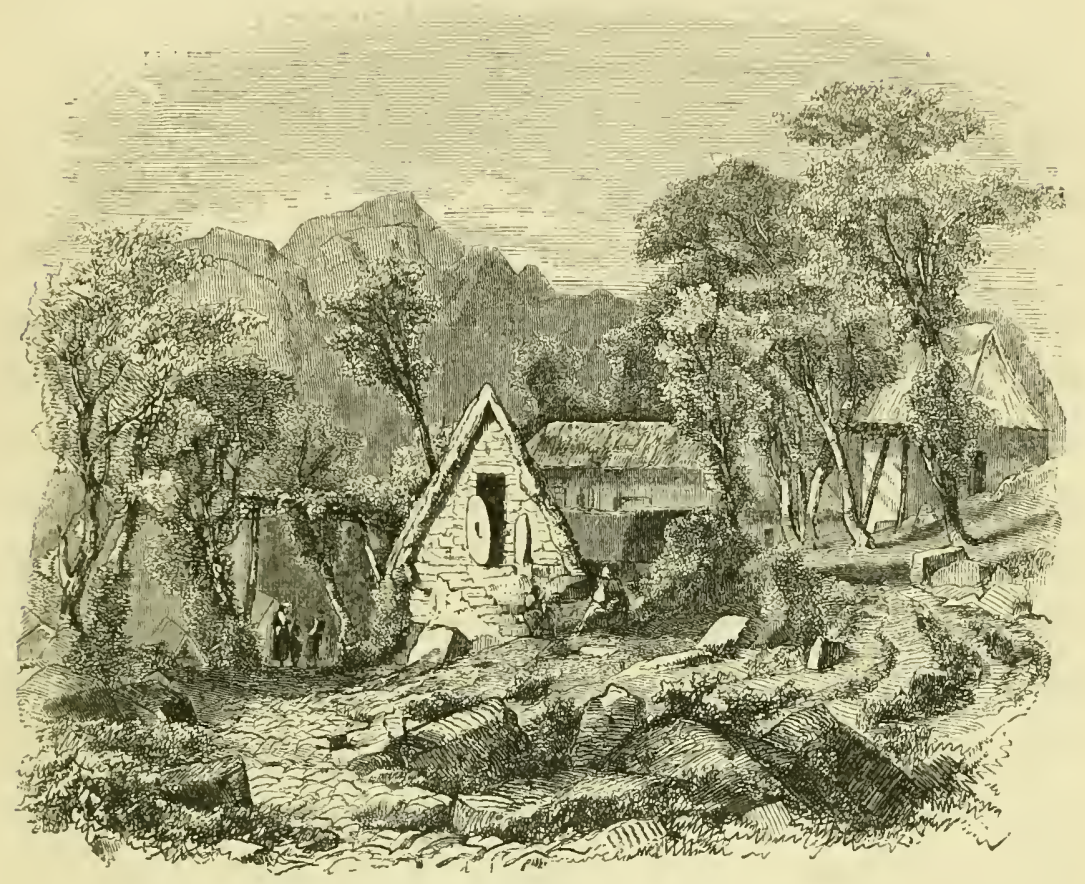

At last, after a ride of eight hours, we reached St. Anna, an extensive village, with a large church and some brick buildings prettily situated in flower-gardens, the most stately of which was-the inn. The good cheer and repose found here for a few hours of the night, compensated in some degree for the fatigues of the past day, and prepared us for those to be encountered on the morrow.

The frequent fogs prevalent in Madeira during the month of June, render it indispensable to start early in the morning, if the traveller wishes to enjoy the beauties of the scenery. 
At 2 A.Mr., therefore, our cavalcade set out, followed by a host of boys and porters carrying provisions and instruments for observations. Nature was still buried in sleep, the air quiet and motionless; the full moon, shedding her pallid light over sea and mountain, feebly shadowed forth the outlines of the hedges and bushes of roses, fuchsias, and hortensias, that lined the narrow path, and brought out dimly in faint relief the ghost-like white figures which, standing at the doors of their poor cabins, looked inquisitively at the riders, that were already so early on their way. The path led up to the mountains in steep and numerous windings, sometimes on soft ground through ravines, sometimes on solid basalt, or over the uneven surface of indurated lava. And when at last, emerging from deep glens, steep precipices, and rocky walls, all yet buried in the shades of night, the blue starspangled sky burst upon us in all its beauty and grandeur, the effect was almost overpowering. A faint glimmer of light appeared on the distant horizon, masses of vapour moved over the ocean, and rising mists gathering into clouds, undulated like the surface of an agitated sea. It was only along the ridges of mountains and through the ravines, that one might glance between mist and land down to the calm boundless expanse of water at our feet.

At 4. o'clock a halt was made near a solitary hut, called Choupana, at a height of 14.00 feet, when the horsemen dismounted, and left their horses behind, preferring to reach on foot the termination of their journey. 
We had just climbed up some steep basalt rock and reached an open spot, when the first rays of the sun tinged the eastern sky. Beaming in all his majesty on the sharply-defined clouds that hovered beneath, they sparkled like so many icecapped peaks of Alpine glaciers; and when the great luminary ascended higher, distributing mingled light and shade in such gradations of tint as only Nature's cunning hand can mingle, the chaotic masses of vapour assumed the appearance of gigantic islands and lofty towering mountains, whilst a chorus of feathered songsters rung cheerfully out from the depths of the wooded valleys. The path wound along a precipitous declivity, grown over with tangled Til-trees, past a group of basaltic columns, which rose isolated to a height of 40 feet above the beautiful grassy carpet that clothes

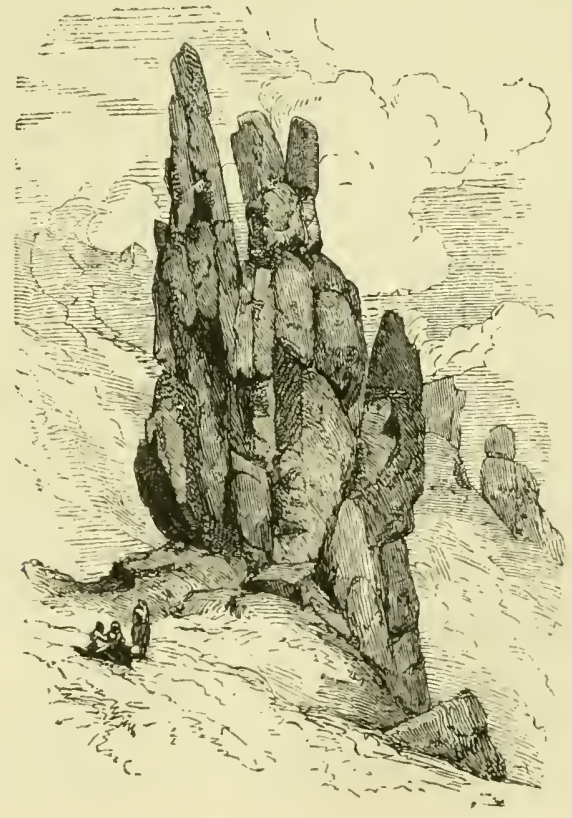


the ground, and in the crevices of which an old laurel, the last of its genus at this height, had taken root. The natives call this singularly-shaped group Homem em pé, or the man standing erect.

Arrived at an open space of meadow ground, the Barreiro, or Encumiada Caixa, a gigantic rocky ridge, suddenly rises to a prodigious height, from a frightful abyss of almost fathomless depth. We now hastened across a plain covered with lara, to the rough basaltic summit of the Encumiada Alta. Safe on an eminence* abore yawning gulfs, beneath a deep blue sky, in the brilliancy of a lovely morning sun, we abandoned ourselves to the thrilling impressions of the magnificent picture which nature here brought forth of earth, rock, and manifold regetation. Towards the south an immense mountain ridge, with serried peaks (called Torres and Torinhas), rises to a height of 6000 feet, declining almost imperceptibly on the left hand, whilst on the right it descends abruptly in terraces, with perpendicular walls of rocks 1000 feet in height, connected by an inaccessible ridge with the imposing, stupendous, cupolashaped summit of the Pico Ruivo. All this is disclosed to the eye within a radius of little more than two miles, Deep clefts and ravines run from the rocky crevices, and unite in a gloomy and profound abyss of 3000 fect, which forms the mouth of the ravine of Ribeiro Secco. Similiar chasms open to the right and to the left, and when they are too distant to be distinguished by. the eye, 
dark shadows rising on the rocky walls indicate the deep crater-like basin of the Curral, and the gulfs of the Metade river, and the Ribeiro Frio. It would seem as if the whole island has, in a series of fearful convulsions, burst from a single central point in all directions; as if entire mountains had sunk into the deep, or had, by the action of torrents permeating their crevices, been converted into rubble, and carricd as sand and fragments into the ocean.

The summits of the Torres and Torrinhas are nothing but barren naked rocks,-not a blade of grass, not a shrub, not a trace of vegetation is to be seen. At the highest points, strata nearly horizontal extend in remarkably regular layers, chiefly distinguished by the most manifold variety of colours and tints.* A dark grey schistus of volcanic ashes alternates with stronglymarked red, yellow, and violet layers of tufa, dross, and scoriæ, together with brown and grey conglomerates. Just as red predominates on the upper part of these Torres, green prevails on the lowcr. From the spot where the springs first issue out of the crevices of the basalt, everything seems covered with a dense green carpet. These are the celebrated "clefts" of Madeira, in which, even on rocks of 1000 fect high, not an inch is to be discovered bare; they afford a rich harvest to the botanist, whilst they fill the spectator with delight and admiration.

Generally speaking, the scenery of Madeira does not owe

* The celebrated American geologist, Mr. Dana, mentions that these wild contorted masses of mountain reminded him of the crater-walls of the Kilauea at the Sandwich Islands. 
its character to the grandeur or magnitude of its trees; the peculiar charm of the landscape arises more from grasses, ferns, shrubs, and different kinds of moss, all of which grow so rank and luxuriant, that the rocks, chasms, and abysses overgrown with them, appear like so many swelling cushions, or as if laid with soft velvet carpets in all directions. The different shades of green indicate the characteristics of successive zones of vegetation. Through the lower parts of the valleys run the beds of those mountain waters which, though nearly dried up in the summer, swell in the winter into torrents. Along these are scattered the straw-thatched huts of the natives, surrounded by vineyards and fields planted with rye, barley, potatoes, yams, and in the lower parts with single bananas.

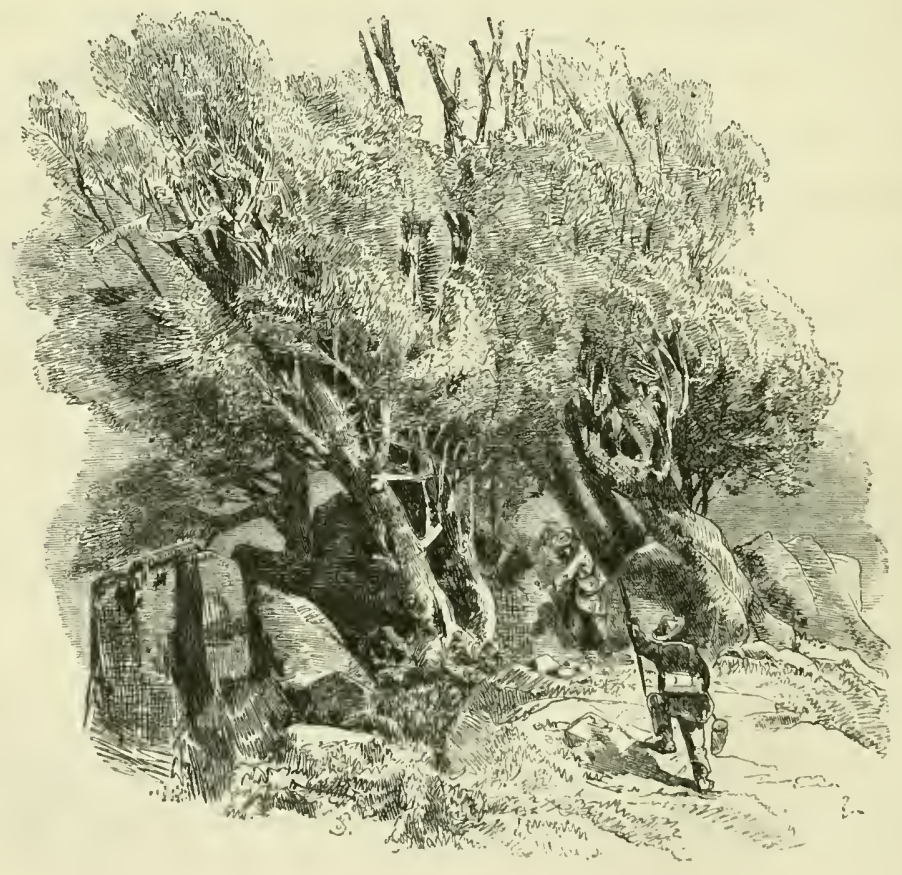


These cultivated lands rise to a height of 2000 fect, and in many places even to 3000 . Wherever on the steep declivities there is the smallest shelf to be found, eren if only a square yard in size, it is turned to account. Next to this region, in ascending, is that of the brush and laurel woods. Vaccinias (blackberries), and different kinds of heath, often attaining a growth of five or six feet, occupy the whole of the ground, and in the month of June, when the broom is in full flower, a bright golden-coloured belt girts Madeira, at a height of from 3000 to 4000 feet. We beheld this golden girdle in its richest splendour, set off by the dark masses of evergreens in the clefts. Higher up is the true region of the Erica arborea, which, with its light-green and paille tint, contrasted with the deeper colour of the laurel, represents the underwood of our secondary mountain ranges. The Erica arborea attains here the height of a large tree, and, on some spots, 30 to 40 feet of its gnarled stems stretch along the ground. Thus it may be traced, in company with other heaths, to the summit of the Pico Ruivo.

After having made some physical observations, and enjoyed a most delightful prospect, we re-packed our instruments, filled our boxes and pouches with plants and geological specimens, and prepared for our departure. The guides, despite their heavy burdens, marched steadily on, humming in plaintive cadence their native songs. We soon reached our horses, and, penetrating through layers of clouds, rapidly descended the steep mountain sides to St. Anna.

A walk on the same evening towards Porto Santo Jorge was 
not less charming than instructive, especially as we gazed on those hardened streams of lava, so interesting as regards the geological history of the island, out of the numerous crevices of which grew luxuriant magnificent rosettes of Sempervivum. Fuchsias and heliotropes were gathered from the bushes, and each took a share, now with the geological hammer, now with the botanical box, or the butterfly-catcher, in the harvest of objects of natural history. We passed in this neighbourhood several houses delightfully situated, surrounded by hedgerows of luxuriant shrubs and splendid native flowers.

In the fine garden of the inn, amidst myrtles, bignonias, euphorbias, and fuchsias, was a handsome Camellia japonica, which had attained the imposing height of 15 feet, with a diameter of 9 inches, the top spreading fan-like in numberless branches.

The following morning we returned to Funchal, accompanied by a troop of ragged and diseased natives, pertinaciously appealing to our charity. Plenteous alms were given them, for where Nature is so prodigal of her gifts, the human mind becomes more sensitive and liberal. At noon, we again reached the beautiful terrace of Nossa Senhora de Monte, and here the excursion was wound up by a diversion of quite a peculiar character; for, instead of returning to Funchal on horseback, we slid down a mountain 1500 feet high, right into the town, on small double-seated wooden sledges, thus travelling down what is probably the grandest natural Montagne Russe in the world. A train of more than a dozen sledges started at the 
same time. These singular vehicles are guided on either side with admirable adroitness by two natives, who avoid slipping by moistening their shoes; and, notwitlistanding the velocity of these conveyances, even slight accidents are unheard of. Sledge parties of this kind, being cheap, constitute the most favourite amusement of the people of Funchal.

The whole company met together once more at a convivial dinner in the hotel, where, agreeably to the custom of the country, not only the room and table, but even every single dish served up, was adorned with garlands of fragrant flowers.

On the 17th June we again weighed anchor. The intention had originally been to steer direct for Rio de Janeiro; but as wo learned, two days before our departure, that the yellow fever, though on the decrease, had not yet entirely ceased, wo were in no hurry to arrive at the capital of Brazil, and therefore determined to employ the time so gained, in investigating the nature of the winds and currents prevalent in these latitudes. For though the proper course of ships between England and North America has been admirably laid down, for nearly every month of the year, by the long-continued ingenious labours of Commander Maury, of the Washington Observatory, yet there still exists great difficulty in steering sailing vessels from Gibraltar or Madeira to South America, by the directions hitherto existing; the more so, as the seafarer in these latitudes, close to the limits of the north-east trade-wind, generally falls in with variable breezes and frequent calms, caused partly by the African coast and partly by the cluster of isles 
from the Azores to the Cape Verde Islands, and which are of still more frequent occurrence in the summer of the northern hemisphere.

We kept Madeira, or rather the clouds which, during the summer, gather daily round the mountains, a long time in view; and on the 19th, at a distance of 120 miles from the island, some persons on board thought they could still distinguish them.

We steered at first in a south-westerly direction, with light breezes and fine weather. Advancing, however, towards the limits of the trade-winds, showers became frequent, and the wind chopped about much oftener; a more southerly course was therefore taken, in order to come as soon as possible under the influence of the north-easterly trade-winds.

There was now an opportunity of directing attention to the formation of the clouds, which, in these latitudes, assume at times very curious appearances. The cirri disappeared by degrees, and the cumuli towered up on the horizon in colossal masses. These latter are formed under the influence of the sun, when most powerful, and are therefore seen chiefly during the afternoon. As soon as they rise they vanish by absorption, just as fast as they are formed by evaporation from the sea. Rain very rarely proceeds from them. The alternation of their shades, tints, and colours, is beautiful in the extreme, particularly at sunset, when their outlines, as they stand out in bold relief on the clear blue sky, vary in hue from the deepest grey to the most brilliant golden yellow. 
The nearer the tropics are approached the more does ocean teem with animated orgasms. A net cast into it was immediately filled with an immense number of little living creatures. Pretty-looking blue cockles, sea-nettles, and various other inhabitants of the deep, all of the most minute size, lay rolled up in one lump with small sea-weeds of beautiful forms and tints, from which those tiny things endeavoured, with great exertion, to extricate themselves. The microscope discloses to the observer an entirely new world in the economy of nature, as displayed in the animal life of the surface of the sea. The entire oceanic creation, from the smallest infusoria to the huge whale, are all specially adapted to the element in which they exist, and organized to contribute to the preservation, as well as the further development, of the whole globe.

This is beautifully illustrated by the operations of the zoophytes; the water of rivers dissolves the chalky substances of the land and carries them down to the ocean,-immense numbers of these form, for themselves, habitations from this matter;-by successive accumulation, produced through the action or the dead bodies of these creatures, the ground is raised gradually into the reefs, banks, and rocks, so dangerous to navigation; or into islands inhabited by man, who, in the development of his moral and physical powers, performs his mission in his high position, just as definitely as the imperceptible animalculæ do in their narrow sphere.

Exceedingly beautiful in the tropic seas are those small physali, a species of Acalephe, known to sailors as "Portuguese 
men-of-war." They sail along by means of their large airbags, exposed to the wind, whilst their numerous long, darkblue tentacles, like fibres or roots, reach deep into the water, extending or contracting in order to secure their food. The fringes of these air-bags are of a violet colour, and resemble, when in sunshine, a splendid flower, floating about the sea in all directions.

Approaching the zone of the trade-winds, the aspect of the sea is animated by flying-fish. It has been long a matter of doubt whether this fish really moves through the air by flying, or whether, being pursued by enemies, it merely darts from fear out of the water, and sustains itself in the air by means of its long pectoral fins, though the long distances it mores are out of all proportion to its size and probable muscular power. This doubt seems to have originated with those who never have had an opportunity of personally observing flying-fish; or who have merely seen these creatures in the Mediterranean, where they are so small as to render it rather difficult to decide in what the movement really consists.

But in the tropics all doubt vanishes, for the fish here attains a length of from 6 to 8 inches, and its pectoral fins are so much developed that they may perfectly well be used as wings. By closely observing them, it is scen that these fins, or wings, have an oscillating or vibratory motion, like that of the grasshopper, by which they assist the oblique spring from the water, produced by muscular power; they move at a height of from two to three feet above the surface of the sea, to a distance 
of from 50 to 100 yards, and at the same time change the direction of their flight in exactly the same way as grasshoppers.

It seems, however, to be neither pleasure nor want of food that drives these creatures from their own element. They have numerous enemies, of which the principal is the bonita (Scomber Palamy); whenever flying-fish were seen the bonitas likewise made their appearance; we often saw the latter darting out of the water and snapping at a flying-fish, when, if they did not succeed, they were perceived hastening under water in the same direction that their prey was taking. But the flying-fish is quite aware of the movement of the enemy, and, therefore, sometimes turns back abruptly, evidently with a view of dodging his pursuer. The advantage of the wings is, however, more apparent than real, for whilst they escape by these means from the bonitas, dorados, and dolphins, they fall a sacrifice to the seagulls and manof-war birds (Tachypetes aquilus), which reach them like arrows shot from a bow, before they are able to conceal themselves again in the ocean. Those which were seen on the north of the equator, were invariably of the smaller kind (Exocotus volitans); whilst in the south, also, the larger species (Exocœetus exulans) made their appearance. They often drop during the night on the decks of small vessels with low bows, but on the Novara, which rose about 20 feet over the surface of the water, this was not possible; however, some fell upon the chains, which were caught and preserved in alcohol by the zoologists. 
On the 27 th June, at midday, we had arrived in $27^{\circ} \mathfrak{Z}^{\prime} \mathrm{N}$. Lat., and $24^{\circ} 7^{\prime} \mathrm{W}$. Long., and lay in a perfect calm, the mirror-like aspect of the sea allowing us to take a deep-sea sounding with what is called Brooke's apparatus. This consists of a tube, which runs through a thirty-pound shot, fastened to a thin line. As the shot, however, cannot easily be drawn up after the sounding, there is an ingenious mechanism, by means of which, on touching the ground, it is detached from the tube, which may then be drawn up, the shot remaining in the sea. The tube has a funnel-shaped opening at its lower extremity, by which a portion of the ground may likewise be brought up for scientific examination.

In the afternoon a boat provided with everything requisite for the sounding, was launched, and the operation began. Unfortunately there were only 4050 fathoms of line, as we did not find at Gibraltar the quality required for the purpose. The whole stock ran entirely out without reaching ground; we could therefore do nothing more than make the attempt to heave the tube without the shot. In this, however, we succeeded only in so far as regarded the first 2000 fathoms; then the line broke, and the remainder was lost. One of the causes of this accident was the sudden rise of the tradewind which increased so much as to engross nearly our entire attention.

To convey an idea of the time a ball of this kind takes to descend through the different strata of water, which increases in density in proportion to the depth attained, we annex the 
length of the different periods required in paying out the line during the experiment:-

The first 1000 frthoms occupied
From 1000 to 2000

As the winding up of the tube requires at least the same period, it may easily be conceived how great is the expenditure of time necessary for such an experiment, and on what chances the success of the whole operation depends. Though this trial was partially unsuccessful, yet so much is certain, that at this point, 21,300 feet of line were run off without reaching the ground. There is always, however, to be taken into consideration the under-current, which draws the line out of the perpendicular, and renders the result of the operation rather doubtful.

We now sailed with a fresh and steady trade-wind towards the thirtieth degree of W. Long., and thence along that meridian to the southward.

In the night, between the 29th to the 30th, we crossed the parallel of the sun's declination, upon which the direction of our shadows, already for several days scarcely perceptible, was of course changed from north to south.

We soon crossed the belt of the north-eastern trade-wind, as we made daily from 180 to 200 miles. On the 3rd o July the wind became very unsteady, and on the 5 th, in $8^{\circ} 30 \mathrm{~N}$. 
Lat. and $29^{\circ} 30^{\prime} \mathrm{W}$. Long., it entirely left us. The sky often became dark and threatening; indeed, its aspect changed at times with surprising rapidity, without any particular disturbance in the direction or strength of the wind; nor had we to complain of as much rain as might have been expected in these regions.

The calms in the so-called "belt of calms" were fortunately not of long duration, for in $6^{\circ} 43^{\prime} \mathrm{N}$., and $28^{\circ} 49^{\prime} \mathrm{W}$., a fresh south-east wind sprang up. When we came within the influence of the south-east trade-wind, we endeavoured to approach the coast of South Amcrica, for the purpose of observing the currents in that latitude, this being one of the investigations suggested by the letter of instructions drawn up by Alexander v. Humboldt. The great oceanic stream, which, on leaving the western coast of Africa takes a westerly direction, is divided by the projecting American Continent into two branches, of which the stronger turns N.W. towards the Caribean Sea, while the wcaker moves south-west along the coast of Brazil.

We had already felt its influcnce whilst in the zone of calms, and it became still more perceptible the more the equator was approached. The continuance of the south-easterly trade forced us to cross the Line at a more westerly point than usual. This, however, causes no disadvantage to a good sailing ship; nay, Commander Maury has proved indisputably that ships make extremely short passages, which reach the Equator so far to the west that they run a risk of hugging the coast too slosely. Those on the other hand, which, from over- 
anxiety to avoid the current, keep too far to the east, lose much time, being compelled to pass weeks in the zone of calms, which increases in breadth towards the east, whereas the others come very little in contact with it, and avail themselves of the changes of wind near the shore, to double the Cape of St. Roque on the American coast, so much dreaded by the former. We cannot here forbear expressing our high admiration of the great merits of $\mathrm{Mr}$. Maury, whose classical work on the physical geography of the sea, as well as his inestimable wind and current charts, deserve the especial attention of all who navigate these seas.

The nearer we approached the Line, the more striking became the aspect of the southern constellations. The light of the northern polar star grew fainter and fainter, its altitude diminished, and it at length entirely disappeared. But, on the other hand, the Southern Cross, the Magellan clouds, the ship Argo on the "coal-bags," or starless, dark spots of the southern hemisphere, became more elevated in proportion as the northern sky moved away, and for a moment we felt some difficulty in recognizing our old acquaintances of the northern hemisphere in their relation to the new stars.

On the 15 th, at 3 A.M., we crossed the Line in $30^{\circ} 50^{\prime}$ W.L. This event, which with all sailors forms a marked epoch in their seafaring life, had in this case the additional feature of being actually the first occasion of an Austrian man-of-war entering the southern hemisplere, and our crew, who had long before enjoyed, in anticipation, the merriment to which 
it would give occasion, had commenced the ceremony the preceding evening. Neptune, accompanied by an appropriate retinue of mermaids, tritons, and nereids, appeared at sunset, to announce with the utmost gravity to the Commodore, in a set speech, the astounding news that the vessel was entering his dominions, demonstrating the fact mathematically by an immense sextant, a chart, and pair of compasses a yard long, all manufactured by the ship's carpenter, and claiming his right to see the act of shaving and baptizing properly performed on all those who for the first time came into his kingdom. Amidst streams of water from the masts and fire-engines he made his exit down the rope ladder in a blaze of blue fire, followed by an ignited tar-barrel, which floated along like a globe of fire on the mirror-like surface of the sea.

The real farce, however, took place the next afternoon, when Neptune re-appeared, accompanied this time by his good lady and a hopeful youth, all decked out in real sea-godlike attire, in a car drawn by six tritons, still accompanied by his fareical retinue blowing a flourish on their bugles, when, after a second set speech to the Commodore, the great ruler of the waves declared that the ceremony was now to begin.

Every sailor was obliged, whether he would or no, to undergo a lathering with a nasty mixture of tar and grease, and submit to be scraped by an immense tin razor; which operation being performed, the unfortunate sufferer was tlrown into a sail suspended by its four corners, and there deluged from head to foot from pails, pumps, hose, pots, dishes, and everything else 
that would hold water. The officers and other gentlemen escaped the ordeal by a contribution in money or wine towards the festivities.

When the greater part of the sailors had undergone this process, and the seene, amidst formidable gushes of water, rioting, uproar, and exeitement, had reached its highest point, behold! a voice thundered from the quarter-deck the words " two o'clock," and everything resumed its wonted aspect.

Though the Line had been erossed at a more westerly point than usual, we were able, in the night from the 18th to the 19th of July, to pass easterly between the rocks Las Roceas and the island of Fernando da Noronha.* On the 20th July we were carried again by unfavourable winds to a distance of 100 miles from the Brazilian coast, where we parted from our faithful companion, the Caroline. She sailed for Pernambuco, whilst we kept out to sea in order to continue the observations on the westerly eurrents, and be able freely to double Cape St. Augustin. Bad weather, showers, and heavy swells prevented complete success in our task; it was, however, ascertained that the current close to the land is not so strong as at some distance from it, and that the extreme point of divergence is, at this particular season of the year, somewhat east of the south point of Fernando de Noronha. In the angle formed by the

* This island, situated 300 miles from Pernambuco, which supplies it with provisions, is at present used by the Brazilian Government as a penal settlement. It is extremely beautiful and fertile, but very little cultivated, and admirably suited for a coal depôt, and a place for ships obtaining stores, particulariy when epidemics are prevalent in Rio de Janeiro. 
direction of the two currents between the point of division and the land, partial currents (according to circumstances and the strength of the wind), run towards one or the other side, of which the stronger tends towards the north-west.

On the 23rd July the weather cleared up; we approached the coast and came in sight of Cape St. Augustin, the first land descried since leaving Madeira. On the 1st of August a rock was announced ahead; as nothing of the kind was indicated in the charts, we were curious to know what this could be. A boat was manned, and we were soon made aware, by our olfactory organs, of the real nature of the object, which turned out to be the carcase of a dead whale in a state of putrefaction, over which a number of birds were hovering, whilst a troop of sharks feasted on the putrid mass, boring themselves into the body. This incident shows how many rocks marked in charts as doubtful may owe their origin to similar circumstances; for, had we not been convinced of the real nature of the object, we should have believed this carcase to be a rock, and thus augmented the number of "doubtfuls" and interrogations in the charts of the Atlantic.

On the 3rd August we made Cape Frio, and after a rough and stormy night reached at last, on the morning of the 5th, the numerous small islands situated in front of the harbour of Rio. The Sugar Loaf, that remarkable black basaltic rock at its entrance, stood grandly forth, as we ran in. Unfortunately the gloomy state of the atmosphere prevented the enjoyment of the exquisite beauty of this so often described charming bay. 
Here we found an English, a French, and an American frigate, as also a dirty old Brazilian sloop of war. Besides these ships of war, a Spanish frigate and galliot lay in the mercantile dock for repair ; they had shortly before their arrival lost their masts in a pampero, ${ }^{*}$ which, however, had borne all the characteristic marks of a cyclone.t The occurrence of tornadoes in the South Atlantic has been so often and so decidedly denied, that the mariner does not readily believe tho violent storms of those latitudes to be hurricanes. This Spanish frigate had accordingly sailed heedlessly into the storm, and, with only such precautions taken as referred to mast and sail, had without further concern proceeded on her course. She thus had got into the very heart of the cyclone, and escaped entire destruction

* A squall of wind of the South American Pampas.

+ The following succinct statement of the characteristics and general laws of cyclones will be found useful by way of reference:-

1. It has been fully ascertained that in both hemispheres the air in the cyclone rotates in a direction contrary to that of the sun. Thus, in the N. hemisphere, the course of the sun being from E. to S., W., and N., the course of the hurricane is fiom N. by W., S., and E. ; and in the S. hemisphere, the sun's course being from E. by N., W., and S., the hurricane runs fiom N. by E., S., and W.

2. They originate in the space between the equator and the tropics, near tho equatorial limit of the trade winds.

3. There is no instance on record of a hurricano having been encountered on the equator, nor of any one having crossed the Line, although two have been known to be raging at the same time in the same meridian, but on opposite sides of the equator, and only $10^{\circ}$ to $12^{\circ}$ npart!

4. Their movement, which is always oblique from the equator to the poles, is usually from E. to W. at first, and towarts the end W. to E., which is but a development of the gyratory motion that forms their most essential characteristic.

5. The "motion of translation" varies from so low as 9 miles an hour to 43 miles an hour. There is no precise estimate of the velocity of the gyratory motion.

6. They are liable to dilate and contract in area, the contraction always implying a great accession of violence. (Seo post, p. 183.) 
only by a fortunate chance. Now, had her commander considered this storm to have been a real hurricane he would have undoubtedly steered a different course, and probably in that case would have reached the harbour in safety. But the notion of the non-existence of hurricanes in these waters is so pertinaciously maintained that it was no wonder the careful and able Spanish commander had also been misled. Our own opinion is, that any storm in the ocean may assume a revolving motion, and it is therefore highly advisable always to bear in mind the well-founded theory of cyclones, in order to act upon it, as circumstances may require. Were this always done, how many valuable lives and property might be saved from destruction!

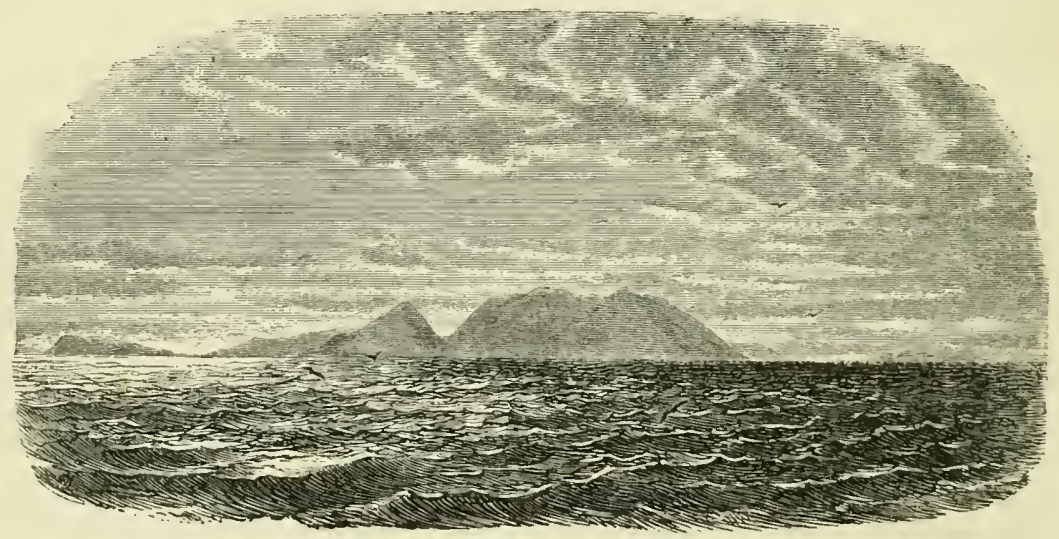



FROM MADEIRA TO RIO DI JANEIRO.

II.

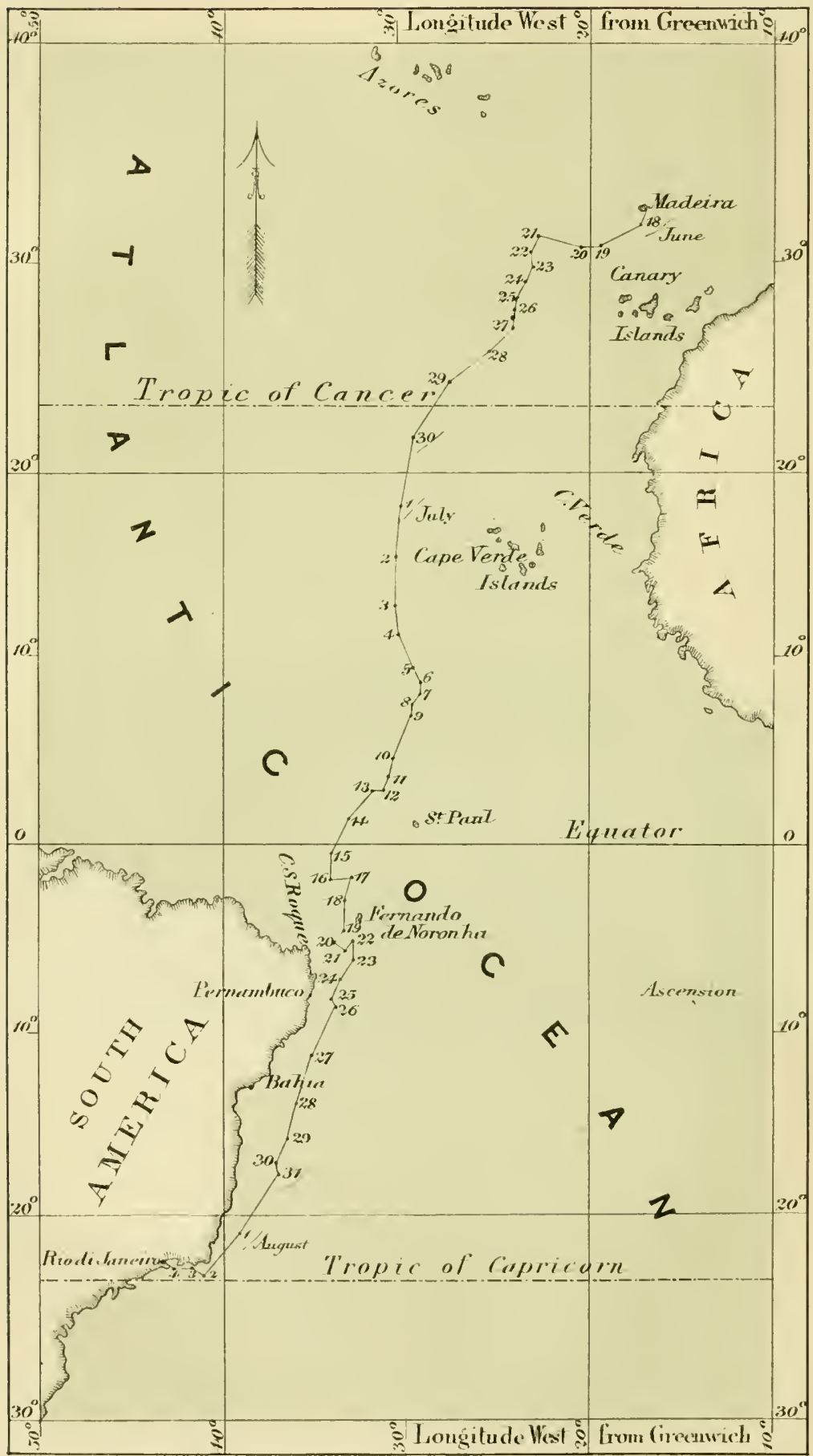




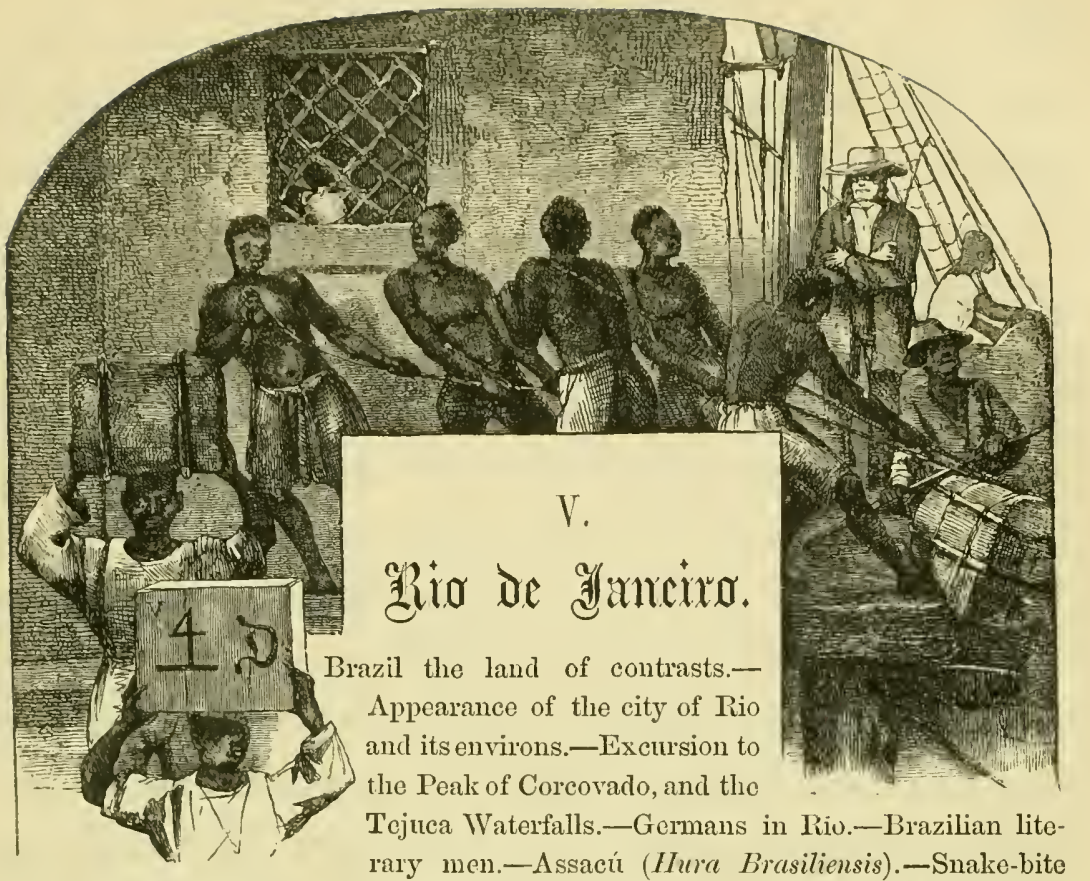
as an antidote against leprosy.-Public Institutions.-Negroes of the Mozambique coast.-The House of Misericordia.-Lunatic Asylum.-Botanical Garden.Public iustruction.-Historico-Geographical institution.-Palastra Scientifica. - Military Academy. - Library. - Conservatory of Music. - Sanitary Police. - Yellow Fever and Cholera.-Water Party on the bay.-Chamber of Deputies.Petropolis.-Condition of the Slave population.-Prospects of German emigration.-Suitability of Brazil as a market for German commerce.-Natural products, and exchange of manufactures.-Audience of the Emperor and Empress.-Extravagant waste of powder for salvoes.-Songs of the sailors.-Departure from Rio.-Retrospect.-South-east Trades.-Cape Pigeons.-Albatrosses.-Cape Tormentoso.-A Storm at the Cape.-Various Methods of measuring the height of waves.-Arrival in Simon's Bay.

BraziL-situated on the ocean-highway to the South Seas and the shores of India, endowed by nature, over the greater portion of her territory, with a salubrious climate, and a soil of tropical fertility, very nearly as large as Europe, and ten times the size of France, and yet containing not above 8,000,000 souls-has, far beyond all other States of South America, con- 
centrated on herself, during more than half a century, the interest of the naturalist, as well as of the political economistof the merchant as well as of the emigrant. Indeed, we may say that there are few countries, beyond the limits of Europe, which in certain parts have already been more thoroughly explored than the Brazilian Empire, while at the same time it can boast the possession of a rich and valuable stock of literature, treating of its history, since its discovery by the Portuguese Admiral, Pedro Alvarez Cabral, on the 22nd of April, 1500, down to the present time.

After so brief a sojourn as ours, we can hardly offer more to the reader than a short sketch of our own few experiences, and some remarks regarding the alterations which took place in the appearance of the eity and in its social and political condition, since the period when Martius and Spix, Rugendas, Prince Neuwied, Helmreichen, Natterer, Pohl, d'Orbigny, Wilkes, Castelnau, Burmeister, and others visited Brazil, and so accurately delineated it both by pen and pencil.*

The magnificent scenery of the Bay of Rio de Janeiro still continues to possess the same absorbing interest for the new comer, wherever it has not suffered by the expansion of the

* Before wo left Europe, the wish was repeatedly expressed to us that, during our stay in Rio, more accurate information should be obtained as to the fate of numcrous scientific works and collections, by several German naturalists who died in Brazil in recent times, such as Frcderick Sello, Dr. Mïller (a companion of Castelnau), Dr. Engler, and others. Unfortunately, we can only give the little consolatory intelligence that, with the exception of the scientific memoranda left behind by Dr. Engler, chiefly relating to Itù in the province of St. Paul, there was nothing further to bo hoped for. The collections have all been dispersed through want of care, and the manuscripts nearly all destroyed through ignorance of their value. 
rapidly-increasing city, or the axe of the emigrant settler; it is but little one can add to or alter in the picturesque deseription which travellers, alive to its natural beauties, had already given, half a century ago, of the wonderful haven of the Brazilian metropolis! Very different, however, is the impression, when the stranger, on disembarking, sets foot on the new world, and has to make his way through narrow, steep, filthy streets, greeted by yelling crowds of blacks and whites, poor negro slaves, and wealthy planters, into the interior of this bustling port. An entirely altered state of affairs has sprung up since the separation of Brazil from Portugal, and he who has not seen Rio within the last ten years would hardly recognize the capital of the Brazilian empire. Along with the most conspicuous deficiencies, in numerous partieulars, one finds such institutions as are not to be met with, in a similarly flourishing condition, in any other State of South America, or among the republics of the Isthmus. But Brazil is emphatically "The Land of Contrasts."

When the traveller, stepping on shore from the anchorage for ships of war, (which is a little to the south of that for merchant vessels), has forced his way through the swarms of human beings at the landing stage, and in front of the hotel Pharoux, he finds himself on the Largo do Paço, or Palace Square. Here on his left rises the singular-looking Imperial Residence, and on his right, close to the shore, the Market Hall. A dense bustling crowd throngs the streets, while numerous vehicles, some drawn by horses, others by mules, as also omni- 
buses of all colours and dimensions, and crammed within and without, dash swiftly about, emulating the din and confusion of European capitals. Turning now to the right, into the Rua Direita, and thence a little further into the Rua do Ouvidor, the two most elegant but none the less most-neglected streets of Rio, there dazzles the eye, in the splendid, richly-decorated shops and arcades, the same profuse luxury as in Regent Street, or on the Boulevards. But how disagreeable the contrast with those cities, presented by the pools of stagnant water, which occur even in the most-frequented streets !

The city proper presents the figure of a square of about one mile and three quarters each way, between the sea beach and the Campo da Santa Anna, and is divided with tolerable regularity by narrow streets built at right angles to each other. Except the most important public buildings, such as the National Museum, the Museum of Fine Arts, the Military Academy, the Naval Arsenal, the Custom House, the Market Hall, the Imperial Palace, the Chamber of Deputies, and several of the churches, only shops and mercantile counting-houses are to be met with.

From the city stretch the suburbs like long tentacles in every direction, on one side along the beach as far as St. Christoph, the winter palace of the emperor, and, in the opposite direction, as far as the charming Cove of Botafogo, while backwards they extend to the valleys leading to the Corcovado, to the suburbs of Larangeiras, Catumby Grande, and in the direction of the Tejuca mountains, as far as Engenho Velho, 
and Andarahý. Elegant little villas, frequently built in the strangest and most bizarre style of arehitecture, alternate in these suburbs with ordinary dwelling-houses, all having most beautifully laid-out gardens. The merchant, the manufaeturer, in fact every individual in easy eircumstances, remain in the city only long enough to transact daily business. Each has his residence in the suburbs, where his family lives, to whose quiet eircle he returns every evening. Among these suburbs, those of Caminho Novo and Catete, along the road leading to the elarming cove of Botafogo, are more specially the diplomatic quarter, and the residence of the moneyed aristocracy of the eapital.

A mid so much that calls for censure in Rio Janeiro, and of which the æsthetic perceptions of the visitor will apprize him in the course of a stroll in any part of the eity, there are two improvements which deserve grateful acknowledgment. The first of these consists in the lighting of the city by gas (prepared from English coal), which had been introduced shortly before our arrival, and is now extended to the extreme outskirts of the suburbs; the second is the magnificent aqueduct, which provides every quarter of Rio with a lavish supply of excellent drinking-water. Howerer ugly Rio may look in the daytime, the gas at night gives it a magnificent and splendid appearance, particularly from the harbour. When, the evening after our arrival, we gazed out upon the brilliantly-illuminated city that lay before us, we could not help thinking there must be some festive occasion for such a flood of light, ignorant as 
we then were of what we learned afterwards, that Rio is as fairy-looking by night as it appears gloomy by day.

Not less surprising, and forming a strong contrast with the deficiencies and requirements in other particulars, are the stately fountains that adorn the squares. Close by the corner of each street, gushes out through metal cocks, a stream of clear, fresh spring-water, which has been conveyed by the great aqueduct a distance of 10 or 12 English miles from the slopes of the neighbouring Carioca or Tejuca mountain-chains. The water supply has been in existence for 120 years, but the present immense reservoir and various improvements in it have been introduced by the Brazilian Government. With the exception of the Croton aqueduct, near New York, which supplies that city with 40,000,000 gallons daily, we do not remember to have seen in any part of the world a similar work of such magnitude.

The dreary, uncomfortable feeling left by the city, gives way to most enjoyable impressions so soon as one emerges from the suburbs of Rio, and seeks compensation for the absence of the appliances of European civilization in the eternal grace and majesty of Nature. Walks may be taken in every direction, each opening up a fresh point of view, while, if the visitor take horse or mule, he may in the course of an hour or two transport himself into the very midst of the most extraordinary features of tropical vegetation.

Among the most charming of these is a ride to the rocky peak called Corcovado, 2300 feet high, the road to which runs 
through magnificent shady forests. On the highest pinnacle of this rocky cone, which rises rather abruptly on the side of the valleys of Clementi and Broca, a parapet has been erected within these few years, so that the traveller can gazo over the delightful panorama below with as much, or even more, comfort and security, than from the Righi or the great Winterberg in the Saxon Switzerland. In the south and south-east rise the two stern-looking mountains, Gavia and Dos Irmaos, both of considerable height, and encircled by the mirror-like lagoon, Rodrigo das Freitas, near which stands out, clothed in the most luxuriant verdure, a part of the botanical garden; thereafter follows the beautiful valley of Clementi and Broca, with the splendid Lunatic Asylum and the fort of Praya Vermelha; beyond which is the smiling cove of Botafogo, and the singular Sugar Loaf, which forms such a characteristic feature of the entrance of Rio harbour; close beside the latter is the fort of San Juan; and lastly, facing the entrance of the bay, that of Santa Cruz, the strongest in the empire. At our feet lay stretched out the city itself, with the beautiful valleys of Larangeiras, Engenho Velho, and Catumbý Grande. On the other side of the bay, just opposite Rio, is Praya Grande, the capital of the province, and in the background the lofty, spectre-like mountain-chain of the Organos-so called from the rocky peaks projecting like so many organ-pipes. What a wondrous prospect 1 It is scarcely possible to have, from a single point of view, a grander or more varied natural picture. We lingered here 
more than an hour, and tore ourselves away with reluctance from all those glories which Nature has shed with so profuse a hand over this enchanting landscape.

One of our companions was the veteran Brazilian naturalist, the venerable Dom Antonio Ildefonso Gomez, who passed several years in Europe when a young man, and had, together with Humboldt, once attended the lectures of Cuvier at Paris. M. Auguste de St. Hilaire, during his visit to Rio, spent several months at Dom Ildefonso's hospitable abode. Although now a septuagenarian, the old physician is uncommonly hale in person, full of his pristine enthusiasm, indefatigable in the pursuit of knowledge, and able to pass an entire day on the back of his mule, so that he can ride to the most distant consultations without betraying any symptoms of exhaustion. He had brought with him a number of large oranges, some cheese and bread, and a bottle of excellent port wine, so that there was no want of wherewithal to recruit our strengtly; and there, on the summit of the Corcovado, our hearts swelling with rapture as the eye ranged over the marvellous landscape that lay unrolled at our feet, we drank to the prosperity of Brazil. Dom Ildefonso, a warm friend to all foreigners, remarked that within forty years Brazil will probably be more German than Brazilian or Portuguese, and expressed a hope it might be so, as only by that means, so far as his observation went, could his beloved native land hope for a prosperous future.

We returned through most charming forest scenery by 
way of Larangeiras and Andarahý. Throughout the entire distance we rode amidst the most exquisite specimens of tropical regetation, palms, ebony trees, bignonias, plantains, mangoes, papayas, and bread-fruit trees, mingling with which we could discern the various trees and shrubs of the Northern Hemispliere, and occasionally strange plants from China, Japan, and Australia, which had been planted here by the enterprising hand of foreign settlers.

Not less charming is the excursion to the Falls of the Tejuca, to which a broad road leads through blooming flowergardens, and past delicious country seats, extending far into the mountains, and surrounded and overshadowed by a wall as it were of verdure, consisting of the flowers of Bignonia bella, intermingling with the shining leaves of the gigantic Bougainvillea. The coral tree (Erythrina coralliflora), the indigenous magnolia, the fan-shaped urania, numerous species of palms, and lofty, carefully-tended screw-pines, plantains with gigantic fruits, bread-fruit trees, eugenias, casuarinas, and melon trees-such are the blooming odoriferous attractions that here adorn garden and field. Ever threading his way among such charming pläntations, the traveller finally reaches the path which, hemmed in between two mountain ridges of moderate height, leads direct to the Tejuca mountains, while to the right branch off numerous narrow paths conducting to the various adjoining eminences, from which a riew can be obtained of the small cascade. The tropical richness and profusion of vegetation, has here crowded togetlıer upon 
a few square feet of soil hundreds of plants of all kinds. They strike into the soil, or struggle upwards to the light, or give out roots from the stems or branches, and all twine and tangle with each other to such an extent that often in these tufts and thickets one sees the top of a fern, without being able to distinguish any part of its stem, or a pascion-flower without any visible stalk or leaves, all suspended in midl-air, like so many elegant festoons.

A short distance from this singular, thoroughly tropical landscape, is the second, known as the Great Cascade, which, however, owes its special attractions rather to the character of the surrounding vegetation than to the rolume of water. The trees here grow on a sort of amphitheatre of rocks, all of colossal size, and the most widely different forms, no two of the same species adjoining each other, their stems and branches adorned with the most beautiful parasites and the blood-red leaves of innumerable creepers, which in their lavish Iuxuriance now stretch like garlands from tree to tree, now hang perpendicularly down from the rery higliest branch of the tree like a network of green lace, till they sweep along the ground.

The water welling out from the granite rock, rushes into the abyss below after traversing a rocky declivity, somewhat resembling a sloping terrace of about twenty fathoms wide. Its track is indicated by the irregularly-shaped blocks piled upon each other, some of which at a little distance below, their huge wide ridges enclosed by retaining walls, serve as spots in 
which to dry in the sun the ripe berries of the coffec plant, which in many parts hereabout forms an almost impervious forest.

As we prosecute our wanderings further, we finally emerge upon the green hills of the vicinity, and obtain a charming glimpse of the ocean; we have now arrived in front of the gigantic outline of the Gavia, and directly facing us lies the salt-marsh, known as Tejuca-Lake, in the midst of which rises an island, thickly overgrown with mango-trees, standing on their distorted hundredfold roots; melancholy-looking examples of the inactivity and absence of all attention of the Brazilian authorities, who permit such a hot-bed of poisonous miasma to remain in the immediate vicinity of the eity, and leave these plants unchecked to carry on their pestiferous vital processes!

Returning from such a delightful excursion to Rio de Janeiro, the stranger feels doubly uncomfortable and lonely in the dreary and sombre city. The Brazilians are in general neither very social nor hospitable, and only, after many year's' acquaintance, is a familiar intercourse formed with strangers.

In this respect they bear a strong resemblance to the Spanish-Americans, whom they also greatly resemble in many of their habits of life. Foreigners settled in Rio spend their evenings generally at their country seats, some distance from the town, so that the occasional visitor is cleprived of the social intercourse that might otherwise be so accessible. We met with a most hospitable reception at the houses of the Austrian 
Minister, Chevalier de Sonnleithner, and our Consul-General, as well as from some German families, and also from the "Germania," a Club founded by twelve Germans as far back as 1821. This Society numbers now about 200 members, and is well supplied with German newspapers and periodicals, besides possessing a well-selected library of several thousand volumes, and a reading-room, with restaurant, smoking, billiard, and dancing-rooms attached. Of the various nationalities represented at Rio, the Germans are the most respected by the Brazilians. They are about 3000 in number, and as the majority are Protestants they have their own church, founded by three Germans in 1827, which now numbers 600 members, and has an annual income of 5000 milreis.* The community is under the protection of the Supreme Ecelesiastical Council in Berlin, and accordingly, as often as public worship is joined in, prayers are offered up for the King of Prussia, as head of the church. Despite its existence for more than-thirty years, the position occupied by the Erangelical church with reference to the State, has never been accurately defined, so that differences are constantly occurring. In connection with the congregation are a school, and a socicty for aiding distressed Germans, which numbers 200 associates, and has an annual income of from 6000 to $\% 000$ milreis ( $f 600$ to

* One milreis $=1000$ reis = about 2s. English. The Brazilian milreis is of this small ralue as compared with that of the Portugnese (3 to $\tau$ ), in consequence of its being represented by paper-money of fluctuating value, which gradually became so depreciatel that Government, when regulating the ralue in 1846 , were not in a position to restoro it to its par value of $3 s .4 l$. sterling. 
$£ 700$ ). The objects of the association are the advance of money, pensions, payment of passage-money for transport, assistance to unemployed or sick German workmen, education of orphan children, and so forth. The German choral union had given a concert in aid of this humane socicty, which alone had realized 3100 milreis (above $£ 300$ )!

It is not alone, however, as merchants, engineers, and artizans, that the Germans in Rio occupy a conspicuous position; they likewise contribute their mite to the advancement of art and science. For example, the most important literary enterprise in the empire is in German hands, viz. the printing and bookselling business of the brothers Lacmmert. Their publications embrace two hundred and fifty works, chiefly of Portuguese (not Brazilian) authors, original or translated, treating of Brazilian legislation, history, medicine, public instruction, poetry, popular literature, works on religion, novels, romances, kalendars, and theatrical pieces. One publication due to the founder of the firm, Mr. C. Laemmert, a Bavarian by birth, has already proved of immense utility, the "Almanak administrativo, mercantil, e industrial," compiled by himself, first published in the year 1843. From a most defective little pamphlet at its start, this periodical publication has, in the course of time, become developed into an elegant, simply-classified octavo volume, 1400 pages thick, which, compiled carefully and kept constantly corrected to the latest moment, despite the most disheartening material difficulties, gives a very interesting insight into the entire internal organization of the empire, and 
at the same time supplies the most authentic information as to the scientific, commercial, and industrial activity of the city and province of Rio. Even more important as a medium for the diffusion of useful knowledge among the masses is a sort of popular kalendar, which is published in duodecimo form, under the title of "Folinhas" (Leaves), and for 320 reis (about $7 \frac{1}{2} d$. English), gives upon 360 pages an immense amount of useful information. Of this publication 80,000 copies were sold throughout the empire in the year 185\%. There are rery few works of importance written by native authors, as they devote their energies chiefly to periodical literature. Of daily and monthly publications there are abundance, both in Rio and in the provinces, but they have only an ephemeral existence. The press enjoys the most unbounded freedom, and probably in very few continental cities would such language be tolcrated as that of the Courier du Brésil, edited by a French refugee. If the influence of journalism in Brazil is as yet insignificunt, it is in consequence of the prevailing ignorance, as four-fifths of the population are unable to read or write, and the papers published are consequently only in the hands of the upper classes.

While we found but few opportunities of intercourse with Brazilian families, the public authorities received and treated us in the most obliging and distinguished manner. In this respect, we were particularly indebted to Dr. de Lagos, Dr. Schüch de Capanema, Dr. F. de Paulo Candido, and Dom M. de Portoalegre. 
These gentlemen took especial pains to make our stay in Rio as instructive as useful, and likewise gave us in reply to various scientific queries the most valuable information and practical hints. Thus, for example, we were favoured by Dr. de Lagos with the following particulars respecting the alleged efficacy of the milky sap of the assací tree (Hura Brasiliensis), and of the bite of the rattlesnake as antidotes in cases of Elephantiasis, as also regarding the "Curaré," that celebrated poison with which the Indians of Brazil tip their arrows.

The assacú had long been employed as a remedy for the frightful malady known as Elephantiasis Grcecorum, and its use was occasionally followed by the happiest results, without any attempt having been made thoroughly to investigate the specific action of the juice, although, like that of so many other Brazilian plants, it would probably surrender, if scientifically analyzed, the therapeutical energies which enable it to overcome occasionally the most obstinate cases of disease. The assacú is a tree growing in the northern provinces of Pará, on making an incision into which there exudes a resinous sap, of a brownish or reddish-white colour, which coagulates, and gradually hardens. This inspissated substance is of a dark brown, rather resembling gum than resin, and readily soluble in water. When dissolved, it regains the colour and odour of the sap as it first trickles from the tree. A committec of physicians of Parí long ago presented to the Brazilian Government a memorandum as to the 
practical efficacy and peculiarities of the assacú in cases of the above malady, according to which it appears, that the symptoms of the patient improve in the most marvellous manner from the very first day on which the remedy is used; the illness seems to be suddenly arrested, or, at all events to make but very slight progress. The milky sap is exhibited internally, in the form of pills, and a decoction of the bark is also administered by way of a beverage for the patient, -externally an infusion of the bark is used for bathing purposes. Some of those affected, to whom this remedy was applied, felt a sensation as of formication, immediately on taking it, while others experienced a feeling as though they had been submitted to a series of shocks of electricity, only weaker and more equable.

It is a well-established fact that in many parts of South America, a popular belief prevails that the bite of the deadly Cobra de cascavel, or rattlesnake, heals Elephantiasis, or pustular leprosy, in which disease, as is well known, the legs and feet of those attacked arc covered with a scurf resembling the cuticle of the elephant. However, instances of the practical application of so terrible a remedy, which seems to be almost more dreadful than the discase it professes to cure, are in all probability of rare occurrence, and are therefore doubly important when, as in the case detailed to us, they occurred under the very eyes of a man of science, and are related by the observer himself.

A native, named Marianno José Machado, from Rio Pardo, 
in the province of southern Rio Grande, fifty years of age, had long been afflicted with morphea (Elephantiasis Grecorum), and had already passed four years in the Lazarus Hospital at Rio, when one day, worn out with his loathsome malady, he resolved as a last chance of being delivered from his dread disease, to submit to the bite of a rattlesnake. All the warnings and representations of the physicians, who entertained well-founded doubts as to the remedial efficacy of so dangerous a remedy, were disregarded. Marianno betook himself to a house in the Rua da Imperatriz, the cccupant of which possessed a living rattlesnake, and there in the presence of numerous witnesses declared, signing at the same time a document to the same effect, that what he was about to do he did of his own free will, without any influence on the part of strangers, and that he assumed to himself the entire responsibility of his own deed. Marianno was of middling stature and athletic build; his entire skin was covered with rugosities, but without any appearance of ulceration, while his face was frightfully disfigured. The points of his finger's, moreover, had entirely lost their form, the skin readily peeling off from them.

The daring sufferer opened the box in which lay the deadly reptile, and roughly seized it; but it at first attempted to escape, as though it too was disgusted at the horrible object before it. When, however, it felt itself once more squeezed, the snake turned round in self-defence, and bit the man on the finger. Marianno was sensible neither of the puncture of the teeth, 
nor of the instantaneous activity of the injected poison, but it became ere long apparent that he had been bitten, from the blood making its appearance, coupled with a slight swelling of the hand. Several physicians watched by the bedside of the sufferer ; almost every half-hour the observed results were circumstantially reported. When, however, the symptoms rapidly became worse, autidotes were applied, and every effort made to save the patient. Nevertheless, the result of the experiment was as anticipated-within twenty-four hours after the bite of the rattlesnake Marianno was a corpse.

Several members of the medical society of Vienna laid great stress on our procuring a considerable quantity of the celebrated poison, "curaré," used in South America for tipping arrows, with the view of instituting fresh experiments-similar to those already made, so as to elucidate its chemical and physiological properties. As the curaré is not to be procured in Rio, but comes thither from the northern province of Pará, where the natives procure it from the sap of the Strychnos toxifera, Dr. de Lagos promised he would take care to procure some, so as to transmit samples direct to the Vienna savans, and at the same time gave us much information as to the latest researches touching this substance, with whose remarkable properties Alexander v. Humboldt had made the scientific world acquainted, more than half-a-century previously, in his classic " Travels through the Equatorial Countries."

One special peculiarity of the curaré consists in the fact that, like most other organic poisons, it is only active when 
absorbed into the circulating system, and proves entirely innoxious, nay in some cases even beneficial, when introduced into the body by otlier means.

The more the faculty became acquainted with the terrific activity, and invariably fatal results of this poison, the more zealously did science bestir itself to discover some means of neutralizing the operation of the curaré. Quite recently the preparations of iodine-natron, when administered in certain proportions, have been recognized as antidotes; dissolved with the curare they seem entirely to obviate its evil effects. Careful observation and a gradual acquaintance with the properties of the curaré, have further led to the conclusion that it may be regarded as a remedy in ccrtain cases, and it has actually been administered with good results to animals affected with tetanic convulsions. May it be reserved to the physicians of our native country, to elicit from the quantity of this subtle and singular poison, which they may expect to receive through the kindness of Dr. de Lagos, such results as shall make its remedial properties available for man, instead of leaving its baleful encrgies as at present solely directed to the destruction of organic life!

In the company of our Brazilian friends, already mentioned, we also visited the most interesting of the public charities and educational institutions of Rio.

On the occasion of a visit we paid to the in part newlyerected Casa de Correçâo, which is managed on what is known as the Auburn system, we were shown three Mozambique 
negroes, who, in 1852, had been smuggled in a "slaver" fron the east ceast of Africa into Brazil, there to be sold as slaves, despite the interdicts against the introduction of slaves, then actually in force. The vessel was, however, captured by the Brazilian cruisers, and the negroes forthwith restored to liberty, when, in their own interest, and with the view of preventing their being a second time sold into bondage, they were removed to a quarter of the prison away from the rest, and specially set apart for what are called "free Africans," where they harl been carefully educated and instructed in various handicrafts, all at the expense of the State. As a vocabulary of the idioms spoken by the Mozambique negroes, was an especial desideratum of the cliss of philosophic history in our Imperial Academy of Sciences, and there seemed to be but little prospect of our expedition visiting the eastern coast of Africa, we gladly availed ourselves of this unexpected opportunity to compile the wished-for vocabulary, in which Professor Portoalegre, Dircetor of the Academy of Fine Arts, materially assisted us. Two of these negroes, Camillo and Ventura, were born in Quillimani, and belonged to the Mananpi race; the third, Jeremias, was born about sixty days' journey from the coast, of the Maqua race, and spoke a dialect of the Mozambique idiom. Ventura, a youth of, at the outside, seventeen years of age, related that he could perfectly remember having been stolen one night from his parents in Quillimani, when he was brought to a slavedealer named Jones, after which he was shipped off in a 
wretched leaky vessel to the coast of Brazil. On our asking these three swarthy fellow-labourers, hearty of aspect and neatly clothed, who had been so carefully tended by the State, and earned, one as a house-servant, the other two as stonemasons, thirty milreis ( $£ 33 \mathrm{~s}$.) a month, whether they did not feel themselves better off in Rio than in their own home,they, with one accord, answered that they longed to return to Quillimani, where it is hardly requisite to work above six months, and the rest of the year may be consumed in a genuine "dolce far niente" existence, instead of being compelled, as in Rio, to work the whole year round!

In spite of long-continued efforts, the vocabulary turned out much less complete than we wished, in consequence of the limited capacity of these negroes. We did not content ourselves, however, with merely transcribing the answers to our questions, but also endeavoured to obtain a more accurate idea of the precise meaning attached to each, by repeating each of the words of the Mozambique language, and translating into it from the questions put in Portuguese. This method seemed to be the most effectual for ensuring the correctness of the pronunciation, so as to permit of its being afterwards reduced to writing. In the arrangement of the vocabulary, we availed ourselves of what is known as Gallatin's method, as it appeared to us more complete and comprehensive than that sent to our academy by the celebrated naturalist and traveller, Dr. Martius, of Munich, with a request that it should have his list of Latin words translated into the 
various languages hitherto unknown, or such idioms as have been as yet but little examined and investigated.

The race, to which these three negroes belonged, seems to have been already converted to Christianity. At least, they all had Christian names, but could give us no information either as to certain heathenish rites in their own country, or concerning an idol of carved ivory which we showed them, brought from the east coast of Africa, and the method of worshipping it.

Two of the most elegant edifices of Rio Janeiro, worthy indeed of being placed side by side with the largest charitable establishments in Europe, are the immense palace-like Hospital of the Santa Casa da Misericordia, in which between 8000 and 9000 patients are received and treated annually, and the really splendid Lunatic Asylum (Asylo dos Alienados), in the core of Botafogo. The latter institution, founded in 1S41, which, whether as regards the tastefulness of its architecture or its munificent endowment, can hardly be rivalled anywhere, owes its existence to one of the most estimable benefactors of his native country, Don José Clemente Pereira, Minister of the Interior at the time of its erection. This genial, benevolent soul, deeply acquainted with the human heart and its weaknesses, hit, as we were told, upon the following eminently original and ingenious method of raising the sums required. All grades of the various Brazilian orders, as well as the titles of Baron, Count, and Marquis, were put up for sale at fixed prices, the proceeds resulting from 
which purposes were applied to the erection and endowment of the asylum! And thus arose, at the south end of the cove of Botafogo, a splendid palatial edifice-a monument less of humanity and love of our afflicted neighbours, than of the vanity and frailty of poor human nature, the tributes to which erected it. Unfortunately, in this establishment, mere succour is all in all, and the cure seems entirely lost sight of, the sanative treatment of the patients lagging far behind their careful supervision; in short, it being rather a place for the safe confinement than the recovery of those deprived of their reason.

One of the most instructive examples of how little the inhabitants of Rio make use of the natural capabilities of the site of their capital, is incontestably furnished by a piece of ground immediately adjoining the Lunatic Asylum, which has been dignified with the name of the Botanic Garden. With the exception of a very fine alley of hundreds of graceful king-palms (Oreodoxa regia), which present a magnificent spectacle, growing as they do with such admirable regularity as to appear rather artificial columns than planted trees, the eye encounters nothing but uncultivated land, abounding with the commonest vegetation, alternating with badly-selected nursery plantations, although both in the climate and the soil every facility is at hand for enabling this garden to be made a means of representing the vegetation of every zone of the globe. Even a large tea plantation, for the cultivation of which 10,000 Chinese were imported at 
the cost of Government, and from which, if the experiment had proved successful, the most important results might have been anticipated, stood there uncared-for and untended, a melancholy witness of how things are inaugurated in Brazil, and then suffered to fall through. When we enquired how long the garden had been laid out, our guide, a witty Portuguese, replied with a sarcastic smile, "Since the beginning of the world!" In that part of the garden which adjoins the Lagune, called Rodrigo das Freitas, stands a common mud hovel, with broken windows, and doors hanging by the hinges. This was pointed out to us by a labourer as the spot at which the Emperor alights and reposes when he visits the Botanical Garden.

Singular to say, Brazil possesses no regular university! The jealousy with which any one city invested with certain privileges and prerogatives is regarded by the rest, is the reason that induced the Government to separate the medical and juridical elasses, so that cach of the four chief cities of the Empire benefits by the presence of a certain portion of the students. Thus the medical schools are in Rio Janeiro and Bahia, while those of jurisprurlence are held in St. Paul and Pernambuco. The entire number of students attending these establishments amounted of late years, on an average, to upwards of a thousand. Great promineince has been assigned by Government, especially of late, to the extension of public instruction. In March, 1857, there were throughout Brazil, 2452 schools, (765 private, and $168 \%$ public,) in which 
instruction was given to 82,243 children of both sexes.* A school of industry, having for its object the instruction of able-bodied persons, was opened in 1856, and classes for teaching natural philosophy and political administrative science, are in process of being introduced. Amongst the scicntific establishments of the country, the Historico-Geographical Institute occupies the first place, the meetings of which are generally attended by the Emperor as honorary president. This institution, which occupies in Brazil about the same position as the Academy of Sciences in Vienna, directs its special attention to the publication of old documents and manuscripts relating to the history of Brazil and the aboriginal population; but investigations relating to natural history are also included in its domain of enquiry. The sittings are held every alternate Friday. The naturalists of the Novara attended one of these meetings, which took place in one of the wings of the palace. At half-past 6 P.ir., the Emperor entered the hall, in plain clothes, attended by two chamberlains. All the gentlemen present approached one after the other and respectfully kissed the hand of their sovereign. On this occasion we remarked that even ladies, when presented to the head of the State, were accustomed to kiss his hand. The Imperial Honorary President, whose simple apparel was relieved only by the star of some order worn on the breast, took his seat at the upper end of a long, wide table, covered with green

* Among the higher class of educational institutions, the Colleg*e of Pedro Segundo ranks foremost, and is at present attended by about 900 students. 
cloth. The associates, with the exception of the Vice-President and Secretaries, seemed to have no fixed seats, but sat in the order of their arrival. During the sitting there was the most marked absence of ceremony, and the business was transacted in the freest and easiest manner.

The proceedings were uninteresting, the greatest portion of the time being occupied in reading over the minutes of the last sitting, and replying to certain strictures upon the incapacity of land-surveyors in Brazil. Sir Robert Schomburgk had, in one of his works published in 184.3, upon the subject of New Guinea, made some disparaging observations as to the method of admeasurement pursued in Brazil, and one member of the society, Dr. Schüch de Capanema, seemed to consider it his duty in his double capacity as a Brazilian and an engineer, to protest-somewhat tardily it must be owned!-against these, according to his opinion, unjust remarks. After the discussion was over, a manuseript was next brought forward concerning some of the native tribes; His Majesty expressed a wish to have this treatise read. The secretary aceordingly made the attempt, but the writing was so illegible, that he was obliged to abandon the task. At the conclusion of the meeting, which lasted upwards of three hours, His Majesty conversed very affably with the Austrian gentlemen, and presented each with a copy of a national poem, "Conferaçao dos Tamoyos," by a native poet, Gonçalves de Magalhaes, and recently printed at His Majesty's expense, which relates the wars of the Tamoyos with the Portuguese residents of San 
Vincente-the last struggle of that heroic Indian race, the founding of Rio, and the subjugation of the entire force, under Nictheroy, by the Portuguese.

The Palcestra Scientifica is a branch of this institution, the members being chiefly naturalists. The gentlemen of the Novara Expedition were invited to one of the meetings, which was inaugurated by the secretary reading aloud an ancient manuscript upon the natural resources of various provinces in Brazil, according to explorations, which had been undertaken in 1798, by the directions and at the cost of the then Portuguese Government. There was also read a memoir upon the culture of linseed, formerly carried on in the province of St. Catharina, which, however, is now entirely discontinued. Dr. Schüch presented to the Society vocabularies of the Croado and Puris languages, compiled by M. R. F. de Senestes, a retired Belgian ship captain, now resident at Minas, who had long traded with these two Indian races. Dr. Schüch also exhibited a pigment, or dyestuff, extracted from the wood of the Ipé-tree, a species of bignonia, extensively used in the manufacture of axles. State Councillor and Senator Candido Baptista de Oliveira, [formerly Minister and Ambassador at St. Petersburg, and at that time publisher and editor of the Rivista Brasileira (Brazilian Review)], brought forward some meteorological tables, and explained his new method for measuring altitudes. The proceedings are usually conducted in the Portuguese language; but out of courtesy to the foreigners, French was 
principally spoken, and the President kindly proposed that Dr. Schüch de Capanema, who is thoroughly versed in German, should translate into that idiom the proceedings as carried on in Portuguese. At the elose of the sitting, the commander of our Expedition and the various members of the scientific commission were named associates of the Palcestra Scientifica.

This society had projected an expedition to explore the western provinces of the empire, and some of their members were appointed to draw up the plan for earrying it out. The arrangements for the enterprise were on the grandest scale. The requisite books and scientific apparatus were ordered from London, Paris, Vienna, and Berlin. Every branch of science had its representative,-an astronomer, botanist, zoologist, ethnologist, \&c., were to accompany the Expedition; each section had a number of assistants, the astronomical as many even as nine. When we arrived in Rio, the printed instruetions for the use of the members were just being distributed; and it was asserted that nothing but the non-arrival of the instruments from Europe prevented the departure of the Expedition. In short, the preparations which were made in the year 1857, justified the hope that a most brilliant success would be the result of an undertaking got up on so expensive a scale. The only pity is, that up till now-more than three years later-the Expedition has had but little result, and, according to the latest intelligence from Rio, some of the nembers in the north-east of the province of Cearì cannot 
proceed any further for want of money (por fulta de dinhero), and expect new funds in order to continue their explcrations and their efforts in search of the wild tribes (em lusea das tribus selvaticas!) in the interior of Maranhao.

There is, generally speaking, in Brazil, as in all other South-American States peopled by the Roman race, much of good-will, and still more vanity, to follow in the wake of northern European civilization in everything pertaining to progress and investigation; but there is wanting that energy, that perseverance so characteristic of the Anglo-Saxon race, which are essential conditions in successfully carrying out any undertaking, however zealously entered upon. This probably is the reason why in Brazil so many things in science and social life are begun and never brought to a conclusion; there is nowhere more talk about what is to be done, than at Rio de Janeiro. Thus, for example, the Museum of Natural History at the Campo Santa Anna, is an elegant building, with magnificent apartments, and large elegantly fitted cases-which, however, contain as yet but few objects of natural history, even those being most unsystematically arranged.

Another educational institution-the Military Academyfounded under Joln VI., in 1810, for the instruction of the engineers and officers of the various scientific corps, has, since then, undergone nine reforms, and was just about to undergo another one! In this establishment the highly objectionable practice still exists, of making every pupil acquainted with the chapter and rerse of the subjects of examination twenty-four hours before it takes place. 
The Public Library, though little more than begun at the period of our visit, already comprised 86,000 volumes, and is annually increased by an addition of five or six hundred. This institution was, in 1856 , visited by 3407 readers, who perused 7717 volumes, mostly in Portuguese and French, consisting of 238 on theology, 1046 on political economy, 2879 on natural science, 153 on the fine arts, 1083 on history, and 2318 on belles-lettres, which furnishes a very fair criterion for estimating the education of those availing themselves of these advantages.

Another institution, which is an evidence of the efforts now making by the Brazilians to gratify their national vanity, is the Conservatorio da Musica, a newly-established institution for the promotion of the opera lyrica nacional, the number of pupils attending which averages 100 . A custom has lately prevailed of sending one or two of the most gifted of these annually to Europe to complete their musical studies. During a four years' residence there, each pupil has a stipend from the Imperial exchequer of 3000 francs per annum; and in the event of obtaining a prize abroad, he receives a gratuity of 1000 francs; his compositions, however, in that case become the property of the parent institution. By this means the Brazilians hope to render themselves entirely independent of foreign musical talent. "Why should we annually pay hundreds of thousands of franes to foreign singers and concertgivers?" said a Brazilian to us one day in all earnestness. "We shall soon have our own artists-Brazilian Thalbergs, Grisis, and Lablaches!" Confessedly the inhabitants of the 
United States have been vain enough in all conscience; but when we consider the wonderful advances made by that active, energetic people, and contemplate their surpassing qualities, such a national foible is readily overlooked. In Brazil, on the contrary, the contempt affected for everything foreign, the fretful impatience to become emancipated from the smallest resemblance to European customs, is exccedingly childish and even ludicrous in a country which can hardly yet be said to be able to stand alone, since the pressure of circumstances is daily making them more and more dependent on other countries, and where it is necessary to import from abroad not merely the evidences of high culture, but the very first necessaries of life, even to obtaining supplies of foreign labour. This overweening self-esteem has rather increased, since it has become the fashion of young Brazilians, of the better classes, to visit Europe for the completion of their studies, as will, perhaps, be best illustrated by the following laughable anecdote:-A young Brazilian, the son of a German father and a native lady, who had but recently returned from Europe, overheard one of his friends asking another if he could tell of what country he thought the fresh arrival to be, at the same time indicating the youth, who just came from the academy of Freiberg. "There can be no doubt on that point," was the reply; " the blue eyes, light hair, and fair complexion, distinctly indicate that the gentleman is a German." "God forbid!" (Deu m'en guarda!) exclaimed the young gentleman, who seemed as it were 
ashamed of his foreign descent, and to fecl even more indignation than a full-blood Brazilian at such a mortifying imputation.

Among the various institutions recently established in Rio, the introduction of which is intended to be made available in promoting the physical well-being of the people, the foremost place must indisputably be assigned to the Board of Health (Junta Central de Ilygiena Publica). It owes its origin to the appearance of the yellow fever and the cholera, which had never been known before in the country. The former broke out on the 29th December, 1850, having been introduced by vessels that had cleared from Bahia, at which port it had been raging for some weeks. The ravages of this pestilence were fearful in Rio; out of a population of 250,000 souls, as many as 120,000 were attacked, and upwards of 5000 fell a sacrifice to the disease.

The first case of cholera occurred a few years later, on the 15th of July, 1855; and during the months in which it prevailed, nearly the same number (to be more precise, 4826) of the inhabitants of the capital were carried off. The fatal cases throughout the empire from this epidemic during the eighteen months between May, 1855, and December, 1856, are said to have amounted to the enormous number of $10 \%, 093$ ! Dr. Francisco de Paulo Candido, one of the most eminent physicians of Rio, and the principal member of the Board of Health, states, in a report to the Government, relative to the statistics of the cholera throughout the empire, that he had observed, 
during the prevalence of the epidemic, thrce phenomena, which seemed to stand in a certain relation to its appearance, increase, and decrease, viz., the almost entire disappearance of the ozon in July and following months, when the disease was on the increase; the gradual increase of that atmospheric agent, in proportion to the decrease of the disorder; and lastly, the influence exercised by humidity and sudden changes in temperature on the intensity of the disease. Dr. Candido has added to his highly instructive report some meteorological tables and a graphical representation of the presence and absence of ozon in the atmosphere, which will be published, in its proper place, in the medical section of the present work.

The consequence of the ravages of these two scourges was, that a variety of other measures for securing the public health were inaugurated by the newly-established Board of Health. Among others, a hospital was set on foot in a charming part of the Cove of Jurujuba, * at the eastern extremity of the Bay of Rio, expressly for the reception of patients aflicted with yellow fever or cholera. Every morning since that attack, (and during the unhealthy season several times a day), a small Government steamer, fitted up for the purpose, plies round the bay, to take up any cases that may happen to occur on board the ships arriving, and convey them hither free of charge. Two medical men on board the steamer commence the treatment, by applying the necessary remedies, during the

* Pronounced Shooru-shooba. 
passage from the ship to the hospital. Any vessel at anchor in the bay with an epidemic on board, has, according to arrangement, simply to hoist a flag on the mainmast, whereupon the Government steamer immediately embarks the sick persons. In order more effectually to keep from all contact with the population of the town, such shipboard patients as are labouring under infectious complaints, another hospital has been established on the Island of Marica, situated beyond the bar.

In consequence of these recent epidemic attacks, much greater attention than formerly has of late been paid to the cleanliness of the capital of the Brazilian empire, though a great deal has yet to be done in this respect. Rio used to be, without exception, the dirtiest city in the world. As there were neither gutters nor sewers, all impurities accumulated during the twenty-four hours used, towards evening, to be carried by negroes on their heads, in pails and casks, to the bay, and, singularly enough, emptied in the immediate vicinity of the Imperial palace, whereby several quarters of the city, particularly in the hot season, were rendered entirely unimhabitable. The execution of proper drainage and sewerage works in a city such as Rio, which lies on a flat and is densely built near the water, must be at all times attended with a very large expenditure of money. But who would boggle at any amount for an object which concerus the bodily health, not merely of the present, but of all succeeding generations? At the period of our visit, the Govermment had entered into a contract with Messis. Joaquim Pereira de Lima and J. F. Russell, by 
which, in consideration of a lease for ninety years of certain taxes specially levied, the two contractors have undertaken to introduce into the capital of Brazil a system of harbour and strect purification, similar to that which has long been in general use throughout England. There had also been lately started a Compantia Reformadora, having for object the widening and beautifying of certain streets, and the improvement of the paving. One must have lived in Rio, where each street and open square is a hotbed of fever and sickness, to be able aright to estimate the importance of the two last-named associations.

A war steamer was, by the command of H.M. the Emperor of Brazil, placed at our disposal, to afford us an opportunity of riewing more closely the most beautiful points in the magnificent bay of Rio. There were on board with us the Captain of the Port, Dom Francisco de Perura Pinto, the captains of the Brazilian men-of-war lying in the harbour, as also several members of the Historico-Geographical Institute. A military band enlivened the party by playing national airs during the day. We first visited the south-east part of the bay at the villages of San Domingo and Ponta da Armacao, opposite to Ponta da Aréa, whence steamers, for navigating the bay and adjoining coast, are run by an English company, which employs 667 hands, (of whom 298 are foreigners, 207 natives, and 162 negro slaves). Except a part of the funds advanced by native capitalists, the whole undertaking is carried out by foreigners. England furnishes the engineers and machinery, 
whilst the requisite timber is brought from Norway and North America. The value of the labour employed during 1856 amounted to nearly $£ 90,000$. W We proceeded hence past the islands of Salinas and Honorio, and between the island of Baretto and the eastern shore of the bay, as far as the luxuriant island of Paquetá, on the lovely shores of which we

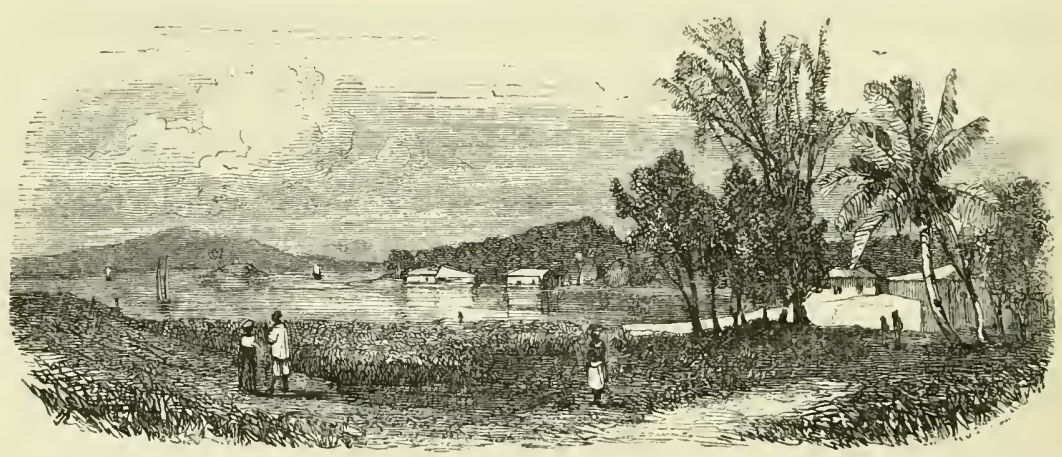

landed. It has a circumference of five miles, and is inhabited by 16,000 persons, who convert shells into chalk; nearly all the houses on shore are chalk-kilns. During the dry season this island is the favourite Sunday resort of the fluminenses, as the Rio de Janeirians delight to call themselves. From this sweet spot the steamer carried us to the north side of the bay. In the hack-ground, the Organos mountains now appeared in all the majesty of their imposing outline, whilst on one of the projecting ridges, the church San Francisco de Croara forms an extremely picturesque object.

The more the northern portion of the bay is approached, the more romantic becomes the panorama of the mountains: from this point stand out in their full grandeur the Serra da 
Estrella, the Serra da 'Tinguá (which is currently believed to be the highest mountain, not merely on the bay, but in Brazil), then the deep valley of Santa Cruz, next to which the mountain-chains of Suaratyba, and the Serra de Iguassoú, rise majestically, melting away into the charming Tejuca chain, the Gavia, and the world-renowned Corcovado, whilst the Sugar Loaf, that gigantic guardian at the entrance of the harbour, splendidly terminates this magnificent amphitheatre.

We passed the largest of the islands in the bay, the Ilha do Governador, which has a circumference of upwards of seven miles, and is inhabited by about a hundred persons chiefly employed in the chalk-kilns, sail-cloth and soap manufactories; and touched at some wild spots that promised a harvest for our naturalists. Here and there, from the deep blue waters, sprang up islands of the most luxuriant vegetation, like tropical idylls of rock and forest, such as the eye marvels to rest upon, but the pen refuses to describe. Indelibly impressed on our minds remains in this respect the lovely islet of Catalán, with its beautiful flowers and palms.

On approaching the capital, towards the east of the bay, passing the island Bom Jesus, with a magnificent Franciscan monastery, and the Ponta do Cajù, with charming country seats, a forest of masts, strikes the eye in bold contrast with the Sugar Loaf in the east, and the Morro de Viracao and the fort Pico in the west, which covers the position of Santa Cruz. Unfortunately we went down, just at this point, to a splendid banquet, etiquette requiring that we should exchange the 
quarter-deck for the state-room; for in Brazil also, upon such occasions, meals and speechifying play an important part, and greatly prejudice the special object of travel-the enjoyment of nature.

We were not yet done, however, with our excursion. Again we turned towards the beautiful Cove of Jurujuba, where on the shore lay pretty little cottages embowered in the richest foliage, while, through a deep depression, appeared the masts of ships which were still on the bosom of the ocean outside, on the point of entering the harbour. As the vessel steamed in, the scenery changed character at every moment, like a fairy landscape, full of the loveliest, most enchanting glimpses of the surrounding country. At Jurujuba, we landed to visit the Hospital Maritimo de S. Isabel, erected in 1853, for the reception of sailors in ill-health of all nations and creeds. It proved of immense utility during the prevalence of epidemics. In the five years of its existence at the period of our visit, there had been admitted nearly 6000 cases of yellow fever.* For the excellent management of this fine hospital the utmost credit is due to the physicians in charge, Dr. Bento Maria da Costa, and Dr. José Teixeira da Souza.

The ground immediately surrounding the hospital has been reclaimed by the hand of man, and transformed into a garden,

* In the year 1856,2452 paticnts were received into the hospital at Jumujuba Cove, of whom 175 died, 2195 were dismissed cured, aud 82 remained under treatment. By comparison with former years, the number of sick seemed to have fallen off 13 per cent., while the expenses of management had increased 9 per cent. 
in which flourish, in solitary majesty, the shady Aleurites triloba and the Anda Gomesii, growing in avenues or other regular groups, after all wild regetation had been cut down. But at the first step beyond, the foot of the wanderer through these solitudes strikes into paths leading through the richest, densest forest scenery Casuarinas (Anacardium occidentale), with its luscious pear-shaped fruits, the Indian mango-tree, the various species of Eugenia, so rich in ethereal oil, the Figuera Branca (ficus doliaria), the canoe-tree, a gigantic species of Bombax, protected by sharp spines, and other lofty forest-children, reach to the very buildings; while, amid the dense underwood that grows unchecked, and a few paces distant only from the dwellings of man, lurk dangerously poisonous snakes, who find here a secure haunt. Within our own experience, as one of the botanists of the Expedition was placing a ladder against a primæval forest tree, the progenitor of numberless scions, he stumbled upon a poisonous Jacaraca, ready to defend from intrusion his accustomed resting-place.

At the north-west entrance of Jurujuba Cove, rises a lofty island, with the appropriate name of Bom Viajem ("a happy voyage"), with its church of the Virgin of the same name, situate on the extreme summit, 400 feet in height. As, during our visit to the hospital, the twilight had crept stealthily on, we returned without further stoppage to Rio; when the company, landing at the usual landing-place of the arsenal, separated, full of the most pleasing impressions, arising from the beautiful scenery enjoyed during the day, and a deep 
sense of gratitude for the noble hospitality shown us by our amiable hosts.

Another favour was conferred by Drs, de Lagos and Schüch, who formed a fishing-party on a grand scale, which was greatly enjoyed by all, though the gun proved more profitable to our naturalists than rod, line, or net.

As the number of days at our disposal in Rio Janeiro began to diminish, we applied ourselves to seeing the utmost possible with the smallest sacrifice of time. The morning after our excursion on board the Santa Cruz, we attended a sitting of the Chamber of Deputies. The hall, oval in shape, is plainly, but comfortably fitted up. The members sit on benches in a semicircle. Opposite the president stand tables for the ministers of state; at the upper and lower end of the hall are galleries for the public, and one is specially assigned to the diplomatic body. Each member speaks from his place. Their language is very free. and their behaviour still more so,-they sometimes carry this so far as not to allow a speaker to proceed; and in screaming, brawling, and violence, they excel even certain members of the late French Chamber of Deputies. There are said to be some very able speakers amongst the Brazilians. The subject of debate was a petition presented to the House for an inquiry into the conduct of a late minister of justice, who was aceused of having tyrannically dismissed a government officer in the province of Maranhao. The subject had created great interest in the public mind, and the galleries were crowded to suffocation; we did not remain till the conclusion of the debate, but the minister 
is said to have justified the procecding by proving that the officer had allowed himself to be bribed.

On the same day we made an excursion to the Serra da Estrella and Petropolis, a place which has of late exeited so much attention in the public journals, since the question of German emigration to Brazil, with its accompaniments of agitations by the Brazilian recruiting agents, began to assume its present remarkable proportions. Though the distance from Rio to Petropolis may be accomplished in four hours, yet three different vehicles are required:-in the first place, a steamer from Rio to the railway-station on the opposite side of the bay, then the railway to Fragosa, and lastly, a carriage to the final destination over an excellent road which runs through the mountains to Petropolis.

This fine work, which*was opened in 1848, is unfortunately the only one of its kind in the whole emprre,* as are

* This road is to be continued from Petropolis as far as Parahyba; and in various other directions also the building of roads for commercial traffic is being fostered by Government. The Brazilian Govermment are at the same time turning their attention to improving the existing means of transport by importing dromedaries for use. As it withstands variation of temperature, and thrives on almost any kind of nourishment, the dromedary is certain to do well, especially in the northerm provinces, and will prove exceedingly serviceable in the transport of the products of that section of the country. The great heat and drought which prevail in Maranhao, Pianhy, Matto Grosso, and that direction generally, is emimently suitable to the dromedary, which does not thrive in hot damp weather. It is calculated that a dromedary, which can carry an average weight of 700 pounds, (bcing six times what a horse, and four times what a mule will carry on his back), costs, in his own country, from $£ 12$ to $£ 16$; and after paying cost of transport to Brazil, will be worth $£ 48$. With the introduction of the "ship of the desert," that of the date-palm must go hand in hand, as that fruit constitutes the chicf food of the dromedary, and will probably simultaneously effect a great change in the articles of consumption by the lower orders. 
likewise the five miles of railway between Maú and Fragosa; and yet how highly important would railway communication prove from the metropolis to the northern provinces,'by means of which the excessive cost of carriage by mules might be so considerably reduced, benefiting alike the landowner and the merchant! As an illustration, the fact may be mentioned, that the cost of transit for an arroba (32 lbs.) of coffee from the coffee district of Vassouras to Rio, a distance of about 50 miles, amounts to from 700 to 800 reis (about $1 s$. $8 d$.). The trouble and expense connected with this miserable mode of conveyance, so much enhance the price of some kinds of natural produce, that it does not pay to transport them to the harbour of the capital. Several companies have latterly been projected, and money subscribed for constructing railways in the various provinces of the empire, and a few of these are already under weigh, as, for example, that of Dom Pedro Segundo, which will put the richest provinces in direct communication with Rio, and for which the amount of money required has been entirely subscribed. But in this, as in all other Brazilian enterprises, energy is wanting to make these good intentions bear fruit; and so long as there is not a greater admixture of foreign go-a-head-ativeness in the country, much must remain confined to the mere expression of patriotic wishes. Ard in this connection, foreign immigration, of which we shall treat further on, will prove of immense importance.

The journey by carriage through the Sierra from Fragosa to Petropolis is extremely beautiful. He who is not fortunate 
enough to enter deeper into the interior, at least obtains here an idea of what constitutes a primeval Brazilian forest. The wonders of tropical vegetation, as manifested not only by vastness of form but also by gorgeous and rank luxuriance, strike the eye at first-sight almost the same way as an overpowering chorus affects the ear. It requires time to collect the thoughts, so as to be able to appreciate and enjoy thoroughly the extraordinary beauties that impress the wondering mind.

If the eye of the astonished traveller has been but in the most cursory manner directed to the vegetable phenomena that surround him, it must have rested on a climbing plant, which constitutes one of the chief marvels of the native woods. This singular creeper is the Cipo matador, a climbing plant of a very peculiar aspect, at once the most powerful and most destructive of all the Cipo tribe. It twines round the stems of lofty trees, which its flattened coils gradually constrict with almost life-like cruelty! Its aërial roots run out from all parts and embrace the tree like artificial clamps, forming in some places complete rings, and in others growing into the very bark. The tree, in consequence of this parasitic embrace, dies away by degrees, whilst its destroyer continues to grow gaily on the corpse of its victim, and spreads its leafy crown until it falls and perishes simultaneously with the support that had hitherto upheld it. To what profound reflections does the contemplation of this spectacle give rise! Involuntarily our thoughts fly from the wild Brazilian forest to the plains of civilization,- to the modern society where, likewise, many a noble human nature 
is slowly undermined by a treacherous Cipo matalor of flesh and blood, till too surely he falls prone on the ground!

Petropolis is, on account of its more temperate and healthy climate, a favourite residence of the wealthy Rio de Janeirians, and during the hot season, when the sultriness of the air, if not something worse, renders life almost unendurable, Petropolis is said to have the appearance of a European spa. It is at the same time the summer residence of the Emperor, and the only place in Brazil where an electric telegraph-uniting it with Rio de Janeiro-has been established. The town contains about 7000 inhabitants; the streets, when completed, will be broad and handsome,-_but only one has as yet been finished, the others being merely marked out, while even among the clean and neat houses already erected, there are frequent and wide gaps.

The German colony, planned by a German engineer, Julius Friedr. Köhler, is at a little distance from Petropolis. The first colonists who arrived on the 30th of July, 184.5, came mostly from Baden and the Rhenish provinces. The Government granted to each family a cottage, with a slice of forest near it, a cow, a dozen of chickens, and about $£ 5$ in money. Such at least was the information given us at Petropolis. Köhler soon afterwards met with a sad end at a newly-formed shooting ground. Many an enigrant family perished in misery; others, however, overcame the difficulties that beset them at the commencement; more emigrants arrived, and now one may walk, within a few hours, through the Rhine and Mosel valleys, 
Nassau, Darmstadt, Ingelheim, Bingen, the Palatinate and Switzerland, as the emigrants, in fond commemoration of their native homes, call their small settlements, which run some distance through the mountain valleys. The German origin of these settlements displays itself distinetly in the cleanliness and neatness of their log cabins, the affability of the people, the heartiness of their greeting, the fair hair, cuily heads, and beautiful blue eyes of the children, as well as the language and music which is now and then heard.

Petropolis is, however, not an agricultural colony in the real sense of the word, the majority of the 2500 Germans settled there obtaining a livelihood as artizans and labourers. The Government has done much to promote the growth of the colony, by making roads, and establishing schools. Still the people never become agriculturists, on account of the sterility of the soil; but as the road to the province of Minas Geraes runs through the place, the settlement will always retain some importance. For the cargoes of coffee which are conveyed by mules from the interior to the harbour, Petropolis is the last station, and will remain so for a long time yet, for the large outlay required renders it unlikely that the projected railway will soon be completed.

Several attempts have been made to establish similar German colonies in various provinces of the empire, but, unfortunately, with as yet even less success than in the Serra da Estrella. However, the activity of the Brazilian emigration agents has much increased in different German ports; for 
the remarkable words of the Emperor, with which he opened the Chambers in May, 1S54, at Rio,- "The necessity of a settled industrious population becomes more and more urgent," -have become since then even more significant; in fact, the result of the endeavours on the part of the Government to increase the amount of labour by immigration, is now a question of life or death for the empire. Every disinterested person fecls that, without an increase of labour, productive activity is impossible; nay, some even apprehend a considerable decrease in the producing capabilities of the country, in consequence of the effect to be anticipated in Brazil from the abolition of the slave-trade by the interference of England. Up to the year 1851, the importation of negro slaves continued undiminished, notwitlsstanding the treaty with England of 1826, in which the abolition of the slave-trade forms one of the conditions on which the recognition of the Brazilian crown by the Government of Her Britannic Majesty was made specially contingent. According to a statement of the Foreign Office, there were from IS4.2 to 1851 (despite the treaty) 325,615 negroes sold as slaves in Brazil, so that the amount of the slave population is now upwards of $2,000,000$ souls.

The condition of the black population in tnis country is materially different from that of the United States and the West Indies. The colour of the skin, which renders the life of even free and prosperous negroes almost intolerable in the northern states of America, where they are subject to so many 
humiliations, makes in Brazil no difference whatever. The question here is not whether white or black, but whether free or a slave. Free negroes may here occupy the highest places in the State, and even exercise a certain influence on the destiny of the white inliabitants. Slaves also are treated here with more humanity and less prejudice than in any other country visited by me, on which the curse of slavery yet rests; yet it must be confessed, without hesitation, that slavery, as beheld in Brazil, scems even a greater misfortune to the white population than to the black; for neither agriculture nor industry can thrive in a country where labour is not considered, as in free States, an honourable occupation-but rather as a disgrace-in consequence of its being performed by slaves. Not merely the blacks, who have no interest in being industrious, but their masters also are lazy, and approaching ruin becomes more and more certain. Free labour alone, by obtaining the upper hand in the country, can remedy these things. Slave labour cannot long compete with it. The intelligence, activity, and perseverance of 100,000 free white labourers will promote the prosperity and the happiness of Brazil, much more than the compulsory labour of two millions of negroes in bondage.

In consequence of repeated and encrgetic remonstrances on the part of the British Government, the slave-trade has now ceased in Brazil, and "one of the grandest monuments of our century," as the celebrated declaration by the Congress of Vienna termed the entire suppression of the slave- 
traile, may be considered by this circumstance approaching its termination.

As the Government became convinced that there was not the least hope of reaping any advantage from civilizing the aboriginal tribes, it had recourse to free immigration, and promoted it in every way.t It endeavoured, particularly in the warmer northern provinces, to replace the deficiency of negroes by Chinese Coolies, who were imported from different parts of China; but they could not stand the climate, and were not found capable of advantageously replacing the negro in his various and often very heavy labour. This partially arose from the indiscriminate selection of the immigrants, as the agents, when they could not obtain able-bodied men, did not scruple to make up their cargo with whatever came to hand.

The Government pays, therefore, the utmost attention to European immigration; it has agents in Portugal, France, Italy, Belgium, and especially in Germany; and endearours to

* Déclaration des puissances sur l'abolition de la traite des nègres, du 8 Février, 1815. L. Neumann, Recueil des traités et conventions conclus par l'Autriche (Leipzig, 1856. Vol. II., p. 502).

+ It may be useful, however, on many accounts to observe, that the Brazilian Government take considerablo pains to adapt this doomed race for a civilized mode of existence. $\Lambda$ law of 19 th September, 1855 , assigned an annual sum of $f 6000$ for the proper execution of this humane project. In order to remedy the very marked defieiency of suitable missionaries, the Government, through its representative in Paris, invited a number of Catholic priests from France-men, whose rearing and zeal for their faith had effected such marrels among the Indians of Canada. But the aborigines of Brazil seem hopelessly degraded, and are destined, after having filled their appointed place in the history of nations, to make room for a more energetically endowed race. 
organize associations that have for their object the settlement of industrious labourers in the country, and to support colonies already in existence, till they are in a position to maintain themselves. In Brazil, the conviction is pretty general, that only an emigration en masse of white labour can save this splendid country from ruin, though there are individuals who entertain a different opinion, and think-perhaps not altogether without reason-that the energy and industry of European settlers might eventually_considering the indolent and careless disposition of their countrymen-prove destructive to the national element!

The most striking proof of how thoroughly in earnest the leading members of the Brazilian Government are in their efforts to procure an immigration of foreign labour, may be found in the report of the Commission upon the new tariff, in which the following passage occurs, illustrative of the advantages which may be expected to be reaped from European emigation on a large scale :- " "These foreign labourers arrive here"poor, and depart from the country laden with our gold and silver, and, like blood-suckers, absorb our natural riches!" is the remark of those who are ignorant of the true interests of Brazil. For to whom are we indebted for our capital, for the industry and commerce which we have? To whom belong those manufactories which the people want to protect, and in whose favour so much is said? Why, to foreigners! Foreign hands and foreign capital cultivate our soil, expand our trade and commerce, and promote the arts. 
The results of their labour remain, though they may themselves quit the country! Foreigners man our ships, build our manufactories, and supply them with hands; foreigners buy our produce and carry it to distant markets; foreigners render our forests and rivers productive; they work our mines, uncover the metallic wealth of our country, and educate our children! Capital, practical science, instruments, and machines, with which we perform our labours, belong mostly to foreigners; and, consequently, these blood-suckers are just the very men who render our land productive, preserving, instead of, as some erroneously imagine, depriving us of our vitality. The money which they take back to their homes is amply replaced by the treasures they leave behind in the product of their labour, and in the branches of industry which they have introduced or improved." *

More explicitly and discerningly it was hardly possible for Government to speak, and to enumerate the glorious results which the country may expect from the introduction of foreign industry and foreign activity, although such an official arowal could not fail to wound the national pride of the Brazilians.

Notwithstanding this strong language of the Government, and all the enticements and zealous activity of the Brazilian agrents in the various ports of Europe, the emigration to that

* Of the sixty-four manufactories and workshops, twenty-eight belong to foreigners; and there is not a single industrial establishnent in which foreigners are not empluyed, either as managers, engineers, or labourcrs. 
country, in 1856, amounted to only 13,800 souls.* Among this number there were but 628 agriculturists, all the others coming merely with the view of obtaining a livelihood in the capital as artizans and labourers. There are probably in all the Brazilian agricultural colonies, at this moment, not more than 40,000 emigrants settled, that is to say, about as many as emigrate in the course of three months to the United States!

The number of Germans emigrating to Brazil is strikingly small, when compared with the total annual emigration from that country. Of 61,413 individuals, who, in 1856, embarked from Hamburg and Bremen, only 1822 went to Brazil. The cause of this may be that, simultaneously with the large promises held out by the agents, warning voices were heard depicting in the most gloomy colours the terrible trials that await the unfortunate immigrant on his touching Brazilian soil.t Of late such excellent works have been published concerning Brazil, that we may advise all who take a special interest in the condition of that empire to study these works, the more so

+ Namely: 9159 Portuguese, 1822 Germans, and 2819 of other nations.

* Among these, the opposition of the late Consul-General for Brazil at Dresden, Mr. John Sturz, deserves special mention, as, despite the threats of losing his appointment, that gentleman was incessantly occupied in exposing the iniquities of the Parceria system (see post), and recommending the immigrant, so long as such a slarish system continued, to refrain from turning his steps towards Brazil. Mr. Sturz had recently the enviable misfortume of being sacrificed to his own strong sense of justice, and dismissed from all employment by the Brazilian administration, thongh not without carrying with him the respect and admiration of every friend of humanity. An excellent and circumstantial description of the present condition of the German colonies in southern Brazil will be foumd in Dr. Avé Lallenant's attractive "Travels throngh Southern Brazil in 1858." (Leipzig, 1859.) 
as the views therein expressed exactly coincide with our own impressions.*

So long as the unoccupied lands are not surveyed, laid out in lots, and sold at a small rate to the settler, as, for instance, in the United States; so long as the immigrant is unable to improve for himself his own plot of ground, but must remain a mere field-labourer, working for some foreign master, according to the iniquitous Parceria, or half-profits system; $f$ so long as the expense of transport of the emigrant is to be worked off by future payments out of his labour, so long must every friend of humanity strongly dissuade the emigrant from proceeding to the great South American Empire.

For Brazil, beautiful, fertile, and abounding in undeveloped natural wealth, two alternatives are alone open at present-

*H. Handelmann's "History of Brazil" (Berlin, 1860), a remarkably profound and instructive work, devotes a special section (p. 933) to the subject of German emigration, and gives a very copious and complete insight into the various missions and works since 1819 to the present day, which treat of German emigration and colonization.

+ The modern Brazilian system of Parceria may be shortly stated as that by which a planter engages in Europe such of the poorer classes as are desirous of emigrating, and has them transported at his own cost to Brazil, where they are engaged as farmers, with lialf profits, npon the coffee and sugar plantations, and contracting to reimburse him, by their personal services and labour, for the outlay he has been at for their transport, maintenance, instrnetion, \&e. Until all these have been repaid by the improvement in the rent or prodnctive powers of the land, they must remain, as working out their emancipation from the lord of the soil, veritable "adseripti glebre." $\Lambda$ fter that has been attained they aro free people, and may leave if they please, or may sink into the rank of "nnattached labourers," which implies their assigning half of the net produce of the land to the ground landlord, the remaining half being their remuneration for labour. Proprietorship in the soil is never attainable by these farmers on half profits, inasmuch as the Parceria system can only exist where the soil is alreatly exclusively vested in a planing aristoeraey. (See Handelmann, ete., p. 568). 
either ruin to the producing power of the population through deficiency of industrial power, or the throwing open the land to foreign emigration by means of the most extensive concessions. The longer this is deferred, the more oppressively will the want of manual labour manifest itself; and the more advantages will foreign emigration secure.

Once, however, these important stipulations are conceded, the German emigrants may forthwith bend their steps to the coasts of Brazil, where the glorious dawn of a magnificent future is surely breaking for them. While, in the United States, the problem to be solved by the German emigrants seems to be, to mingle German industry, German capacity, and German knowledge, with the keen spirit of enterprise and restless energy of the Anglo-Saxon race, and gradually to assimilate with it,-on the other hand, in the South American continent, it appears as though the German element were about gradually to gain the upperhand of the Latin stock, and permanently to conquer for German industry and German commerce, one of the fairest countries on the globe with the weapons of peace-the spade and plough.

Brazil is, however, of great interest to Germany not merely on account of the prospects she holds out for its overflowing population. A market, teeming with the most important colonial products, with an area* of 3,956,800 English square miles; and an annual consumption of nearly $£ 10,000,000$, must it the highest degree attract the attention and excite the most

* According to the computation of the Historico-Geographical Institute of Brazil. 
favourable anticipations of a country such as Germany, the majority of whose inhabitants are engaged in manufactures.

The chicf article of Brazilian trade at present is coffee, the production of which, in consequence of the great profit of late years derired from it, has increased so much, that it has superseded the cultivation of all other produce; thus, notwithstanding the fertility and capability of the ground, even the commonest necessaries of life, as, for instance, potatoes, must be imported from abroad, the majority of the rural population being engaged in labour for the foreign market, and only very few for home consumption. This is the principal cause of the enormous prices which, even the most indispensable necessaries have reached in Rio de Janeiro.

Brazil grows annually, in the provinces of Rio, Bahia, and Santa Catharina, 5,190,000 quintals of coffee, consequently more than three-fifths of the entire amount produced on the whole earth, and of this the province of Rio de Janeiro alone yields two-thirds.

The most important objects of export, besides coffee, are sugar, rice, cotton, hides, and dried meat, together with dye and cabinet woods. The progressive decrease of late years in these articles may probably be ascribed to the want of sufficient labour, as well as to the great extent to which the culture of coffee has been carried.

Although the trade carried on between Brazil and Europe, and its great importance, will form the object of a special work, we cannot help noticing in this place as a very inte- 
resting fact, that among the importations, that of wheat-flour holds a very conspicuous place, above 300,000 barrels of 200 lbs. each being annually consumed, of which seventeen twentieths are supplied by the United States, two twentieths from Trieste and Fiume, and the remaining one twentieth from Lisbon and Valparaiso. The flour from Trieste, by reason of its whiteness and superior quality, commands a high price, so as to necessitate its being mixed in baking with that from Baltimore. We were told it occasionally happens, that the best quality of the much-appreciated Trieste or Fontana flour reaches the price, altogether unapproachable by the finest American flour, of 64 to 66 shillings the barrel.

As in the interior of the country the flour chiefly used is that called Mandioca, prepared from the root of Jatropha Manihot, it follows that the chief consumer of wheaten flour is Rio itself, the monthly consumption amounting to upwards of 16,500 barrels. The reason for the small sale of the Austrian manufactures in Brazil must be sought for, not so much in the deficient supplies of the articles required; as in the circumstance that the Austrian manufacturers have not hitherto found it much their interest to study the Brazilian market, so as to make the requisite alterations in the method of producing their fabrics, and thus render them suitable for that purpose. What little of our Austrian manufactures is at present exported for Brazilian consumption, seems at present to follow the, to all appearance, much less natural route northwards, and instead of proceeding from Trieste direct, is exported from Bremen or Hamburg as fabrics of Northern Germany. 
During our stay at Rio, Commodore Wüllerstorf, accompanied by Captain Pöck, and one of the members of the scientific commission, had the honour of being presented to the Emperor and Empress of Brazil, at a private audience. The reception took place at the winter residence of St. Christoph. It is an old unsightly building, and still unfinished, the central part especially having been for some years in a ruinous condition. The Emperor seems not to be partial to display, and a very characteristic anecdote in this respect, which does him great credit, is very generally reported. On the occasion of a visit to the splendid lunatic asylum of Botafogo, one of the ministers remarked to His Majesty that the inmates of the establishment were better and more elegantly lodged than him. self. "It will always afford me great pleasure," was the reply, " to know that these unfortunate people are better provided foi" than I am."

At the entrance of the palace at St. Christoph, the gentlemen of the Expedition were received by an ecclesiastic, who led them into an exceedingly plain ante-chamber, the furniture of which seemed to belong to bygone centuries. Sereral of the ministers of state, whose servants carried large portfolios, exchanged compliments with the Austrian minister, and entered the contiguous apartments. Chamberlains and domestics of the court looked stcalthily at the strangers, and disappeared as rapidly as they had come. It seemed as though these presentations were of infrequent occurrence. At last, about half-past 6 P.M. the door opened, when His Majesty and the ministers walked through the room into the hall of audi- 
ence, into which the gentlemen of the Expedition were soon afterwards conducted by a chamberlain. 'The Austrian minister presented each separately to His Majesty Dom Pechro II., who is the son of an Austrian Arehduchess, and received the gentlemen in the uniform of an admiral, surrounded by all his ministers. He is a fine-looking man, of some 30 years of age, of stately appearance, but with a voice somewhat too thin for so robust a person. The portrait on the Brazilian coinage is remarkably like. The conversation was carried on in French; it is said, however, that the Emperor speaks German fluently. $\mathrm{He}$ conversed very affably and graciously with every one, and had something agreeable to say to each, expressing much interest in the Novara Expedition. After sereral questions, the Emperor wished us success on our future-voyage, and retired, upon which the audience was at an end.

After the members of the Expedition had remained a short space in a corner of the audience chamber, they were conducted through a narrow boarded passage to the apartments of the Empress. In the ante-chamber we again encountered the Emperor, who had exchanged his admiral's uniform for plain clothes, and now stood before us in the undress black frock he usually wears.

We were now ushered into the small and very plainly furnished reception-room of the Empress, in which there was nothing to attract attention except a couple of highly-finished portraits. Her Majesty, a sister of the late King Ferdinand II. of Naples, and of Queen Maria Christina of Spain, 
was in mourning owing to a death in the family. She was only attended by one lady in waiting, and received us with infinite grace. She is rather short in stature, and although still young, looks aged; in conversation she becomes how. ever very animated, and thereby gains in gracefulness; her favourite theme was Italy, on which she dwelt with childlike fondness. Speaking of Naples, its charming bay, of the Vesuvius, and the lovely walk of Santa Lucia, near the sea, the tone of her voice became involuntarily more lively. Notwithstanding the tropical splendour, and an Imperial throne, the Princess scems to have a great longing for her native land. Alas! even an inperial crown is no protection against the yearning for home!

During our stay here, the anniversary came round of the birth of our gracious Emperor, which was celebrated in the most festive manner. From early dawn the frigate appeared decked out in her gayest flags, which was similarly responded to by the English and French ships of war in the harbour. At S A.M., with the eustomary salutes of the ensign, a salute of twenty-one guns was fired, as also at mid-day and sunset. At 11 A.M., the crew were paraded and divine service was performed, to which our resident envoy and his family were invited, together with the acting Consul-General, the captain of an Austrian vessel, and a few Austrians who happened to be at that time in Rio. After service, the foreign guests and several officers of the staff were entertained by the commodore at breakfast In the evening there was a banquet at the 
hotel of the envoy, at which were present several notabilities of the empire of Brazil, among others, Viscount Maranguapè, minister of forcign affairs, and the Senator Viscount de Uruguay. In the garden of the club the frigate's band of music played chiefly German and Austrian pieces, which awoke in the bosoms of many the most tender recollections.

The frequent arrival of men of war in the bay of Rio gives rise to an almost continual firing; each vessel entering fires a royal salute, which is answered by the fortress and the other ships of war in the harbour. During our stay we discharged not less than 432 salvos, while all the men of war together fired at least 1500 salvos, thus making, within three wceks, about 5250 rounds of gunpowder, used merely in salutes.

The 31st of August had been fixed as the date of our departure. During the latter days of our stay, there had been frequent collations on board to make some return to those who had shown us attention. Several of the sick, one midshipman and two sailors, had to be left behind in hospital, where they received the most careful treatment, while Dr. Avé Robert Lallemant, who, by the kind recommendation of Humboldt, had been permitted by the Archduke to accompany the Expedition with the rank of surgeon of corvette, for the purpose of prosecuting his studics of yellow fever, was, at his own request, put ashore at Rio, whence he afterwards undertook the journey through Southern Brazil already alluded to.

The night previous, three sailors had deserted from a boat 
sent on shore to bring back some officers. 'The system of kidnapping, as is well known, flourishes in Rio, and many a ship is said to have lost, in this way, from thirty to forty men. The crimps, who make their living by this traffic in man, entice young and robust sailors to desert by means of all imaginable allurements and promises, making advances in money, and leading them into a dissolute life, in order that, when afterwards they find themselves in a desperate state, and without resources, they may be sold by the scoundrels to the captains of vessels, as sailors, or, what is worse, as white slaves, to the planters in the interior. This abominable trade is said to be carried on, on a great scale, by an Italian, in Catumbý Grande, and though the Brazilian police is perfectly cognizant of the haunts of the fellow, yet it seems not to be powerful enough to put a stop to the nuisance.

These incidents did not, however, interfere with our departure at the specified hour, when we were towed out by the tug steamer Perseverancia, which we had hired for $£ 25$. Almost every large ship on leaving Rio is towed clear of the bay, so as to avoid having to tack between the islands, or perhaps have to anchor, so that the tug, which belongs to a private individual, and accompanied us eastward as far as the island of Razza, must be a source of considerable profit.

On 31st August, at six A.M., we bade farewell to the splendid harbour of Rio. We had fortunately reached Rio after the visit of the yellow fever, but the almost continual rainy weather had spoiled many an excursion, and deprived us 
of the opportunity of more closely examining the environs of the eity. Nor were we more successful in making ourselves at home here, notwithstanding the kind reception with which we were favoured by the Government and some private individuals. There is, in short, a great want of sociability, and we may add, almost utter indifference to scientific pursuits, which indeed appeal in vain to the great majority of the Brazilian population. Of course there are numerous and agreeable exceptions; but slavery, the mixture of races, the egotism and indolence of the wealthier elasses, are all reasons why a European, just arrived, cannot feel himself comfortable. The white Brazilians bear, in some respects, a strong resemblance to the Italians, but they are deficient in their pleasing, insinuating demeanour, in their cheerful humour, quickness of perception, and lively imagination. They occupy a lower scale in social culture, without depth of thought or feeling, and seem almost incapable of persevering activity. This perceptible deficiency of hearty, energetic temperament, in addition to the confused intermingling of other foreign nations, which seem to regard the country as booty, to be abandoned so soon as success has crowned their labours, imparts to each new arrival a feeling of depression, which, so far from being weakened, is yet more keenly felt by those who have lived some time in the country, so that not merely among foreigners recently arrived, but with those also who have spent years at Rio, the desire to leave these shores becomes rather increased than diminished by a longer acquaintance. 
At nine a.m., we cast off from the tug, not far from the little island of Razza, with its lighthouse, and spread our sails to the breeze, which gradually freshened, but blew from the N.E., which was foul for our course. However, we could still derive some advantage from even this, as it was our intention to steer southerly from Rio, so as to be able to make almost exclusively a great circle course to the Cape of Good Hope, after we should have got further south than the Antarctic limit of the S.E. trades.

The near termination of the winter quarter in this southern hemisphere, the approximation of the sun towards the south pole, and the consequent tendency of the zones of wind and currents of air to pursue the same direction, gave us reason to hope, that when approaching the limits of the trades, we should find a change of wind, which should shorten the voyage, or at all events keep us clear of storms.

In the open ocean, where there are no hills or extraordinary conformations of land to break the uniformity of the carth's surface, and where the expanse of water is unbroken by any extensive group of islands, the disturbances in the atmospheric belt must necessarily be much less strongly marked than where eontinents are interposed, or in the narrow seas. The winds themselves, under such circumstances, display even in their shifts a certain amount of regularity, which is usually dependent upon the universal laws of nature.

Once any one is so fortumate as to comprehend the latter in all their extent, so as to be cognisant of their results, it becomes 
a mere question of the study of local conditions in order to be able to declare how these universal laws operate, and to elucidate by the most simple explanations many of the phanomena of nature that have till now baffled science. Thus, when a wind hitherto steady shifts its direction, there must necessarily be certain active causes for its doing so; if these causes perpetually recur in well-marked periodical intervals, the change of the wind must follow a definite law. Under certain circumstances the direction of the wind is well-defined; as, for instance, at certain seasons in the open ocean it remains always the same, or changes with a certain regularity, whence it becomes apparent that the causes must remain unchanging, and the recurrence of the phenomenon must accordingly admit of explanation.

We know, for example, that in the case of hurricanesthose most terrific exemplifications of the tendency of the atmosphere to move in circles-the wind does not blow in straight lines, but rather in curves described round a central point, which again is not immovable, but has a regular progression along a definite curve. In that curved plane, however, which has been termed a cyclone, the wind always blows in one and the same direction, and in the Northern Hemisphere runs counter to the motion of a watch-hand, while in the Southern Hemisphere it, on the contrary, follows that motion.

These facts once granted as accounting for such phenomena, it follows as a natural consequence of the general principles 
laid down, that they hold good in minor cases, and must remain of the same efficacy, whether it be a hurricane or a dust-whirl which may be under consideration.

So, too, in conformity with those laws, light winds may be found subject to a rariation in direction of a similar nature, such as may not perhaps be fully exemplified in every case, but simply serve to indicate the tendency of the wind to follow the same general direction as the hurricanes themselves.

The importance of ascertaining such curvilinearity in the direction of the winds will be especially manifest at the limits within which the regular winds prevail, and when they must necessarily become intermingled with other regular currents of the atmosphere.

Accordingly, as we neared the limit of the S.E. Trades, which always extend somewhat further south, as the sun's southern declination increases, we had to traverse regions where necessarily we encountered variable winds, owing to the increased area of the Trades. There are also found occasional spots at which a more rarefied atmosphere seems to fill the surrounding space, when there is seen a similar process to that in the case of hurricanes, first visible perhaps in the higher strata, but afterwards extending to those which are lower.

The winds, then, shifted with much regularity, and with them the atmospheric pressure, just as in the case of cyclones, except that neither the wind nor the sea erer presented the characteristics of a tempest. The wind, which began to blow from the North-East, drew gradually to North, thence 
$W^{\top}$ est and South, and returned to S.E., after short intervals of calm. We could thus perceive, on referring to the ship's $\log$, that the entire cycle was completed in five or six days; so that it became quite possible, by examining the central direction of the daily variation, to foretell the wind which must be blowing twelve hours later, when, upon taking into consideration the path described by such central direction from day to day, it appeared that the wind described very nearly a parabolic curve.

Even the aspect of the heavens, and the state of the weather, were only one degree less regular in their alternations than the hurricanes. With the S.E. wind, the sky was bright, but as soon as it began to veer round, towards afternoon, a few white belts of cirrhous clouds began to appear in the western heavens, constituting a well-marked division of the vault of the sky from one side quite to the other. As it drew still further round, and neared the line of centres, the weather grew foul, a driving scud covered the heavens, and a succession of splendid rainbows were seen, till the ship had reached the nearest spot to the storm-centre when there were sharp squalls of wind, accompanied by heavy showers of rain. The lower strata of clouds, mere vapour, drove before the wind, while those above moved in a directly contrary direction, generally that of the forthcoming wind. The atmospheric pressure, which at first would be considerable, gradually decreased as we approached the central line; as we drew away from that centre the barometer rose again, 
the weather improved, and the sky under the influence of southerly winds once more cleared.

Unfortunately it is not practicable with a single ship to ascertain whether the veering of the wind follows an exact curve, as we can only say what is the direction at the spot where the observation has been made, and it is impossible to determine what it may be at other points. But it is at all events certain that the shifts of wind are amenable to the same general laws as hurricanes. A number of ships sent out for the special purpose of this branch of investigation, could render immense services to science and navigation, and achieve most interesting results.

We availed ourselves of these general laws to traverse the ocean as speedily as possible, in order to reach early our next anchorage, and in so doing we experienced altogether three well-marked cycles of wind at short intervals. We cannot afford space to prosecute all the interesting consequences that result from these phenomena of nature, such investigations being more properly reserved for the meteorological section of the scientific portion of this work. Here, however, the facilities for observation of a sca-faring life have been directed towards an object of inquiry, which must prove of immense utility in navigation and commerce. And, perhaps, even landsmen may not find it uninteresting, that even that proverbially fickle element, air, obeys certain fixed laws, a more accurate acquaintance with which must be of the utmost importance to the denizen of terra firma, as well as 
those "that go down to the sea in ships, that do business in great waters."

On this passage from the American to the African coasts, we were continually accompanied by our winged friends, the sea-birds, which, notwithstanding the unkind treatment they received at the hands of the zoological sportsmen, followed us with the utmost pertinacity, probably attracted by the numerous fragments of provisions thrown overboard.

The Cape pigeons (Procellaria $s p$.), those prettily-marked sea-birds, about the size of doves, the albatrosses, (Diomedea $s p$.) the largest of the ocean feathered tribe, with their quiet majestic flight, stormy petrels of all sorts and sizes, from the smallest swallow to the largest of its kind; all these winged inhabitants of the sea's surface followerl the frigate in motley groups, and seemed never to weary in their active search for food.

Sometimes they alighted, rested on the surface of the water, and were left far behind; but they collected again with great rapidity as soon as anything eatable appeared, and overtook the frigate in a swift flight from the remotest point of the horizon. This singular attachment to ships very probably arises from their being accustomed to follow whalers, from which such a large quantity of garbage is thrown overboard, very much affected by these aërial parasites, whence they learn to expect from all vessels their favourite food.

They possess a remarkable capacity for remembering the exact time when they are likely to receive a large quantity of 
eatables from on board. Every day, about noon, the vicinity of the ship became animated, and towards one o'clock, after the crew had finished dinner, these lively creatures were close behind, and even fought for the pieces of tow with which the coppers had been cleansed. The boldest amongst them was the Cape pigeon, which pounced, with the utmost avidity, upon the dainty morsels thrown overboard, raising a loud scream, swimming round its prey, diving for sinking fragments, or snatching from each other those they had secured. Then came the black and brown-spotted and white albatrosses. As soon as one of these colossal birds appeared on the scene of strife, the uproar of the screaming pigeons at once became still; they kept themselves at a respectful distance from the voracious albatross, which quietly consumed its lion's share. In a few moments, yet greater numbers of these assembled, of which the black ones (Phœbetria fuliginosa), like the large petrels, are extremely shy, and rarely approach the ship within gun-shot. The other large-sized petrels acted similarly, the brown spectacled-petrel, so named from two singular-looking black rings round the eyes, being the most numerous. Along with these were several small Mother Carey's Chickens, and flights of other winged creatures swarming over the sea. The darker the sky, the more agitated the sea, the more actively do the Cape pigcons tumble and toss behind the ship; it appears that in rough stormy weather they see less distinctly and find food with difficulty, in consequence of which they are in a famished state. Only under these circumstances, 
and when the ship is moving slowly, can they be caught with a line. To angle for birds may appear rather odd to the reader, and yet it is common enough in the Southern Ocean, amusing the sailor, and providing the zoologist with means of obtaining these birds alive. For this purpose, however, circumstances must be comparatively favourable; that is to say, the weather must be rough, the sea agitated, and the ship making but little headwar. When the sky is serene, and the sea calm, even the Cape pigeons do not think it worth their while to throw a glance at the bait; and if the ship is moving fast, they have not speed enough to catch it, because they only swim, and the ship outspeeds them. The line, moreover, must be of tolerable length, so as, in the event of any bird evincing a desire to snap, to allow as much to be paid out as is necessary to leave the bait precisely in the same spot, without towing it through the water. It sometimes also occurs, particularly after sunset, that these birds, continually following in the wake of the ship, do not see the line, strike against it, and entangle themselves so that they may be easily drawn on board. The scream of the storm-pigeon when caught, makes it betray its fate even before those on board have an idea that it has been captured.

For the albatross, it is of course necessary to use a stronger hook, which it is best to attach to a copper wire, because this being thinner than line, is not so readily perceived. In order that the whole apparatus may swim on the surface of the water, a few cork floats are also made fast. 
When an albatross has hooked itself, the full strength of a man is requisite to draw it on board, for the bird, in its despair, dives and keeps its wings spread under water, so that the resistance is very considerable, and frequently even the strongest lines are broken. This cannot be wondered at when their size is considered, as they measure from 10 to 14 feet across the extended wings, while their weight amounts to from 10 to $18 \mathrm{lbs}$. Arrived on deck, none of these sea-birds are able to fly away; they move very clumsily on their webbed feet, and can only rise after a slanting spring, which, however, they cannot accomplish on firm ground; if in the water these birds want to rise into the air whilst swimming, they flutter their outspread wings for a little, and use their webbed feet in a kind of rowing motion, in order to acquire the requisite impetus. The albatross defends itself with its bill, which is often four to five inches long, and care must be taken to avoid being wounded in catching them. We also remarked that the Cape pigeons, in their rage at being captured, vomited up a slimy greasy substance.

The latter bird was of course new to us, and afforder us much amusement. Many were knocked over with the fowlingpiece, especially when, in their inquisitiveness, they came too near the boats, which, as often as our rate of progress admitted, were launched with the view of adding to our collection of objects of natural history.

In shooting an albatross large shot must be used, as, at a distance of 15 or 20 feet, small shot do not penetrate the 
feathers and the down of the bird. What is most remarkable as regards these birds is the numerous parasites that live upon their bodies. It is most extraordinary how certain of these birds (as for instance, the Puffins and Procellarice) are infested by insects, their plumage sometimes swarming with small specimens of Crustacece.

On the 26th of September, the famous Table Mountain of the Cape was visible, after we had, the evening previous, at a distance of fourteen miles, sighted the lighthouse of Table Bay.

The twenty-six days of our voyage hither had flown quickly past, and we were still able vividly to recal the impressions made by Brazil, and the scenes we had gone through in mid-ocean, as the southernmost point of Africa came in sight with its characteristic hills, and our eyes and our thoughts were directed to another quarter of the globe. On the one hand, excited with the prospect of new scenery, and on the other, anxious to complete our elaborate observations upon Brazil, so as to be able to send them home from the Cape, we found ourselves in a frame of mind which kept us alternately hard at the desk, or drove us on deck to admire the remarkable outline of Cape Colony. We did not, at the present season, think it advisable to run right into the bay, so as to anchor near Cape Town, but resolved to double the Cape, and proceed to Simon's Bay, the usual anchorage for ships-of-war. We were, however, sadly disappointed in the hope of soon reaching it, as the south-east wind freshened so much that on the 
27 th it had become a gale, which forced us out to sea again. The world-known swell off the Cape began under the everincreasing wind to run high, and we were soon involved in one of those famous Cape storms which justified the Portuguese in calling the promontory of South Africa, "Cabo Tormentoso," or the Cape of Storm."

The wind and spray roared and lashed through the rigging: higher and higher rose the huge mountains of water, with their white crests, that tossed the ship like a plaything from side to side. The waves foamed in through the port-holes on the gun-deck, while masts, cordage, timbers, every part of the ship groaned and creaked, a perfect medley of sights and sounds, including woful destruction of crockery, and the heavy rolling of erratic cannon-shot that had broken loose from the rack, and were rushing about the deck-above all which was heard the shrill whistle of the pipe of the boatswain's mate. The scene fairly baffled all powers of description, and must have been eminently impressive for those who for the first time experienced what is meant by "a gale at sea," especially at night, when the moon, struggling through the flying vapours, lit up the appalling scene with a livid supernatural tint.

On the afternoon of the $2 S$ th the gale reached its highest point, and raged fearfully for some hours. The frigate proved herself, in this turbulence of the waters, to be thoroughly

* "Through such mad seas the daring Gama fought,

Iucessant toiling round the stormy Cape."

(Lord Stranyford's Camoens.) 
seaworthy. At the same time the sun shone brilliantly, the sky was clear and beautiful, and only here and there some feathery clouds were to be seen. There was a curious sense of dualism in this serenity of the sky, in contrast with the fury and agitation of the waves. Gradually the wind chopped round towards the east, which gave some hope that the gale would abate, but, nevertheless, the ship was tossed about worse than ever.

The waves, like gigantic ridges, mounted, according to measurement, to the height of from 30 to 35 fcet above the mean level of the sea, and occasioned that terrible rolling of the ship, and those fearful lurches, which, once experienced, are not readily forgotten.

Hitherto the altitude of a wave has been generally measured merely by the eye, so that the result depended too much on the accuracy of individual observation to admit of its being exactly ascertained; and it is for this reason that the statements relative to the maximum height of the ocean wave are so various that they cannot be considered reliable, for whilst some observers estimate them to be from 60 to 70 feet, others reckon them only at from 30 to 40 feet.

On board the Novara the folluwing method of admeasurement was adopted: we first determined, by a chronometer, the time that a wave takes to pass from one end of the ship to the other, whereby the velocity of the progressive motion of the wave could be calculated in relation to the ship's course and speed, regard being had to the direction and 
velocity of the ship against it. With this velocity ascertained, we were in a position to determine and fix the arerage distance between two consecutive waves. Lastly, the height of the wave was ascertained from the angle at which the frigate rose and fell in the line of its keel, by the influence of each successive wave and by means of the ascertained distance from the trough of the sea to the crest of the ware. Though this method, likewise, has many difficulties and deficiencies, yet it appears well suited to make correct comparisons between the different waves; and, under certain favourable conditions, it yields so accurate a result, that at any rate it is to be preferred to mere guess-work, besides that the experiment itself is susceptible of many improvements. It seems safe to assume that wares scarcely ever attain an elevation of more than 40 or 45 feet.

The gale had driven us a long distance out, and only after great trouble did we again near the land. On the 1st of October the Cape came once more in sight; we tacked, in order to get into the wide gulf termed False Bay, by which in some respects the peninsula of the Cape is formed, being separated only by a low sandy plain from the Atlantic. Whittle's rock renders tacking in its neighbourhood in so far more difficult, as the existing charts of the bay are not sufficiently exact to be implicitly relied on. Buoys have often been fixed in that quarter, but every new gale carried them away again; so that the position of the rock is not indicated. An English pilot now came on board, who brought papers, 
and intelligence that a number of letters were waiting for us. Our impatience became stronger when towards evening the light breeze entirely ceased, and we thereby were forced to bring up at a distance of a mile and a half from the actual anchorage. About the same time an officer arrived from the British line-of-battle-ship Boscawen, under the flag of Rear-Admiral Grey, in order to serve as a guide should no pilot have boarded us.

On the 2nd of October, at 7 A.M., the anchor was let go in Simon's Bay, a spacious but gloomy-looking sheet of water. Here ships ride much more secure than in Table Bay, from which, in a stiff westerly or north-westerly breeze, vessels are often forced to run out to sea to avoid being driven on shore, The communication with the land is thus sometimes interrupted for days. From Simon's Bay to Table Bay, round the Cape the distance is forty miles, whilst by land the journey to the capital of the colony is, with good horses, performed in three hours.

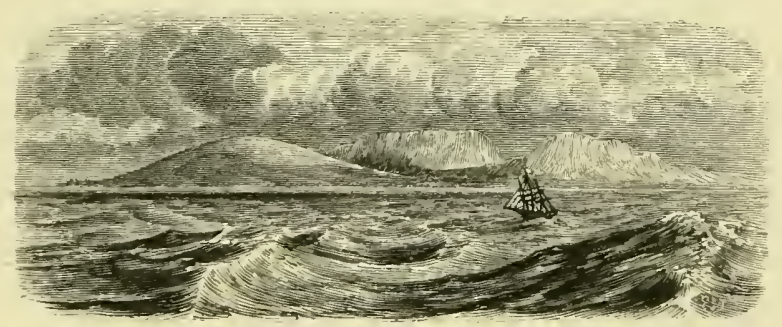




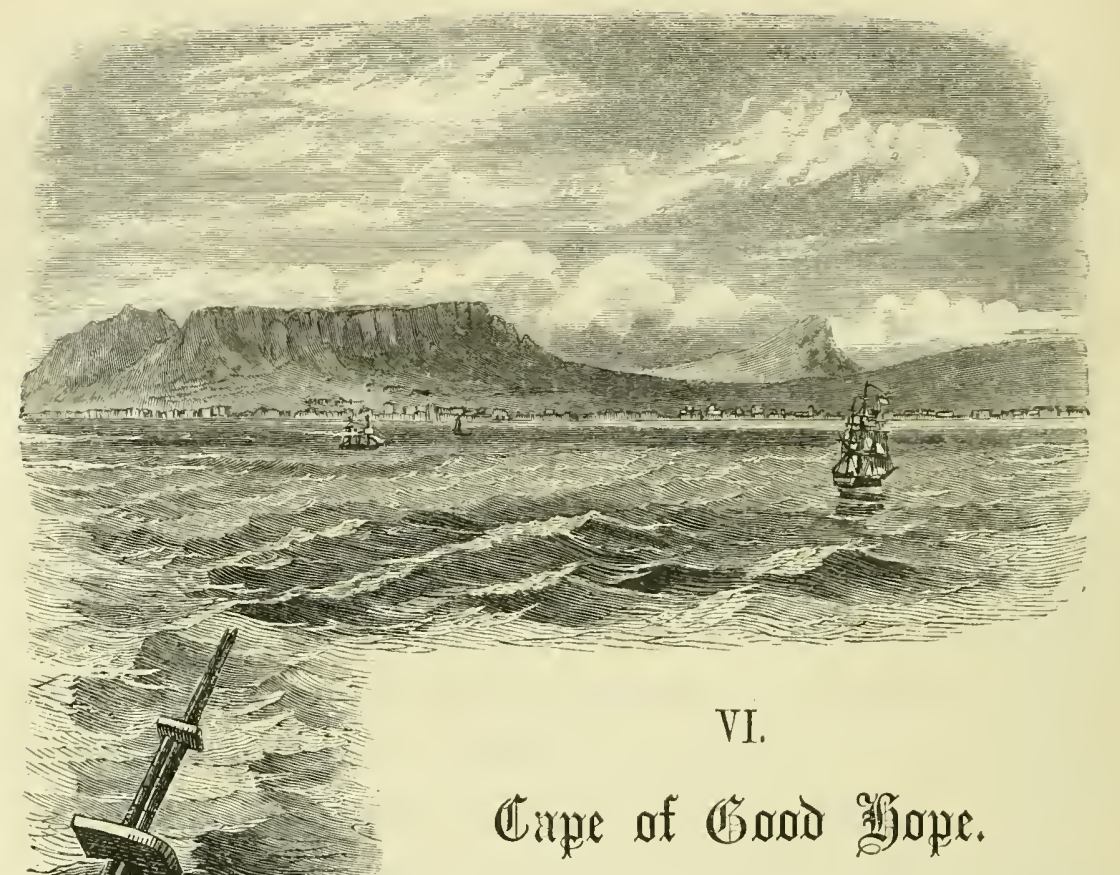

Stay from 2Nd to 26th October, 1857.

Contrasts of scenery and seasons at Cape Colony. Ramble through Simon's Town.-Malay Population. -The Toad-fish, or Sea-devil.-Rondebosch and its delightful scenery.-Cape Town.-Influence of the English element.-Scientific and other Institutions. Botanical Gardens.-Useful plants.-Foreign Emigration.-A Caffre prophet and the consequences of his prophecies.-Caffre prisoners in the Armstrong Battcry.-Five young Caffies take service as sailors on board the Novara.-Trip into the interior.-Stellenbosch.-Paarl.- Worcester. -Brandvalley.-The Mission of Moravian Brethren at Genaadendal.-Masticatories and intoxicating substances used by the Hottentots.-Caledon.-Somerset West.-Zandvliet.-Tomb of a Malay Prophet.-Horse Sickness.-Tsetse-fly.Vineyards of Constantia.-Fête champetre in honour of the Novara.-Excursion to the actual Cape of Good Hope.-Departure.-A life saved.-Experiments with Brook's deep-sea sounding apparatus.-Arrival at the Island of St. Paul in the South Indian Ocean.

There can searcely be a landscape more gloomy and desolate than the sterile, rocky mountains, and white sandy plains, 
FROM RIO DI JANEIRO TO THE CAPE OF GOOD HOPE.

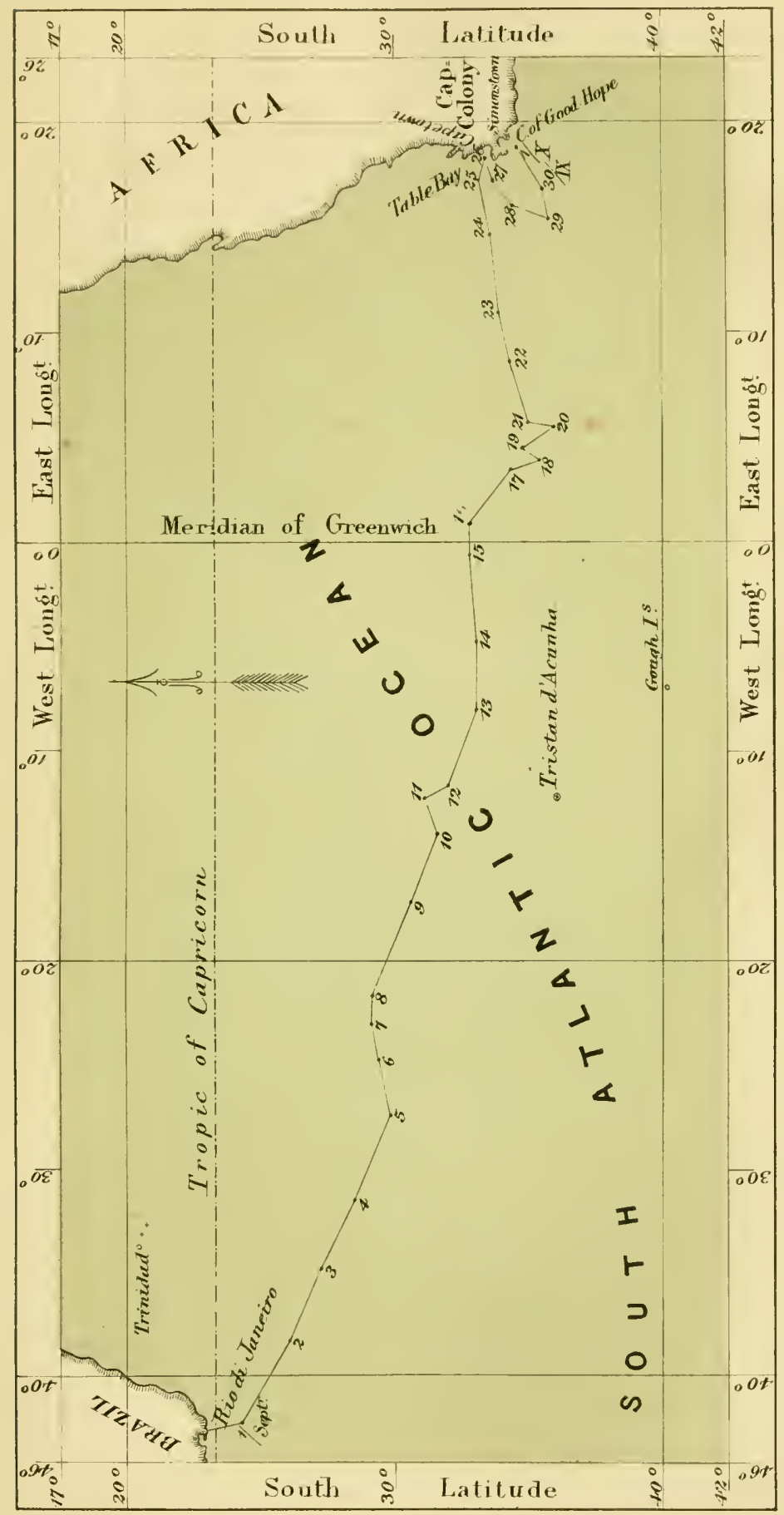



which, like snow-fields, inclose Simon's Bay. Coming from the cliarming coast of Brazil, with its luxuriant verdure, the contrast becomes doubly unpleasing. A narrow green strip of land, running along from a small fort, forms a refreshing sight and a resting point for the eye fatigued with looking at these grim masses of stone. The traveller who merely touches at Simon's Bay without pushing into the interior, or who visits the Cape in the winter of the southern hemisphere (from April to September), can scarcely form an idea of the voluptuous loveliness which reigns during spring and summer in the interior of the colony, and will regard as fictitious those brilliant descriptions of its natural beauties, related by travellers who have been fortunate enough to visit this point of South Africa at those genial seasons.

Had we left the Cape without seeing anything else than the melancholy neighbourhood of False Bay and the dull little settlement of Simon's Town, on its left bank, we should have carried away very different impressions and ideas to those entertained after having during spring passed some weeks in the delightful interior, and obtained at the same time an insight into the social condition of the colony.

On the very day that we cast anchor in the bay, we took a stroll (our first footfall upon the soil of Africa) through Simon's Town, which consists of a single street of about forty clean, neat, and tidy-looking houses, straggling along the shore. 'The principal buildings are the Arsenal, the residence of the admiral of the station, five churches (one 
of which belongs to Roman Catholics), and two tolerably large hotels.

It is hardly possible to conceive any town occupying a more dreary dismal site, with the exception, perhaps, of some of the Peruvian settlements on the west coast of South America. While the eye, below this row of houses, beholds nothing but granite rocks thickly strewn with shells, the main street is overhung by steep sandstone rocks, which, despite the marvellous richness of the blooming flowers, that well repay the researches of the naturalist, have a naked gloomy aspect, riewed from a distance, and are environed right and left by waste patches of white sand.

The favourite walks of this small place seem to be along the shore, or on the road to Cape 'Town, into the soft sand of which the foot of the traveller is continually sinking. A number of ladies and gentlemen whom we met walking appeared to be somewhat surprised at the unusual appearance of an Austrian manof-war, the flag of which was gaily fluttering in the gloomy bay. The residents in Simon's Town, amounting to about 800 souls, are mostly Malays, descendants of thase numerous compulsory emigrants, who, during the period of Dutch ascendency at the Cape, had been transported from Java and other islands of the Indian Archipelago, owing to the want of labour or for political causes. For the Dutch used to send to the Cape Colony, as a place of banishment, many wealthy and influential Malay families, by whom the first germs of Mohammedanism were introduced into South Africa. It would even seem that the religious 
opinions of the Malay population exercise some influence on the habits of the Christian settlers of Simon's Town, as no butcher, for instance, would venture to kill and sell pigs for fear of giving offence to his Mohammedan customers.

On a fine spring morning we started in a handsome vehicle from Simon's Bay to Cape Town. The road runs close along the seashore, which, seen from a distance, apparently consists of nothing but sand and rock, but, on more near acquaintance, exhibits at various points delightful nooks decked with most beautiful flowers. Everything indicated, by its glorious blooming garment, the bursting forth of spring.

One hour's ride led us to a neat little fishing hamlet where an immense number of fish were hanging up to dry in the sun. The bones of whales are used by the inhabitants for all sorts of purposes; they fence their fields and gardens with the ribs, build walls with the vertebræ, make steps and stairs of the shoulder bones, and use the large jaw-bones as arches at the entrances of their huts. One of the owners of this fishing station was kind enough to offer us, as a particular dainty, a piece of flesh cut from the jaw of a whale and boiled in fat; but we were not exactly of the same opinion after having, from curiosity, tasted a few mouthfuls. The bay is very rich in the snook-fish (Thyrsites Atun), of which several hundred tons are pickled here annually and sent to the Mauritius.

Another fish caught here is said to be extremely injurious to health, and even to endanger life-the small toadfish ( $T e$ - 
traodon Honkenyi), which exists in shoals, and may easily be caught with a line. One of the harbour regulations consists of a special paragraph warning seamen against using this poisonous "sea-devil." Foreign sailors who have eaten of it have died a few minutes after.

On leaving this fishing station the road, leaving the coast, proceeds in a straight line over the plain which unites the Cape with the continent. The mountains recede, and the eye of the traveller gazes, charmed and surprised, on the mountain range of the peninsula, the celebrated Table and Devil's Mountains. The plain, which, during the dry season, is nothing but an arid desert, was now seen in its fullest beauty, like a flowery carpet, on which innumerable blossoms of varied lues and forms were interwoven. On the left lie the renowned vineyards of Constantia, and to the right stands what is called Halfway-house, the property of a native of Würtemberg who, some twenty years before, came to the Cape a poor emigrant, and is now a wealthy and respected man, known far and wide, holding several official appointments, and showing himself a warm patron of his German countrymen. Being a zealous sportsman, and intimately acquainted with the locality, Mr. Rathfelder was of great service to our zoologists, who took up their residence at this place.

From the Halfway-house to Cape Town the character of the landscape completely changes. The road leads through a park-like country; charming wood plantations, pines and oaks, stretch on either hand to the extreme limits of an undulating 
plain, intersected by long shady paths, the vistas terminating with elegant villas built in the Dutch or English style. Here are Cape waggons, drawn by ten to twenty oxen, side by side with elegant two or four-horse carriages and densely-packed omnibuses, such as one may see in Cheapside. We have now arrived in the charming Rondebosch, a village that might well aspire to the dignity of a town, chiefly inhabited as a summer residence by the wealthier inhabitants of Cape Town. The impression made by this beautiful road will never be obliterated from the memory of any one who has ever ridden over it in the spring. We were as much delighted by the sight of this smiling and verdant landscape as we had been depressed by the sandy plains of Simon's Bay. There, extended in charming variety before the fascinated eye, lay Table Bay with its ships, Cape Town, and the gigantic rocky wall of the Table Mountain resting on its granite base, and rising nearly perpendicular to an altitude of 3500 feet, together with the Lion's Head and the Devil's Peak. The distant background on the other side of the plain is bounded by the precipitous face of high, rugged, and broken mountain walls, the summits of which were covered with snow.

Convenient and comfortable quarters were found in the Freemasons' Hotel, situated in the Parade, a large square planted with pines. Here, to our surprise, we met an Austrian, attending as waiter, who had been driven by the wild waves of the late revolution into the wide world, until he met with a peaceful existence at the Cape of Storms ! 
Favoured by introductions to the most eminent men of science, who received us in the most friendly way, we succeeded, in the course of a few weeks, in acquiring rich and valuable scientific collections, and forming important connections for the future supply of our museums. A most cordial reception was accorded us by Mr. Julius Mosenthal, the Austrian Consul, and the head of one of the leading mercantile firms of the colony. In his hospitable house, German music and German song made us entirely forget that we were sojourning thousands of miles from home at the southernmost point of Africa.

Cape Town is oblong in plan, with long wide streets, intersecting at right angles. It is destitute of imposing buildings; a commercial place, with pretty dwelling-houses, built in the English style and comfortably furnished, all of a light brown hue, owing to the dust, which, in south-east or north-west winds, envelopes the town in whirling clouds, and may indeed be considered the only plague of this healthy delightful climate. The English element, which, with the stereotyped customs of its life and its equitable laws, possesses, wherever it obtains a footing, so powerful an influence, has almost entirely superseded the Dutch, which continues to exist only in the lonely farmhouses far in the interior. There is scarcely anything remaining to indicate that Cape Town was founded by the Dutch; and were it not for the yellow Malay faces, with their gaudy head-coverings or umbrella-shaped straw hats, and the tawny mestizoes, who remind us of the aboriginal inhabitants, and give a completely foreign colouring, one might easily fancy 
one's self to be in an old English provincial town. Generally speaking, any one arriving here with preconceived notions of finding himself amongst Hottentots and Bushmen, or in a state of society differing materially from that of Europe, will soon discover that he las been entirely mistaken. 'The aborigines whom Jan van Riebeck found, when, with three Dutch ships, he landed in 1652 at Table Bay, and in the name of the Dutch East India Company established a settlement, have now almost entirely disappeared from the capital. If any one desires see a veritable Hottentot or Bushman, he must undertake a troublesome journey, of weeks' duration, into the inhospitable interior. In Cape Town this singular race is only now and then to be met with in prisons or hospitals, and even then of a mixed breed.

The colony has now a population of 280,000 white and coloured inhabitants, of whom about 30,000 live in Cape Town; half of these are whites, and probably not more than 1000 form the higher and influential class. There can be no doubt that when, in 1815, the English took possession of the Cape, a firm foundation had been laid already by the Dutch 150 years before; but the real progress of the country, and the development of its natural resources, date only from the commencement of British rule, by which those shackles were thrown off with which the narrow-minded colonial policy of the Dutch had fettered this settlement, like all others that owned their sway.

'The Cape Colony since 1850 has possessed a Legislative 
Council of 15 members, and a House of Assembly of 40 deputies. The executive power rests in the hands of the Governor-General, appointed by the British Government. All bills passed by this parliament require the royal assent before they become law.

It is impossible to speak in too high and eulogistic terms of Sir George Grey, whom we had the happiness at the time of our stay to find in the important position of GovernorGeneral of the colony. Owing to the wisdom with which Sir George governed this important colony, he gained for himself the love and admiration of the people to such an extent that, after the expiration of the regularly fixed period of his office as Governor, they petitioned the Queen of England for his re-appointment. Sir George is not only an able statesman, but also a sound scholar, possessing a most complete collection of books and manuscripts on the Australian, Polynesian and African languages, and he is a most zealous patron of the numerous scientific institutions of the colony.

'The astronomical observatory, under the superintendence of $\mathrm{Mr}$. Maclear, has preserved the celebrity which it attained by the great work on the constellations of the southern hemisphere, the materials for which were collected by Sir John Herschel during his residence here some twenty years since. There is now a transit instrument, which in accuracy excels even that of the Observatory at Greenwich, and which is said

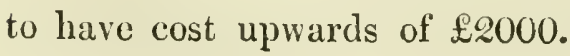


The South African Museum, containing collections of natural history, is now under the superintendence of $\mathrm{Mr}$. L. Layard (brother of the celebrated investigator of Nineveh). This institution, as well as the South African public library, the literary, scientific, and mechanics' institutions, besides nearly fifty other establishments and societies for religious, benevolent and industrial purposes, owe their foundation and flourishing condition to the public spirit and the charitable disposition of the inhabitants of the colony. In 69 schools scattered over its surface, upwards of 18,000 pupils are educated according to a system introduced in 1841 by Sir John Herschel.

The Botanical Gardens, likewise founded and kept up by private subscription, are not only a most agreeable resort, but also afford much instruction, arising from the many interesting and useful plants gathered here from all quarters of the world. To those which are adapted for cultivation in the sandy plains of the Cape, great attention is deroted. Some of them have been found available in forming as it were vegetable walls of protection against the inroads of the sand, so destructive to all cultivation. As particularly serviceable for this purpose, were mentioned to us Fabricia variegatu, a sea-shore shrub of from 6 to 10 feet high; Protea myrtifera; the so-called Hottentot fig: Mesembryanthemum edulis; and the Cape wax-myrtie Myricacordifolia; -all these are found to thrive in the sand without cultivation, put a stop to its ravages, and in some respects may be considered as the 
pioneers of all other plants, which do not thrive before the sandy soil has been prepared for them. Nay, singularly enough, some of these (as for instance the Hottentot fig), become extinct as soon as others make their appearance, just in the same way as the pioneer of civilization, the backwoodsman in the west of the United States, leaves his lonely blockhouse and hurries on as soon as overtaken by the peaceful settler. The wax-berry shrub is also otherwise useful to the inhabitants; from its berries a substance is prepared well suited for making candles. According to a treatise on its culture two workmen are able to realize with a defecator daily $100 \mathrm{lbs}$. of white wax from the berries gathered by six persons. The expense of labour, \&c., does not exceed $18 s$. per 100 lbs., or abont $2 d$. per pound. A large quantity of this vegetable substance has lately been sent to London, where it is said to have met with a profitable market. In the Botanical Garden of Cape Town we first met the two celebrated grasses known as Holcus Caffirorum and Holcus saccharatum, which, by their usefulness in domestic life, have more extensively, and perhaps quickly, than any other plant, spread over the world. We are indebted to the Secretary of the Board of Public Roads, W. De Smidt, Esq., for some seeds of these and other plants, as also to Mr. McGibbon, manager of the $\mathrm{B} 0$ tanical Gardens, for similar favours.

Considering the deficiency of labour, and the large sections of fertile land as yet uncultivated in the colony, Sir George Grey has directed great attention to the immigration of German 
emigrants of respectable characters, of all trades, as well as those attached to agricultural pursuits. The plan adopted is an excellent and thoroughly honest one. Every emigrant, if single, obtains from the Government thirty acres of good land, and, if married, fifty ; five for each child above one, and ten for every one exceeding ten years of age. The rate of the land is to be fixed by Government at a fair and reasonable sum, and, together with the passage-money, to be paid four years after the location of the emigrant, in five annual instalments. From the moment the colonist steps on African ground he is an independent owner of land, although not entitled to sell his property until his obligations to the Government are liquidlated.

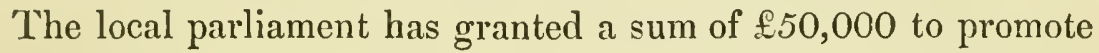
emigration. The Cape probably offers to an industrious emigrant a more advantageous field for active energy than any other country in the world. Some of the German colonists, the remnant of the British Legion engaged in the Crimean war, who, under General Stuttersheim, have settled in British Caffraria, are thriving prosperously. They are the first pioneers of the German element in South Africa, and, under the protection of a liberal and free government, are increasing in number annually in consequence of the farourable reports which they transmit to their native country.

An emigration of a peculiar kind has unexpectedly taken place. An impostor amongst the Caffres, who had assumed the character of a prophet, pronounced the end of the .world as imminent, in consequence of which large numbers of them 
slaughtered their cattle and left their fields uncultivated. Being thus, in a short time, reduced to a state of perfect destitution, not less than 19,000 of starving Caffres sought help and an asylum in the British territory during the year 1857, and before its close the number had increased to 30,000. The colonial Government, out of consideration to the welfare of the colonists, admitted only those Caffres who bound themselves to act as servants, for at least one year, at reasonable wages, and in order to prevent any danger arising from being congregated in too large numbers, they were located by the Government officers in various detached parts of the colony.

A very active society of philanthropists exists here, under the title of "The Committee of Emigration from Holland." Its object is to bring over orphans and children of the poor from the overpopulated Dutch provinces. These useful emigrants are partly located as apprentices to farmers, and remain until they are of age under the eare of the Committee. During our stay a party of seventy boys and girls just arrived from Holland assembled, with their conductors, in one of the large avenues of the Botanical Garden, to be inspected by the Governor-General. They all looked healthy and cheerful, and seemed to have but little suffered from the fatigues of a long voyage. When Sir George Grey made his appearance the children sang the English National Anthem, translated into Dutch, and afterwards the sweet, affectionate song, "When the swallows homewards fly." Some young emigrants, who, two years ago, had come under similar circumstances from 
Holland, had already obtained good situations, and greeted their little compatriots most heartily. Being asked if they wished to return to Holland, they replied, without the slightest hesitation, in the negative, declaring that they felt very happy where they were, - an announcement of course peculiarly agreeable to the new-comers.

An interesting opportunity was afforded to us of seeing a large number of Caffres, of both sexes, who had been brought in as prisoners in consequence of having made predatory incursions into the British territory. They all arrived in a state of nudity, and in most wretched plight, but were immediately provided with European clothes-blue striped shirts, sheepskin trousers, shoes, a Scotch cap, and a blanket which served during the day as a cloak, and at night as a covering. Their food was tolerably good, but their abode during night, in the damp casemates of the fort, seemed not to agree with them, and many were visibly in a diseased state of health. Nearly all were muscular, and some were really specimens of manly beauty. Not one of them knew his age. Their only mode of calculating is by certain important events, as by the death of a chieftain, or the various wars with the English. The superintendent, Mr. Walsh, a very obliging Irishman, had the kindness to cause them to perform some of their national dances, wild exercises which served the purpose of exciting their warlike spirit. The first dance they performed they called "Ukutenga." Six handsomely-built dancers advanced, whilst about thirty men closed in a circle around them, and, by 
their howlings and elapping of hands, formed as it were a musical accompaniment to this singular performance. The dancers sighed, groaned, hissed, and made the most extravagant grimaces and contortions, in order to arouse in themselves an artificial excitement. One, a lad twelve years of age, engaged so earnestly in the sports, that he perspired from his whole body. There is another dance, called "Tklombo," performed in the presence of diseased persons whilst the quack doctor practises his deceptive remedies; and a third, called "Umduta," which is only practised at weddings and other festive occasions. This last seemed to be the most characteristic. The semi-nude, slender men hopped, their arms clung together, in ranks of six, hissing with scorn, occasionally uttering a cry, then suddenly separating and marching one after the other in slow time, in a circle, uttering the most singular sounds. Now they bent forward the whole upper part of the body, and then back again, each of them making the same violent gestures as in the former dance, and pronouncing some words to excite their companions, such as, "Be active !" "Be alert!" intil they all trembled and became fearfully and feverishly excited. The surrounding Caffres, who were at first mere spectators, by degrees were seized with this singular dancing mania, till at last the entire number, as if stung by a tarantula, lashed themselves into a wild and apparently ungovernable frenzy. The great difference in the colour of the skin of these Caffies was particularly striking, as they evidently belong to one and the same race. From the blackness of coal to 
bronze, all tints and shades were observed, and one of them, called "Ngduba" (Sea-shell), appeared to be even of a reddish yellow. He belonged to the tribe of the Fingoes, and said that both his parents were of the same colour.

The governor permitted five young Caffres to be engaged on board the Novara, with their own consent, as apprentices, and although they were prisoners sentenced for several years, yet the Government took every care to secure their welfare. An agreement was signed to provide that their return, should they desire it, might be facilitated in every possible way. Faithful subjects could not be cared for with more anxiety than were these legally-sentenced Caffre prisoners by the colonial Gorernment. Two of them went one day on shore, during our stay at Auckland, in New Zealand, and never came back; the other three made the whole voyage with the Novara, and are now sailors on board the imperial yacht Fancy. They, of course, understood, at their embarkation, only their own singular mother-tongue; yet the chaplain of the expedition, the Rev. E. Marochini, after having made himself acquainted with their idiom, succeded in instructing these black youths, by means of their own language, in the doctrines of Christianity, and, by degrees, imparted some knowledge of the Italian and German languages, the happy results of these endeavours being a complete vocabulary and a small catechism in the Caffre language, which the reverend gentlemen composed during the voyage; and such progress did his three pupils make, that, on our return to Trieste, they were so far prepared as 
to be fit for reception, by baptism, into the Christian community.

In the house of correction there were a number of female Caffres who had been made prisoners at the same time with their brothers and husbands, some belonging to the family of chiefs. One, the sister of the ehieftain Sandilli, was a handsome, tall and slender woman, with mild features and piercing small black eyes; another, by the name of Mnovenkeli, the sister of the chieftain Mkoseni, was an imposing and earnestlooking figure. Several of these women bore a long stripe tattooed on their breasts as an ornament. Several were deficient of a little finger of the left hand : this mutilation is the effect of superstition, as it often occurs that, in case of the severe illness of the child, the distressed mother eauses a finger of hel offspring to be cut off and sacrificed to the evil spirit, in order that the rest of the body may be saved and permitted by the evil spirit to recover.

One of these young Caffre women had her child wrapped up in a piece of linen tied to her back, and endeavoured to lull it to sleep by continually moving the left elbow, by which the baby was kept in a swinging motion, and an effect was produced like that of a cradle. Various questions were put, through an. interpreter, to several of these females, who, after their timidity was overcome, answered with great readiness. Polygamy is said to prevail amongst them. Many women have from ten to twelve children. The ehildren are suckled sometimes from two to three years. A numerous progeny is the pride of a 
family. As a proof of the legitimacy of a child, there is said to exist a kind of milk trial. Notwithstanding considerable trouble in endeavouring to procure information, we were unable to obtain a very lucid idea of this singular experiment: it consists in the father giving the infant, in the bottom of his hand, directly after its birth, some cow's milk to drink, and if the child refuses the draught it is considered illegitimate. Caffre women very rarely salute their husbands with a kiss, except after a long separation, and even then only on the cheek-never on the lips.

In the ethnographical part a detailed description will be presented of this most peculiar race, of whom the Bushmen are cvidently only a decrepid branch. Here it will suffice to observe that a girl, only sixteen years of age, was noticed, whose father was a degenerate Hottentot, and whose mother was a Bushwoman. The girl measured 4 feet $6 \frac{1}{2}$ inches, and weighed 75lbs. Another Bushwoman, thirty years of age, measured 4 feet 9 inches. All the individuals we saw of this race were remarkable for their exceedingly small hands and feet.

One week of our stay at the Cape was devoted to an excursion into the interior. On the 1st October, early in the morning, we left Cape Town in a light two-wheeled vehicle, drawn by four horses-a turn-out which certainly seemed better suited for a drive in Hyde Park than a journey, however short, in South Africa: for who would suppose that the principal roads on the southernmost point of the most unknown quarter of the 
globe, are, in consequence of English civilization and the geognostic nature of the ground, in a better condition than most bye-roads in the civilized states of Europe? For a country where labour is so deficient and expensive, such enormous works could only be executed by means of compulsory labour: in this respect the high-roads and mountain passes of the Cape afford the most evident proofs of how much more beneficially and usefully convicts may be employed in colonial works than in allowing them to rot within prison walls, alike a burden to themselves and to society.

Only ten years ago the streets of Cape Town looked at least highly dangerous, and the steep rugged old roads, which sometimes run parallel with the new ones, evince very clearly the great difference between bygone days and the present, as regards the internal communications of the colony. The uncultivated state of the country formerly, which indeed, in some parts, continues even yet to exist, is the cause of the ancient custom having been retained of placing before every vehicle, however lightly laden, sixteen to twenty powerful oxen, even on perfectly level roads. All longer journeys into the interior are undertaken in heavy waggon-like vehicles, exclusively drawn by oxen. As a family is sometimes compelled to take up abode in such waggons for weeks together, they are completely covered and provided with all possible conveniences; indeed, it is a sort of locomotive house. The waggon, which much resembles the goods-trucks used on European railways, is at least 18 feet long, and the entire length of the set-out, ineluding the 
oxen, embraces not less than from 120 to 180 feet. It may readily be imagined how such a custom impedes speedy intercourse, and how much more usefully a great part of the animal power might be employed. On the excursion from Cape Town to Stellenbosch, a small place only ten miles distant, we met more than 100 waggons, of which not one had less than ten, and many double that number of oxen, so that at least 1500 heads of cattle were employed in a work which might easily have been performed by a third part of the number.

The coachman was a Malay, and wore that singular screenformed straw hat, which so peculiarly distinguishes the male population of his race. These men have the reputation of being particularly skilful drivers, and thus form a considerable portion of the coachmen of the place. The Malay driver had an assistant by his side, who seemed, however, chiefly to serve as ballast, in order that our two-wheeled vehicle might not lose its equilibrium; for the disconsolate condition of the horses rendered the fear of their running away quite superfluous. Our charioteer drove his horses, which now and then were rather restive, with so much adroitness, that we arrived as early as nine o'clock in that charming settlement Stellenbosch, which Wilkes, the American Commodore, even in 1839, designated as the loveliest and most beautiful in the whole colony. It has completely preserved the aspect of a little Dutch town; the streets are straight and wide, adorned with avenues of oaks, many centuries old; the houses are extremely tidy and clean, and are built in the genuine Dutch style. There is no trace of English 
influence perceptible. Its 4.000 inhabitants mostly speak Dutch, and cultivate the vine, grain, and fruit. No country town seen in the whole course of our long voyage made a deeper impression, or left more pleasing recollections, than Stellenbosch. The occasion of our visit was certainly of an uncommonly cheerful and festive character. On the day of our arrival the Governor was about to review a corps of volunteers, raised in Cape Town and its neighbourhood, to supply the place of the regular troops about to be dispatched to the Indian battle-fields. Extraordinary enthusiasm and interest was manifested everywhere in the military movements. Thousands of visitors had assembled even from great distances to witness this novel national spectacle. The Governor had proclaimed the day as a general holiday; all shops were closed; the streets presented an extremely animated appearance, and in front of every house was a crowd. The Austrian Consul had been kind enough to favour us with a letter of introduction to one of the first families in the place; but, taking into consideration the general bustle and continual arrival of strangers, we were much afraid of being, at this moment, very unwelcome guests, as every nook and corner would already be occupied; for in this colony visitors do not come, as with us, for a short time, and without encumbrance, but with waggons, horses, servants, household and all, regularly to settle down for an indefinite period.

Our own party consisted of five persons provided with four horses, and we were now, for want of other lodgings, about to claim the hospitality of Mynheer Van Schultze. A pretty, 
youthful, rosy-cheeked lady, who appeared at the door, took -not without some embarrassment-our letter of introduction, and disappeared with it into the interior of the stately house. We were requested to enter, and were shown into a suite of very neat rooms, and were received, not merely with great politeness, but with the heartiest welcome.

At ten o'clock we drovo out with our hospitable friend, Mynheer Van Schultze, to the review, which took place on the common in the neighbourhood of the village. The number of spectators was probably twenty times greater than that of the volunteers; they had surrounded the ground with a wall of carriages, on the tops of which women and children were grouped in every picturesque attitude. The rifle volunteers marched, with the Governor, Sir George Grey, at their head, and preceded by a band, to the ground. There might have been about 300 cavalry and 200 infantry, with several pieces of artillery. They all looked very well; their uniform was plain and remarkably suitable for the purpose, consisting of tunics and trousers of black cloth with metal buttons, and a common cap with a silver ornament. They went through the usual manœurres, whilst a good deal of gunpowder was expended. The evolutions of the cavalry were executed with wonderful precision, a result due chiefly to the circumstance that, at the Cape, every inhabitant is a good equestrian, and is trained from childhood to manage a horse.

The review finished, a breakfast was served at the Drosdy, or Municipality, on long tables, in a magnificent avenue of 
oak trees; nearly 600 volunteers and many other guests sat down, whilst in the back-ground a large number of ladies and gentlemen were present as spectators. The presence of some members of the Novara Expedition at the festival led the Burgomaster, after the toast of the Queen was given, to propose the health of the Emperor of Austria, prefacing it with various laudatory remarks on the Expedition. The toast was most heartily received, the whole company raising

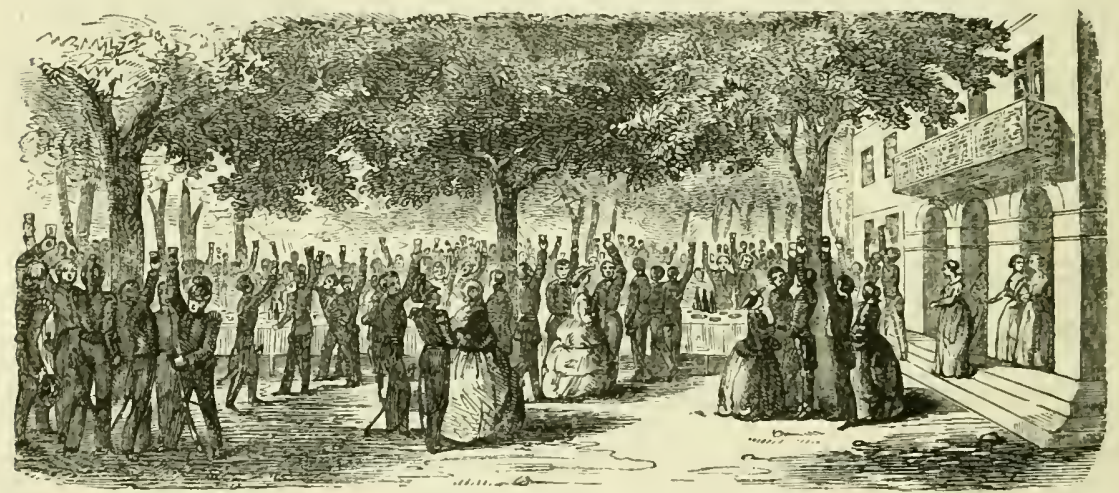

their glasses, whilst the band performed the Austrian national anthem. The officer to whose lot it fell to return thanks, said:- "That he felt deeply gratified with the honour done to his country and nation by the enthusiasm with which the health of his sovereign had been received by so distinguished an assembly, and that he could not forbear expressing his admiration and delight in observing the prosperous condition of this fine country, which, like all others where the Anglo-Saxon race was predominant, was blessed with freedom, with the spirit of progress, and the blessings of Christianity;" and he concluded by proposing "Old England for ever." 
On the day after the review the journey was pursued early in the morning to the village of Paarl (Pearl), about four hours distant. We har come as strangers to the hospitable Stellenbosch, and left as old friends, the entire family accompanying us to the earriage, and the worthy old mother of our amiable host, a thoroughly genuine Dutch matron, was visibly touched on taking leave of those whom, in all probability, she would never see more.

On the route to Paarl seqveral immensely large ant-hills were met with, some of which measured from two to two-anda-half feet in diameter, by about three feet high. The insects were partly black and partly of a greyish-brown colour, and must be very troublesome to the farmers.

Paarl, an extremely neat village, consists of a single long street, and contains nearly 4000 inhabitants, chiefly occupied in the growth of the vine. They are the descendants of those French Protestants who, at the close of the 17th century, left their native country in consequence of religious persecution. All the detached farm-yards were extremely neat, and bore evidence of the wealth of their owners. Nothing reminds one of Africa and the neighbourhood of Hottentots, Bushmen, or Caffres. The landscape becomes grander the more the mountains, 4.000 to 5000 feet high, are approached. Among them lies the little town of Wellington, charmingly situated; though but a few years in existence, and numbering only 2000 inhabitants, it has already a joint-stock bank with a capital of $£ 45,000$, several schools, and some neat places of worship. 
While taking an evening stroll, we passed a well-lighted Reformed Dutch Church, from the interior of which the devotional tones of a pious Christian congregation floating through the night air, died away among the mountains.

Singular to say, the small, and, one would think, essentially prosaic and practical little town of Wellington boasts a quack doctor, named Brabna, whom the common people, far and near, come to consult, more, one would imagine, to be relieved of their money than their ailments.

The route to Worcester, whither we set out the following

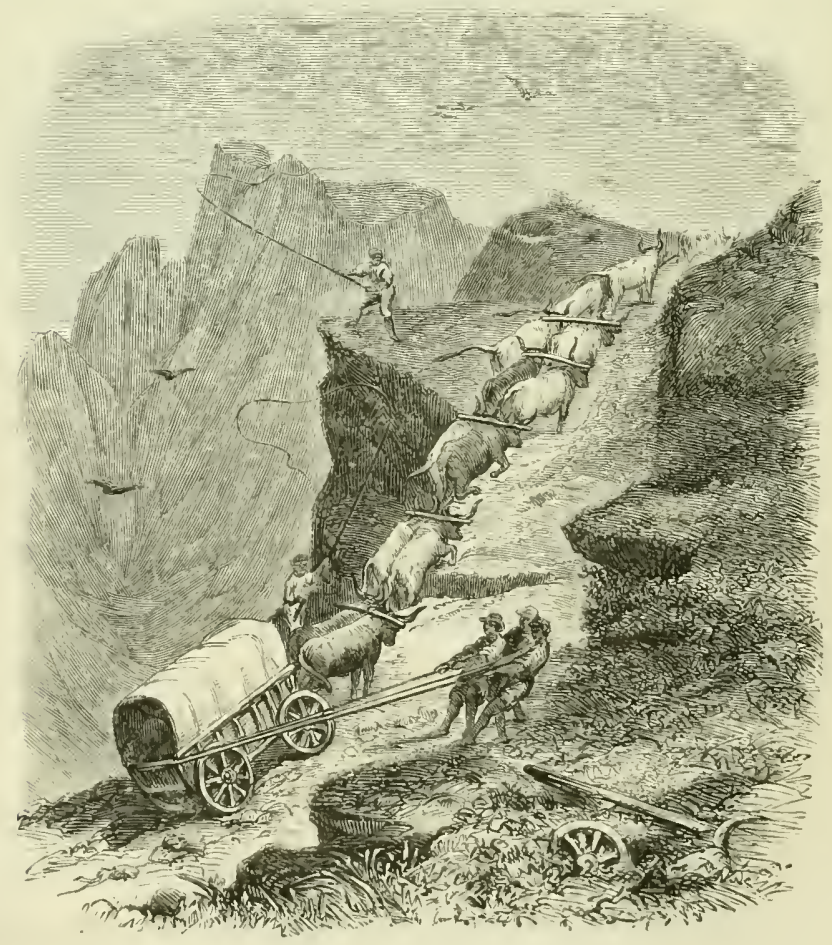


morning, leads at first through the wide, highly-cultivated Waggonmakers' Valley, adomed with numbers of rich farmsteads (so named from a number of artisans of this handicraft having settled here in former times), after which it passes over the difficult pass called Paine's Kloef, 4000 feet high, which frequently recalled the well-known road over the Sömmering Alp, or that at Optschina. This mountain-pass, first completed in 1853 , by the engineer, Mr. Paine, greatly facilitates the traffic between Cape Town and this fertile district, which previously was quite inaccessible, and whose immense natural resources are only now beginning to be developed.

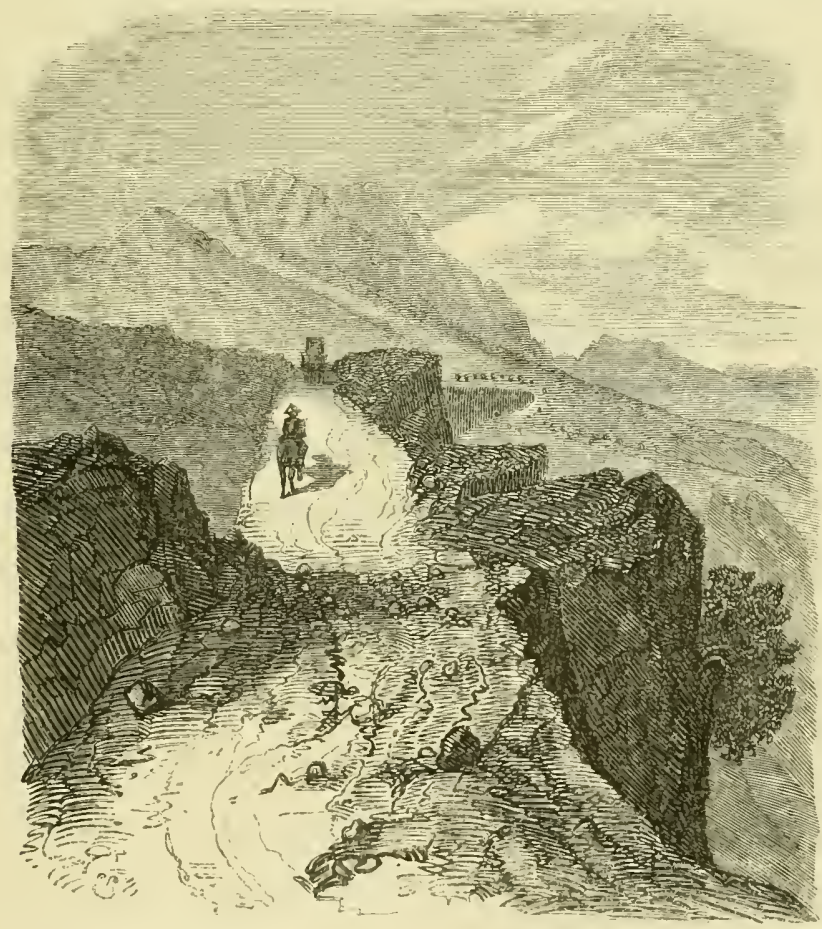

PAINE'S KLOEF AS IT IS. 
When we reached the highest point of the pass we found a strong south-east wind blowing. The thermometer marked $55^{\circ}$ F., and when plunged in a spring that issued from the mountain close at hand, $48^{\circ}$. South-east winds are especially prevalent here, particularly in summer, when they frequently cause scrious damage; hence all the upper branches of the trees incline to the north-west

We now came to the finest bridge in the country, named Darling Bridge, after. a late governor, which is thrown across the broad stream called by the Dutch, Breede River, and by the English, Broad River, a frequent source of error. The English colonists are bent upon driving out the Dutch names of rivers and localities, and supplying them with new names of English origin. The Dutch, however, hold on obstinately to the names they have been accustomed to, and continue to use the ancient nomenclature.

In the neighbourhood of Darling Bridge is a farm where the traveller can be comfortably accommodated, and from which, being a post-station, letters can be forwarded to all parts of the country. It has regular communication with the rest of the colony three times a week. The vehicle, however, in which the letters and packets are forwarded, in consequence of the wretched roads in the interior, and with the view of expediting the transmission of mail matter, is simply a light, open, eminently uncomfortable, two-wheel waggon, in which but one passenger can be taken each trip. Day and night, up hill and down dale, it continues its journey, changing driver and 
horses every two hours, only the unfortunate passenger being condenmed to remain glued to the jolting uncomfortable ear, until he has attained the end of his journey. We were told of an English captain, who once travelled on urgent business 400 miles in fifty hours in this fashion, and arrived at his destination in such a pitiable plight, that he had to be lifted from the car and put to bed forthwith, which he kept for several weeks, before he was able to get about again. Unfortunately, we were not told whether this unlucky passenger returned to Cape Town by a similar conveyance.

In the dining-room of the farm we made acquaintance with several families from Graaf Reinet, in the north of the colony, who were en route for Cape Town, and had been already three weeks on the road, during which they must have passed every night in their unwieldy waggon, or under tents. There was also among the assembled travellers a Quaker Missionary, of Worcester, who was on his way to the opening of the Spiritual Synod at Cape Town, and who was so kind as to furnish us, on the spot, with some introductions to his friends in Worcester, a lovely little town, which we reached towards the evening. There are places which charm at the first glance, just as there are many men who take us by storm as it were. Worcester is one of these; so neat, so clean, with a pretty garden in front of each little house, every wall of which was entwined with roses, and in the back-ground all around, bare, but picturesque groups of lofty hills of a blueish-grey tint, which imparted to the entire landscape a peculiar and 
almost magical colouring. Worcester, a creation of yesterday, has about 4500 inhabitants, chiefly employed in vine growing and sheep pasture. There are some of the peasantry here who own flocks of 3000 to 4000 sheep! The rich vegetation of the valley has an eminently northern character. Alongside of oaks, pines, poplars, willows, will appear a tree of Australian origin, of the order of Myrtacex, the blue gum-tree (Eucalyptus Globulus), which, on account of its rapid growth, is planted before each door for the purpose of shade. One of these trees was shown to us of but four years' growth, the stem of which was already twenty fect high! The leaves have a highly aromatic odour, and must be especially suitable for the extraction of oil, as the rind is full of camphor; as yet, however, the tree is not used by the colonists for any other purpose than to supply shade to their gardens.

It is surprising what comfort the traveller encounters among these new settlements, from which, even already, all traces have been eradicated of the difficulties that originally beset the colonist; so that at every turn one meets with evidences of the highest European civilization. Whenever, indeed, he finds himself at a settlement, he will remark that it is not merely provided with the necessaries of life, or the mere products of the soil, but that it sparkles with numerous objects of luxury and refined taste; such as handsome furniture, pianos, and other musical instruments, engravings, English classics, besides telescopes, barometers, thermometers, and other similar evidences of high cultivation. At the hotel at Worcester, we met 
with a degree of comfort such as is found only in the chief cities of Europe. Several of the inhabitants, among others Dr. Esselin, a missionary of the Moravian brotherhood, and Dr. Meynard, of the Episcopal Church, laid us under particular obligations by their participation in the objects of our inquiry. The latter gentleman sought us out at our hotel, and, after a hearty welcome, remarked that he possessed, in his collection, several highly interesting petrifactions from Beaufort, about 4.00 miles north-west of Worcester. We satisfied ourselves, however, by a visit which we paid to Dr. Meynard at his own house, that his collection was far from possessing the interest he claimed for it. In all probability, however, judging by what we heard, Beaufort must be a classic soil for the palæontologist, as there are numberless fossils in that district, especially of reptiles. In like manner, the stalactite grottoes, known as "The Congo Caves," 300 miles from Worcester, have never yet been scientifically examined or described.

Dr. Esselin, who is a native of Hesse, was so kind as to accompany the naturalists of the Novara Expedition to the hot springs of Brand Vley the following morning. The road thither, which lies through a valley partly overflowed towards the end of the rainy season, was exceedingly trying to the horses, and, but for the kind offices of Dr. Esselin, who was acquainted with the difficulties of the route, and undertook the guidance of the waggon through the constantly recurring swamps and morasses, we should in all probability have had to retrace our steps halfway, or even have stuck fast, which 
would have been a still more serious matter. Only after unspeakable exertions did we succeed in threading the valley of Worcester as far as the shores of Breede (or Broad) River. Several times we were compelled, in order to lighten the waggon, to dismount, and wade up to our knees in water. Once the quag was so deep, that to avoid sinking in it we had to be carried, one by one, on the back of our Malay driver.

On the bank is the cottage, (boeren plaats), of a peasant who avails himself of his proximity to convert the stream into a source of profit, by ferrying travellers, who have occasion to pass here during the floods, across the river in a small skiff, the waggon and horses being swum across afterwards. In summer, on the contrary, the stream is readily forded on horseback, and is indeed dry at several points. At the period of our visit (in October, 1857), towards the end of the rainy reason, this Breede River was about 150 feet wide, and about 28 feet deep, and we accordingly found ourselves compelled to call in the assistance of the ferryman. Under his superintendence the work was gone about quite systematically. First of all

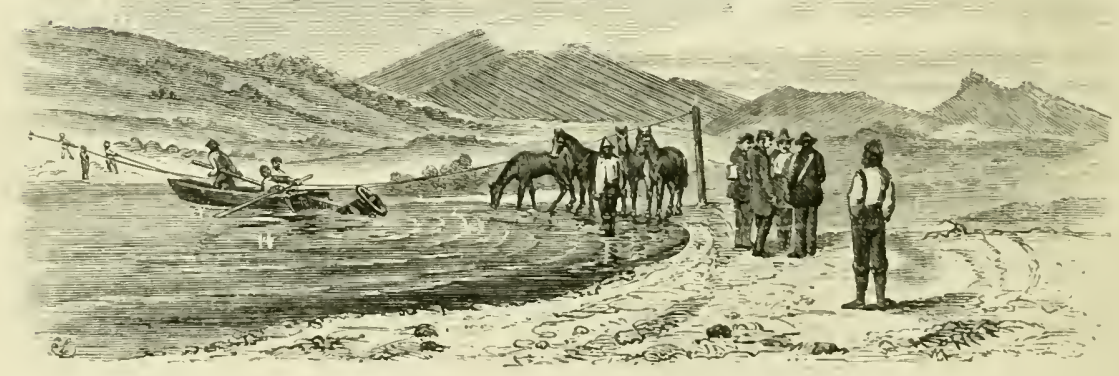


the four horses were swum across, by a halter round the neck; after which the luggage was transported to the opposite bank in a small boat. Last of all came the waggon, with the travellers therein. It was thought that the upper portion of the waggon might be towed across, swimming on the surface of the water, by fastening an empty watertight cask between the wheels; the cask, however, proved unequal to the weight. As the waggon left the shore it sank deeper and deeper in the water, till about mid-current it fairly eapsized, hardly a spoke of the left wheel reaching the opposite bank.

Amidst our perplexities, a violent shower of rain came on, making the waggon leak in every corner, just as we succeeded, after great trouble, in getting it to land, and were busy repairing it. Fortunately, every requisite precaution had been taken to remedy any such disaster occurring at this dangerous spot; so that the whole affair, though sufficiently uncomfortable at the time, left only the recollection of a pleasant adventure.

At last, towards noon, we reached the hot springs of

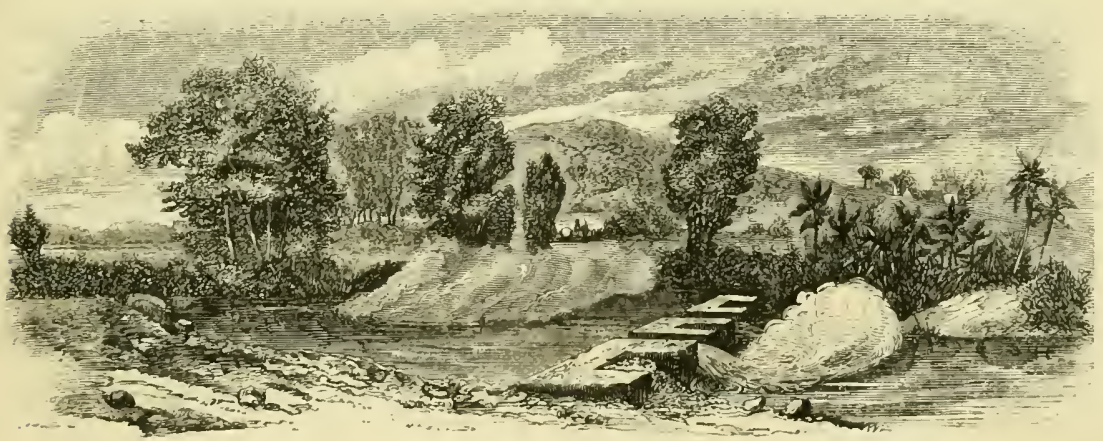


Brand Vley, or Brand Valley. This hot spring, which is quite exposed, like a pond or tank, and even at the least accessible points is adorned with rich vegetation, is about 100 feet in circumference, and is of a triangular shape, rounded off at the corners. Among bananas, ferns, and cacti of all sorts, spring up numerous specimens of Calla Ethioptica, silver poplars, pines, reeds, and canes, in wild profusion. Many fruits even, such as pine-apples, mangoes, rose apples, \&ce, which as a rule do not flourish at this elevation, grew all round the edges of the basin. Some twigs of a rose tree, which, growing luxuriantly in the warmth and moisture, spread across the spring, like a green canopy, must have been a second growth of the same year. We in fact enjoyed the unusual spectacle of seeing one portion of the tree in the flush of its utmost beauty, while the upper and more distant branches had not as yet put forth their leaves. The water at the hottest point reached $145^{\circ} \mathrm{F}$, while the temperature of the air was $75^{\circ} \mathrm{F}$. It is remarkably elear, has not the slightest taste, and in many particulars greatly resembles the springs of Wildbad Gastein. The number of patients during the season (October to April) does not exceed from 100 to 150 , the waters being chicfly used in chronic maladies, rheumatic affections, scrofula, erysipelas, cutaneous eruptions, and similar complaints. Immediately adjoining is a small brook, with a temperature of $68^{\circ} \mathrm{F}$., which rises at the foot of a neighbouring eminence, and has water enough during the entire year to keep a mill in constant work. 
The only animal inhabiting the spring is the larva of a Tipularia, which frequents one quarter of the pool where the temperature of the water does not exceed $113^{\circ}$.

On the 14th of August, 185\%, two shocks of an earthquake were felt in rapid succession in Brand Valley, of such violence as to arouse the inhabitants out of their sleep, when several of the smaller houses were found to have rents and fissures in their walls. The proprietor of the bath alleged that the shocks in Brand Valley were much more severe than at Worcester, although that town is but six miles distant.

At Brand Valley we took leave of our hospitable companion, Dr. Esselin, who presented us with scveral books on leaving, and set out on an excursion to the mission of the Moravian Brethren in Genaaden Dal, in the district of Caledon. En route we encountered several families, who came from far in the interior of Cape Colony, driving before them enormous herds of oxen, some of which were yoked to the waggons that formed the caravan, these being fitted up something like dwellinghouses on wheels. As night fell, a halt would be called at some selected spot, when the draught oxen were unharnessed, a fire lit in the open air, and the evening repast prepared. Horses are very rarely used on long journeys, although these are in consequence seriously lengthened thereby, especially as it is the custom all over the country to unyoke every two or three hours, so as to allow the beasts to enjoy a roll on the ground, if only for a few minutes at a time.

As neither of our drivers was acquainted with the road we 
were now to pursue, we hired a black guide from Brand Valley, who accompanied us on horseback as far as the next farm-house, where we were to pass the night. Just as one requires a pilot to take a ship into an insecure or unknown harbour, so we now had to avail ourselves of the services of this limber young negro, who was an excellent rider, in piloting us through the endless morasses and pools of water. Renden was the name of the solitary farm (the property of $\mathrm{Mr}$. Pretorius, a landed proprietor, to whom we had letters of introduction), where we were to pass the night.

As we approached, we were saluted with the loud barking of a hound that had been unchained, and who seemed ready to rush upon his unexpected prey, so that we hardly dared to advance one step. At last a man made his appearance at the door of the house, with a lantern in his hand, speedily followed by the whole family, anxious to learn who could be in the neighbourhood at so late an hour. We handed him the letter, which we begged him to read, and requested to know whether we could be received for the night. We were at once admitted, and speedily found a most cordial welcome. We were shown into apartments very plainly furnished, but neat, and scrupulously clean, after which we were invited to join the household at supper. It was a very numerous family. The father and mother, genuine Dutch figures, sat at the head of a long table; next to whom sat the son-in-law, who had married the eldest daughter, and then commingled with each other, the sons and daughters that were as yet ummarried. They all seemed 
hearty and healthy, and their indurated hands were the best diploma of their industry. The youngest son said a short prayer; after which venison, potatoes, mutton, vegetables, bread, butter, and cheese were set down in huge dishes, besides which two bottles of Cape wine, of their own manufacture, went the round of the table. Although this place had been only settled four years previously, an immense deal had been already accomplished by this stirring, cheerful family to make the soil thoroughly productive, and render the house habitable. Even a small garden had been laid out in front of the dwellinghouse.

The chief article of cultivation in the valley is the grape, for wine manufacture, which must in this place return a very handsome profit.

From Renden to Genaaden Dal is a four-hours' journey. The road passes by Donker's Hoek, a tolerably high mountain, to ascend the summit of which cost our horses some strenuous exertion, although we marched a considerable distance on foot. A wide belt of sandstone formation presented a marvellous display of flowers, and gave us in little an idea of the South African Karroos, a series of terraced clay-patches, estimated at from 3000 to 4000 feet high, which, hard and steppe-like in the dry season, are speedily transformed in the rainy season into smiling, flower-bespangled plains, quite sponge-like under foot, and rich in alkaline products.* We advanced some six

* The English appellation "Karroo" seems to be derived from Kr "hard" in the Hottentot language, and to refer to a quality appertaining to the 
hours before reaching another farm-house. This was known as Kleene Islea Plaats (Little Island Farm), near which flows the Zonderend River (River Without End), the property of a kind and hospitable family of French extraction, whose parents emigrated hither from France during the revolution in 1793. As it was Sunday, the servants had gone to church, so they could only offer us cold mutton, syrup, butter, and bread. Before and after our repast, the devout old lady of the house put up a short petition.

Here, too, we remarked that those born in the country of European parents are called Africans: only the English form an exception to this rule, and remain with persistent patriotic obstinacy, "Englishmen."

The journey from Kleene Islea Plaats to Genaaden Dal is extremely picturesque. One first catches sight of this retired Moravian settlement only when actually entering the place itself, embowered as it is among lofty trees. What a surprise, when, still fancying one's self at a considerable distance from the village, on reaching the end of a beautiful valley at the entrance to Bavian's Kloef, one sweeps by a circuit into the very heart of the settlement. We alighted at what is called "The Lodgment," a house set apart for visitors, and conducted by a brother, in conformity with the laws of the community. The dwellings of the Hottentots lie scattered among the 
rising grounds in the neighbourhood, and with their povertystricken aspect impart a somewhat melancholy impression. These are built of loam, low in the roof, as though intended for a stunted race of men, and rarely have windows, so that the door is, generally speaking, the largest aperture in the entire building. Our Malay driver laughed at them, and called them oete kripp (oxen stalls).

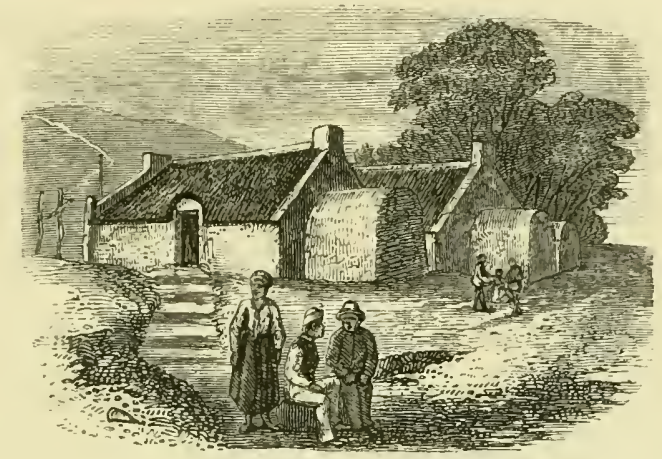

There seem to be three distinct kinds of these dwellings, which apparently indicate so many grades of social and pecuniary consideration among the resident Hottentot families. The first sort, which consists simply of a single apartment, serving at once for kitchen, work-shop, and sleeping place, and receiving air and light through a narrow, low-pitched door-way, is that most usually met with, and may not unaptly be compared to a bee-hive. The next class is of a better description, and may at once and definitely be distinguished from the first-mentioned, in so far as it possesses a second room, which, if dark and windowless, is at any rate partitioned off, and serves as a sleeping apartment. Finally, the third kind, which can only 
be said to be the least poor-looking, consists of one large, almost empty chamber, for occupation during the day, with wings on either side, one of which is used as a kitchen, the other as a bed-room. The wretched ventilation, and damp, moist location of these habitations, combined with the bad quality of food, may be regarded as the main causes of the unfavourable state of health of the coloured portion of the inhabitants of Genaaden Dal, among whom, especially as regards the female portion, pulmonary complaints are rife.

We were provided with letters of introduction to the Superintendent of the Community, Dr. Köbling, as also to the Physician and Pharmaceutist, Dr. Roser, a Würtemberger by birth, and experienced a most cordial reception. We availed ourselves of the last hours of declining day to make an excursion to the hills, in the country immediately adjacent, so as to command at a glance the entire colony. The principal buildings, the Church, the school, the workshops, the warehouses, and the dwellings of the missionaries, are assembled in a quadrangular open place, to which a number of lofty, massive, leafy, venerable oaks impart a sombre, but poetical, appearance, eminently characteristic of the community. All the buildings are of a uniform dingy-grey tint. Close in the rear of these buildings is a large garden, which reaches as far as what is called " $\mathrm{Ba}$ vian's Kloef "(defile), in which, even at present, apes, antelopes, and zebras, abound. Near the kitchen-garden is the cemetery of the community, which seems to be used by meditative brethren as a favourite resort and promenade. 
This settlement, situated at the entrance of a mountain defile, at the foot of an immense sandstone range, of from 3000 to 4000 feet high, was founded in the year 1787 , by a brother of the persuasion, named George Schmidt, from Moravia, who settled fifty-five miles east of Cape Town, near Sargent's River, with a number of Hottentots, whom he began to convert to Christianity, and called the station "Bavian's Kloef." From the year 1806, the settlement assumed the beautiful name of "Genaaden Dal" (Vale of Benevolence), so exquisitely correspondent with the benevolent exertions of the brotherhood. It at present numbers 3100 souls, mostly a race crossed between Hottentots and Mozambique negroes, of the latter of whom a considerable number have settled here since the Slave Emancipation Act of 1826. The settlers are partly proprietors of the land, partly artisans, cutlers, waggon-makers, tanners, carpenters, millers, \&c. In the workshops the most exemplary cleanliness and neatness are imperatively insisted on. At the Great Exhibition, held in London in 1851, the wood-work of the Hottentot carpenters of Genaaden Dal received "Honourable Mention," and this elegant testimonial in recognition of their efforts now hangs, framed and glazed, in the library hall of the community. It somewhat surprised us that the cutlers did not receive, in their section, a similar distinction, since, in that department of industry, the Hottentots produce articles, which, so far as concerns quality and cheapness, are really astounding. The workpeople receive a fixed weekly payment, which they may expend as they please. 'The net proceeds, however, of the 
various articles manufactured belong to the community, and are expended in defraying the expenses of, and supporting, the mission. The inhabitants of Genaaden Dal are closely connected, by religious ties, with the community; and only those who profess the principles of the Moravian brotherhood are permitted to settle among them.

The field-labourers, who hire themselves out to labour elsewhere, are frequently absent from the settlement for months at a time, and return to Genaaden Dal immediately after the com. pletion of seed-time or harvest. It is significant that these labourers regard this period of emancipation, as a sort of relaxation from the severe discipline and rules to which they are subjected in the religious community.

The principal articles of food of the inhabitants consist of maize, beans, pumpkins, rice, fruits, tea, coffce, and occasionally mutton. Wine is strictly prolibited throughout the settlement, and when a member of the Novara Expedition, never imagining that this interdict extended to strangers as well, desired the attendant at the house we were occupying to fetch a bottle of sherry, that individual regarded him with as horror-stricken an air as though he had asked him to participate in some crime.

Aithough the first settlers in Genaaden Dal were pure Hottentots, not more than five or six at present speak the idiom of their fathers, the rest knowing only the Dutch tongue. The Superintendent had the kindness to allow an old blind man, of the name of Sebastian Hendrik, to be presented to us, born in the colony in 1775 , of Hottentot parents, "een opregt Hottentot" 
(an out-and-out Hottentot), as he called himself, and who still could speak a number of phrases in his mother tongue, with its extraordinary "clicking" sounds; but, on the other hand, no longer had the slightest recollection of the customs, usages, or proverbs of that nation to which he belonged by birth. In the library of the community, where this conversation took place, there were also shown to us numerous sketches by Hottentot and Caffre lads, which gave great hope of future excellence. It is an especially gratifying indication of intellectual progress, that several works of natural history are to be found on the shelves of the library.

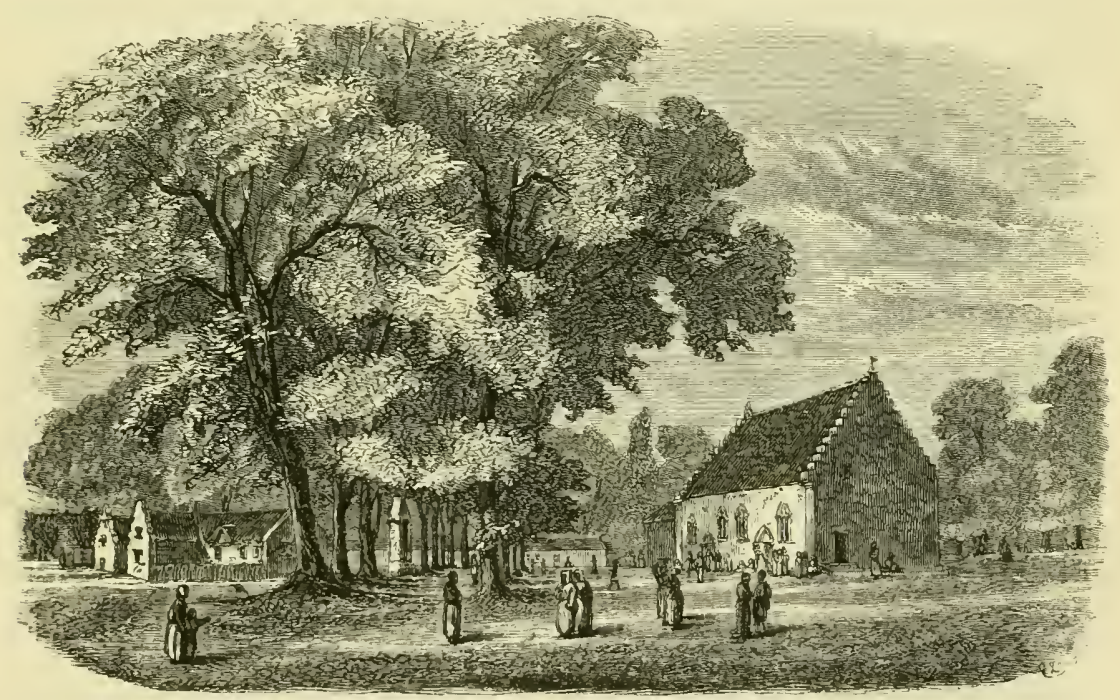

We also found time to listen to the singing in the church, quite a plain wooden building, erected in 1800 , with whitewashed walls, a spacious gallery, and an elegant organ, the gift of a benevolent lady of Hamburg, who spent some months 
of the year 1843 at Cape 'Town in search of health, and took an opportunity of visiting the Moravian brethren at Genaaden Dal. One of the missionaries sat in the middle of the chapel at a table covered with green cloth, and gave out, verse by verse, a hymn in the Dutch language, which was afterwards sung, with accompaniment by the organ, by the entire community assemble in the edifice. The men and women sat apart from each other, on smooth wooden benches, the former on the left, the latter on the right of the officiating minister. The chapel was only illuminated with a few tallow candles; but the devotional feeling of the community seemed to gain by this simple unostentatious ritual, and the mysterious solemn obscurity of their place of congregational worship.

Next morning, 12th October, some of the brethren paid us the attention of examining in our presence the scholars of the Seminary for Teachers, so that we might personally satisfy ourselves of their progress in the various branches of education. This academy for the education of suitable instructors, was originally established in 1838, through the generous assistance of a Saxon nobleman, Count Schönburg, and year by year since, has been so liberally assisted by that benevolent nobleman, that its future prosperity seems fairly established. At present there are in the seminary 14 pupils (Hottentots, Caffres, and half-breeds). Since the rear of its establishment, 50 young persons in all have been sent out hence; of whom, however, only one half proved to be available for the duties of teachers. Up to the year 1856, 
twenty-two pupils were already at work in the service of the community, fourtecn had been rejected as unsuitable, and fourteen were still in the institute. They entered at from ten to fifteen years of age, remained within its walls six years for instruction, when they were clothed and maintained, and thereafter, without further obligations to the society which had educated them, were dispatched into the most remote districts of the colony as teachers and apostles of Christianity. The examination of the pupils of the seminary took place at the Library Hall, which boasts a portrait of a highly meritorious brother, the venerable C. J. Latrobe, who, in the year 1815-16, visited South Africa as a missionary, and, two years later published, in London, his very remarkable book of travels. The examination commenced with a peřformance on the piano by a Mestizo lad of about sixteen, son of a Mulatto father by a Hottentot motleer. This youth displayed a decided talent for music, coupled with truly admirable execution; and besides the piano, played the organ, the violin, and the violoncello. Next, a variety of questions in geography and history were put to the pupils present. These consisted chiefly of easy intelligible questions, principally relating to England. Those examined were surprisingly well acquainted with the history of Liverpool, London, Manchester, Dublin, \&c., and could enumerate many particulars about the Thames and Westminster Abbey. What proved most disagreeable, was the singular custom that prevailed, of all the pupils answering at once, each hoping, by out-clamouring his fellow, to prove his 
intimate acquaintance with the subject under discussion. The examiner, for example, put a question to a scholar, whereupon all the pupils yelled out the reply in chorus. But it was, on the whole, astonishing, and indeed eminently suggestive, to hear Hottentots, Caffres, and negroes, at the extreme southernmost part of Africa, speaking of England, and her influence over the destinies of humanity, as a commercial, maritime, and industrial power. Already the youth of the settlement are thoroughly interpenetrated with esteem and affection for the mother country and its mighty people. As a finale, the assembled pupils sang a Duteh Bergmann's Gruss, "The Miner's Welcome," and one of Mendelssohn's delightful songs.

Before we quitted Genaaden Dal we breakfasted with the missionaries. 'They are all married, and manage their households in common, and accordingly partake of their various meals together, each with his family, all seated at one table, one of their wives attending to change dishes and wait at the table. Nowhere are any particular qualifications to be remarked, and it is difficult to conceive more thorough harmony than exists among the unpretending, yet zealously religious missionaries of Genaaden Dal.

As we were preparing for our departure, Dr. Roser unexpectedly packed up a number of objects of natural history and scientific interest, which he kindly presented to the Imperial expedition as a souvenir of Genaaden Dal. Besides these, there were also given to us two valuable little books, -one a small work upon the Nicobar Islands, written about the beginning of 
this century by a Moravian brother of the name of Gottfried Hensel; the other a treatise composed by the excellent Dr. Roser himself, upon the pharmaceutics and natural history of Genaaden Dal. With respect to the various substances chewed as stimulants, or intoxicants, by the Hottentots, in order to deprive themselves of sensation, or rouse themselves to a state of high excitability, we found the following particulars in this interesting essay. That most in use is composed of the bruised leaves of the "Leonotis Leonurus." This plant, which grows in great quantity in and beyond the Genaaden Dal, is called by the natives "Dagga," as also frequently, "Tacha or Takka," and this variation in pronunciation is very probably the reason that we find in Berghaus's "Völker des Erdballs" (Races of the Globe), this celebrated smoke-weed, marked as "Donha." What the same author says of certain stimulating properties of the plant may well be considered as an exaggeration. It is curious how the properties of this plant seem to be inextricably mingled with the destinies of the Hottentots. In many places it has been extirpated, in order more readily to wean the aborigines from the practice of chewing: at other places again, "Leonotis Leonurus" is expressly planted in order to attract the Hottentots, and so supply any deficiency in hands for labour, reckless of the moral consequences. Another narcotic, and the most widely prevalent, is the wild hemp (Canabis Sativa), the dried leaves of which are smoked by the natives. Dr. Juritz, one of the most respectable apothecaries in Cape Town, assured us he had been compelled, during a previous 
residence at Stellenbosch, where he was engaged in his business, to keep always on hand in his store a large quantity of wild hemp for sale to the natives.

The poison with which the Bushmen tip their arrows, rendering them such dangerous and terrible weapons, is extracted from the "Cestrum venenatum."*

Among the animal products of Genaaden Dal of importance in a scientific point of view is Hyrazeuma, a substance obtained from the urine of the Cape Marmot (Hyrax Capensis). It is of a dark-brown colour, somewhat tenacious, and nearly hard, of a very penetrating odour, and is found in cavities resembling a molehill. This article is made use of with much effect in hysterical complaints by the Hottentots. Dr. Roser is of opinion, that this Cape Marmot is in all probability the same animal which Martin Luther, in Leviticus, c. xi, v. 5, and Proverbs, c. xxx, v. 26, has translated by the word "kaninchen" (conies).

On our way from Genaaden Dal to Caledon, to which there is an excellent level road, we perceived a large number of silver poplars, with pendent nests of finclies. On a single tree we counted more than forty such pendent nests, constructed in a very singular manner.

Caledon is a cheerful, ambitious little town, important as the centre of the wool trade, as also for the thermal springs in the neighbourhood. These, situated about two English miles out-

* The Dyaks of Bornco poison their arrows with the juice of Strychnos Tieute and Antiuris Toxicuria (Upas). 
side the town, on a rising ground, in a romantic and highly attractive neiglıbourhood, are impregnated with iron, and of a considerable temperature. Even in the bath-house, distant about a mile from the source of the spring, a thermometer held in a stone trough, filled to overflowing, marked from $100^{\circ} 4$ to $104^{\circ}$ Fahr. At their respective sources the one spring has a temperature of $116^{\circ} .6 \mathrm{Fahr}$. and the other $114^{\circ} .^{\circ} \mathrm{S}$ Fahr. The colour of the water is ochre yellow. From the terrace of the bath-house a rather extensive landscape opens to the view, backed by a splendid range of mountains, including the Tower of Babel, as the inhabitants have christened the highest peak in this vicinity.

Caledon has 600 inhabitants. About twenty years ago there were not more than ten bales of wool grown in the entire district. At present about 800,000 lbs. are shipped annually. One Merino sheep supplies from $1 \mathrm{lb}$. to $1 \frac{1}{2} \mathrm{lb}$. of wool, worth from $1 s .2 d$. to $1 s .4 d$. sterling per pound. Besides Caledon, the principal wool districts of Cape Colony are Swellendam, Beaufort, and Graaf-Reinet. All these districts united produce yearly about $15,000,000 \mathrm{lbs}$. of wool, worth about $£ 1,000,000$ sterling. Within two years the wool produce of the entire colony has increased 30 per cent.s and during last year a strenuous and very costly experiment has been made to introduce the Angora breed, with the intention of increasing the wool-producing powers of the less fleecy race by a judicious cross with the native species.

The road to Somerset-West leads over the high and pictu$\mathrm{R} 2$ 
resque Haw -Hoek Pass and Sir Lowry's Pass; the latter is very steep, and parts of it are hardly, if at all, inferior in extent and variety of landscape to those presented by the Styrian Alps. At the culminating point of the latter pass, which surpasses even Paine's Kloef in height and width, one stands as upon the ruins of a lofty tower, from which the eye can range at will over the entire country beneath. South-east and eastward towers the Hauw-Hoek Pass, while southwards and westwards the charming Lowry's Vale, and far in the distance the smiling settlement of Somerset-IVest come into view, while all around, farther than the eye can reach, are luxuriant pasturages, that only wait to be settled and cultivated in order to produce magnificent returns.

Somerset-West, a prettily-built, and very charmingly situated settlement, already supports so considerable a traffic with the eapital, that a daily omnibus has proved a remunerative speculation to the promoters.

We now proceeded to Zandvliet, the property of one of the oldest and most highly considered families in the colony, named Cloete, where we spent the night. With these genial kindly people we soon felt ourselves as entirely at home as if with our own families; we sang, laughed, and frolicked, till far into the night.

The following morning we drove to a hill, about a mile and a half distant from Zandvliet, known as Macassar Downs, on which is the spot of interment, (Krammat or Brammat), of a Malay prophet. 


\section{Tomb of a Malay Prophet.}

This individual, so honoured in death, was, if we are to believe the Malays, a direct descendant of Mahomet, named Sheikh Joseph, who, expelled from Batavia by the Dutch Government for political reasons, settled in the colony about a century and a half ago, and died and was buried in the neighbourhood of Zandvliet. An especial deputation came over from Malacea to Cape Coluny to fetch away the corpse of the defunct prophet, for conveyance to the land of his birth; but at the disinterment it happened that the little finger of the prophet, in spite of the most persevering research, could nowhere be found. This circumstance appeared to those simple believers sufficient reason for erecting a monu-

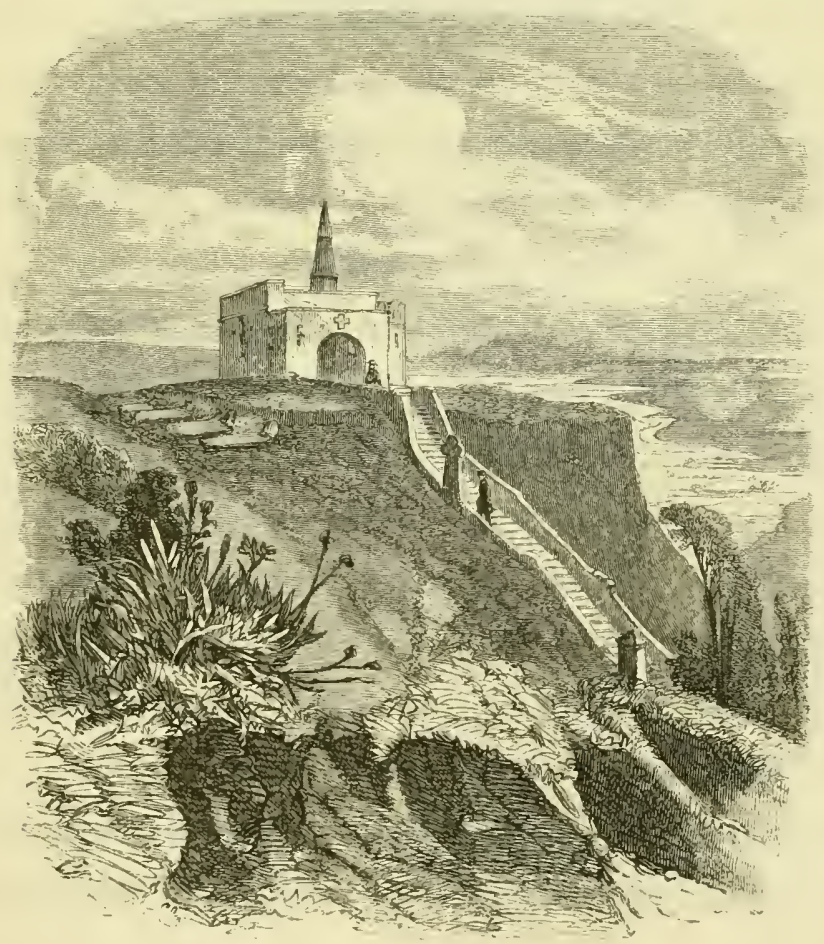


ment over the spot in which the finger of a Malay prophet lay hid from view. Even to this day the Malays from time to time perform a pilgrimage to the Colony and celebrate their religious ceremonies at the Mausoleum. Four followers of the prophet are buried with him, two of them Mahometan priests, who are regarded with much veneration by the Malays. An extensive flight of stone steps leads to the tomb, the exterior of which is very insignificant, and, but for a small pointed turret, hardly differs from an ordinary dwelling-house. On entering, a low-roofed vault is visible, a sort of front outhouse, which rather disfigures the façade, and much more resembles a cellar than the portal of a Mausoleum. Above the arch of this vault an Arabic inscription has been engraved with a stylus; but this is so painted over in brick colour that it has already become almost illegible. Judging by the few words that have been deciphered, it scems to consist of the first propositions of the Koran.

The inner room, provided on two sides with modern glazed windows at irregular intervals, is about the size of an ordinary room of 12 feet long, 9 wisle, and $r$ high. In the middle rises the monument, to which access is had by some more brick steps. Immense quantities of unwashed white linen cloth are heaped upon it, which scem occasionally sprinkled with a brown odoriferous liquid (dupa). As at the head of Sheikh Joseph, so at his feet several figures, resembling those in enamel used to ornament tarts, are drawn upon the linen cloth with the overflowings of the unguent. These have un- 
doubtedly been formed accidentally, and it appears wrong and unfair to attribute to them any more recondite significance. The monument rests upon four wooden pillars, with pyramidal pinnacles or ornaments, and is richly decorated with fine white muslin, which gives to the whole very much the ap-

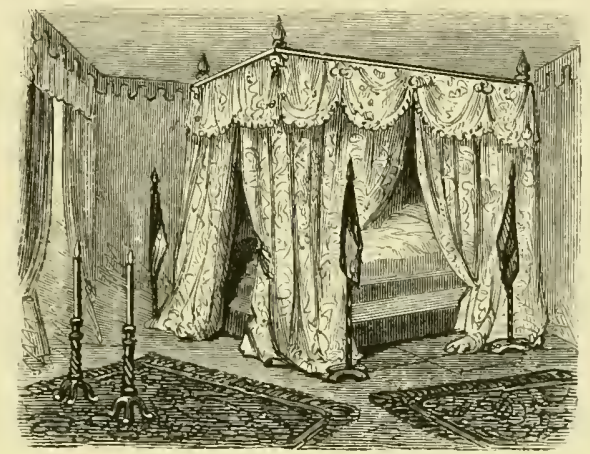

pearance of an old-fashioned English "fourposter," with its costly drapery and curtains. While the curtains are spread out all around, several small green and white bannerets stand at the upper and lower end of the sarcophagus. The whole interior is, as it were, impregnated with the incense which devout Malay pilgrims from time to time burn here, especially after the forty days' fast (Ramadìn), or leave behind upon the steps of the tomb in flasks or in paper-boxes. On such occasions, they always bring wax-candles and linen cloth as an offering, with the latter of which they deck the tomb afresh, so that a perfect mountain of white linen rises above the stone floor. During their devotions they unceasingly kiss this white mass of stuff, and as they are continu- 
ally chewing tobacco, this filthy habit produces disgustingly loathsome stains.

On the same hill which boasts the tomb of Sheikh Joseph, there are also, in ground that is common property, nine other graves of eminent Malays, enclosed with carefully-selected stones, and likewise covered over with large broad strips of bleached linen cloth, protected by stones from any injury by weather or violence. At the head and foot of each individual interred, is a single stone of larger size. Formerly the black inhabitants of the neighbourhood made use of this store of linen cloth to make shirts for themselves, without further thought upon the propriety of the matter. Latterly, however, a shrewd Malay priest spread a report that one of these ebony linen stealers had lost all the fingers off one hand, since which the graves of those departed worthies remain inviolate and unprofaned.

At the foot of the hill are some small half-fallen-in buildings, near a large hall, painted white, red, and yellow, consisting of a small apartment and a kitchen, the whole in a most dirty, neglected, and desolate condition. At this point the Moslems must have accomplished certain prayers, before they can climb the hill and proceed to visit the tomb. Over the door of this singular house of prayer some words are likewise engraved in the Arabic character, which, however, are now entirely illegible.

On quitting the Malay Krammat, we next undertook a tolerably difficult walk to the Downs or sand-dunes, which at this 


\section{Return to Cape Town.}

point extend along the entire coast line, on which the waxberry shrub, as already mentioned, grows wild in vast quantities, and visibly prevents the further encroachments of the moving sand. The Eerst Rivier (First River) may be regarded as the limit of demarcation between the sand-dunes and the soil adapted for regetation.

The same evening the naturalists of the Expedition left hospitable Zandvliet, though not till after they had been presented by Herr Cloete with a splendid collection of fruits indigenous to Port Natal. Having been everywhere received with distinction, and enjoyed every sort of assistance in our researches, we set out on our return so richly freighted with objects of natural history, that the waggon, as we drove through the wide streets of Cape Town, presented such a various and substantial assortment of each as spoke volumes for the success of our journey. Every available corner was called into requisition to dispose of our prizes-even between the open windows hung suspended the bottle-shaped nests of the finch, and the slender sticks that supported the tilt were entwined with gigantic festoons of flowers. In a word, the whole waggon, with its variegated contents, resembled a holiday-van on its return from a country excursion, so gaily and cheerfully was it decorated.

During our residence in the Cape colony, severe depression existed among the agricultural inhabitants of the Western and Eastern districts, in consequence of an epidemic which, within two years, had carried off 64,850 horses (draught horses, 
mares, and foals), of the value of $£ 525,000$ sterling.* Many landowners in consequence entirely gave up rearing horses, and turned their attention almost exclusively to the breeding of sheep. The visitations of this malady are by no means of late introduction, but hitherto they had made their appearance at such long intervals, that but little attention was paid to them and people regarded their return without much alarm. This disease of the horse, usually endemic in Cape Colony, assumed every twenty years, owing to some inexplicable causes, an epidemic character, and on those oceasions extended over an extensive area, as happened with extraordinary regularity in the years 1780, 1801, 1819, 1839, and 1854. Hitherto no further precaution was taken, than, so soon as the disease appeared, to drive the horses from the grass pastures to their stables or covered sheds, and there supply them with fodder, the night dew being considered a main cause of the complaint. A resident in Stellenbosch, indeed, maintained that the dew which was deposited during the continuance of the disease tasted quite bitter, and was of an unusual brownisl tinge. Singular to say, not the slightest symptoms of illness manifested themselves in the swine, dogs, and birds of prey which devoured the carcases of horses that died of the disease,

* At the same time 92,793 head of cattle (dranght oxen, cows, and calves) fell a sacrifice to a disease of the lungs, and we were assured that the original cause of this terribly fatal malady (Pleuropneumonia) is attributable to a bull having been imported from Holland, in the year 1854, in a diseased state. The English public will remember the severe panic under which Continental graziers, and others connected with the cattle trade, laboured during the years 1854-55 and the commeneement of 1856 . 
while the consumption, whether boiled or roasted, of mutton which was ever so slightly tainted with the mere germ of this malady, never failed to produce the most mischievous consequences on the human species. According to Dr. Livingstone the same malignant ulcerous imposthumes were produced, if even sound portions were used of the carcase of an animal that had died of this complaint. These observations, founded on innumerable examples, run counter to the opinion of the French physicians and physiologists, that the malignity of the poison in such cases becomes neutralized by the process of cooking. Considering the importance of the subject to a land-holding colony, it could hardly fail that numerous individuals should devote themselves to elucidating the causes of this devastating epidemic; but it must ever remain a striking and significant fact, illustrative of the high standard of cultivation in Cape Colony, that within a very few years 112 different authors published treatises respecting this complaint among the horses. The result of these numerous researches was, that the malady is epidemic, but not contagious; that horses driven into the stable before sunset, and not permitted to go out to pasture till the dew has evaporated off the grass, are as a rule exempted from attack ; that those horses which are kept at night in open pounds, or in places where there are heaps of dung, take the disease in a milder form than if suffered to roam at large day and night; lastly, that horses for which no covered shelter can be provided, may with great advantage be sent to hilly localities and dry runs of land. The practical remedy which was most resorted 
to, consisted in immediate and prolonged bleeding, pushed to actual exhaustion of the animal, in the first stage of the malady, as also the exhibition of 1 drachm of tartar emetic and 2 drachms of calomel, or, at a later stage, of 30 grains of tartar emetic twice a day.

Another appalling scourge of the settlers in the south-west district of Cape Colony is a minute, almost imperceptible insect, of terrible omen, the tsetse-fly (Glossina morsitans), a

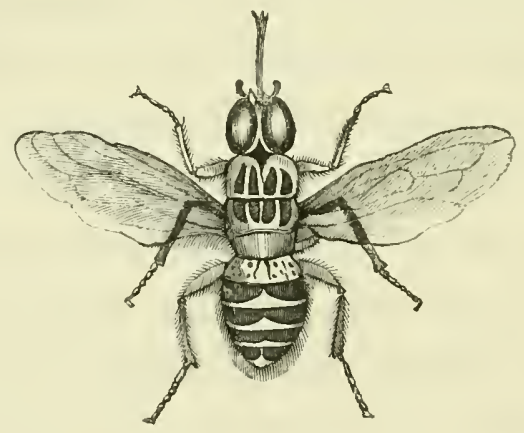

puncture from which produces such terrible destruction anong horses and cattle, that several runs of land are uninhabitable -nay, even the mere passing through districts which they frequent, proves fatal to the draught beasts of the caravans. This insect is principally encountered in copses and brushwood, very seldom in the open country, and is about the size of a common house fly, but with wings a little longer. In colour it resembles the honey bee. The tsetse is uncommonly active, and usually escapes all attempts to catch it with the hand; but in the cool of the morning or evening it is less active and quick in its movements. The poison which it 
carries is so powerful that the bite of three or four individuals is sufficient to kill the most powerful ox. Many animals, especially such as appear perfectly sound or in the best condition, die speedily after being bitten, but the majority are ill for an entire week, and usually become blind before death. One remarkable circumstance is that the bite of these insects is fatal to dogs, even when fed with milk, while calves and other young animals, so long as they are sucking, remain perfectly exempt from the malefic powers of the tsetse. It is especially noticed that the danger scens to be confined to domesticated animals, while such as are wild or only half reclaimed, such as buffaloes, zebras, jackals, oxen, horses, and wild dogs, have not the slightest occasion to dread this insect; nay more, it attacks man himself without the least ill consequences. The sensation which their bite produces on the the hand, or other portion of the human frame, would be confounded by any one travelling in the tsetse district, with that of another minute and most troublesome, though by no means dangerous insect, the flea. Fortunately the tsetse-fly has an appointed circuit to range in, in the south-west of the Cape Colony, which it never changes or extends. The landowner may erect his cattle-pound on one side of the stream in perfect security, although the opposite bank may resound with the hum of swarms of these insects. When the natives, who are acquainted with the localities in which the tsetse-fly abides, are compelled, as they constantly are, to shift their ground, and, in changing their pastures, to transgress 
upon the district of the tsetse, they usually select the moonlight nights of winter, when the insect, during the quiet hours of the cold season, is not likely to molest their charge.

Many travellers whose draught oxen and horses have been killed by the ravages of this insect, are annually not merely frustrated in their journey, but, it appears, have their personal safety seriously imperilled by being deprived of all means of locomotion. Anderson, in his admirable work upon "Lake Ngami," relates that some twenty aborigines of the Griqua race, who had been elephant-hunting in the north-west of that lake, and were provided with three large waggons and numerous oxen and horses, found, on their return to their encampment, that they had lost the whole of their cattle-team by the bite of the tsetse. So, too, Dr. Livingstone, during a short journey orer a district frequented by the tsetse, lost forty-three strong and useful oxen, although by dint of great vigilance scarcely twenty flies had been able to settle among the entire herd. We have dwelt at length on the description of the ravages caused by this so much dreaded insect, with the view of pointing out the numerous and amazing difficulties which present themselves to the traveller or settler in certain localities, and how often not only wild and rapacious animals, but even small, hardly perceptible insects endanger the life of the wanderer, and render large tracts of lands valueless for settlement.*

* Most valuable compreliensive details, as to the natural history of the tsetse-fly, its ravages, and its migration into the districts which it frequents, are to be found in the "Transactions of the Royal Society:" Volume XX., page 148; "Procecdings of the London Geological Society," page 217; Cliarles Joln Anderson's "Lake 
No stranger ean well leave Cape Town without having visited Constantia, the chief seat of the wine cultivation of the country. Accordingly we had a day of exceedingly pleasant relaxation while visiting High Constantia. Mr. James Mosenthal, the very hospitable Austrian Consul, had carefully selected the most beautiful spot in the immediate vicinity of Cape Town, the charming residence of his friend Mynheer Van Reenen, at which to get up a splendid fête champêtre on an extensive scale, in honour of the visit of this the first man-of-war that had borne the flag of our country into these remote seas. The entire staff of our frigate was invited, and over a hundred guests, comprising the flower of the fair sex of Cape Town, took part in the festivities. Immense four-horse coaches conveyed the company in the forenoon to the hill of Constantia. The company wandered at leisure under the gigantic oak trees, or in the beautifully laidout garden of this extensive domain, and after a sumptuous déjeuner, the majority set to dancing. A small orchestra of stringed instruments played alternately with the ship's band in the garden, and in the tastefully decorated apartment. Those who did not care to dance, or whom a burning afternoon

Ngami; or, Explorations and Discoveries during Four Years' Wanderings in the Wilds of Western Africa," London, 1856; Dr. Livingstone's "Missionary Travels and Researches in South Africa," London, 1857. The agent of the London Missionary Society at tlie Cape of Good Hope, the estimable, higllly respected Dr. Thompson, gave us a small piece of a root called fly-root, which is considered to grow from a parasite, and a decoction of which is reckoned by the aborigines an antidote to the bite of the tsetse-fly. Unfortunately the requisite material was not in sufficient quautity to admit of determining the plant itself, or of instituting further researches with it. 
sun prevented from walking in the open air, might escape into cool and most elegant cellars, where our hospitable entertainer had stored large quantities of "spiritual treasures." The costly nectar which the Cape, and especially High Constantia, produces, finds its way but seldom to European tables, because the quantity produced is very much below the demand; for although the first cultivation of the grape for wine dates in Cape Colony so far back as 1668 , the wine manufacture has only of late years expanded in a marked degree,-viz., 45 per cent. from 1855 to 1856 , and 70 per cent. from 1856 to $185 \%$, so that at present the entire quantity produced of red and white Cape wine (Pontac and Frontignac) may be stated at 24,000 pipes, worth $£ 380,000$ sterling.

At the conclusion of the fête we sat down to a splendid banquet in the open air, in a shady avenue, so as to admit of all the guests sitting at one long table. At the upper end, under the umbrageous boughs of some venerable oaks, that towered like a canopy overhead, fluttered the flags of England and Austria. The mayor of Cape Town occupied the chair; the toasts customary on such occasions were given and responded to, allusion being made to the pleasure felt at the arrival of an Austrian man-of-war, as also to the gratitude of the members of the Expedition for the hearty welcome prepared for them, and expressing an earnest hope that both Governments may ever continue faithfully allied, as both nations are, by descent, sympathy, and intellectual pursuits. A few days after this splendid entertainment, we returned to Simon's Bay, 
whence the Novara was already preparing to sail. The several wecks' stay of the frigate at the little settlement of Simon's Bay, together with a certain quantity of repairs, had called forth a most unwonted briskness of business. Amid so circumscribed a population, the sudden influx of more than three hundred additional consumers, with their varying wants, speedily made itself perceptible in every class of the community, the more so as most of the heavy stores for the voyage were bought here, so that the sum set in circulation during

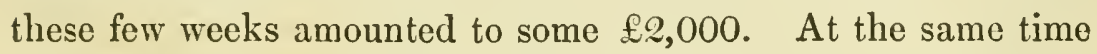
the Expedition were readily permitted to contribute a mite towards building the Catholic Church in Simon's Town, and to present some priests' garments, altar cloths, and church fittings, which had been intended by the Austrian Government for distribution among four Catholic Missionaries in the various quarters of the globe visited.

Some members of the Expedition also set out on an excursion some thirty nautical miles, to where the peninsula of the Cape stretches out to the real Cape of Good Hope itself-a longer, more difficult, but also more interesting expedition, which gave fresher impressions, and conveyed a pretty accurate and more just idea of the physical features of the Peninsula of the Cape, its regetation, zoology, and geological structure, than could be obtained by a cursory examination, of the natural features of a large portion of South Africa. For whoever has clambered up the torn, broken, rocky masses of 'Table Mountain, worn out and eaten away by the atmosphere, and has scrambled among 
its wild hollows, with its forests of the greyish green Pratea Gargentea at his feet, amid its far extending rocky plateaux, full of stagnant water-pools; whoever has strayed thence among the wine-producing terraced hills of Constantia, with their rich vegetation; over the sandy table-lands backed by rocky ridges, over streams of copper-coloured water, and the boggy tracts that extend to the extreme south-west point, as far as the Sandstone rocks, 800 feet high, which, descending sheer into the tempest-tossed, fearsome, boiling ocean, constitutes the actual Cape of Good Hope-obtains a tolerably just and correct idea of the appearance of Southern Africa for one hundred miles into the interior, and along the coast line, 400 English miles in length, which stretches from St. Helena Bay as far as the River Samtoos, west of Algoa Bay. All is sandstone or clay-slate, with occasional granitic knobs cropping out; no trees, but such as are planted in clumps around the sparsely scattered farms, conspicuous from an immense distance; while, on the other hand, in spring, an indescribable flush of blossoms and flowers, and instead of trees, millions of ant-hills, with their regularly,shaped cones from three to four feet high, impart a peculiar character to the landscape of South Africa. But on the so-called Lowlands of Algoa Bay, beyond the River Samtoos, Nature assumes an entirely different character in her forest vegetation. Unfortunately, the original designs of the geologists of the Expedition, of Examining the petrified treasures of this renowned district, fell through, which was all the more to be regretted as this geological Eldorado promised a great accession to our collection. 
During our stay at Simon's Town, we also experimented with our astronomical instruments, which, at our next station, St. Paul's Island, were to be brought fully into requisition for the first time. On this occasion, as on many others, the unfailing courtesy and kindness of the renowned astronomer and director of the Observatory of Cape Town, Mr. Thomas Maclear, assisted us most materially in the observations for comparison with our own physical instruments.

On the morning of the 26th October it fell calm, changing to variable breezes and light puffs of wind, that made it doubtful whether we could sail that day, as we needed a catspaw from the West in order to weigh anchor. From the English line of battle-ship Boscawen, there floated across the bay as we worked out, the Austrian National Anthem, played as a farewell-a graceful mark of recognition-which was replied to by our band performing the sister hymn, "God Save the Queen."

We steered between Noah's Ark and Roman Rock, coasting along till we made Whittle Rock, but the wind shifting, we were, ere long, compelled to tack. Had we not seized the favourable moment to get away, it would, a couple of hours later, have been impossible to put to sea, as the wind sprang up from the S.E. and blew fresh. Towards sundown, the sky cleared up, and we once more caught sight of the serrated outline of the southernmost point, with its desolate, worn, hollowedout, rocky masses, which, however, with the souvenirs of the hearty reception that had been accorded us in Cape Town 
seemed on this occasion much more home-like and habitable. All of us, indeed, carried with us in our breasts the most cordial and agreeable reminiscences of the Cape of Good Hope.

In spite of many drawbacks and deficiencies of physical requisites, which oppose the rapid development of its natural resources, Cape Colony possesses in its healthy climate its valuable indigenous products, and its free political institutions, a guarantee for its perhaps gradual, but on that account more substantial, progress. It is a favourable specimen of a prosperous agricultural colony able to maintain itself, whose inhabitants, seeking in the peaceable cultivation of the soil their sole reward, are exposed to none of those ruinous reverses of fortune, which make life in those lands that are rich only in a metallic currency so stormy and uncomfortable, and render their future so problematical.

A colony, which already employs annually, in its commerce all over the world, a thousand ships, which has a trade valued

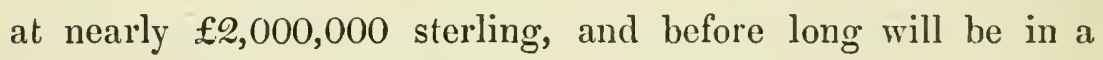
position to export 30,000,000 lbs. of wool a year, besides an unlimited quantity of wines already in great demand, whose soil, owing to its prolific nature, returns, under human cultivation, crops of one hundred-fold, while in its unexplored districts as many additional vegetable and mineral treasures lie unavailable as yet-such a colony carries in itself the germs of a splendid development into a great and most enviable future. Provided with laws of a most liberal scope, and institutions corresponding to the spirit of our times, which leave each 
colonist entirely at liberty to develope his powers and capabilities in whatever direction he pleases, Cape Colony must, ere long, stand forth as the pattern colony for all others in the different countries beyond sea, - a majestic monument of the reward so justly due to the English nation for its policy in promoting the moral and material progress of mankind in the most remote corners of the earth.

We lay a southerly course in order to strike the regular Westerly winds, which we might hope to fall in with in the neighbourhood of $40^{\circ} \mathrm{S}$., and already we again saw our old friends, the albatross, the cape pigeon, and the stormy petrel, in innumerable quantities.

By the evening of the 28th we had attained our limit in the South-west, but the West winds had not yet made their appearance, so that we had to contend till 1st November with baffling light winds alternating with calms. At length in $37^{\circ} 30^{\prime}$ S. and $18^{\circ} 4^{\prime} \mathrm{E}$., we encountered Westerly breezes, which, ere long, freshened, veered to the southward, and compelled us to shorten sail. We were at this time not quite as yet in the zone of West winds, but had to do with variable winds; which, however, as the prevailing winds must be west or south, could generally be made available to enable us to lay our course for St. Paul. Although in the month corresponding to May in the southern hemisphere, we found ourselves shivering with cold, the thermometer barely reached $18^{\circ}$ Cent. $\left(64^{\circ} 4^{\prime}\right.$ Fah.) during the day in the open air, and our bodies, 
accustomed of late to a milder temperature, felt as though it were twice more rigorous than it actually was, in consequence of the wind coming from the ice-bound antarctic regions.

On the afternoon of 4 th November, a great excitement arose on board; a violent shower filled the lifeboats with water, and a large black object was observed swimming in the sea. Fortunately, it was not a man, though it proved to be a great favourite that had fallen overboard. Bessy, an ape, had got loose from her chain, and while being chased, fell in her cagerness into the sea, which fortunately was tolerably smooth. The droll little brute had quickly made itself such a favourite with the crew from its comical attractive ways, that its sudden fall overboard awoke universal sympathy. A boat was lowered, and Bessy rescued, who speedily recovered from her fright, and although dripping wet, proceeded to consume an orange that was handed her with an expression of entire satisfaction.

On reaching $40^{\circ} \mathrm{S} ., 31^{\circ}$ E., the West winds became more steady, with a perceptible increase of motion, giving an average of 33 feet as the height of the waves, while the frigate rolled heavily. Sometimes several "Rollers" would follow one after" the other, which made the ship heel over from $20^{\circ}$ to $25^{\circ}$ on either side. At each roll, streams of water poured in upon the gun-deck. The cannon-shot kept up a deafening dance from one side to the other, while stools, tables, chests, and in short everything that could move, were unmistakably "lively." The 
temperature of the air during the night fell to $4: 1^{\circ}$ Fahrenheit, and was felt yet more keenly in squalls accompanied by rain, which made our life on board anything but agreeable, although the certainty that we were proceeding favourably with the socalled "Fair" Westerly winds indemnified us in some degree for the discomfort.

On 14 th November, in $40^{\circ} 44^{\prime} \mathrm{S}$., $60^{\circ} 8^{\prime} \mathrm{E}$, we availed ourselves of a dead calm and smooth sea to try a cast of Brooke's Patent Deep-sea Lead.

While at Rio, we had been supplied, through the kindness of Don José de Barnabé, Commander of the Royal Spanish Frigate Bilbao, with a large quantity of lead-line, after an unsuccessful attempt to purchase it there. Unfortunately, however, the line had become somewhat decomposed by moisture, and gave way at 6,170 fathoms (37,020 English feet) while still running out, so that on this occasion also, we could only tell that bottom had not been reached with the portion of the line paid out.

The times occupied by the line in running out were as follows :-

\begin{tabular}{|c|c|c|c|c|c|c|c|c|c|c|}
\hline 1st $1000 \mathrm{f}$ & thoms & . & . & . & . & & & $\mathrm{nu}$ & 36 & conds \\
\hline 2nd & , & . & . & . & . & . & 26 & , & 59 &, \\
\hline $3 \mathrm{rd}$ & , & . & . & . & . & . & 34 & , & 20 & , \\
\hline 4th & , & . & . & . & . & . & 43 & $"$ & 25 & ", \\
\hline 5th & , & . & - & - & - & . & 61 & , & 5 & , \\
\hline 6 th & , & . & . & • & • & • & 75 & , & 55 & , \\
\hline last 170 & ", & . & - & - & . & • & 11 & " & 40 & $"$ \\
\hline
\end{tabular}


To the apparatus two 30lbs. shot were attached, and the first 100 fathoms of line were doubled. By this observation we satisfied ourselves that such soundings are only succesful when none but the best materials are employed, and, moreover, that the line becomes deteriorated in an extraordinary degree by long stowage on boardship, so that it is better in long voyages not to take such large supplies of line, but to adopt most stringent measures to prevent its being weakened by damp. Very probably a light coating of tar over the line would tend to keep it in good preservation, and it also seems advisable proportionately to strengthen the first 500 or 1000 fathoms.

On the 18th November the look-out man descried from the main topgallant mast-head the. Island of St. Paul, the goal of our wishes, the object which had so long occupied our thoughts, and on which our scientific capabilities were to be called into enviable activity. The necessary arrangements were completed for facilitating astronomical observations, the instruments and other necessaries taken out and got in readiness to be conveyed to the island, and the various stations and duties of the different members specified, so as to admit of the observations being completed in the shortest possible time.

On the 19th November, at daybreak, we found ourselies close in with St. Paul's Island, while on our port-side the outline of New Amsterdam was visible in the shape of two lofty peaks on the horizon. As the wind blew from the N.W., we kept the ship's course past the north promontory of the 
island, and ranged along the eastern side to the selected anchoring ground. As we doubled the northernmost point, the conical-shaped Nine-Pin Rock came into view, while the high and precipitous margin of the island in the N.E. with the entrance into the crater became visible. How great, however, was our astonishment, when we observed some neatly laidout terraces, of a fresher green hue than were observed in the upper table-lands of the island! These were evidently spots cultivated by former or present residents in the island. But no traces of habitation were seen, whether of mankind or of the seal. Only flights of albatrosses, bryons, ospreys, and sea-swallows, with now and then the protracted screams (like human groans) of immense flights of penguins, those singular-looking sea-birds, which awaken so deep an interest alike for their striking appearance as by their mode of life.

An examination of the rock of the island showed layers of black lava, alternating with yellow and red tufa, which seemed stratified regularly from the rim of the crater to the extreme circumference of the island. "Thirty fathoms, and no bottom," sung the wearied leadsman; and presently, "Thirty fathoms," - and a few minutes before 9 A.ir. the anchor rattled out, on the 24th day after we left Simon's Bay, after retracing our steps Eastward some 3000 miles. Our anchorage, as we afterwards became aware, was not the best possible, as we ought to have lain closer in to the island. But when one 
anchors nearer the land in a less depth of water, one is by no means more protected from storms sweeping in from seawards, to which the entire eastern half of the island lies exposed. Only on the west side does the island, with the steep margin of the crater some 700 or 800 feet high, afford any protection against the west winds, which, however, seldom blow here.

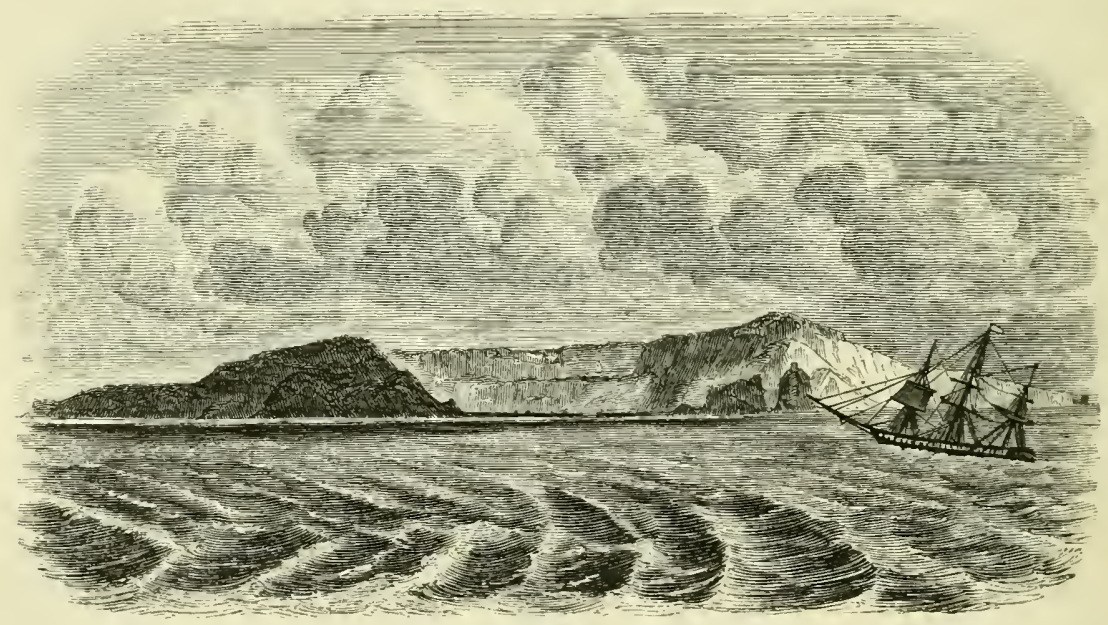




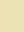


FROM THE CAPE OF GOOD HOPE TO ST PAULS ISLAND.

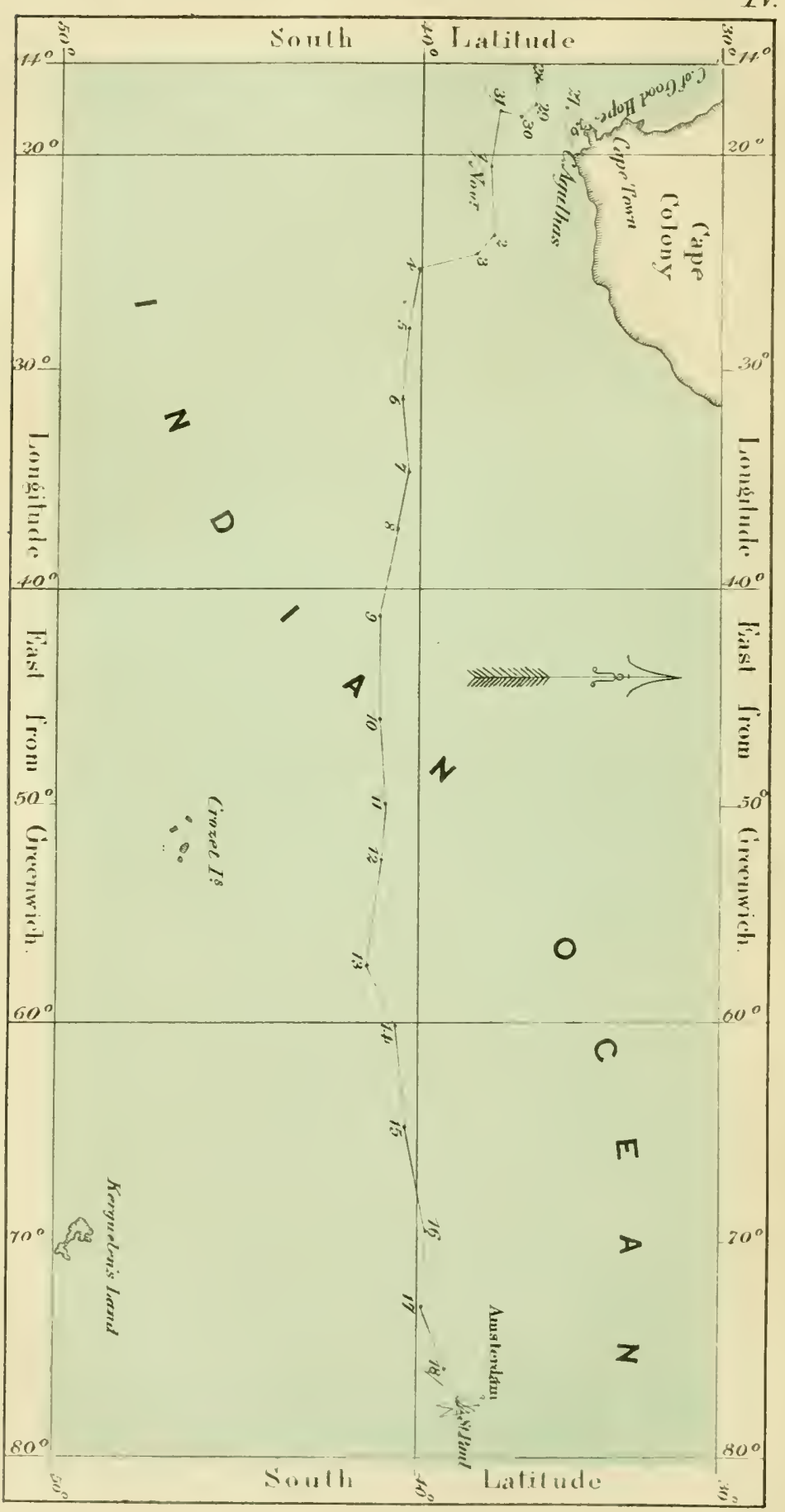



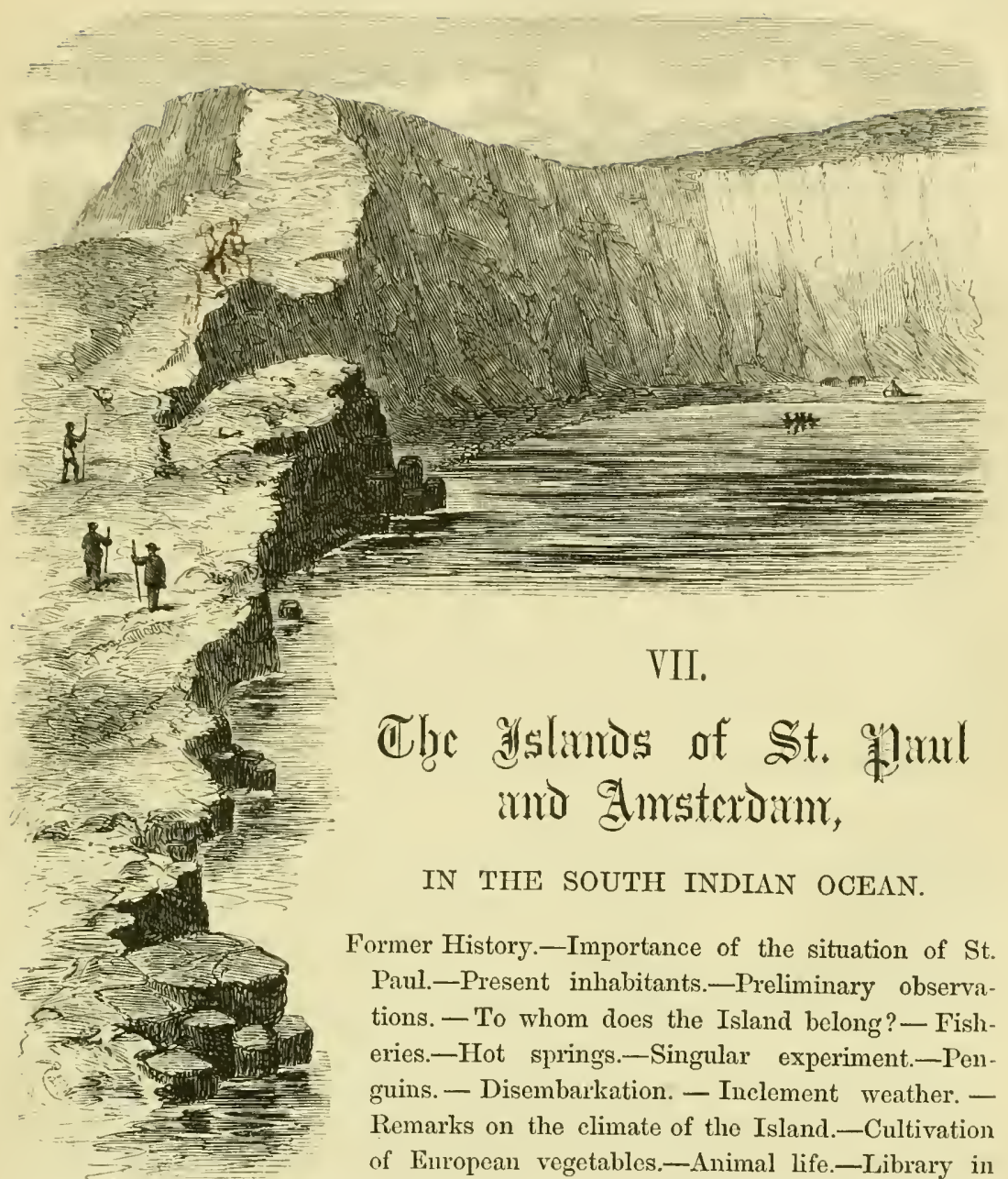

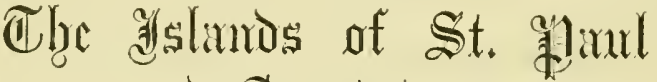 nino Amsteroinm,}

\section{IN THE SOUTH INDIAN OCEAN.}

Former History.-Importance of the situation of St. Paul.-Present inhabitants.-Preliminary observations. - To whom does the Island belong? - Fisheries.-Hot springs.-Singular experiment-Penguins. - Disembarkation. - Inelement weather. Remarks on the climate of the Island-Cultivation of Enropean vegetables.-Animal life-Cubrary in a Fisherman's hut.-Narrative of old Viot.-Reembarkation.-An official doement left behind.-Some results obtained during the stay of the Expedition.-Visit to the Island of Amsterdam.-Whalers.-Search for a Landing-place.-Remarks on the Natural History of the Island.-A Conflagration.-Comparison of the two islands. - A rencontre at sea.-Trade-wind.Christmas at sea.- "A man overboard."-Cingalese canoe.-Arrival at Pont de Galle, in Ceylon.

The visit of the Austrian frigate Novara to the Islands of Amsterdam and St. Paul, so long confounded with one another, 
was one of the cherished objects of interest to the immortal Alexander von Humboldt.

Although St. Paul has been in very recent times visited and surveyed by illustrious English navigators,* and although the doubt hitherto existent as to the precise discoverer, and the correct application of the names of the two islands, has been set at rest by the discovery of the original $\log$ of Antonio Van Diemen, kept on his voyage from the Texel to Batavia (16th December, 1632, to 21 st July, 1633), by which it is made plain, beyond possibility of contradiction, that that renowned navigator passed for certain on 17th July, 1633, between both islands, and conferred on the northern the name of New Amsterdam, and on the southern that of St. Paul; $\nmid$ yet the

* Captain C. P. Blackwood, of H.M.S. Fly, 1842, and Captain Denham, C.B., of H.M. Surveying Ship Herald, 1853. MI. Tinot "capitaine du long cours," who visited St. Paul in the summer of 1844, published likewise some interesting memoranda relating to that island, in the "Nouvelle Annules de la Marine et des Colonies," for November, 1853.

t Previons to the resuscitation, after considerable difficulty, of this important, indeed decisive document, by Mons. L. C. D. Van Dyk, among the archives of the East and West India Company of Amsterdam, of which he was Librarian, the utmost uncertainty prevailed as to the discovery, name, and geographical position of the two islands. Now, William Van Flaming, a Dutch navigator, was supposed to be the discoverer,-now, the harly Van Diemen. Atlases, charts, and books of travels, spoke of the name St. Paul belonging, here to the northern island, there to the southern. This long-continued confusion of names had naturally left ample space for the most contradictory statements as to the position, conformation, and geological conditions of both islands. One traveller, for instance, describes Amsterdam as an island with good anchorage on the North side, and an extinct crater, into which ran a fissure, forming a natural link with the ocean; while, on the other hand, he described St. Paul as a desert island, with stecply sloping shores, which make it matter of difficulty, if not utterly impracticable, to effect a landing; while other voyagers, again, give directly contrary accounts of both islands. Compare the following:- "An authentic account of an Embassy from the King of Great 
two islands still continue to present points of great interest on closer examination and observation. Of the various ships which, since the discovery of those islands, have visited them for scientific purposes, hardly any have remained long enough to be in a position to acquire a thorough acquaintance with the various objects of natural history and scientific interest that present themselves. Even the visit paid by the naturalist attached to the expedition on board the English ship Lion and Hindostan, which, on the 2nd of February, 1793, touched at St. Paul, en route to China, and to whom we are indebted for the first detailed account of this island, erroneously spoken of as Amsterdam (following the example of former English navigators), did not come within the original design of that Ambassadorial expedition. It was the result rather of accident that, as the Lion and Hindostan were passing close in

Britain to the Emperor of China, together with a relation of the voyage undertaken on the occasion by H.M.S. Lion, and the ship Hindostan, E.I.C.N., to the Yellow Sea and Gulf of Pekin, as well as of their return to Europe, taken chiefly from the papers of H.E. the Earl of Macartney, \&c., by Sir George Staunton, Bart. (London, 1797), vol. I., pp. 205-27."- "Rélation du Voyage à la recherche de La Pérouse, fait par l'ordre de l'Assemblée constituante pendant les années 1791-92, et pendant la $1^{\text {re }}$ et la $2^{\text {de }}$ année de la République Française. Par le citoyen La Billardière, Correspondent de l'Académie des Sciences de Paris. Au VIII. de le République Française. Tome I. pp. 120-123."- “Johnston, A.K., General Gazetteer of the IVorld (London, 1855)."-“"Hamburgh, James, India Directory ; or, Directions for Sailing to or from the East Indies, China, Australia, and the adjacent parts of Africa and South America (London, 1855). 7th Edition, vol. I., p. 101."-" Voyage to the South Pole, and Round the World, by Captain Jas. Cook, R.N. (London, 1777)." An interesting and tolerably circumstantial treatise on these islands is also to be found among the transactions of the Imperial-Royal Geographical Society of Vienna for the year 185T, second division, pp. 145-56, by Mr. A. C. Zhishman, Professor of Geography and History, in the I. R. Nautical Academy at Trieste. 
with St. Paul, two human beings were descried on the shore, waving in the air a piece of canvas fastened on poles, who apparently were anxious to convey to the expedition their desire to communicate with their ships. It was supposed these were shipwrecked mariners, stranded on this dangerous coast, who regarded the arrival of the Lion as an unexpected means of rescue. To save these fellow-creatures from so desperate a position, the Captain of the Lion declared to be a pleasing duty assigned by Providence, and rejoiced to have been selected as the instrument of their deliverance. When, however, the boat of the British man-of.war, which was despatched to take off the castaways and bring them on board ship, had landed on the island, the crew speedily discovered the singular delusion which all had laboured under. The men, whom motives of humanity had intended to rescue from this inhospitable place, turned out to be anything but involuntary residents on the island, being seal-hunters, who for five months had dwelt here, and purposed remaining ten months longer, with the intention of completing a cargo of 25,000 seal.-skins, for which at that time there was a very considerable and lucrative demand in the Chinese markets,* and

\footnotetext{
* "It seems," says Lord Macartney, "that the Chinese possess remarkable slill in the dressing of seal-slins, by which they remove the long coarse hair, so as to leave mercly the soft tender skin, and simultaneously manage to render the hide thin and pliant. Only the prospect of some such enormous profit could at any time induce luman beings to pass fifteen months at a stretch on so ungenial a spot, which, moreover, their occupation must render yet more loathsome. They lilled the seals as they basked in the sun on the rocks along the shore, and around the broad natural rock basins. $\Lambda$ s only the skins were of any value to them, they left the flayed
} 
the signals which had first attracted their attention, it now appeared were for no other object than to cnable them to feel themselves once more, after such an interval, in the company of their fellowmen.

Owing to the important situation of St. Paul, midway between the southernmost point of Africa and the Australian continent (from each of which it is about 3150 miles distant),

carcases exposed to rot on the ground, and these lie heaped together here in such masses that it was difficult to avoid treading on them, when one reached the shore of the island. At every step some disgusting spectacle presented itself, while an unutterably nauseous smell of decaying matter poisoned the surrounding atmosphere. In the summer months the seals flock hither, all at the same period, in herds sometimes numbering 800 to 1000 , of which usually only about one hundred are killed at a time. This is the utmost number that five men can skin in the course of a single day, it being necessary to peg them together on the spot, on account of the drying up of the skin. For want of the requisite vessels only an inconsiderable quantity of the train-oil, which these animals contain, is collected. A portion of the best of the blubber is melted, and serves these people in lieu of butter. The seal which frequents these islands is the Southern or Falkland seal (Arctocephalus Falclandieus of GrayPhocu fusillu of Schreber). The female weighs ordinarily from seventy to one hundred and twenty pounds, and is from three to five feet long, the male usually considerably larger. In their natural state these animals are not partieularly timid; sometimes, indeed, they plunge all together into the water when any one approaches them; but quite as often they remain sitting quietly on the rocks, or raise themselves erect with a menacing growl. A sharp blow on the snout with a stick seems sufficient to kill them. Most of those that approach the shore are females, the proportion they bear to the males being about thirty to one. This apparent disproportion between the sexes, according to observation hitherto, is explained as follows:-The Southern seal at certain periods often undertakes distant wanderings from one tract to another ; and certain of these tracts, such as the Cape of Good Hope and the islands of St. Paul and Amsterdam, are only fiequented by the females when about to bring forth, and by the younger males of the school. In winter the huge snouted seal, or Sea Elephant (Macrorhinus, "long snout," elephantinus of Gray-Phoca leonina of Schreber), which sometimes attains a length of twenty-five or even thirty feet, comes in great numbers to these islands, where they herd together like sheep in the natural coves which the coast is broken into, in which the males announce the presence of a herd by a vehement growling, deepcuing into a loud roar." 
a complete, accurate survey of the island seemed of great importance, not merely to the scientific world, but also in the interests of navigation; as most of the ships bound for China, Australia, and New Zealand, as well as the East India liners, pass pretty close to these islands, especially during the winter season. Many captains trading in the Indian ocean see in St. Paul an advantageous haven for recruiting the strength of their scurvy-stricken crews, while the ships of others, shattered almost to the point of foundering in the storms of a tract of ocean where for thousands of miles there is no other land, can find here their only prospect of preservation.

For the voyagers on board the Novara, an interest of an entirely personal sort attached to their visit to the island. Among the unfortunates, who on the 24th August, 1853, suffered shipwreck on the shores of New Amsterdam, in the British ship Meridian, was a native of Brienz, in Switzerland, named Pfau. This person, together with the captain, Richard Hernamann, and a Frenchman had disappeared, leaving no trace, when, on the following morning, the surviving passengers of the wrecked ship were rescued by a whaler that happened to be cruising in the neighbourhood. It was supposed that the three unfortunate men had endeavoured to reach the adjacent island of St. Paul in a small boat, and probably were still living there. The father of the Swiss made application, through an indirect channel, to the chief of the Expedition, earnestly requesting him on his visit to the island to institute some enquiries with the view of finding some trace of his ill-starred 
son, still unwilling to renounce all hope that he might yet be found living at St. Paul.

We hove to about one mile and a half distant from the great crater-basin, in whose eastern buttress a natural communication has been opened with the sea through a breach in its side. When the Dutch captain, William Van Flaming, cast anchor before the island in 1697, the wearing action of the waves had not yet completed this breach, there existing at that period a dam of some five feet high between the sea and the cavity of the crater. At present small boats can, at any hour of the day, pass into the crater-basin, protected from the swell of the ocean by two natural barriers, which leave between them a passage of about 300 feet wide. Our last admeasurement gave a length of 600 feet for the southern barrier, and 1002 feet for that in the north; while the intervening water passage measured 306 feet in breadth, with a depth of 9.6 feet at high water, and from 2 to 3 feet at ebb tide. On the north side of the entrance to the straits stands a lofty pyramidal rock, called Nine-Pin Rock, round which circle innumerable sea-fowl, which to all appearance brood among the chinks and crannies of the rock, while in the water below crowds of sharks lash the water into foam. It must be highly dangerous hereabouts to be capsized in a boat, as there would be little possibility of any one being rescued, no matter how speedily assistance might be rendered.

Scarcely were we anchored, ere we in the ship perceived a boat approaching from the island, which rapidly neared the 
frigate, with three men who had taken up their abode in eren this desolate wilderness. Our imagination deluded us with the pleasing idea that these three forlorn, forsaken figures might be the long lost men wrecked in the Meridian, whom pitying billows might have wafted to this solitary island.

Presently there stepped on deck by the side-ropes a grizzly figure, with deeply-furrowed features and long, grey beard, clothed in a blue blouse and coarse linen trowsers, that seemed to have weathered many a winter's storm. This primitivelooking old man proved to be a Frenchman named Viot, who had lived here for a considerable time as overseer of a fishing establishment on the island. Our first question had reference to the missing men from the Meridian. But how sore was our disappointment when the old sailor in the blouse told us he knew all the particulars of the catastrophe of the ship, but that he had never come across the slightest trace of the three unfortunates whom we had enquired about. Viot had risited the island regularly every year since 1841, except that in which the Meridian had been lost. The fate of these three shipwrecked men must therefore remain for ever undetermined, although, considering the tempestuous weather which usually prevails in the Indian Ocean in the month of August, it is highly improbable that a boat of such small dimensions as that to which the captain and his two unhappy fellow-travellers committed themselves, could reach St. Paul, which was distant 42 miles from the spot at which the ship was wreeked.

About 11.30 A.s. the naturalists, accompanied by the officers 
appointed to assist in the scientific operations, proceeded in two boats to the shore, for the purpose of making some preliminary observations. When we reached the bar there opened to our view, covered with luxurious grass growing in tufts, the walls of a majestic crater, the exquisite regularity of the cavity of which left the exact impression of an enormous natural amphitheatre.

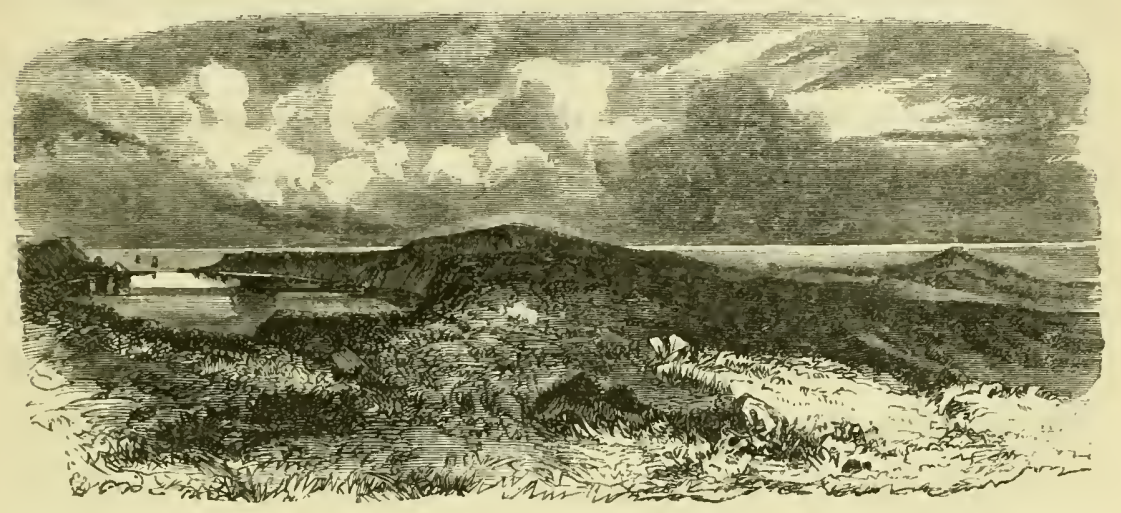

On either side the ground rises nearly perpendicularly to a height of about 800 feet, which probably is likewise the average height of the walls of the crater. On the north side of the basin, a kind of terrace was seen low down, with huts thatched with straw, while on the shingle of the bar was planted a not very perpendicular flagstaff, on which, in honour of the arrival of a ship of war, old Viot had run up the French ensign. As the Novara's boat swept into the crater-basin, he saluted with the proverbial courtesy of his nation, which not even the rough occupation of a whale-fisher had been able to rub out of him. Viot had last come hither in the preceding 
March, with a mulatto and a negro on board of a fishing craft, named the Alliance, of 45 tons, in which he had sailed from St. Denis, on the Island of Bourbon, anew to take charge of the little fishing station here, which is at present the property of M. Ottovan, a French gentleman domiciliated in St. Denis.

While at Cape Town we were informed, in reply to our enquiries, by the first authority in the country, that the Island of St. Paul belonged to England, and was a dependency of the Mauritius; here, to our astonishment, we on the other hand learned from the inhabitants that St. Paul at present was under the protection of the French Government, and, in fact, was an appendage of the Island of Bourbon, the governor of which long previously had ordered the French flag to be hoisted, with all the naval formalities, by a detachment of French soldiers who had been landed from a French ship of war. According to Viot-who is to all appearance a thoroughly trustworthy man, but on whom, however, we throw the responsibility of the correctness of the following information,- the island seems, in fact, to have been, some twenty years since, the property of a French merchant of St. Denis, named Camin, who somewhat later entered into partnership with a person named Adam, a Pole by birth, to whom he ultimately resigned the entire island.* Adam, who was described to us as a man of exceedingly fierce and determined character, did wonders for the cul-

* According to Captain Denham, who visited this island in 1853, the present proprietor called this fishing station, Marie Heurtevent, and sail he had bought it about five Jears previously for 6000 dollars from a Polish merchant of St. Denis, where he himself also resided. (Nautical Magazine, pp. 68, 5 ). 
tivation of the island. He left a number of Mozambique negroes, whom he compelled to work through the entire year, exposed to the severest privations, and employed in hewing stone from the rocks, with which huts were erected, in preparing a landing-quay on the north side of the basin, and in sowing a number of plots of ground along the lower margin of the crater with European vegetables.

About eight or ten years since, Adam (who afterwards, in the course of a voyage from Bourbon to New Zealand, met a disgraceful death, having been thrown overboard for his cruelty by the black crew of a small vessel, whom he had driven to desperation) sold the islands to their present possessor, M. Ottovan, a ship-chandler of St. Denis, who since then has twice each year, during the fine season, despatched a small craft of some 30 to 45 tons, manned by from 15 to 18 fishermen, from St. Denis to St. Paul Island, so as to turn to advantage the unusual abundanee of this fishing-ground. This vessel leaves St. Denis regularly every November on its royage of from 24 to 30 days to St. Paul. The return voyage to St. Denis takes place during the prevalence of the South-East Trades, and occupies a much shorter time, rarely exceeding 14 to 16 days. The fishing sloop, during its stay at the island, anchors inside the basin of the crater, so as to discharge her provisions for the fishermen, and to facilitate the freighting for the homeward voyage with the fish that have been eaught, as also to guard her against sudden changes of weather, which in these latitudes, as we ourselves experienced, is, even during the best 
season, very stormy and dangerous. The fishermen use the excellent whaleboats (or baleinières), so admirably suited to the heavy swell of the Indian Ocean, in which they go out in the morning, returning to the shore at nightfall. The species of fish which is found in greatest numbers, and is caught exclusively by the hook, is usually called by the fishermen, "Indian Cod :" it is by no means, however, of the genus Haddock, and very slightly, if at all, resembles the codfish of northern waters, or common stock-fish, but seems to belong to the class of finger fish (cheilo-dactylus-fasciatus), which is usually classed among the crow fish (sciance). These are salted, dried in the open air, packed in casks, and dispatched in large quantities to the markets of St. Denis. It is calculated that the number thus sent off in the course of each year amounts to about 4,0,000. which are sold in the market of St. Denis by the hundred, for

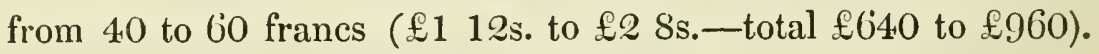
The expenses of maintaining the settlement is very small. - Viot

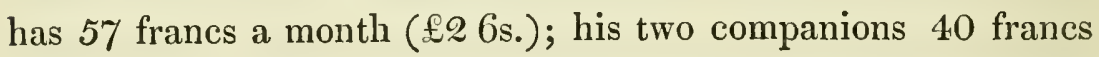
and 2.5 francs respectively ( $\mathfrak{f} 112 \mathrm{~s}$. and $\mathfrak{f} 1$ ); the men engaged in the fishery receive 25 to 30 francs a month, besirles provisions. The second voyage of the vessel ordinarily takes place in January or February, so as to return in April or May, with a similar cargo. It often happens that the owner of the vessel finds some more profitable employment for it, when it only returns during the second year, and their provisions, as meal, rice, biscuit, tobacco, \&c., get rather short. The settlers, however, employ what leisure time remains after their work is 


\section{Available for growing fresh Vegetables.}

done, in cultivating a number of plots of ground with cercals and vegetables, potatoes especially returning from time to time an excellent yield. Of these useful tubers, which grow with remarkable luxuriance in the turf-soil of the island, they raise from 60 to $80 \mathrm{cwt}$. annually. Fresh vegetables being articles in great request are more particularly made available by the inhabitants of St. Paul, by way of barter, when trafficking with the whalers, from 20 to 30 of which touch here in the year, to exchange their salt fish, rice, tobacco, cheese, brandy, \&c., for the fresh provisions grown on the island. The number of vessels that pass within sight of St. Paul in the course of a year may be reckoned at from 100 to 150 , of which, however, only a very few, except the whalers, visit the island.* In the year $185 \%$, for example, it occurred only twice (one case being an English man-of-war), that passing ships sent boats to the island, five months of the year having elapsed in the first instance, and two in the second.

When the take of fish in the immediate vicinity of the island does not seem sufficiently remunerative, the fishermen occasionally launch out to greater distances. They then bring out from the basin of the crater the barque that brought them from Bourbon to St. Paul, and remain at sea for several days,

* All the Dutch Indiamen on the home voyage from Batavia, during the months of October till May, have been for many years in the habit of running south till they sighted St. Paul, so as to catch the S. E. Trades. But it has never been the policy of the Dutch to attract attention to the eastern seas, and accordingly no information found its way to Europe respecting these interesting islands, till the period mentioned in the text. 
or make for the adjoining island of Amsterdam, the shores of which are even more frequented by the fish than those of St. Paul.

As already remarked, our first movements were directed solely towards an examination of its physical features. We were accompanied on this tour of inspection by Ferdinand, an active, intelligent Mulatto, with thoroughly French manners. The French stock has this peculiarity as compared with the German, that it remains unmistakably French, even when mixed with two-thirds African blood. Ferdinand was for the first time in St. Paul, having been conveyed hither in the Alliance in the previous March, to work for M. Ottovan. Family troubles had been the cause of his banishment to this dismal island. Although only 24 years of age, he was already the father of two children, whom, he informed us, he had placed at school in St. Denis; and in sheer despair at the worthless conduct of their mother, had hired himself hither as a labourer at 40 franes a month, paid by the owner of the island. He proposed returning to St. Denis in the next ship that left St. Paul, in the hope that peace might be by that time restored in his family.

At various spots in the lower rim of the crater-basin, within which Ferdinand acted as guide, we perceived heavy volumes of smoke emerging from the shallow parts of the water, which obviously implied the existence of hot springs. The two most active and largest in circumference were on the north side of the crater-basin, and were known, the one as the Bath, the 
other as the Drinking Fountain. Moreover, at several points on the north bar, hot water bubbles up from the soil, of such a temperature that the same person who, with a hook and line had caught a fish in the cold water basin, might, with the same motion of his hand, let them drop into the hot adjoining spring, where, in fact, it is boiled within a few minutes and fit for eating! We have ourselves made this experiment, which is also mentioned by Lord Macartney, and found the fish thus prepared exceedingly palatable.

At high water the whole of the hot springs become mingled with the brine of the ocean, and thus indicate a temperature which is barely perceptibly higher than that of the latter. Adjoining the landing-place, several late visitors to the island have endeavoured to perpetuate the record of their fleeting presence on some compact granite blocks of rock, which are scattered in the path to the hot springs. Thus, on one of those stones, fast becoming obliterated by the weather, may be read :-“"Savouret, 1841 "_-“J. D. Rogers, 1855, Mars.”-On a second huge block:- “Hte. Rogers, 1852 to 1857;" and lastly, these names, with difficulty decipherable, "Pallefournier-Emile, Mazarni-Denoyarez, Grenoble, Canton de Sassenage, Département de l'Isère, 1844." In general we found none of the inscriptions on the island that can be recognized.

On reaching the plateau above, which is reached by a narrow, steep, and in many places rather fatiguing path, from the settlers' huts on the north side of the basin of the crater, we came to a breeding-place of the yellow-tufted "Crested or Hopping. 
Penguin" (apterodytes chrysocome), in which we found at the lowest estimate from 500 to 600 of these singular creatures, which are adorned with grey-yellow tufts of feathers arranged in a semicircle above the eyes, and which, as was well remarked by the naturalist attached to the Lion, with the peculiar plumage and the almost scaly covering of their fin-like wings, suggest a remote resemblance to the form of a fish. Living part of the year in the water, and passing most of the remainder on land, Nature has, in a manner, adapted them for these widely differing modes of life. The dirty greyish-brown attire of the young contrasts so strongly with the gay plumage of the old penguin, that at the first glance they hardly seem to belong to the same species. The females lay only one or two eggs, usually in October, so that at the time of our visit, the young were only about a month-and-a-half or so old. These penguins, so graceful and nimble in the water, as if it were their proper element, are very awkward on land, so as to be easily caught, or knocked down with a stick. Only in so doing it is necessary to be on one's guard against a blow from their long sharp bills, with which they can inflict on their pursuer a by no means trifling wound. In the course of centuries, during which they have paid undisturbed visits to this island, they have trodden a well-marked path from their breeding-place to the edge of the sca; and it is a proof of the wonderful instinct

* Called also tho "Jumping Juck" by the English sailors, from its custom of jumping quite out of the water, like a porpoise, on its encountering the slightest obstacle. 
of this creature, that this place is almost the only point on the entire island, at which it would be possible for it to reach the sea. A flock of these hopping penguins presents an odd and peculiar appearance, as, after leisurely bathing in the sea, and providing a sufficient supply of food for their young, their elegant heads emerge from the water, when carefully calculating the effect of the breakers, they ride their crest and allow themselves to be deposited on the beach; or, after hopping from stone to stone, the plumes on their heads nodding to and fro, suddenly plunge headforemost into the sea, like so many somersault-throwers! Not less diverting are the movements of these animals when, returned from their laborious wanderings, which they undertake two or three times a day in search of food for their young, they bend their tottering steps back to the roostingplace, waddling in their walk like ducks. One always leads the way as guide and forager-in-chief, and the rest, usually from ten to fifteen in number, follow him in a column; on reaching the roosting-place, a piece of level winding ground, they give a shrill cry, and comport themselves anything but peaceably towards their neighbours, especially if these have possessed themselves of their accustomed seats. Continual squabbling and disputing go on, and their croaking and screaming are prolonged far into the silence of night. They show much tenderness for their young, shelter them with

* Called by the English sailors "Port Egmont Hens" from their frequenting Port Egmont in the Falkland Isles. They secm to be identical in species with the "skua," or "bonxie" of the Shetlands. 
great care, and defend them with extraordinary courage and pertinacity against the southern hawk gull* (stercorarius antarcticus), which frequently swoops upon the breeding-ground, and even ventures within reach of man, from whom it defends itself by violently striking and biting with its beak. Always at war under ordinary circumstances, they are nevertheless the most faithful of allies in moments of common danger or necessity. The flesh of the old penguin has so rank a smell that it is only used by those frequenting the island in case of the most extraordinary necessity; that of the young, on the other hand, has a far more agreeable flavour.

The breeding-place of the penguin is about 300 feet above the level of the water in the basin of the crater.* Four hundred feet more of laborious, steep scrambling, brings the adventurer to the plateau at last, from the highest peaks of which he readily obtains a view of the greater part of the island, which is utterly treeless. At many places we found the ground quite warm, and at one slimy tract, about 600 feet wide, which was noticed by the naturalists on board the Lion, there was positive danger of sinking several feet into the hot, yielding soil, if we did not advance with great care. On the other hand, the fierce tongues of flame, which Lord Macartney alleged were

* $\Lambda$ second breeding-place, somewhat larger, but much more inaccessible than that deseribed, occurs on the north-west side of the island. There among rugged funtastically broken masses of rock, these extraordinary creatures can sun themselves undisturbed, and have hardly anything to dread from the destroying hand of man, who conld only get thither with much diffieulty, and not without peril to life, by clambering along the face of a precipitous wall of rock. 
visible at night from the deck of the ship, and which greatly resembled the celebrated nocturnal fires of Pictra Mala, in the mountains between Florence and Bologna, were nowhere visible, at least during the time we were on the island.

On the north-west side of the islands, facing the sea, two lofty pinnacles of scoriæ, with truncated summits, rise in cones of such exquisite regularity of form as speedily attracted the attention of our geologist, and became somewhat later the chief scene of his activity. In the immediate vicinity, many traces of lava-streams are visible, which plainly show the direction in which their currents had flowed. From the upper edge of the great basin of the crater the ground slopes gradually to the sea, ending abruptly in a precipice, descending sheer 150 or 200 feet into the sea.

In order to avoid retracing our steps by the same path, we directed our guide, the ever active Ferdinand, to conduct us back to the shore by some other track than that by which we had clambered up to this point; whereupon he stopped at a point of the upper rim of the crater, where the ground fell suddenly away quite perpendicular, grasped the rich luxuriant grass hand over hand, and having proceeded a few steps, invited us to follow. At the first glance we involuntarily recoiled at the bare idea of descending into the abyss by such a route, but presently we found our advance less dangerous and appalling than had at first appeared, when it was found we might, without any misgiving, let ourselves down by the long tough grass, the strong stalks of which supplied a safe means of descent. 
In less than three-quarters of an hour we had descended from the upper margin of the crater to the settlement, and at once proceeded on our return to the frigate. A pretty fresh N.W. breeze had sprung up in the meantime, which rendered our re-embarkation in our small short boats, totally unsuited to the tremendous swell of the Indian Ocean, exceedingly uncomfortable. Arrived at the ship's side, the sea ran so high, and had so increased the difficulty of laying the boats alongside, that we at first endeavoured to reach the deck by the Jacob's ladders suspended at the poop. When, however, one of the sailors (who confessedly have much greater readiness in clambering than ordinary mortals), while holding on to one of the ladders, was reached by a tremendous wave, and half his body being in the water, ran a risk of being carried off by a shark, the scientific gentlemen in the boars preferred making for the starboard side of the ship, whence they reached their haven of refuge by the man-ropes.

Although this accident sufficiently manifested the impracticability of our original plan of returning every evening on board, and of being able to remain beside the ship during the carrying out of the objects of our visit, no man supposed as yet that, at this season, the summer of St. Paul's, the weather might suddenly become so stormy and generally unfavourable, as thus early to necessitate our re-embarkation, and that the ship would be compelled, with all speed, to leave her anchorage, and put to sea for a weck under most uncomfortable circumstances. 
On 20 th November, about 6 A.M., the officers and naturalists, together with a portion of the crew, 32 in all, left the frigate with a large quantity of instruments, scientific apparatus, and baggage. This little expedition was supplied with provisions and water for six days, there being no springs of fresh water on the island, the frequenters of which are compelled to depend for their whole supply of drinking-water, partly on the rain-fall, partly during long-continued dry seasons on the water of one of the hot brackish springs which occur on the north side of the lower circuit of the crater. Long accustomed to these fluids and to their peculiar taste, the inhabitants feel no evil results from their employment, which very probably would not be the case with those persons who visit the island for the first time, and whose arduous exertions necessitate their drinking daily large quantities of water.

On a small eminence, about 150 feet high, above the fisherman's huts on the north side of the crater-basin, a small wooden cottage was erected for the protection of the astronomers; and at a distance of about 40 feet, a second for the magnetic instruments, both of which, with their contents, were entrusted to Lieutenant Robert Müller. Lieutenants Batlogg and Eugen Kronowetter, were respectively entrusted with the observations by theodolite, and with the surveying board. To the last-mentioned gentleman were also confided the observations with the meteorological instruments, the researches with the tide-guage, the instruments for measuring the velocity of currents, as also the soundings in the basin, and on either 
side of the bar,- - to assist him in the execution of which Cadet Count Borelli and Head Quartermaster Cian were detached. We quartered ourselves as well as we could in the wretched filthy huts which, in summer, serve the fishermen from St. Denis as a shelter. In one of these hung several pictures-one representing Napoleon I. riding the inevitable white horse, the majority consisting of female portraits and scenes of Parisian life, so that the whole place had quite a Frenchified appearance.

Hardly had the instruments, apparatus, men, and baggage been placed under shelter, when once more a strong north wind came on, which, during the night between the 20th and 21st, increased to such a height, that it blew down the two huts intended for the observations, which had not been quite finished, and in which, fortunately, the instruments had not yet been placed-exposing the work already begun to very considerable interruption. :

Early in the morning, a whaler approached the island, and sent one of her boats off for fresh provisions. She proved to be the Herald, of New Bedford, Massachusetts, U.S., out 27 months, and expecting to require to remain out 11 months longer, in order to complete her lading of oil and whalebone. She was last from St. Augustin's Bay (Madagascar), which place she had left two months previously. When the eaptain, who chanced to be in the boat, saw the activity of the scientific corps, the results of which were already beginning to be visible in the hitherto deserted island, he said that one of his crew 


\section{Tempestuous Weather.}

had fallen from the mast a few days previously, and severely injured himself, and forthwith asked whether we could render him any surgical assistance. Considering the precarious circumstances under which wo ourselves were on the island, we judged it more advisable to reccive the unfortunate whaler on board the frigate, where wo could give him all necessary assistance. As we afterwards learned, the surgeon of the frigate, Dr. Ruschitztha, notwithstanding the inclemency of the weather, was ordered from the frigate, and had the satisfaction of rendering valuable assistance to the invalid.

The foul weather continued all day, and during the night of the 21 st, it bccame so tempestuous that the frigate was at last compelled to put to sea. About 3.30 A.r. she began to labour neavily with an unusually high sea and frequent shifts of wind, accompanied by showers of rain, after a heary blow from the N.W., so that at first it was thought on board that one of these furious gusts, which for several hours past had followed each other at regular intervals, had sprung the cable, and that the anchor would be lost. The jib accordingly was hoisted, and the fore-topsail set with four reefs in it, and an attempt made to weigh anchor. This operation, at all timcs laborious, was now especially so, and seemed as though it would never have an end. Although the capstan was manned, as already said, at 3.30, it was not till past seven, or four hours later that the anchor hove in sight. It was the port anchor that had been weighed, and it was now perceived that one of the flukes had given way, and was entirely broken off. In such stormy 
weather it seemed very uncertain whether the anchor could be brought on board, as it struck with much force against the ship-side, in consequence of her severe rolling, and it was only secured at great risk to the life of the men employed. The cable was unbent, and the anchor slipped, so as to relieve the ship (for which the anchor still on board was sufficient in the meantime), from the vehement thumping. The frigate now had to encounter a regular North-wester, and only after three days of the most furious rolling or pitching, was she able, aided by northerly breezes, again to reach her former anchorage. The members of the Expedition, left at St. Paul to prosecute their scientific labour's, occasionally experienced a somewhat peculiar feeling when the frigate, owing to the severity of the weather, remained invisible during these three long days; and fancy involuntarily depicted themselves in the position of men whom the stormy waves of destiny had cast away on this lonely island in the Indian Ocean, there perhaps to languish for weary months out of reach of assistance or means of rescue.

Old Viot, who had come for the sixth time to the island, allegred that such rainy tempestuous weather at this season of the year was quite an unusual phenomenon, - an opinion which somewhat later was confirmed by the reports of several North American whalers. Ordinarily the fine season commences at the begimning of November, at which period the South wind is the most prevalent, the sky often remaining clear and hot for weeks together. The lottest month of the year is Janumy, 
the coldest June. From May to October it is exceedingly difficult to land with boats on the island, and cases not unfrequently occur during the continuance of the stormy season resembling that which is instanced by the historiographer of Lord Macartney's embassy to China, in which, during September, 1792, a ship anchored on the east side of the island, was only able twice, during the lapse of eight weeks, to send a boat to the island with provisions. On this station the fishery is confined to the fine season (from November to April), while for the rest of the year the various liuts of the fishermen are entirely abandoned, being only inhabited by a couple of men, in whose charge are left the few but by no means valueless implements and apparatus of the island. These men lead a very monotonous life, though not one of privation, for the crater-basin supplies the whole year round the most delicious fish, and craw-fish of the finest kind.

Our sailors used to hang a basket with bait close to the edge of the crater-basin, sunk a few feet in the water, which they would draw out every time full of lobsters. In a few hours they frequently caught from eighty to one hundred pounds? weight of these large and extremely delicate species of shellfish. An excursion which was got up one morning to the South side of the island, in a fisherman's boat, was rewarded in a few hours with some fifty different sorts of denizens of the deep, scme of which weighed twenty to twenty-five pounds each.

According to Viot's account, snow does not fall often in 
winter, and in consequence of the heat inherent in the volcanic soil, never lies long on it. On the other hand, hail is a tolerably frequent visitant. Rain is of constant occurrence, and sometimes falls in immense quantities. Viot was never weary of expressing his astonishment at the enormous size of the drops of rain which for many a year he had seen fall at St. Paul. The cold is often pretty severe; while the almost entire want of firing on the island (for the dung of animals is not obtainable in sufficient quantities to make its storing worth the requisite labour), deprives the poor residents of the comfort of a fireside. "If the last storm had not blown down our hut, we should for long have had to do without fuel," was the naïve remark on one occasion of the old Frenchman, as he lay stretched out on a dirty bed, carefully rolled up in his rough woollen blanket. Winter begins in May and ends in September. During this period the Northerly winds are often very strong. On 27th June, 1857, there blew for six or eight hours here so terrific a tempest that the inhabitants of St. Paul did not venture outside of their huts for fear of being rapt away by the wind. These storms of winter occasionally rage to such a degree that they drive before them into the basin of the crater huge masses of water, which they whirl in wild confusion to an enormous height, showing that the tract in the Southern Ocean traversed by the hurricanes which occasionally do such damage about Mauritius and Rodriguez, occasionally embraces the islands of St. Paul and Amsterdam. In November, at the commencement of the fine season, the 
winds are rather variable, and so continue to the end of March, when the N. and N.W. winds begin once more to blow regularly; these bring heavy rains and foul weather, after which, except that it is cold when the wind changes to West with a Southerly tendency, a warmer and drier climate is experienced. During our stay we frequently had an opportunity of verifying by observation the steady return of certain winds in regular succession. For instance, after the N.E. wind had prevailed for some days, it veered to N.N.W. whence it invariably went to $\mathrm{W}$. by $\mathrm{S}$., where it usually stayed some little time, after which it once more went to N.E.-a phenomenon which went through its phases every six days with surprising regularity.

There are heavy mists during autumn, but thunder on the other hand is far from frequent, nor is it particularly violent when it ocrurs. During a residence of eighteen days we never saw the centigrade thermometer stand higher than $66^{\circ} 2^{\prime}$ Fahr., or lower than $53^{\circ} 6^{\prime}$ Fahr. Lord Macartney gave $62^{\circ}$ Fahr. as the average of the thermometer during his visit in February, 1793.

As for earthquakes, a phenomenon whose occurrence at St. Paul would possess an uncommon interest, Viot averred that during sixteen years that he had visited the island, off and on, he neither himself had perceived any indications of one, nor had he at any time heard of any such having been observed.

On the contrary, Ferdinand (who, nevertheless, had lived but eight months on the island) affirmed that his predecessor, 
Rosemond, had told him of shocks, comparatively slight it is true, which he (Rosemond) had felt during his several years' abode here. Considering the small circumference of the island, and the violent surf on its shores, slight oscillations may not improbably be felt, which are caused by other than volcanic agencies. Morcover, on the outer margin of the craterbasin, the island presents at those numerous points, from which at ebb-tide roll volumes of smoke and steam, so many natural vents for the escape of the confined subterraneous gases, that in their ordinary state, and so long as they continue open, in future, there is no especial reason to suppose there will be any upheavings of the earth's crust in consequence of volcanic agencies. The earthquake of 14th August, 1857, which was pretty severely felt in Cape Town and the vicinity, does not seem to have included St. Paul within the circle of its influence. The present inhabitants of St. Paul, at all events, unanimously assert that they cannot recal having perceived, either on the 14,th August, or at any time about that period, any shocks of earthquake whatever, or to have observed any unusual appearances either in the surface of the earth or in the atmosphere.

We purposely say "at any time about that period," because the inhabitants of the island do not avail themselves of that assistance so universal now-a-days of a printed calendar, but trust to memory for keeping a reckoning of the flight of time. That mistakes should frequently occur with such a method of computing time is rendered the more probable 
that not one of the three denizens of the island can write. For instance, we once remarked to our worthy Viot that by his own reckoning he had marked one day more than he had actually lived. "We always get into a mess with these confounded months of thirty-one days!" was the good-humoured reply of the ancient wanderer from Nantes.

Although the volcanic soil of St Paul is everywhere especially adapted for scientific study, it nevertheless presents few objects with which to enrich collections of natural history. An island, on which not a single tree or bush is to be found, and on whose tufa soil, though well adapted for fruit, only a few grasses, ferns, and mosses thrive, must, so far as regards the value of his rescarches, prove as little interesting to the botanist as the zoologist, who, as we shall see more circumstantially further on, came across but few representatives here of the animated kingdom.

At several places, the practical gardener who accompanied the frigate was ordered to plant a number of European vegetables and anti-scorbutic plants, such as cabbage, horseradish, turnips, of various assorted species, celery, garden-cress. and spoonwort,* it is to be hoped with favourable results. At all events, we had the satisfaction during our stay, of seeing the tender shoots of some of the vegetables already sprouting through the surface of the earth. At that time there were

* The vegetables planted were as follows:-Brassicu rapa (rape); Brassice olevacen crpitata (sea kail); Brassica rapa alba (white tumip); Brassica rapa flava (yellow turnip) ; Rrphams sativus (radish); Lepidium sativmm (dittandu) ; Cochlerin offirinalis (scurvy grass). 
not above a dozen or so cultivated spots on the Island; if, however, these are carefully cultivated, they can always furnish enough excellent nourishing provision for from 80 to 100 men. A quantity of potatoes, from 6 to 8 sacks, planted in June, yield, in January or February, a crop of from 60 to 80 casks of 100lbs. each, or between 3 and 4 tons.

Wheat, maize, and barley, also thrive at St. Paul, and their cultivation has only been discontinued, in consequence of their conversion into bread requiring a much larger amount of fuel than is at the command of the residents. On the other hand, all attempts to cultivate beans and peas have utterly failed hitherto. All kinds of nutritive plants give but one crop in the year. So also several kinds of trees, which promised to grow well, considering the resemblance between the climate here and that to which they were indigenous-such as Pinus maritima, various kinds of Protea, \&c., and the successful rearing of which would ultimately prove an extraordinary benefit to all who frequent the island, in consequence of the great scarcity of firewood-were planted as seedlings by the gardener attached to the Expedition, in the vicinity of the two huts used for the observations. Assuredly it will not be one of the least important benefits of the Novara Expedition, which it will have conferred on St. Paul, if the growth of the seedlings, planted in its soil with such a noble purpose in view, should result in the gradual and at all events partial clothing of the island in the forest.

As to the Fauna of St. Paul, there appears to be one kind of 
sea-swallow (storna) not hitherto described, the bill and feet of which are of a coral-red colour, and delicate silver-grey plumage, undoubtedly the most beautiful of the feathered inhabitants, as the penguin is the most extraordinary and peculiar creature on the island. Besides these there is also a pretty grey diver (Prion Vittatus), which builds its nest among the rocks; also a brown gull (Stercorarius antarcticus), as also three kinds of albatrosses (Diomedea exulans, D. fuliginosa, D. chlororhinchos).

The Crater-basin was somewhat less unproductive than the dry land. The depth is from 100 to 175 feet. Close to the edge, the sounding line gave a depth of 10 fathoms (60 feet). Experiments with the dredging-net, although frequently made, gave by no means satisfactory results. On the other hand, the rod and line brought up many an interesting addition to our collection, and frequent strolls at ebb-tide along the barely uncovered masses of rock that skirted the basin of the crater were rewarded with numerous discoveries of specimens of conchology. In the centre of the basin we came upon slimy ground at a depth of 204 feet; near the hot springs (about 100 fect distant), 19 fathoms ( 114 feet); and at a third point, on the south side, 23 fathoms (138 feet). Viot said, that after repeated soundings at different points, he had found the depth of the basin varied from 10 to 35 fathoms ( 60 to 210 fect). The seals (Arctocephalus Falclandicus) of which, according to Macartney, at the end of last century, thousands daily came to the coast of the island to bask in the sun, have almost entircly 
disappeared, so that these animals are very rarely seen or captured by the inhabitants. Even of the skeletons of these marine mammals, which, when the naturalists of the Lion were roaming through the island, used to lie about in such numbers that one could almost walk upon bones all round the crater, not a vestige is left, and one can hardly realize that formerly hundreds of thousands of these animals were slaughtered at this island.

Almost all the quadrupeds of the island are domestic animals that have been brought hither from Europe and the French colonies-such as swine, goats, cats, rabbits-which at present live here in a wild state. The goats, which were first introduced in 1844, are most numerous on the N.W. of the island; the swine, on the contrary, are not so frequently met with. During our residence, a boar and a wild cat were killed; a few days after, the five young of the cat were found, having been compelled to emerge from their lair in search of food. A female hare, which we had brought from Cape Town, was also set free on the island, and it was fortunate for the propagation of these useful animals that there was already a male hare on the island. A pair of geese was also presented to the colonists, which perhaps have continued to breed there.

As we thought the island was uninhabited, it was originally our intention to leave several kinds of domestic animals of different sexes with a view to propagation; and with that object, when at Cape Town had made virious purchases of useful animals; but, under the circunstances, we relinquished this intention, as there seemed but little chance of their being 
left undisturbed sufficiently long to secure the desired object. Occasionally cows would be landed from the whalers for the sake of the fresh fodder, and taken away again after the lapse of a month or two.

The projected scientific operations of the Expedition might easily have been carried out within eight days, had we not been so obstinately persecuted with unfavourable weather. Violent north winds, which rendered it impossible to make any use of the surveying-board in the open air, alternated in an extraordinary manner with rainbows. Our astronomical observations were as yet nothing to speak of. Observations with the barometer, thermometer, current-measurer, and tide-guage, could alone be prosecuted, the last of which especially gave the following interesting result, that the hour of high water, both at full moon and new moon, is not 11 A.Mr., as given by Horsburgh (7th edition, Vol. I. p. 102), but at 1.10 P.I.**

The proper carrying out of the objects of the geognostic enquiries was hampered by unforeseen obstacles and difficulties. One day the rain would be so heavy, that the slight covering of our apartments would be insufficient to protect us any longer from the beating of the rain which fell in bucketsfull, and began to leak through innumerable seams and cracks on to the beds, tables, and floor. Did any one think to shelter himself in the hut of a neighbour?-ere long there commenced a

* According to Lord Macartney, the tide rises at full and new moon, between 8 and 9 feet perpendicular. A northerly wind always causes the highest tide, the current of which is from S.E. by S. to N.W. by N., and has a velocity of about 3 miles an hour. 
regular emigration, which very speedily came to a conclusion, by each and all having the melancholy satisfaction of perceiving that Fortune had set to work with rigorous impartiality, and had resolved to let each one of us feel the weight of her displeasure. And so we passed the long dreary hours in our comfortless huts, that gave free entrance to wind and rain, with

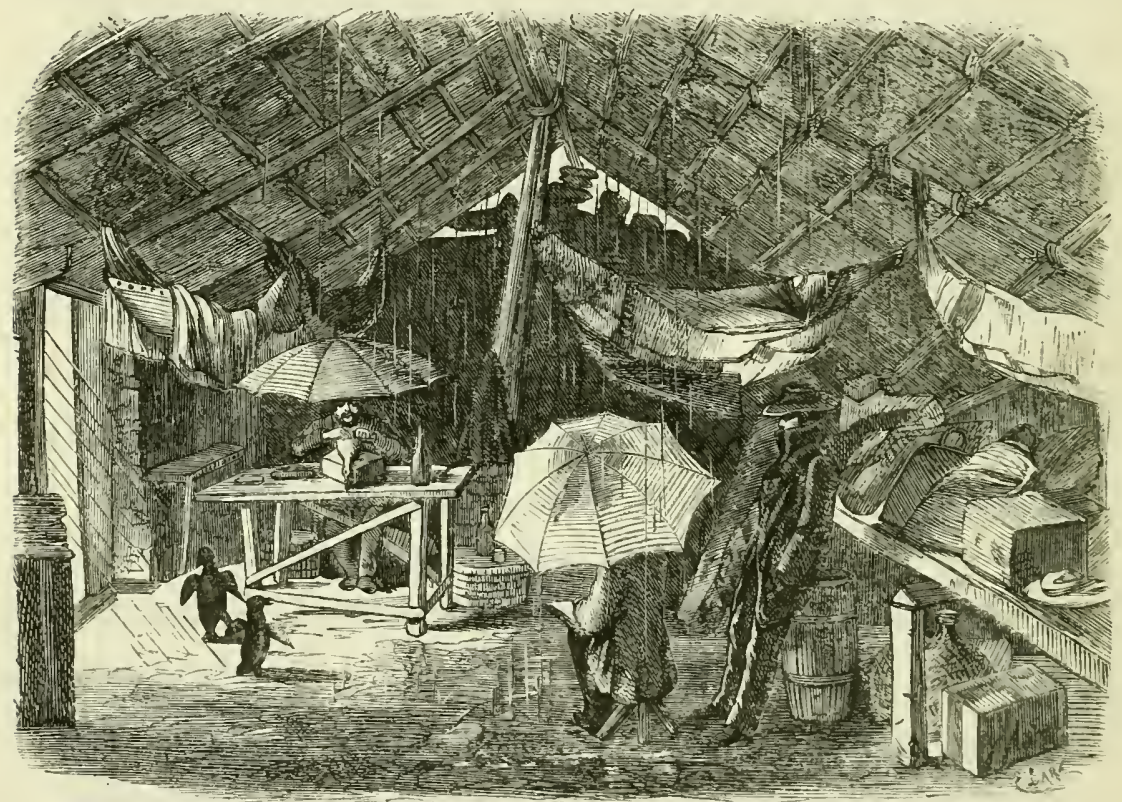

umbrellas outspread or wrapped in our India-rubber cloaks, gazing moodily at the numerous cases full of valuable instruments, which, instead of being serviceable to science, were, by the loss of so many splendid opportunities, doomed to inactivity.

Fortunately, all showed themselves animated by the utmost zeal for the undertaking and its successful issue; and, in a word, 


\section{Traces of former Civilization.}

each fiesh avalanche of difficulties, which sought to thwart our exertions and impair our forces, served only to reawaken the energies and reanimate the confidence of each and all amid all our calamities.

So soon as the hovel we inhabited, which had enabled us to make observations upon the direction and strength of the wind rather than secured us any accommodation for sleep, had been in some degree restored to its original condition, we availed ourselves of the slight improvement in the weather, to examine a tolerably numorous collection of very beautifully bound books, which were found stowed away in one of the recesses for books running into the four partitions, and had in all probability much to dread from the rain-water trickling through the covering of the roof. These had been brought hither by a former proprietor of the island, and when it was sold were transferred with the rest of the stock of tools, \&c., to M. Ottovan, who occasionally resided at St. Paul for a month or two, but seemed, so far as the condition of the books went, rarely to meddle with them. It was curious enough, however, to encounter in a lone desert island, so many evidences of the most refined eivilization, so we shall cite in a note some of the most interesting of this library of about 150 different works, which deserved a better fate than to moulder away undisturbed till they fell into dust.*

* Among these were the worlis on Natural History, by Charles Bonnel (Neufchâtel, $1783)$; J. S. Laharpe's "Abrégé de l'Histoire Générale des Voyages, Paris, 1816;" Dacicr's "Translation of Horace into French, with Notes and Critical Remarks. I'aris, 1816;" "De la Félicité Publique; ou, Considérations sur le sort des Hommes 
Less fortunate were we in our researches for any document which could in any way throw any light, direct or indirect, upon the former history of St. Paul. 'The only piece of writing which we found that had reference to the island, was a licence drawn up during the reign of Louis Philippe, dated 20th February, 1846, to M. Adam, of St. Denis (in the Island of Bourbon), to proceed to carry out a certain undertaking in the schooner "La Mouche," 30 tons' burthen, under the protection of the French flag. " "La Mouche," is the same boat in which Viot had made so many voyages to and fro between St. Denis and St. Paul. This document, which the poor old Frenchman drew out one evening from a drawer thickly strewn with dust, insensibly led the conversation to the quondam owners of St. Paul, and thence naturally to an enquiry, on our part, as to the number of graves which dotted this romantic offshoot of Père la Chaise. "The climate is far too healthy, and the island far too little frequented, to admit of there being many graves in St. Paul," replied Viot. Of the blacks, whom dans les Différentes époques de l'Histoire: $\Lambda$. Bouillon : from the Printing Establishment of the Typographical Soeiety, Paris, 1776;" "Essay on the Life of the Great Condé, by Lonis Joseph, Prince de Condé, at present in England, London, Ist May, 1807 ;" "Préeis des Journées 15, 16, 17, and 18 Juin, 1815, on Fin de la Vie Politique de Napoleon Buonaparte, par M. Giraud, auteur de la "Campagne de Paris en 1814;" Paris, 1815, Ist vol. 8; "Histoire des Guerres des Gaulois et des Français en Italie, avee le tableau des évènemens civils et mílitaires qui les accompagnèrent et leur influenee sur la eivilisation et les progrès de l'esprit humain." "Depuis Bellerise jusqu'à la mort de Louis XII., par lex Adjutant-Général Auguste Jubé, tribun." "Depuis Louis XII., jusqu’àu Traité d'Amiens, par Joseph Servan, Général de Division. Dediées à S. MI. l'Empereur. Paris, an. XIII. (1805)." "Mranuel des habitans de St. Dominique, contenant un préeis de l'histoire de cette isle depuis sa découverte, ete. par S. J. Ducoeurjoly, ancien habitant de St. Dominique; Paris, 18e0, au. $\mathrm{X}, 2$ vols. 
M. Adam had once worked so unmercifully on the island, very many perished here owing to the severity of their treatment, but no one knows where their bodies lie;-very possibly their bones lie scattered about the island, like the remains of the much persecuted petrel (prion turton), which the predatory gull throws carelessly from him after he has stripped off the flesh, and gorged himself on the most delicate morsels. Only two graves are known to the present residents, - - one is the resting-place of an Englishwoman, who died on board a merchant-ship which happened to be near the island, and whose grave was dug in the earth on the north side of the craterbasin; the second covers the body of a ship captain, who was accidentally drowned in the basin by the upsetting of a small boat, as he was approaching the bar in heavy weather. His grave is at a short distance behind the huts of the colonists, and bears traces to this day of the solemn feelings with which it was erected; an enclosure of large stones neatly arranged, make the site and its object at once recognisable.

Shipwrecks are unheard of at St. Paul; at least, none such have been known to occur since it has been occupied by man. On the other hand, they are of more frequent occurrence at the sister island, as has very lately been evidenced by the catastrophe of the Meridian. However, the elements are not always to blame for such lamentable occurrences. Ships are sometimes dashed to pieces on the shores of Amsterdam in the finest weather, so that one is almost induced to believe that these misfortunes are occasionally resorted to intentionally, so 
as to realize some high insurance on a vessel which has probably already become half unseaworthy-a not very conscientious method of cloing business, of which, however, some of tho natives of Greece and the borders thereof are not unfrequently guilty. In February, 1855, a Norih American whaler struck upon the north-east side of Amsterdam in a calm, and with a clear sky overhead, so that the entire crew, 30 in number, were able to secure the provisions and their kits. The captain, with one of the ship's small boats, made for the Island of St. Paul, 42 miles distant, in the hope, probably, of getting assistance thence. A lucky destiny so willed it, that (the accident having occurred in the finest season of the year), a vessel of M. Ottovan's, which by a strange coincidence was named L'Ange Gardien (the Guardian Afgel), lay at anchor inside the crater-basin, loading with fish. The shipwrecked crew were indebted to his circumstance that, within 14 days more, they found themselves at Mauritius. A report circulated among the residents of St. Paul that the captain of the stranded ship had landed with some of his companions in a boat on the N.E. of Amsterdam, with the intention of searching for a sum of several thousand dollars which a previous visitant to this island was said to have buried there for some mysterious reasons. While the captain was on shore, vainly searching for a considerable time after the buried treasure, the shipmaster left in charge in his absence came too near the island, whereupon the ressel had been lost upon one of the numerous reefs which lie off the shore. A part, it 


\section{The Frigate regains the Island.}

was added, of the buried money had, in fact, been recovered. According to Viot, the captain had dug up 1000 dollars

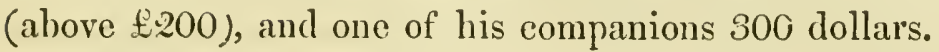

At last, on the morning of Srd December-the fifteenth of our stay at the island-the sky shone so brightly that one could, with more probability than hitherto, cherish the hope that the various operations we had been compelled to lay aside might finally be brought uninterrupted to a successful conclusion. However, the very wet day was again exceedingly unfavourable for open-air observations, especially astronomical, inasmuch as a pretty strong North-east wind incessantly drove over the island clouds of rain, the very heaviest of which, attracted by the mass of the island, broke right over our heads. Fortunately this spell of bad weather did not last as long as the first; and when, on 6th December, the Novara once more made her appearance at the island, and enquired by signals as to the progress made in our appointed work, we were so fortunate as to be able to reply by the same means, that the most important portion had been completed, and that the officers and naturalists were ready to re-embark.

About 9 A.x., the frigate anchored in 2.5 fathoms, close to the spot where the English ship Fly, Captain Blackwood, lay in 1842. It was the third time that the Novara anchored off St. Paul. Twice before had she experienced unusually tempestuous weather, which compelled her to sheer off from such a perilous coast, and expose herself to be lashed for days sogether by the raging giant waves of the infuriated element. 
One of the boats sent by the frigate to take us off to the ship, brought at the same time some presents, in memory of the Expedition, for the residents of the island, who had been so hospitable and obliging during our stay. The presents consisted of ship biscuit, salted meat, and various other edibles, wine, a musket, woollen blankets, clothes, shoes, tools, medicines, vinegar, oil, \&c. The simple, modest fellows were immensely pleased with these unexpected presents, and Viot especially seemed overjoyed on seeing a number of tools, for want of which many of the repairs necessary in the interior of their anything but air-tight wooden habitations, were daily bccoming more apparent.

We left a book on the Island of St. Paul, in which the principal memoranda of what we had achieved were set forth in three languages (German, English, and French), with the view of supplying to future scientific visitors, data for further researches and observations, and at same time incite them to prosecute these we had ourselves made.

We insert here this document, which will yet give witness, probably, of the scientific activity of the Austrian Expedition at the Island of St. Paul in the Indian Ocean, at a period when those engaged in it will long since have voyaged to

"That undiscovered country from whose bourno No traveller returns."

"The Imperial Austrian Frigate, Novarn, 44, under the command of Commodore the Chevalier von Wüllerstorf-Urbair, engaged in a voyage round the globe for scientific purposes, 
anchored at nine in the morning of 19 th November, $185 \%$, on the Eastern side of St. Paul, with the purpose of prosecuting astronomical, magnetic, meteorological, and geodesical observations and measurements, and at same time examine thoroughly the natural history of the island. Extremely unfavourable weather in great measure delayed the expedition; and, after having successfully carried out a series of observations and researches, the results of which will in due time be published, the officers and naturalists in charge of the various departments, on the 6th December of the same year, quitted St. Paul, each bearing with him the most pleasing reminiscences of that interesting island, and of its three poor, but eminently kind inhabitants.

"For the guidance of future observers the following memoranda may prove useful :-

"I. That the spot at which observations were taken was on a small eminence, north of the huts of the colonists, and which may be recognized by a small pyramid of stones, on which the Austrian Expedition marked the observed latitude $38^{\circ} 42^{\prime} 55^{\prime \prime}$ S., and the longitude $77^{\circ} 31^{\prime} 18^{\prime \prime}$ E. of Greenwich.* Further that :-

* The time, which we took from the Cape Observatory by four excellent chronometers, gave, on our voyage between the Cape and St. Paul, a period of forty-six days, a difference of $3 \mathrm{~h}$. $56 \mathrm{~min}$. 11 sec., which the island was E. of the Cape, so that adding the Longitude of the latter East of Greenwich (by nantical almanack), $1 \mathrm{ll}$. 13 min. 55 s., we have the Longitude of St. Paul 5h. 10 min. 6 s. East of Greenwich $\left(7^{\circ} 31^{\prime} 30^{\prime \prime} \mathrm{E}\right.$.) Between Madras and St. Paul, during a long passage of sixtyseven days, and with six chronometers somewhat less accurately set than the preceding, St. Paul was found by observation to be $0 \mathrm{~h}$. $10 \mathrm{~min}$. $51.8 \mathrm{sec}$. West of Madras $\left(2^{\circ} 42^{\prime} 55^{\prime \prime} \mathrm{W}\right.$.) By the longitude of the Observatory of Madras, $5 \mathrm{~h}$. $20 \mathrm{~min} .57$ sec. East of Greenwich $\left(80^{\circ} 14^{\prime} 15^{\prime \prime} \mathrm{E}\right.$.), as furnished by the Director of 
"II. That the direction of the true meridian line drawn from this point to the nearest opposite shore of the South side of the crater-basin was marked by an oblique (St. Andrew's) cross.

"III. That the tidal-gauge was situated on a rock near the landing-place, and that the rise of the tide above the mean level of the water ( 3 feet 5 inches), was marked on a slab of rock smoothed for the purpose.

"IV. Lastly. The magnetic observations were taken in a hut erected for that express purpose on the little plateau behind the settlers' huts, where at the same time various sorts of useful trees were planted by the Expedition.

"The names of the officers and naturalists who, under the superintendence of the commander of the Imperial Expedition, took part in the various scientific operations were:-for Astronomy and Terrestrial Magnetism, Liuteenant Robert Müllar; Botany, Dr. Edward Schwarz and M. Jellinck; Geodesy and Meteorology, Lieutenant Eugen Kronowetter; for the Trigonometrical Measurement of the Crater-basin, Lieutenant Gustavus Battlogg; for Geology, Dr. Ferdinand Hochstetter; Ethnology and Physical Geography, Dr. Karl

the Observatory, Major Jacobs (whereas the nantical almanack gave $5 \mathrm{~h} .21 \mathrm{~m}$. $\left.3.77 \mathrm{sec} .=80^{\circ} 16^{\prime} 0 \frac{1}{2}^{\prime \prime}\right)$. The longitude of St. Paul wonld be 5 h. $10 \mathrm{~m} .5 .2 \mathrm{~s}$. East of Greenwich ( $77^{\circ} 31^{\prime} 23^{\prime \prime} \mathrm{E}$.) The average of the two measurements gives as the arerage $5 \mathrm{~h} .10 \mathrm{~m} .5 \cdot\left(\mathrm{s}\right.$ sce., or $77^{\circ} 31^{\prime} 26^{\prime \prime} \mathrm{E}$. to be assumed as the final longitude of St. Panl, while the latitude was taken fiom the rarions means of the height of the sun at the meridian on an average of days. An additional computation in which allowances were male for the rarious corrections, gave, as the latitude, $38^{\circ} 12^{\prime} 47^{\prime \prime} \mathrm{S}$. 


\section{Retrospect of our Visit.}

Scherzer ; Zoology, G. Frauenfeld and J. Zelebor ; Draughtsman and Artist, Joseph Sellemy."

Towards 5 p.m. the last boat came off with the measuring and levelling instruments, and various articles of baggage.* The embarkation was finally completed. Half-an-hour later the Novara weighed anchor, and we steered, favoured with most splendid weather and full of pleasing anticipations, for the adjacent island of New Amsterdam. Not without sundry twitches of sadness did we remark the sharp crater of St. Paul gradually fade away like a vision in the gloom of approaching night; and many undying memories must attach to our residence on that lonely, world-forsaken island.

And now, at the moment of our departure from the island, be it permitted us to cast a retrospective glance at the various results obtained by the Expedition of the Novara during her stay at St. Paul.

Never hitherto on this island, so important by its geographical position for ships trading with China, the East Indies, Australia, and New Zealand, have astronomical and magnetic observations and geodesical measurements been so thoroughly ascertained as by the Novara expedition. Upon a carcfully measured base-line, various points of the upper and lower

* Remembering how many bottles and glass tubes were shattered, we have not thouglit it beyond our province to recommend future scientific travellers to bring witl them a good supply of duplicates of all instruments liable to breakage, as it is very difficult to get such insignificant articles replaced out of Europe, and we frequently found on this occasion the want of some such little instrument interposed an obstacle to the further usefulness of the instruments. 
margin of the crater were accurately laid down by means of the Theodolite, and the whole island submitted to a geometric network of angles. At the same time the geologist, with the aid of the compass and the patent levels, prepared a chart originally intended for geological purposes only, while the draughtsman of the expedition added to its value, by skilfully sketching in from these given points the configuration of the coast-line of the island. By their united efforts there has been published a chart of St. Paul, which gives even to the minutest details an entirely correct and accurate representation of the form and surface of the island. This minute chart, or plan, was prepared on a scale of 132 Vienna fathoms to one Vienna inch, or $\frac{1}{9504}$ of the natural size. Moreover, it is intended preparing, from this map and from the various outlines and views taken on the spot, a plastic model of the island after Nature, which, moulded in gypsum, will give scientific inquirers the most accurate conception of its singular structure. Not less interesting for navigators in the Indian Ocean will be the publication of the various observations which, during our stay of 18 days, were made with the barometer, thermometer, tide-gauge, and gauge of the velocity of currents, taken at certain fixed hours; day and night, as also the soundings in the crater-basin, and on both sides of the bar. Although the complete publication of these data must await the appearance of the nautical portion of the present work, we shall give here the most important of these results. The extreme length of the island from N.W. 
to S.E., is three nautical miles; the superficial area is 1,600,000 Vienna square klafter-1 Vienna klafter $=1$ fathom $=6$ English feet-100 English square feet $=92 \frac{986}{1000}$ Vienna square feet. The highest point of the crater-basin is 846 fect; the greatest diameter of the upper rim of the crater is 5490 feet; the least 4590 feet; the greatest diameter of the basin at the level of the sea is 3984 feet, and the least 3444 Vienna feet.

The observations on the state of the weather, taken with much difficulty, are not intended to include the regular observations on the exterior of the island, and in like manner some of those taken in the harbour, or basin of the crater, must be accepted with a certain linitation. For similar reasons, we were unable to fix the rate of the current setting from the sea into the basin, although we secured most extraordinary results considering the circumstances. The amount of specimens of natural history which was procured, was very limited, but on that account was the more valuable. To the geologist, it must be of the very highest interest to find that St. Paul has been classified, with scientific precision, and by dint of personal examination and research, in one of the four main divisions in which, according to the scheme of Alexander Von Humboldt, the volcanic formations of the earth may be divided. Measured by the latest distribution of the volcanic strata by the description of stone found, as laid down by the greatest of German naturalists, St. Paul belongs to the same class as Chimborazo, Popocatepetl, Teneriffe, \&c., 
in a word, to what is known as the Chimborazo formation. A section of the east-side, taken in profile, lays bare its entire geological history, and forms one of the most instructive means of coming to direct conclusions as to its geological structure.

The birth of this island from the bosom of the deep, combined with eruptions of lava and scoriæ, was the last effort of the subterranean forces. Since that period it has been subject wholly and solely to the various terrestrial influences, although the lapse of centuries has not been able to extirpate the last traces of the volcanic fire which once poured forth its currents of molten lava. A large proportion of the level ground is hot, and at the lower edge of the rim of the crater appear several hot springs, the temperature of which, as already remarked, is so high that fish, eggs, potatoes, \&c., can be cooked on them in a few minutes. The highest point of St. Paul rises $8 \% 0$ feet above the basin of the crater. Its walls rise abruptly at an angle of about $85^{\circ}$, while the upper surface of the island (with the single exception of a small plateau of about 400 feet on the north side) stretches, at first level from the periphery of the upper margin of the crater, gradually falling away towards the sea-coast, at an angle of about $13^{\circ}$. On its North-west coast, where it is from 100 to 200 feet in perpendicular height, the island presents several small pyramids of pumice, like parasitic warts on the principal mass.

Like the geologist, the botanist also found in this wild spot an unusual opportunity of acquiring accurate information as to 
the occurrence and propagation of certain kinds of plants in a primitive soil. Six grasses and one reed (cyperacea) form the vegetation of the island, one rush and thrce or four of the grasses forming the majority. The botanist having ascended to the plateau found there two grasses, both of which grew to a certain height only, and at certain places; the one (in the immediate vicinity of the settler's huts, ) the oat, or avena; the second a digitaria, in the neighbourhood of the terraced fields, directly opposite the entrance to the crater, in warm positions, which, so soon as the earth is a little disturbed, emit jets of steam. It is still uncertain whether the other kinds of grass, Poa and Setaria Holcus, belong exclusively to St. Paul, or are to be included in the more general group of geographical plants known as that of the islands of Edward's Island, Kerguelen's Island, and St. Paul.

Among the grasses there spring up here and there, but on the whole very sparsely, some wild regetables which have been planted by previous chance visitors.* In the crater there are also Sonchus arvensis and one Plantago (Plantain). On the south margin of the crater are Cerastium (maize-ear chickweed), and Stellaria media (chickweed); both grow on a small piece of ground, and are far from thriving. Of Cryptogamia the botanist found four sorts. Two Parmelias,

* Such as Rumex acctosella, Cymara Scolcymus (artichoke); Solunum tuberosum (species of nightshade); Dutucus carottu (carrot); Petroselinum sutivum (parsley); Brassica oleracea (sea-kail); Raphanus satirus (horse-radish). 
one Evernia, and one Cladonia, the first-named overrunning the blocks on the edge of the crater with great luxuriance.

Of Alga there were found 33 species. The stones rolled backwards and forwards by the action of the waves, as also those surfaces which remained covered at lowest tide, were entirely covered with Dicurella flabellata. Most numerous was Gigartina radula, just in a state of fructification. Every movement of the water calls up slender, delicate conferve, and pale and coloured luminarice. The breakers have crowned the stones with festoons of the Macrocystis pyrifera. Of Liverworts there were found Marchantia and -Jungermania; of foliaceous mosses, Sphagnum (bog-moss), and two kinds of Bruym. Two ferns, just beginning to bear fruit, were found on the plateau, and one Lycopodium (clubmoss), which thrives pretty well, and frequently grows on the Sphagnum. On the whole, the botanist of the expedition found on the island, 11 Phanerogamia, 4 Lichens, 33 Algre, 2 ferns, 2 Liverworts, 3 foliaceous mosses, 1 Lycopodium. In this enumeration are included the European vegetables cultivated by the residents, as also some untended plants, which apparently have been introduced with the vegetables, or have been brought hither by previous visitors. The stony substratum of this island is barely covered with a plastic vegetable substance, which fills the cracks. The walls of the crater, as also the entire plateau, present to view a plain, unrelieved expanse of grass; not, however, like ficlds clothed with sward, but single tufts pressing one upon the 
other, which seem like the grave-mounds of a hundred bygone generations of plants. Frequently, at the foot of a block of pumice, all overrun with grasses of all sorts, one comes upon a moss or a stem of fern on one of the pieces of lava that has been washed up, or perceives with amazement in some outof-the-way place, and utterly neglected, good old acquaintances from Europe, such as carrots, parsley, potatoes, \&c., which apparently have been begun to be cultivated on some of the terraces, whence they have propagated themselves in a wild state all over the island. But not a tree, or bush, is to be met with throughout the island.

In like manner, although the zoologist seemed to have but a poor prospect at St. Paul, it presented materials for most satisfactory speculation to the attentive naturalist. Only one of the grasses is infested by an insect, which appears in great numbers, a very tiny cicada (cricket), the Delphis hemiptera, of which, according to the zoologist of the expedition, it is hard to say whether it became indigenous to St. Paul before, or contemporaneous with the arrival of man. Among other insects that have certainly been introduced here, the zoologist found the common bluebottle-fly, a gnat, the universally found cockroach, the book-tick (acarus eruditus), one kind of earwig, and the flea; besides the Isopodis, our common barrel-worm, ${ }^{*}$ in almost fabulous quantities. These animals invariably follow man wherever he plants his foot, living upon garbage or

* These loatlisome animals cover the island in sucl quantities that one of the naturalists reckoned them at $6,000,000,000$, counting 100 as the minimum to each square foot of the island. 
decaying organic matter. With the exception of the clothesmoth, which has probably been introduced among the wool. stuffs, there are in the island no butterflies, none of the been tribe, no Neuroptera. Mites also need scarcely be reckoned, since the only representative, the common cheese-mite, is more apt to become extinct than to thrive; on the other hand, there are two kinds of spiders, for which the enormous number of flies furnish sufficient food.

The species belonging to the sea are somewhat more plentifully represented, although, with few exceptions, very small and insignificant. The largest shell fish, a Tritonium, only attains a length of 3 inches; Patella, which is very plentiful all round the island, is only 1 inch long; several sorts of snails (such as Buccinum, Defrancia, Mangelia, Paludinella, Adenrbis, Janthina, Fissurella, Scutellina, Lepidopleurus, Bulla, Asteronotus, Doto), are barely a few lines in length, or even less.

The Brachiopoda are represented by a very inferior member, the Terebratulina, only two lines long, which, however, is a giant compared with one of the two only kinds of mussel, Kellia and Lima, which are occasionally met with here, and are only half-a-line in length.

Among the Vertebrate, the fishery of which is the principal object of the visits annually paid to the island, one, the Cheilodactylus, a spinous-finned fish, which is extraordinarily abundant all round the island, supports an important fishery, while Thyrsites Atun were frequently caught with rod and line from the frigate. 
Of Amphilice, there is not a vestige to be found on the island; the birds belong for the most part to the powerful-winged web-footed birds that frequent the open ocean, as, for example, the Diomedea exulans (great albatross or man-of-war bird), $D$. chlororhynchus (yellow-billed albatross), D. fuliginosa (a new one not determined), Lestris catarractes, Storna $s p$ : Prion Vittatus, of which the four last-named, at the time of our visit, had both eggs and young. Of birds with fin-shaped wings, there was the golden-crested penguin (Apterodytes chrysocoma S.), living in two distinct colonies among the precipitous overhanging cliffs, with innumerable young, already of a pretty good size** We also remarked several other winged denizens of the deep, which had alighted on our ship during the last few days immediately preceding our arrival at St. Paul. According to the fishery-people, the other birds of the island quit it altogether so soon as their young have grown sufficiently, and only return when the next breeding season comes round.

In contradistinction to the sea-birds, M. Frauenfeld remarked but one single land-bird, a swallow, whose movements seemed to indicate that he was watching a breeding female. A stray bird on this lonely spot of earth, nearly 3000 miles

* One of the zoologists, Mr. Zelebor, endeavoured to kill two penguins that had been caught alive in the island, the one with arsenic, the other with chloroform. Of the latter, a quantity was alministered enongh to have killed a man, but which scarcely affected the penguin, who, in a quarter of an hour after, seemed quite restored to himself. The second, which had swallowed two tea-spoonsful of arsenic, died eight hours later. 
away from the main land! Hundreds of questions suggested themselves on thus unexpectedly coming upon so well-known a wanderer. What could have condemned him to this selfimposed exile? Was he a straggler? Was it the first time he had selected this island for a home? Had it been his own cradle? And would he at some future period find companions to visit with him, and ultimately share these solitary desolate abodes?

There were no seals visible, - they have retreated before the attacks and stratagems of their insatiate pursuer the sealhunter, and for a long period have ceased to frequent the island. Indeed, St. Paul furnishes not a single specimen of mammal peculiar to itself; for all the members of this great natural division at present on it,-such as goats, swine, cats, \&c.,-having become wild, must necessarily be classed, however unusual, with rats, mice, and the like. In other respects, all these have not varied in the slightest from the type of the domesticated animal (although they liave probably lived wild for a hundred years past), except that they are very shy and avoid the presence of man.

While upon these various points, the stay of the Imperial Expedition at St. Paul gave many splendid results by means of observations and scientific collections, it was also productive of a number of important practical benefits for seafaring people. The geodesical results, for instance, obtained by the Expedition, demonstrate that there is formed by the basin of the crater at St. Paul's, despite the small extent of its coast-line, a secure natural 
haven which would afford substantial facilities for ships, to which, on their voyage to China, Australia, or anywhere in the East Indies, any accident has happened, necessitating complete and speedy repair, or which might require fresh provisions for their crews, stricken with scurvy after a long voyage. For, although the depth of the basin of the crater in the centre is very considerable, and although the squalls of wind from the N.IV. are often very violent, the ship can always make fast to the land, and so ensure the requisite security. How far the assistance so cheerfully rendered by science may have been called for, or how far the route at present traversed by sailing vessels makes that assistance desirable, must be left to the judgment of those nations, such as the English, French, and Dutch, which, as having possessions washed by the Indian Ocean, have a direct interest in the future condition of such a harbour of refuge, situate equidistant from Asia, Africa, and Australia.

The morning after our departure from St. Paul, that is to say, on 7th Dec., we found ourselves not more than ten miles distant from Amsterdam. The first view of the island greatly resembles that of St. Paul, and the hypothesis gained constantly in probability that the geological formation of Amsterdam is nearly identical with that of St. Paul.

A whaler was cruising in the neighbourhood of the island, while one of his slim whaleboats was pursuing a school of sperm whales, which sported about in great numbers.

Towards 7 A.s., a boat approached from the whaler 
Esmeralda, Captain Pierce, of New Bedford, Massachussets, to ask for surgical assistance for a sailor who, while engaged a few days previously in hauling a captured fish alongside, had had his left hand so severely injured by one of the lines, that amputation had seemed the sole remedy. The Captain had, in genuine Yankee fashion, assumed the duties of surgeon, and performed the operation himself. Now that it was over, and when neither praise nor censure could benefit the patient, he was anxious to know whether he had done right or wrong. While one of the ship's surgeons was getting ready, as requested by the captain, to proceed to the bedside of his patient, the whaler informed us he had already been absent from his family in the States five months, and would proceed hence to the Sandwich Islands and the Northern grounds, and finally return home round Cape Horn. If the take of fish proved good, he hoped to complete the voyage within two years. Whale-fishing, in truth, is not only a very dangerous and laborious, but also a most precarious pursuit. Occasionally a ship gets loaded within a brief space with oil and whalebone, by which, of coursc, the owner or charterer makes a splendid profit, and the entire crew obtain a handsome share. But frequently does it happen that, after a voyage of fifteen months and more, there is not a single fish taken, in which case the hardy sailors, who are entirely dependent for their pay upon a share of the spoil, have had all their lahour and undergone all their privations in vain, while the freighter is poorer by a good round sum. The bare chance, 
however, of a rich haul is sufficient to raise to 8000 , the number (probably on the increase) of the ships of varying tonnage and nationality, which at present encounter the anxieties, dangers, and hardships attaching to the whale-fishery. It is calculated that, were it possible to anchor them within signalling distance of each other, they would form a complete girdle round the earth at the Equator. In other respects, the incessant activity of the whaler is not without its advantages for science, since the observations and communications of many of the captains connected with the whaling business have essentially contributed to extend our acquaintance with atmospheric phenomena, especially in high latitudes, on both sides of the Equator.

The loquacious captain, an uncommon quality in a Yankee, could not conceal his astonishment at encountering an Austrian man-of-war in such a latitude in mid-ocean, and adverted to this unexpected phenomenon. Captain Pierce further complained bitterly of the weather, and said that, as long as he had sailed the Indian Ocean, he had never at this scason experienced such tempestuous weather as during the last week; which was further confirmed by several other whalers, regular visitors to these waters. Respecting Amsterdam, Captain Pierce, unfortumately, could give us but very little information. He had never set foot on the island, nor did he know whether it was accessible at all. But he spoke highly of the availability of the coasts for valuable fish. Nowhere in the Indian Ocean, the Captain remarked, was there such an abundance of 
fish of all descriptions as at the Southernmost point of this little-known island. Consequently most whalers, on their course Southwards, approach this island, and send out boats to bring in supplies of fish suitable for the table. Usually the boat is filled in a few hours with delicious food canght with the rod and line, when the fish are forthwith salted, in sufficient quantities to supply the crew for several weeks.

Is Amsterdam really a sister-island of St. Paul? Is it, too, of volcanic origin, upheaved by the same subterranean energy, and does it still show similar traces of long-continued activity? These questions pressed on us for solution all the more vividly as we neared this inaccessible island, when we recalled to mind the mysterious phenomena which D'Entrecasteaux had observed here in March, 179\%, and which have remained unexplained to this day.* The French Expedition saw, it is true, clouds of smoke emerging alternately from a subterranean opening close to the shore, but without being able to satisfy themselves whether the vegetation had been set on fire by the hand of man or by volcanic action, the wind which blew direct from the island making it impossible to land, unless one was prepared to run the risk of being suffocated by the rolling masses of smoke. There was, therefore, to be solved, at Amsterdam, the mystery as to whether the pillars of smoke, which were observed by the naturalists of the French Expedition of

* La Billardière, Rélation du voyage à la recherche de la Peyrouse, fait par ordre de l'Assemblée Constituante pendant les aunés 1791-94, Paris, 1800. (Tol. I., pp. 112, 113.) 
1792 , issuing from the soil adjoining the sea, were produced by an actual eruption, or were caused by subterranean fires in activity.*

About 11 A.M., the two jolly-boats of the Novara were lowered to look for a landing-place on Amsterdam, while the frigate stood off and on, under easy sail, at an offing of five or six miles. Our whaling informant had told us the most abundant fishing-station was at the south point of the island, while the best place for disembarking was on the N.W. shore. As, however, upon consideration, it was deemed advisable, looking to the probability of a N.E. gale springing up, to get to windward of the ship, so as to be able to fetch her more speedily on our return, the S.E. side was selected, and our course laid for it accordingly. Along the acclivities of the coast pyramids of loose stones were visible, resembling those on St. Paul, but more numerous and of larger dimensions, the entire island seeming altogether on a much larger scale, and more lofty. On the West side we observed rocky precipices of from 1000 to 2000 feet in height, fissured with deep clefts and rents, whereas on the South and S.E., these presented a more gradual slope.

For above an hour we steered along the shore, which rose sheer out of the water, without being able to detect a single point at which it was at all practicable to disembark, so as to scramble up to the high ground. The entire Eastern side is

* Vide Alexander v. Humboldt's "Kosmos," Vol. IV., pp. 412 and 585; also Physical and Geognostic Remarks, by the same author, prefixed to this volume. 
hemmed around with steep abrupt precipices of 150 to 200 feet high, not unlike skilfully-erected bastions, and clothed with long thick grass.

As we drew near, we could plainly discern in the water-courses that descend upon the upper slope-radiating, as it were, from all sides of the highest peak, which was enveloped in cloudsrumerous streams of water, each pouring through a rift like a thread of silver, after which, precipitating itself over the steep precipices on the shore, it washed like a small torrent over terraces and banks of lava, till it was lost in the sea. If these streams are swollen by the heavy rain in winter, they may form waterfalls, as mentioned by early navigators, which must impart a far less pleasing character to the landscape. 'Two small patches of dazzling white, like fresh fallen snow, which were visible high above the slope, we could not make out with the utmost power of our glasses. The green colour which enveloped the entire island seemed to indicate the existence of grass vegetation resembling that of St. Paul.

At last, when we had got within two cables' length of the shore, we encountered enormous green flakes of floating seaweed, which, becoming entangled with the rudder, made further progress possible only by dint of most strenuous exertions. This proved to be the same gigantic sea-tangle of the Southern hemispheres (Macrocystis Pyrifera), which likewise constitutes a barrier of fucus on the East side of St. Paul. 'The sea-calves mentioned by older describers were nowhere to be seen; but on the other hand we had an opportunity of. 
satisfying ourselves as to the immense abundance of fish which frequent the coast of the island in a truly astonishing degree, although the American whaler had prepared us by his remarks. From bow and stern of the boat looks and lines were hung out, and several of the crew were at once kept busy hauling in the lines, at the end of each of which there usually struggled a fish of some two or three feet long. These were chiefly umber fish, which are also very plentiful about St. Paul, where, from their delicacy, they formed a favourite dish at our otherwise very frugal repasts.

We had now got so near, that we could distinctly perceive grass and the stems of ferns growing among the clefts of the rocks. However, although there was a dead calm, and the sea outside was as smooth as glass, the long ground-swell of the ocean, with its broad flat billows, caused such a heavy surf on the rock-bound stony beach, that the attempt to pass it was not to be thought of. The further we advanced along the coast in a northernly direction, the more distant we got from the ship, and unluckily in an equal degree our hopes were disappointed of finding a spot at which we could land, and scramble from the strand up the steep bank to the level ground above. The south-easternmost point, which at a distance presented the appearance of a low headland jutting out into the sea, behind which we had hoped to find a good landing-place, now that we had got close to it, proved to be a small detached rock; while the shore, as far as the eye could reach, rose like a wall to a height of from 150 to 200 feet. There now hove in sight five 
whalers, who seemed hunting that most valuable of all the inhabitants of the deep, of the spots frequented by which Maury's renowned Whale Charts have lately supplied so interesting and useful a code of instruction. These charts, which are based on a vast number of observations, of the tracts of ocean and seasons of the year at which whales are most frequently seen, will at the same time greatly tend to a solution of the question as to the migration of these enormous mammals; for it has never yet been settled, whether these animals flee from the pursuit of man to remote seas, thus continually constraining their pursuers to seek their prey in new waters, or whether, (as is the most prevalent opinion), they are always entirely extirpated from one locality, and accordingly are only to be met with in any numbers in some different area, in which man has as yet only rarely, if ever, disturbed them.*

After an hour-and-a-half of continuous rowing, and when, in our very unsuitable boat, we had got about 7 nautical miles distant from the frigate, we at last found a smooth spot between two reefs, which projected above the level of the sea like a breakwater, and at once let go the boat's anchor. A regular landing-place, however, was not to be hoped for at this point. It was necessary first to make a spring to a block of rock, and thence, picking one's way among stones rendered slippery by being covered at flood-tide, endeavour to reach the beach.

* Some very valuable and detailed particulars of the Whale fishery are to be found in Maury's incomparable work, "The Physical Geography of the Occan," and in Dr. Hartwigs' "Popnlar Treatise on Animated Nature in the Ocean. (Frankforton-the-Main, 185̃.)" 
This we all succeeded in accomplishing over the rough rocks, without any mischance, and at last we stood on the firm soil of the Island of Amsterdam, at a spot which assuredly had never before been trodden by human feet, unless by some castaway. For only in consequence of the sea being perfectly calm, which at this season was quite unusual, were we able to reach the shore at this point.

What a scene of wildest desolation, and inaccessible solitude now met our gaze! Around us nothing but huge blocks of basalt, some rolled about by the breakers, and so slippery with half-dry $\operatorname{alg} e$, that one was in danger of falling at every stride; others with their angles and indentations as sharp, as when first violently torn from their original bed; and behind these gigantic blocks, a perpendicular wall of rock rising 200 feet sheer, composed of a schistus of basaltic lava lying regularly and horizontally one over the other, intermixed with red or brown slag, and yellow tufa. Immense holes and cavities in the rocky wall, as also the empty spaces between the broken blocks that had fallen down, and the vast air-holes scooped out in the lava beds, furnished an undisturbed nestling-place for flocks of a beautiful sea-swallow, with glossy black head, silver-grey body, and bill and feet of carmine red-the most elegant and attractive contrast of colours that can well be imagined upon any bird. These pretty creatures afforded great amusement to the sportsmen of our little party, while the geologist acquired a better idea and more information as to the mineralogy and geognosis of the island beneath the steep wall of rock, than he could 
have obtained above, where all seemed to be covered with thick green grass. But the botanist and zoologist found but little to repay their search on the beach. The same Algce, the same grasses, the same patella (limpets), as at St. Paul, even to the same caterpillars swarming upon every tuft of grass in num. berless quantities. At several points, fresh, perfectly good, sweet spring-water trickled down from the heights, and we could thus confirm the relations of former explorers, that the island contains fresh water; but whether it can be got at, still remains a very uncertain question. As we were convinced, after several examinations and much exertion, that to ascend the precipice from this spot was impossible, it was resolved, after the men had rested, and a few observations had been made with the sextant; to re-embark and endeavour to find a more suitable spot for disembarking.

We quitted this first spot about 2 P.M., and continued to steer along the coast in a N.E. direction. The character of the scenery remained almost unaltered. The steep shore wall indeed dipped somewhat occasionally, but it was never less than 100 feet above the level of the sea. At various points there appeared, as at St. Paul, between the tufa strata, black veins of basalt, and fragments of scorie, lying upon reddish-brown slag. Our curiosity, however, was especially excited by the appearance of small trees and low bushes. At first, while we were yet at some distance, we could barely distinguish a few dark, clear, green spots amid the universal dull olive appearance of the vegetation that covered the island; now that we were 
keeping eloser in, we plainly saw small trees, which scemed most to resemble forests of pine, as also what appeared to be thick elose brushwood of a light green colour, with which large patches of the middle and lower slopes of the island were covered. In vain did we wateh for some spot in this singular island at which we might land and elimb; at length, after steering several miles further along the coast, and passing several promontories advancing from the island, and numerous isolated rocks, we came, towards 3.30 P.M., upon a number of lava-blocks that had fallen from above, and, forming a sort of dam or bulwark between the sea and the shore, seemed to render disembarkation possible. 'The boat's anchor was again dropped, and we proceeded to make for the shore by dint of jumping, as before, from rock to rock; a method of reaching land more agreeable and better suited to penguins than decorous philosophers!

Among the rocks on the strand lie fragments of shipwrecked vessels_pieces of masts and yards_dumb witnesses of human disaster, and suffering, and death! At this point the shore was not very steep. The masses of rock piled here on each other in wild confusion, made our ascent more practicable than at our former landing-place, though perhaps they necessitated greater circumspection. Dr. Hochstetter and $M$. Zelebor, as also Lieutenant Kronowetter, and a sailor, started for the height. A ridge, grown over with grass and rushes, and forming a line of communieation between the upper and lower portions of the island, secmed the most accessible point. 
at which to mount to the high ground above. At first the path led over the colossal rampart of broken rocks and through the surf, after which came clumps of rushes and clods, in which the former grew, and thence upwards over masses of slag. It was a regular Sisyphean task. On the loose rolling débris beneath the feet, for every five feet forwards, one slipped four backward, so that to climb this height of little over 100 feet, took nearly a whole hour. At last the adventurous scramblers stood on the top of the island, on a small bare cone of scorix, whence they were able to overlook a portion of the ground. Dense rush.like grass, as high as a man, thickly covered the entire surface-half-withered, half of a lively green; here broken short off by wind and rain, there still standing erect. Further progress was not to be thought of, not even as far as the green clump of bushes which had already been observed from the boat, although it was scarcely a hundred paces distant, on the surface of the declivity, and although a closer examination promised to afford many interesting details as to the vegetation on the island. It would have been necessary to make one's way either through heaps of withered rushes, requiring to be broken down at every moment, or across thick, matted, fiesh, slippery grass, in order to get anywhere near the copse that resembled the pinewood. Moreover, owing to the short allowance of daylight that remained, both were for the present inaccessible.*

- One of the shipwrecked crew of the Meridian, in an article in the Nautical Mugazine, for 1854, p. 75 , describes at some length the difficulties of access 


\section{Evening was coming on, and it was necessary to think of} our return, as we were at a distance of at least eight miles from the frigate. With the help of pocket-handkerchicfs, which they had tied to the reeds, the explorers readily found again the place at which they had ascended, and now speedily returned to the improvised landing-place, where, meanwhile, the naturalists that had remained behind had occupied them-

to this island. We quote it here as a supplement to our own experiences:- "After we had clambered up to the top by means of ropes, and after much exertion and considerable danger, we found the island for a space of two or three miles thickly corered with reeds, from 5 to 8 feet high; behind rose a lofty hill, also clothed with reeds. Fortunately, during our stay on the island, there was a sufficiency of fresh water, although in summer, in all probability, there is a great seareity. So long as we remained, constant rain fell upon the summit of the mountain, and kept the numerous little brooks full of water. In order to signal our situation to any ship that might be passing, we set the reeds on fire; but the flames spread more furiously than we had anticipated, so that our lives were endangered. A considerable quantity of young birds were picked up, which had fallen vietims to the flames. On the 29th August, to our great joy, a ship, the Monmouth, hove in sight, and observed our signal; but the surf was at this time so violent that no boat could reach us. At last, on 31st August, a boat came near enough to the shore to make us a signal to proceed eastward over the rocks. We set off at once, but found the path very rugged, and owing to the inmense masses of rock lying around, excessively diffieult. Besides reeds and brushwood, there were no other plants but parsley and endive (cichorium intylus). During the first half of the following day we found no water, bnt we found the hail very grateful, which day and night fell incessantly, alternating with rain. At the first watering-place we came upon an English sailor, whom the captain of the Monmouth had despatehed to assist us. He informed us we must make for the north side of the island, as no boat could reach the shore at the spot where we had gone ashore. The south-coast is the worst part of the island; there the surf breaks continually against the iron-bound coast; there there is nothing resembling a beach-only here and there enormons blocks of a hard species of stone, that have fallen from time to time from the cliffs above. On 2nd September, we had neither provisions nor water. The following day, however, we found water, and a few cabbage-stalks, which several years before had been sown by some whalers, and fortunately had thrived. On 5th September, we reached what is called the Cabbage Garden, and the same erening arrired at the place where the boat was arraiting us." 
selves with collecting specimens on the beach, and amid the surrounding rocks. A singular spectacle now presented itself to the astonished view. A couple of lucifer matches that had been thrown aside without further thought, had burst into flames amid the parched rush beds, and dense volumes of black smoke forthwith rose upon the surface of the island. The fire speedily spreading among the thick dry grass, soon assumed a formidable breadth, and ere long a considerable portion of the east coast of the island was in a light flame. There was now presented to the members of the Novara expedition, the same spectacle as that witnessed by the naturalists of the Recherche, when D'Entrecasteaux passed here some sixty years before. It may safely be assumed that the fire, and the thick wreaths of smoke then visible were like those of to-day, the result of man's hands, and not of subterranean forces-in fact, kindled in all probability by fishermen, who were elearing this uninhabitable island of the close impervious brushwood that so grcatly impedes locomotion, and were rendering it capable of being traversed, as well as susceptible of cultivation. During the night of 7 th and 8th December, 1857, the sky was clear and cloudless, and the flames crackled and leaped high above the beach, in an elliptical area, which must have measured a couple of miles in its major axis. A dense, copper-coloured, luminous cloud of smoke rose straight into the air, where it sprear out horizontally, till at last a long trail of smoke stretched in a S.E. direction to the furthest horizon, entirely 
covering the upper part of the island. About 2 A.M., according to the report of the officer of the watch, the spectacle was still more grand and imposing. The conflagration at that time extended over an immense surface, so that the imagination might naturally enough be disposed to regard this as the bursting forth of the pent-up flames of a volcano, with the usual accompaniments of red-hot streams of lava, clouds of floating ashes, and pillars of flame mounting to heaven.

Fortunately, this gigantic conflagration must have done far more good than harm to this desolate island, covered as it was for the most part with reeds, since, without destroying any of the vegetation that could be of scrvice to man, it will greatly facilitate examination by future voyagers, and adapt it for settlement by fishers and others, who at present seem to leave it utterly abandoned.

Towards 6 P.M., as it was already getting dark, our two boats set out on their return to the frigate, from which in the course of the day they had been distant about fifteen miles. However a fresh Northerly breeze having sprung up we were able to make sail, and at 7.30 p.м. once more reached the frigate, when we were received with a storm of questions, principally turning upon the mysterious far-visible conflagration,-which had been kindled by a couple of humble Vienna lucifers! During our visit to the island a variety of observations were also made on board the frigate, to obtain the position of Amsterdam, as also to determine the elevation of 
the most prominent peaks of the island, and the outline of the shore. The results of these gave the following: latitude $37^{\circ}$ $58^{\prime} 30^{\prime \prime}$ S. ; longitude, $77^{\circ} 34^{\prime} 44^{\prime \prime}$ E. of Greenwich ; elevation of the highest summit (nearly corresponding with previous observations), 2891 English feet; of the second highest, 2651 feet; the length of the South coast, as measured from the frigate, 32,359 fect; of the Western shore, 5507 feet.

There was still some faint hope that we might visit the island next day. However, during the night the wind sprung up, the weather became variable, and we saw ourselves compelled to renounce our cherished desire to investigate the island thoroughly, the rather that, owing to the unpropitious weather during the last few weeks, the stay of the Novara in these latitudes had been prolonged so considerably beyond the period fixed, that no more time could be spared, if it were desirous to avoid sacrificing the objects of the Expedition with reference to other and more important departments of scientific enquiry, by engaging in them at a season in all probability highly unfavourable for the purpose.

Consequently our observations in Amsterdam remained most imperfect; although the geologist of the expedition was enabled to clear up the uncertainty hitherto prevailing as to the geological structure of the island, and to determine upon scientific data, that Amsterdam is an extinct volcanic eone, of precisely the same character, and belonging to the same order of volcanic formation as the sister island of St. Paul; that it probably contains on itself all the usual indications of its 
volcanic origin, and that its upheaval probably took place at the same period. On the other hand, the naturalist regretted to see slip the opportunity so rarely vouchsafed, of instituting a comparison between the respective vegetations of these islands, and of making evident how, simultaneously with the advance of a more luxuriant, and more multiform vegetable organization, there also appears an entirely new race of animals, and how closely allied in the economy of nature is the existence of individual specimens with certain fixed pre-existent types. In any case St. Paul, which we enjoyed an opportunity of examining in the utmost detail, is, of the two islands, the most important to the commerce of the world, not merely as a finger-post on the most frequented deep-sea route in the Indian Ocean, but also as a haven of refuge for ships and crews. Already the crater-basin of St. Paul has served in case of need as a desirable asylum for ships that are half unseaworthy. Not many years since an English man-of-war steamer came to St. Paul, after a severe storm in the Indian Ocean, during which her engine broke down, and her rudder was knocked away, after which she, for twelve days, was steered by a temporary rudder. The vessel, after discharging the heaviest part of her equipment, was easily brought into the interior of the crater-basin, and was there hove down for screral months on the Northern barrier, undergoing repairs.

On the 8th December, about 4 A.M., only a dark cloud of smoke in the distant cloudless horizon indicated the position of Amsterdam. The island itself, properly speaking, was 
actually out of sight, for a fresh N.W. breeze had driven us merrily along during the night. The last hope was now dissipated of being able to obtain a view of the North side of Amsterdam. We were now rapidly approaching the region of the S.E. Trades. The breeze freshened and erept gradually to the West, thence to the South, and finally to the Eastward. This veering of the wind proved to be a fore-runner of the Trades, which we got into on 14th December, in S. latitude $28^{\circ} 1^{\prime}$, E. longitude $85^{\circ}$.

On that day a merchantman hove in sight, which, with favouring breezes and all sail set, soon bore down on us. She came down without any flag, and stood right across our bows at so short a distance that we could plainly read her name-the Bunker's Hill, of Boston-on her stern. Thereupon we ran up our flag; and, as it is as gross a breach of the code of maritime politeness for a ship to pass across the bows of another in the open ocean without saluting, as for a man on land to brush quickly across another's path without apologizing, a blank shot was fired at this unmannerly American. To this manifestation etiquette lays it down that, as the hoisting of her flag by a man-of-war is a direct challenge for any merchantman that may be in sight to hoist its flag, any neglect of these universally recognized rules must involuntarily give rise to suspicions. After we had fired the blank shot, the American, by a telegraph of flag-signals, enquired the latitude and longitude, which in merchant ships in the open sea is pretty frequently resorted to, in order to know where precisely they are, as they 
are not able to make such frequent observations as ships of war. Before anything else, however, it was necessary to settle the question of saluting; and this the obstinate Yankec, in spite of the warning signal, seemed resolved not to notice, although he well knew the seriousness of his position, as was abundantly evident in the celerity with which several ladies and gentlemen, whom we could discern on deck, flew to seck shelter below! A second report, accompanied by a ball over his stern, at last brought this pertinacious captain to his senses, and the whistling of the shot had the desired effect. The "Stars and Stripes" were run up, upon which we signalled the required latitude and longitude. Probably it was but a petulant explosion of a silly national vanity, as also the consciousness of commanding a handsome crack "clipper," that could speedily run out of gun-shot, which led to this premeditated and persistent violation of one of the most ordinary rules of politeness. Indeed, even the vessels of the North American navy itself are frequently compelled in the open sea to treat their fellow-countrymen in a similar manner; and the captain of the war-steamer Minnesota, looking after the North American interests in China, was obliged, as we learned afterwards at Shanghai, to enforce a compliance with established sea usages on one of his seafaring compatriots, by dint of cannon-shot, in accordance with the undoubted practice of all maritime nations.

The south-east Trade, which we had hoped would drire us on our destined course, was not so strong or so steady as we 
had expected, chiefly perhaps in consequence of the influence exercised by the Australian continent, the temperature of which during this, the summer season of the Southern Hemisphere, is raised to an extraordinary degree by its sandy surface, that when the air has becorne thus warmed, it ascends and becomes more rarefied in its lower strata, in consequence of which its elasticity becomes so great as to drive back the surrounding colder atmosphere, and only admit it to contact with the heated air at its most remote limits. This oecurs the more readily, that the heated air, after it has risen to the more rarefied tracts, expands on all sides, and at a certain distance from the lower level, begins to add to the pressure of the atmosphere. In this self-acting zone of increased atmospherie pressure, the winds, however, are naturally more faint, and, to observers who happen to be on the exterior of this zone, always appear to take their rise from the further side. For this reason, probably, we fell in with easterly breezes, so long as we had the Northern portion of Australia to the eastward of us.

At any rate, the equilibrium of the air secmed to be disturbed, as we could plainly pereeive from the weather and the confused sea. At last on 18th December, the heavens seemed somewhat more propitious, though the wind still continued eastcrly; indeed occasionally blew from the north, and frequent squalls of rain poured pitilessly down upon us. The more, however, we increased our distance from the Australian continent, that is, from all land to the eastward, the more steadily blew the south east Trade. And so we kept standing steadily 
forwards, till at last, on the 24 th December, in $6^{\circ} 4: \mathrm{S}$. Lat., and $82^{\circ} 34^{\prime} \mathrm{E}$. Long., we reached the eastcrn boundaries of the Trades and got into that of calms.

The heat, which thus far had spared us, began now to be most oppressive, and was felt all the more owing to the air being extraordinarily damp and dense. Frequently in the afternoon a passing shower of rain, which would sometimes completely flood the deck, would cool the air for a fow flecting moments. Occasionally indeed we had westerly and more rarely north-westerly breezes, but these were never of long duration, and were incessantly broken by rains and squalls.

And at this same season, at which in our distant Fatherland, palace and hut are decked out with unwonted attention, when golden fruits and elegant presents glitter from the green firbranches of the Christmas Tree, all lit up with the neat little wax-tapers, when man's lieart scems to overflow with cheerfulness and love of his fellow-creatures, - at this season we were languishing far from our dear ones, tormented with the intense heat, scarcely able to realize to ourselves, that at home it must now be snow and frost, while keen Boreas is whirling the snowflakes aloft, and howling a grim accompaniment the while! However, we promised ourselves the satisfaction of enjoying these pleasures at our own firesides, whereupon our recollections of home and dear friends imparted to our minds a wholesome stimulus, arising from the soul-inspiring conviction, that we too were present in their minds and hearts at this hallowed season. Nay, several of the officers of the Novara Expedition were sur- 
prised when far at sea, in the very midst of the Indian Ocean, with Christmas gifts, which thoughtful friends had many months before entrusted to the care of discreet fellow-voyagers.

After constantly struggling against calms and contrary winds, exactly at the first stroke of the New Year, at midnight of 31st December-1st January, we reached the Equator, which we were now crossing for the second time, and began the year 1858 in the Northern Hemisphere.

On this New Year's Day we had nearly had a great disaster. A lad who was coming down the shrouds fell overboard. The sea was perfectly ealm and smooth, but already on the morning of this very day we had seen many sharks, those dreaded foes of man in the domain of ocean, so that the life of the unfortunate youth seemed seriously imperilled. The same instant in which the youth fell, saw a life-buoy thrown over, a boat prepared for lowering, and all usual appliances for a rescue made available. But although an excellent swimmer, he seemed to lose all presence of mind, probably through fear, and must undoubtedly have been drowned, had not the boatswain's mate, and two other sailors, leaped into the water and made all haste to his assistance. Meanwhile the boat had been got into the water, by which rescued and rescuers were got safe on board again.

A few months later, the boatswain's mate, for his gallant conduct on this occasion, received, by the express orders of His Majesty, the silver cross of merit, while the sailors were adranced one grade. 
The current, which runs northward along the coast of Australia, but turns off to the westward about the tenth degree of South latitude, so as to pass southward of Ceylon, directly along the Equator to the Coast of Africa, carried us far to the westward, in consequence of which we had overcast, uncertain weather, with, for the most part, calms or light breezes. As we found ourselves approaching the fourth degree of Northern latitude, a rather fresh N.E. wind sprung up, probably the trade wind of the Northern Hemisphere, which, however, as we neared Ceylon, again died away to a calm,

At the same time, in lat. $5^{\circ} 32^{\prime} \mathrm{N} ., 79^{\circ} 5^{\prime} \mathrm{E}$., we fell in with a current running more than two miles an hour. We had, as it turned out, got to the westward of the roadstead of Point de Galle, in Ceylon, and found some little difficulty in making headway against the current. On 7 th January, toward 3.30 P.Mr., land was made to the eastward, and an hour later, a Cingalese canoe was perceived making for the frigate under sail. It was the pilot boat, whose crew, having been informed by a Hamburg brig that a large ship was in sight, had put to sea to meet us.

At the first sight of this little canoe, it was hardly possible to refrain from amazement at the courage and hardihood with which the half-naked Cingalese boatmen could put off some 30 or 40 miles to sea in such a tiny, narrow boat, that barely gives them room to sit lengthwise. Two cross-bars, or outriggers, projecting on one side, where they are fastened 
externally to a rather massive beam, which swims parallel with the boat, gave this canoe, apparently so fragile, such stability and seaworthiness, that it is at all times not less safe than a boat of European construction.*

The natives steer with short paddles, and continue an incredibly long time at this most exhausting work, as we must conceive it to be. And yet they are to appearance a feeble race, except that the muscular system of the upper part of the body is remarkably developed.

The dress of these people is remarkably simple, and usually consists only of a piece of coloured linen cloth or calico, which, worn short like a woman's petticoat, is thrown single-fold round the loins.

The pilot, though he could only make himself intelligible in broken English, speedily came to a good understanding, and offered to sell us bananas, pirie-apples, and cocoa-nuts, as also Ceylon jewels, the latter of which he carried on his person, secured in a parti-coloured cotton belt. This reminded us that we were nearing the shores of the country in which costly stones are found, but precisely on that account, as was natural, our speculative pilot found but a poor market for his wares.

Off the coast we caught a shark 7 fect long, and $135 \mathrm{lbs}$. weight-a rather juvenile specimen-whose teeth, which we

* These canoes resemble very closely the "proas," of the Polynesian Islands, carrying a beam on one side, which is quite straight, and always kept on the lee of the wind and sea, the change of course being eflected by simply shifting the sail, and stecring with the paddle from the opposite end. 
examined, were already strong and sharp enough to seize a man, and strip the flesh off him. Also a number of large dolphins and other fish, sported in the dead water under the frigate's stern, and provided plentiful employment for the harpoon and the rod. Presently we found ourselves within six miles of the land, when a large number of pirogues forthwith came swarming about us, all of a construction similar to the pilot boat, and each manned by. four half-naked bronze natives. These offered fruits for sale, especially magnificent, gigantic clusters of banana. On one such cluster we counted, arranged in five rows, one over the other, not less than 175 bananas.

On the Sth January, we anchored in the unpicturesque haven of Point de Galle, surrounded by groves of cocoa-nut palms, directly opposite the lighthouse tower, and in a fine quartz sand bottom of $16 \frac{1}{2}$ fathoms (103 feet English). All large ships, that only intend remaining a short time, anchor in the open roadstead, the entrance into the inner harbour being rather difficult, owing to numerous coral reefs. In the roads also lay the English frigate Shannon, from which, in the absence of her captain, the first lieutenant immediately came on board the Novara, and in the handsomest manner put his services at our disposal.

As the only Austrian Consul on the island was resident in Colombo, M. Sonnenkalb, the Consul for Hamburg, had the courtesy to receive us with the most hospitable of welcomes, and procecded to do us the honours of the place. 
On the 10th we hauled the frigate into the small inner harbour, in order to facilitate the shipping of stores. The entrance is rather winding, owing to the numerous shoals, and it is with some little difficulty that one can find a comfortable, commodious berth among such a crowd of shipping. IVe only saluted the flag of the dominant nationality - a customary courtesy-and were replied to by the batteries on shore. An officer of the frigate was then dispatched to announce our arrival to the governor of the station-a major in the English army. This gentleman seemed not to think it incumbent on him to put himself in the least out of his way for us. Indeed, we even experienced some little difficulty in procuring a sufficient supply of drinking water for shipment as stores; but we must at the same time add, in justice to the representatives of England in distant countries, that during our entire voyage this was the one solitary instance in which English military official men did not display that universal readiness to oblige, which, to their credit, is so conspicuously and so kindly displayed by them in their intercourse with foreign nations.

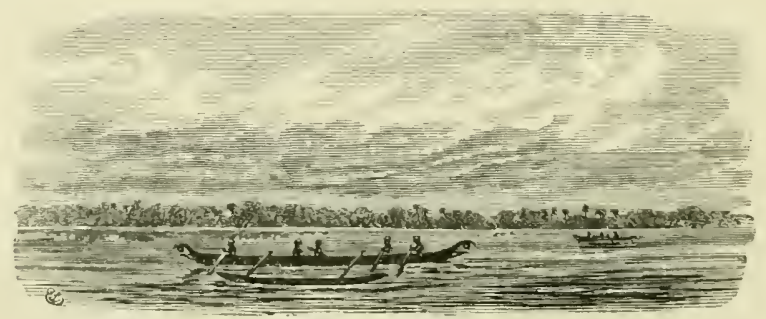





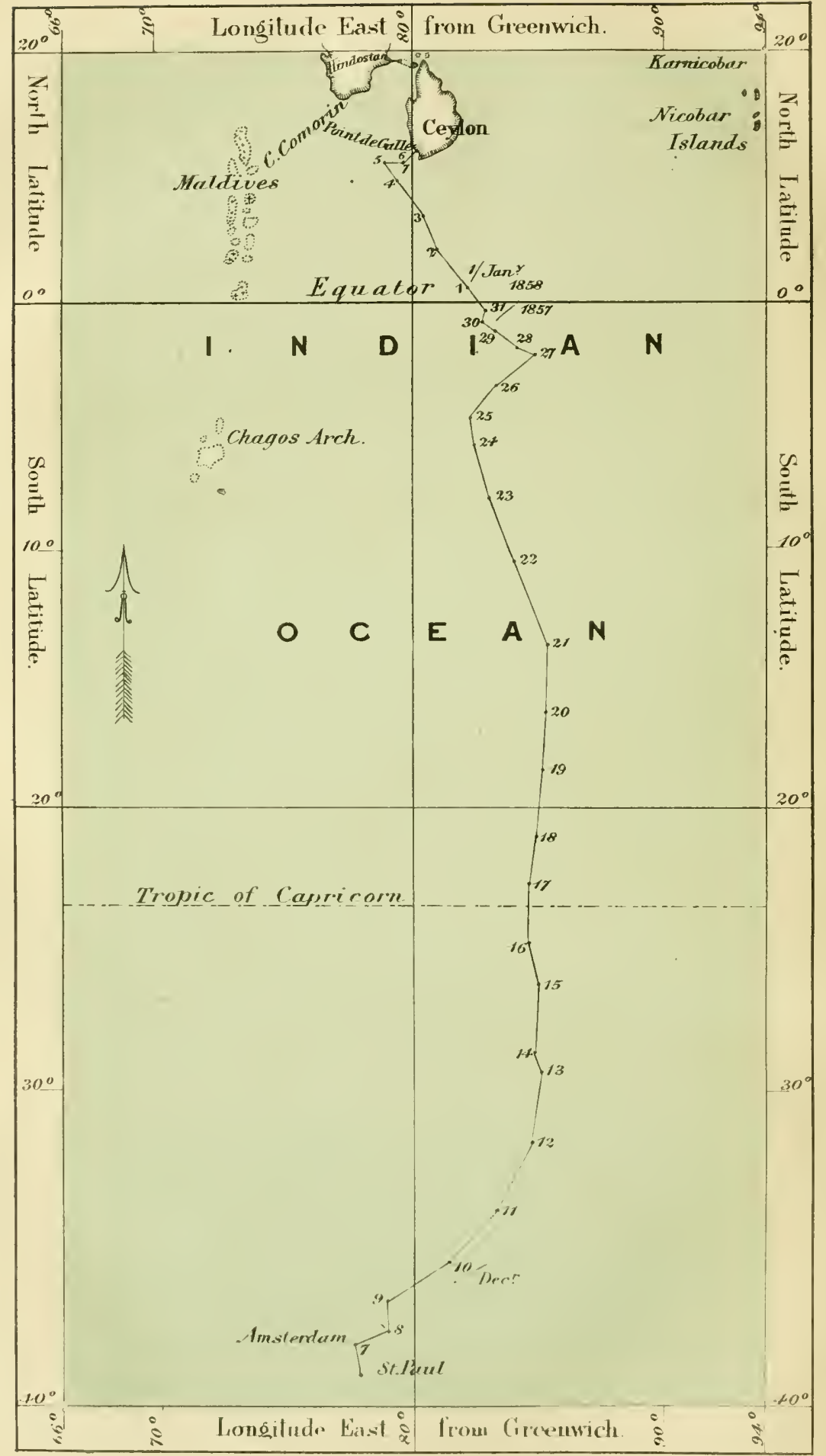




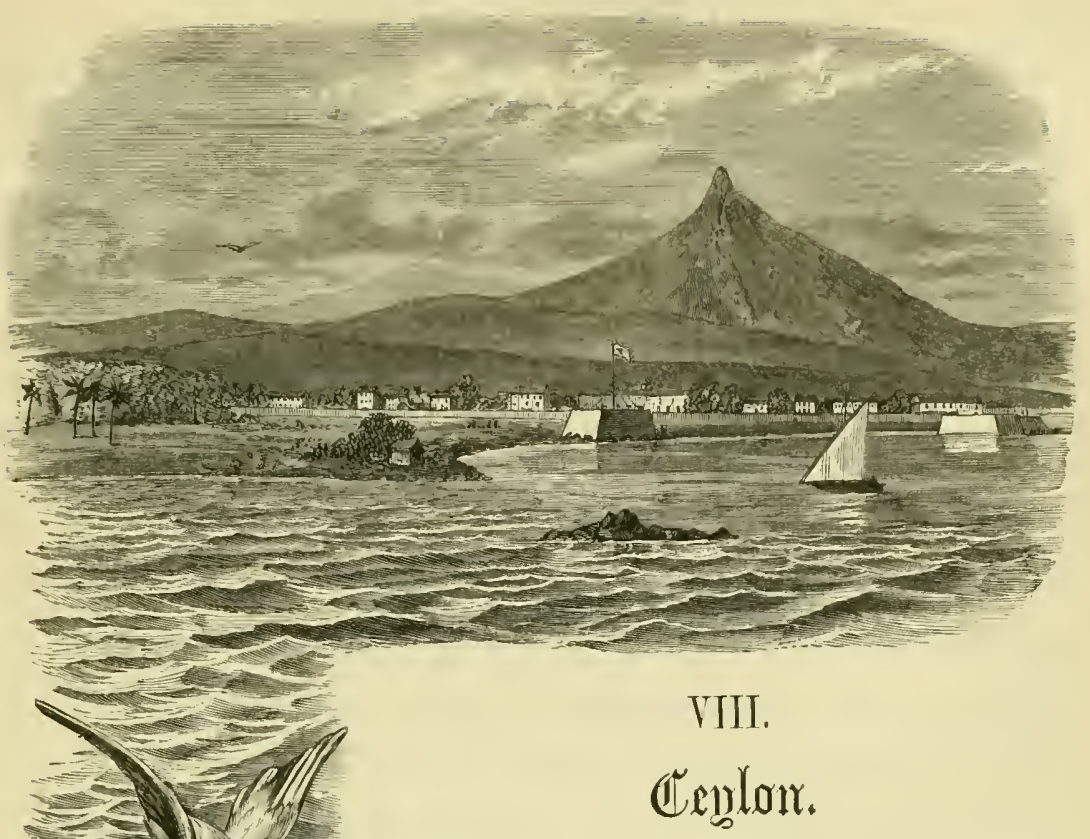

(Stay fron 8th to 16th Jan., 1858.)

Neglect of the Island hitherto by the English Government.-Better Prospects for the Future.-The Cingalese, their Language and Customs.-Buddhism and its Ordinances.-Visit to a Buddhist Temple in the Vicinity of Galle. - The sacred Bo-tree.-Other Aborigines of Ceylon.-The Weddahs.-Traditions as to their Origin.-Galle as a City and Harbour.-Snake-charmers.-Departure for Colombo.Cultivation of the Cocoa-nut Palm, a benevolent, Buddha-pleasing work.-Polyandria; or, Community of Husbands.-Supposed. Origin.-Annual Exportation of Cocoa-nuts. - Rest-houses for Travellers. -Curry, the National Dish.-A Misfortune and its Consequences.-The Catholic Mission of St. Sebastian de Makum, and Father Miliani.-Annoying Delays with restive Horses.-Colombo.-A Stroll through the "Pettah," or Black Town.-Ice Trade of the Americans with Tropical Countries.-Cinnamon Gardens and Cimnamon Cultivation.-Consequences of the Monopoly of Cinnamon.-Rise and Expansion of the Coffee Culture in Ceylon.-Pearl-fishery.Latest Examination of the Ceylon Banks of Pearl Oysters, by Dr. Kelaart, and its Results.-Aripo at the Season of Pearl-fishing.--The Divers.-Pearl-lime, a Chewing Substance of wealthy Malays.-Amnual Profit of the Pearl-fishery.-Origin of 
the Pearl.-Poetry and Natural Science.-Artificial Production of the Pearl.-The Chank-shell-_-The VVealth of Ceylon in Precious Stones.-Visit to a Cocoa-nut Oil Manufactory.-The Cowry-shell, a Promoter of the Slave Trade.-Discovery of valuable Cingalese MSS. on Palm-leaves.--The heroic Poem of "Maliawwanso," and Turner's English Translation of it.-Hospitality of English Officials in Colombo.-A second Visit to Father Miliani.-Agreeable Reception.-The Anticloteoil against Bites of Poisonous Snakes.-Adventures on the Journey back to Galle.Ascent of Adam's Peak by two Members of the Expedition.-The sacred Footprint. -Descent.-The "Bullock-bandy," or Native Waggon.-Departure from Galle for Madras.-The Bassos (shallows).-A Berlin Rope-clancer among the Passengers. -Nyctalopia ; or, Night Blindness.-Fire on board.-Arrival in Madras Roads.

THE inquirer who becomes acquainted by personal examination with the important geographical position of the Island of Ceylon (called also Seilan or Singhala), her commodious harbours, her productiveness, and her marvellous climate, involuntarily wonders at the stepmother's part that England has hitherto played with respect to this renowned island of palms and spices, the Malta of the Indian Ocean, which of all the British possessions in distant parts of the earth, has, till recently, received the least care or attention.

It must be borne in mind, however, that Ceylon is an appanage of the British Crown, and it is not an independent, self-supporting colony. Those shortcomings of administration, for which the mother country is exclusively responsible, have been hitherto a complete drag upon her development. But the English people have this advantage over all other nations, that once anything has been recognized to be useful and imperatively required, they proceed to apply it with such energy, that they are enabled to make up for any neglect with giant strides. Durng late years many fetters have been knocked off which 
formerly impeded the more active development of agriculture and commerce. The harbour of Point de Galle (also called only Galle for shortness) has become a central station for the steam-boat trade with the East Indies, the Burmese Archipelago, China, and Australia. A telegraphic wire will ere long stretch from Ceylon to England, such as even now unites the island with the Coromandel Coast and India; a railway is in course of construction between the most important commercial centres of the island, and so obvious are the fundamental benefits it must confer, that ere long the classical and incomparably beautiful island of Ceylon is destined to shine a star of the first magnitude in the azure of the Indian Ocean, one of the most prosperous, wealthy, and blest of islands!

The scientific researches of all kinds, which have in modern days been instituted in Ceylon, have been attended with the most important results, bearing upon its history and its various tribes, as well as on its natural wealth; and the masterly and marvellous work Sir Emerson Tennent lately published on the isle of Ceylon, seems intended to compensate for many instances of neglect which Ceylon and its inhabitants have experienced from the English since they seized on it.

Embracing all the three kingdoms of nature, and following up with learned accuracy the history of the inhabitants, from the obscure traditions attending their earliest settlenent down to the present day, Sir Emerson 'Tennent's work is a perfect pattern of a monography, although upon this subject the German inquirer will involuntarily, and not without an emotion 
of pride, recall to mind Carl Ritter's admirable, well-digested publication upon Ceylon, in his classical work on Eastern Asia, doubly meritorious by the very fact that the German scholar never set foot in the country itself. There are, however, indeed few spots on earth which present such inexhaustible subjects for the study of the historian as well as the inquirer into physical science, of the poet and the political economist, as this romantically-beautiful island, which we have been taught to regard as the Garden of the World, as indeed the special site of the Garden of Eden, the first abode of the progenitors of the human race.

We have not to do here, as in most of the islands of southern seas, with a savage people, that have only, since the first appearance of Europeans, emerged from a state of barbarism, and been raised one step towards civilization, but rather find, as in the East Indies and China, a peculiar type of civilization, which, although widely differing from that of Europe, yet seems not less valuable and extraordinary. The whites (scarce 7000 in number, of whom 2482 are females), who live scattered over an area of 24,700 English square miles, have hitherto been too few in number to exercise any marked influence on the customs or mode of life of a native coloured population of $1,726,640$ souls, and hence it is that Ceylon exhibits a more romantic and characteristic air than any other British settlement in distant parts of the globe.

A people like the Cingalese, of such ardent imaginativeness, with a splendid history, and a religion professed in the varieus 
realms of the East by more than 300 millions of people, gains in interest the more we become acquainted with them, and the more we make their traditions, their mode of life, and their customs, the object of special inquiry.

The Cingalese, or indigenous natives (so named to distinguish them from the other inhabitants of the island, belonging to other stocks and amalgamated races, who at various periods had settled here, and who call themselves Ceylonese), were cntirely the offspring of Hindoo emigrants, who, about five centuries before the birth of Christ, came from Hindostan to Ceylon, and imported their own mode of government, and system of caste, as also their arts, language, and religion, from the continent into the island.

They constitute the germ of the present population, and early divided themselves into four leading castes :-1st, that of the royal family;-2nd, the Brahmins;-3rd, the merchants, peasants, and shepherds; - and 4th, the sixty inferior common castes. At present there exist in Ceylon only the two latter. The most numerous is that of the peasants, who, however, meddle but little with the cultivation of the soil, but have arrogated to themselves the exclusive and hereditary possession of all employments, lay or ecclesiastical. The dress of the Cingalese usually consists of a cloth wound turban-fashion round their head, and long white drapery. On festive occasions they wear richly-adorned tight-fitting jackets of velvet or wool, and on such occasions rank and power assert themselves by the number of garments, to such an extent that frequently 
a wealthy man makes his appearance in several of these habiliments, worn one above the other. The Cingalese are shorter in stature than the Europeans, their average stature being 5 feet 4 inches to 5 feet 5 inches, English. Their physique, though graceful and delicate, is powerful and muscular, with a brawny breast, broad shoulders, the muscles of the thigh strongly developed, but with disproportionately small hands and feet. Their colour is commonly a light-brown, their hair black and quite straight. The women are beautifully formed, but even when they can, like Asokamalla of historic fame, boast all the forty and six marks of the Cingalese ideal,* they must fall far short of the European standard of female beauty, with their bodies anointed with oil, and their mouths stained with the betel-nut. As the Cingalese girls usually marry so early as 12 years of age, they speedily lose the bloom of youth, and frequently have the appearance of crones at 20. Another especially loathsome habit of the Cingalese is the chewing the betel-nut, a custom so universally prevalent among all Indian races, that not merely the men and women, but the very children exhibit an extraordinary predilection for it. The ingredients of this masticatory consist of the green tender leaves of

* Of these forty-six perfections of womanly beauty we extract the following by way of example, from a Cingalese author:-hair, glossy as the tail of a peacock, and hanging in ringlets to the knee, eye-brows like the rainbow, eyes like sapphire, and the leaves of the manilla flower, a hawk nose, lips lustrous and red as coral, teeth small and regular, like the buts of the jasmine, neek thiek and round, haunehes broad, breast firm, and eonieal like the coeoa-nut, the figure slight, capable of being spanned by the hand, the limbs spindle-shaped, the sole of the foot without any hollow, the skin free from any prominence of the bones, sweeping in rounded curves, soft and tender. 
the Betel-pepper-shrub (Piper betle), the nut of the areca-palm (Areca catechu, or cabbage-tree), some lime made of calcined shells, and tobacco, which, according to the rank of the individual, they keep ready prepared by their side, in silver or brass boxes, resembling snuff-boxes. These corrosive substances at the same time stain the saliva so deep a red, that, after long use, the lips and teeth seem as though smeared with blood.

The language is an offshoot of the Sanscrit, copious, harmonious, and full of expression, with threefold grammar, and as many vocabularies, viz. for the royal tongue, the official or court tongue, and that of society at large. To these there must be added the Pali, the learned, but obsolete written language of the priestly caste, which the Cingalese have in common with the kingdoms of Siam and Ava, in the further Indies. In this language, itself but a dialect of the Sanscrit, all their sacred books, traditions, and poetry are written. In many parts of the island the knowledge of language and written lore are held in such high honour, that grammar and literature form the entire study of the inhabitants. Reading and writing are as common among the Cingalese as in England, except that in Ceylon the women take no part therein. They do not write as we do, with quill or steel pen upon paper, but engrave the characters with a finepointed iron graver, or stylus, upon the leaves of the Talipot palm-tree (Corypha umbraculifera), from which they slice a broad strip for the purpose about 2 feet long, and several inches broad. These require no further preparation than that 
they must be well smoothed beforehand, and all incqualities removed. In order to render the writing more clear and legible, the Cingalese rub it with a mixture of cocoa-nut oil and fine pulverized wood-ashes, which imparts to it durability and prevents obliteration. Great numbers, however, use the leaves of another species of palm for writing upon, viz. the Palmyra palm (Borassus fabelliformis), but those of the Talipot are preferred to all others for their closeness of texture, and are alone used in important records and other documents.

The religion of the Cingalese is Buddhism, which in Ceylon still flourishes in these times in all its pristine vigour. Buddha is not the name of the founder of this belief, who is called Gautama, or Sakja-Muni, but is only one of the numerous titles of honour invented by that personage, who in the Sanscrit figures so conspicuously as a sage. Gautama was born in the province of Maghada (now known as Reha), in Northern Hindostan, в.c. 624. His parents were Suddhodana, King of Magadha, and his consort Maja. Contemplating the degeneracy and misery of man, sunk in deepest woe, Gautama attacked the doctrine of Brahma, rejected the Vedas, or holy books, and founded the new faith, which consists of the following fundamental propositions:-The Creator and Ruler of the world is a supreme, invisible, purely spiritual (and for that reason obviously impossible to be figured) Being, almighty, wise, just, beneficent, and merciful. Man most fitly recognizes and honours the Deity by silent contemplation: by the practice of chastity, temperance, and 
virtue he attains to happiness. The complete fulfilment of all his duties confers on him here on earth the dignity of a Buddha, or sage, and after death consigns him to the beatific repose of non-existence* (Nirwana). Condemned souls are born again in the forms of wild animals. According to Gautama's teaching a fresh Buddha always appears at certain epochs, whose existence is manifested by his extraordinary spiritual powers, by his deeds, and by his prophecies, selected by destiny for the purpose of enlightening the world as to the decrees of the Supreme Being, and to restore religion to her pristine purity. The death of a Buddha is also the commencement of a new reckoning of time. Gautama, who died about B.c. 542 , or some 2400 years since, was the forty-fifth and last Buddha that appeared to the Cingalese; his doctrine must continue to operate for 5000 years, when, according to the Cingalese traditions, the next Buddha, or Purifier, will appear. Gautama's belief, bequeathed by him to his disciple, the Brahmin Mahakaja, was immediately translated into Sanscrit, and speedily spread. Several hundred temples and monuments dedicated to him are scattered in various parts of the island, and remain to this day an evidence of the extent and influence of Buddhism.

On the day of our arrival we at once set off to visit one of

* The ten precepts of the moral code of Buddhism are as follows:-Kill no living creature-do not steal-follow no unclean occupation-tell no lies or untruths-drink no fermented liquors-live exclusively on regetables-anoint neither the head nor the body-go to no singing parties or spectacles-do not sleep on a raised nor on a wide bed-eat but once a day, and before noon. 
these Buddhist temples, in the vicinity of Galle. The edifice is small and insignificant, only the carved woodwork of the door presenting any object of interest as a work of art. In the interior is a gigantic figure of Buddha, carved in wood, and in a reclining position; it is 20 feet long, and painted yellow and red, with long flaps to the ears, and a lotus flower on the head; while on the walls around, richly decorated with scrollwork, dragons and lions, part painted, part sculptured, various interesting episodes are represented in the history of Buddhism. Right in front of the figure are placed a number of offerings of the most miscellaneous description, beneath which are flowers and fruits; a small tin box is also particularly conspicuous, into which every stranger is expected to

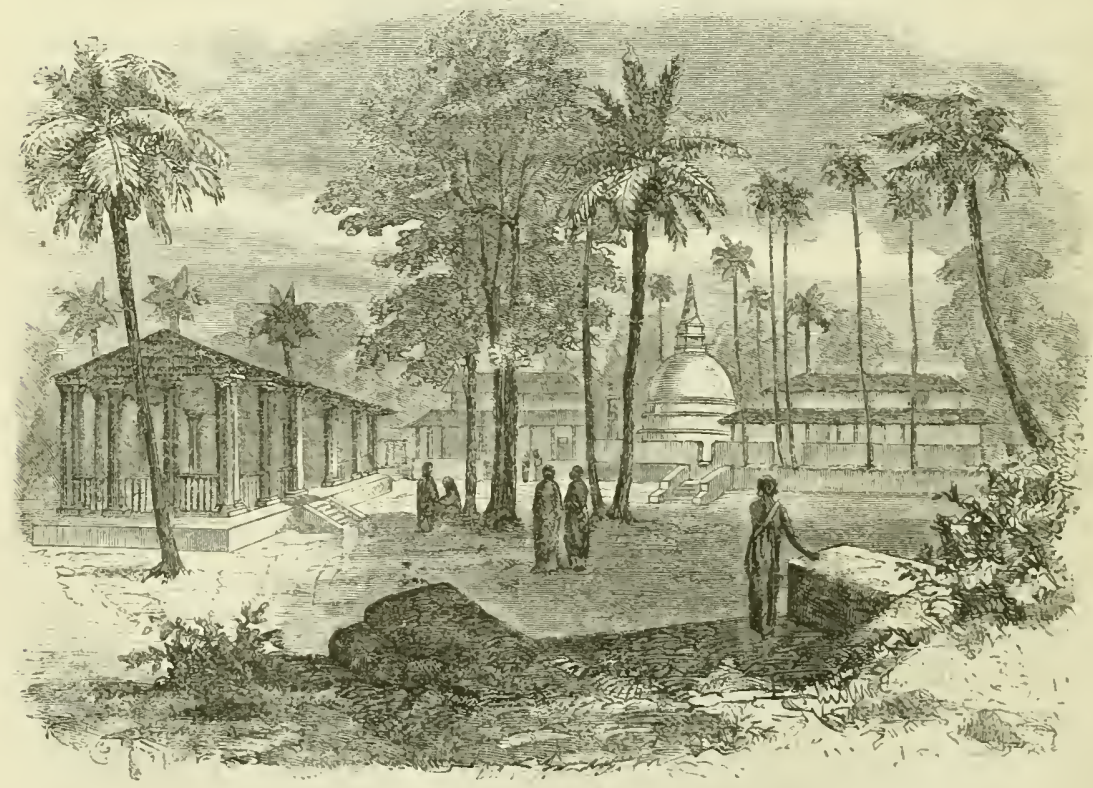


drop a piece of silver by way of present. Adjoining such a temple are always to be found the wiharas, or residences of the priests (hamaduruhs), and the spot where preaching and teaching are carried on. The priests wear long wide restures, yellow or white according to their rank, or else only a single yellow outer garment, which falls in the form of graceful drapery over the naked shoulders; their heads are shaved, and they walk about quite barefoot, with a parasol of Talipot palm in their hand, and observe with strangers a reserved, distrustful demeanour.

We were conducted all round by a young priest, of about 20 years of age, who spoke a little English, which is not a very common accomplishment, since the Buddhists have a great dislike for all that is foreign. Only at the conclusion of our visit did the old, grey, half-blind superior priest make his appearance, saluted us, but immediately left us to snatch from a boy a shaddock (Citrus decumana), which is especially prized by the Cingalese on account of the refreshing qualities of its juice.

The priestly office, however, does not deter a native from indulging the disgusting habit of chewing the betel-nut, and this aged hamaduruh became much more sociable on receiving some.

Adjoining the temple, which stands in a charming cocoa-nut grove, we first got an idea of the extraordinary luxuriance of the vegetation of this island. In a single enclosure, not much larger than an ordinary house-garden, we saw coffee-trees, 
cinnamon-bushes, clove-trees, nutmeg-trees, (Areca catechu), oranges, lemons, pine-apples, and bread-fruit trees (Arctocarpus incisa), flourishing in wildest profusion.

A second temple, which we also visited, was the Dadále Panzela, the largest in the province, and the seat of the high-priest of the Buddhists. This worthy personage, a septuagenary, is named Nanalangara Seresumana Mahdamaradjigurù Ganatchari-Naikunangi, and is surrounded by a staff of priests of the temple who are reputed holy, and who apparently venerate him as a superior being. This temple did not differ much in construction and arrangement from the first; but the place set apart for instruction, where, at the time of our visit, some youths were busily engaged in copying the sacred books upon palm leaves, as also the residences of the priests, made a much more imposing impression, and spoke of a certain degree of opulence. In the midst of a piece of ground laid out like a garden was planted the sacred Bo-tree, which is looked upon as holy by the Buddhists, because, according to an ancient tradition, Buddha was in the habit of reposing under the shadow of its branches, as often as he visited the earth. Towering above everything wherever a Buddhist temple is raised, there a Bo-tree is planted; but the particular sacred tree, the original plant from which the legend took its rise, grows at Anaradnapura, in the northern part of the former kingdom of Kandi, whither it had been suddenly translated from a far-distant land, and spontaneously took root in the spot where it at present stands, in order to serve as 
a protection and shelter for Buddha.* Ninety Cingalese monarchs are interred around it, all of whom, by the temples and statues they erected to Buddha, are deemed worthy of this pre-eminent mark of distinction.

The grey-headed high-priest permitted the library of the temple to be shown to us, which consists of a large number of Pali manuscripts, inscribed on Talipot leaves, each of which was enclosed between two elegant boards made of calamander wood (Diopyrus hirsuta), fastened with strings, and enveloped in numerous folds of cloth, the whole guarded with singular reverence, in lofty, broad, wooden cupboards, richly carved. When we returned, the chief priest requested us to give him our names, and that of the country we came from, upon which a young priest carefully wrote down with a goose quill on a sheet of paper, in Cingalese language, apparently with the view of showing us civility, some superficial remarks respecting the Novara Expedition.

Besides the pure Cingalese, the island is also inhabited by Hindoos from the Malabar coast, Moors (the descendants of wandering Arabs and Mahometans from northern India, who

* The sacred Bo-trec (Ficus religiosa) of the Buddhists is frequently confounded with the Banyan Tree (Ficus Indica), held in such honour by the Brahmins, from which latter it differs in this, that it does not throw out from its branches numberless twigs which take root again in the earth. The incessant waving and rustling of the leaves and branches, which is common to both species of Ficus, is regarded by the faithful Buddhists as the effect of a fear-instilling scene of which the sage was once witness under the Bo-tree; just as the Syrian Christians deduee, from the fact that the Holy Cross was manufactured ont of aspen-wood, that this tree is trembling, even in our days, with anguish and terror. Singular, what an important part the fig-tree seems to play in all religions, including the Cluristian and the Mahometan! 
at present carry on the greater part of the trade of the island), Malays, Javanese; then Portuguese, Dutch, British of the various nationalities comprised under that title; and, lastly, Negroes from Mozambique and Madagascar, who have formed alliances with the Cingalese, and are rearing a numerous mixed race.*

Deep in the interior of the island, in the province of Bintang, N. E. from Kandi, and towards Trincomalee and Batacalva, in holes in the earth, or under the palm-leaves, reside the tribe of the Weddàns or Veddàhs, the most savage race in the island, traditionally said to be the aborigines proper, who go about naked, with the exception of a girdle round the loins, and use only bows and javelins, which however they manufacture and handle with great dexterity.

According to one of the varions Cingalese traditions, these Weddàhs are the descendants of a very bloodthirsty, cannibal monarch, who, deposed by his people, was only permitted the

* What is related by various writers of the practice of "running a muck" (a custom that seems to recal the frightful blood-fends of the Corsicans), long supposed to be peculiar to Ceylon, in which a Malay thirsting for rerenge, and armed with a naked "kreese," or dagger, rushes through the streets like a madman, yelling "Amock, Amock" (kill, kill), and runs the fearful weapon through the body of the very first person he meets,- seems to be founded on a mistake. No one could give us any particulars on the subject from personal observation. Sir Emerson Tennant too, in his work on Ceylon, passes over this custom of "1unning a muck," without a syllable of mention. Eridently the custom is not naturalized in this island. It now prevails among the Malays of the Suncla archipelago, while in Ceylon no instance has occured within the memory of man. That this tendency to murder is caused by the use of opium likewise appears improbable. Cranford, in his most excellent descriptive dictionary of the Indian islands, speaking of "running a muck," pretends it results frequently from a monomania taking this particular form, and originating in disorders of the digestive organs. 
alternative of death, or of withdrawing with the ministers of his cruelty to roam for ever amid the solitudes of the forest. The dethroned king chose the latter alternative, and thus became the little-to-be-envied progenitor of this rude savage race. At any rate it seems worthy of note, that these Weddàh, destitute though they are of the remotest traces of civilization, are still regarded as belonging to the privileged caste.

Owing to the shortness of our stay, we unfortunately had no opportunity of visiting the interior of the island, or of seeing these Weddàhs. With difficulty did we tear ourselves from the zone of the cocoa-nut growth, and therefore only got acquainted with two places on the island, Galle and Colombo, the latter the seat of government.

Galle is, from its position, as also from its configuration, indisputably the best and most important harbour in the south and west of the island, as Colombo can only be regarded as an open, insecure roadstead. Founded in the sixteenth century by the Portuguese, conquered at a later period by the Dutch, and finally, at the peace of Amiens, transferred to the English, Galle displays singularly fow traces of its different masters. The streets are narrow, but cleanly; the houses are for the most part constructed of earth, with verandahs, or airy colonnades towards the street, and rooms within, plastered to imitate stone, of spacious dimensions, as is desirable, considering the heat of the climate. As one enters from the roadway at once into the sitting apartment, and as the door stands wide open all day to admit a free current of air, a sort 
of open screen-work is usually put up before the entrance, to prevent a too minute inspection of the interior, by the prying

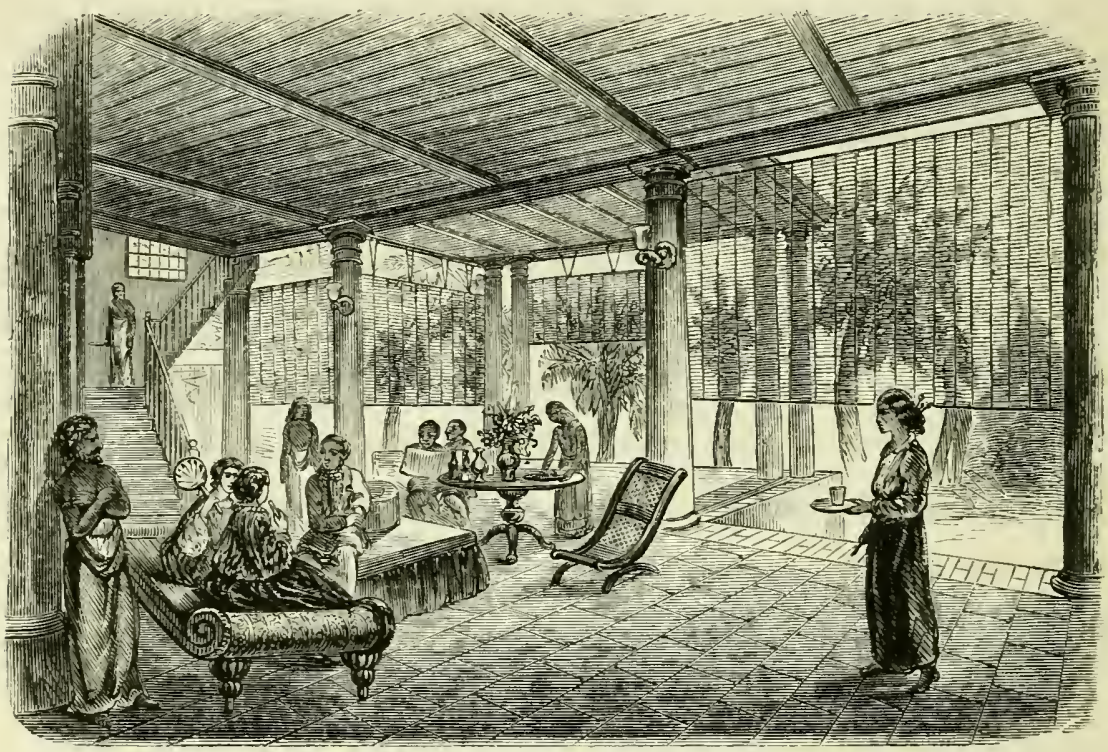

eyes of inquisitive passers-by. At Galle we, for the first time, saw the "Punkah," a sort of fan peculiar to India, which stretches from one end of the roof of the room to the other, and being swung to and fro by a servant produces a refreshing coolness. Here, too, we first became acquainted with the "Gecko" (Hemidactylus maculatus), an elegant little house-lizard, which, with graceful agility, runs to and fro upon the walls, windows, and roofs, and speedily becomes as familiar with man as a pet-dog or kitten. They usually make their appearance towards evening, when, without the slightest symptoms of timidity, they begin their surprising evolutions, during which they catch gnats with astonishing dexterity, and although they 
are disagreeable objects to all new comers, one speedily becomes accustomed to these harmless, innocuous, playful little animals, of which the Ceylonese are in the habit of relating many interesting and amusing anecdotes.

Of late years, during which Galle has risen into considerable importance, as the converging point of the lines of steamers to Eastern India, China, and Australia, the number of substantial houses has greatly increased, and several large hotels are found here replete with every comfort. Like most European settlements in India, the Cape, and China, Galle possesses a fort in which, at an earlier period, the European colonists dwelt with their wives and families apart from the natives, and has also a "Pettah," or Black Town, a sort of Cingalese Ghetto, exclusively inhabited by the black population. At present this separation is not so strenuously enforced as in earlier times, but whoever would seek to form a more accurate idea of the various races of this population, its mode of life and its demeanour, must leave the so-called "Fort," and wander through the native or Cingalese quarter. Here are the fruit and vegetable markets; here all was devoted to buying and selling, which seemed to excite the otherwise listless little covetous disposition of the Cingalese; here jugglers and snakecharmers exhibit, who excite interest rather by the horrible nature and the foolhardiness of the performances, than by their executing any surprising feats. A belief is prevalent among the people that this singular class of men, greatly resembling our own gipsies, possess the art of depriving a poisonous 
serpent of its venom, and rendering it innocuous. And, in fact, one does see them produce from a white cloth the dreaded Cobra di Capello, 4 or 5 feet long, and exquisitely marked, irritate it violently, and go through all manner of unpleasant performances with it on their naked bodies. Frequently the serpent, weary of being constantly brought out for exhibition, endeavours to escape from its tormentor, whereupon a general scramble for escape takes place among the spectators. Every one hurries off to a safe distance, and the unfortunate charmer is left alone on the scene with his eminently intractable pupil, and has, into the bargain, given his exhibition in vain. As, however, it not unfrequently happens that the bite of the Cobra di Capello is followed by fatal consequences to the snake-charmer himself, it is highly probable that the whole mystery resolves itself into courage, and the shrewdness with which, availing themselves of the uncommon dread and aversion with which this animal is regarded, they are able at once to prevent him from making use of his deadly poison fang, and to put forth their own sleight of hand. This explanation seems also to account for the very remarkable fact that men have ventured to domesticate this dangerous reptile in more places than Ceylon. Indeed, within the experience of Major Skinner, a thoroughly trustworthy personage, who has resided for many years on the island, and to whom the naturalists of the Expedition are indebted for many acts of kindness, an instance actually occurred in the neighbourhood of Negombo, in which a 
wealthy man, who keeps large sums of specie in his house, bethought him of the singular precaution of having several deadly cobras to watch the treasure in lieu of dogs. Day and night they glide about, a terror to thieves, while they are quite harmless to the inmates who feed them and attend to them!

In former times snake worship (Nagas) was universal throughout Ceylon, and, as in India, the cobra received divine honours from the natives, because it was supposed to be a metamorphosed king. This serpent, however, is so singularly and wonderfully endowed by nature, its appearance and motions are so peculiar, that an imaginative people like the Cingalese may well be excused for associating the idea of metempsychosis with its aspect of mystery.

From Galle, an excellent road, following the coast-line the entire distance, leads to Colombo, the seat of government, 75 English miles distant. Every morning there starts from Galle for that destination, the "Royal Mail" coach, an uncomfortable, somewhat dangerous, mode of conveyance, in which this distance is traversed in from 8 to 10 hours. In order to travel more at our ease, we engaged an extra waggon. In Ceylon people usually employ, on long excursions, but one horse, which is changed at distances varying from 6 to 10 miles. We had some difficulty in reconciling: this custom with our predilection for travelling at our leisure. The first few hours of our journey passed away very pleasantly; the road was excellent, and the 
country magnificent and charming. We seemed as though driving through a park inhabited by thousands of men, and planted with cocoa-nut palms-amidst which occasionally the white dome of a Buddhist temple, or the minarets of a Mahometan mosque, shooting up above the summits of the palms, imparted an aspect of life to the landscape-while in the gay bazaars that fringed the road, the few necessaries of life required by the exceedingly frugal natives were exposed for sale, temptingly arranged on palm or plantain leaves. The whole south-western coast district is so populous that the huts of the natives were continually in sight, right and left, under the forest shade, and the scenery in consequence seemed as full of life and careless enjoyment as though the people had nothing else to do but walk about under palm-trees. This impression was the more strengthened, that we rarely perceived a man with anything else in his hand than a Talipot leaf, or a Chinese parasol, to protect himself against the burning rays of the sun, which shone almost directly overhead. Of the women, on whom for the most part fall all the troubles and hardships of life among the Cingalese, we only saw a few carrying to the city heavy baskets balanced on their heads.

The luxuriant, widely-extending cocoa-nut forests, which on the south and west sides of the island stretch down to the sea-shorc (whereas on the eastern coast they are altogether absent), seem independently of the necessity of paying all due care to the maintenance of one of the necessaries of life, 
to be specially indebted for their existence to the circumstance that additional planting of this tree, as also its careful cultivation, is one of the religious observances and duties of the servants of Buddha. Whoever plants a cocoa-nut, palm, or bread-fruit tree, performs a work agreeable to Buddha. At the birth of a son, or on any similar festive occasion, it is customary to plant a few cocoa-nut shoots in the earth. Cocoa-nut palms form a very important part of the property of a family. The father divides them as heritable property into equal portions for bequest to his children. Not one single palm but has an owner, though instances occasionally occur in which several families are supported by the produce of a single palm!

This peculiar phenomenon has been followed by most remarkable results bearing upon the social condition of the native population. Increasing poverty, and the ever present grinding necessity of preventing any further subdivision of the joint property, have impelled the natives to resort to the unnatural remedy of the brothers of a family having but one wife among them! The fact that there are in Ceylon fully one-tenth more men than women, was the cause of the rapid spread of this custom, and upheld Polyandria, or plurality of husbands, as a desirable invention for remedying the deficient supply of females. Many a female has three, four, or even seven husbands, and all children that are born of such a wedlock have equal rights, and are (differing in this respect from the law of Hindostan, by which only the 
children of the eldest brothers are registered, as the entire property belongs to him, while all the younger brothers serve him as vassals, and can be driven by him out of the house), the lawful, recognized heirs of the different fathers. In order to guard against the rise of law-suits respecting birth and heritage among the Cingalese, in consequence of their local customs, the British courts of justice, singular to say, find themselves constrained to recognize this disgraceful custom, and to interpret the law with reference to it. Although in the maritime provinces plurality of husbands has been signally on the decrease, owing to foreign influences, it still prevails to a great extent in the interior of the island. The submissiveness of the Cingalese to their superiors and their monarchs is assigned as the origin of this in other respects very ancient custom, which seems to have been universally in use among the various races of the mainland of India from time immemorial. Constrained to apply their own manual labour in cultivating the land of their tyrants, and frequently to accompany them on distant journeys, they thought they could, during their absence, most surely protect their own fields and crops against utter ruin, by apportioning wife and chattels among brother's and nearest relatives, and thence the family tie was gradually converted into a socialist community.

The almost endless cocoa forests, which we were traversing by splendid, broad, level roads, not alone provide the native with, to him, the most important necessary for supporting 
existence, but the fruit itself forms at the same time so important and valuable an article of produce, that the cultivation of the cocoa-nut has been regularly and systematically carried on by European enterprise since 1841at present covcring an area of 23,000 English acres-while the proportion of native land on which this, the most useful growth of the tropics, is cultivated, amounts to about 100,000 acres. Formerly, the nuts were shipped to foreign parts for the extraction of their oil; but for this purpose there are now on the island itself, especially in Colombo and Galle, a considerable number of manufactories, at which the oil already expressed from the nuts is usually at once put into casks for exportation. The quantity of oil thus exported annually is estimated at from $1,000,000$ to $1,500,000$ gallons, worth from $£ 100,000$ to $£ 150,000$. Besides this, the elastic fibre of the outer husk of the cocoa-nut is used in the manufacture of ropes, door-mats, \&c., and, under the name of Coir, forms an important article of export, the annual consumption averaging between 30,000 and 40,000 quintals (centner weight), worth from $£ 20,000$ to $£ 25,000$.

The first station on leaving Galle for Colombo is Bentotte, where, as is the custom all through the country, there is a "resting-house" open to all travellers, similar to the "Choultries" in India, the "Caravanserais," or lodgings for pilgrims, in Eastern countries, or the "Pasangrahans," of Java. These resting-houses, which all through the interior of the island are found on the highways and forest roads, 
are among the oldest institutions of the country, and were formerly maintained at the expense of private individuals. The resting-houses, which have been erected under the English rule on the main roads of the island, are in all respects of a far higher class, and strongly resemble the waiting-rooms of our own (German) railroads. One is not merely provided in these with shelter, but also with food and drink, at a fixed tariff. A special committee (the Provincial Road Committee) is appointed to superintend the management of these resting-houses.

Here we partook of a luxurious "tiffin," as the customary meal between breakfast and dinner is called in Ceylon, as well as throughout India ; and in so doing, made acquaintance for the first time with the renowned Indian dish "Curry," which consists of flesh or fish prepared with a powder compounded of spices. It tastes so hot that the European palate only gets accustomed to it by degrees; but in these countries it is looked on as the favourite dish, which must never be absent from any meal, because the cayenne pepper plentifully sprinkled over it, stimulates the stomach and promotes digestion. Hence the curry-powder is in immense request, and is largely exported. The assertion that this dish was first invented by the Portuguese is quite erroneous, as the chronicles of the country establish that it was in request in Ceylon in the second century before Christ.*

* According to Professor Wilson, "Curry" is but a corruption of the Carnatic term Majjkki-Kari, a dish composed of rice, sour milk, spices, and red pepper. 
As we mounted into our vehicle again, after a short halt at Bentotte, in order to resume our journey to Colombo with a fresh horse, we perceived that our driver, a negro, had been too free of his visits to the brandy-bottle, and occasionally took to rolling on the box. In the hope that he might become sober by the way, we ventured to proceed, but ere long he lost his balance, and fell to the ground, compelling us, to avoid further mishap, to retrace our steps on foot to the nearest village-thus reversing the order of matters, and, so to speak, escorting our horse, coach, and driver. This occurrence, unimportant and hardly worth mentioning in itself, was the occasion of an interesting adventure. As it was only with much difficulty that we could make ourselves intelligible to the natives, we resolved to apply to the authorities in the very first place we came to. It turned out that we were in the vicinity of the Catholic mission of St. Scbastian de Makùn, whose superior was a Benedictine from Rome. The church is situated amid the rich vegetation of the primeval forests, the gigantic trunks of whose trees, supporting a huge diadem of luxuriant foliage, are arched into a natural dome of the most graceful proportions. With curiosity whetted to the uttermost, we advanced along a beautiful path, beneath cocoa-palms, cabbage trees, breadfruit trees, screw pines, tree-like ferns, and broad-leaved bananas, till we reached the dwelling-house of the Mission, and introduced ourselves to the missionary. Forthwith the latter, a tall, stately figure, with handsome features and 
cultivated manners, and dressed in a woollen robe, ushered us into a darkened chamber opposite, and received us most cordially. This worthy priest, by the name of Miliani, was not less surprised at being visited at this solitary mission by Austrian travellers, and with the most lively satisfaction and the utmost readiness to oblige, offered us all the assistance in his power. In spite of our hurry, we had to take a cup of coffee à la Romagna, with our hospitable missionary, and to promise to visit him on our return journey. Father Miliani has already lived many years in this country, and ministers to a Christian community of more than 1000 souls. Altogether there are in Ceylon about 50 Catholic missionaries under a Bishop whose residence is in Colombo. Our priestly host was greatly respected by the Cingalese, but he evidently was overjoyed at being able once more to express his thoughts and feelings in his native Italian.

It was evening ere, with many a hearty shake of the hand, we tore ourselves away from the cordial hospitality of St. Sebastian de Makùn. Horse and driver this time gave hope of faster progress. But we were doomed once more to experience a severe disappointment, and although we were only about 10 or 12 miles distant from Colombo, which was our destination, it took us five long hours to get over the ground. The night was very dark, but the road was continually illuminated with torches of palm, carried by the homeward plodding natives, which emitted a gloomy light alternating with showers of sparks. 
When at last we got to Colombo about midnight, pretty well knocked-up, we comforted ourselves with the reflection that the inconveniences attending personal transport between Galle and the scat of government, can by no means be classed among events of rare occurrence; since, in conscquence of the inveterate obstinacy of the native horse, one must have recourse to the most incredible expedients to get the carriage under weigh. For instance, at every station the ears of the post-horse were twisted together and then suddenly relaxed in order to set the vehicle in motion; and, when this torture failed, a pole, or thick stick, was inserted under the tail of the recalcitrant, and rubbed up and down till the poor animal, smarting under this painful operation, took to the collar. Once the carriage is started in this extraordinary fashion, the coachman swings to and fro at the peril of his life, and endeavours by continually "pitching into" the horse, to keep him at the gallop. Thus between whooping and whipping the next station is reached, where the same trial of patience awaits the traveller, and a similar martyrdom for the next horse.

Our first business the following morning was to take a walk through Colombo, which, like Galle, consists of "The Fort," or White City, and the "Pettah," or Black Quarter, in the latter of which are situated the houses and shops of the natives, and where the chief traffic and the greatest activity are combined. Here one rarely encounter's a white man, for even the soldiers and police belong to the brown 
and black races. The natives, however, manifest, outwardly at least, a great respect for the whites, and everywhere draw aside reverentially when one makes his appearance.

In the middle of the main street are some Buddhist temples. We were not, however, permitted to enter, unless we consented to take off our shoes. At several of the natives' houses the entrance porch and windows were gaily adorned with plantain leaves. On inquiring of our Cingalese attendant what was the occasion of this manifestation, he replied in broken English that the inmates were celebrating "Christmas," wishing probably to express that the natives celebrated a feast analogous to our Christmas.

The filth and unsavoury odours which prevail in the Black Quarter, and the noise and yelling of the natives, speedily drive visitors back to the European portion of the city, which altogether, with its gloomy, decayed aspect, makes anything: but a favourable impression. The public buildings, the houses of the mercantile community, the warehouses, and fortifications, all bear the impress of the Portuguese settlement of bygone centuries; and as its commerce is attracted more and more every year to Galle, ${ }^{*}$ there remains but faint hope that this quaint type will not ere long be effaced by a new style of building, albeit the inluabitants of the capital promise themselves a restored reign of activity and energy, as the result of railway communication with Galle.

* The value of the produce exported annually from the island (cliefly cocoa-muts,

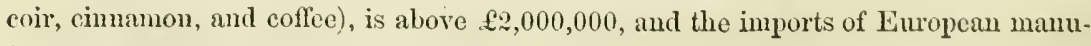
fictures are abont the same amoiut. 
During our random promenade through the streets of what is called the Fort, we perceived at a sugar-baker's in Chatham Street-the most select quarter of Colombo, and containing the most important warehouses, which, however, are far from elegant in their appearance-some rough ice offered for sale, which had a curions effect in a town so near the Equator, and presenting such few evidences of luxury in other respeets. This ice is brought round the Cape of Good Hope from the United States, and is chiefly shipped from Boston. The daily consumption of iced-water, ices, and so forth, is estimated at about 1000 lbs., costing about one shilling the $8 \mathrm{lbs}$. It is impossible to repress a feeling of astonishment at these speculative Yankees who, despite all obstacles interposed by temperature, transport in all direetions and over thousands of miles an article so perishable, so easily destructible as ice, and are able to drive a profitable business in it in the hottest and most diverse regions of the globe-in the West Indies and South America, in Asia, and in Africa.

The traveller who visits Colombo will hardly fail to make an excursion to the Cinnamon Garden, in order to inhale the fragrant and peculiar aroma, and enjoy tasting the tender rind of this remarkable shrub, which plays so conspicuous a part in the listory of Ceylon. During the palmy days of cinnamon culture, the fire principal cimnamon plantations of the southern half of the island extended some 15 or 20 miles. For this one lucrative product of the soil all others 
on the island were abandoned, with most deplorable consequences. The cinnamon culture, a monopoly of the various governments which one after another conquered Ceylon, and domineered over its inhabitants, was carried on, especially by the Dutch East India Company, with terrible severity. The slightest embezzlement of cinnamon, or wilful damage to the plant, was visited with death. The unintentional breaking off of a twig of the cinnamon bush was punished with amputation of the offending member. Every cinnamon bush, even to those growing in the gardens of private individuals, was the property of the Gorernment, and the cinnamon collector, or even cinnamon-peeler alone, had the right to strip off the rind when ripe. To destroy such a plant, or even to dispose of it to any one, was regarded as a crime affecting life. The labourers, who were employed in the cutting off, peeling, and preparation of the rind, belonged to the caste of Chalias, and constituted the lowest grade of that class. In like manner, under the English rule, the monopoly of cinnamon was at first continued, with such disastrous consequences to the trade that it was finally abandoned in 1832, and the merchants of Colombo and Galle were left to divide among themselves the exportation of this important article, under an exporting duty of $3 s$. per $\mathrm{lb}$. These duties, however, were found much too high, as the highest price obtainable in Europe was from 6s. to $7 s$; and this advance in the price to the trade of the genuine article, was the cause of foreign merehants turning their 
attention to the supply of various species of cinnamon-bearing laurels and cassias, growing in Cochin-China and Java.

When Gorernment, recovering at last from its delusion of treating cinnamons, which at first had seemed indigenous to the island of Ceylon alone on the earth,* as a national monopoly, reduced the export duty to one slilling, and ultimately repealed it altogether, the various substitutes had already found their level in Europe, as affording a larger supply at a much more moderate rate, and the cultivation of the finer kinds became less and less each year. Prices fell, and the consumption was diminished. Only the coarser sorts repaid exportation. Nay, it even led to the interesting and curious result, that just as, previous to the high price under monopoly, the low-priced cassia displaced the finer sort of genuine cinnamon, at the present day the coarser sorts of cinnamon are beginning to oust the cassia from the English market, whence all the world are supplied. At present there are from 14,000 to 15,000 acres planted with cinnamon, chiefly in private hands, and producing annually from 800,000 to $900,000 \mathrm{lbs}$. of cinnamon, worth from $£ 40,000$ to $£ 50,000$ stcrling.

* Sir Emerson Tennent, in his work (vol. i. p. 599), challenges the assertion that Ceylon is the native country of the cinnamon-tree. In no European or Asiatic chronicles is any mention made of cinnamon as a product or article of comsnerce in Ceylon up to the end of the thirteenth century. Although it was from the earliest times imported into Europe from Africa through Arabia, the natives trading with Ceylon first knew of the existence on the island of this important shrub about the twelfth or thirteenth century. Hence Sir Emerson looks upon Africa as the native country of the cinnamon-tree. 
The chalias, moreover, are no longer, as formerly under the Portuguese and Dutch, adscripti glebe for life, or slares that could be purchased with the soil, but free labourers, who are entitled to demand proportionate pay for the lightest services rendered.

The Cinnamon Gardens in the neighbourhood of Colombo, although for the most part gone to decay, nevertheless impart to the whole scene a singularly cheerful, agreeable aspect. The bushes, from 4 to 6 feet in height, with their smooth, beautiful, light green leaves, resembling those of the bay-tree, and their pale, yellow flower-stamens shoot up doubly fresh and succulent, from the snow-white quartz soil in which they best thrive. The flowering season of the cinnamon is in January, and the fruit ripens in April, when the sap is richest in the shrub. In May the bolighs are begun to be "barked," which process continues till October. The pruning and gathering of the yearling shoots, which are about the thickness of a man's thumb, is very laborious, and employs many hands. Each labourer cuts off as many as he can conveniently carry in a bundle, then, with the point of a crooked knife, made for the express purpose, strips the entire rind from the wood, carefully scrapes off the exterior corticle and innermost layer, and lays the stripped-off cinnamon rind, now reduced to the thickness of parchment, in the sum, where it dries and curls together. All round the hut, in which the peeling of the rind is carried on, is diffused a most exquisite aroma, caused by the breaking of the leaves 
or twigs. What is related, however, by varions travellers of the fragrance of the cinnamon forests, which they have scented at a great distance seaward, would seem to indicate that this delicious odour emanates from various other aromatic plants in which Ceylon is so rich, rather than the cinnamon groves, the aroma of which, indeed, is not perceptible beyond the immediate vicinity. The best description of cinnamon is not so thick as stout paper, and is finegrained, flexible, light brown, or golden yellow, sweet and pungent; the coarser qualities are thick-skinned, dark brown, acrid, stinging, and leaves a bitter after-tastc. In the warehouses, the cinnamon rinds and canes sorted for shipping are piled upon each other, packed in bales of about 90 lbs. weight each, and carefully sewed. In all cavities and spaces between each layer an immense quantity of pepper is strewn, to preserve the cinnamon during its seavoyage, by which both spices are benefited, the black pepper absorbing all the superfluous moisture, and gaining by the fragrance of the cinnamon.

Consequent on the diminution of cinnamon cultivation, which undoubtedly has resulted in great measure from the altered taste of mankind and the consequent extraordinary falling off in the demand for this once highly-prized spice, the cultivation of coffee in Ceylon has, during the last 20 years, increased tenfold; and it is solely owing to the dearth of arailable labour that this branch of produce, considering the splendid profits it returns, is not even more extensively 
carried on. In 27 districts there are 404 coffee plantations, covering a surface of 80,950 acres, of which, however, only 63,771 acres are really productive. These produced last year, 347,100 cwt., or $5 \frac{1}{2}$ centners per acre. To this must be added the quantity under cultivation by the natives, who possess about 36,000 acres of coffee plantations, and in the year 1859 alone, exported 180,000 cwt. We may safely assume, therefore, that the cultivation of coffee is on the eve of transforming this island of Ceylon, from a mere military station of England, into one of the most flourishing colonies of the British Empire. Twenty years ago there were exported barely 60,000 centners, worth $£ 180,000$. In September, 1858, the export exceeded 600,000 cwt., which represented on the spot a value of $£ 1,500,000$ sterling. " "When capital and labour shall have become more plentiful," remarked to us a by no means over-sanguine resident, "Ceylon will have in its mountain districts 240,000 acres planted with coffee trees, yielding at the lowest estimate, 1,680,000 cwt. of coffee annually." Here, as among the high table-lands of Guatemala and Costa Rica, we have the reassuring evidence how one of the most important plants for the civilized man can be profitably cultivated, without having recourse to the blighting influences of slave-labour, at the same time making the lands in which it is produced both rich and prosperous.*

* The coffee-tree frequently suffers, especially in Ceylon, from an insect called the coffee-bug (Lecunium Coffec); as, however, this troublesome insect has only infested 
While the cultivation of the coffee-plant has been followed by such splendid results, the repeated attempts to introduce the sugar-cane have been on the contrary as uniformly failures-so that of the numerous plantations established by Europeans, there are at present no more than five remaining. In all those localities where the temperature seemed adapted to the growtl of the sugar-cane, the nature of the soil, and the too great humidity have prevented its thriving.

On the other hand, the island possesses two natural products in which but few spots on the globe are qualified to enter the lists with her, and which may be expected to increase in value and importance in proportion as science assumes her share in their exploration. These products are PEARLS and precious stones.

The most productive pearl banks lie on the west coast of Ceylon, between the 8th and 9th degrees of North latitude, near the level, dreary beach of Condatchy, Aripo, and Manaar. The pearl fisheries are a monopoly, and, therefore, under the inspection of the Government. Former governors had counted too much on the abundance of this natural treasure, and in their blind haste to fill the coffers of the State, had so exhausted the banks, that suddenly, from a source of revenue they became an item of considerable deficiency, and, from 1838 to 1854, could no longer be dredged. From

the coffee plantations since 1848, and this branch of cultivation has nevcrtheless increased so surprisingly since then, there seems no reason to dread that the coffee plant will suffer by these bugs, in the same manner or to the same extent as the vine by the ravages of the fungus. 
a net annual return of $£ 120,000$ sterling, the yearly return had sunk to $\mathfrak{E} 10,000$, of which nearly one-half was consumed in the attendant expenses. Now-a-days the work is gone about more circumspectly, a scientific examination having been made by a native naturalist, Dr. Kelaart, of all the oyster banks on the west coast. We had the pleasure, while at Colombo, of becoming personally acquainted with this very able, unassuming gentleman, who presented us with several memoirs of his own, touching upon the latest facts that had been ascertained with reference to the pearl oyster. One special result of his varinus researches has been the demonstration of two facts of the utmost importance to the pearl fishery, and which hitherto had not been fully ascertained-that this mollusc possesses locomotive powers; that its occasional disappearance is perfectly natural; and that, moreover, the pearl oyster may, without any injury, be transplanted from one locality to another-nay, even from salt to brackish water. The first-named observation explains the occasional disappearance of the pearl oyster from certain beds, * even when they have not been inordinately thinned

* This singular property of the oyster, in virtue of which it can be fed to as confirmed obesity as a prize-ox, and admits of nearly as much dexterity in "crossing," if we are to trust the palates of "gomrmets," as the Southdown and Leicester breeds of sheep, has received its most extraordinary development in the vicinity of New York, where the amount of eapital sumk in the oyster trado consilerably exceeds

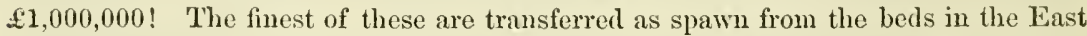
River, or Idong Islant Sound, to the "nurseries," which aro situated in the brackish water near the head of the tide-way, just below the "Highlamds of the Hudson." Here they are carefully tended for some months, till, their education being completed, they are re-transferred to their native heds, and fed there with oatmeal daily; 
by too keen a quest after gain; the latter opens up the pleasing anticipation of the pearl oyster being susceptible of very extensive propagation, by a process similar to that of pisciculture, or artificial breeding of fish (such as the colonies of edible oysters which are met with in the South of France), by transplanting them to such places as seem best suited to the conditions necessary to their highest development. What a splendid conception it were to plant the sea-coasts of Ceylon with pearls, and thus throw the wealth of the island in precious stones into the shade, by the treasures she would possess in the depths of the sea!

Exactly at the period of our arrival at Colombo, the preparations were being resumed at Aripo for the take of the oysters, which commences at the beginning of February each year, and lasts about three weeks. It is, in fact, a sort of jubilee time for the people, at which the Governor and numbers of the wealthier classes mingle with the populace. Ordinarily this spot becomes at that season a rendezvous for the poor and the wretched, and a rallying point for all manner of abominable odours, filth, troublesome flies, and intolerable heat, despite which drawbacks the fishery is visited by thousands of boats, and hundreds of thousands of men, who flock hither with the alluring prospect of speedy and abundant wealth, or have been attracted from all parts of the Indian Continent by the singularity of the spectacle. Sud-

while, by some mystery of the craft, the spawning season is postponed, except in the ease of those that are selected for propagating the race. 
denly, as though evoked by the wand of a magician, a regular town starts into existence, of tents, or eren neat huts, with bamboo and cabbage-tree palings, roofed over with palmleaves, rice-straw, or coarse thick woollen cloth; booths for the sale of merchandise "rise like an exhalation " during the night to supply necessaries of all sorts to the converging multitudes from the interior, as well as the fleets of visitors from seaward; and last, not least, the divers themselves. Swindlers and mountebanks throng hither, adroit thieves creep stealthily about, all Indian customs and fashions are represented, all castes jostle each other. Priests, and the subordinate hangers-on of the various sects, hurry about, and jugglers and Nautch girls vie with each other in amusing the noisy multitudes.

The result of numerous experiments has proved that no diving apparatus can replace the human machine, the cost of which, moreover, is a fixed definite quantity, viz., the fourth part of the pearls brought up, which is the diver's share. In each boat, or "Dhonie," are ten divers, each having an assistant. Before the divers proceed to descend, a number of quaint ceremonies are gone through, and incantations murmured, as well in the boats as on shore, by the so-called "shark-charmers;" indeed, the superstition of the divers, who for the most part come from the Coromandel coast, is so great, that not one of their number, Christian or idolator, would continue in this employment without the countenance of the sorcerer; and the Government finds itself compelled to 
pay the impostors.* They levy a tribute of ten oysters upon each boat.

Accidents with sharks are of rare occurrence: the noise of 1000 divers on the water at once seeming to scare the animals. Morcover, the dark colour of the skin of their bodies, acts as a considerable protection to the divers, so that there are numbers who blacken their legs, in order still more to alarm the monster. $\dagger$

After these preliminaries, the divers go down into the water, each carrying a basket-shaped net, in which to bring up the oysters, when selected-a stone of from 15lbs. to 25lbs. weight being fastened round the body, so as more readily to enable him to sink to the bottom. When at a depth of some 5 or 6 fathoms, the diver unfastens the stone, which is forthwith hauled up. He now throws himself forward on his face, and keeps himself as close as he can to the ground, while he rapidly rakes up and collects together all that is within his

* In 1857, the chief shark-charmer was a Roman Catholic!

+ An encounter in the water between a shark and an expert swimmer, armed only with a knife, is not so unequal an affair as might at first be supposed. The pearl fishers of the Gulfs of Panama and Nicoya only use a short stick, with which, if the sharks get above them, they stir up the mud, under cover of which they swim along the bottom for a little distance, and then shoot up to the surface. Of the equality in which a good swimmer armed with a knife feels himself in encountering a shark, there are numerons instances. Many years ago, when shipping was more plentiful in Kingston Harbour, Jamaica, than at the present day, vessels had occasionally to put up with somewhat awkward berths, when they used regularly to "foul their anchors," whereupon it became necessary, of course, to send some one down to free the cable. For this purpose, negro divers were employed, and one man attained a wide reputation from having limself, nuscathed, slain in fair combat at different times, no less than five sharks! Ultimately the sharks steered clear of any black man who had a knife suspended round his neck. 
reach, so as to fill his landing net. He crawls along in this manner during the minute of his submersion, over a space of from 40 to 50 feet; and so soon as he pulls the cord attached to his plaited basket-edge, it is immediately hauled up, and he himself speedily follows it to the surface.*

The utmost depth at which the diver can safely remain seems to be about 40 feet, beyond which blood is apt to issue from the nose and ears. They seldom remain above 50 or 60 seconds under water, although cases occasionally occur in which the stay under water is protracted to 80 seconds. The diving is carried on for 5 or 6 hours without intermission, so that each of the ten divers can, in the course of a day, bring up from 1000 to 4000 oysters. By dint of good fortune, and close packing, about 150 oysters are brought up in each basketnet, while occasionally an unprolific bed does not give more than five or ten oysters. So soon as the oysters have been dragged to land, they are sorted in shares, of which one goes to the oyster fisher as his remuneration, and the remainder are sold in lots of 1000 each to the highest bidder. Now begins speculation. Chance presides here, quite as capriciously as at a lottery or another game of hazard. It often happens that a single oyster contains thirty or forty pearls, of which some may be worth a sovereign on the spot;

* The divers are mostly old men, vigorous and healthy in appearance, thus dispelling the general notion that deep-sea diving weakens the boly and shortens life. We were told of one diver, employed during the year 1856, in the pearl fishery, who was so stont and fat, that in addition to the ordinary diver's stone, he had to make fast a considerable weight to his body, in order to sink himself in the water. 
but it more frequently occurs that several hundred oysters do not yold a single pearl. The small, valueless pearls, called also "seed pearls," are burnt down; and sold as pearl-lime to the wealthy Malays, by whom it is used as a luxurious addition to the betel and cabbage nuts, as masticatories. 'The Ceylonese mix the lustreless pearls with other grains, witl which they feed the poultry, in whose croops the pearls regain their former brilliancy after a few minutes' grinding. The croop is then slit up, and the glittering stones extracted, white as the most beautiful pearl-muscular tissue.*

The pearl oysters caught on the coast of Ceylon are all of the same species (Meleagrina Margaritifera), uniformly oval in shape, and about $9 \frac{1}{2}$ inches in circumference. The number taken in Ceylon annually nust be numbered by millions. In the year of our arrival to Ceylon (1858), the pearl fishery yielded 224,120 . According to the last returns, before us as we write, there were in the year 1859, 1352 boats engaged during eighteen days in the pearl fishery, the gross take of which amounted to $9,534,951$ oysters, sold for $£ 48,216$. The divers' shares amounted together to 2,126,749 oysters.

The wide-spread popular delusion, that the pearl in the

* This method of procedure, which is adopted by the rest of the Indian races, and in which the lustreless pearls are swallowed by hens, pigeons, and ducks, so as to be polished up, after being subjected to the preliminary digestion of these birds, has been proved to be anything but beneficial to the pearls as regards loss by attrition. Careful observation has established, for example, that four pearls, weighing twelve grains, have lost four grains by undergoing this process during twelve hours, while eight others, weighing thirty grains, were reduced to twenty grains after a sojourn of two days in the gizzard of a duck. 
oyster is but a produce of disease in the animal, has long been refuted by scientific research, and although the great German poet, Henry Heine, in his "Romanzero," sings,

“Those world-famed pearls,

They are but the wan mucus

Of a sad oyster,

Dimly sickening in the depth of the sea!"

it is rather a poetic fancy than a scientific fact. We have latterly been especially indebted to the German naturalist, Theodore von Hessling, for a very circumstantial and thoroughly exhaustive memoir on the natural history of the pearl oysters and their pearls, ${ }^{*}$ in which the learned author seeks to establish that the enveloping matter of the germ of the pearl is identical with the covering of the animal, and that in the process of growth two influences are at work, an external and an internal. The first is called into play by the property peculiar to the hinge system that unites the double shell, of gaping wide open, in consequence of which extraneous substances rush in with the current of water, such as minute fragments of quartz, molecules of plants, \&c., which, being detained either circling in the cavity, or eddying round the hinges, are seized on in the course of their revolutions, and entangled in the parenchyma of the various organs, which is specially secreted from the mantle, till it becomes enveloped by layers of solid shell. On the other hand, the internal development

- Die Perlen-Muschel, und ihre Perlen, Naturwissenschaftlich und Geschichtlich mit Beriicksichtigung der Perlen-gewässer Baycrns, beschrieben von Theodor von Hessling, Leipzig, 1859. 
is closely allied to the conditions of deposition and subsequent growth of the shell-matter. Molecules, either a single grain or congeries of grains, varying from 9.01 to 0.05 of a line $\left(\frac{3}{4}\right.$ of an inch down to the $\frac{1}{240}$ th of an inch), enclosed in the epidermis of the shell, constitute usually the nuclei of the pearls, which, to a certain extent, may be considered as nothing but a portion of the epidermis not applied to the formation of shell. The pearls also are simply independent concretions growing in the creature, and consisting of the substance of theshell, which are with difficulty discriminated from the various descriptions of growths which constitute the inner surface of the shell.

The great importance of the pearl as an article of luxury and commerce, has naturally led to numerous attempts to manufacture them by artificial means, in the course of which extraneous bodies have been introduced between the mouth and shell of the animal, sometimes with, sometimes without injury to it. The Chinese especially are adepts at placing certain small bodies, specially prepared, in the shells of the pearl oyster, which, after a short time, becomes coated with mother-of-pearl, or nacre. This manufacture of artificial pearls is carried on on a large scale in the neighbourhood of Hong-Chow-Foo. During our stay at Hong-Kong and Shanghai respectively, we ourselves saw several musselshells, in which a mother-of-pearl covering had formed over small neatly carved figures, mostly sitting figures of Buddha, ${ }^{*}$

* The antiquity of this experiment is proved by the fact that the Topographia of Ischiliang speaks of a pearl, which had been sent to the Imperial Palace at Pelin,

C C 2 
the singular appearance of which would, at the first glance, tend to make the observer suspect that the pearl had been fastened to the mussel by some adhesive substance. But we had so frequently an opportunity of satisfying ourselves by actually witnessing the entire process, that we could no longer doubt that the carved figures are with the utmost care introduced into the animal, and, after remaining a few days in the water, become attached to the mussel by a distinct membrane. This, their membrane, afterwards becomes interpermeated by the calcareous matter, till, finally, layers of mother-of-pearl are deposited all around the nucleus, the whole formation corresponding with the chalk-like concretions occurring in other creatures.

Besides the pearl-shells, the northern shores of Ceylon, especially between the Island of Manaar and Karativoe, are especially rich in beds of a volute mussel (Turbinella rapa, or soluta gravis), which are exported in great numbers to India, where the Hindoo women saw them into rings of all sizes, to be worn as ornaments on the arms, legs, fingers and toes. The chank-shell is likewise a chief instrument of the Buddhists, who, amongst other devout customs, blow three times a day on this sacred shell, to summon believers to worship.* It is also used as a festive ornament of the Indian

490 B.c., which resembled Buddha, and apparently must have been produced by this same method; although likewise the priests of Buddha, at that early epoch, might not have objected, in the interests of their religion, to make capital out of such a specimen of artistic skill.

* According to the most ancient annals of the Cingalese, the chank-shell is sounded 
temples, as well as a donation to the dead, which, inspired by a religious feeling, the survivors place in the grave alongside of the corpse of their illustrious departed.

The gems found on the island are distinguished, less for their intrinsic value than for the great variety of precious stones which are present. They are, with few exceptions, found to have been disengaged from the primitive rocks, and washed into the alluvial soil, especially in the outskirts of the nountainous districts, where they are rolled along the beds of the streams together with other pebbles, or are washed out of the alluvial deposits. Hitherto, they have only been searched for for purposes of trade, and then only in the most desultory and thriftless way, no one having as yet examined the rocks themselves, by the disintegration of which the valuable stones are disengaged. There was, indeed, no detailed information as to the wealth in precious stoncs of the island, until the researches of the English mineralogist, Dr. Gygax, who has very lately published on this subject many interesting observations and remarks. The locality in which precious stones are most abundant is, so far as present experience goes, the district of Saffragam, the capital of which in consequence takes the name of Ratnapoora, or Anarhadnaporra, "the city of rubies." They are. also found at various other parts of the island; in the plains on the West coast, between Adams' Peak and the sea, at

in one of the superior heavens of the demigods (similar to the conk-blowing Tritons of Grecian mythology), in honour of Buddha, as often as the latter wanders abroad on the earth. 
Nuwera Ellia, Kandy, Matelle, and Ruanwelli, near Colombo, as also in Matura, and the river courses on the eastern side, towards the ancient Mahagam. The geologist of the Expedition visited some mines of precious stones near Ratnapoora. These are situated on the Kaluga-Sella, a small tributary of the Kalu-Gunga, and lie, some in the very bed of the river, some on the steep bank. They are about thirty feet deep, but having been some time disused, they are full of water. The uppermost stratum of these pits or mines is a rich fertile yellow loam, exactly resenbling our diluvial loams. This is succeeded, according to the report of the proprietor of the mines, by a slimy black clay, and clayey sand, beneath which again is a bituminous clay, holding numerous organic remains, such as leaves, trunks of trees converted into a substance resembling lignite, and not infrequently elephants' tusks and bones of animals; thereafter sand, and lastly a bank of rolled gravel, forming a species of conglomerate with red, yellow, and occasionally blue claybeing, in fact, what is known as stone-gravel. This bank of pebbles is the layer in which the precious stones occur, and these are most commonly found between the larger masses of agglutinated matter, that are always found especially to abound in gems, whenever they are superposed upon what is called malave, which appears to be a sort of greenishcoloured talc-like half-decomposed mica. The most valuable stones that are obtained from these mines are rubies and sapplires. In the Kalu-Gunga, also, precious stones are 
occasionally washed down, and as the geologist of the Novara Expedition was descending the river in a boat, from Ratnapoora to Caltura, he perceived at several places, more particularly at the various rapids, men standing in the water, provided with flat pan-shaped baskets, in which they sifted the sand and pebbles.

The gems found on the island are rubies, sapphires topazes, amethysts, garnets, cinnamon-stone, and tourmaline. On the other hand, all the diamonds, emeralds, carnelians, agates, opals, and turquoises, which the natives offer for sale, are imported from India. One precious stone, on which the Cingalese set an exceedingly high value, because they erroneously believe that it is peculiar to the island of Ceylon, whereas it is also found on the southern shores of Hindostan, is the "Cat's-eye," a greenish transparent quartz, which, when polished in its natural shape, or" "en cabochon," exhibits in its interior a varying reflected light, undoubtedly arising from the presence of fibres of asbestos, and which, in fact, bears some resemblance to the eye of a cat. The natives, as a rule, estimate the value and symmetry of this stone by the brilliancy and tenuity of the beam which it emits, and the clear olive-coloured ground upon which it shines in relief.

A vast number of men give themselves up to the exciting but most uncertain occupation of searching for precious stones, and barter what they have found, chicfly to Mahometan merchants, for clothes and salt. As, however, the 
natives themselves set a high value on jewels, in consequence of their small bulk admitting of their being readily concealed and easily carried about, the finer descriptions are readily disposed of at a good price, and, singular to say, it has frequently happened, as we ourselves found by personal experience, that precious stones are dearer in Colombo and Galle than in the European markets! The explanation of this paradox is probably that the steady copious influx into the London and Paris markets of precious stones from all parts of the earth where jewels are found, admits of by no means such excessive fluctuations in value as at Ceylon, where the supply actually on hand is so varying, and where the value of the article almost always depends upon the rank and wealth of the Indian purchaser. The foreign traveller very often cannot restrain a feeling of surprise at seeing the fingers of the stately Mahometan jewellers adorned with rings of costly gems, which are only offered for sale to himself at an exorbitant sum.

The value of the precious stones of all sorts found in Ceylon in the course of a year is estimated by Sir Emerson Tennent at about $£ 10,000$, one-fourth, at least, of the entire quantity finding a market on the island, a full half being sent to the jewel-polishers of India, so that only the remaining fourth is exported to Europe.

The scant time allotted to us at Colombo was zealously occupied in seeing the utmost that we could of the many interesting objects that invited attention. Among others, we 
visited one of the largest industrial enterprises in Ceylon, known as Hultsdorf Mill, a cocoa-nut-oil factory, the proprietorship consisting in shares, of which the largest holder is David Wilson, Esq., the Austrian Consular Agent. Here are carried on all the various processes connected with the manufacture, the preparation of the oil-cake from the cocoanut, the expressure of the oil, \&c., which are carried on by apparatus, partly sent out from England, partly put up in this country, all set in motion by steam-engines. The task assigned in these factories to the natives, of whom above a thousand are employed in the various departments, is, nevertheless, not the less important and significant, that, while machinery is used in those processes where it is necessary to use an agency far transcending the powers of mere human labour, all collateral products, such as soap, candles, perfumery, as also the implements and tools required for the works, and even the barrels and chests required for the transport of the manufactures, are prepared and used by handicraft labour.

To the thoughtful visitor it is a scene of no ordinary interest to behold several hundreds of Cingalese, Hindoos, and Mozambique negroes, all thoroughly conversant with the management of the most magnificent invention of the nineteenth century. Here are a number of artisans employed at the hydraulic presses and iron turning-lathes; in another apartment the various parts of the different machines are being constructed or put together, which regulate the pressure of 
the steam supplied to the apparatus when in activity; in a third, persons are busy examining and testing the resulting products with scrupulous precision. With all its development, European industry has, in this quarter, exercised but an obscure influence; and, thus far, has been productive of but small results as a civilizing element among this population, which has hitherto shown itself so little disposed to accept the Christian form of civilization.

In the large warehouse belonging to Mr. Wilson, we also saw huge heaps of "Kauris," or Cowries, (cyprea moneta), the renowned, or rather ill-reputed, species of mussel, which comes from the Maldive Islands, and plays so important a part in the commerce with the coast of Malabar and the interior of Africa; while here, it constitutes the sole medium of exchange, which is used by way of barter for almost all sorts of agricultural produce, chiefly among the blacks.* These mussels are sent from Ceylon to London, and thence back to the Eastern Coast of Africa, and thus indirectly uphold the slave-trade, as the native merchants of that region barter these shells, so greatly sought after by all African tribes, as ornament, for negroes and negresses, who are in turn sold to the "speculators in human flesh." A ton of these shells, of which the smaller description are most

* The Malay name for this mussel is "beya," implying duty, toll, tax, thus learing it open to conjecture that that nation, in their commerce with the $\Delta$ siatic and $\Lambda$ frican continents, lave for untold ages employed the same principles of eurrency and expressions of valne as ourselves. 
in request, and therefore the most valuable, costs in Ceylon about $£ 70$ to $£ 75$.

To the kindness and active interest in our objects of $\mathrm{Mr}$. Wilson, in whose agreeable villa at Mootwall-the plan and method of construction of which reminded us of the beautiful planters' houses on the sugar estates of Louisiana-we spent the last night of our stay at Colombo, we are also indebted for a copy, with which he presented us, of the most ancient annals of Ceylon, inscribed with an iron graver upon Talipot palm-leaves in the highly-esteemed Pali language, and preserved between richly-carved boards of the costly wood of the Kalamander tree (Diospyrus Hirsuta). This carefully-preserved MS. includes, among others, the celebrated epic poem "Mahawanso," (an abbreviation "Mahantaman Wanso," "Genealogy of mighty men,") which recites under 100 heads, and in 9175 verses, the most important events connected with the interior constitution and history of the island, as also of all the battles fought by the inhabitants in foreign countries from B.c. 543 to the year 1758, A.D. Of these, the most renowned historic relics of the Cingalese, 38 chapters, of 262 pages 4to, were translated into English by George Turnour, Esq., an eminent Pali scholar, and printed at Ceylon, in the year 1837. Unfortunately, his earnest desire to publish the rest of this highly-interesting work was destined not to be gratified. The grave closed over him ere he could realize his wish. At present, however, there is a prospect of the translation of the "Mahawanso" being com- 
pleted by Mr. James de Alwis, a worthy follower in the footsteps of Mr. Turnour, chiefly through the munificence of Gorernment and of the Scientific Institutes, which were invoked to supply the requisite assistance for the prosecution of an undertaking likely to prove so unremunerative.

In addition to the copy of the "Mahawanso," we also procured a number of other important Cingalese MSS. on Talipot palns, which were made use of by Turnour, partly in his translation of the "Mahawanso," partly in his other works upon Ceylon, and which embrace numerous valuable historical details not comprised in the "Mahawanso." This complete collection of the most antique annals of the Island of Ceylon, in the purchase of which we were kindly faroured with the advice and assistance of Mr. Wilson at Colombo, together with a variety of other Cingalese MSS. on palm leaves, collected at a subsequent date, now form part of the collection of valuable books in the Imperial Royal Library at Vienna.

Besides Mr. Wilson, our very best thanks are due to the Colonial Secretary, Sir C. J. McCarthy, who had the kindness to provide several of the members of the Novara Expedition with the requisite letters of introduction to the authorities in the interior of the Island: also to Mr. John Selby, the rery obliging proprietor of the Examiner; to Dr. Kelaart, physician and naturalist; to Charles P. Layard, Esq., the Government Agent for the Western Provinces; and to Captain Gosset, Surveyor-General, for their numerous 
attentions. The last-mentioned gentleman very kindly provided us with a pair of level-tubes which we urgently needed for one of our levelling instruments, and which, in this quarter of the globe, were more rare and difficult to be met with than pearls or precious stones.

Our return from Colombo to Galle, was not less marked by misadventures than our journey thither. As far as Caltura, where our amiable Father Miliani was in waiting for us with his neat single-horse equipage, to convey us to the beantiful parsonage of St. Sebastian Makùn, all went tolerably smoothly with us. We arrived, as had been concerted, to breakfast with this hospitable shepherd of souls. On our way to the parsonage, we noticed that great respect was paid to the worthy Father, by such of the Cingalese as met us. Their usual salutation was to bend themselves to the earth, veiling their eyes at the same time, and bending forward the outstretched head as though to implore a blessing. Father Miliani, who held the reins in his left hand, while his right hand flourished a long heavy whip, slightly inclined his body upon the cabriolet, and so dismissed in peace the poor folk that besought his benediction. When we had now got pretty near the parsonage, we were suddenly brought to a halt by a couple of natives, of whom one implored the spiritual ministration of the Father for his wife, then lying almost in articulo mortis, while the other had brought with him, from the sacristy of Makùn, the Communion-plate required for the purpose. The priest, to whom this 
interruption seemed to come as a matter of course, stopped, apologized for the unexpected delay, threw the reins to one of the party, sprang from the waggon, and disappeared in the gloom of the forest. It was not for long, as it proved; for the stately, handsome, figure of the priest of Makin presently appeared between the cocoa-palms. He had found the woman much less dangerously ill than he had been led to expect by the report of the husband, the native converts to Christianity being very much given to requesting the administration of the rites of the Church, upon being attacked by the slightest indisposition, because they anticipate much more benefit from spiritual treatment than from the medicines of their body-curers. And now we proceeded on our way to the parsonage at a smart gallop, which, however, did not prevent a zealous, much-believing Cingalese from keeping up with the mettled horse, stride for stride, for the entire distance, keeping close to the waggon as he ran alongside. We were not then aware, indeed, whether this violent bodily exercise was undertaken as a matter of choice or as a penance, but it seemed to us, in any case, an act far less meritorious than prejudicial to health.

In St. Sebastian de Makùn, the entire community were awaiting our arrival, and escorted us by a romantic hill, and through a delicious palm-forest, to the priest's abode. Here we found the porch of the house gaily adorned, and metamorphosed with tropical fruits and flowers into a smiling fragrant bower, with the feathery leaf of the cocoa-palm cut 
into thin strips. The inventive ingennity of the Cingalese had endeavoured to represent the various birds found in tropical forests, which were suspended in ornamental baskets of green leaves among the festoons. Over the entrance to this bower, improvised ont of materials supplied by the primeval forest, was placed a picture painted by the good Father himself, representing a large anchor, with the superscription in Italian "La speranza non confunde!" (Hope never disappoints!) This was evidently a delicate allusion of our kind-souled entertainer to the hope which he had expressed during our previous visit, that he should see us on our return from Colombo, "which had not been disappointed."

In the interior of the arbour appeared an elegantly appointed table, that seemed ready to give way under the weight of good things spread upon it, around which were placed a number of arm-chairs, worked in tapestry, while the plastered floor was strewed with the glistening green leaves of the Ficus religiosa. As soon as we had taken our seats, the members of the community, consisting of more than a hundred tawny, half-naked Cingalese (principally men and children), arranged themselves in a circle, and some half-dozen dancers began to execute a very ordinarylooking dance to the sound of a drum. The entire figure consisted in their simply approaching each other from opposite sides, during which they struck the hollow-sounding instrument pretty sharply, holding it in their hand the while, after which they drew away from each other, and wound 
up by dancing round in a circle in couples. A boy of eight, in glittering costume, next performed a dance, in which he was accompanied by a grown-up Cingalese who sung, occasionally accompanied by drum and fife. Frequently we enquired what was the meaning of the rocal accompaniment to the dance, but could get no information upon the subject. But we have always had occasion to remark among the various primitive races, that they are rarely able to give any connected account of the history of their dances or even their songs, but simply go through a set of mechanical figures which they have learned, or rehearse a set of words by rote, without being able to assign any signification to either. Over and over again have we put the question, only to receive the same stereotyped answer from Hindoos, Negroes, Chinese, Malays, and Polynesians, that they could tell us nothing more than that these songs and dances took their origin in the "olden times." Breakfast was served in the arbour by Cingalese boys. As often as the hospitable Father turned to apologize for his scanty means, which prevented him from ministering to our entertainment as he could wish, some new dish would be forthcoming, or some fresh kind of wine would be produced, till one knew not which most to admire, the variety of the entertainment, or its cost in preparation.

On inquiring of Father Miliani, in the course of conversation, whether he had any acquaintance with the plants to which the natives ascribe healing properties, he sent for a 
phial containing an oily substance, which, according to the Cingalese herbalists, is composed of 57 different roots and as many flowers, and has already been wonderfully efficacious in cases of persons bitten by poisonous serpents. It is called by the natives, Visanili-Katail (oil against poison); and the pricst of Makìn remarked to us, he had himself had an opportunity of satisfying himself as to the marvellous curative qualities of this vegetable substance, in the case of persons who had been bitten by the most venomous snake in the whole island, the Cobra di Capello, who had entirely recovered by the copious use of this antidote. The application is very simple. The mouth is rinsed out with it, and the patient further takes from 15 to 20 drops of the oil internally. Unfortunately, we were not able to inquire more particularly as to the ingredients from which the VisaniliKatail is compounded, of which we eventually got a small quantity to carry away with us, after much entreaty; but by way of compensation, Father Miliani was able to give us much valuable information as to the manners, customs, and traditions of his flock. He regretted, however, that they were all of a highly impassioned strain, and that they constantly passed from one extreme to the other. The following trait, which was pointed out to us by the Father in the course of conversation, may serve to indicate the modes of thought and observation of the natives. When the Cingalese perceived how eagerly and with what warmth of friendship the Father received us, they inquired of him whether he had 
been previously an acquaintance of ours, as they were unable to conceive the existence of such hearty good-will between persons who were utter strangers to each other. The priest, readily appreciating the results which must flow from the reply he should give, in confirming the devout souls of his children, replied that the reputation of his name had long since penetrated to us, and we were unwilling to ride by without turning aside to salute him, to which he had readily expressed his assent, and had also long since been apprized of the important mission of the Austrian ship of war, whose commander was termed by the natives, with the bombast of their native tongue, "King of the Sea." At.our departure, the kind Father presented us with several interesting articles, as souvenirs of Makùn, while we, on our part, left with him a donation in money to defray the expenses of erecting his church.

Father Miliani, the band of musicians, consisting of ten or twelve wild-looking fellows, with all manner of barbarous musical instruments, of which they made not less barbarous use, together with a laughing, yelling, gesticulating crowd of half-naked Cingalese, with long raven locks floating over their shoulders, accompanied us to our travelling chariot. Here we took leave of the hospitable Father, the vehicle set out on its route, and the whole brown retinue at once dispersed.

Hardly had we left the Mission of St. Sebastian Makùn behind us, cre our troubles began afresh. At almost the 
very first station we came to, we had to hire a horse from a resident at an exorbitant rate-the animal belonging to the station, and which had been engaged for us, being utterly useless. This gave occasion for fresh delays. The party letting the horses was what is called a native doctor, who assumed the title of "native vaccinator," and bitterly complained, that for his attendance four days in every week, as required by the law, for the purpose of inoculation, he only received from Government a monthly salary of $£ 25 s$. sterling. Whatever deficiency existed in his salary, he seemed determined to make up for in the hire of his horse, which he charged for at the rate of ten shillings for six miles! On the cash being forthcoming, our "native vaccinator" did not disdain himself to take the reins, and, with his own hands, apply the whip to his mare between the shafts of our vehicle. But this mark of distinction was destined, ere long, to cost us dear. Hardly had we proceeded a couple of miles under his care, when the hind-wheels of the vehicle sunk into a rut, whence our Esculapian steed lacked the strength to extricate us. To complete the sum of our misfortunes, at the very moment we were using our utmost endeavours to replace the waggon on the regular track, it came on to rain heavily, and we were, in a twinkling, wet to the skin. Some thirty young Cingalese, in the full dress of Adam before the Fall, who were standing open-mouthed round the waggon, could only be roused by threats from their passive attitude; and when, finally, they lent a hand to

D D 2 
assist, they, in their ill-timed zeal, came near oversetting the waggon into the ditch on the opposite side. Next, we exchanged this stubborn brute for one that was blind. For a brief space we hoped the latter might probably be the more easily driven in consequence of his not seeing what was going on around lim; but these anticipations were speedily dispelled, and in a rather unpleasant manner. The short distance that now separated us from our destination seemed as though it would never have an end; and, in a word, it was already verging on midnight ere we reached Galle, where we had been expected to dinner five hours before, by our hospitable friend, the Consul for Hamburg. Some of the invited guests had already left this agreeable house, while others were still seated at the whist-table, as, wearied and exhausted, we entered the drawing-room. The circumstances that had so seriously delayed our arrival were explained by way of apology, and proved the subject of some goodnatured quizzing on our misfortunes by the guests present; and in such agreeable society, and over a sumptuous supper, we speedily forgot the trifling annoyances of om latest experiences.

In the course of a desultory agreeable conversation about the natural beauties of the island, many were the plans of more distant excursions which we projected this eveningwhich, however, upon more mature consideration, all proved impracticable, owing to the scanty time at our disposal. Thus we found ourselves, much against our wishes, com- 
pelled to forego a visit to Kandy, and its beautiful environs, in which is situated the renowned temple that enshrines the tooth of Buddha, the occupation of which by the English was, in the eyes of the Cingalese, the most manifest indication of their being the legitimate conquerors of the kingdom.* Neither were we able to take part in an elephant hunt, although these animals are found in the island in such quantities, that it is related, with every appearance of accuracy, of a single elephant hunter, the late Major Rodgers, who was struck dead by a flash of lightning a few years since in the midst of the forest, that he had, in the course of his life of active exercise, laid low fifteen liundred elephants with his own hand! But permission was granted by the commander of the Expedition to the geologist and one of the zoologists to remain in Ceylon, and rejoin the frigate at Madras by the steamer which runs fortnightly, so as to enable them to ascend the world-famous Adam's Peak, 7000

* The legend relating to these relics, about which so many wars were waged, goes back as far as the third century of the Christian era, when Mahasana, a true believer, having become King of ,Ceylon, purchased these teeth for numerous valuable presents, of one of his kindred, a Calinga king in Bengal, who sent them over by his princes. The tooth Dahata Wahansa immediately achieved a miracleit illumined the entire island, and supplanted all heretical teaching. It was forthwith enveloped in a hundred cloths, and a temple erected to enshrine it, since which it has been regarded as the Palladium of Ceylon. When, in 1560, this tooth was transferred to the temple at Manaar by the Portuguese under Constantin de Braganza, the ling offered the Portuguese bigots 600,000 pieces of gold by way of ransom. Braganza judged it more advisable to destroy the tooth. But he little knew the adroitness and subtlety of the Buddhist priesthood. The very next morning the tooth, that had been supposed to be destroyed was marvellously found in a Lotos leaf in the temple, where it had been deposited by Buddha himself! 
feet high, one of the loftiest peaks in Ceylon, where, according to tradition, the founder of the Buddhist doctrine, when last he visited the earth, in answer to the supplications of a priest, left behind the print of his footstep (Sri-pada), as a visible sign of his presence.

We cite, in the following extract, the most prominent features of this venture, as supplied by the two members of the Expedition who undertook it, so as to complete the description of the Novara's visit to Ceylon:-

"On 13th January, 1858, we proceeded from Colombo to Ratnapoora, en route, to visit Adam's Peak, a tolerably long. and tedious journey. On the margin of a river we encountered an elephant, who was engaged in assisting the labourers on the public roads in that vicinity. While our car and the baggage were being embarked here, and again put in order, this animal went through a number of tricks, such as swaying to and fro, lying down, raising his trunk, and trumpeting, the latter of which, at a sign from his driver, he did with a vengeance, and for so doing was rewarded with a few plantains. These exercises seem to constitute the first steps in taming, as they were gone through in a similar manner by all the elephants we afterwards saw, whether employed like this one in task-work, or maintained for show, or made use of in the Temple service.

At mid-day we reached Ratnapoora, and as we were anxious to shorten as much as possible our next day's journey, we decided on pushing forward in the course of 
the afternoon, as far as the little village of Gilli-Mali, seven miles further on. We had been provided by C. W. Layard, Esq., the Government Agent in Colombo, with letters of introduction to his deputy, Mr. Mooyart, at Ratnapoora, who, however, we unfortunately found was absent from home. Next day, however, we had unmistakable evidence that our letters had, very shortly after our departure, reached the hands they were intended for, by a variety of precautions which the hospitable gentleman must have at once arranged with a view to our greater comfort. While yet on the second-half of our road to Gilli-Mali, night overtook us, and we prosecuted our march by torch-light through the dense jungle. Our guides and porters had shown some reluctance to enter this jungle, partly on account of the swarms of land-leeches (litchies, as they are termed here, doubtless by a corruption of the English name), which are especially active during the night, partly from other causes of anxiety. Accordingly, they kept reciting Cingalese ditties, alternated with shrill yells, or shouted, so as to be heard at a distance; whether to drive away evil spirits, or to frighten the chetah or leopard, we could not ascertain. No long time elapsed ere we ourselves began to perceive traces of having been victimized by that most uncomfortable of guests, the land-leech. The naked Hindoos were incessantly occupied with pulling off these painful blood-suckers, and we had to call a halt from time to time, in order to loosen and carefully fling them away, as they had succeeded in reaching the skin, 
through the trousers immediately above the boot. They are found up to an elevation of 4000 feet above the sea on the mountains, chiefly in damp or wet localities, and are most active during the evening and night in the selection of a victim.

At Gilli-Mali, we fell in with Mr. Braybrooke, an English engineer, who most hospitably invited us to his bungalow, and with whom we conversed upon topics relating to Ceylon, till far into the night.

Next day we had to ascend the Peak itself; which is in so far a diffieult undertaking on the side from which we approached it, that one has gained no vantage-ground at Gilli-Malli, our last night's resting-place, towards reaching the summit, so that one sees it in its entire colossal height of above 7000 feet directly in front; whereas, in ascending from Kandy, one has already, at Neuwera Ellia, attained an elevation of 4000 feet, which can be performed in a carriage. We set out at 7 A.M., and after an hour-and-ahalf's march, gained the last village, Balahab-a-Dullu, in the Buddhist temple of which is kept a flat metal dish, adorned with silver rosettes, with which the imprint of the holy footstep is covered over at the season of the annual pilgrimage, On the table, before a colossal figure of Buddha, were strewn, as usual, a quantity of flowers presented by the faithful; these were the flower-shrubs of the Areca palm, Hibiscus, Alamanda, Tagetes; also, close to the wooden statue, are placed several small figures of silver or wood, 
3 or 4 inches long. The priest also showed us a magnificent manuscript of at least 1000 palm leaves, closely and beautifully engraved on both sides with Cingalese characters, which belonged to the temple, and was guarded with great carc.

At a solitary house on the road, we left our guides and porters to discuss their modest repast, which, in consequence of the strict ordinances of the Buddhist faith, consists of vegetable substances only. Reclining on a mat spread on the ground, each took a piece of green plantain leaf, scattered upon it a little rice which they had just brought with them, and some chili (red Spanish pepper), and thence conveyed their simple food to their mouth with the hand. This frugal meal was speedily concluded, and we once more pushed forward. From this point we had the dense covert of the high forest trees, the lofty foliage of which afforded a most agreeable shade, and kept us comparatively cool. The path, which consists simply of ravines, formed by the rush of torrents during the rainy season, is so steep that it seems like one uninterrupted flight of stairs, the steps of which seem partly constructed by Nature, partly by the hand of man. Frequently they are artistically chiselled in the solid rock; at one stupendous precipice a Cingalese monarch has had four flights, of 250 steps in all, hewn out of the living rock. Here and there, also, ladders have been contrived, the rounds of which are composed of pieces of bamboo bound together, by which one clambers up. The whole route bears marks of being much used, and is considerably 
worn, the stones being rubbed quite smooth. Under the damp shade of the forest are found a vast quantity of the most beautiful ferns and Lycopodium (Club-moss; or Wolf's-claw, as it is called in Sweden, whence the Linnæan name); from the delicate beauty of the Jungermania (Star-tip), to the tree-like fern, Filius Phyllophisidos, which vies with the giants of the forest. The more deeply sluaded spots are adorned here with beautiful balsams, a genus of plants which, besides being unusually Juxuriant and beautiful in this district, exhibits certain peculiarities of form not usually met with.

At one place, called Nihilabellagalla, there was pointed out to us, at a few paces to the side of the road, near a rugged projecting rock with a steep declivity in front, a narrow valley which seemed to be closed in by perpendicular walls of rock on the opposite side. This cul de sac, we were informed, was a favourite resort of numerous wild elephants. A shot fired at this point, with the gun directed towards the rocks opposite, returned a thundering echo.

By 4 P.M. the last halt, or resting-place, was reached, above which the singular-looking cone towers sheer overhead, some 500 or 600 feet high. The vapours which, during the entire day, had been playing about the summit, from time to time lifted like a veil, as though to indulge us with an opportunity of beholding this sublime mountain-peak under the magical effect of twilight. Our native retinue, which had gathered fresh accessions of strength at every place we passed, and now consisted of from $\mathbf{2 4}$ to 30 persons, showed no in- 
clination to proceed farther, but appeared desirous of passing the night at the last halting-place, which was nothing but a sort of hovel. It was only by a resolute expression of our determination to reach the summit the same evening that they gave in. Their reluctance arose from an idea that no one could with impunity pass the night on the highest point of the mountain-which, indeed, is natural enough, since the sharp nightair at such an elevation may well be prejudicial to the health of those who are not sufficiently protected against its attacks.

The last portion of the ascent is so steep, and so difficult, that all superfluous baggage was left behind, and we took with us only what was absolutely indispensable. Thus far we had seen occasional traces of elephants, sometimes so fresh, that they could not have been more than an hour old. According to a report of Major Skinner, the unmistakable marks of one of these animals was remarked in the year 1840 quite close to the rock which bears the sacred footprint! At the steepest points, iron ladders have been made fast, by which the visitor has to scramble up. There were, also, innumerable chains fastened to the rock, of every description and variety of link, which swung to and fro by dozens on either hand, some eaten away with age and rust, some forged quite lately, it being considered a meritorious work to provide such as a protection against the occurrence of accidents. By 6 P.M., we at last reached the summit, and were rewarded with a panoramic view of indescribable magnificence. The mists were almost entirely dispersed, and in the clear, calm, evening light, the eye wandered 
at pleasure over the vast, almost limitless, panorama at our feet, as far as the sea, barely visible in the grey distance. Bounding our view from north-west to east, the mountain ranges rose by three distinct terraces of hills, each behind the other, and in regular gradations, till they culminated in the highest peak on the island, the Pedro-talla-galla, which overtops Adam's peak by nearly 1000 feet, ${ }^{*}$ but presents no pre-eminent peak, similar to that on which we now stood. The remainder of the horizon was filled with low mountains, which gradually became more and more flat as they approached the coast. The followers of three religions,Buddhists, Brahmins, and Mahometans, stand face to face with each other on this space of barely a few steps, in order to bow before these visible emblems, in sincere devotion to the invisible Deity. The highest surface, which is nearly level, is of an irregular oval form, and is about 60 or 70 feet in length, by from 36 to 40 feet in breadth, and is inclosed within a wall 5 feet in height, with two entrances on the west and south, while the north-east corner is shut out by an artificially rounded rock, easily surmounted, however, by any one who ascends it. In the middle of this enclosure stands a block of rock some 10 or 11 feet high, which, on the extreme top, has a depression, the divine Sri-pada, or Holy Footstep. The adora-

* The precise relative elevations of the two mountains are, Pedro-talla-galla 8280 feet, Adam's Peak 7420 feet. Two other peaks of the main range are also higher than Adam's Peak, viz. Totapella $7 \gamma 20$ feet, and Kirrigal-potta $7 \$ 10$ feet, while the plains, or table-lands, of Welinani and Neuwera Ellia are, lespectively, no less than 6990 feet and 6210 feet above the level of the sea. 
tion consists chiefly of offerings of flowers which are brought up hither, and presented with innumerable genuflections, invocations, and exclamations of "Sadoo," which corresponds to the Christian Amen. The impressed foot-print is ascribed by the Buddhists to the last incarnation of Buddha, the gentle hermit Gautama; while it is regarded by the Brahmins as the footstep of Siva, and by the Mahometans as that of Adam, as being the spot on which the progenitor of the human race stood so long, doing penance after his expulsion from Paradise, until the Almighty pardoned him.

This depression, in which only the most unbridled imagination can see any resemblance to the human foot, is about 5 feet in length by $2 \frac{1}{2}$ in breadth, and is set, as it were, in a level stratum of mortar, several inches in height, by six in breadth, shaped to resemble the outline of the human foot. At its anterior extremity, it presents a straight line, on which the five toes are artificially formed by several tolerably thick, narrow crevices, filled with mortar, and about 8 or 9 inches in length, which jut inwards, the great toe being on the right or east side, and thus indicating that it is a representation of the left foot. At the heel end the setting of mortar is somewhat narrowed and rounded off. Over the whole affair a wooden temple with balustrades open on all sides, has been erected, which is fastened by iron chains to the rock, and to beams of rhododendron fastened on the N.W. side, outside the wall, to prevent its being swept away by the storms which, on this lofty, exposed peak, occasionally rage with great 
vehemence. These cables, as also several of the poles by which the temple was supported, were thickly hung with carved figures of Buddha enveloped in linen cloth, which, originally the votive offerings of pilgrims, and bleached by long exposure, fluttered in the breeze. On the front of the temple is erected a penthouse roof, shading a bench beneath, on which several of our porters, who regarded our impious presence, and still more impious admeasurements of the holy footprint, with a horror which they flattered themselves was unobserved, deposited their offerings of flowers, and humbly bent the knee. On the west side, under two small distinct roofs, were two bells, and quite apart, on the rock itself, and somewhat in the background, a smaller temple. Between the block of rock and the inner half of the enclosure, a small house has been erected, 12 feet long by 6 feet broad, which is used as a shelter at night by the priests who are on duty during the pilgrimage season,* in which we too took up our quarters. Suddenly, from the depths below there arose, through the unbroken silence of the night, a confused murmur, in which the sounds of human voices were plainly recognizable. The singularity of such a phenomenon produced a certain degree of excitement among our superstitious spectre-dreading followers, inasmuch as it had never happened that strangers undertook the ascent of the peak at night, seeing it gives trouble enough

* The dry season, occurring in the south-west side of the island from January to April, is likewise the chief season of pilgrimage, at the end of which the entire amount of the offerings, annually averaging from $£ 250$ to $£ 300$ sterling, is handed over to the High-Priest of Buddha. 
to reach the summit by daylight. By degrees we perceived a number of torches borne by natives, who, with loud and longcontinued cheers, set about slowly ascending the ladders. To the inquiries of our followers they made no reply; and we had, in a word, to wait a considerable interval, until, indeed, the leading torch-bearer had reached the summit, ere we were enlightened as to the object of this mysterious nocturnal visit. How great, and let us add, agreeable was our surprise at finding ourselves suddenly surrounded by a choice array of wines, with food of various sorts, which the overflowing hospitality of Mr. Mooyart had dispatched after us to the summit of Adam's Peak, together with his card, the whole being conveyed in huge baskets by the supposed spectres! A cheerful fire speedily blazed up, at which our tea and provisions were cooked, and, as may well be supposed, while, enjoying our delicate fare, we thankfully toasted the kind and thoughtful donor.

Deep silence once more fell on all around, no cry of any wild beast reached us at this elevation, no hum of insect broke upon the awful stillness. Our coolies lay cowering together around the drooping blaze, seeking some shelter against the night air. One division stowed themselves away in a second sleeping-house for priests, which had been run up some twenty paces distant, in which we also were in the end fain to seek shelter from the ever-increasing keenness of the air, the temperature of which fell to $54^{\circ} .5$ Fahr., where, with our wrappers drawn close around us, and stretched at full length on the bare rock, we awaited the approach of morning. 
The first faint glimmer of dawn invited us once more to the open air, in order to contemplate the wonderful aspect of Nature at this elevation. We had, after leaving Ratnapoora, taken barometrical and thermometrical observations, with the view of determining the elevation at nine different stations, which had been, wherever practicable, selected in such manner, that by means of them the various limits of certain classes of vegetation were indicated, which in many instances are marked out with extraordinary distinctness upon the perpendicular side of the peak. These series of observations, which were at the same time supplemented by investigations as to the temperature of the soil and of various springs, will be compared with the results of previous scientific visitors to the summit of Adam's Peak, and publisbed in another form. The geology of the isolated pinnacle of Adam's Peak, so far as the dense covering of primeval forests permitted us to observe, is uncommonly simple and uniform. The chief directions of the lofty chain of mountains in Southern Ceylon, separated from each other by level plateau-like depressions, is from S.S.E. to N.N.W., corresponding likewise with the chief directions of the strata of gneiss, of which these mountains are composed. The gneiss is uniformly of a species not often met with, studded with garnets, and between its strata are inserted single beds of hornblende-gneiss and splinters of pure hornblende, as also granulite-gneiss and pure granulite. The steep, final cone of the rock consists of a granulitic gneiss of varying texture from coarse to fine, and abounding in garnets. Every- 
where, even up to the highest summit, the gneiss is decomposed on the surface into laterit-like products. The huge blocks of brown ironstone, however, which are found near the summit, in the hollow path by which it is customary to ascend, owe their origin to the decomposition of the hornblende.

After these interesting observations, admeasurements, and investigations, made at the summit of the most remarkable peak in the world, had been brought to a conclusion, we set out on our return to Gilli-Mali, which we reached late at night. Here we found, at the abode of our hospitable entertainer, Mr. Braybrooke, a fresh guest, who likewise intended to ascend Adam's Peak the following day. This was the well-known Count Medem, a Russian gentleman, who has frequently traversed both the old and new worlds, and was now about making a second visit to China.* The next day saw us at Ratnapoora, from which point we continued our return journey on the waters of the Kalu-Gunga, or Black River, as far as Caltura.

Our boat consisted of two trunks of trees hollowed out and fastened together, upon which was erected a semicircular tilt, covered with the leaves of the Fan Palm (Borassus Flabelliformis), under which one might sit or lie at pleasure, sheltered from the sun. As the mail-car that runs daily from Colombo to Caltura was already full, we were compelled, in order to pursue our journey to Galle, to make use of the native waggon, or bullock-bandy. This is a two-wheeled cart drawn by oxen,

* Count MIedem died the same year at Shanghai. 
and covered with a semicircular tilt of palm-leaves, beneath which there was room for two persons to lie at full-length packed closely together. The oxen, of a breed that have humps and erect horns, are small, and walk with a quick, short tramp, while their entire bodies are tattooed with Cingalese characters and ornaments. The horns are usually adorned with metal tips, and frequently are dyed, the one red, the other green. The cross-piece of the pole is fastened to the neck instead of the customary yoke, and the cord for guiding the animal passes through the nose. The driver either strides along between the two oxen, or sits with his back to them on the pole. The rate of progression by this national conveyance is so slow, that the mail-car which left Colombo the day after overtook us long ere we reached our destination, and it was with some difficulty we reached Galle in time for the overland steamer which was to bring us to Madras."

At 6 A.n. of the 16th January, the Novara set sail from the roads of Point de Galle with light breezes off the land, and steered southerly in order to avoid the Basses or Baxos, a much-dreaded rocky shoal, traditionally alleged to be the remains of the island of Giri, swallowed up by the sea, and which, owing to the very strong current, require the utmost care to be observed, in order to avoid drifting right upon them.*

* A late surrey, instituted with the intention of erecting a lighthouse on the "Basses," proved a failure, in consequence of the ground having sunk in while an examination was being made by the diver, and left nothing but holes filled with water, in which, according to the report of the fishermen, besides fish and molluscs, sea-snakes are occasionally seen, of a light-gray colour, and about 4 or 5 feet in length. 
The evening before our departure, the Consul for Hamburg had requested from the Commander of the Expedition the favour of a free passage to Madras, on board our frigate, for a native of Berlin, named Neupert. This man had come to Ceylon a long time previously with a company of rope-dancers, and had at first made a good deal of money as an acrobat and juggler, despite the dangerous competition of the Indian practitioners, but had afterwards lost his all, and had been for some weeks in a pitiable plight. The request was at once acceded to, and Neupert came on board during the night. His luggage did not encumber him much. However, although the greatest part of his effects had disappeared in Galle, he fortunately had kept his various apparatus; and, by way of showing his gratitude for the free passage that had been accorded to him, professed his willingness, in the course of the voyage, to give us some specimens of his skill on deck. Accordingly, one fine afternoon, he gave us an entertainment out on the open ocean, which not alone hugely pleased the sturdy tars grouped together on the forecastle, but ultimately, in consequence of a collection set on foot for the unfortunate Berlin acrobat, procured him enough ready money to enable him to pass the first week after his arrival at Madras free from anxiety, besides supplying him with a fresh outfit.

Within a few days after our departure from Galle, several severe cases occurred of hemeralopia, chiefly among members of the ship's band. Every evening, as darkness set in, these men lost all power of distinguishing objects, and had to be led 
about like blind men. In Vienna, we had been advised by various physicians there, with a view to the confirmation or refutation of the popular belief, to try the use of boiled oxliver; * and, as one of the oxen shipped at Ceylon had been slaughtered, we were in a position to make the desired experiment, which, it must be confessed, proved eminently successful. This time, morever, several of those thus afflicted were treated with cooked pig's-liver, which was given them to eat, while the steam rising from the dish was applied to their eyes. But we had, on our return voyage, the most convincing proof of the efficacy of the liver of animals of the ox tribe in cases of night-blindness, when above twenty of those afflicted, after frequent relapses during the voyage from Valparaiso to Gibraltar, were treated in the last-named port with ox-liver, and dismissed permanently cured. $\dagger$

The voyage from Ceylon to Madras was, on the whole, monotonous and void of interest, with the exception of one single event, which no one on board is likely to forget for the remainder of his life. About 3.30 p.m. of the 2nd January, 1858 , there suddenly resounded from the hold, the astounding cry of "Fire! fire !" Everyone rushed, in the utmost excitement, on deck. It turned out that a by no means

* This cure is likewise very much resorted to, even of late years, among the Highlands of Seotland!

+ During the entire voyage round the globe, there occurred 75 cases of Hemeratopia ; the largest number of which, 60 , oceurred between Cape Horn and Gibraltar. The remainder were isolated eases, occurring at Rio, Ceylon, the Nicobar Islands, and on the voyage from Clina to Syduey. 
insignificant quantity of pure alcohol, which was stowed arvay in the liold for the preservation of specimens of natural history, had, from some unknown cause, caught fire. Forthwith the pumps were manned, the sails clewed up, all the portholes closed, so as to cut off the slightest draught, and all the hammocks of the crew trundled, péle-mêle on deck anyhow, out of the quarter-nettings, in which they are stowed away during the day, there to be dipped in sea-water, and in that wringing-wet condition applied, partly in extinguishing the flames, partly in preventing the fire from spreading. In less than a quarter of an hour the worst danger was over, and our wonted quiet restored, despite the first terrible excitement. On a more searching investigation, several of the tin carboys in the hold, filled with spirits of wine, and kept between layers of sand in iron chests, were found to have been corroded till the liquor had oozed through, while the air, having free access to the sand, had become strongly impregnated with gas. This atmosphere, impregnated as it was with alcoholic fumes, took fire on one of the sailors carelessly entering the hold with a badly-fastened lantern, and in a moment the light flames which speedily enveloped the man in such a confined space, at once gave the alarm. The full carboys remained uninjured by the fire. Had such a catastrophe happened, and the whole quantity of spirit (about 40 gallons) taken fire, considering the immense quantities of combustible matter we had on board, among the rest a ton-and-a-half of gunpowder, the upshot 
must have been of a far less agreeable nature. The extraordinary lightning-like activity displayed by the entire ship's company on this occasion was something wonderful. Each man seemed to have got wings. There was the most laudable emulation displayed by all hands in seeking to save the lives of themselves and others from such a terrible doom.

On the 30th January, at 7.30 P.M., we anchored in Madras Roads, so dreaded for their insecurity, about three nautical miles from the shore, and in 9 fathoms (56 feet English). Even in the calmest weather there is a tremendous surf on this coast, and from October to December, in which strong gales blow from the N.E., it is all but unapproachable. For this reason, so soon as the wind increases so as to endanger the ships in the roads, a flag is hoisted on a staff at the Master Attendant's office, that they may put to sea at once. On the second signal, all ships must quit the Roads for fear of being dashed through the surf upon the beach.

From the city we heard a running fire of musketry and some salutes with cannon, which, considering the prevalence of warlike rumours and movements in the then circumstances of India, made us conjecture that the natives of the Coromandel coast were also in insurrection against the English. However, we learned afterwards that the musketry and salvoes proceeded from the troops stationed near the drilling-ground, who were receiving their general on his return from parade with a salute. The following day (Sunday, the 31st January, 1858) 
the European community of Madras fell into a precisely similar error in consequence of our salute, which they, being at that hour assembled at worship, mistook for a much less peaceful and agreeable intimation, so that the majority, dreading an outbreak, hurried to their houses in deep anxiety.

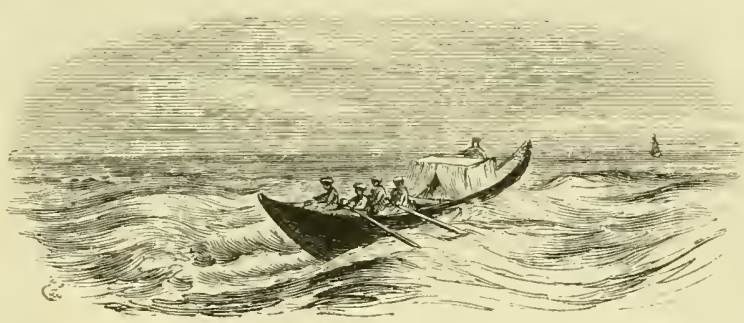



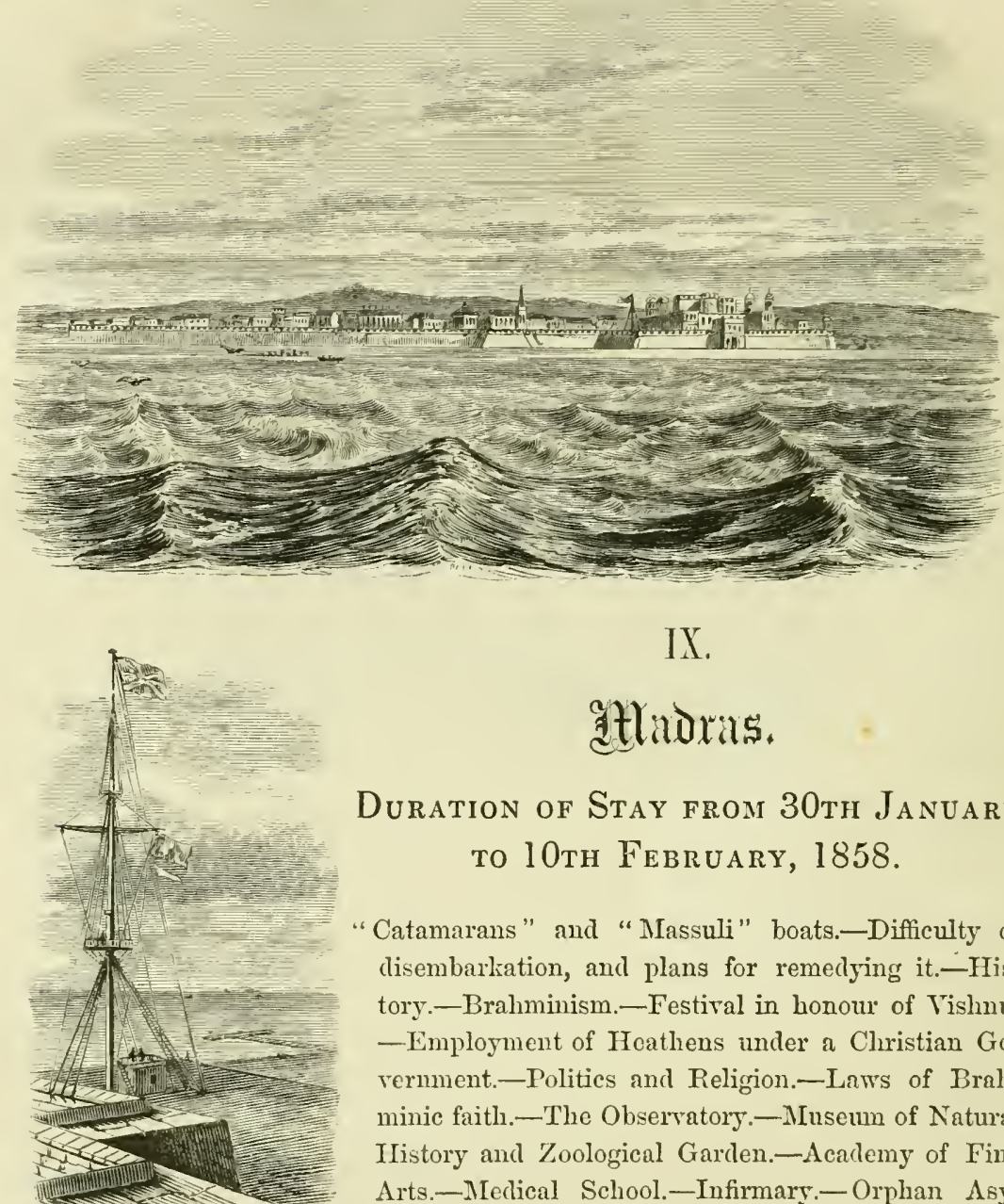

\section{IX. \\ attrourias.}

\section{Duration of Stay from 30 th January to 10th February, 1858.}

"Catamarans" and "Massuli" boats.-Difficulty of disembarkation, and plans for remedying it.-History.-Brahminism.-Festival in honour of Vishnu. - Employment of Hoathens under a Cliristian Govermment.-Polities and Religion.-Laws of Brallminic faith.-The Observatory.-Nuseum of Natural Iistory and Zoological Garden.-Academy of Fine Arts.-Medical School--Infirmary-Orphan Asylum.-Dr. Bell.-Lancastrian Method of Teaching Children first applied in Madras.CColonel Mackenzie's Collection of Indian Inscriptions and Manuscripts. -The Palace of the former Nabob of the Coromandel Coast.-Journey by rail to Vellore.-Fête given by the Governor in Guindy Park.-Visit to the Monolithic Monuments of Mahamalaipuram.-Excursion to Pulicat Lake.-Madras Club. - Fête in honour of the members of the Novara Expedition.- "Tiffin" and dance on board.-Departure from Mardras.-Zodiacal light.-Shrore Tuesday in the tropics.-Arrival at the Island of Kar-Nicobar.

The morning after our arrival in Madras Roads, a native boat came alongside, of the sort known as "Catamaraus," 
FROM POINT DE GALLE TO MADRAS.

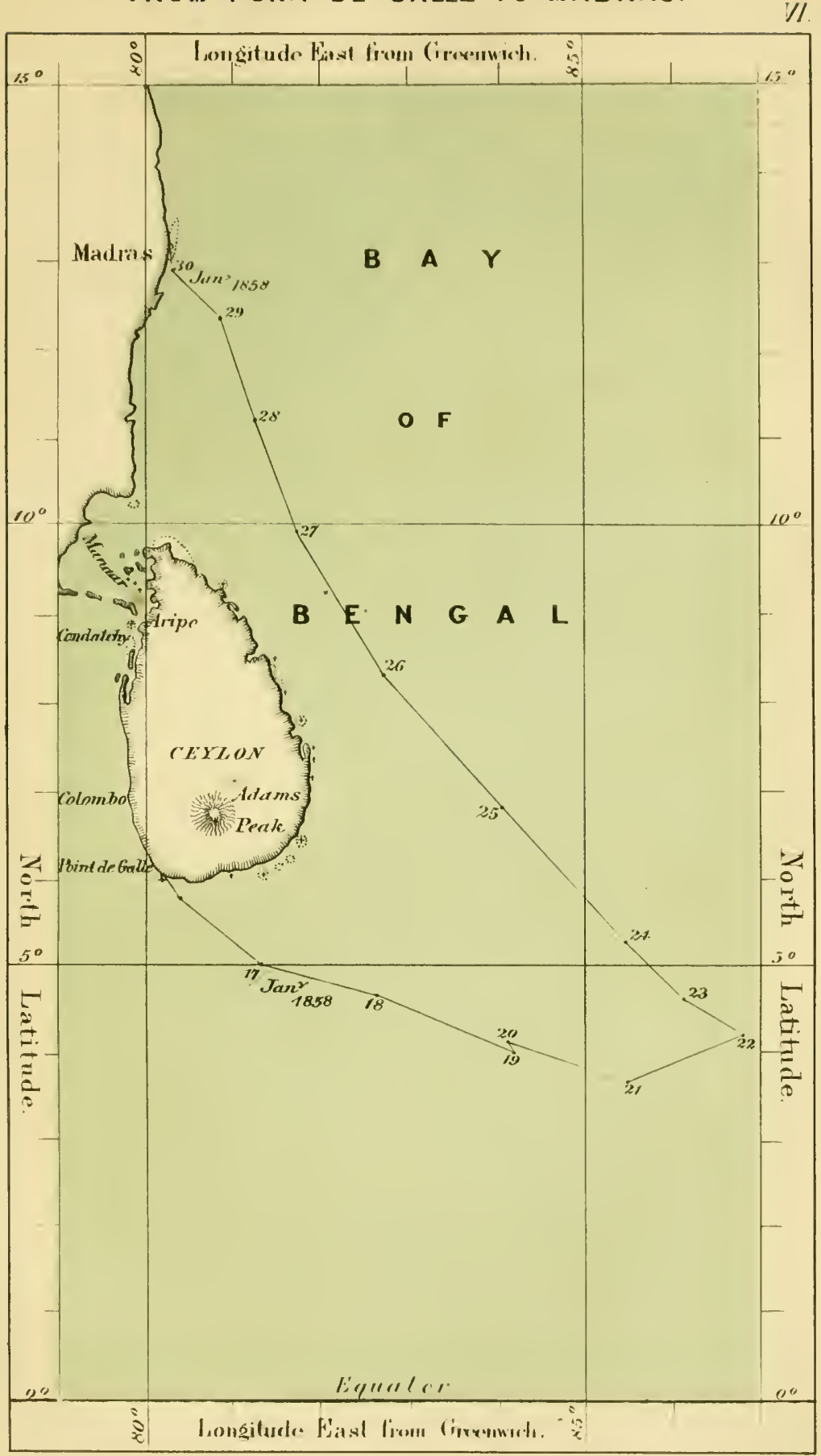



having on board two natives, who brought off from the authorities of the port the customary papers to be filled up. This extraordinary and very primitive boat consists of merely two or three trunks of trees bound together raft-fashion, on which these daring boatmen kneel. As a great part of their body is necessarily under water, they carry the papers and letters entrusted to them for transmission to the ships in the Roads, in turbanlike wrappings which envelope their heads. Ordinarily, these men are excellent swimmers, a most requisite accomplishment to enable them to regain their boats, in the event of being swept off by the waves, or to save themselves and others from the innumerable sharks, which frequent the entire Coromandel coast, and render it eminently dangerous. About noon, a larger boat approached us, manned by from 15 to 20 natives, who offered their services as caterers, washers, agents, servants, in short as "Dubashes," a sort of Hindoo factotum ; while each individual, shrieking and vociferating at the top of his voice, held high in the air, with outstretched arm, a number of written testimonials of ship-captains that had already employed him. These boats, called "Massuli," or "Musli" boats (from Muchly-fish), about 36 feet long by 5 or 6 in width, and in which alone it is possible to bring passengers and goods to land, are light, as flexible as if made of leather, and are fastened together with the elastic fibres of the cocoa-nut, being in every particular specially adapted to yield to the tremendous blows of the heavy surf, which a boat of ordinary construction could not possibly live through. They are for the 
most part pretty deep, and are usually manned with from 12 to 15 naked natives, who make use of an exceedingly smooth pallette-shaped paddle. In one of these boats, the officers of the frigate on leave, and the naturalists of the Expedition, were conveyed to land in the midst of a fresh breeze from the N.E. The more we approached the shore, the more formidable was the appearance of the tumultuous tempestdriven waves. Amid frightful yells and hurrahs, we passed in safety the first and second lines of surf. But we had yet to encounter the third, and by far the most furious. The boatmen spread a couple of cloths over our heads, to prevent our getting a soaking; the boat made several violent plunges forward, and was for an instant apparently covered by the tremendous foaming billows, but seemed to glide in a most extraordinary manner over these, and finally was neatly laid alongside the beach on the crest of the last breaker. This is the critical moment, and the most disagreeable, because the boat is, by this manipulation, thrown on its side, and one feels disposed to rush out, ere the returning wave throws the boat high and dry on the sand. The noisy shrieks of the boat's crew and Coolies, or Lascars (Indian porters), with which the disembarkation is accompanied, combine to render it still more annoying and unpleasant. One feels a sensation of satisfaction at having gone through this remarkable, and to some extent wholly peculiar, experience; but no one was ever known to cncounter it voluntarily a second time. The glowing picture, which numbers of travellers have drawn of the landing at Madras, might impress 
many readers with the idea that their representations were most probably tinged somewhat with a colouring of romance; but, in view of our own experience at what is confessedly the pleasantest season of the year, there can be at certain times no description, however vividly sketched, but what must lag behind the reality.

There could hardly have been selected a more unsuitable site for a city, than that of Madras, and it is only the circumstance that the entire Coromandel coast presents no more eligible haven, as also the importance of the place as the chief city of the Carnatic, which alone has a population of $5,000,000$, that has enabled Madras to boast a population of 700,000 inhabitants, and a commerce of such magnitude that 6000 vessels, British and foreign, are annually* cleared inwards and outwards, laden with upwards of 650,000 tons of produce and goods of a total value of more than $£ 8,000,000$ sterling.

The spot at which vessels anchor can by no stretch of terms be called a roadstead, being in fact nothing but an open strip of coast running nearly due north and south, so that during the N.E. monsoons, the sea that sets in is something extraordinary, and produces a tremendous surf. At no season of the year is it practicable to reach the shore by ordinary ship-boats,

* In the year $185 \%$, the number of trading vessels was 6241 , carrying 652,146 tons merchandise, of which 1438 were square-sailed ships; and 4803 native boats and Chinese junks. The imports of goods and metals amounted to Rs. 40,563,826 (about $\& 4,050,000$ in round numbers); the exports to Ris. $40,060,656$ (about $£ 4,000,000$ in round numbers). We are indebted to the kindness of Dr. Balfour for a variety of interesting statistical datu, the information contained in which must be transferred to the statistical portion of the Novara publications. 
because the beach, being utterly unprovided with any artificial appliances, is left in its natural state-that is to say, covered with fine sand, which lies so level that the depth is only nine fathoms two miles out at sea! Singular to say, no steps have to this day been taken to carry out the proposition, made many long years ago, of remedying this difficulty in reaching land, by the construction of a mole or pier, although three or four plans have already been presented by distinguished engineers. The last and most feasible scheme, and the most likely to be put in execution, consists in constructing a mole 1000 feet in length and 60 feet in breadth, to be erected upon iron piles driven into the sand, and with a cross-piece at the seaward extremity - the mole construction resembling the letter $T$. On either side of the mole, tramways will be laid down to facilitate the transport of goods that have been discharged. The entire cost of this undertaking would be about $£ 100,000$-an entirely disproportionate, and, indeed, insignificant amount, when one takes into consideration the important consequences which must result to trade and passenger traffic on the completion of this erection.

The earliest British settlement was at Armegon, about 36 miles north of Pulicat (or about 78 miles N. by W. of Madras). The cession of a piece of land by the native Rajah of Besnayor induced the president of the old factory at Armegon, Mr. Francis Day, to abandon the latter, and in the year 1639, the Fort of St. George was erected at the newlyselected station, where formerly stood the little Hindoo 
village of Ischinapatam. This fort formed the nucleus, at a later period, of the city of Madras, which is built on the flat alluvial soil along the coast, and at present comprises an area of about 30 (English) square miles. Its extent along the beach from north to south is about 9 miles by an extreme width of $3 \frac{3}{4}$ miles. Madras, like all the rest, consists of a White town, exclusively inhabited by Europeans, and a Black town, or Pettah, in which the natives and all coloured residents carry on business.

The White town, which, however, presents none of the carefully laid-out streets and compact blocks of houses involuntarily suggested by the word "town," but rather resembles a gigantic park, in which are situated a vast number of comfortable ornamental villas, rises at its highest point 20 feet above the sea; whereas the Black town, at several points-for instance, Popham's Broadway-is hardly 8 feet above the level of spring floods.

While in Ceylon we had had an opportunity of becoming acquainted with the influence exercised by Buddhism over the political and social condition of the island; here we, for the first time, found ourselves confronted with the followers of Brahmah. At the moment of our arrival, the principal festival of the year was being celebrated in honour of Vishnù, one of the three godheads of the Brahminical faith. It lasted fourteen days, and was celebrated with much pomp. Temples were improvised, and some dancing platforms erected for the female servants of the temple and "bayadères." In 
one of these dancing saloons, adorned in the most marvellous manner, a sort of altar rose in the background, richly hung with gold filagree work and stained cut-glass, and fringed with singular representations of the god. In the doorway stood, on the left hand side, a copy of the statue of the Venus de' Medici; on the right, of the Apollo Belvedere; on a small table were visible butterflies, fire-flies, and conchs, in ornamental glass cases. On the walls, of plain deal boards, were suspended on one side, adjoining the portrait of Anthony da Padua, a number of representations of voluptuous Oriental "odalisques;" on the other, near an engraving in copper of Carlo Barromeo, all sorts of obscene engravings, such as are offered for sale only in the most abandoned quarters of Paris and London, and then under the cover of night. For that matter, we believe that the Hindoo priests, who superintended the erection of this hall consecrated to the worship of Vishnù, gave themselves less anxiety respecting the subjects treated of in the pictures suspended round, than that the walls should appear richly decorated with engravings and pictures. Adjoining this half-open dancing booth for the women in attendance on the temple, rises the chief Hindoo temple in Madras, a stately edifice of blocks of syenite, and surrounded by a lofty wall painted with the usual white and red streaks; and on which a fleecycoated long-tailed baboon was performing his antics. Two gloomy pyramidal towers shoot up from the wall of the temple, and a beautiful colonnade leads to the entrance porch. 
A huge tank, almost resembling a pond, in which the Hindoos thrice daily performed their ceremonies, and went through their ablutions, lies in front of the temple, surrounded on its remaining sides by buildings for various purposes, while a stately elephant, specially consecrated to the service, is kept on the side next the temple, which carries up a pitcher of water every forenoon from the pool in front of the pagoda, one of the servants attached to the temple sitting on his back holding it, while a second, seated behind hin, keeps waving a fan in either hand. The elephant is first conducted round the temple and then inside, in order to present the water to the god. This elephant (which animal it seems is itself an incarnation of Vishnù) had the distinguishing mark of the sect, as also several other indications of a similar nature richly tatooed upon his huge broad forehead. Every evening during the continuance of the fourteen days' festival, the various temples and dancing booths were brilliantly illuminated with wax tapers and oil lamps, but admission was refused to the profane, and in the eyes of Brahmah, unbelieving Europeans, a rule which was everywhere enforced with much politeness but unvarying firmness. Moreover, everything that the hand of a European has touched is unclean to the Hindoo. Only the Pariah, or "outcaste," the very lowest class of the people, eats any food that has been prepared in the kitchen of a Christian.

The most substantial part of the festival, however, was 
fortunately not confined to the interior of the temple, but took place in the streets, through which, during the perior the festival lasted, immense processions of Hindoos, praying, singing, and dancing, used to pass every evening about 11 P.M. on their way from one temple to another, so that we were in no want of picturesque objects. First, a band of musicians would lead the way, with the peculiar little drum or tom-tom, whining pipes, and blaring clarinets. It was more like the noise of a lot of children's instruments than music. Next came a Hindoo riding on a gaily-bedizened $\cdot 0 x$, after whom appeared a number of girls and "Bayadères," dressed in white clothes, their hair richly dressed, and with rings through their nostrils, while the flaps of their ears were adorned with richly-gemmed ear-rings hanging down to the neck, and moving both hands and feet as they danced before the sacred figure, which was drawn along by 24 sturdy believers in Vishnù. The image was placed on a daïs thickly overspread with flowers, filagree work, and small mirrors, approached by steps, and with a parasol outspread overhead; in a vehicle in front was a sort of figure dressed up in flowers. On either side a multitude of torch-bearers strode along, with sulphurous lights and other means of illumination, or iron frames, on which were disposed in pyramidal form or like a bow, from 7 to 13 fireballs, which, let off at intervals alternately with Bengal lights and rockets, formed a veritable ocean of light. A tub filled with cocoa-nut oil was dragged behind, from which the cotton wicks were kept constantly replenished, so that the flames continued 
unintermittently. Wherever the procession passed the bystanders stood with hands reverentially folded. Many had the thresholds of their houses gaily adorned with flags and illuminated with paper lamps, others let off sky-rockets. From time to time, the procession halted for a moment, the female dancers formed two rows, and some of their number went through a sort of dance, in which they performed a set of stereotyped motions with their hands, and chaunted the praises of the god in a most monotonous chorus. Thousands upon thousands of Hindoos joined the procession, so that we could hardly make way through the crowds. The yelling, heat, odour of oil, and stink of sulphur were absolutely intolerable. As often as the procession paused, the noise was redoubled, the confusion became tenfold. Itinerant confectioners, who offered for sale all sorts of sweetmeats, prepared either from the kernel or milk of the cocoa-nut, drew back reluctantly when the eye of a stranger was directed towards their piled-up delicacies, through dread lest a mere glance from him should blight their stock in trade. On the other hand, we remarked some of these vendors pressing forward with eagerness to satisfy the curiosity of strangers by offering small samples of their eatables, so as the more easily to propitiate and get rid of these dangerous guests, and leave the poor Hindoo in peace and unharmed! As Christianity makes but slow progress among the Hinduos, and as the tendencies of the English residents in India do not point, as of yore among the Spaniards in America, towards the violent conversion of the heathen 
natives with the alternative of annihilation, but rather towards political and commercial influences, we find the British Government regarding with placid indifference the abominations of Hindoo worship, which, even to this hour, take the form of laceration of the flesh and self-immolation, rather than, by ruling with the strong hand, fan the religious fanaticism of the multitude, without the possibility of Christianity becoming a gainer. Among the thousands upon thousands who were celebrating the festival of Vishnù in such a heathenish fashion, there undoubtedly were many who are in the employ of Government, which has no scruples about appointing Hindoos of all sorts to the various posts in the public service. The English State Church which held that such appointments tended, not very indirectly, to support heathenism,* earnestly remonstrated against the practice, but the Government becoming daily more convinced that the doctrines and homilies of the Christian faith continued to be entirely a dead letter among the Hindoos, seems to hold fast to a policy of seeking gradually to introduce Christianity and European civilization among the Indian races, by means of equality of rights and assimilation of laws, by a system of well-organized national, trade, and industrial education, and, above all, by the influence of personal example. This, to be sure, is a very slow and arduous method of conver-

* The East India Company even undertook the maintenance of the Hindoo temples, and defrayed the receipts of the annual festival in honour of Tishni out of the revenues. There exist in the Presideney of Madras alone 8292 Hindoo temples, with an annual revenue of about $\$ 100,000$, all under the protection and control of the Company. (See "India, Ancient and IIodern," by David O. Allen, Boston, 1856.) 
sion, inasmuch as a life of religious observances is more deeply intertwined with the very foundations of the social system in India than in any other country of the globe, and fairly blocks the way against the expansiveness of European civilization. For as simple as the Hindoo religion appears in its primitive principles, the proper observance of its various rites is proportionately difficult, and full of subtle distinctions for the sincere Hindoo believer.

The worship of Brahma, according to the doctrines enunciated by Brahma's own lips in the Vedas, or holy books, took its rise in the adoration paid to the powers of nature, regarded as so many divinities, especially in the exalted transcendentalism of their ideas respecting the sun, the moon, the stars, and the firmament. Thence was readily developed the belief in a sole, eternal, Almighty Creator and Ruler of the world, Brahma, represented as having four faces looking to the four quarters of the globe, and reposing on a swan. This simple monotheistic belief was gradually developed into the divine manifestation of Brahma as a Triune divinity, namely, as the Creating power (Brahma), the preserving power (Vishnù), and the destroying, and at the same time renewing, energy of nature (Siva).

Although the revelation of Brahma has long since been completed, while Vishnù and Siva are still active agencies in the world as Supporter and Augmenter respectively, Brahma is assigned a very inferior rank in the worship of the masses, although, according to the lawgiver Menù, the Moses of India, 
be created the Brahmins out of the substance of his head, to guide and instruct man; from his arms the Chetriyas, to protect and defend him; from his trunk the Veisigas, to nourish and support him; and, lastly, from his feet the Sadras, to serve and be the property of all the other castes.

To Brahma, the fulness of whose existence no earthly notions can embrace, there are no temples dedicated, these being rather erected in honour of Vishnù, the Intercessor and Supporter, who manifests himself in the atmosphere and in water, and Siva the destroyer and regenerator of the various races, as also to, the other divinities whom the Hindoo religion numbers by millions, although the majority of these have several names, and the lower classes are simply Avatars, that is incarnations or manifestations, of the superior deities. This peculiarity of the Hindoo religion makes it impossible correctly to classify or define Indian mythology. The god Rama, for example, is frequently named for Krishna, and the latter again for Vishnù. Vishnù, on his part, sometimes figures as Rama, when he is to destroy Ravana, the tyrant of Ceylon, or as Buddha, in order to found Buddhism. Like the Proteus of Grecian fable, the Hindoo mythology assumes a thousand different shapes,-it is, in short, Pantheism in its most perfect development.

A zealous Hindoo requires about four hours of each day to get through his religious ceremonies, these being performed at different periods, as he must bathe in the morning, at noon, and again at night, in a tank or pool before the temple, and 
recite certain prayers. For purposes of recognition, the two chief castes wear special marks, the worshippers of Vishnì having a triclent painted on the forehead in either white or yellow, while those of Siva, on the other hand, sport three horizontal stripes, or one round spot marked with the ash of burnt sandal-wood. Many Hindoos write on their foreheads the distinguishing insignia of both Vishnù and Siva, and look thus the more strange and peculiar.

After every ablution these marks are painted afresh, and with much care upon the forehead, so that paint and rougeboxes play an important part in a native household. No Hindoo can partake of his exclusively vegetable nutriment, if cooked in a European kitchen, such being entirely contrary to the principles of his faith. Every servant, therefore, leaves his master regularly at noon, in order to partake of his simple meal of rice and vegetables, either with his family or in one of the numerous Hindoo cook-shops. The frequent holidays of the Hindoos, of which there are twenty-one within two months, seriously interfere with trade among the natives, and still more with the instruction of the young.

Hindooism, however, appears to have lost much of its originality by constant contact with Europeans, and by the various political revolutions, and although many of these ceremonies are still kept up, and the bodies of their dead are still burned on pyres, yet the modern Hindoo has so far relaxed from his ascetic austerity, as to admit of his being employed in the various pursuits of active life. And it is not a little sur- 
prising to see these handsome, tall, brown figures, with their insignia of Vishnù or Siva marked on their foreheads, and dressed in their sweeping plaited togas of pure white, employed on the telegraph, the railway, the arsenal, and even the observatory, all which employments demand the utmost exactness and punctuality, and thus afford the most gratifying evidence of the adaptability of the Hindoo race to be impressed and to benefit by European civilization. With the exception of Major Jacob, the director of the astronomical and magnetic observatory, the whole of the employés are natives, who are not indeed employed in making the actual observations, but are found perfectly competent to compute the various calculations, and make the requisite reductions. The institution itself is at present of but little importance as a place of scientific observation, in consequence of the small support it receives, but it is to be provided with a meridian circle, similar to that in the Royal Observatory at the Cape of Good Hope, when it must become an important station. Strange to say, here, as at the Cape, there are no observations made on the Sundays, which in the course of a year gives rise to lamentable deficiencies, especially when some natural phenomenon of rare occurrence happens to fall upon a Sunday.

We were greatly surprised at the flourishing condition of the Central Museum, with which is united a Zoological Garden, both set on foot in 1851. In the spacious rooms of this stately edifice are ranged costly Indian antiquities and sculptures, inscriptions in Sanscrit, in stone, or marble slabs, 
antique fragments of Indian monuments, ${ }^{*}$ as also an instructive collection of technical and ethnographical subjects, models of fortresses, ships, agricultural implements, instruments, tools, machines, and native forts. The geological department of the Museum is the weakest and poorest department; and as spirits of wine and glass jars are expensive articles in India, the greatest number of the animals, even the fish and snakes, are simply stuffed. In the garden which surrounds the museum buildings are a considerable number of cages inclosing living animals, such as monkeys, panthers, bears, giraffes, stags, gazelles, cobras, Indian hens, pigeons, marsh-birds, and singing-birds. In addition there were Aquaria with fishes arranged in groups at various spots all round the garden. Of objects of special interest there was a powerful baboon (Pithecus Satyrus), above 5 feet high, fastened to a chain in a large monkey-house, around whom were gambolling a number of smaller species, as also a number of cobras in a large box with glass sides, so that one could examine them at leisure on every side. Here we witnessed the uncomfortable spectacle. of a native engaged in cleaning the panes inside the cage and directly beneath these formidable animals, which thronged around him in such numbers that he was continually compelled with one hand to resist their importunate caresses. Anyone not aware of the fact that these animals have been

* These important inscriptions are explained and described in the Selections from the Records of the Madras Government, Report on the Elliot Marbles (p. 191) by R. IV. Taylor, Madras, 1857. 
rendered harmless by the extraction of their poison-fangs, must experience a feeling of terror and astonishment at the sight of this brood of malign, stealthy-moving, hissing serpents, with a naked Hindoo in their midst!

Most astonishing and gratifying is the immense number of casual visitors that frequent this institution for advancing education. The book for inscribing names lying in the Museum, showed for a single month no less than 36,522 visitors, mostly natives, and this it seems has been about the average number since the foundation of the Museum. There is also a small, valuable library, which, by means of purchases, gifts, and exchanges, is being visibly added to with each year, and is accessible to visitors of all classes, the custodian and inspectors being all natives.

The Madras Literary Society, an offshoot of the Royal Asiatic Society in London, and now reckoning but a small number of associates, publishes from time to time the most valuable information as to the latest achievements of science in Incia, and serves in a measure as a medium by which to compare the intellectual progress of Asia and Europe. To the members of this society the naturalists of the Novara Expedition are specially beholden for their great attention during their stay in Madras, as also for their hearty participation in the objects of the Imperial Expedition as evidenced by their sending copies of their own various and useful publications.

There are in Madras numerous institutes devoted to the diffusion of uscful knowledge among the masses, part founded 
and maintained by Government, part by private enterprise, and this liberality is the more praiseworthy that the European community of Madras does not comprise much more than 1600 persons, of whom only a very few settle any length of time. The Europeans resident here are chiefly military men and merchants, who leave the country after remaining five or ten years, as almost every one regards his stay in this hot, sandy capital of the desert Coromandel coast, as purely provisional, and views it as a stepping-stone towards attaining some better post, or becoming suddenly wealthy by some favourable conjuncture of circumstances. That the majority of these institutions have more practical objects in view admits of ready proof, and is but one instance the more of the moulding power of surrounding circumstances. In the school of arts for instance, under Dr. Hunter's superintendence, there are 20 pupils, mostly Hindoos, who are receiving instruction in drawing; sculpture, lithography, woodcutting, etching, and photography. But in order to reduce, as far as possible, the expenses of this institution, there is also included a manufacture of earthenware, the proceeds arising from the sale of which are applied to the support of the school.

Another eminently usefui institution, the Medical College, which, as well as most of the other professional foundations, we visited in the company with our hospitable and influential friend, Dr. Kelly, possesses one division, in which such of the natives as purpose to set up as apothecaries, are at the same time so far educated as to be able, in case of necessity, to perform a few of 
the minor surgical operations. Of the hundred of an auditory who at the period of cur visit were attending a lecture on chemistry, the majority were half-blooded Indians, dressed in the European faslion, with a sprinkling of barely 9 or 10 Hindoos in their white robes, and with the Vishnù or Siva marks on their forehead. We frequently heard the professors, among whom are several gentlemen of high scientific attainments, such, for instance, as Messrs. Evans, Lorimer, Mudge, Montgomery, Mayr, \&c., express their regret at the severe check which the development of science sustained by the outbreak of the late revolt. Plans for a new university, a hospital, and a medical school to correspond are all ready, and but for that ruinous catastrophe would have been by this time in working order.

In other respects the present Infirmary is an ugly and unsuitable building, making up about 100 beds for patients. Several of these were occupied by soldiers, who had been severely wounded under Havelock at the storming of Delhi. The introduction of punkahs, or wind-fans, into the wards has proved so salutary, that there is an intention to have them worked without intermission day and night, by means of water power, instead of by manual labour as hitherto. In order to be able to estimate the boon conferred by such an improvement upon the condition of the poor invalids, we must call to mind that the average annual temperature of Madras is about $94^{\circ}$ Fahr., which is slightly in excess of the average temperature at the equator, although Madras is 10 degrees north of the line. 
Under such climatic conditions, it is no wonder that the invigorating wholesome breeze is known at Madras as "The Doctor."

Among the benevolent institutions visited by us, we found the twin asylums for male and female orphans of soldiers well worthy of notice in many particulars. These are for the most part the offspring of European soldiers married to native women, and are known as "half-castes," or "Mestizoes." In the Military Female Asylum, there were at this time 216 girls, who were brought up to all manner of female work, as well as taught reading, writing, and arithmetic, and remained in the institution until suitably provided for in marriage. The marriage outfit, as also a small wedding present of Rs. 50 ( $£ 5$ ), for each girl is provided by Government, and the entire working expenses, which amount to about Rs. 30,000 (£3000) annually, are defrayed by a Government grant of Rs. 1000 $(£ 100)$ a month, together with the interest of the funded capital, upon which Government pays 8 per cent. interest.

The Military Male Orphan Asylum was founded in 1788 by means of voluntary contributions, supplemented by a Government Subvention, and possesses a special historical interest from the circumstance that it was here that Dr. Bell, who held the post of Head-Master in the establishment, first projected and put into execution the method of imparting elementary instruction, afterwards so widely renowned as the Lancastrian method of teaching, which since that period has traversed the globe, and has been introduced into every capital in Europe. 
The course of instruction of the institution includes writin. reading, arithmetic, grammar, geography, history, Englisi Tamil, and music. The capital of the institution is vested $\mathrm{k}$ Government in the 4 per cent. stocks, paying 8 per cen interest, which, with the large amount realized within th establishment itself, is sufficient to defray all expenses withor any further assistance. The number of boys is about 24: The head teacher, who obligingly conducted us over the whol establishment, which is very handsome, called a dozen boy forward just as we were leaving, who played a few simpl pieces on wind instruments, on which they performed a variet of national airs with great precision. The music master was . German.

Among its casual attractions, Madras has occasionally flower shows, and exhibitions of industry, and it is exceedingly gratifying to observe how European science is even here called in to elicit the treasures of nature, and administer to the necessities of mankind. The catalogue of the industrial exhibition of 1857 shows, inter alia, 17 sorts of spices, 20 varieties of resin, 64 plants suitable for the distillation of oil, and 41 different drugs, and Dr. Kirkpatrick, a physician in Mysore, has taken the trouble to enumerate, by their botanical and Indian names, 24c native drugs, which had been sent to the Madras exhibition, as also their market value, and at the same time has subjoined the modes in which the natives use them.

Among the most remarkable private museums which 
have been formed at Madras for the illustration of the history and monuments of the southern provinces of the Deccan, must undoubtedly be included the collection of rative inscriptions and manuscripts of the well-known Colonel Mackenzie, which first attracted the attention of all friends of Oriental science, as also the British Government, through a memoir* of Alexander Johnston, Esq. It is a magnificent testimony to the conservative spirit of the British resident among heathen nations, as compared with the barbarous spirit of destruction that characterized the Spanish colonists. From an erroneous idea that they were in so doing promoting the interests of Christianity, these Romanist conquerors destroyed all sculptures and monuments of the pagan Indian races, and, by this fanatical Vandalism, at the same time prevented the hand of science from unfolding, as it might have done from these important vestiges, the history of these very remarkable races from the most remote ages.

In the immense old palace, surrounded by adjacent edifices and gardens, once occupied by the King of the Coromandel coast, the renowned nabob of the Carnatic, the offices of the English Government employés are at present located. The last of these sovereigns died a few years since, and his former minister receives from the British Government a pension of Rs. 1300 (£130) a month. Great men who have

* On Colonel Mackenzie's Collection, in the Journal of the Royal Asiatic Society of Great Britain. London, 1835, p. 4, vol. ii. 
fallen do not ordinarily like to be sought out or gazed at. There is, however, on the contrary, no difficulty in obtaining access to the last minister of the last monarch of the Coromandel coast, who seems to feel flattered by a visit from strangers. On our entering, the venerable old gentleman rose from a rich thick carpet, on which he was sitting crosslegged, held out his hand in the most affable manner, and did us the honour of accompanying us through the palace. He had a long white beard, and wore a white turban on his head, while his person was enveloped in white linen. A splendid staircase conducted to a council-room, adorned with a portrait of the late nabob, life-size, executed in London. A second room has a likeness of George Augustus Frederick, Prince of Wales, dedicated to his friend, Omadal-Omrah, nabob of the Carnatic, 1st January, 1797, and of Lord Cornwallis, arm in arm with a nabob, the former represented as walking among pines, the latter among palms. In the harness-room and coach-house adjoining, our obliging attendant revealed to us an endless array of golden howdah trappings, gilt with cunning hand, which seemed to have formerly borne the mighty nabob, when riding on his elephant. As we emerged from this lumber room, filled with dust and mud, we perceived in the square before us an immense dust-cloud, which approached nearer and nearer in its gyrations, and gradually assumed the shape of an elephant. It was a gigantic and magnificent specimen, and proved to be the favourite elephant of the last nabob, which, 
like the minister himself, was reduced to eat the bread of charity. His enormous tusks were sawn half off, for which his attendant assigned the singular reason that the tusks of an elephant must be cut, just as we pair our nails! This pensioner-elephant, however, seemed to find himself in very good quarters, and was a carefully-tended gentle creature, who carried about his chain with his proboscis, and knelt down at the word of command.

Among the other spacious apartments of this deserted palace was the banquetting hall, as it is called, which was represented by various writers as one of the largest rooms in the world, which, however, is a transparent fallacy. It is hard to believe that above a thousand persons could find room in it. At the period of our visit this apartment was used as a barrack for the English troops, in consequence of which the splendid full-length pictures already mentioned were carefully covered. One of the soldiers, anxious to show them to us, tore away the covering of one before we could interfere, when we found it to be a splendid likeness, painted in London, of Sir Thomas Monroe, a former governor of Madras.

In the first few days of our stay in Madras, we made an excursion to the fort of Vellore, distant about 80 miles (English) from Madras, formerly a renowned native fort, which is now reached in a few hours by rail. This line passes through a flat uninteresting country, which is barely relieved here and there by a couple of solitary palms or 
a Hindoo temple, and altogether presents a strongly African character in its scenery. Only at those points, at which there are tanks, or artificial basins, either excavated or formed by damming the water, does there occur a luxuriant green vegetation covering the parched, brown, dusty soil. These tanks are filled in the rainy season, and during the dry season, which continues for months, supply the rice-fields with water for irrigation, the culture of that plant requiring an unusually large supply of water.

If English railroads are proverbially comfortable in the mother-country, they certainly fall off lamentably in that particular in the cars used in India. This deficiency is the more provoking and remarkable, considering the various other appliances for comfort which are to be found in this country The conductor, as well as the other servants of the Company, was a Hindoo. On the entire line we saw but five or six white men employed. The fares are pretty moderate, that fur the entire distance, 80 miles, being Rupees $7 \frac{1}{2}$ (15s.), for firstclass, and Rupees $3\left(6 s\right.$.), second (about $2 \frac{1}{4} d$. and $1 d$. per mile, respectively). The line is to be extended from Bejapoor, so as to unite the eastern and western coasts of the peninsula. There are also lines projected from Madras to Bombay by Poonah and Bellary, and from Madras to Calcutta. The Governor, who (the evening previous to our departure, as we were being entertained at his summer residence, Guindy Park,) had been apprized of our intention to visit Vellore, was so attentive as to order the commandant to be informed by telegraph of our 
projected excursion at a late hour of the evening, and when we reached Vellore at 11 A.m., Captain Stevens was awaiting us at the station, to greet the voyagers by the Novara in the name of the commandant of the fort, and convey them to the fort, three miles off, in a waggon drawn by oxen, as is the custom of the country. The waggon was about as large as an ordinary sized sitting-room, and contained several arm-chairs and cane stools, the position of which could be altered at pleasure.

Vellore was once one of the strongest fortresses in India, the wells of which were formerly rendered inaccessible by numerous colonies of alligators. These Hindoo fortifications have, however, lost their military importance for Europeans, as they are on all sides "overcrowed," as Rittmeister Dugald Dalgetty would say, by eminences, from which they could easily be cannonaded. Within the fort itself are several extraordinary buildings, once pagodas and houses of entertainment for priests and pilgrims (choultries). The former sanctuary, now used as an arsenal, is a chef-d'cuvre of architectural skill, with splendid relievos and figures sculptured in granite blocks. Most of the divinities have four arms, symbolical of the universality of their power. The various edifices seem to have been once an abode of Brahmins, a sort of Hindoo monastery in which, in addition to the pagoda, there were ranged all round, a temple, colonnades, and halls for the residence of the priests. In some of the smaller apartments there still are openings for windows, with a finely carved grating hewn out of the solid granite, the workman- 
ship of which even the stone-cutters of our own days might feel proud of. Captain Mitchell, an Englısh officer stationed at Madras, had hit upon the idea of photographing the most interesting of these monuments.

The fortress of Vellore has been fortified for about 1000 years! Captured by the English at the close of the last century, the then Nabob, a Mussulman, was taken prisoner, and his descendants have ever since inhabited the fort as State prisoners, without ever being permitted to leave it. We inquired of the officer who accompanied us, whether the Nabob was permitted at least to make use of the space within the fortress for exercise in the open air. "The Mussulmen," replied the cautious Englishman, "do not care to show themselves in public; they prefer taking their exercise in the court in front of their residence, or in the garden." Accordingly, the aged prince is rarely known even to take an airing in a palanquin. The town of Vellore itself is, in a great measure, another place altogether, whose inhabitants are Mahometans, about 80,000 in number, chiefly engaged in rice culture.

We originally intended to return the same day to Madras, the length of the journey, as well as the distance of the fort from the railway station, having been represented to us as much shorter than was actually the case. Accordingly, we telegraphed to the Austrian Consul, M. Campbell, Esq., an exceedingly courteous gentleman, that we should not return till the following morning. How great was our astonishment to find that the telegraph employés at Vellore, both in the trans- 
cribing department, and in the management of the apparatus, which was on Morse's system, were Hindoos, with their curious marks upon their foreheads, and their old-fashioned costume! They went, however, through the duties connected with this modern invention with great adroitness. The telegraph is already in operation to Bombay, and in this direction has two separate lines. There are, moreover, other lines in course of construction, - - along the coast to Calcutta,-along the coast to Pondicherry by Adam's Bridge, " from Madras to Point de Galle, and from Madras to Hyderabad, Bangalore, and Bellary.

In proceeding from the fort to the town of Vellore, which is charmingly situated and regularly laid out, and is inhabited by numerous pensioners of the East India Company, we must cross the river Palaar (or Peliar), which, during the rainy season, is a headlong dangerous torrent, while in the dry season its bed, 1000 feet wide, is but a bare expanse of sand. It is only by dint of strenuous exertions that the traveller is able to pass this sand waste in a waggon, as it sinks at some points above the hubs of the wheels. We had four buffalo oxen yoked, and even then had to be propelled at certain points by the assistance of some 30 coolies or Indian porters besides. This serious inconvenience was shortly after our visit to be remedied by the erection of a splendid bridge of solid masonry,

* Adam's Bridge-called by the IHindoos Rama's Bridge,-is a bank extending between Ceylon and the mainland of Hindostan, by the islands of Manaar and Ramisseram. It is about 30 miles in length, running in a N.W. by W. direction, about a quarter of a mile in breadth, and principally composed of shelving sand, through which are three main openings or channels, that admit the passage of boats of very light draught. 
which was to span the river by 42 arches, and will reduce the time of transit from the station from $1 \frac{1}{4}$ hour to 20 minutes. Hereabouts oxen are usually employed for draught, which are of the same humped species as those we had previously seen in Ceylon. These animals trot with uncommon swiftness, so that the rapidity of transport may stand comparison with that where horses are employed.

A few miles distant from Vellore, and visible from the hills around, lies Arcot (Arucati), the residence of the nominal nabob of the Carnatic, who has long been a pensioner of the British. The population of Arcot are mostly Mahometans, who speak a dialect of Hindustani, and drive a very active trade.

At Vellore we resided in the house of the hospitable Lieut.Colonel McCally, who, in the absence of the Commandant, did the honours of the Fort to the members of the Novara Expedition. Here we experienced a most cordial reception, and passed a few most delightful hours in the domestic circle of his amiable family. In the evening we made out an excursion to an adjoining eminence, 1400 feet above sea-level, 300 above Vellore, from which there is a commanding view over the town and neighbourhood. Seen from this point, the Fort looked charming, presenting itself to us, surrounded as it is by moats and watercourses, like an island in the foreground. On the top of this hill is the bungalow or country-seat of the collector of revenue, W. A. Sulivan, Esq., where we revelled in the enjoyment of the exquisite natural scenery, and partook of refreshment. 
In the evening a number of officers, with their wives, met us at dinner at Lieut.-Colonel McCally's house. The gaieties were prolonged till far in the evening, music and songs alternating with round games and dancing, so that we had hardly composed ourselves to sleep ere we were awakened by the servants, in order to avoid missing the train, which leaves Vellore for Madras at 6.30 A.M. By 11 A.M., we were once more in the clief city of the Carnatic.

The same afternoon the officers of the Novara, and the naturalists of the Expedition, were invited to an Indian fête, which Lord Harris gave every year at this season in his palace at Guindy Park, and to which it was customary to invite the majority of the European residents at Madras, together with their families,-military, civil service, and mercantile community, all being honoured with cards. This festival originated in a children's entertainment, which the governor had been in the habit of giving on the birthday of his son; the latter had long since gone to an English University, but the custom had survived, and the day was equally carefully observed this year also, having been looked forward to for months before by the "white " young folks of Madras. The entertainment still retains the character of a children's party, inasmuch as on the present occasion there were assembled above 250 children of both sexes, varying from 5 to 12 years of age. The total number of guests who, in addition to these, shared in the festivities was probably more than a thousand. The fête began with 
the performances of some 30 Indian jugglers and acrobats, on a large lawn in the park. These, as may be conceived, had been selected from among the most athletic and skilful. They presented a singularly-picturesque appearance, from the diversities of age, agile boys, athletic young men, slender voluptuous-looking Bayadères, old grey-headed men, and marvellous-looking old hags, with streaming white hair, and dark, piercing, gleaming eyes, recalling in their manners and appearance our own gipsies. All played at once, and performed with the most astonishing precision a succession of breakneck feats, that set the spectator's hair on end. It was a spectacle entirely sui generis, thoroughly Indian in short, to behold these wild-looking brown figures, unawed by the presence they were in, going through their various performances and feats of agility. In front of us knelt an old man who played with a dozen knives, which he kept circling around him with wild yells, apparently without looking at them, till he finally turned them in such a manner that it seemed as though the sharp points of the knives had transfixed his hand. Next youthful acrobats sprang through paper balloons set on fire,-girls in boys' dresses climbed up bamboo poles 100 feet high, in the midst of continual yells,-boys executed on the damp meadow ground the most extraordinary feats of agility and contortions of the limbs, while one old fellow, to the intense astonishment of the assembled children, swallowed swords, as also tow and other combustible matter, whereupon flames 
presently seemed to issue from his mouth. These, indeed, are feats of conjuring which have been performed in Europe, usque ad nauseam, but here all was done with such precision and dexterity (each man especially playing entirely con amore, evidently not to impress the spectators, but because he felt a pleasure in it himself), that the whole exhibition left quite a different impression from anything of the sort elsewhere.

After this introductory amusement, the children invited were regaled with a refection under an enormous tent. This was for the grown-up guests another source of great amusement. More than 300 children took their seats at a long well-covered table, while their fathers, mothers, governesses, \&c., stood behind the benches, and took special care to supply the little watering mouths with a sufficient supply of the many delicacies before them.

A distribution of souvenirs to the various children present succeeded the repast, the various articles being fastened to a gigantic tree under a tent. The tree was profusely hung with elegant paper lamps, and although there were no pinebranches, only palm leaves, the "tout ensemble," bore a strong resemblance to a genuine Christmas tree. Fathers and mothers expressed to us their own feelings of pleasure at beholding the glee of their children, and, indeed, seemed to think this the most entertaining part of the fête. The distribution lasted a considerable time, and many of the children affected to coquette disparagingly with the presents 
of their neighbours, which these latter held fast with both hands, till at length the whole joyous train were dismissed homewards, thoroughly pleased with the day's proceedings.

After this interlude there were fireworks on the lawn for the grown-up children, which seemed intended to serve merely as a stop-gap to while away the time between the distribution of the presents to the children and the supper, which was laid out in the brilliantly-illuminated dining-room of the palace. The fine band, which a few days previously had so pleased us by its performances during dinner at Guindy Park, drew up on the large lawn fronting the ball-room, and during this interval played a few select pieces with admirable precision. At last, supper was announced by a flourish of trumpets. Despite the spacious proportions of the apartment, the company was too numerous to admit of all sitting down at once. We calculated the number of guests still remaining at at least 500. The ladies supped first, and afterwards the gentlemen-the Governor, Lord Harris, doing the honours in person, in the most courteous and kindly manner After supper the party proceeded in couples to a splendid ball-room, where dancing speedily began, while over their heads an omnipresent punkah, of rich tapestry-paper, and elegantly adorned with beautiful arabesques, swung to and fro, and kept the half-breathless dancers continually fanned by its currents of air.* In spite, however,

* In many English families in India there prevails a sort of punkah mania, so that there is a regular hurricane incessantly blowing over their heads. Undoubtedly 
of this artificial ventilating machine overhead, one must have had an extraordinary love for the dance to find pleasure in a polka or galop at a temperature of $86^{\circ}$ of Fahrenheit.

Lord Harris had taken measures for ensuring our proceeding direct from his residence in Guindy Park upon the favourite excursion from Madras - that, namely, to the Seven Pagodas. We had accordingly provided ourselves with only what was indispensable in the way of luggage; and towards 1 A.M., we left the ball-room, and proceeded on our way to the renowned Hindoo Temples to the south of Madras. A waggon conveyed us to the Adyar bridge, where a Government boat was in waiting for us, together with some Hindoo servants of the Governor, who were to be our guides to the Seven Pagodas. One of these peons, as they are called in India, named Iritschapa, presented us with a document, in which he was commissioned to place himself at our disposal during the whole period we were absent, and anticipate all our requirements without further authorization, to the best of his ability, so as to ensure our comfort and assist the objects we had in view.

these artificial gales are particularly agreeable in apartments where, a large numbcr of persons being assembled, the atmosphere becomes intolerable-as, for instance, courts of justice, churches, hotels, and hospitals. Under such circumstances, they are, indeed, a most valuable contrivance. But their application is entirely overdone; and there are persons who, even while they are sleeping, have a Hincloo servant continually working the punkah, which, under such circumstances, is usually worked from an adjoining room by means of silken cords, so that the motive power is not visible from the apartment, but only the effect felt. Strangers at first find these artificial currents very apt to superinduce headache, until continued residence makes him regard the pmkah as a most necessary article of furniture. 
The Government boat was supplied with everything that could minister to our comfort, a second boat following us exclusively for the conveyance of our heavy baggage, personal effects, tents, and provisions. Towards 2 A.M., we embarked on the Eastern Coast Canal, which goes as far as Sadras, and by which we reached the Seven Pagodas, called also Mahamalaipuram, the city of the Great or Holy Mountain, at 9 A.M.

These singular and majestic specimens of architecture are about 3 miles from Sadras, being situated on the coast northwards, and about 500 paces from the canal. They consist

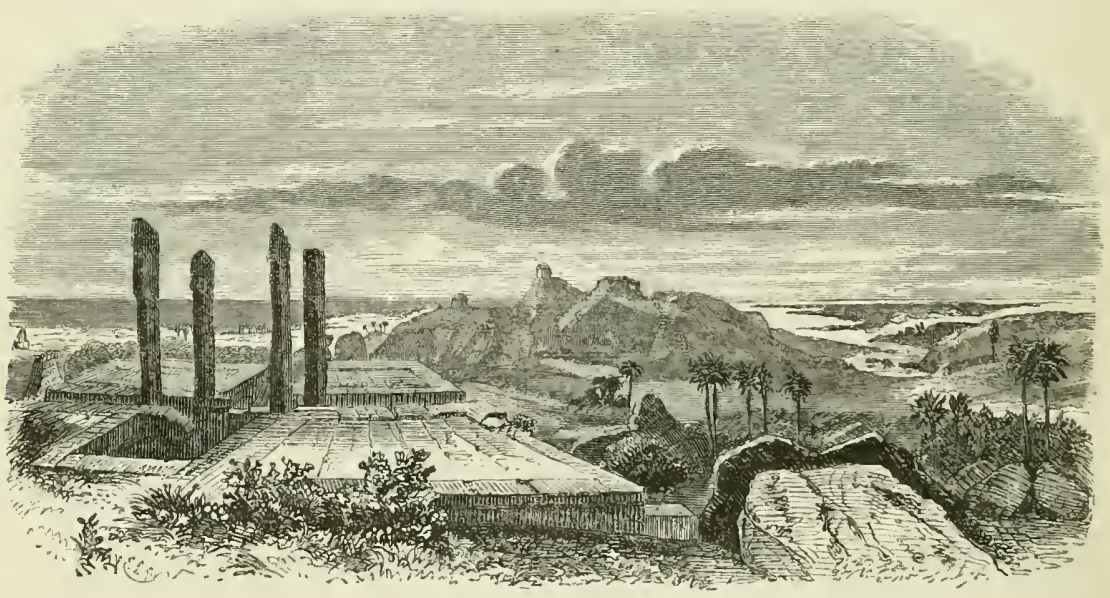

of temples, grottoes, bas-reliefs, cisterns, stone-benches, and thousands of sculptures in long ranges of bas-reliefs, which afford an abundant store of antiquarian research. They go by the name of the Seven Pagodas (from Baghavali-Holy House, whence the European corruption, Pagoda), from the circum- 
stance, that there are, upon the very brink of the ocean, seven temples hewn out of one piece of rock. The Brahminical legends speak of an entire city having existed here, of which only the fragments are now washed by the sea. But, according to Babington's and Heber's minute researches in this neighbourhood," there seems no doubt that there never existed any large city here, but that the whole was a mere myth of the Brahmins, who procured a royal gift, an Agrabaram in this neighbourhood, and with subtle forethought left here a caste of stone-cutters, who from time to time, under the guidance of their priests, executed these sculptures for the adornment of their sanctuary, which are justly the objects of wonder to their descendants. To this day, even, there dwell here certain families of stone-cutters, who work these singular rocks as granite quarries, and make money by the trade. The Seven Pagodas, specially so-called, are monolith temples, hewn on the spot out of massive blocks of rock. The mountain itself, a huge block of granite, to which the entire locality owes its reputation as a site of works of art, is covered, behind as well as in the front slope, with innumerable figures.

After our arrival, we made a hasty circuit through the place, so as first of all to be able to indentify them, and be in a position to recognize the various sculptures and bas-reliefs cut out in the solid granite rock. The greater number of the

* Benjamin Guy Babington. An Account of the Sculptures and Inscriptions of Mahamalaipuram, illustrated by Plates I.-XVIII., in the Transactions of the Royal Asiatic Society of Great Britain, London, 1819, p. 258. Bishop Heber's Narrative, Isondon, 1828, Vol. III., p. 216. 
sculptures represent either the one or the other descriptions of the Avatars (the incarnations or transfigurations) of Vishnù, to whom the larger proportion of the temples is dedicated. In one of these temples, we perceived the god Vishnù in the fifth, or Dwarf Incarnation, in the course of which he had, under the guise of a Brahminical dwarf, begged of King Balitscha-Kravathi-who, by his piety, had acquired so much power over the gods, that they had to transfer to him the dominion of sea and land, and had in consequence waxed arrogant-as much soil as he could traverse in three steps! The wealthy Rajah made no objection to complying with the apparently moderate request of the pigmy being before him. On the opposite wall of the temple we now see, in a large admirably executed bas-relief, how Vishnù, represented on this occasion with eight arms, at once embraced heaven and earth with his left foot, and as there was thus no more room left for the next step, Vishnù released the haughty Rajah from his promise, on condition that he should descend to the infernal regions. From this feat, Vishnu bears the name of Triwikrama and Tripadas (thrice-stepper).

In the next rock grotto we came to, we beheld the Life of Krishna, the shepherd-god, represented, first as tending his sheep, surrounded by cows, goats frisking about, \&c. Walter Elliot names this representation "Krischna's Choultry," or the abode of the priests. The temple has a frontage of 50 feet, is from 30 to 40 feet in depth, and has about twenty figures.

From this spot, our guide, a Brahmin, brought us to what is 
called the Ganeza Temple, a monolith Pagoda. When we expressed a wish to touch the face of Ganeza (a son of Siva), cut in stone and plentifully besmeared with oil and lard, one of the Hindoo attendants hurried forwards to prevent us from being guilty of insult to this much-beloved divinity. The inscription to the right, in front of the niche in which Ganeza,

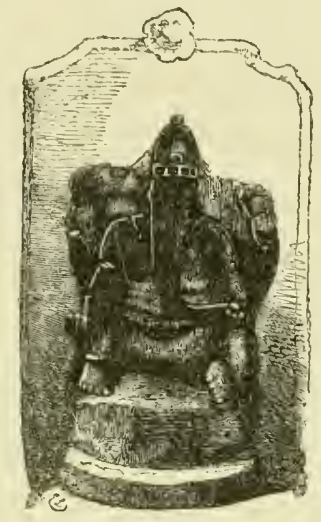

hewn out of a single block of granite, is represented in a sitting posture, consists of verses and prayers to Siva, written in Sanscrit.

We also remarked, on our way to the village, an ellipsoidal block of rock, 68 feet in circumference, by 25 in height, which, from its very peculiar position, seems to shift every moment, and presents a very extraordinary appearance.

As we were proceeding to the beach, we came upon the $\mathrm{Pa}$ goda of Kovulgobrom, which is at present in use (first constructed in the days of Rajah Apatsch, 400 or 500 years since), situated on a large oblong plot of ground, which is surrounded by a wall from 6 to 8 feet high. We were not per- 
mitted to cross the threshold of the pagoda, the door of which always stands wide open, and the minor apartments of which, so far as we could discern at a little distance away, were quite empty. We could just descry a few sculptures on the walls.

The whole village contains at present about 400 inhabitants, ${ }^{*}$ who reside in eighty small dwellings. Of these, three, built of bricks and with tiled roofs, belong to the caste of Brahmins, thirty to the Parias, five to families occupied in fishing, and two mere hovels of palm-wood to the Willis, the lowest and most wretched caste of all. The families of stone-cutters reside outside the village. One remarks here that the walls of the houses are hidden by heaps of cow and horse-dung, which the inhabitants, as in Egypt, use for fuel, and which they pile up to dry against those of the walls which are most exposed to the sun. The peon of the settlement, by name Randghajaneik, a sort of overseer, gave us a drawing of the various groups of houses, their inhabitants, and also the names of the various castes in Tamil, engraved as usual with an iron tool upon palmleaves, and very elegantly rolled up in a small envelope. Among the customs and fashions of the inhabitants which attracted our, notice, we were informed that they always burn their dead from four to five hours after life has departed-usually four hours and forty minutes-alleging that the released soul takes that length of time to reach heaven! The bones are collected and thrown into the sea. Widows are no longer required, on the death of

* Of these inhabitants 50 belong to the Bralumin caste, 250 to the Malabar, Sentù, and Siva castes, and 100 are Pariahs. 
their husbands, to ascend the pyre with them. Accordingly, the mortality upon this score is small enough in Mahamalaipuram. All seem hale and hearty, although for the most part they live upon rice and fruits, tasting flesh but seldom, as it is never used by the Brahmin caste. The Brahmins will not even eat eggs, because they are the produce of hens; nor drink milk because it is procured from cows! The girls generally marry at thirteen. They are, however, usually betrothed from the time they are two or three years of age, the bridegroom-elect taking the bride-elect to reside with himself.

All the natives whom we fell in with could read and write, but the Sanscrit inscriptions on the rock-temples were quite unintelligible to thern, as they only spoke Tamil, Telìgu, and Malabar. The greater number had their foreheads painted according to the caste they belonged to. Those worshipping Siva wore, suspended by a cord round the neck, small silver amulets, called Lingams, which have images of Siva enclosed. The adherents of Brahma, as already mentioned, wear no distinguishing mark upon the forehead, except that those that are married wear a five-ply cord (panul), tied obliquely across the upper part of the body. One must not, however, attach too much faith to these varieties of external markings, since many tattoo their foreheads with red, or yellow, or ashen-gray punctures, which usually have no special signification, but simply imply that on account of the pressure of business requiring frequent absence, they have neither time nor opportunity to have the distinguishing insignia of their caste properly designed. Ac- 
cording to the natives, the yellow colour is procured from the crushed, yellow-tinted root of the Curcuma longa, (a species of spice), the red from the Cardomum (Amomum repens), citronjuice, and red rice; while the white is prepared from common chalk.

Lord Harris had, with true Indian hospitality, made the most admirable arrangements for our accommodation while at the Seven Pagodas. When, after our first survey of the locality, we came down to the beach, we found two large and two small

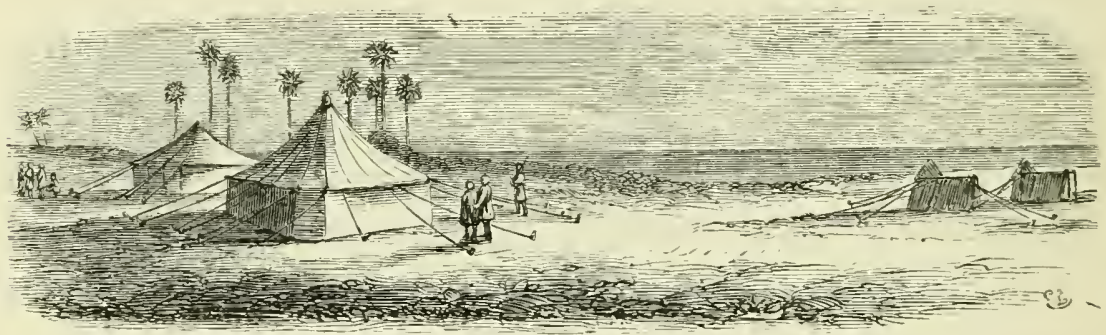

tents ready pitched, and a number of men collected round a fire preparing our breakfast. But how great was our astonishment, on entering the first tent, to find it spread with carpets, with an elegant sleeping-apartment with two large commodious bedsteads, and fitted up with all the usual necessaries for the toilette; while, in the passage which ran between the inner and outer walls of the tent, stood two immense baths ready filled with soft water to reinvigorate our exhausted frames! Ere we had recovered from our surprise, we were advised of the voice of the Government Peon, apprising us that breakfast was served in the second tent. This was used exclusively as a dining and 
reception room, and was also furnished with every conceivable appliance to promote our comfort. His lordship was even so attentive as to send his own travelling canteen for our use on the excursion. This tent, likewise, had double walls, with a passage between; the exterior wall being lined with blue, by means of which the glare of the sun and of the blinding white sand was rendered less painful and more tolerable to the eye. A number of coolies were employed in sprinkling water from time to time upon the fine-grained sand, which produced a most refreshing coolness all around. The Government Peon, as also the chief of police of the district, wore their best uniforms of white, with bran new bandoliers over their shoulders, of broad deep-red scarves, with gold-lace edgings, and, in the centre, a gilt plate, with the words, "Government Peon" engraved on it. A number of men and children ran hither and thither,-in a word, the whole village seemed in an uproar to see the strange gentlemen, and supply them with flowers, in the hope of receiving some trifling present. At 12.30 P.M., the thermometer suspended within the tent marked $84^{\circ}$ Fahr., although a gentle treeze was blowing from seaward through the fragrant luxuriant grass (Kus-kus, or Vetiveyr), which hung like a curtain over both entrances. It is an exceedingly happy idea to use this fragrant Kus-kus, (Andropogon muricatum) in the manufacture of mats, which are intended to be suspended in the entrance-halls of houses, and to be sprinkled with water, whereupon the penetrating, hot, parching wind is passed through the fine damp texture, 
which thus at once tempers the heat, and fills the air with perfume.

Towards 5 P.м., the heat having somewhat abated, we strolled to the Five Pagodas, distant about one English mile from our encampment. The prevalent tree in this locality is the Palmyra palm, which, though it does not boast the majestic proportions of the Oreodoxia Regia, or the cocoa-nut palm, presents, nevertheless, a very imposing appearance. Geuerally speaking, however, the district is quite bare and destitute of trees; and, in short, like all the rest of this coast, has very much the appearance of the flat coasts of Africa.

Of the five monolith temples, four were dedicated to the brothers of Vishnù, Dharma Rajah, Bimen, Nagulan, and Sawadewen, the fifth being excavated in homour of Dubrotis, the consort of Dharma Rajah. The legend relates that the four brothers lived in a state of Polyandry, or plurality of husbands, and had but one wife in common, who was a species of Amazon. All these temples are tolerably sculptured, which, indeed, constitutes their chief claim to attention; but they are far from showing the artistic finish of the bas-reliefs and sculptures, at what is known as the Holy Mount.

Rhanganatha Swami, for instance, is the finest, though not the most important of these artificial grottoes. The sculptures here are incontestably the most highly-finished. The upper portion, to which access is obtained by some steps cut in the rock, rises above the huge granite block, known as Jamapuram; the lower portion is a temple hewn out of 
one piece of rock, and with the most marvellously-executed allegories.

Among the reliefs on the north wall is perceived Donga, Siva's wife, riding on a lion (according to the natives, on a tiger), and bending her bow in conflict with Mahishasura, a giant with the head of a buffalo, who brandishes a club.

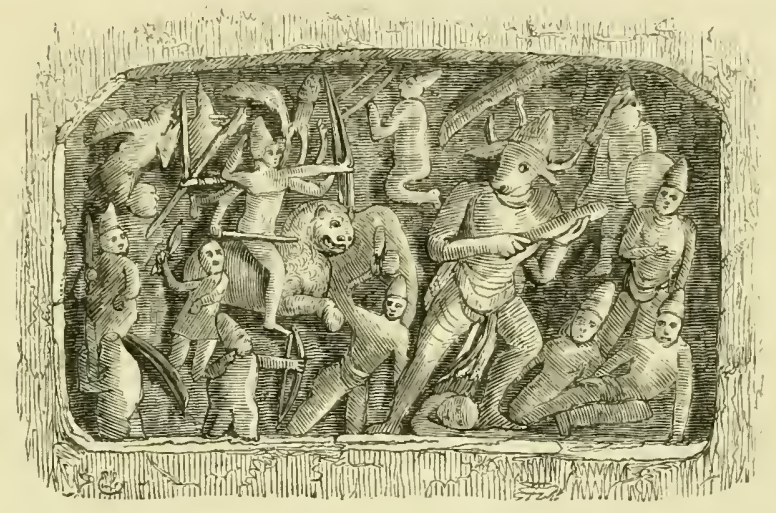

According to Elliot's interesting interpretation, this represents the contest between the matronly Amazon and heroine, Donga, the representative of active virtue, and the bull-headed Mahishasura, the personification of brute strength and animal passion. Over the head of either figure, a parasol, such as is used by the natives, is outspread, giving a most grotesque appearance to the group.

The relief on the southern wall represents a sleeping Vishnù (Rhanganatha), $9 \frac{1}{2}$ feet high, apparently representing the idea of the Creation, as the serpent, Sescha, with its five heads, encircles his head. At his feet one perceives two rajals or princes, and one female figure, in a praying attitude, with 
uplifted hands, only the bust being represented. In one of the niches at Swami are two busts, life-size, of Siva, and his wife Paravathi, the latter holding an infant at the breast, his offspring Supramanión. Above this representation, and, like them, only showing from the shoulder upwards, are represented on the right Brahma, on the left Vishnù, each with four arms, symbolical of their power and dominion.

The superstructure of these rock sculptures is a sort of platform of loose stones accurately fitted to each other without mortar, so as to make an ornamental whole. The interior is adorned with much more highly-finished specimens of art, to view which, a large number of Hindoos, doing penance, annually climb, with great difficulty, into this part of the building, and make their way into the unfinished interior apartments. While we were giving free scope to our surprise at all we saw, we were greatly annoyed in our contemplations by the natives, who offered us bouquets of flowers, wreaths, and fruit. Also, a couple of flute-players (Pulanpolen) who were passing, made their appearance to give us a specimen of their musical skill. One old man, of whom we procured a curious figure of Vishnù, neatly carved in wood, as also several manuscripts, remarked that there was in the neighbourhood, written upon Palmyra leaves, a manuscript, known as the Istálam-purànam which gave the history of the Seven Pagodas, written in Tamil.

The late president of the Madras Society, the learned Walter Elliot, who formed an extensive collection of the various valuable Hindoo manuscripts and inscriptions of 
Mahamalaipuram, and has partly published a translation of them,* told us afterwards, that this renowned Tamil Manuscript consisted of nothing but fables, and did not give one single reliable particular as to the history of the Seven Pagodas.

In Varaha Swami, one of the pagodas at present in use, and surrounded by a modern walled cemetery, there is visible, on the exterior of the Temple, an inscription in Tamil, which is, however, utterly unintelligible to the natives. This inscription, deciphered latterly by Babington, refers to a donation to the pagoda by a sincere Hindoo believer, and gives the most complete detail, together with signature of the donor. The name Mahamalaipur, $\dagger$ the "City of the Sacred Hill," occurs frequently in it.

In the course of conversation with some of our Hindoo followers, we remarked that they made no difference between a "kovül" or praying-house, in which the divinities are never produced, but are guarded under lock and key, and a pagoda, which is a residence of the gods, from which they can be carried forth and afterwards brought back. Hence it is that a pagoda is more readily accessible than a kovül, the sanctity of which it is forbidden him to violate.

In 1845, Mr. Elliot, by a private arrangement with the Brahmins, was permitted, on pajment of Rs. 30 (£3), to break away the partition which divided the inscriptions into two portions, in order to prepare three copies, and have

* Journal of the Madras Literary Socicty, 1846, Nos. 30 and 31.

$\dagger$ Dr. Elliot writes Mamallaipuram; the natives call the place Mahawalipuram, obviously a mere corruption of the customary mode of spelling. 
them translated by three Tamil scholars. One of these translators was the learned Tandavaraya Mudaliar, of Chingleput. The inscription contains the history of two donations, on the enlargement and laying the foundation-stone of the temple, accomplished by the "Kanattan" of the village, and, lastly, a gift of 90 goats by the Siva Brahmin Paramesvara-Mahavari, on the stipulation that a lamp should be kept constantly burning in the temple: the whole dating from the year 1073. It results from this interpretation that the inscription was put up towards the end of the llth century, thus supplying some clue to the age of this rock temple, which, according to Mr. Elliot's researches, does not exceed a thousand years.

To this Vahara Swami, which seems to contain their whole history, the natives wander regularly every morning, and

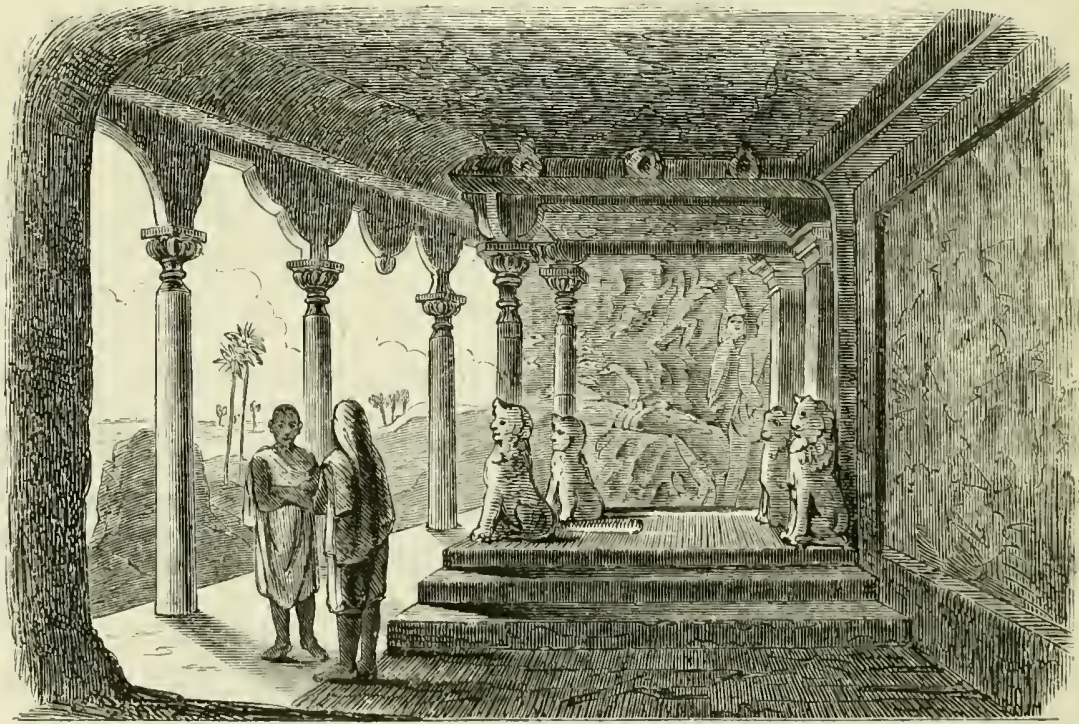


sometimes two or three times during the day, to offer flowers, cocoa-nuts, and other fruits. A flight of steps cut in the rock leads to the highest platform, whence there is an excellent view over these monumental edifices.

That fancy has been called in to invest these unique unfinished sculptures with the character of pleasure-grottoes, baths, \&c., \&c., of historical personages, is readily intelligible. Thus, for example, the guide does not fail to point out to the stranger a sort of stone cistern hewn out of the solid rock, traditionally reported to have been once the plunge-bath of Dubrotis. This colossal basin has about $2 \frac{1}{2}$ feet water during the rainy season, which gradually evaporates, or is drawn off for use. The water, tinged with the yellow colour of the soil, leaves a mark behind on the stone sides, which naturally becomes very visible during the dry season. This the natives maintain marks the height of the water as often as Dubrotis, (Dharma Rajah's consort), bathed herself in it. Another similar block of gneiss was transformed into a stone couch, and is called Dharma Rajah's bed, at the upper end of which, near the head, a tiger is crouched to guard it. This gigantic ellipsoidal block of rock, which seems as though balanced on a sharp point, could neither be displaced nor made to oscillate by continued leaping. Some masses of rock piled up above the grottoes were once Siva's kitchen, and so forth. All these spots, however, have in reality not the slightest historic significance; it is only the present generation that have tacked on to them legends, traditions, 
and interpretations, which assuredly never were in the intention of the constructors.

On a slope on one side of the mountain are a number of sculptures of remarkable beauty, representing the history of Tapasa, or the deep penitence of Ardschuna. On the right hand, close to the figure of the penitent Ardschuna, one perceives a multitude of people, two elephants as large as life and wonderfully finished, a tiger, and a figure, half woman half serpent. This relief, one of the finest we have seen, is a huge sculpture on the rock, 20 feet long by 30 in height, comprising hundreds of figures, with an idol in the centre, to which from all sides worshipping deities, men, and beasts, bow the knee in supplicatory attitudes; along the edge are elephants, life size, with their young. The colour of the rock, somewhat resembling that of the animal, tends still more to deceive the eye, and make the beholder doubt whether he is looking upon sculptures or upon living elephants. Elliot and others who have described these rock temples, assign to them, as already mentioned, a comparatively small antiquity. They are representations borrowed from the poem of Mahabharata, in the Hindoo mythology. The five roundish temples to the south of the village are beyond all question the oldest of these monuments. They are pagodas that have never been completed; solid, and here and there showing marks of work, but only adorned externally, the interiors being masses of unhewn granite; each of these temples is 30 feet in length by 20 in breadth and height. Thus 
$f_{a r}$, the inscriptions have been ascertained to be in threefold characters, of which two are as yet undecipherable. Babington was the first to attempt to decipher them, or at all events to find the key by which to decipher them. The most important has been copied and interpreted. But neither the inscriptions nor the various representations give the slightest historical clue as to the object of these monuments. Taylor's researches seem to establish the fact, that in the 17 th century this district was inhabited by the Corumbas, a half-civilized race of the Dschaina religion. About this period, or a little later, in the reign of Abondai, one of the princes, whose capitals were Conjeveran and Tripetty, the Brahmins were introduced to this neighbourhood. The extent of these works, however, their nature, and the immense expense incurred, all point to a long-continued influence of the Brahmins. Most of these temples seem to have been first erected in the 17 th century, under Prince Sinhamanayadu, and Elliot assigns to several even a much later date.

As for the report of a smaller pagoda, of which only an old pyramidal pagoda-stone is visible on the very edge of the sea, peering up from amid the furious foaming surf, it seems to be altogether a myth, so that such enquirers as Ellis, Mackenzie, and Heber, making allowance for what Hindoo traditions are known to be, will no longer take the trouble of searching for any traces of the sunk pagoda, or of seeking to recover the ruins of the submerged city. Several writers, indeed, are of opinion, that the sea on the Cormandel coast is retiring; but 
this appears to be a mistake, for here the sea seems encroaching rapidly, as is the case at Fort St. George, which 80 years ago was at some distance from the sea-shore, whereas its walls are at present washed by the tremendous surf.

But the inroads of the sea could hardly have been so sudden and extensive as to have swallowed up an entire city, without leaving any traces. Not one of the natives to whom we spoke in the place could say for certain, that the sea had materially gained upon the land within the memory of man. Nowhere are there any traces visible of the ruins of a city. One can safely assert that there never existed such a city at Mahamalaipuram, but that it has always been a mere abode of priests, with temples, sanctuaries, \&c., without any more extensive settlement, similar to Copan, Quirigua, or Peten, in Central America, but altogether larger and more artistic, and evidencing a far higher culture on the part of the artist. The supposed antiquity of the sculptures at Mahamalaipuram is too low, to admit of our supposing that since their erection the greater part had been swallowed up in the sea. None of the sculptures that we saw belonged to any prediluvian period, whereas they are all susceptible of explanation out of the modern Hindoo mythology, with the aid of the Epic poems of Mahabharata, all referring to Vishnù and his world of deities.

While some of the Novara expedition were visiting Mahamalaipuram, others made out a trip to the Pulicat Lake, near the shore, northwards from Madras. About 40 or 50 miles 
on the road thither, the Neilgherries (or Blue Hills), with their jagged outline, came into view on the gray horizon to the N.W., the height of which may be about 1,500 to 2000 feet. A narrow bulwark or quay of unequal breadth, varying from 20 feet to 5 miles, separates this salt lake from the ocean, the fierce surf of which, at some narrow places, actually breaks over, and mingles its waters. The lake varies in breadth, from 5 to 10 miles, and is about 60 to 70 miles long. The level of its bed is so remarkably regular, never exceeding from 3 to 5 feet, that when the wind fails, the boats that navigate the lake can be pushed along with poles, and one everywhere sees the naked inhabitants of the coast standing in the very middle of the water, with their landing or drag-nets, or busily occupied with rod and line! Being but a few hours distant from Madras, the lake is connected with the city by an artificial canal, along both sides of which are a number of outlets, carefully faced with masonry, so as to convert the adjoining land into lagoons, in which during the rainy seasons the strongly brackish water enters, and is used to make sea-salt.

In the canal there is considerable trade, as well by fishingboats, as by those laden with wood and fruit, which they convey to the city for disposal. Most especially remarkable is the enormous number of fen-birds, which frequent its shores and all around it. At several places where the shores, for a width of about a mile, are mere swamps with barely a foot of water, they are literally covered with myriads of curlews, which fly 
about in flights of incredible numbers, and stretch out like clouds. Long rows of flamingoes stand, their bodies half bent to the earth, seeking their food in the mud; far as the eye can reach, one saw whole ranks of these birds blending with storks, perched upon scattered stumps; while in the water itself, vast flocks of sea-mews swam about, and the sea-swallows, in pursuit of their prey, flew to and fro in the air. As evening came on, the naturalists of the Novara were sailing as though in a sea of fire. Hundreds of fish, as they sprang out of the water, left a fiery wake behind them, like a rocket, while a flame-coloured ever-widening circle marked the spot at which they struck the water again. Hundreds of various notes of birds, above, near, and round the boat, united with the singular melancholy cry of the jackal, which resounded from the shore, while overhead flights of birds flew restlessly about in the air, whirring in the ear like the rustling of disembodied spirits.

From the lake, a short excursion was made to one of the artificial canals, which unite this basin of water at various points and in different directions with the surrounding country, so as to get to the Strihoricotta Forest, which supplies Madras with fuel. This consists of a sort of underwood or brush, which grows again within the extraordinary short space of ten to twelve years. Sisyphus vulgaris (Rhamnea), Gardenia Ficus, tamarinds, and several species of Mimosa, form the principal part of the forest, which is thickly grown with immense quantities of climbers. The wood is cut by the natives, who 
have constructed huts in the jungle, into pieces of about 2 feet in length, which are transported in ox-carts to the shore, whence they are forwarded by boat to Madras.

When the members of the Novara Expedition had returned, greatly pleased, from their various excursions, the Madras Club gave a grand banquet in honour of the captain and staff, to which the élite of Madras society were invited. Immediately on our arrival the managing committee of the club had the courtesy to place the officers and scientific members of the Expedition upon the free list of the club during the ship's stay. The Madras Club-house, though not so luxurious or magnificent as the Clubs of London, fairly surpasses them in extent and commodiousness. It is, in fact, a small portion of the city in itself, in which one finds assembled all that can conduce to a comfortable, agreeable mode of existence; parlours, with wide arm-chairs and American rocking-chairs; reading-rooms, in which are all the best journals and an excellent assortment of the best and newest literature; dining apartments, in which one can dine in either the English or French style; billiard-rooms, shower and plunge-baths, and a large swimming-bath. Members from the country, or strangers, can be accommodated with lodging as well.

At the splendid banquet in honour of the Expedition, at which above 200 persons sat down, the chair was taken by the Chief Justice Sir Christopher Rawlinson-next to the Governor, the most influential person in the community. The extremely 


\section{friendly disposition manifested on that occasion found its ex-} pression in toasts on all sides, which in few, but appropriate words, welcomed the foreign guests; while, on the other side, they gave unmistakable evidence of the admiration and sympathy which the voyagers by the Novara carried away with them from the hospitable shores of Madras.*

* After the customary official toasts had been proposed by the chairman, and thanks retumed by the Commander-in-chief of the Expedition, the health was also proposed of the scientific staff, on which occasion one of the naturalists present expressed his thanks for this howour, in his name and that of his colleagues, in the following speech, which may be permitted to find a place here, as best showing with what impression the members of the Expedition left Madras.

"Gentlemen,-It is not without some feeling of auxiety that I an rising, for I have so many things to say, and yet it is but the thousandth part of what $I$, of what my fellow travellers all feel! Surely, it is always flattering to a man to be clistinguished by his fellow-men; but such a distinction becomes the more honouring if those who concur to distinguish him are-as this is the ease with you -a most estimable part of the British nation! Of a nation, which has done more than any other on the globe for the propagation of Christianity, the diffusion of knowledge, the advancement of science, for the progress of civilization, industry, and commerce. I do not intend, gentlemen, to return with the shiny crureucy of flattery the many proofs of attention and kindness which all the members of the Expedition have witnessed during our short, but most pleasant, ever-remembered stay in this eity, the birth-place of hospitality! What I say is but truth! Every page in modern history certifies my words! Which nation has clone more for the propagation of Christianity amoug savage tribes all over the world? Some years ago, when I was rambling in British America, and along the north shores of Lake Superior, I often found villages of 300 or 400 Indians, and but one single white man amongst them. And who was that white man, who voluntarily shared their misery, their wants, and their privations? Ho was an English missionary!

"And again! Which nation has made greater and moro serions efforts to suppress the slave trade, and to abolish slavery in all countries where it still exists, a shame to the nineteenth century?-Slavery! that hideous leprosy on the limb of tho gigantic body, called the United States! Who is even now anxionsly engaged to open, with the heartblood of its noblest sons, a vast empire-the Chinese linglomto eivilization, to Christianity, to the traffic of all seafaring nations of the globe ! 
As a number of our new-found friends expressed a wish, notwithstanding the difficulties of getting out to, and back from the roads, to visit our ship, the commodore invited some forty guests, shortly before our departure, to a "tiffin" on board. Although the frigate rolled pretty heavily, yet we, nevertheless, had the pleasure of the company of some twenty gentlemen and ten ladies. After "tiffin," which was served on the poop, under a tent improvised with flags for the occasion, all felt sufficiently comfortable to try a dance on the quarter-deck, our band of music being called into requisition for quadrilles, polkas, and waltzes; and, indeed, our guests paid so little attention to

"And is not this very city, Madras, where we have been so heartily welcomed, the best proof of the energy and perseverance of the political and commercial greatness of the British nation? Nothing but English steadiness and English perseverance could suceed to build on this barren, inhospitable, and even most perilous coast, a vast, flourishing eity, rivalling in size and the number of inhabitants the largest capitals in Europe! And what is still more pleasing and satisfactory, is the intellectual and physical condition in which one finds the Indians, especially if compared with the condition of the natives in North and Central America, \&e. There he meets a population, rapidly dying away, in proportion as the axe of civilization is resounding from the backwoods. One may almost determinate the day when the last of the red men will have disappeared from the North American Continent, the land of his ancestors! Here in India, on the contrary, the traveller meets with a thriving, industrious population. Who can see Hindoos, Malabar, Sentus, \&c., occupy most important employments at the observatory, at tho telegraph offiees, at the railroad, in any braneh almost of the publie service, and still believe the Hindoo race like the Indians of North America to be a doomed people-to be a people that has no future? No, it IIAs a future, and, under the wise and humane govermment of the British Crown, I am sure the coloured race of India will even have a most glorious future?

"'These aro the impressions and feelings, gentlemen, with which we part from Madras, with which I and my scientific colleagues bid you all a most sincere and heartfelt farevell." 
the approach of night, that their return was postponed till it was absolutely dark, of which opportunity we gladly availed ourselves to light our pleasant guests homewards with Bengal lights.

At length, on 10th February, shortly after noon, we set sail. As the frigate was perceived, from Fort George to weigh anchor, a thundering salute was fired of 21 guns-an extraordinary honour and mark of attention, to which we responded by a similar salute. In consequence of calms and light winds, we were 48 hours ere losing sight of land; and it was not till the 12 th February we could proceed on our voyage. For several evenings after, that magnificent, and as yet unexplained, phenomenon, the Zodiacal light, which is conjectured by the greatest physicist of ourage, to be the beams radiated from a vapour-like, flattened ring, revolving in the space between the orlits of Mercury and Venus, was visible with much regularity. What was afterwards observed, however, of this remarkable zone of light, during the course of our voyage, will be found detailed in the meteorological portion of the scientific volumes. Unbroken fine weather accompanied us during our entire voyage to the Nicobar Islands, our next station. But although, as was rendered necessary by the climate so near the Equator, we were clothed entirely in summer apparel, and there was nothing to remind us of its being winter and carnival at home, our sailors did not let Shrove Tuesday pass over without celebrating that day, to be marked with a white stone, by masking 
MADRAS TO THE NICOBAR ISLANDS.

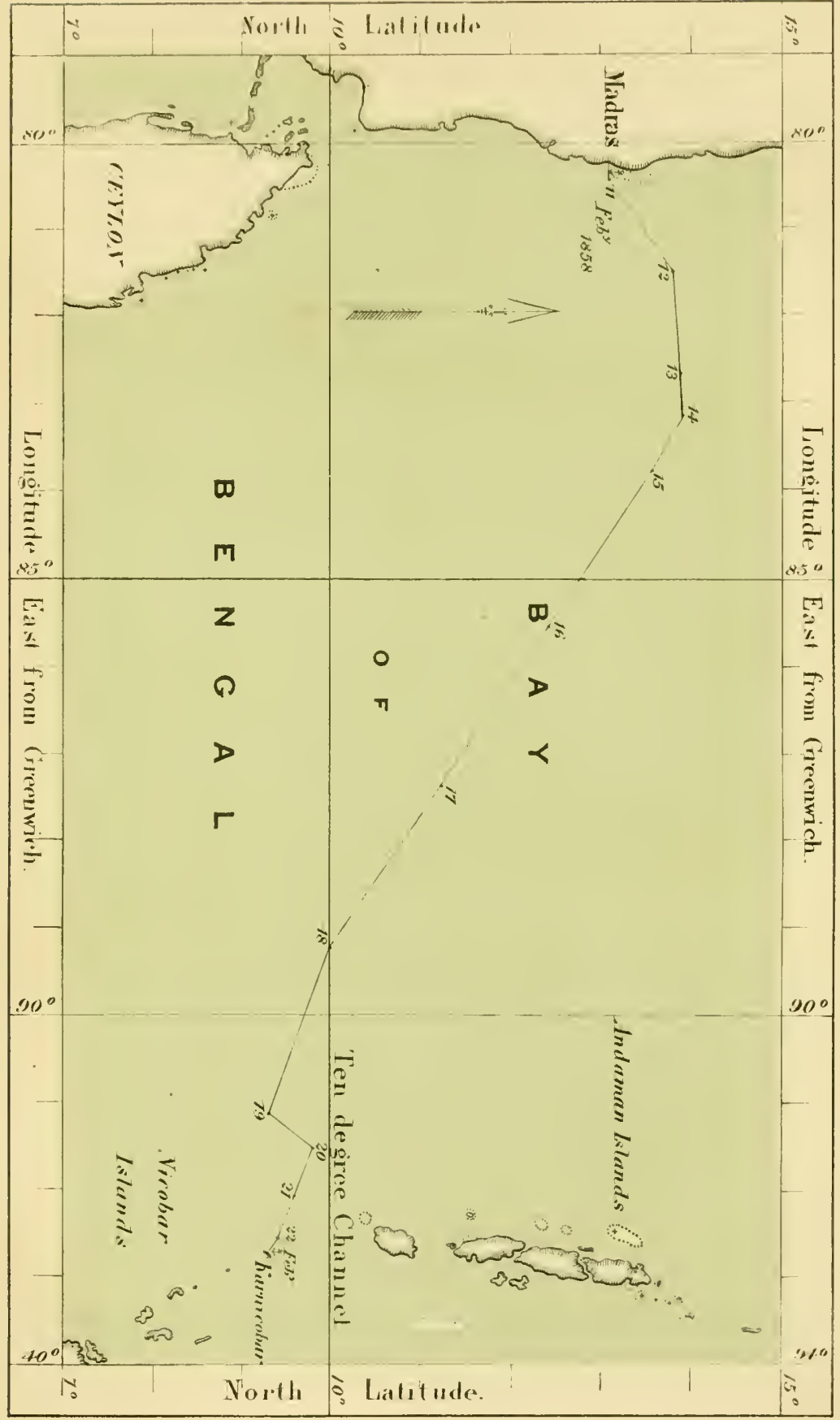



and dancing according to ancient custom. Jack has an especially good memory for the return of such junketings, and is by no means prone to letting the sensible vicinity of the Equator put him out of his reckoning; so he danced near the line also, not because he had any pleasure therein, but because it has alivays been his custom to do so at carnival-time!

The state of health of the ship's company was excellent, there being but eight on the sick list, of whom only two were seriously ill.

On the 22nd February towards 10 a.m. the Island of KarNicobar hove in sight, and towards afternoon we found ourselves but a few miles distant. The land secmed for the most part level, only a low eminence thickly covered with frost rising towaras the centre. The coast was overgrown with cocoa-nutpalm. In the N.W. and S.E. we could see three Malay boats at anchor. On the beach were some huts of beehive-like shape, in and out of which naked brown figures were seen moving; while, as night fell, numerous lights glimmered from the shore.

The following morning, Tuesday 23rd February, 1858, we anchored off the N.W. side of the island, in $14 \frac{1}{2}$ fathoms coral sand, about 2 miles distant from the shore, and just between the two villages of Mosse and Saui, each consisting of a few huts. One can approach within 3 or 4 cable-lengths of the shore, where there are still 10 fathoms, with clay bottom. Several natives, some naked, some with their bodies covered in the most ludicrous fashion with cast-off European clothes, 
approached the frigate while she was being secured, in small but elegant canoes, and called out anxiously when within hailing distance, in an inquisitive tone and a broken English, "No fear? good friend?" which we interpreted into an inquiry as to whether they had anything to fear, and whether we were disposed to be friendly. When, however, we did not immediately throw them a rope to make fast their little canoes, and they got sight of our numerous guns, they speedily turned. tail and hurried away.

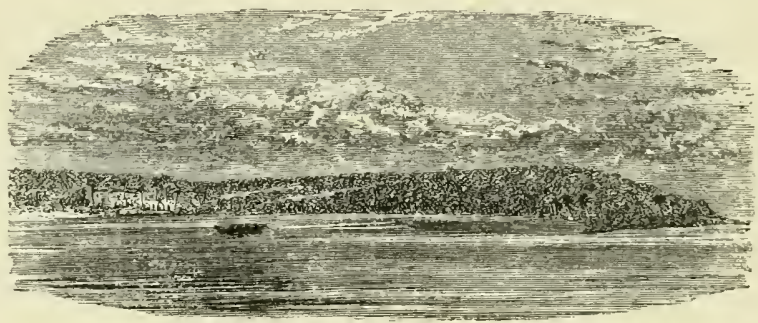

END OF VOL. I. 


\section{APPENDIX A.}

LIS'T OF THE OFFICEISS OF THE "NOVARA" EXPEDITION.

Gommodore-B. v. Wällerstorf-Urbair, Commander-in-Chief.

Captain-Frederick Baron Pöck.

First Lieutenant-Bela Saal de Gyula.

Licutenants-Manrice Monfroni de Montfort.

" , Alexander Count Kiehnansegge.

, , William Lund.

, , $\quad$ Robert Müller.

, " " Ernest Jacoby.

, " , Eugen Kronowettcr.

, , Gustavus Battlogg.

Pu'ser-Antonio Basso.

Principal Surgeon-Dr. Francis Seligınann.

Assistant Surgeons-Dr. Avé Robert Lallemant.

" $\quad$ Dr. Edward Schwarz.

Chaplain-Edward de Marocehini.

Midshipmen-Henry Fayenz.

, " Joseph Natty.

, " Gustarus v. Semsey.

, , Richard Baron Walterskirchen.

, " Lonis Meder.

, , Alexander Kalmar.

" " " Augustus Baron Skribanek.

" " Andreas Count Borelli.

, " " Francis Baron Cordon.

, , Frederick Baron Haan.

, , Edward Latzina.

" , Michal de Mariassi.

" , Engen Prince Wrede.

" " Joseph Berthold.

Engiueer-Wenceslas Lehmann.

Naturalists.

Geology-Dr. Ferdinand Hochstetter.

Botany-Dr. Edward Schwarz.

Mr. Anthony Tellinek, horticulturist.

Zoology-Mr. George Frauenfeld.

" MLr. John Zelebor.

Ethnography-Dr. Charles Scherzer.

Artist-Mr. Joseph Selleny.

The entire crew, including sailors, marines, gummers, servants, and the ship's band, amounted to $352 \mathrm{men}$. 


\section{A PPENDIX B.}

List of the various Provisions and Stores furnished to the Frigate "Novara," before her departure from Tricste.

Coals-23 tons (at 260 pounds daily consumption) for 198 days.

Water-86 tons (the daily consumption was furnished by the distilling apparatus)

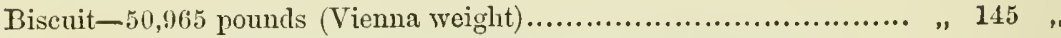

Wine-(light red Istrian wine), 8777 mass $(=3510$ gallons $) \ldots \ldots \ldots \ldots, \quad 50$ "

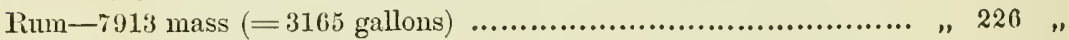

Salt Beef-17,800 pounds ...............for 105 days

Preserved Meat (in tins) .................. 122 ". Meat (boned) " 204 "

Pork-5760 pounds weight .............. 37, ,

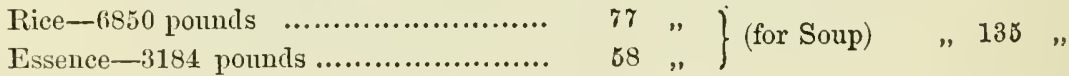

Mélanges d'Equipage, 40,000 rations ...... 114 days.)

Sour-crout, 16,000 rations

Cabbage, 16,000 rations

$\begin{array}{ll}40 & \text { " } \\ 46 & \text { " }\end{array} 6$ Vegetables , 298 "

Potatoes, 32,000 rations

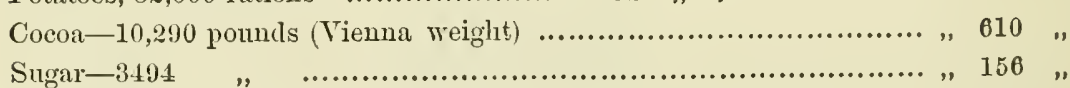

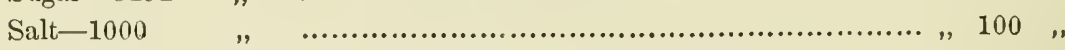

Vinegar -831 mass $\left(=332 \frac{1}{3}\right.$ gallons $) \quad \ldots \ldots \ldots \ldots \ldots \ldots \ldots \ldots \ldots \ldots \ldots \ldots, \quad 95 \ldots \ldots \ldots \ldots \ldots \ldots$, 


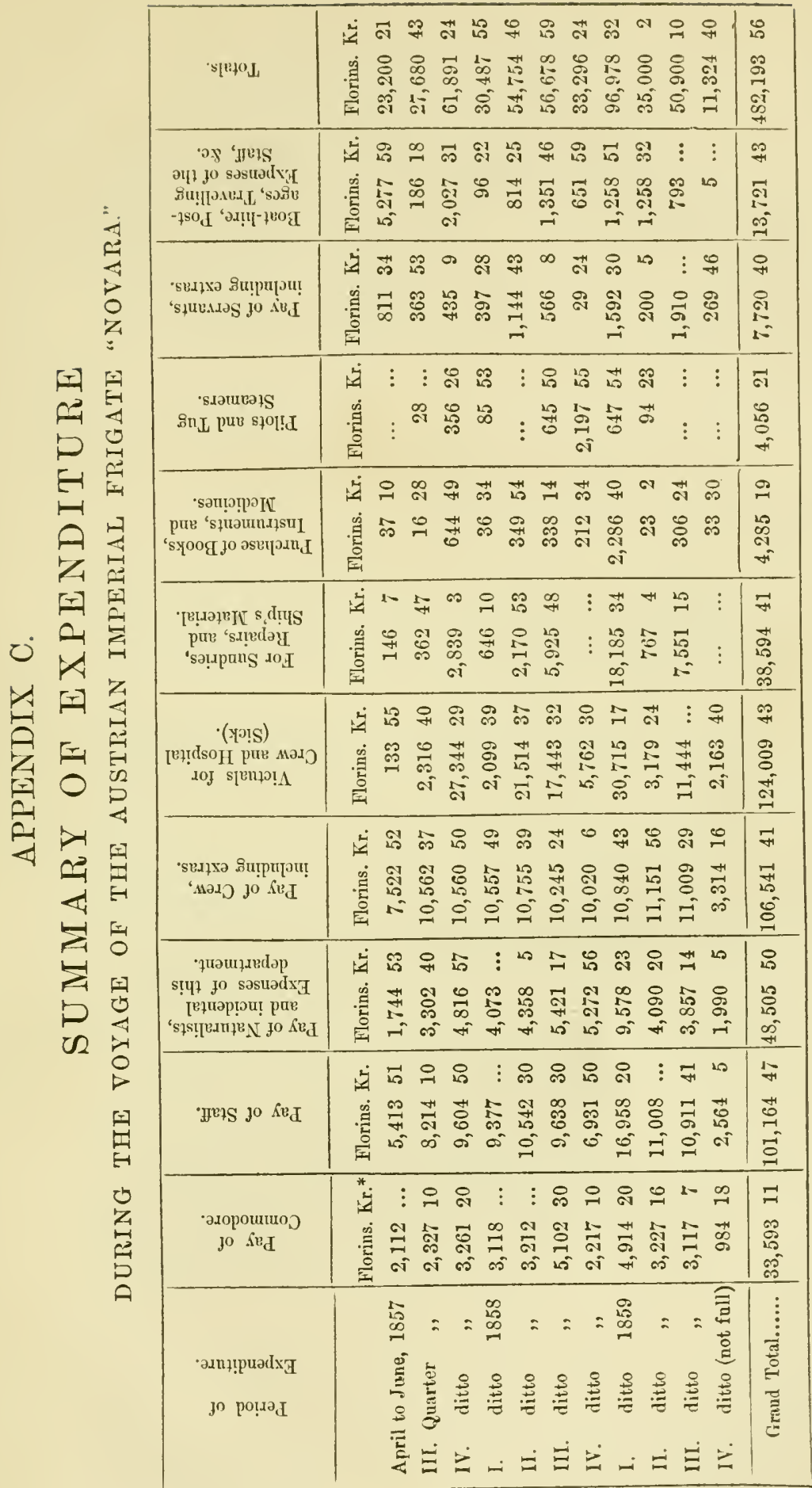


LONDON:

PRINTED BY WOODFALL AND KINDER, ANGEL COURT, SKINNER STREET. 
66, Brook Street, Hanover Square, W.

\section{MrssRs. SAUNDERS, OTLEY, \& Co.'s LITERARY ANNOUNCEMENTS.}

THE VOYAGE OF THE NOVARA ROUND

THE WORID. The Circumnavigation of the Globe, by the Austriar Frigate Novara. English Edition. Containing an Unpublished Letter from Baron Humboldt. With numerous wool engravings. Dedicated, by special permission, to Sir Roderick Murchison. 3 vols., 8 vo.

THE MARQUIS OF DALHOUSIE'S ADMINISTRATION of BRITISH INDIA. By Edwin Arnold, MI.A., of University College, Oxford.

THE POLITICAL LIFE of the EARL of DERBY.

THE LIFE of the RIGHT HON. BENJAMIN DISRAELI, M.P.

'THE SPEECHES AND ADDRESSES of the LORD BISHOP of OXFORD from 1811 to the Present Time. Edited by the Author. I vol., 8vo.

THE LIVES of the SPEAKERS of the HOUSE of COMMONS. By William Nathaniel Massey, Esq., M.P., author of "The History of England," and Chairman of Ways and Nieans.

\section{THE LATITUDINARIANS.}

A Chapter of Church History, from the Accession of Archbishop Tillotson in 1691, to the Death of Archdeacon Blackburne, in 1787. Ey Edward Churton, M.A., Archdeacon of Cleveland.

THE LIFE OF THE RIGHT HON. W. E. GLADSTONE, MI.P. 1 vol., 8vo. 


\section{Messrs. Saunders, Otley, Eo Co.'s Literary Announcements.}

ECCLESIA RESTITUTA.

By F. C. Massingberd, M.A., Prebendary of Lincoln and Reetor of Ormsby.

SEVEN ANSWERS to the 'ESSAYS and REVIEWS,' BY SLIVEN IVRITERS IN SEVEN SEPARATE ESSAYS.

THE HISTORY OF THE CONSERVATIVE PARTY, from the Defection of Sir Robert Peel to the Present Time. 1 vol., 8 vo.

\section{THE HISTORY OF THE CHURCH OF}

ENGLAND, from the Death of Elizabeth to the Present Time. By the Rev. Geo. G. Perry, M.A., Rector of Waddington, late Fellow and 'Tutor of Lincoln Collegre, Oxforl. 3 vols., 8 vo.

CHURCH RATE A NATIONAL TRUST. By the Venerable Archrleacon Denison. 1 vol., 8vo, 10 s. Gal.

THE CHURCHES OF THE EAST.

By the Rev. George Williams, B.D., Senior Fellow of King's College, Cambridge. 1 vol, 8 vo.

THE AMERICAN CHURCH and the AMERICAN UNION. By Henry Caswall, D.D., of Trinity College, Connecticut, and Prebendary of Sarum. I v., post 8 vo.

PHILOSOPHY; or, THE SCIENCE of TRUTH, being a 'Treatise on First Prineiples, Mental, Physical, and Verbal. 13y James Haig, Escl., M.A., of Lineoln's Inn.

\section{RECOLLECTIONS OF GENERAL GARI-} BALDI; or, TRAVELS FROM ROME TO LUCERNE, comprising a Visit to the Mediterranean Islands of La Madalena and Caprera, and the Home of General Garibaldi. 1 vol. 10s. 6d.

THE 'TRAVELS AND ADVENTURES OF

DR. WOLFF, the Bokhara Missionary. 2d. edition, 2 vols. 8 vo. 36 s.

AN AUTUMN TOUR IN SPAIN.

By the Rev. R. Roberss, B.A., of 'Trinity College, Cambridge, and Viear of Milton Abbas. With numerous Lingravings. 2 ls.

HISTORICAL MEMOIRS OF THE SUCCESSORS OF ST. PATRICK AND ARCHBISHOPS OF ARMAGH. By James Henthorne Torld, D.D., F.S.A., President of the Royal Irish Academy, 'lreasurer of St. Patrick's Cathedral, Regius Professor of Hebrew in the University, and Senior Fellow of 'Trinity. College, Duhlin. 2 vols, 8 ro 
Messrs. Saunders, Otley, Eo Co.'s Literary Announcements.

THE LIFE OF GEORGE FOX,

The Founder of the Quakers. From numerous original sources. 10s. 6u.

THE PRIVATE JOURNAL

OF THE MIARQUESS OF HASTINGS, Governor-General and Commander-in-Clief in India.

Edited by his Daughter, Soprin, the Marchioness of Bute. Second Edition, 2 vols. post 8vo, witlı Map and Index. $21 \mathrm{~s}$.

NAPOLEON THE THIRD ON ENGLAND.

Seleetions from his own writings. Translated by J. H. Simpson. 5s.

THE HUN'TING GROUNDS OF THE OJD

WORLD. By H. A. L. (the Old Shekarry). Second Edition. 21s.

HIGHLANDS AND HIGHLANDERS;

As they were and as they are. "By Wiltian Grant Stewart. First and Second series, price $5 \mathrm{~s}$. each; extra bound, $6 \mathrm{~s}$. $6 \mathrm{~d}$.

THE ENGLISHMAN IN CHINA.

With numerous Woodcuts. 10s. 6d.

LECTURES ON THE EPISTLE TO THE EPHESIANS. By the Rev. R. J. M'Giree. Second Erlition. 2 vols, Reduced price, $15 \mathrm{~s}$.

PRE-ADAMITE MAN ; or, THE STORY OF OUR OLD PLANET AND ITS INHABITAN'TS, TOLD BY SCRIPTURE AND SCIENCE. Beautifully Illustrated by Hervieu, Dalziel Brothers, \&c. 1 vol, post 8vo, 10s. Gd.

LOUIS CHARLES DE BOURBON : THE "PRISONER OF THE TEMPLE." 3 s.

A HANDY-BOOK FOR RIFLE VOLUNTEERS. With 14 Coloured Plates and Diagrams. By Captain W. G. Hartley, author of "A New Systen of D rill." 7s. 6d.

RECOLLEC'TIONS of a WINTER CAMPAIGN

IN INDIA, in 1857-58. By Captain Oliver J. Jones, R.N. With numerous illustrations drawn on stone by Day, from the Author's Sketches. In 1 vol. royal 8 vo, $16 \mathrm{~s}$.

TWO YEARS IN SYRIA.

Ry 'T. Lewis Farley, Esq., Late Chief Accountant of the Ottoman Bank, Beyrout. 12s. Second Edition.

DIARY OF TRAVELS IN THREE QUARTERS OF THF GLOBE. By an A Ustralian Setteer. 2 vole, post $8 \mathrm{v} u, 21 \mathrm{~s}$ 
RECOLLECTIONS of the COUR'T of NAPLES in OUR OWN TIMES.

MOUNT LEBANON AND ITS INHABITANTS: A 'Ten Years' Residence from 1842 to 1852. By Colonel Снurchil.t, Staff Olficer in the British Expedition to Syria. Second Elition. 3 vols. 8 vo, £1.5s.

\section{FROM SOUTHAMPTON TO CALCUTTA.}

Sketches of Anglo-Indian Life. 10s. 6d.

THE TABLET'TE BOOKE of LADYE MARY KEYES, OWNE SISTER TO THE MISFORTUNATE LADYE JANE DUDLIE. Post 8vo, 10s. $6 \mathrm{~d}$.

TRAVEL and RECOLLECTIONS of TRAVEL. By Dr. John Shaw. 1 vol, post 8 vo, 7s. 6d.

\section{LETTERS ON INDIA.}

By Edward Suldivan, Esq., Author of 'Rambles in North and South, America;' 'The Bungalow and the 'Tent;' 'From Boulogne to Babel Mandeb;' 'A 'Trip to the Trenches ;' \&c. 1 vol. $7 \mathrm{~s}$.

CAMPAIGNING IN KAFFIRLAND; or, SCENES AND ADVENTURES IN THE KAFFIR WAR OF 1851-52. By Captain W.R. KING. Second Edition. 1 vol. $8 \mathrm{vo}, 14 \mathrm{~s}$.

\section{THE RELIGIOUS TENDENCIES OF THE} AGE. 6s. 6d.

\section{ADVENTURES OF A GENTLEMAN}

in Search OF A HORSE. By Sir George Stephen. With illustrations by Cruikshank. New and cheaper Edition, $5 \mathrm{~s}$.

THE LANGUAGE OF FLOWERS,

Elegant Gift Book for the Season. Beautifully bound in green watered sılk, with coloured plates. Containing the Art of Conveying Sentiments of Esteem and Affection. Eleventh edition, dedicated, by per. mission, to the late Duchess of Kent. 10s.6d.

THE MANAGEMENT OF BEES;

With a deseription of the "Ladies' Safety Hive." By SAmuec BAGSTER, Jun. I vol., illustrated. 7s.

THE HANDBOOK OF TURNING,

With numerous plates. A complete and Practical Guide to the Beautiful Science of 'Turning in all its Branches. 1 vol. $7 \mathrm{~s}$. 6d.

TEXTS FOR TALKERS.

by Frank Fowlek. 3̈s. 6d. 
THE SUMMER TOUR of an INVALID. 5s. 6d. ARMY MISRULE : BARRACK THOUGH'TS. By a Common Soldier. 3s.

\section{WHY PAUL FERROLL KILLED HIS WIFE.}

By the Author of "Paul Ferroll." Third Edition. 10s. 6d.

OUR NEW RECTOR.

Edited by the Author of 'Mr. Verdant Green.' 10s. 6d.

THE RECTOR'S DAUGHTERS.

A Tale of Clerical Life. 10s. 6d.

SWEETHEARTS AND WIVES.

A Novel. By Marguerite A. Power. 3 vols., 31s.6d.

AN M.P. IN SEARCH OF A CREED.

A Novel. 10s.6d.

ROTTEN ROW. A Novel. 2 vols., 2 Is.

CRISPIN KEN. By the Author of 'Miriam May.'

Dedicated, by special permission, to the Right Hon. Sir E. B. Lytton, Bart., M.P. 2 vols., $21 \mathrm{~s}$.

WHO SHALL BE DUCHESS? or,

THE NEW LORD OF BURLEIGH. A Norel. 2 vols., $21 \mathrm{~s}$.

THE LIGHTHOUSE. A Novel. 2 vols., 2 Is.

THE SKELETON IN THE CUPBOARD.

By Lady Scott. 2 vols., 21s. Cheaper Edition, 5s.

TOO LATE! By Mrs. Dimsdale. 7s. 6d.

HELEN. A Romance of Real Life. 7s. 6d.

THE CASTLE and the COT'TAGE in SPAIN.

By Lady Wallace, Author of 'Clara; or, Slave Life in Europe.' 2 vols., 21 s.

CYRUS. By Lady Julia Lockwood.

GERTRUDE MELTON ; or,

NATURE'S NOBLEMAN. $\Lambda$ Tale. 7 s. $6 \mathrm{~d}$.

RUTH BAYNARD'S STORY. I vol., ios 6d. 
VANITY CHURCH. 2 vols., 2 Is.

MY WIFE'S PINMONEY.

By E. E. NeLson, a grand niece of the great Lord Nelscn. 5s.

THE EMIGRANT'S DAUGHTER.

Dedieated, by permission, to the Empress of Russia. $5 \mathrm{~s}$.

MIRIAM MAY. 4th Edition. 10s. 6d.

WHISPERING VOICES OF THE YULE.

Tales for Christmas. $5 \mathrm{~s}$.

THE SENIOR FELLOW.

A Tale of Clerical Life. 10s. 6 d.

ALMACK'S.

A Novel. Dedicated to the Ladies Patronesses of the Balls at Almack's.

New Edition, 1 vol, crown 8vo, 10s, 6d.

NELLY CAREW.

By Miss Power. 2 vols, $21 \mathrm{~s}$.

MEMOIRS OF A LADY IN WAITING.

By the Author of 'Adventures of Mrs. Colonel Somerset in Calfraria.' 2 vols, 18 s.

HULSE HOUSE.

A Novel. By the Author of 'Anne Gray.' 2 vols. post 8vo, $21 \mathrm{~s}$.

THE NEVILLES OF GARRETSTOWN.

A Historical Tale. Edited, and with a Preface by the Author of

'Emilia Wyndham.' 3 vols, post 8vo, 3ls. 6d.

CORVODA ABBEY.

A Tale. 1 vol, post 8 vo, 10 s. $6 \mathrm{~d}$.

THE VICAR OF LYSSEL.

The Diary of a Clergyman in the 18th century. 4s. 6d.

GOETHE IN STRASBOURG.

A Dramatic Nouvelette. By H. Noel Humphreys. 7s. 6d.

SQUIRES AND PARSONS.

A Church Novel. 1 vol. 10s. 6 d.

THE DEAN ; or, the POPULAR PREACHER.

By Berkeley Aikin, Author of 'Anne Sherwood.' 3 vols. post 8vo, 3 is. 6 d.

CHARLEY NUGENT; or,

PASSAGES IN THE LIFE OF A SUB. A Nuvel, 3 vols, post 8 vo.

$31 \mathrm{~s} .6 \mathrm{~d}$. 


\section{Messrs. Saunders, Otlcy, छ̛ Co.'s Literary Announcements.}

PAUL FERROLL.

By the Author of 'IX Poems by V.' Fourth Edition. Post 8vo, 10s. 6d.

LORD AUBREY; or,

IVHAT SHALL I DO? By the Author of 'Every Day.' A Novel. 2 vols., 2]s.

THE IRONSIDES.

A Tale of the English Commonwealth. 3 vols., 31 s. Gd.

AGNES HOME. A Novel. Ios. 6d.

LA CAVA; or,

RECOLLECTIONS OF THE NEAPOLITANS. 10s. Gol.

ANSELMO.

A Tale of Modern Italy. 2 vols., 2]s.

the

THE DALRYMPLES; or,

LONG CREDI' AND LONG CLOTH. 10s. 6.1.

INSTINCT; or, REASON.

By Larly Julia Lockwood. 5s. 6d.

CARELADEN HOUSE. A Novel. Ios. 6d.

\section{jortive}

Sir E. L. Bulwer Lytton's Eva, AND OTHER POEMS.

Sacred Poems.

By the late Right Hon. Sir Robert Grant, with a Notice by Lord Glenelg.

Eustace ;

An Elegy. By the Right Hon. Charles Tennyson D'Fyncourt.

Oberon's Empire.

A Mask.

The Shadow of the Yew,

AND OTHER POEMS. By Norman B. Yonge. 


\section{EAS'I INDIA ARMY ANI) COLONIAL AGENCY.}

66, Brook Street, Hanover Square, LONDON, WV.

(In the immediate vicinity of the New East India House and the Oriental Club.)

Messrs. Saunders, Otrey, and Co. beg to invite the attention of Regimental Messes, Officers, Members of the Civil Service, and other Residents in India, Australia, and the Colonies to their East India Army and Colonial Agency, and to the advantages it offers.

\section{BANIKING UIIPARTMITT.}

Pat, Pensions, Fond Allowances, Dividends, \&c., drawn aud remitted with regularity. Sales of, and Investments in, Govern. ment Stock, Foreign Securities, \&c., effecterl. Every other ilescripion of Financial Business transacted.

\section{SUPPLY DEPARTHITIT'}

Miscellaneous Supplies op eqery description, including Provisions, Wines, Plate, Jewellery, Books, Guns, Band Instruments, Clothing, \&c., carefully selected and despatched by Overland Route, or Sailing Ship, to Regiments and Nesses in India, Australia, and the Colonies.

Privatb Orders from Officers, Members of the Civil Service, and Residents in India, Australia, and the Colonies generally, are executed with care, economy, efficiency, and promptitude.

All orders should be accompanied by full and detailed directions.

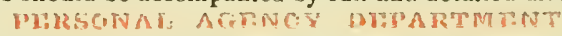

The Coustituents of Messrs. Saunders, Otley, and Co. may depend upon receiving every attention to their requirements and instructions. Every assistance will be afforded to their Constituents and their Families on their arrival in England, with the view to relieve them from every possible inconvenience.

Charge, when required, will be taken of children coming from India and the Colonies, and arrangements will be made for their education in England.

To those going out to India, Australia, and the Colonies, Messrs. Saunders, Otley, and Co. offer their services to secure passages Overland, or by Ship, and to afford them all necessary information connected therewith.

All Letters, Parcels, \&c., will be received by Messrs. Saunders, Otley, and Co., for their Constituents (whether in England, India, or the Colonies), to whom they will be forwarded regularly.

$$
\text { T?TRTS }
$$

No Commission CHARfied on the execution of Orders, whether from Regimental Messes or Private Individuals, when ACCOMPANIBI B A REMitTance, and a small Discount at all times allowed.

\section{LITERARY AND POLITICAL NEIVSPAPER FOR INDIA $\triangle N D$ THE COLONIES.}

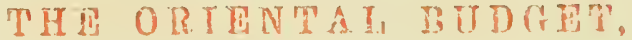 Price One Shithing (Post Finer).}

Published on the First of every Month by Saunders, Otley, and Co., 66, Brook Street, Hanover Square, London. 


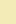






